\title{
EXPOSIÇÃO OCUPACIONAL À SÍLICA E SILICOSE ENTRE TRABALHADORES DE MARMORARIAS, NO MUNICÍPIO DE SÃO PAULO
}

\section{ANA MARIA TIBIRIÇÁ BON}

Tese de doutorado apresentada ao Departamento de Saúde Ambiental da Faculdade de Saúde Pública da Universidade de São Paulo para obtenção do Grau de Doutor

Área de concentração: Saúde Ambiental

ORIENTADOR: PROF. DR. SERGIO COLACIOPPO

São Paulo 
Autorizo, exclusivamente para fins acadêmicos e científicos, a reprodução total ou parcial desta tese, por processos fotocopiadores.

Assinatura:

Data: 
Aos meus pais: Catharina Massariolli Tibiriçá e João Baptista Tibiriçá (in memoriam) 


\section{AGRADECIMENTOS}

À FUNDACENTRO, pela oportunidade e fornecimento dos recursos técnicos e financeiros necessários para a realização deste projeto.

Ao meu orientador, Prof. Dr. Sergio Colacioppo, pela confiança permanente, apoio e incentivos durante todo o meu programa de pós-graduação, transmitindo tranqüilidade no desenvolvimento deste trabalho e sobretudo pela amizade.

Ao Prof. Dr. Eduardo Algranti, pela coorientação deste trabalho, incentivo constante, críticas e sugestões desde a primeira versão da proposta de trabalho e pelo apoio amigo, fundamental nos momentos difíceis.

Ao meu esposo Waldemar Bon Junior, muito obrigada pelo apoio no desenvolvimento dos bancos de dados, pela troca de experiências, incentivo constante e especialmente pelo amor e dedicação irrestrita à nossa família não só durante a execução deste trabalho.

Aos Doutores Iracema Fagá, Sonia Pereira Garcia Cecatti, Victor Wünsch Filho e Ivan Sergio Cavalcanti Mello, pela acolhida carinhosa, sugestões e discussões durante o processo de reuniões de pré-banca, que sem dúvida contribuiu para o aperfeiçoamento do texto final desta tese.

À Dra. Elisabete Medina Coeli Mendonça, amiga, sempre presente, que abraçou este projeto deste os primeiros trabalhos de campo, na organização e realização das avaliações médicas, e principalmente pela dedicação, carinho e amizade.

Às colegas de trabalho Norma Conceição do Amaral e Leila Cristina Alves Lima, agradeço carinhosamente pela amizade, dedicação, comprometimento, competência técnica e apoio fornecido nas etapas de coleta e análises das amostras de ar deste estudo.

Ao Marco Antonio Bussacos, colega de trabalho querido, pelo apoio fundamental na etapa das análises estatísticas. 
À MSc. Elayne de Fátima Macãira, pelo apoio no desenvolvimento dos instrumentos de avaliação, na coleta de dados em campo e sobretudo, pelo carinho, dedicação e amizade.

Ao Dr. Ubiratan Paula dos Santos, pela concessão e realização de parte dos exames de radiografia de tórax no Ambulatório de Pneumologia do Instituto do Coração da Universidade de São Paulo.

Aos Doutores Eduardo Mello De Capitani e Jefferson Benedito Pires de Freitas pela, amizade, dedicação e colaboração nas avaliações das radiografias de tórax.

Ao colega José Geraldo Aguiar, pelo apoio técnico sobre os processos de mineração e beneficiamento de rochas ornamentais, na organização de visitas técnicas e trabalhos de campo e pela valiosa amizade.

Ao MSc. Irlon Ângelo da Cunha, pela troca de experiência constante durante a realização deste trabalho, pelo apoio no árduo trabalho de campo e especialmente pela valiosa amizade.

Aos colegas MSc.Teresa Nathan, Nilce Aparecida Honrado Pastorello, Amarildo Aparecido Pereira e Guillermo Francisco Pérez Díaz pelo apoio na calibração e manutenção dos dispositivos de coleta e nos trabalhos de campo.

À Luiza Maria Nunes Cardoso, pela compreensão, confiança e apoio durante o desenvolvimento deste trabalho.

Aos colegas dos Centros de Referência em Saúde do Trabalhador da Secretaria de Saúde do Município de São Paulo, especialmente na pessoa do Dr. Manuel A. Ramos de Paulo, pela troca de informações técnicas sobre as condições de trabalho e de saúde dos trabalhadores encontradas no Projeto Marmoristas. 
Aos trabalhadores de marmorarias, em especial aos que participaram deste estudo, que me ensinaram muito, colaboraram sem restrição alguma na realização da coleta das amostras de ar e forneceram informações importantes para este trabalho. Fica meu agradecimento ao Sr. Aristóteles da Silva Magalhães do STIMAGRAN e ao Sr. Luiz C. J. de Queiros do SINTRAMOG.

Aos empregadores de marmorarias, em especial aos que compreenderam os objetivos deste estudo, participaram dele, colaboraram sem restrição alguma fornecendo informações importantes e já iniciaram melhorias nos ambientes de trabalho. Fica meu agradecimento ao Sr. Tarcísio Miguel Sevegnani do SIMAGRAN-SP.

Aos colegas do SENAI, Unidade Mario Amato, Centro Tecnológico de Mármores e Granitos, na pessoa do Dr. Eleno de Paula Rodrigues, pelo apoio técnico e acesso aos laboratórios, máquinas e ferramentas.

Aos Srs. José Roberto Barros e Gilberto Rodrigues Prado, profissionais que colaboraram imensamente na execução dos trabalhos de campo e de laboratório.

Às secretárias Maria Teresa Ramos de Souza, Creonice Maria de Oliveira Costa, Luciana São Pedro Dilser, Elaine Cristina de Oliveira e Alice Santana pela amizade, colaboração e atenção na execução das atividades administrativas envolvidas neste trabalho.

A todos os colegas da Coordenação de Higiene do Trabalho e da Coordenação de Saúde do Trabalho da FUNDACENTRO que colaboraram e me incentivaram nos momentos felizes e nos difíceis até a finalização deste trabalho.

Aos meus familiares, sempre presentes, na minha vida e no meu coração, que com amor me forneceram a energia necessária para chegar ao final deste trabalho.

Aos meus filhos queridos Fábio Tibiriçá Bon e Paula Tibiriçá Bon, pela compreensão e tolerância com minha dedicação a este trabalho. 


\section{RESUMO}

Bon AMT. Exposição ocupacional à sílica e silicose entre trabalhadores de marmorarias, no Município de São Paulo. São Paulo; 2006. [Tese de Doutorado Faculdade de Saúde Pública da USP].

Objetivo. No Brasil encontram-se em crescimento os índices de prevalência das doenças crônicas causadas pela exposição dos trabalhadores a poeiras minerais. Realizou-se estudo com objetivo de avaliar as condições de trabalho e de saúde dos trabalhadores em marmorarias e propor ações preventivas. Métodos. Realizou-se estudo transversal em 27 marmorarias, no Município de São Paulo que executavam o beneficiamento final de rochas ornamentais, incluindo: a) avaliação da exposição a poeiras e à sílica cristalina respirável por meio de coleta de amostras de ar $(n=762)$, análise por gravimetria e Difração de Raios X e acumulação das exposições estimadas por função conforme história ocupacional; b) aplicação de questionário de sintomas respiratórios (n=267) e avaliação médica, por espirometria e radiogradia de tórax; d) correlação dos resultados de exposição acumulada com achados clínicos e radiológicos por meio de análises estatísticas; e) levantamento de informações sobre os processos de trabalho e alternativas de controle. Resultados. Para os acabadores encontrou-se a maior exposição: concentração de $0,36 \mathrm{mg} / \mathrm{m}^{3}\left(\operatorname{IC}_{95 \%} 0,29\right.$ e 0,42) para os granitos e de $0,19 \mathrm{mg} / \mathrm{m}^{3}\left(\mathrm{IC}_{95 \%} 0,16-0,22\right)$ para a mistura de matérias-primas. Para estimativa de exposição acumulada à sílica cristalina respirável com mediana de $0,56 \mathrm{mg} / \mathrm{m}^{3}$-anos existiu risco de Odds Ratio igual a 1,2 ( IC $_{95 \%}$ 1,02-1,40) de o trabalhador exposto apresentar classificação radiológica com alterações, presença de pequenas opacidades - profusão $\geq 0 / 1$, em relação a um trabalhador nãoexposto. A população possuía baixo nível de escolaridade e de renda familiar, com média de idade 35,8 $( \pm 11,6)$ anos. Conclusões. Há exposição excessiva à sílica cristalina respirável nas marmorarias, com valores de concentração ultrapassando até 54 vezes o valor de referência recomendado pela NIOSH $0,05 \mathrm{mg} / \mathrm{m}^{3}$. As matérias-primas mais perigosas foram rochas silicáticas (silestone ${ }^{\circledR}$, granitos, arenitos e quartzitos). Entre as medidas de controle para as poeiras, caracterizaram-se como mais eficientes as aplicadas a úmido em máquinas e ferramentas.

Descritores: Quartzo; Estimativas Quantitativas de Exposição; Exposição Acumulada à Sílica Cristalina Respirável; Pneumoconioses; Morbidade; Rochas Ornamentais. 


\section{SUMMARY}

\section{BON AMT. Occupational exposure to silica and silicosis among sheds workers in Sao}

Paulo - Brazil Sao Paulo; 2006 (Doctor Thesis-University of Sao Paulo School of Public Health).

Objective. In Brazil it can be seen growing prevalence rates of chronic diseases due to occupational exposure to mineral dusts, being silicosis the greater prevalence of pneumoconiosis. A study was carried out with the aim to evaluate the work conditions and of the workers' health in granite and marble sheds and to propose preventive actions.

Methods: A cross sectional study was performed among 27 sheds in Sao Paulo county that perform the finishing work of ornamental rocks. The study included: a) evaluation of dust exposure and respirable crystalline silica, by means of air sampling $(n=762)$, analysis by gravimetry and X-Ray diffraction, and cumulative silica exposure estimates in each job according to the occupational history; b) applying a questionnaire of respiratory symptoms $(n=267)$ and medical evaluation, espirometry and chest X-Ray; d) results correlation of cumulative exposure with the clinical and radiological data by statistical means; e) search of working process information and control alternatives. Results: Finishing workers had the greater exposition: concentration of $0.36 \mathrm{mg} / \mathrm{m}^{3}\left(\mathrm{CI}_{95 \%} 0.29\right.$ 0.42 ) for granites and of $0.19 \mathrm{mg} / \mathrm{m}^{3}\left(\mathrm{CI}_{95 \%} 0.16-0.22\right)$ for the mixture of raw materials. To the estimated cumulative exposure to respirable crystalline silica with median equal to $0.56 \mathrm{mg} / \mathrm{m}^{3}$-years there was a risk Odds Ratio $=\mathrm{OR}=1.20\left(\mathrm{CI}_{95 \%} 1.021 .40\right)$ of the exposed worked to present an altered radiological classification with alterations, presence of small opacities - perfusion $\geq 0 / 1$, in relation to a non exposed worker. The population studied had low scholar education and low familiar income, with average age $35.8( \pm 11,6)$ years. Conclusions: There is excessive exposure to respirable crystalline silica in sheds with concentrations 54 times over the recommended exposure limit by NIOSH of $0.05 \mathrm{mg} / \mathrm{m}^{3}$. The most dangerous raw materials were silicatious rocks (silestone ${ }^{\circledR}$, granites, sandstones and quartzites). Among the control measures for dusts, were characterized as more efficient the applied ones the humid in machines and tools.

Descriptors: Quartz; Quantitative Exposure Estimates; Cumulative Respirable Crystalline Silica Exposure; Pneumoconiosis; Morbidity; Ornamental Rocks 


\section{ÍNDICE}

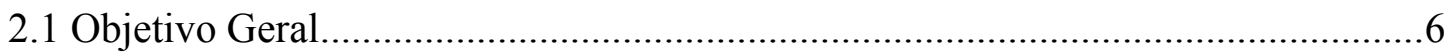

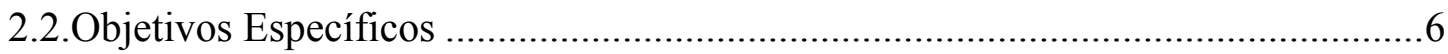

3 ASPECTOS TEÓRICOS SOBRE EXPOSIÇÃO OCUPACIONAL À SÍLICA, EFEITOS À SÁUDE ASSOCIADOS, MINERAIS E ROCHAS .. 8

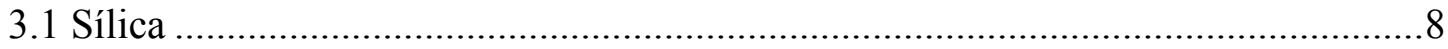

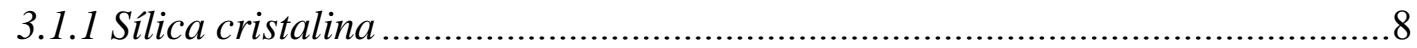

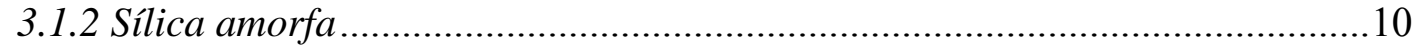

3.1.3 Exposição ocupacional à sílica cristalina .....................................................10

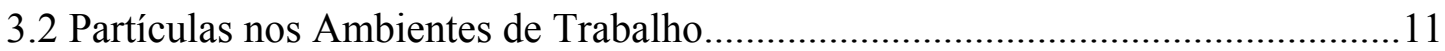

3.2.1 Avaliação da exposição ocupacional a partículas ..........................................12

3.2.2 Análise das propriedades de superfície das partículas .................................17

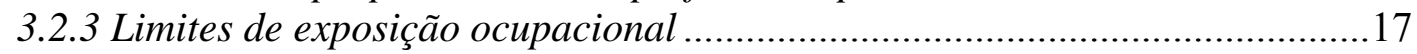

3.3 Toxicidade, Penetração, Deposição e Eliminação de Partículas no Pulmão .........21

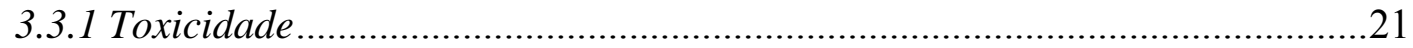

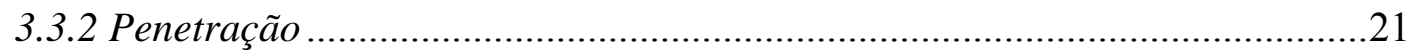

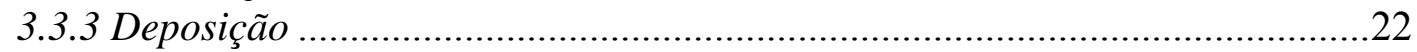

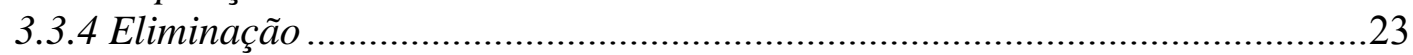

3.4 Doenças Associadas com a Exposição Ocupacional à Sílica Cristalina.................24

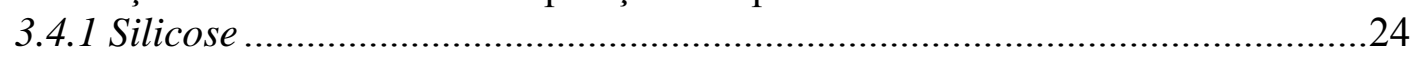

3.4.2 Tuberculose e outras doenças associadas à silicose ....................................26

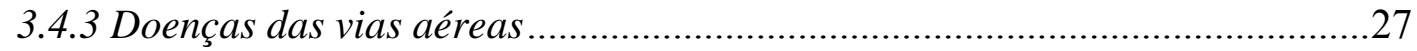

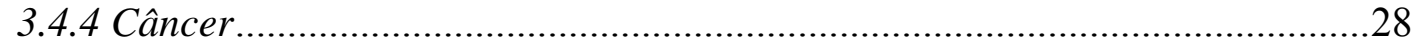

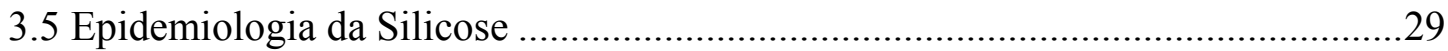

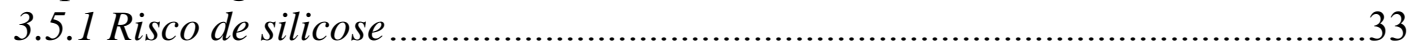

3.5.2 Estudos epidemiológicos e de exposição à sílica cristalina relacionados com rochas ornamentais e para revestimento ................................................................36 


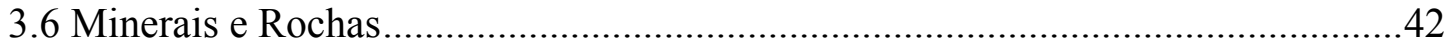

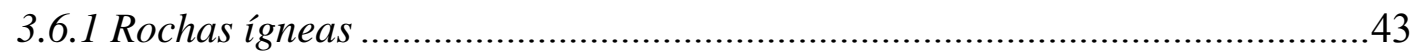

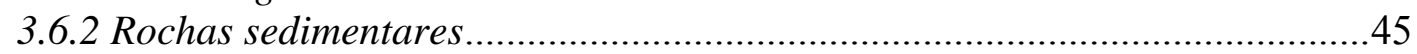

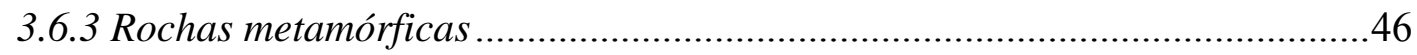

3.6.4 Rochas Ornamentais e para Revestimento .................................................46

3.7 Beneficiamento de Rochas Ornamentais e para Revestimento em Marmorarias..50

4. MATERIAIS E MÉTODOS …............................................................53

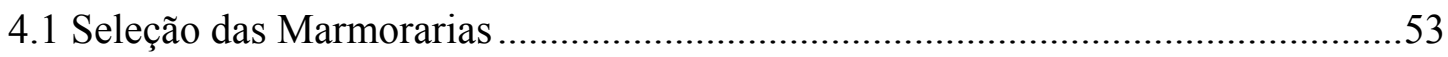

4.1.1 Estudo de exposição ocupacional à poeira e à sílica cristalina respirável e

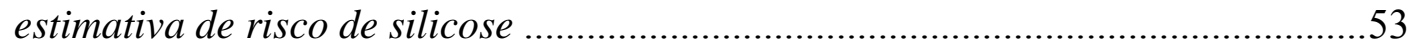

4.1.2 Estudo de alternativas de controle de poeira ...............................................56

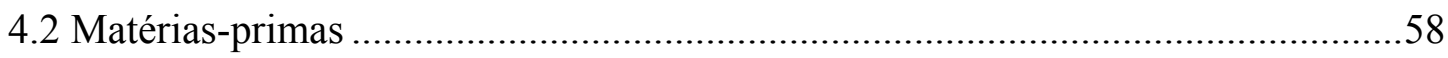

4.3 Avaliação Ambiental de Poeira e Sílica Cristalina Respirável..............................59

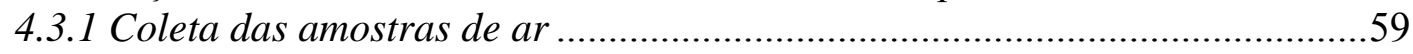

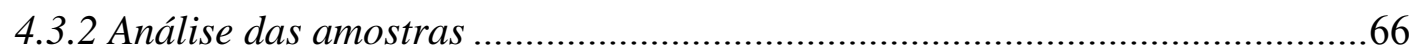

4.3.3 Concentração média ponderada pelo tempo ...............................................68

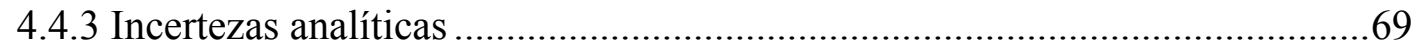

4.4 Caracterização da Exposição Ocupacional ..............................................................70

4.4.1 Estimativa da média aritmética de uma distribuição lognormal .....................71

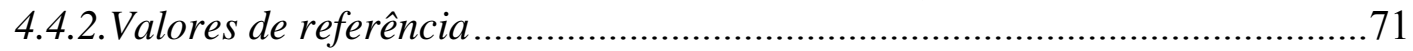

4.4.3 Porcentagem de resultados acima do Limite de Exposição Ocupacional.......72

4.4.4 Cálculo da exposição acumulada à sílica cristalina ........................................73

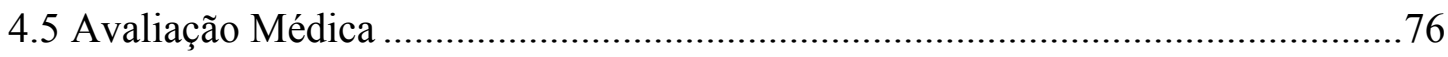

4.5.1 População de Estudo e Instrumentos de Avaliação.........................................76

4.5.2 Questionário de histórico ocupacional...........................................................76

4.5.3 Questionário de sintomas respiratórios ..........................................................77

4.5.2 Avaliação da função pulmonar - espirometria ..............................................79

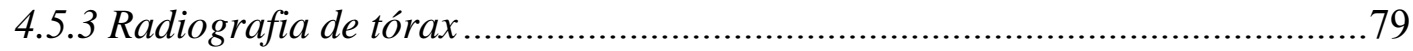

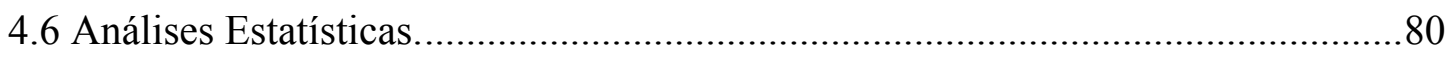

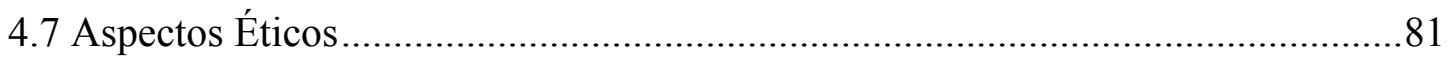




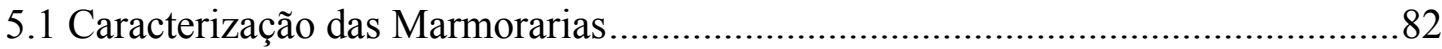

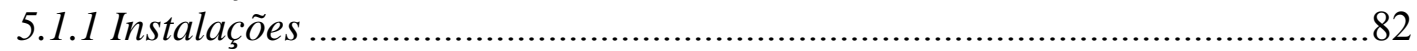

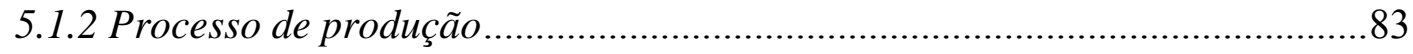

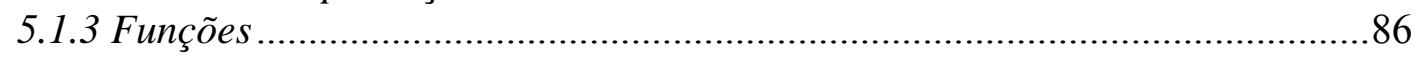

5.2 Caracterização da exposição ocupacional à poeira e à sílica cristalina respirável e estimativa de risco de silicose.

5.2.1 Resultados de análise de poeira e sílica cristalina respirável por jornada de

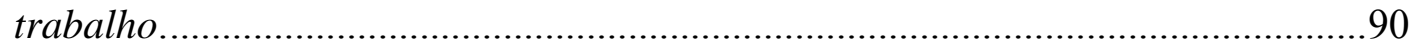

5.2.2 Resultados por função para as empresas .....................................................96

5.2.3 Resultados for função para o Município de São Paulo ..................................105

5.2.4 Resultados for função e tipo de operação para o Município de São Paulo.107

5.2.5 Resultados por função, matéria-prima e tipo de operação para o Município de

São Paulo 110

5.3 Caracterização das alternativas de controle de poeira ........................................115

5.3.1 Resultados por função e por empresas ..........................................................115

5.3.2 Resultados por função e por tipo de operação ...............................................119

5.3.3 Resultados por função, matéria-prima e tipo de operação ...........................122

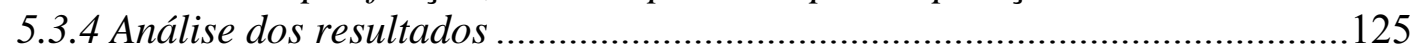

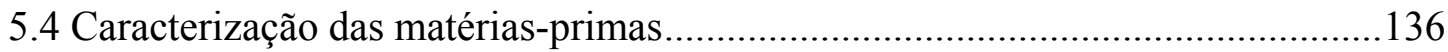

5.5 Caracterização da População do Estudo e Avaliação Médica ..............................140

5.5.1 Caracterização demográfica, antropométrica e sócio-econômica.................140

5.5.2 Caracterização da população por função .................................................... 142

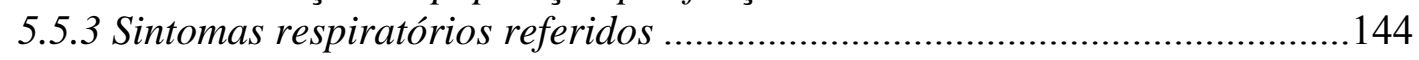

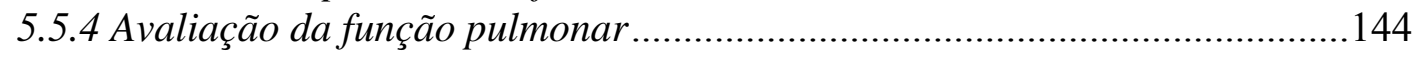

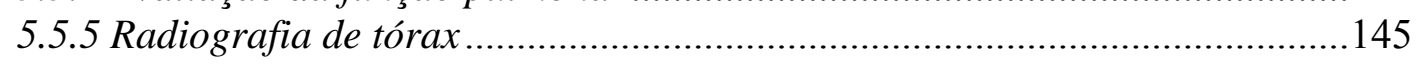

5.6 Correlações entre Exposição Ocupacional e Avaliação Médica .........................147

5.6.1 Exposição acumulada à sílica cristalina e classificação radiológica...........147

5.6.2 Classificação radiológica e tabagismo..........................................................153

5.6.3 Exposição acumulada à sílica cristalina, classificação radiológica, e

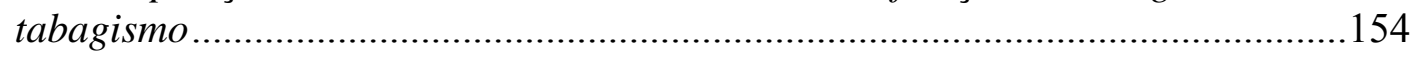

5.6.4 Classificação radiológica e tempo de exposição............................................156

5.6.5 Classificação radiológica, tempo de exposição e tabagismo ..........................158

5.6.6 Correlação entre Exposição Ocupacional e Avaliação Médica para a Função

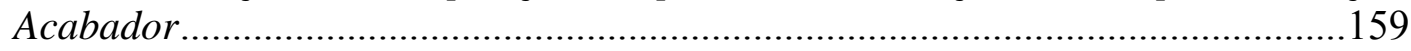

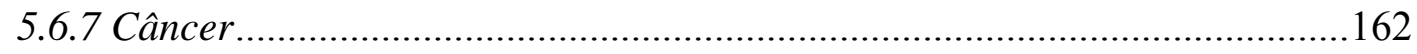


6.1 Avaliação da exposição ocupacional, alternativas de controle para poeira em marmorarias e matérias-primas.

6.1.1 Exposição ocupacional à poeira, à sílica cristalina respirável e estimativa de

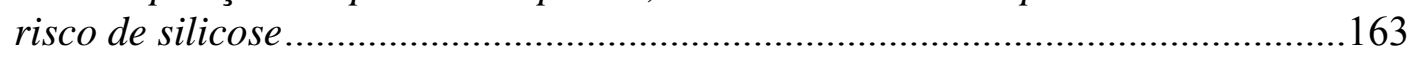

6.1.2 Alternativas de controle para poeira em marmorarias ..................................168

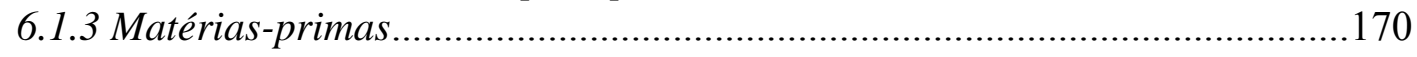

6.2 População de estudo e avaliação médica .........................................................172

6.3 Correlações entre Exposição Ocupacional e Avaliação Médica .........................174

6.3.1 Exposição acumulada à sílica cristalina ...................................................174

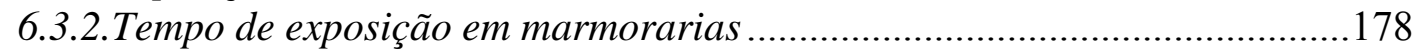

6.3.3 Considerações de possíveis vieses ............................................................179

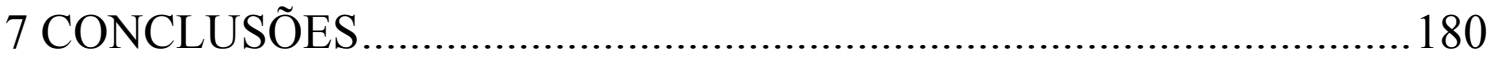

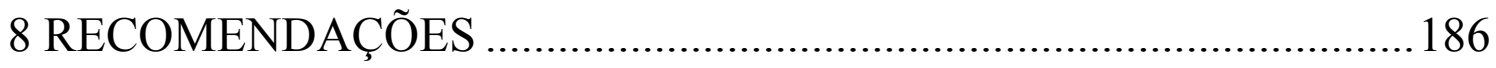

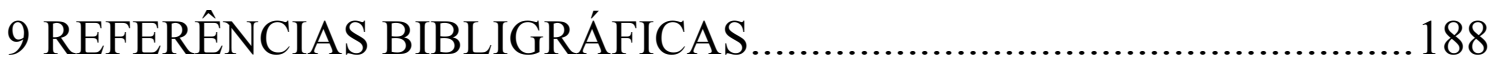

\section{ANEXOS}

Anexo 1 - Tabela de atividades onde há presença de sílica........................................ A1

Anexo 2 - Áreas de abrangência dos Centros de Referência de Saúde do Trabalhador no Município de São Paulo em outubro de 2002 ............................................ A2

Anexo 3 - Tabela para amostragem aleatória de Grupo de Exposição Similar .............. A3

Anexo 4 - Classificação Brasileira de Ocupações para os trabalhadores de pedras

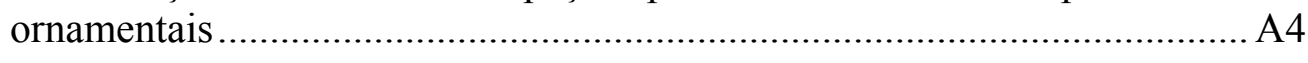

Anexo 5 - Cálculo de média aritmética de uma distribuição lognormal ...................... A7

Anexo 6 - Valores percentuais da Distribuição t de Student com n graus de liberdade. A8

Anexo 7 - Função da distribuição normal padrão. 
Anexo 8 - Instrumentos de avaliação.................................................................... A10

Anexo 9 - Termo de consentimento livre e esclarecido .......................................... A17

Anexo 10 - Termo de responsabilidade ........................................................... A18

Anexo 11 - Resultados de análise de poeira e sílica cristalina respirável e informações complementares do estudo de exposição ocupacional nas marmorarias estudadas

Anexo 12 - Resultados de análise de poeira e sílica cristalina respirável e informações complementares do estudo de alternativas de controle nas marmorarias estudadas.

Anexo 13 - Fotos das alternativas de controle da poeira nas marmorarias estudadas .. A91

Anexo 14 - Lista das matérias primas encontradas nas marmorarias estudadas A93 


\section{LISTA DE TABELAS}

Tabela 3.1 - Valores recomendados e limites de exposição ocupacional de instituições dos Estados Unidos da América e do Ministério do Trabalho do Brasil para o ano de 2005

Tabela 3.2 - Estudos epidemiológicos sobre silicose no Brasil em alguns ramos de atividade industrial.

Tabela 3.3 - Abundância relativa dos principais grupos minerais na crosta continental.

Tabela 3.4 - Classificação do CNAE para Marmorarias

Tabela 4.1 - Distribuição da amostra inicial por região e porte das marmorarias para estudo de exposição ocupacional a poeira e sílica cristalina respirável.

Tabela 4.2 - Distribuição da amostra estudada por região e porte das marmorarias para estudo de exposição ocupacional a poeira e sílica cristalina respirável no Município de São Paulo, 2004 -2005.

Tabela 4.3 - Distribuição das marmorarias selecionadas para estudo de alternativas de controle de poeira segundo o tipo de processo de acabamento e controle implantado, Município de São Paulo, 2004 -2005

Tabela 4.4 - Distribuição do número de amostras e jornadas de trabalho por função do estudo de exposição ocupacional à poeira nas 22 marmorarias estudadas, no Município de São Paulo 2004 2005

Tabela 4.5 - Distribuição do número de amostras e jornadas de trabalho por função do estudo de alternativas de controle da poeira nas 5 marmorarias estudadas, no Município de São Paulo 2004 2005.

Tabela 4.6 - Distribuição do número de amostras por tipo de matéria-prima segundo a função para as 27 marmorarias estudadas, no Município de São Paulo, 2004 -2005.

Tabela 5.1 - Concentração de poeira e de sílica cristalina respirável e informações complementares. Marmorarias, Município de São Paulo, 2004-2005...

Tabela 5.2 - Concentração média de poeira respirável $\left(\mathrm{mg} / \mathrm{m}^{3}\right)$ por função e para amostras de área nas marmorarias estudadas no Município de São Paulo, 2004-2005. 
Tabela 5.3- Concentração média de sílica cristalina respirável $\left(\mathrm{mg} / \mathrm{m}^{3}\right)$ por função e para amostras de área nas marmorarias estudadas, no Município de São Paulo, 2000 -2005.

Tabela 5.4 - Concentração média de poeira respirável por função e para amostras de área nas 22 marmorarias estudadas, no Município de São Paulo, $2004-2005$

Tabela 5.5 - Concentração média de sílica cristalina respirável por função e para amostras de área, nas 22 marmorarias estudadas, no Município de São Paulo, $2004-2005$.

Tabela 5.6 - Concentração média de poeira respirável por função e para amostras de área, por tipo de operação, nas 22 marmorarias estudadas, no Município de São Paulo, 2004 - 2005

Tabela 5.7 - Concentração média de sílica cristalina respirável por função e para amostras de área, por tipo de operação, nas 22 marmorarias estudadas, no Município de São Paulo, 2004 -2005

Tabela 5.8 - Concentração média de poeira respirável por função e para amostras de área, por tipo de operação e de matéria-prima, nas 22 marmorarias estudadas, no Município de São Paulo, 2004 -2005.

Tabela 5.9 - Concentração média de sílica cristalina respirável por função e para amostras de área, por tipo de operação e de matéria-prima, nas 22 marmorarias estudadas, no Município de São Paulo, 2004 -2005.

Tabela 5.10 - Concentração média de poeira respirável por função e para amostras de área em cada empresa do estudo de alternativas de controle de poeira. Município de São Paulo, 2003 -2005

Tabela 5.11 - Concentração média de sílica cristalina respirável por função e para amostras de área em cada empresa do estudo de alternativas de controle de poeira. Município de São Paulo, 2003 -2005

Tabela 5.12 - Concentração média de poeira respirável por função e para amostras de área das empresas do estudo de alternativas de controle de poeira. Município de São Paulo, 20032005.

Tabela 5.13 - Concentração média de sílica cristalina respirável por função e para amostras de área das empresas do estudo de alternativas de controle de poeira. Município de São Paulo, 20032005.

Tabela 5.14 - Concentração média de poeira respirável por função e para amostras de área, por tipo de operação das empresas do estudo de alternativas de controle de poeira. Município de São Paulo, 2003 -2005. 
Tabela 5.15 - Concentração média de sílica cristalina respirável por função e para amostras de área, por tipo de operação das empresas do estudo de alternativas de controle de poeira. Município de São Paulo, 20032005.

Tabela 5.16 - Concentração média de poeira respirável por função e para amostras de área, por tipo matéria-prima e operação das empresas do estudo de alternativas de controle de poeira. Município de São Paulo, 20032005

Tabela 5.17 - Concentração média de sílica cristalina respirável por função e para amostras de área, por tipo de matéria-prima e operação das empresas do estudo de alternativas de controle de poeira. Município de São Paulo, 20032005

Tabela 5.18 - Distribuição das marmorarias segundo as alternativas de controle da poeira no ambiente, nas máquinas e ferramentas quando existiam ,e ferramentas utilizadas na etapa de acabamento a seco. Município de São Paulo, 20032005

Tabela 519 - Concentração média de sílica cristalina respirável para a função de acabador, segundo as alternativas de controle da poeira existentes no ambiente das marmorarias estudadas. Município de São Paulo, 20032005

Tabela 5.20 - Características demográficas, antropométricas e sócio-econômicas dos trabalhadores estudados em marmorarias, no Município de São Paulo, $2004-2005$

Tabela 5.21 - Número, média e desvio padrão para idade em anos segundo a função, entre os trabalhadores de marmorarias, no Município de São Paulo, $2004-2005$

Tabela 5.22 - Distribuição do número de trabalhadores, tempo médio de trabalho na marmoraria atual, tempo médio total de trabalho em marmorarias segundo a função, no Município de São Paulo, 2004 -2005

Tabela 5.23 - Distribuição dos trabalhadores segundo número referido de marmorarias em que haviam trabalhado anteriormente. Município de São Paulo, 2004 -2005.

Tabela 5.24 - Prevalência de sintomas respiratórios referidos em trabalhadores de marmorarias (n=267) no Município de São Paulo, em 20042005.

Tabela 5.25 - Prevalência de $\mathrm{CVF}, \mathrm{VEF}_{1}$, e a relação $\mathrm{VEF}_{1} / \mathrm{CVF}$ reduzidos em trabalhadores de marmorarias $(n=261)$, no Município de São Paulo, $2004-2005$ 
Tabela 5.26 Número de trabalhadores segundo diagnóstico do tipo de alteração encontrada nas marmorarias estudadas, no Município de São Paulo, $2004-2005$

Tabela 5.27 - Resultados da classificação radiológica, segundo a profusão em trabalhadores de marmorarias $(n=250)$, no Município de São Paulo, $2004-2005$

Tabela 5.28 - História ocupacional resumida dos 27 trabalhadores que apresentaram resultados de classificação radiológica com profusão $\geq 0 / 1$ com pequenas opacidades nas marmorarias estudadas no município de São Paulo, $2004-2005$

Tabela 5.29 - Comparação entre história ocupacional, achados de alterações radiológicas - profusão $\geq 0 / 1$, e os resultados de exposição acumulada à sílica cristalina entre os trabalhadores das marmorarias estudadas. Município de São Paulo 2004 -2005

Tabela 5.30 - Resultado do teste de Savage de comparação de médias de exposição acumulada à sílica cristalina para o Modelo 1, segundo resultados da classificação radiológica, entre os trabalhadores de marmorarias, no Município de São Paulo, 2004 -2005.

Tabela 5.31 - Resultado do teste de Savage de comparação de médias de exposição acumulada à sílica cristalina para o Modelo 2, segundo resultados da classificação radiológica, entre os trabalhadores de marmorarias, no Município de São Paulo, 2004 -2005

Tabela 5.32 - Resultado do teste de Savage de comparação de médias de exposição acumulada à sílica cristalina para o Modelo 3, segundo resultados da classificação radiológica, entre os trabalhadores de marmorarias, no Município de São Paulo, 2004 -2005

Tabela 5.33 - Resultado do teste de Qui-Quadrado para tabagismo, segundo resultados da classificação radiológica, entre os trabalhadores de marmorarias, no Município de São Paulo, 2004 -2005.

Tabela 5.34 - Resultados da regressão logística multivariada opção "stepwise", da classificação radiológica, para a exposição acumulada à sílica cristalina - Modelo 1, e tabagismo entre os trabalhadores de marmorarias, no Município de São Paulo, 2004 -2005.

Tabela 5.35 - Resultados da regressão logística multivariada opção "stepwise", da classificação radiológica, para a exposição acumulada à sílica cristalina - Modelo 2, e tabagismo entre os trabalhadores de marmorarias, no Município de São Paulo, 2004 -2005 
Tabela 5.36 - Resultados da regressão logística multivariada opção "stepwise", da classificação radiológica, para a exposição acumulada à sílica cristalina - Modelo 3, e tabagismo entre os trabalhadores de marmorarias, no Município de São Paulo, 2004 -2005.

Tabela 5.37 - Número de trabalhadores, média e desvio padrão para tempo de exposição em anos segundo resultados da classificação radiológica, entre os trabalhadores de marmorarias, no Município de São Paulo, $2004-2005$

Tabela 5.38 - Resultados da regressão logística multivariada opção "stepwise", da classificação radiológica, por tempo de exposição e tabagismo entre os trabalhadores de marmorarias, no Município de São Paulo, 20042005

Tabela 5.39 - Resultado do teste de Qui-Quadrado para a relação $\mathrm{VEF}_{1} / \mathrm{CVF}$, segundo a função atual dos trabalhadores das marmorarias estudadas, no Município de São Paulo, 2004 -2005.

Tabela 5.40 - Resultados da regressão logística multivariada opção "stepwise", para razão $\mathrm{VEF}_{1} / \mathrm{CVF}$ reduzida, segundo função, tempo de exposição, tabagismo, entre os trabalhadores de marmorarias, no Município de São Paulo, 2004 -2005

Tabela 5.41 - Resultados da regressão logística multivariada opção "stepwise", da classificação radiológica, segundo exposição acumulada à sílica cristalina Modelo 1, função de acabador e tabagismo entre os trabalhadores de marmorarias, no Município de São Paulo, 20042005

Tabela 5.42 - Resultados da regressão logística multivariada opção "stepwise", da classificação radiológica, segundo exposição acumulada à sílica cristalina Modelo 2, função de acabador e tabagismo entre os trabalhadores de marmorarias, no Município de São Paulo, 20042005 


\section{LISTA DE FIGURAS}

Figura 3.1 - Representação das principais regiões do trato respiratório

Figura 3.2 - Deposição de partículas no trato respiratório para três regiões distintas.

Figura 3.3 - Seqüência hipotética de eventos que direcionam o desenvolvimento de silicose e câncer devido à sílica (quartzo)

Figura 3.4 - Distribuição do embasamento cristalino no território brasileiro.

Figura 3.5 - Participação das várias categorias comerciais na mineração de rochas ornamentais e para revestimento no Brasil.....

Figura 4.1 - $\quad$ Porta-filtro de poliestireno carregado com filtro do tipo membrana e suporte de celulose, usado para coleta de poeira.

Figura 4.2 - a) Ciclone separador de partícula do tipo Dorr-Oliver desmontado.

b) Dispositivo de coleta para a fração respirável de poeira

Figura 4.3 - Sistema de amostragem utilizado, mostrando o dispositivo de coleta para a fração respirável de poeira acoplado à bomba de ar.

Figura 5.1 - Concentração de poeira e sílica cristalina respirável por amostra, respectivas matérias-primas e tipos de operação. Marmorarias, Município de São Paulo, 2004 -2005.

Figura 5.2 - Porcentagem de resultados de concentração de poeira respirável $\left(\mathrm{C}^{\circ} \mathrm{PR}\right)$ acima do LEO-Brasil, entre o LEO e NA e abaixo do NA nas marmorarias estudadas, Município de São Paulo, 2004 -2005.

Figura 5.3 - Porcentagem de resultados de concentração de sílica cristalina respirável (C-SC) acima do REL-NIOSH, entre o REL e NA e abaixo do NA nas 22 marmorarias estudadas, Município de São Paulo, 20042005

Figura 5.4 - Médias e intervalos de confiança (95\%) da concentração de poeira respirável para função de acabador nas 22 marmorarias estudadas no Município de São Paulo, 2004 -2005

Figura 5.5 - $\quad$ Probabilidade da concentração cristalina na fração respirável (C-SC) ultrapassar o valor do REL-NIOSH para as funções de acabador e cortador nas 22 marmorarias estudadas no Município de São Paulo, 20042005 
Figura 5.6 - Probabilidade da concentração de sílica cristalina respirável (C-SC) ultrapassar o valor do REL-NIOSH nas funções de polidor, ajudante e encarregado e para amostras de área nas 22 marmorarias estudadas no Município de São Paulo, 2004 -2005

Figura 5.7 - Média e intervalo de confiança de 95\% da concentração de sílica cristalina respirável, para a função de acabador nas 22 marmorarias estudadas, no Município de São Paulo, 2004 - 2005

Figura 5.8 - Média e intervalo de confiança de 95\% da concentração de sílica cristalina respirável segundo a função dos trabalhadores nas 22 marmorarias estudadas, no Município de São Paulo, 2004 -2005.

Figura 5.9 - $\quad$ Média e intervalo de confiança de 95\% para concentração de sílica cristalina respirável segundo a função e o tipo de operação (a seco e a úmido) nas 22 marmorarias estudadas, no Município de São Paulo, $2004-2005$

Figura 5.10 - Média e intervalo de confiança de 95\% para concentração de sílica cristalina segundo a função e o tipo de matéria-prima nas 22 marmorarias estudadas, no Município de São Paulo, 2004 -2005.

Figura 5.11 - Média e intervalo de confiança de 95\% para concentração de sílica cristalina respirável segundo a função, matéria-prima e tipo de operação nas 22 marmorarias estudadas, no Município de São Paulo, $2004-2005$

Figura 5.12 - Média e intervalo de confiança de 95\% para concentração de sílica cristalina respirável segundo a função e para amostras de área, por tipo de matéria-prima e tipo de operação das empresas do estudo de alternativas de controle de poeira. Município de São Paulo, 20032005

Figura 5.13 - Concentração de sílica cristalina respirável para a função de acabador segundo os tipos controle da poeira existentes nas 27 marmorarias estudadas. Município de São Paulo, 2003 -2005

Figura 5.14 - Atividade de desbaste com politriz manual e rebolo para processo com a etapa de acabamento a seco em marmorarias. Município de São Paulo, 2003 -2005

Figura 5.15 - Atividade de desbaste com politriz manual e rebolo para processo com a etapa de acabamento a úmido em marmorarias. Município de São Paulo, 2003 -2005.

Figura 5.16 Atividade de desbaste com politriz manual e disco diamantado para processo com a etapa de acabamento a seco em marmorarias. Município de São Paulo, 2003 -2005 
Figura 5.17 - Atividade de desbaste com politriz manual e disco diamantado para processo com a etapa de acabamento a seco em marmorarias. Município de São Paulo, 2003 -2005.

Figura 5.18 - Vista geral de marmoraria que utilizava processo com a etapa de acabamento a seco. Município de São Paulo, 2003 -2005.......

Figura 5.19 - Vista geral de marmoraria que utilizava processo com a etapa de acabamento a úmido. Município de São Paulo, 2003 -2005....

Figura 5.20 - Distribuição percentual das matérias-primas encontradas nas 27 marmorarias estudadas. Município de São Paulo, 2003 -2005.

Figura 5. 21 - Porcentagem de sílica cristalina encontrada na fração respirável de poeira gerada nas atividades de desbaste, com disco diamantado, para os diversos tipos de granitos utilizados nas 27 marmorarias estudadas. Município de São Paulo, 2003 -2005

Figura 5.22 - Médias de exposição acumulada à sílica cristalina em $\mathrm{mg} / \mathrm{m}^{3}$-anos e intervalos de confiança de $95 \%$ em função dos resultados obtidos de radiografia de tórax, segundo a profusão, para os trabalhadores de marmorarias, no Município de São Paulo, 2004 -2005.

Figura 5.23 - Prevalência de resultados de radiografia de tórax com presença de pequenas opacidades (exames com alterações) por quartis de tempo de trabalho exposto em marmorarias, na população estudada, Município de São Paulo, 2004 -2005 


\section{ABREVIATURAS E SIGLAS}

ABHO

ABNT

ACGIH

AIHA

ASTM

ATS

BC

CEN

CRST

DNPM

EPA

FUNDACENTRO

HSE

IARC

IBGE

IEC

ILO

INCOR

INMETRO

IPT

ISO

IUPAC

LEO

LCFA

LOAEL

MTE

MPESP

MPT
Associação Brasileira de Higienistas Ocupacionais

Associação Brasileira de Normas Técnicas

American Conference of Governmental Industrial Hygienists

American Industrial Hygiene Association

American Society for Testing and Materials

American Thoracic Society

Bronquite Crônica

European Committee for Standardization

Centro de Referência em Saúde do Trabalhador

Departamento Nacional da Produção Mineral

Environmental Protection Agency

Fundação Jorge Duprat de Figueiredo de Segurança e Medicina do Trabalho

Health and Safety Executive

International Agency for Research on Cancer

Instituto Brasileiro de Geografia e Estatística

International Electrotechnical Commission

International Labor Organization

Instituto do Coração

Instituto Nacional de Metrologia, Normalização e Qualidade

Industrial

Instituto de Pesquisas Tecnológicas do Estado de São Paulo S/A

International Organization for Standardization

International Union of Pure and Applied Chemistry

Limite de Exposição Ocupacional

Limitação Crônica do Fluxo Aéreo

Lowest Observed Adverse Effect Level

Ministério do Trabalho e Emprego

Ministério Público do Estado de São Paulo

Ministério Público do Trabalho 
NIOSH

NOAEL

NR

OIT

OMS

OR

OSHA

PCMSO

PEL

PMSP

PNES

PPRA

RAIS

REL

SEBRAE

SENAI

SESI

SIMAGRAN-SP

SINTRAMOG

SMR

STIMAGRAN

SRI

SVLE

TLV

TWA

VR

WHO
National Institute for Occupational Safety and Health

No Observed Adverse Effect Level

Norma Regulamentadora

Organização Internacional do Trabalho

Organização Mundial da Saúde

Odds Ratio

Occupational Safety and Health Administration

Programa de Controle Médico e Saúde Ocupacional

Permissible Exposure Limit

Prefeitura do Município de São Paulo

Programa Nacional de Eliminação da Silicose

Programa de Prevenção de Riscos Ambientais

Relação Anual de Informações Sociais

Recommended Exposure Limit

Serviço Brasileiro de Apoio às Micro e Pequenas Empresas

Serviço Nacional de Aprendizagem Industrial

Serviço Social da Indústria

Sindicato da Indústria de Mármores e Granitos do Estado de São

Paulo

Sindicato dos Trabalhadores na Indústria da Construção e do Mobiliário de Mogi das Cruzes.

Standardized Mortality Ratio

Sindicato dos Trabalhadores na Indústria de Mármores, Granitos e

Pedras Ornamentais de São Paulo

Standardized Incidence Ratio

Sistema de Ventilação Local Exaustora

Threshold Limit Value

Time-Weighted Average

Valor de Referência

Wordl Health Organization 


\section{INTRODUÇÃO}

A exposição ocupacional à sílica cristalina pode ocorrer em vários ramos de atividade econômica no Brasil. Entre eles se destacam a mineração de minerais metálicos e nãometálicos, a fabricação de produtos de minerais não-metálicos, a indústria naval e da construção civil, em que são adotados processos de trabalho que geram partículas em suspensão com altos teores de sílica cristalina.

Entre as estimativas de número de trabalhadores expostos à silica cristalina no Brasil, pode-se citar o trabalho de RIBEIRO, 2004, indicando que 5.447.828 trabalhadores estavam expostos com freqüência superior a $1 \%$ da jornada semanal de trabalho. $O$ número de trabalhadores expostos representou 14,6\% do total de trabalhadores vinculados ao mercado formal. A base da dados utilizada neste estudo foi a RAIS 2001.

Para as atividades relacionadas à mineração e beneficiamento de não-metálicos no Brasil, os dados do Ministério do Trabalho e Emprego de 2001 indicavam a existência de 16.746 estabelecimentos. No ano de 2003 este número era de 20.008 estabelecimentos, com 399.262 trabalhadores. No Estado de São Paulo existiam 4.934 estabelecimentos, com 115.981 trabalhadores (RAIS 2001, 2003).

Em estudo recente MELLO, 2004a, apresentou dados que indicam que as atividades de mineração, de beneficiamento e de transformação de minerais não-metálicos, denominados rochas ornamentais e de revestimento, se encontram em expansão no Brasil. No Estado de São Paulo aproximadamente 3.000 marmorarias realizavam o beneficiamento final destes minerais (40\% das marmorarias do país), estando em torno de 1.000 marmorarias localizadas na Grande São Paulo. O número estimado de trabalhadores em marmorarias no Estado de São Paulo encontrava-se entre 20.000 e 30.000 .

Em São Paulo, município com maior consumo de rochas ornamentais e de revestimento do país, em 2002 existiam aproximadamente 312 marmorarias no mercado formal, com aproximadamente de 2.440 trabalhadores (MPESP 2001). 
A silicose é uma doença pulmonar causada pela inalação, retenção e reação pulmonar a partículas na fração respirável contendo sílica cristalina em suspensão no ar. É caracterizada por fibrose do tecido pulmonar e, uma vez a doença iniciada, é irreversível e geralmente progressiva (NIOSH 2002).

Partículas contendo sílica cristalina são muito tóxicas para o organismo humano e, além da silicose, podem causar bronquite crônica, limitação crônica ao fluxo aéreo, aumento da incidência de tuberculose, doenças auto-imunes e câncer (ATS 1997; NIOSH 2002; ALGRANTI et al. 2003).

A sílica cristalina foi considerada carcinogênica na forma de quartzo e de cristobalita provenientes de fontes com exposições excessivas como as ocupacionais. A Agência Internacional de Pesquisa sobre o Câncer da Organização Mundial da Saúde avaliou o risco de câncer com base em extensa bibliografia e publicou uma monografia sobre o assunto (IARC 1997).

As informações disponíveis sobre os fatores de risco que determinam o desenvolvimento da silicose, bem como sobre os respectivos métodos de prevenção e controle, são suficientes para considerar a doença como um problema de saúde pública.

A silicose é uma pneumoconiose importante, não só no Brasil. É grande o número de casos novos diagnosticados por ano no mundo. Por ser uma doença com altos índices de prevalência, a Organização Internacional do Trabalho e a Organização Mundial da Saúde lançaram em 1995 o "Programa Internacional da OIT/OMS para a Eliminação Global da Silicose" (ILO 1997; GOELZER 2001).

No Brasil, desde 2001, o Programa Nacional de Eliminação da Silicose (PNES) sob a coordenação técnica da FUNDACENTRO desenvolve ações de caráter nacional e setorial com o objetivo geral de reduzir significativamente as taxas de incidência da doença e até a sua eliminação como problema de saúde pública. Este objetivo foi estabelecido em consonância com os objetivos do programa global da OIT. Compõem o PNES instituições públicas, privadas e de pesquisa, incluindo representações de 
empregadores e de trabalhadores de vários ramos de atividade econômica (FUNDACENTRO 2005).

A FUNDACENTRO desenvolve, desde 1980, estudos de avaliação da exposição à sílica cristalina. Entre eles, se encontram os trabalhos realizados: na indústria cerâmica no estado de São Paulo (FUNDACENTRO 1980,1989); na mineração de carvão no estado de Santa Catarina (FUNDACENTRO 1985); na mineração de granito e mármore no estado do Espírito Santo (FUNDACENTRO 1995); na mineração de gnaisse e basalto no estado do Paraná (RODRIGUES 2004); e em pedreira de granito na Grande São Paulo (GRUENZNER 2003).

Em 2000 a FUNDACENTRO ingressou no Projeto Marmoristas coordenado pelo Ministério Público do Estado de São Paulo (Promotoria de Justiça de Acidentes de Trabalho da Capital), Centros de Referência em Saúde do Trabalhador (CRSTs) do Município de São Paulo e Instituto do Coração (INCOR), com objetivo de realizar parte dos exames médicos e cooperar nas ações de prevenção e controle da silicose.

Em 2001 as instituições que compunham o Projeto Marmoristas realizaram ações técnicas e educativas, entre elas a organização do Seminário sobre a Prevenção $e$ Controle da Exposição Ocupacional na Indústria de Mármore, Granito e Pedras Ornamentais. As conclusões do seminário convergiram no sentido da necessidade de melhoria das condições de saúde e segurança dos trabalhadores com a implantação de controle da exposição ocupacional às poeiras minerais e ao ruído.

No final de 2001 o Ministério Público do Estado de São Paulo divulgou ao público os resultados do Projeto Marmoristas, apresentando as ações de vigilância e inspeções em locais de trabalho realizadas e os dados dos exames médicos realizados na população de trabalhadores com diagnóstico de vários casos de silicose (MPESP 2001).

Entre o ano de 2002 e 2003 as atribuições do Ministério Público do Estado de São Paulo relacionadas à Promotoria de Justiça de Acidentes de Trabalho da Capital foram transferidas ao Ministério Público do Trabalho e o Projeto Marmoristas deixou de 
existir na forma e composição anteriormente descritas. Mas as instituições continuaram atuando de forma independente. Em agosto de 2004 por iniciativa do PNES foi criado um Grupo Técnico de Marmorarias (GT) com objetivo de integrar as diversas ações em desenvolvimento neste ramo de atividade. Este GT foi composto por representantes de instituições de governo (FUNDACENTRO, MTE, MPT e Centros de Referência em Saúde do Trabalhador da PMSP), empregadores (SIMAGRAN/SP), trabalhadores (STIMAGRAN e SINTRAMOG) e instituições convidadas com trabalhos nesta área, (IPT, SENAI, SEBRAE e SESI).

Este estudo foi iniciado em 2002 devido à: possibilidade de se encontrarem novos casos de silicose em um ramo de atividade em expansão no Brasil, como é o caso da fabricação de produtos de rochas ornamentais; existência um grande número de trabalhadores no beneficiamento final destes minerais em marmorarias e principalmente porque os dados disponíveis indicavam que nestes ambientes de trabalho não existiam controles eficientes, e a exposição ocupacional à poeira e à sílica cristalina respirável continuaria ocorrendo. Outro motivo para a realização deste estudo foi a ausência de dados epidemiológicos sobre silicose com a realização simultânea de avaliação das exposições ocupacionais à sílica cristalina em marmorarias no Brasil.

Foram realizadas avaliações nos ambientes de trabalho para caracterizar a exposição ocupacional a partículas respiráveis de poeira contendo sílica cristalina de 27 marmorarias do Município de São Paulo. Foram considerados diversos fatores que poderiam determinar maior ou menor exposição ocupacional, como a função exercida pelo trabalhador, o tipo de processo de acabamento (a seco ou a úmido), a presença ou não de medidas de controle nos ambientes de trabalho, nas máquinas e nas ferramentas e os tipos de matérias-primas utilizadas.

Um estudo transversal analítico foi desenvolvido para correlacionar os resultados de exposição ocupacional com achados de história ocupacional, clínicos e radiológicos, procurando obter estimativas de risco de silicose por meio de modelos de exposição acumulada para partículas respiráveis de sílica cristalina. 
Os modelos desenvolvidos de estudo de exposição acumulada à sílica cristalina, utilizando o Município de São Paulo como exemplo, poderão ser modificados e aperfeiçoados para aplicação em outros municípios do país.

A introdução de medidas de controle nas marmorarias do Município de São Paulo é ainda incipiente. Os resultados de exposição a poeira respirável e a sílica cristalina encontrados são representativos do que ocorre no Brasil, devido ao grande números de empresas e a presença de todo espectro desta atividade econômica.

Este estudo contribui para que sejam tomadas medidas preventivas para não ocorrerem novos casos de silicose neste ramo de atividade econômica. Os resultados encontrados já estão subsidiando as ações do Grupo Técnico de Marmorarias do Programa Nacional de Eliminação da Silicose. 


\section{OBJETIVOS}

\subsection{Objetivo Geral}

Avaliar as condições de trabalho e de saúde dos trabalhadores decorrentes da exposição ocupacional a poeiras minerais contendo sílica cristalina em marmorarias que beneficiam rochas ornamentais e de revestimento do Município de São Paulo.

As condições de trabalho nas marmorarias impõem aumento do risco dos trabalhadores adquirirem silicose e doenças associadas, e há alternativas operacionais e tecnológicas para o controle e diminuição destes riscos. Partindo-se desta tese pretende-se atingir o objetivo geral por meio dos seguintes objetivos específicos.

\subsection{Objetivos Específicos}

Correlacionar os resultados de exposição à sílica cristalina respirável com achados de história ocupacional, clínicos, radiológicos e funcionais dos trabalhadores.

Avaliar a exposição ocupacional à poeira e à sílica cristalina respirável nas marmorarias.

Realizar a caracterização demográfica, antropométrica, sócio-econômica e quanto ao hábito de fumar da população de trabalhadores em marmorarias.

Realizar a avaliação médica em trabalhadores de marmoraria utilizando exames clínicos e radiológicos.

Propor e testar modelos de exposição acumulada à sílica cristalina respirável para estimar o risco de silicose em marmorarias. 
Caracterizar os processos de beneficiamento final de rochas ornamentais e de revestimento em marmorarias, levando em consideração os tipos de operação a seco ou a úmido, os tipos de matérias-primas e a porcentagem de sílica cristalina na fração respirável que eles podem gerar, e as alternativas de controle da poeira existentes, a fim de propor ações preventivas de riscos à saúde relacionados com exposição ocupacional a poeiras e à sílica cristalina respirável. 


\section{ASPECTOS TEÓRICOS SOBRE EXPOSIÇÃO OCUPACIONAL À SÍLICA, EFEITOS À SÁUDE ASSOCIADOS, MINERAIS E ROCHAS}

Foi realizada revisão bibliográfica sobre a sílica e os efeitos que ela pode causar ao organismo humano, a exposição ocupacional a poeiras minerais contendo sílica cristalina, a epidemiologia da silicose, minerais e rochas, destacando os não-metálicos e seu beneficiamento final em marmorarias. Estes assuntos serão apresentados nos itens a seguir.

\subsection{Sílica}

A sílica pode ter origem mineral, ser biogênica ou sintética. Sua classificação pode ser realizada de várias formas. A classificação conforme a estrutura é útil neste trabalho devido aos diferentes efeitos à saúde que a sílica cristalina e a amorfa podem causar. $\mathrm{O}$ foco principal deste trabalho é a sílica de origem mineral e estrutura cristalina.

\subsubsection{Sílica cristalina}

A sílica ou dióxido de silício $\left(\mathrm{SiO}_{2}\right)$ é o componente predominante na crosta terrestre. O termo sílica cristalina refere-se ao composto unitário $\mathrm{SiO}_{4}$, com átomo de silício em posição central e quatro átomos de oxigênio nas pontas de um tetraedro. Esta unidade estrutural básica combina-se com outras semelhantes formando moléculas maiores cuja fórmula média é $\mathrm{SiO}_{2}$.

As formas de sílica cristalina ou polimorfos mais comuns são o $\alpha$ e $\beta$-quartzo, a $\alpha$ e $\beta$ tridimita e a $\alpha$ e $\beta$-cristobalita. Outras formas possíveis de serem encontradas na natureza são a coesita, stishovita e moganita. A nomenclatura usada designa de " $\alpha$ " a fase cristalina formada em baixa temperatura, e de " $\beta$ " a fase cristalina formada a alta temperatura (IARC 1997; NIOSH 2002). 
O $\alpha$-quartzo é a forma de sílica termodinamicamente estável em condições ambientes. A maior parte da sílica cristalina natural existe como $\alpha$-quartzo. As outras existem em forma metaestável. É um mineral de natureza dura, inerte e de baixa solubilidade. Suporta a ação de vários agentes atmosféricos e é encontrado desde traços até grandes quantidades em várias rochas (KIRK OTHMER 1997).

As diversas estruturas dos polimorfos têm propriedades diferentes como solubilidade, características de clivagem, morfologia e propriedades de superfície das partículas, que podem influenciar na resposta biológica à sílica cristalina. Também a composição dos polimorfos pode modificar a resposta biológica, devido à presença de quantidades significativas de impurezas (GUTHRIE JR. 1995).

Partículas de sílica cristalina com superfície recém-fraturada são mais tóxicas para células do pulmão que partículas com superfície definida há algum tempo (BOLSAITIS e WALLACE 1996).

É conhecida a contaminação do quartzo por íons inclusos em sua rede cristalina, sendo os mais comuns o alumínio, ferro, germânio, lítio, magnésio, sódio e potássio. Estudos indicam que esta oclusão pode aumentar ou diminuir sua toxicidade. A toxicidade da sílica é maior quando o elemento estranho é o ferro (ou arsênio, berílio, cádmio, cobre, cobalto, mercúrio, chumbo e níquel), e menor quando ele é o alumínio (DONALDSON e BORN 1998; CASTRANOVA 1997; WALLACE et al 1996, 2002).

Como as características da superfície do quartzo implicam em diferentes respostas biológicas, ou variabilidade do perigo do quartzo, alguns estudos apresentam mecanismos para o desenvolvimento da silicose e do câncer baseados em estudos com animais e in vitro e indicam como fatores determinantes a deposição de certa dose de sílica no pulmão, a reatividade na superfície da partícula e a presença de traços, por exemplo, de ferro que induzem a geração de espécies reativas de oxigênio (Reactive Oxygen Species), ou radicais livres. Estes, por sua vez, causam um estresse oxidativo que leva ao desenvolvimento da fibrose e do câncer de pulmão (FUBBINI 1997,1998; VALLYATHAN e SHI X 1997). 
Diante da existência de "evidências suficientes", o IARC classificou a sílica cristalina inalada, sob a forma de quartzo ou cristobalita, proveniente de fontes ocupacionais, como cancerígeno para os humanos, Grupo 1. Para o IARC existem "evidências limitadas" do caráter cancerígeno da tridimita em estudos com animais (IARC 1997).

\subsubsection{Sílica amorfa}

A sílica amorfa de origem natural pode ocorrer como: opala; sílica biogênica, definida como qualquer sílica proveniente de matéria orgânica, tendo como fontes conhecidas as bactérias, os fungos, as algas, as esponjas e as plantas; terras diatomáceas - produtos geológicos da decomposição de organismos unicelulares com carapaça silicosa; sílicas vítreas, produzidas pela fusão de materiais que contêm silício, seja de origem vulcânica ou resultado do impacto de meteoritos (IARC 1997).

Pode ocorrer a presença de sílica cristalina (cristobalita) de forma natural na opala, ou em processos de fabricação da diatomita a partir de terras diatomáceas e de sílicas amorfas sintéticas, devido à falta de controle no aquecimento e na calcinação.

A sílica amorfa não está classificada como cancerígena para os humanos (Grupo 3), devido à avaliação de que existem “evidências inadequadas”. O IARC também avaliou que existem "evidências inadequadas" do caráter cancerígeno da sílica amorfa em estudos com animais para as terras diatomáceas e para as sílicas amorfas sintéticas (IARC 1997).

\subsubsection{Exposição ocupacional à sílica cristalina}

Devido à grande ocorrência da sílica cristalina na crosta terrestre, e ao grande uso de materiais em que ela está presente, os trabalhadores podem se expor à sílica em grande número de ocupações de vários ramos de atividade econômica. 
Assim, a exposição ocupacional à sílica cristalina pode ocorrer em atividades de mineração, lavra e beneficiamento de rochas (como granito, por exemplo), nas indústrias de vidro, de cerâmicas, de cimento, da construção e nas fundições. Segundo estudo da OSHA nos Estados Unidos, no período entre 1980 e 1992 foi encontrado quartzo na fração respirável de amostras coletadas em 255 tipos de indústrias (FREEMAN e GROSSMAN 1995). No Anexo 1 são apresentadas algumas das principais indústrias e atividades em que a sílica cristalina pode estar presente.

\subsection{Partículas nos Ambientes de Trabalho}

"Partículas em suspensão no ar" é o termo aparentemente mais adequado para o correspondente em inglês "aerosol", que é definido como o conjunto de partículas sólidas ou líquidas dispersas em meio gasoso em tempo suficiente para sua observação e medição (JOHNSON e SWIF 1998; WHO 1999; SANTOS 2001).

As partículas podem se dispersar no ar na forma de poeiras, névoas, fumos e neblinas. Todas estas formas, quando geradas nos ambientes de trabalho, podem estar relacionadas com doenças ocupacionais.

Partículas geradas por ruptura mecânica de líquidos formam as chamadas névoas. As neblinas são produzidas por condensação de líquidos à temperatura ambiente (SOTO et al. 1991).

As partículas geradas por ruptura mecânica de sólidos, como rochas, por exemplo, resultam nas poeiras. Enquanto aquelas produzidas por condensação de vapores de sólidos à temperatura ambiente originam os fumos (SOTO et al. 1991).

O caráter higroscópico e as propriedades físicas das partículas sólidas (poeiras) como a forma, o tamanho e a densidade determinam em grande parte seu comportamento no ar e sua eficiência de inalação e de deposição no trato respiratório. 
As poeiras, são associadas a difundidas e conhecidas doenças do pulmão, tais como pneumoconioses, câncer, asma, alveolites alérgicas e irritações (WHO 1999).

Portanto, as poeiras podem ser perigosas, como agentes de risco à saúde. Do ponto de vista da higiene ocupacional, é de vital importância o seu reconhecimento nos ambientes de trabalho e sua caracterização para o estabelecimento de medidas de prevenção e controle.

Existem várias definições para o termo poeira. Para a IUPAC, 1990, poeiras são partículas sólidas, secas, de pequeno tamanho, projetadas no ar por fontes naturais como vento, erupção vulcânica, e por processos realizados pelo homem, como esmagamento, trituramento, moagem, mineração, perfuração, demolição, remoção com pá, carregamento, peneiramento, empacotamento e varrição. Partículas de poeira têm normalmente faixa de tamanho entre 1 a $100 \mu \mathrm{m}$ e assentam lentamente por efeito da gravidade (IUPAC 1990 apud WHO 1999).

\subsubsection{Avaliação da exposição ocupacional a partículas}

Reconhecer, avaliar e controlar a exposição de trabalhadores a partículas tem sido objetivo de muitos pesquisadores e outros profissionais ao longo da história, pois os danos que elas podem causar são conhecidos há muito tempo.

Avaliar a exposição ocupacional a partículas é tarefa importante, pois no desenvolvimento de doenças muitos fatores se encontram relacionados à exposição. A intensidade, isto é concentração de partículas de poeira existente no ambiente, a distribuição do tamanho e a forma de partículas são alguns destes fatores. Podem ser determinantes também a origem, a estrutura e as propriedades químicas e físicas. 
Segundo a EPA, 1992, a complexidade dos problemas gerados pela contaminação dos ambientes encontra-se de tal forma agravada que a avaliação da exposição necessita combinar elementos de três áreas de conhecimento: higiene ocupacional, epidemiologia e medicina.

A avaliação da exposição é utilizada para obtenção de informações qualitativas e quantitativas que caracterizam a magnitude e importância de um determinado risco à saúde dos trabalhadores. Pode ter como objetivo encontrar uma relação exposiçãoresposta em estudo epidemiológico, comparar resultados de medidas com os limites de exposição ocupacionais ou avaliar a eficiência de sistemas de controle.

Para CHECKOWAY, 1989, exposição é a "presença de uma substância no ambiente de trabalho que pode interagir com o trabalhador". Ela é caracterizada em função da concentração da substância no ambiente de trabalho e da duração da exposição. A exposição acumulada é uma medida de exposição em um tempo integrado, isto é, a soma das concentrações em um tempo total.

A expressão 1 é uma expressão geral de exposição acumulada para a qual geralmente a unidade é apresentada em $\mathrm{mg} / \mathrm{m}^{3}$-anos.

$$
\text { Exposiçãoacumulada }=\sum_{\mathrm{i}}\left(\mathrm{T}_{\mathrm{i}} \times \mathrm{E}_{\mathrm{i}}\right)
$$

Onde:

$\mathrm{T}_{\mathrm{i}}=$ tempo em anos em cada função $\mathrm{i}$

$\mathrm{E}_{\mathrm{i}}=$ estimativa da exposição em cada função i

Serão apresentados de forma resumida alguns métodos de avaliação de exposição ocupacional a partículas de poeira e de análise das propriedades de superfície das partículas de sílica, fatores importantes no desenvolvimento da silicose. 


\subsubsection{Avaliação da exposição baseada na concentração de poeira respirável}

A avaliação quantitativa e a análise de risco podem ser complexas, pois é necessário caracterizar as propriedades das partículas, além da intensidade da exposição. A concentração de poeira na fração respirável (constituída de partículas menores do que $10 \mu \mathrm{m}$, capazes de penetrar e se depositar no pulmão na região de troca de gases), tem sido parâmetro utilizado para caracterizar a intensidade da exposição. Por ser considerada fator determinante no desenvolvimento da silicose, desde 1959 o British Medical Research Council recomenda seu uso.

A fração respirável é coletada nos ambientes de trabalho por meio de um dispositivo composto de porta-filtro, suporte de celulose, filtro de membrana de PVC de $5 \mu \mathrm{m}$ de poro e ciclone separador de partículas. Este dispositivo é acoplado a uma bomba de amostragem individual, calibrada com vazão específica para que a eficiência da coleta seja compatível com a curva de distribuição do tamanho da partícula e com a sensibilidade do método analítico adotado (OSHA 2002; NIOSH 2003; FUNDACENTRO 2006).

$\mathrm{Na}$ seqüência, a massa de fração respirável coletada é analisada para determinar a quantidade de sílica cristalina presente, pois esta é extremamente danosa aos macrófagos alveolares. A concentração de sílica cristalina é fator importante na caracterização do risco de silicose, cuja magnitude aumenta com o aumento da concentração (KREISS 1996; MANNETJE 2002).

Neste estudo, os métodos de amostragem e análise para determinação da concentração de poeira e de sílica cristalina respirável serão descritos no item 4.4. Os resultados serão utilizados para: a) avaliar a exposição ocupacional; b) verificar a eficiência das alternativas de controle; c) e determinar a percentagem de sílica cristalina respirável que pode ser gerada pelas diversas matérias-primas em condições específicas. 


\subsubsection{Avaliação da exposição por seleção de tamanho das partículas}

A medição do diâmetro aerodinâmico da partícula é o modo mais adequado de avaliar seu tamanho nas situações de interesse para a higiene ocupacional. A WHO, 1999, definiu o diâmetro aerodinâmico de uma partícula como o diâmetro de uma esfera hipotética com densidade de $1 \mathrm{~g} / \mathrm{cm}^{3}$ que possui a mesma velocidade terminal que a partícula considerada, com relação a seu tamanho geométrico, tipo e densidade.

Segundo a WHO, 1999, o diâmetro aerodinâmico das partículas está fortemente associado à habilidade que as partículas possuem para penetrar e se depositar em diferentes locais do trato respiratório. Também é importante na definição do modo de transporte das partículas nos dispositivos de amostragem e filtração. Eis porque sua medida é uma abordagem apropriada.

A American Conference of Governmental Industrial Hygienists (ACGIH), a International Organization for Standardization (ISO) e a European Committee for Standardization (CEN) recomendam a amostragem de partículas sólidas por seleção de tamanho das partículas. As partículas sólidas, na forma de poeira e pelos critérios harmonizados da ACGIH/ISO/CEN, possuem teoricamente uma faixa de tamanho que varia de 0 a $100 \mu \mathrm{m}$ (JOHNSON e SWIF 1998; HEARL 1998; LIPPMANN 1999; WHO 1999; SANTOS 2001; FUNDACENTRO, 2006).

A avaliação seletiva do tamanho das partículas deve ser realizada por meio de dispositivos com capacidade de separar as partículas em frações correspondentes àquelas que são retidas nas principais regiões do trato respiratório, conforme mostrado na Figura 3.1.

A fração de particulado inalável é aquela constituída por partículas de diâmetro aerodinâmico menor que $100 \mu \mathrm{m}$, que entra pelo nariz e pela boca, penetra no trato respiratório e pode ficar retida em qualquer lugar dele. A concentração da fração de particulado inalável é o parâmetro utilizado para avaliar risco daqueles materiais que 
causam efeito adverso quando depositados em qualquer lugar do trato respiratório (ABHO 2005; FUNDACENTRO 2006).

A fração de particulado torácico é aquela constituída por partículas de diâmetro aerodinâmico menor que $25 \mu \mathrm{m}$, que penetra e pode ficar retida nas regiões traqueobrônquica (vias aéreas dos pulmões) e na de troca de gases. A concentração da fração de particulado torácico é o parâmetro utilizado para avaliar risco daqueles materiais que causam efeito adverso quando depositados em qualquer lugar no interior das vias aéreas dos pulmões e na região de troca de gases (ABHO 2005; FUNDACENTRO 2006).

A fração respirável é constituída por partículas de diâmetro aerodinâmico menor que 10 $\mu \mathrm{m}$, que penetra e pode ficar retida na região de troca de gases ou região pulmonar. A concentração da fração de particulado respirável é o parâmetro utilizado para avaliar risco daqueles materiais que causam efeito adverso quando depositados na região de troca de gases (ABHO 2005; FUNDACENTRO 2006).

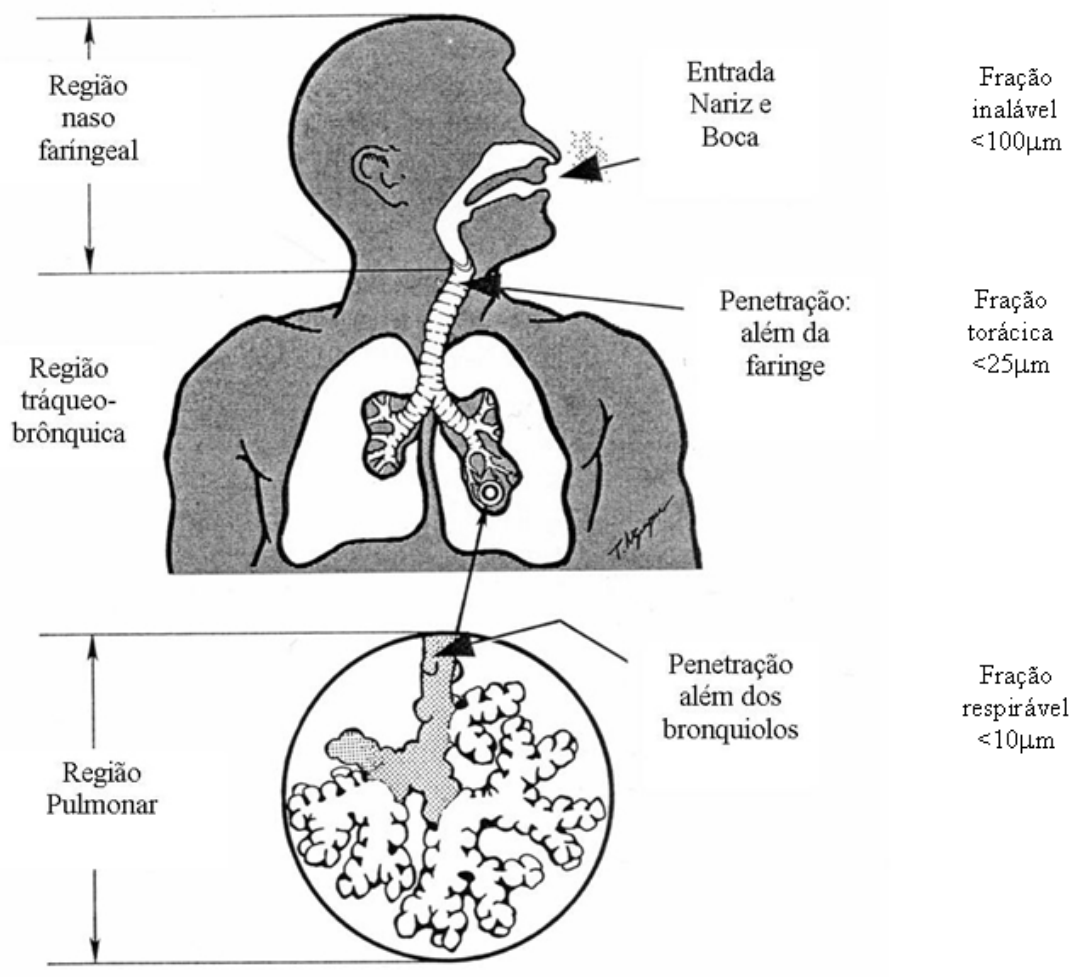

Figura 3.1-Representação das principais regiões do trato respiratório

Fonte: extraído de LIPPMANN 1999. 


\subsubsection{Análise das propriedades de superfície das partículas}

Como apresentado acima, as propriedades de superfície das partículas de sílica determinam sua toxicidade, e consequentemente o grau de perigo de uma determinada poeira para o organismo. Existem várias técnicas e métodos para conhecer a composição e as propriedades de superfície das partículas. Serão citados aqui alguns como exemplos.

WALLACE et al., 1990, desenvolveram método para detectar a presença de elementos que ocluem as partículas respiráveis de sílica com a técnica de análise por microscopia eletrônica de varredura com raios X dispersivo.

TOURMANN e KAUFMANN, 1994, desenvolveram um método alternativo ao de WALLACE et al., 1990, para determinar a composição da superfície da partícula pela técnica de análise de massa por microssonda a laser. A técnica utiliza um laser para vaporizar e ionizar um pequeno volume de material próximo à superfície de uma única partícula. Os íons gerados são identificados pelo "tempo de vôo" por espectrometria de massa (IARC, 1997).

Em FUBINI, 1998a, 1998b; e BOLSAITIS e WALLACE, 1996, encontram-se descritos métodos para investigar as propriedades de superfície de partículas, tais como, capacidade de absorção de água, hidrofilicidade e potencial para liberação de radicais livres entre outras.

\subsubsection{Limites de exposição ocupacional}

Os Limites de Exposição Ocupacional (LEO) para poeiras contendo sílica cristalina foram mudados ao longo do século $\mathrm{XX}$ em função da melhoria das técnicas de amostragem e análise. Atualmente, são baseados em concentrações médias ponderadas pelo tempo, parâmetros que se correlacionam com efeitos crônicos, como é o caso da silicose. 
Segundo a AIHA, 1998, os valores de referência mais adequados para exposições ocupacionais a substâncias de efeito crônico são os limites de exposição ocupacional da média de exposição de longa duração Long-term Average Exposure - LTA. No entanto, não existem valores de LEO-LTA para poeira e para sílica cristalina respirável.

Assim, até o momento os LEOs utilizado, como de referência são valores de média ponderada pelo tempo para jornadas diárias ou semanais. Não há um LEO universal para sílica cristalina. Vários países estabelecem seus próprios limites ou adotam os de instituições como o NIOSH, ACGIH ou OSHA. Na Tabela 3.1 são apresentados vários exemplos de LEOs para poeira respirável, inclusive o adotado no Brasil.

Os LEOs são considerados padrões de referência importantes para o controle dos ambientes de trabalho e tomada de decisão com relação à melhoria destes controles, a fim de prevenir as doenças ocupacionais.

O NIOSH, em 1974, recomendou o limite de exposição ocupacional conhecido pela sigla REL, Recommended Exposure Limit, de $0,05 \mathrm{mg} / \mathrm{m}^{3}$, baseado nos efeitos à saúde devidos à exposição à sílica cristalina, quartzo, tridimita e cristobalita, para reduzir o risco de desenvolvimento de silicose, câncer de pulmão e outros efeitos adversos à saúde.

O NIOSH, 2002, após revisão recente de vários estudos epidemiológicos, reconheceu que poderiam ocorrer de 1 a 7 casos de silicose por 100 trabalhadores expostos a uma concentração de sílica cristalina respirável de $0,025 \mathrm{mg} / \mathrm{m}^{3}$ - metade do LEO proposto em $1974\left(0,05 \mathrm{mg} / \mathrm{m}^{3}\right)$. Como essa concentração não pode ser medida com acurácia nesse momento, por razões relacionadas aos procedimentos de amostragem e análise, o NIOSH mantém ainda o limite de 1974. 
A ACGIH, em 2000, em virtude da sílica cristalina na forma de quartzo ser considerada cancerígena, diminuiu o LEO de $1,0 \mathrm{mg} / \mathrm{m}^{3}$ para $0,05 \mathrm{mg} / \mathrm{m}^{3}$. Em 2004, colocou em nota a intenção de alterar o valor de TLV-TWA ${ }^{\circledR}$, Threshold Limit Values-TimeWeighted Average, para a sílica cristalina na forma de quartzo e cristobalita reduzindoo para $0,025 \mathrm{mg} / \mathrm{m}^{3}$ (ACGIH 2000, 2005; ABHO 2005).

O LEO brasileiro para poeira respirável contendo sílica cristalina, na forma de quartzo, foi definido em legislação como limite de tolerância. Ele está vigente desde 1978, e encontra-se na Norma Regulamentadora No 15 (NR 15), anexo12 (BRASIL 1978). Este LEO foi baseado na recomendação da ACGIH de 1974, e corrigido para a jornada de trabalho 48 horas semanais. Na Tabela 3.1 encontra-se a expressão para o cálculo deste limite. Na legislação brasileira, NR 9 encontra-se a definição de nível de ação, metade do valor do LEO. (BRASIL 1994)

A OSHA adotou a expressão de Pemissible Exposure Limit (PEL) para seus limites, e regulamentou-os desde a década 70 nos Estados Unidos. Os PELs para as várias formas de sílica cristalina são calculados conforme as expressões apresentadas na Tabela 3.1 (OSHA 2004). 
Tabela 3.1 - Valores recomendados e limites de exposição ocupacional de instituições dos Estados Unidos da América e do Ministério do Trabalho do Brasil para o ano de 2005

\begin{tabular}{|c|c|c|c|}
\hline Instituição & Nomenclatura & Substância & $\begin{array}{l}\text { Valor Recomendado ou LEO } \\
\qquad\left(\mathrm{mg} / \mathrm{m}^{3}\right)\end{array}$ \\
\hline $\mathrm{NIOSH}$ & $\begin{array}{l}\text { REL-TWA (recommended exposure limit- } \\
\text { time-weighted average) } \\
\text { Jornada } 10 \text { horas diárias ou } 40 \text { horas semanais }\end{array}$ & $\begin{array}{l}\text { Sílica cristalina na forma de Quartzo, } \\
\text { Tridimita ou Cristobalita como poeira } \\
\text { na fração respirável. }\end{array}$ & $\mathrm{REL}=0,05$ \\
\hline OSHA & $\begin{array}{l}\text { PEL-TWA (permissible exposure limit-time- } \\
\text { weighted average) } \\
\text { Jornada } 8 \text { horas diárias ou } 40 \text { horas semanais }\end{array}$ & $\begin{array}{l}\text { Sílica cristalina respirável na forma de } \\
\text { Quartzo }\end{array}$ & $P E L=\frac{10}{\% \mathrm{SiO}_{2}+2}$ \\
\hline & & $\begin{array}{l}\text { Sílica cristalina respirável na forma de } \\
\text { Tridimita ou Cristobalita }\end{array}$ & $\begin{array}{c}\mathrm{PEL}=\text { Metade do valor calculado } \\
\text { para quartzo }\end{array}$ \\
\hline ACGIH & $\begin{array}{l}\text { TLV - TWA (threshold limit value - time- } \\
\text { weighted average) } \\
\text { Jornada } 8 \text { horas diárias ou } 40 \text { horas semanais }\end{array}$ & $\begin{array}{l}\text { Sílica cristalina respirável na forma de } \\
\text { Quartzo, Tridimita ou Cristobalita }\end{array}$ & $\mathrm{TLV}=0,05$ \\
\hline
\end{tabular}




\subsection{Toxicidade, Penetração, Deposição e Eliminação de Partículas no Pulmão}

\subsubsection{Toxicidade}

A dose, isto é, a quantidade fisiologicamente ativa do agente tóxico que permanece em contato com o tecido ou órgão afetado durante um intervalo de tempo definido (CHECKOWAY 1989). Em se tratando de partículas inaladas, elas exercem seus efeitos tóxicos em contato com os tecidos do pulmão, e a toxicidade depende de muitos fatores inerentes às partículas, como as propriedades físicas e químicas, as condições de exposição e o estado de saúde do trabalhador (IARC 1997; JOHNSON e SWIF 1998; ALGRANTI et ${ }^{\circ}$ al. $\left.{ }^{\circ} 2003\right)$.

Entre as características importantes das partículas estão: a composição química, o diâmetro da partícula, a área de superfície da partícula, forma, densidade, solubilidade em água e em lipídeos, a reatividade química, seu caráter higroscópico e as propriedades eletrostáticas.

Quanto às condições de exposição, os fatores importantes são a concentração ambiental de poeira respirável, a duração da exposição, a temperatura, a velocidade do ar e o atividade física do trabalhador.

Quanto às características individuais do trabalhador exposto, fatores importantes são gênero, área corporal, idade, estado geral de saúde, doenças pré-adquiridas, hábito de fumar e grau de atividade física despendida na realização do trabalho.

\subsubsection{Penetração}

Para haver penetração de partículas na região pulmonar é necessário que o seu diâmetro aerodinâmico seja inferior a $10 \mu \mathrm{m}$, faixa de diâmetros denominada fração respirável. 
A composição da poeira respirável depende do material que a gerou, e pode possuir os mesmos constituintes, no entanto em proporções diferentes. Por exemplo, em operações de lixamento de granito, pode-se encontrar entre 15 e $30 \%$ de quartzo na fração respirável, enquanto na rocha original o quartzo estava presente numa proporção entre 30 e $40 \%$ (ALGRANTI et al. 2003).

Para o mesmo tipo de operação o tamanho da partícula na fração respirável da poeira também pode variar com a natureza do material que o gerou. Ou seja, existe a possibilidade de no fracionamento de diferentes minerais ocorrer geração de proporções diferentes das diversas faixas de diâmetros de partícula. Por exemplo, o carvão antracitoso gera uma proporção maior de partículas de menor diâmetro que o carvão betuminoso. Isto leva a uma diferença em área de superfície de contato entre as partículas e a região alveolar, afetando a reação tecidual correspondente (ALGRANTI et al. 2003).

\subsubsection{Deposição}

As partículas maiores que $10 \mu \mathrm{m}$ de diâmetro ficam retidas na região nasal e na região torácica, enquanto as menores se depositam em qualquer nível. Os principais mecanismos de deposição das partículas no trato respiratório são os mesmos que atuam na captura de partículas pelas fibras constituintes dos filtros para particulados: a deposição inercial, a sedimentação, a difusão, a interceptação direta (ALGRANTI et al.2003; TORLONI e VIEIRA 2003).

A influência do tamanho das partículas na deposição é representada pelas curvas de deposição de partículas para as três regiões do pulmão, conforme Figura 3.2. Os valores são calculados para freqüência respiratória de 15 ciclos/minuto e volume de ar de 1,45 litro. A deposição pode variar em função das condições fisiológicas respiratórias do momento e, portanto, as curvas são apenas um retrato de uma determinada situação fisiológica (ALGRANTI et al. 2003). 


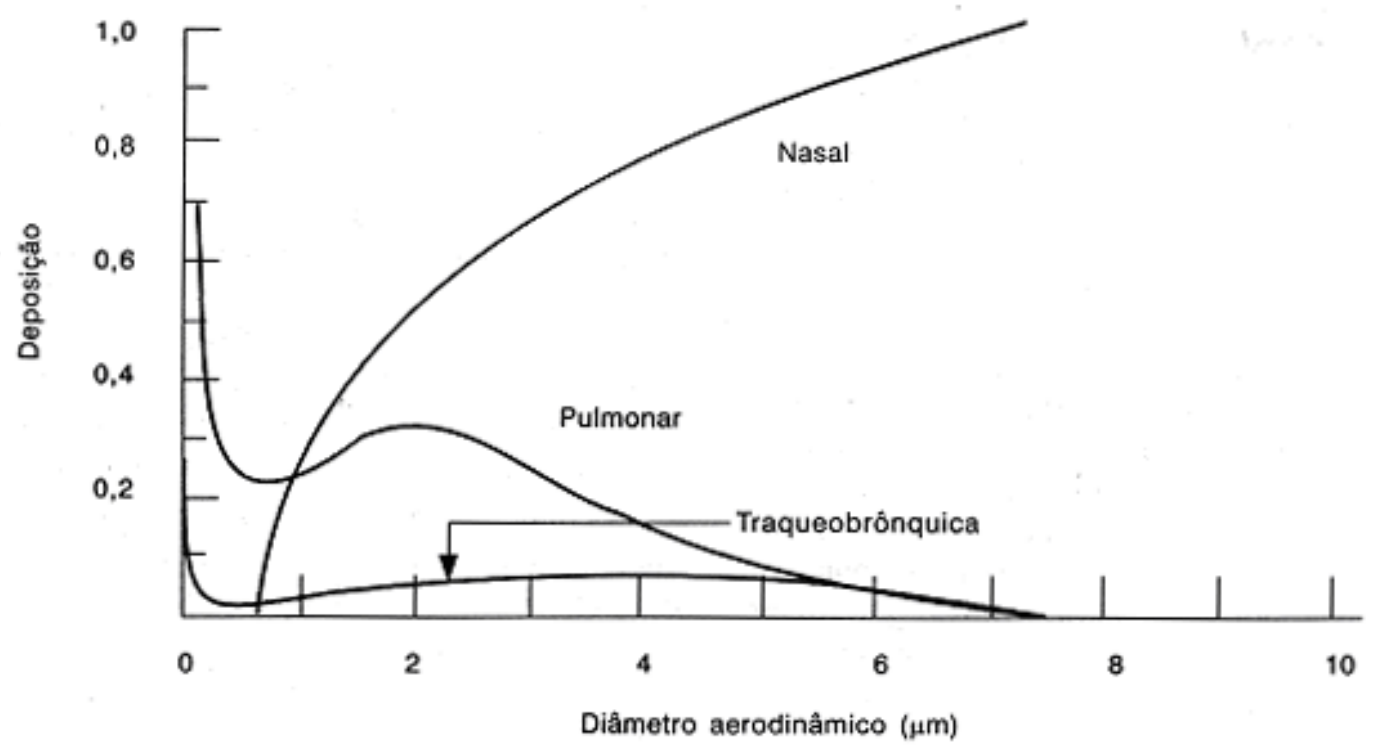

Figura 3.2 - Deposição de partículas no trato respiratório para três regiões distintas

Fonte: extraído de Task Group Lung Dynamics 1966

\subsubsection{Eliminação}

A eliminação das partículas do pulmão e da região alveolar ocorre em grande parte em função de dois mecanismos de defesa: o do sistema mucociliar e o dos macrófagos alveolares. Estes sistemas atuam de forma independente e complementar, pois possuem locais de atuação distintos.

O sistema mucociliar atua principalmente nas vias áreas superiores, onde a mucosa é revestida por um filme líquido (fluido brônquico), que representa a primeira barreira a se interpor entre os agentes tóxicos inalados e o tecido das vias aéreas. Este fluido possui um efeito citoprotetor, pois, além de sua capacidade de agir como tamponante é um antioxidande e bactericida.

O muco é responsável pela adesão das partículas depositadas nas vias aéreas. O batimento ciliar por sua vez é responsável pelo transporte do muco e, por conseqüência, das partículas nele aderidas, em direção à orofaringe, onde o material exógeno é eliminado pela tosse ou deglutido. 
As partículas pequenas que penetram e se depositam além dos bronquíolos terminais, na região de troca de gases, são eliminadas por três mecanismos principais, em que o macrófago alveolar desempenha um papel de extrema importância: 1) fagocitose por macrófagos e posterior processamento; 2) mobilização no interior dos macrófagos até o bronquíolo terminal, onde alcançam o transporte mucocilar; 3) a passagem transepitelial e drenagem linfática (ALGRANTI et al. 2003).

Quando a dose ou a toxicidade das partículas encontra-se acima da capacidade funcional do sistema, pode ocorrer dano ao território alveolar. Em situações nas quais o fator preponderante é a dose, isto é, a concentração de partículas e o tempo, os danos poderão ser doenças como o enfisema pulmonar, a fibrose e a compressão das vias aéreas e dos vasos pulmonares. Nas situações em que as partículas são tóxicas aos macrófagos alveolares, os danos podem ser doenças como a silicose.

\subsection{Doenças Associadas com a Exposição Ocupacional à Sílica Cristalina}

A exposição ocupacional à sílica cristalina encontra-se relacionada ao risco de desenvolvimento de doenças como: silicose e proteinose alveolar; limitação crônica do fluxo aéreo; tuberculose; doenças auto-imunes e câncer de pulmão (ATS1997; ALGRANTI at.al. 2004).

\subsubsection{Silicose}

A silicose é uma doença pulmonar incurável causada pela inalação, retenção e reação pulmonar às partículas contendo sílica cristalina respirável. É caracterizada pela fibrose do tecido pulmonar. Uma vez iniciada, a doença é irreversível e geralmente progressiva.

O principal fator de risco de desenvolvimento de silicose é a concentração de sílica cristalina respirável do material particulado suspenso em ambientes de trabalho. Outros fatores importantes são: tamanho da partícula; origem da sílica; duração da exposição 
do trabalhador; tempo entre a primeira exposição e o diagnóstico e suscetibilidade individual (HNIZDO et al 1993a; STEENLAND 1995; KREISS K E ZHEN B 1996; NIOSH 2002).

A silicose é um tipo específico de pneumoconiose, classicamente descrita por três formas clínicas distintas: crônica, acelerada e aguda, com diferentes expressões radiológicas e histopatológicas (SILICOSIS and SILICATE DISEASE COMMITTEE 1988; ALGRANTI et al. 2003):

\section{a) Silicose crônica}

ALGRANTI et al., 2003, descreveram a silicose crônica como de forma nodular simples e de ocorrência após longo tempo do início da exposição (10 a 20 anos), a níveis relativamente baixos de poeira contendo sílica. É caracterizada pela presença de pequenos nódulos difusos, menores que $1 \mathrm{~cm}$ de diâmetro, que predominam nos terços superiores dos pulmões. O exame histológico mostra presença de nódulos silicóticos peribronquiolares e perivasculares, com estruturas birrefrigentes à luz polarizada. Com a progressão da doença, os nódulos coalescem formando conglomerados maiores que eventualmente substituem parte do parênquima pulmonar por fibrose colágena. No Brasil, foram observados casos na indústria cerâmica (MORRONE 1979; BAGATIN 1988).

\section{b) Silicose subaguda}

É caracterizada por apresentar alterações radiológicas mais precoces, normalmente após cinco anos de exposição à sílica. A anatomia mostra presença de nódulos, porém com componente inflamatório intersticial intenso e descamação celular nos alvéolos. A evolução radiológica é mais rápida, com tendência à conglomeração e grandes opacidades. Os sintomas respiratórios, nessa circunstância, costumam ser precoces e limitantes. É o caso da silicose observada em cavadores de poços e mineiros de ouro de subsolo na Bahia (HOLANDA et al. 1995; ALGRANTI et al. 2003). 


\section{c) Silicose aguda}

É uma forma rara de doença, associada às exposições maciças à sílica. O tempo de exposição pode variar de alguns meses até quatro a cinco anos. Este tipo de exposição ocorre no jateamento de areia ou moagem de rochas. A expressão anatomopatológica é de uma proteinose alveolar pulmonar associada a infiltrado inflamatório intersticial. A dispnéia atinge grau de incapacidade e pode evoluir para a morte por insuficiência respiratória (FERREIRA 1999; ALGRANTI et al. 2003).

\subsubsection{Tuberculose e outras doenças associadas à silicose}

Devido à silicose ser uma doença progressiva, ela predispõe o organismo a uma série de co-morbidades, pulmonares e extrapulmonares, como a tuberculose, o enfisema, as doenças auto-imunes e o câncer (ALGRANTI et al. 2003).

A tuberculose (TB) associada à silicose é uma complicação muito séria, pois normalmente implica em rápida progressão da fibrose pulmonar. A grande suscetibilidade à tuberculose de pacientes com silicose se explica provavelmente pela baixa capacidade dos macrófagos (que contêm as partículas tóxicas de sílica) de matar a micobactérias. Outra explicação pode ser dada por alterações na drenagem linfática pulmonar (MENDES 1978). Devido à gravidade desta doença, a ATS, 1997, recomenda a investigação diagnóstica de TB em pacientes com silicose.

O enfisema pulmonar associado à silicose encontra-se descrito em vários tipos de estudos, inclusive com a técnica de tomografia de tórax, que possibilitou melhoria do diagnóstico. BÉGIN et al. 1995, que estudaram 207 casos de trabalhadores expostos à poeiras minerais, encontraram 111 casos de enfisema entre os expostos à sílica. Nos expostos à sílica e não-silicóticos, o enfisema ocorreu em excesso somente entre os tabagistas (BÉGIN et al 1995). 
Doenças do colágeno, como a esclerose sistêmica progressiva, a artrite reumatóide e lupus eritematoso sistêmico, foram relacionadas à silicose. Existe um grande número de estudos e relatos de casos indicando a associação de silicose e de exposição à sílica com doenças auto-imunes, e em especial com a esclerose sistêmica progressiva (NIOSH 2002). Segundo ALGRANTI et al. 2003, possivelmente este fato está ligado à contínua estimulação imunitária em nível alveolar em pacientes suscetíveis de desenvolver doenças auto-imunes.

\subsubsection{Doenças das vias aéreas}

As doenças das vias aéreas são caracterizadas por limitação crônica do fluxo aéreo, geralmente irreversível. Entre elas incluem-se quatro doenças: o enfisema, a bronquite crônica e a asma (NIOSH 2002).

A bronquite crônica (BC) e a limitação crônica do fluxo aéreo (LCFA) são duas entidades distintas, podendo ou não estar relacionadas. A principal causa destas doenças ainda é o tabagismo, que agride tanto grandes vias aéreas, preferencialmente acometidas na $\mathrm{BC}$, como as pequenas vias aéreas, preferencialmente acometidas na LCFA. Embora, a exposição a poeiras minerais contendo sílica contribuam para o desenvolvimento dessas doenças, existem estudos com resultados discordantes sobre quanto o tabagismo e a exposição ocupacional contribuem proporcionalmente (ALGRANTI et al. 2003).

Para o desenvolvimento da LCFA, por exemplo, a contribuição da exposição ocupacional à sílica e a do tabagismo entre mineradores de ardósia foi semelhante em relação a perdas funcionais (ELMES 1981), enquanto que entre mineradores de ouro o tabagismo teve uma contribuição maior (HNIZDO 1992). 


\subsubsection{Câncer}

O câncer de pulmão é um dos efeitos da exposição ocupacional a partículas de sílica cristalina. Como apresentado anteriormente, o IARC classificou a sílica cristalina sob a forma de quartzo ou cristobalita como agente carcinogênico para o ser humano (IARC 1997).

Um esquema hipotético sobre os principais eventos que podem direcionar o desenvolvimento da silicose e do câncer, proposto por DONALDSON e BORN, 1998, como base para o mecanismo proposto anteriormente pelo IARC em 1997, é apresentado na Figura 3.3.

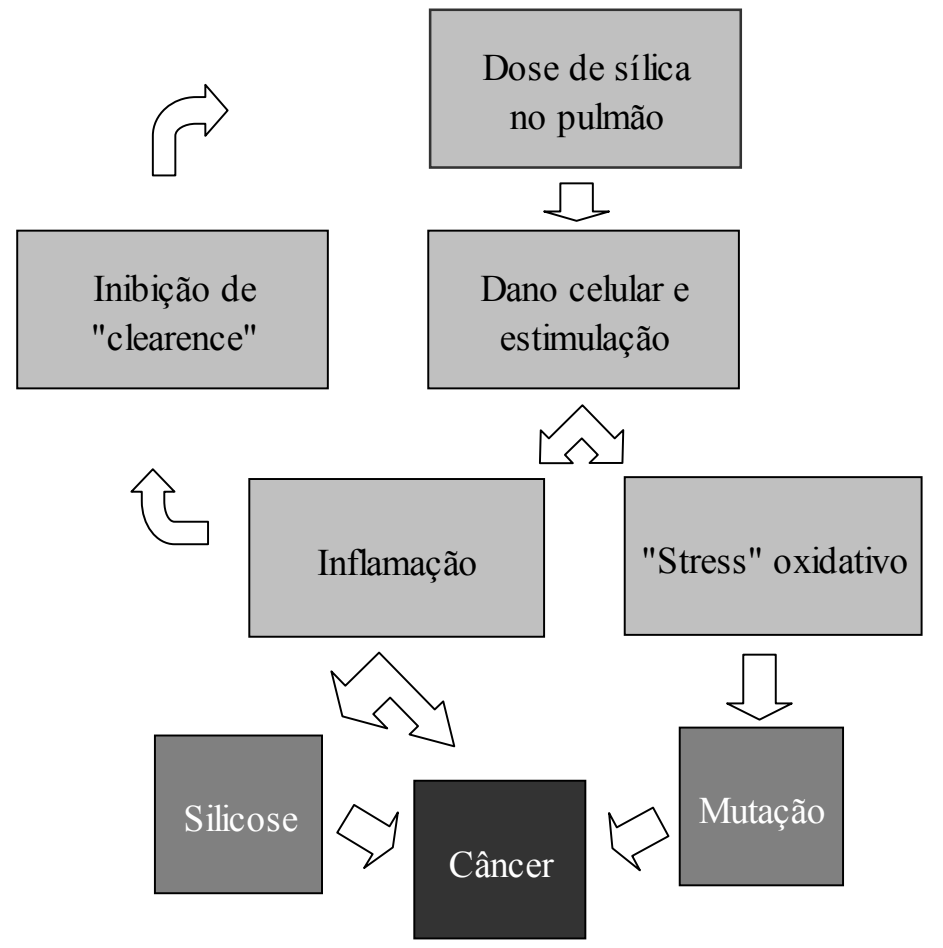

Figura 3.3- Seqüência hipotética de eventos que direcionam o desenvolvimento de silicose e câncer devido à sílica (quartzo)

Fonte: extraído de DONALDSON e BORN 1998. 
Esse mecanismo, baseado em estudos com animais e células in vitro não necessariamente pode ser extrapolado de forma direta para humanos. Considerações devem ser feitas, pois a carcinogenicidade pode depender das características inerentes da sílica cristalina, de fatores externos que afetam a sua atividade biológica ou distribuição dos seus polimorfos (IARC 1997; FUBBINI 1998b).

Segundo DONALDSON e BORN, 1998, deve-se considerar que exposição excessiva a partículas não-tóxicas também deprimem as defesas pulmonares, e células inflamatórias que carregam efeito pré-cancerígeno podem levar ao câncer por esse mesmo mecanismo.

\subsection{Epidemiologia da Silicose}

A silicose é a uma doença de origem ocupacional causada pela exposição e inalação excessiva de poeira de sílica cristalina respirável. É uma doença de distribuição global e um problema de saúde pública com altos índices de incidência e prevalência. Segundo a OIT e OMS existe um grande número de casos de silicose notificados em países desenvolvidos e em desenvolvimento em todos os continentes (ILO 1997).

Em países desenvolvidos a introdução de medidas de controle ambiental ou a substituição da sílica por produtos menos tóxicos resultaram em diminuição destes índices. No entanto, a doença não foi eliminada e novos casos ainda são notificados.

Nos Estados Unidos a silicose foi registrada como a principal causa, ou contribuiu para a morte de 4.313 trabalhadores no período de 1979 a 1990. Em quatro estados participantes de um programa de avaliação foram relatados 447 casos no período de 1978 a 1988 (ATS 1997). 
Em países emergentes, com atividades econômicas em que as condições de trabalho são precárias e não existem medidas preventivas de controle no ambiente, os índices de morbidade e mortalidade podem atingir valores altos (ILO 1997).

$\mathrm{Na}$ África do Sul, por exemplo, num estudo entre 17.000 mineiros negros que morreram de causas não-naturais enquanto eram empregados de minas de ouro, no período de 1975 a 1991, a prevalência de silicóticos na autopsia foi de 9,7\% (MURRAY 1996).

No Brasil, a silicose é uma doença conhecida desde antes da II Guerra Mundial. Existem casos diagnosticados por médicos do Departamento Nacional da Produção Mineral nas minas de ouro de Morro Velho em Minas Gerais, que atuavam antes de 1930 (LESSA 1949).

A primeira estimava do número de trabalhadores com silicose no Brasil foi realizada por MENDES, em 1978. Em estudo de busca de casos de silicose em portadores de tuberculose (principal causa de complicações em silicóticos) em sanatórios da região Sudeste, o autor estimou entre 25.000 e 30.000 o número de portadores de silicose no país.

Embora estudos epidemiológicos sobre silicose no Brasil sejam raros, existem dados em relação a grupos ocupacionais, que incluem cálculos de número de casos, prevalência pontual e estimava de casos de silicose no país (ALGRANTI et al. 2004). Entre estes, alguns se encontram apresentados na Tabela 3.2.

Entre os trabalhos apresentados na Tabela 3.2, existem dados de exposição ocupacional no ramo de pedreiras e dos cavadores de poços. Em seu estudo FRANCO, 1978, coletou 29 amostras de poeira respirável, sendo que para 13 amostras os resultados ultrapassaram o limite de tolerância e estavam acima de $1 \mathrm{mg} / \mathrm{m}^{3}$. Nas pedreiras avaliadas por ARAUJO, 2001, para todos os postos de trabalho avaliados o limite de tolerância foi ultrapassado, com somente uma exceção. 
$\mathrm{Na}$ escavação de poços de rocha de arenito no estado do Ceará, os resultados encontrados para avaliação de poeira total ultrapassaram o limite de tolerância brasileiro em centenas de vezes, enquanto os de poeira respirável foram ultrapassados aproximadamente 30 vezes (HATEM e CAVALCANTI 1988).

Em estudo de mortalidade por pneumoconioses nas macrorregiões do Brasil realizado por CASTRO et al., 2003, ficou evidenciado o aumento do coeficiente de morte por estas doenças entre os anos 1979 e 1998. A silicose, por ser a pneumoconiose mais freqüente no Brasil, pode ser responsável pelo aumento deste coeficiente. 
Tabela 3.2 - Estudos epidemiológicos sobre silicose no Brasil em alguns ramos de atividade industrial

\begin{tabular}{|c|c|c|c|c|c|}
\hline Atividade Industrial & Tipo de estudo & $\begin{array}{c}\text { Número de } \\
\text { Trabalhadores } \\
\text { envolvidos }\end{array}$ & Índices* & Referência Bibliográfica & $\begin{array}{c}\text { Tipo de } \\
\text { publicação }\end{array}$ \\
\hline Indústria urbana & Descritivo & $?$ & $278(\mathrm{c})$ & MINERVINO et al. 1964 & Anais \\
\hline Pedreiras & Transversal & 200 & $3,5 \%(p)$ & FRANCO 1978 & Trabalho \\
\hline Geral & Prevalência & & $30.000(\mathrm{e})$ & MENDES 1978 & Tese \\
\hline Cerâmicas & Transversal & 4.000 & $3,9 \%(p)$ & OLIVEIRA 1988 & Resumo \\
\hline Borracheiros & Transversal & 85 & $13,7 \%(\mathrm{p})$ & SOUZA FILHO 1992 & Resumo \\
\hline Cavadores de poços & Transversal & 687 & $21,3 \%(\mathrm{p})$ & HOLANDA et al. 1995 & Trabalho \\
\hline $\begin{array}{l}\text { Geral (principalmente } \\
\text { cerâmicas) }\end{array}$ & Descritivo & $(-)$ & $818(\mathrm{c})$ & BAGATIN et al. 1995 & Trabalho \\
\hline Indústria naval & Transversal & 728 & $23,6 \%(p)$ & CASTRO e BETHLEM 1995 & Trabalho \\
\hline Pedreiras & Transversal & 447 & $16,5 \%(\mathrm{p})$ & ARAÚJO 2001 & Relatório \\
\hline $\begin{array}{l}\text { Geral (principalmente } \\
\text { mineração) }\end{array}$ & Descritivo & 300 & $126(c)$ & CARNEIRO et al. 2002 & Trabalho \\
\hline
\end{tabular}




\subsubsection{Risco de silicose}

Risco é a probabilidade de ocorrência de um evento (dano ou exposição) geralmente indesejado. A gravidade do risco (efeito) pode ser determinada pela probabilidade de ocorrência do evento indesejado e as conseqüências geradas pelo evento indesejado. $\mathrm{O}$ risco ocupacional é a possibilidade de uma pessoa sofrer determinado dano para a sua saúde em virtude das condições de trabalho. Para qualificar um risco de acordo com a gravidade, avaliam-se conjuntamente a probabilidade de ocorrência do dano e a severidade do mesmo (FUNDACENTRO 2001).

Existem vários métodos desenvolvidos para avaliar a exposição e estimar risco a saúde. Os métodos qualitativos como, por exemplo, os utilizados pela a AIHA, 1998, ou pela BSI 1996 BS-8800, utilizam escalas de gradação de risco estabelecidas com base em critérios técnicos reconhecidos, são simples e de rápida aplicação. Os métodos quantitativos como, por exemplo, AIHA 1998; LEIDEL-NIOSH 1977; EPA 1992; CHECKOWAY 1989, embora sejam mais complexos e necessitem de mais recursos que os métodos qualitativos, são os mais reconhecidos pela comunidade científica para avaliar a exposição e estimar o risco.

Os estudos epidemiológicos, que buscam estabelecer as relações de exposição-resposta para a sílica cristalina e a silicose, utilizam dados de exposição acumulada. Estes estudos podem estimar o risco de silicose, para uma poeira em especial, por um período. Existem estudos epidemiológicos que utilizam, por exemplo, a duração da exposição como parâmetro no lugar da exposição acumulada (NIOSH 2002).

Segundo MANNETJE et al., 2002, os estudos quantitativos com análises de exposiçãoresposta são os que provêem forte evidência para a causalidade e podem fornecer bases para o estabelecimento de padrões. 
Existem na literatura exemplos de estudos para estimar o risco de silicose com base em exposição acumulada. Podem ser citados como exemplos os estudos epidemiológicos realizados por HNIZDO E SLUIS-CREMER 1993 e por KREISS E ZHEN 1996.

Em seu estudo de coorte em minas de ouro da África do Sul, HNIZDO E SLUISCREMER 1993, encontraram um risco acumulado de silicose de 25\% para os trabalhadores com exposição acumulada de $9 \mathrm{mg} / \mathrm{m}^{3}$-anos de poeira respirável, aproximadamente $2,7 \mathrm{mg} / \mathrm{m}^{3}$ de sílica cristalina respirável (assumindo conteúdo de quartzo de 30\%), com uma média de 28 anos de trabalho na mina e uma média de concentração de poeira respirável de $0,33 \mathrm{mg} / \mathrm{m}^{3}$. A partir deste valor de exposição acumulada o risco acumulado cresceu rapidamente até atingir $77 \%$ a $15 \mathrm{mg} / \mathrm{m}^{3}$-anos de poeira respirável, 4,5 mg/m³-anos de poeira de sílica respirável, e fornecendo um período de latência de 35 anos.

KREISS E ZHEN, 1996, investigaram as relações exposição-resposta de poeira respirável contendo sílica e silicose. O estudo foi realizado em Leadville, no estado de Colorado, EUA. Participaram do estudo 134 indivíduos que haviam trabalhado em vários tipos de minas, molibdênio, chumbo, zinco e ouro. A taxa de prevalência de silicose foi de 32\% entre homens com tempo médio de 36,1 anos desde a primeira exposição à sílica cristalina. Dos mineiros com exposição acumulada de $2 \mathrm{mg} / \mathrm{m}^{3}$-anos ou menos, $20 \%$ dos trabalhadores tinham silicose, enquanto os mineiros com exposição acumulada de sílica cristalina de $2 \mathrm{mg} / \mathrm{m}^{3}$-anos ou mais a prevalência era de $63 \%$. O estudo revelou uma forte associação entre a exposição ocupacional à sílica cristalina e as taxas de prevalência de silicose, $13 \%$ dos silicóticos estavam expostos à concentração média de sílica cristalina entre 0,025 e $0,05^{\circ} \mathrm{mg} / \mathrm{m}^{3}, 34 \%$ entre aqueles com exposição com valores superiores a 0,05 até $0,1^{\circ} \mathrm{mg} / \mathrm{m}^{3}$ e $75 \%$ entre aqueles com exposição com valores superiores a $0,1^{\circ} \mathrm{mg} / \mathrm{m}^{3}$. 
RICE E STAYNER, 1995, revisaram estudos epidemiológicos com os seguintes objetivos: 1) identificar resultados de concentração de quartzo que não são associados ao aumento de silicose, isto é, o maior nível para nenhum efeito adverso observado, NOAEL; 2) identificar a menor concentração associada com silicose, isto é o menor nível com efeito adverso observado, LOAEL; 3) identificar estudos com modelos estatísticos atuais das relações quantitativas entre exposição à sílica e risco de silicose. Os autores encontraram 6 estudos, que possuíam informações sobre concentração e efeitos leves. Estimaram os valores de NOAEL e LOAEL para estes estudos e encontram para o NOAEL uma faixa de 7 a $100 \mu \mathrm{g} / \mathrm{m}^{3}$ e para o $L O A E L$ uma faixa de 8 a $252 \mu \mathrm{g} / \mathrm{m}^{3}$.

Segundo os autores as razões para estas faixas tão grandes são: 1) as propriedades de superfície e tamanho das partículas de diferentes minas; 2) a definição e as classificações radiológicas dos casos de silicose; 3) os métodos utilizados para estimar a exposição e os riscos; 4) as concentrações de fundo (background) de sílica cristalina no ar; 5) o tamanho das amostras; 6) os métodos utilizados para converter as unidades de concentração, que eram em contagem de número de partículas, para unidades de massa.

Para comparar os estudos com modelos estatísticos de sílica acumulada e risco de silicose, os autores utilizaram o REL da NIOSH, isto é, a exposição dos trabalhadores correspondente à média ponderada de $0,05 \mathrm{mg} / \mathrm{m}^{3}$ para 45 anos de trabalho. Os estudos comparados foram o de HNIZDO E SLUIS-CREMER 1993, realizado na população de trabalhadores das minas de ouro da África do Sul os estudos de MUIR et al., 1989a, 1989b, 1991 e de VERMA, 1989, nas minas de ouro e urânio do Canadá. Para o estudo da África do Sul a exposição acumulada encontrada foi igual a 2,25 mg/m $\mathrm{m}^{3}$-anos e um risco acumulado de 0,127, e para o estudo do Canadá a exposição acumulada era de $2,0 \mathrm{mg} / \mathrm{m}^{3}$-anos e um risco acumulado na faixa de 0,0009 a 0,0062 . As razões para esta discrepância são semelhantes às apresentadas anteriormente. 
MANNETJE et al., 2002, realizaram estudo de associação com 10 coortes de trabalhadores para diferentes ramos de atividade econômica e várias funções, que possuíam resultados quantitativos de exposição à sílica cristalina. $\mathrm{O}$ estudo evidenciou um aumento regular do risco de mortalidade por silicose com o aumento da exposição acumulada de sílica cristalina, embora existissem diferenças entre as faixas de exposição acumulada dos diversos estudos. Para a mediana, calculada com base na média de concentração de exposição de sílica cristalina respirável dos 10 estudos, encontraram uma faixa entre 0,04 e $0,59 \mathrm{mg} / \mathrm{m}^{3}$. Para mediana da exposição acumulada, encontraram uma faixa de 0,13 a $11,37 \mathrm{mg} / \mathrm{m}^{3}$-anos.

\subsubsection{Estudos epidemiológicos e de exposição à sílica cristalina relacionados com rochas ornamentais e para revestimento}

As atividades de mineração e beneficiamento de rochas ornamentais são executadas pelo homem desde o início da civilização, sendo o período da pedra considerado o marco inicial das atividades tecnológicas. Estas atividades são realizadas em vários países do mundo e envolvem grande número de trabalhadores com risco de desenvolvimento de silicose e câncer.

Segundo COSTELLO e GRAHAM, 1988, quando as ferramentas pneumáticas foram introduzidas no processo de mineração de granito, no século IX, ocorreu um aumento dos níveis de poeira com aumento enorme das taxas de morbidade e mortalidade e em especial em relação à silicose e tuberculose.

RUSSEL et al. em 1929, apud COSTELLO e GRAHAM,1988, realizaram o primeiro estudo de mortalidade entre trabalhadores da indústria de granito. O estudo de RUSSEL, realizado na mineração de granito de Vermont nos Estados Unidos da América, forneceu um grande número de informações sobre os efeitos à saúde devidos à exposição à poeira de granito. As recomendações deste estudo forneceram a base para o estabelecimento do primeiro padrão de exposição à poeira de 10 mpppc (milhões de partículas por pé cúbico), e para a implantação de medidas de controle em 1940, como sistema de ventilação. 
DAVIS et al., 1983 realizaram estudo proporcional de mortalidade entre os trabalhadores da indústria de granito de Vermont entre 1952 e 1978. Neste período haviam falecido 969 trabalhadores. As taxas de mortalidade foram analisadas em relação: a data da contratação, antes e depois da introdução das medidas de controle; ao nível de exposição e à função. Foram observadas tendências de aumento de silicose e tuberculose com o aumento do tempo de exposição. Utilizaram os resultados de concentração de sílica para estimar a exposição acumulada e estudar as relações exposição-resposta. Converteram os resultados de concentração expressos em mpppc para poeira total e poeira respirável $\mathrm{mg} / \mathrm{m}^{3}$, usando a seguinte expressão: 10 $\mathrm{mpppc}=0,075 \mathrm{mg} / \mathrm{m}^{3}$ de sílica cristalina respirável. Antes de 1938, a concentrações médias se encontravam em 48,8 mpppc para os cortadores. Após o programa de controle, as concentrações médias se encontravam em 8,8 mpppc. Convertidas estas concentrações para o sistema decimal, equivalem às concentrações de sílica cristalina de $0,37 \mathrm{mg} / \mathrm{m}^{3}$ e $0,07 \mathrm{mg} / \mathrm{m}^{3}$, respectivamente.

COSTELLO e GRAHAM ,1988, realizaram um estudo de coorte envolvendo 5414 trabalhadores que exerciam atividades de mineração e beneficiamento (cortador, polidor) de granito em Vermont, entre 1950 e 1982. Dentre estes, 1643 trabalhadores já haviam falecido neste período e as causas de mortes de 1527 para os quais haviam registros foram analisadas.

Foram observadas 41 mortes por silicose com taxa de mortalidade padronizada, Standardized Mortality Ratio (SMR), de 635,6 que foi estatisticamente significante a um nível de 1\%, com intervalo de confiança (IC) de 95\% de 456,1 a 862,2. Ocorreu excesso de mortalidade para o câncer de pulmão e do aparelho respiratório entre os mineiros expostos a altas concentrações de poeira antes de 1940. Dentre as 41 mortes, 38 eram dos galpões de beneficiamento e 3 eram das pedreiras. Para câncer de pulmão, os dados estratificados para os mineiros com data de contratação anterior a 1930, apresentam 47 observações com SMR de 143,5 (estatisticamente significante a um nível de 5\%). 
Os resultados apontam para um decréscimo da mortalidade, para todos os tipos de doença (câncer de pulmão, tuberculose, doenças do aparelho respiratório e silicose) no período pós-controle. A introdução das medidas de controle foi fundamental para a diminuição dos riscos relativos das doenças, em especial para a silicose. Embora na história dos casos de câncer tenha aparecido o fator fumo em $100 \%$ dos casos observados, não foi excluída a possibilidade da poeira de granito em altas concentrações ser um cofator.

COSTELLO et al., 1995, realizaram um estudo de coorte no ramo de beneficiamento de rochas calcárias, granito, rochas ígneas, arenito, mármore no período de 1940 a 1980, nos Estados Unidos da América. Foi estudada a mortalidade de 3246 homens que haviam trabalhado neste período em 20 empresas do setor, que incluíam operações de trituramento, seleção e limpeza de rochas. As empresas foram selecionadas de forma aleatória e pela localização geográfica das atividades no ano de 1978. Os resultados de avaliação da exposição obtidos por KULLMAN et al., 1995, para o ano de 1978 foram utilizados por COSTELLO et al., 1995, e indicavam que $45 \%$ das amostras de granito ultrapassavam o valor recomendado pelo NIOSH de $0,05 \mathrm{mg} / \mathrm{m}^{3}$. Para as poeiras respiráveis de granito, por exemplo, a média geométrica era de $0,06 \mathrm{mg} / \mathrm{m}^{3}$ e conteúdo de quartzo de $37 \%$. Os resultados deste estudo de coorte que abramgeu um período maior que o estudo de COSTELLO et al.1988, indicam um aumento significativo na taxa de mortalidade atribuída as pneumoconioses e outras doenças não malignas, com SMR de 1,98 e IC de 1,21 a 3,05. Na subcoorte de trabalhadores com granito a taxa para estas mesmas doenças apresentou um SMR de 7,26 e IC de 1,97 a 18,59.

Para o câncer de pulmão os dados com tempo na função, raça, e tipo de rocha com pelo menos 20 anos de latência apresentaram um SMR elevado e estatisticamente significante para o granito com SMR de 3,35 e IC de 1,34 a 6,90.

GUÉNEL et al., 1989 realizaram um estudo de coorte entre os trabalhadores dos setores que compõem a Indústria de Rocha da Dinamarca, indústria de lapidação que produz monumentos de granitos e arenitos e indústria de matérias para construção civil e 
rodovias que utiliza granito e sílex (flint) triturado e classificado. Dos 2175 trabalhadores do setor, 2071 fizeram parte da coorte no período de 1943 a 1984.

Os resultados de exposição à poeira de sílica cristalina respirável para o período de 1948 a 1980 demonstraram que os mais altos níveis de exposição foram encontrados na construção de rodovias na década de 70 , com média de exposição para poeira de sílica respirável (na forma de quartzo) de $0,16 \mathrm{mg} / \mathrm{m}^{3}$, com faixa de 0,02 a $12,7 \mathrm{mg} / \mathrm{m}^{3}$. Na indústria de corte de pedras a média foi de $0,05 \mathrm{mg} / \mathrm{m}^{3}$ com faixa de $0,02-0,57 \mathrm{mg} / \mathrm{m}^{3}$.

As taxas de incidência padronizadas, Standardized Incidence Ratio (SRI) para o câncer de pulmão foram ajustadas para o fator fumo, dependendo da região e as análises separadas para trabalhadores habilitados e não-habilitados. O número total de observações para morte de câncer de pulmão entre os trabalhadores habilitados (com inicio na profissão com 15 anos de idade e trabalharam a vida toda na empresa) da Dinamarca foi de 44 com SRI de 2,00 e IC de 1,49 a 2,69 (estatisticamente significante, na borda do teste). O tempo de latência desde a primeira exposição foi maior do que 20 anos para todas as subcoortes.

As taxas de mortalidade por câncer de pulmão tornaram-se mais significativas à medida que os dados foram estratificados. Por exemplo, para os lapidários habilitados da região de Copenhagem e para o tipo de rocha, o número total de observações foi de $18 \mathrm{com}$ SRI de 3,06 e IC de 1,81 a 4,82. Para o granito, foram 11 observações com SRI de 4,04 e IC de 2,02 a 7,23 e para o arenito foram 7 observações com SRI de 8,08 e IC de 3,23 a 16,57. Eram poucos os dados de exposição para os lapidários ou canteiros na década de 1970 . A média de exposição foi de $0,06 \mathrm{mg} / \mathrm{m}^{3}$ para o quartzo respirável.

Foi encontrado um excesso de risco de câncer de pulmão e de silicose para os lapidários habilitados de Copenhagem, para os trabalhadores não-habilitados da indústria de materiais de construção de estrada e de materiais para construção civil em Bornholm e para lapidários de toda a Dinamarca, especialmente no período anterior a 1950 quando não existiam medidas de controle. 
Na Finlândia, KOSKELA et al., 1994, realizaram estudos epidemiológicos de morbidade e mortalidade numa população de 1026 trabalhadores entre 1940 e 1989. Os trabalhadores exerciam atividades na mineração e beneficiamento de granitos (vermelho, cinza e preto) em três diferentes regiões da Finlândia e haviam sido contratados entre 1940 e 1971. O objetivo principal destes estudos foi avaliar a possibilidade de associação direta entre a exposição à poeira de sílica cristalina e o câncer de pulmão.

Outro objetivo deste trabalho desenvolvido por KOSKELA et al., 1994, foi conhecer a citotoxicidade para diferentes frações dos três granitos e sua capacidade de induzir a de geração de espécimes reativas de oxigênio (ROS) em leucócitos, por meio de testes com células "in vitro".

Os resultados de exposição existentes foram utilizados para os cálculos de exposição acumulada de poeira de quartzo Lifelong (cumulative) quartz dust exposure. As exposições acumuladas foram utilizadas na coorte e nos estudos aninhados da coorte (caso-controle e caso-a-caso). Os resultados das medições de exposição para o períodod de 1970 e 1972 foram obtidos com a indústria de granito. A concentração de poeira total, média geométrica, encontrava-se entre 1,7 e $39,8 \mathrm{mg} / \mathrm{m}^{3}$, e de poeira de sílica cristalina (na forma de quartzo) na faixa de 1,0 a $1,5 \mathrm{mg} / \mathrm{m}^{3}$ para a operação de perfuração.

Para a coorte de mortalidade por câncer, no período de 1940 e 1985, foram observadas 31 mortes por câncer de pulmão com SMR de 156 e IC de 106-221. Com seguimento da coorte até 1989 o número de observações foi de 36 mortes com SMR de 140 e IC de 98-103. O excesso de mortalidade por câncer, deveu-se principalmente ao aumento da mortalidade dos trabalhadores com granito vermelho e cinza.

KOSKELA et al., 1994, observaram excesso de mortalidade por câncer de pulmão repetidas vezes na coorte de trabalhadores do ramo de granito que estavam expostos a sílica cristalina. A média de exposição à poeira de granito foi de 12 anos (para uma faixa de 0-49 anos). O risco de câncer de pulmão aumentou com o aumento do período 
de exposição e dos anos de latência. A co-ocorrência de câncer de pulmão e silicose foi rara. Entre os 37 casos de morte por silicose registrados e que fizeram parte da coorte somente 8 tinham câncer.

Quanto às outras doenças pulmonares como pneumonia, bronquite e asma, por exemplo, as prevalências foram semelhantes nas três regiões. Para tuberculose pulmonar, pleurite, enfisema e silicose as prevalências foram significativamente mais baixas na subcoorte de granito preto em relação às subcoortes de granito vermelho e cinza.

Outros estudos de exposição à sílica cristalina relacionados com mineração e beneficiamento de rochas, também apresentaram altos níveis de exposição principalmente em operações de perfuração, trituração, corte nas minas e pedreiras e corte e acabamento de placas de rochas. Em Hong Kong, nas operações de moagem, a média de quartzo respirável em 1982 para furação de rocha foi de $0,93 \mathrm{mg} / \mathrm{m}^{3}$, para moagem entre 0,10 e $0,42 \mathrm{mg} / \mathrm{m}^{3}$ e para peneiramento entre 0,11 e $1,19 \mathrm{mg} / \mathrm{m}^{3}$ (IARC 1997).

No Brasil, PIVETTA, 1996, realizou estudo em marmorarias de Cuiabá e VárzeaGrande no estado de Mato Grosso, para estimar a prevalência de sintomas respiratórios nos trabalhadores. Nas 12 marmorarias, 84 trabalhadores desempenhavam funções expondo-se à poeira direta ou indiretamente, com média de idade de $26,2( \pm 7)$ anos, com baixo tempo de exposição às poeiras de rochas ornamentais. Pôde-se verificar uma prevalência aumentada de sintomas compatíveis com bronquite crônica. Neste trabalho não foram obtidos dados sobre avaliação de sílica cristalina respirável.

SILVA et al., 1998, em estudo de exposição ocupacional a poeiras minerais de rochas ornamentais nas pedreiras de Pirenópolis encontraram uma faixa entre 0,30 e $21,67 \mathrm{mg} / \mathrm{m}^{3}$ para poeira respirável, e 0,02 a $4,64 \mathrm{mg} / \mathrm{m}^{3}$ para sílica cristalina respirável com $88 \%$ dos resultados acima do limite da legislação brasileira. A percentagem média de sílica cristalina na fração respirável foi igual 76\%. Mais de $90 \%$ dos trabalhadores clinicamente avaliados apresentaram alterações radiológicas compatíveis com silicose. 
MOREIRA et al., 2004, realizam estudo denominado Projeto Especial Marmorarias na cidade de Belo Horizonte. Este projeto foi iniciado em 2000, com a parceria de várias instituições, Centro Regional de Minas Gerais da FUNDACENTRO, Sindicato das Indústrias de Mármore e Granito do Estado de Minas Gerais, Confederação Nacional dos Trabalhadores do Setor Mineral e outras. Na caracterização da exposição ocupacional a poeiras minerais foi utilizada metodologia qualitativa de gradação de risco com base na norma BS 8800 e no método AIHA. A estimativa de risco foi considerada Intolerável para a exposição ocupacional à poeira de granito para os acabadores. Dos 1027 trabalhadores, 39 foram atendidos no SUS-BH. Foram realizadas 19 radiografias de tórax e confirmado 1 caso de silicose.

\subsection{Minerais e Rochas}

Minerais são elementos ou compostos químicos com composição definida dentro de certos limites, cristalizados e formados naturalmente por meio de processos geológicos inorgânicos, na Terra ou em corpos extraterrestres. A composição química e as propriedades cristalográficas bem definidas do mineral fazem com que ele seja único dentro do reino mineral e, assim, receba um nome característico (MADUREIRA et al. 2000).

A sílica $\left(\mathrm{SiO}_{2}\right)$ está presente na maioria dos minerais, seja sob a forma livre (grupo do quartzo, sílica amorfa), seja associada a outros elementos e grupos químicos, metálicos e não-metálicos, como no caso dos minerais denominados feldspatos, feldspatóides, micas, cloritas, olivinas, piroxênios, anfibólios, epidotos, etc., todos eles também constituintes comuns de grande parte das rochas extraídas e beneficiadas para uso ornamental ou como revestimento.

De fato, os minerais silicáticos constituem 97\% do volume da crosta continental. A Tabela 3.3 apresenta a abundância relativa dos principais grupos minerais. 
Tabela 3.3 - Abundância relativa dos principais grupos minerais na crosta continental

\begin{tabular}{ccc}
\hline Classe Mineral & Espécie ou Grupo Mineral & \% Volume \\
\hline Silicatos & feldspatos & 58 \\
& piroxênios e anfibólios & 13 \\
& quartzo & 11 \\
& epidotos, granadas e outros & 10 \\
& & 3 \\
Carbonatos, óxidos, sulfetos, etc. & 2 \\
\hline Total & 3 \\
\hline
\end{tabular}

Fonte:MADUREIRA et al. 2000.

Rochas correspondem a associações de minerais que, por diferentes motivos geológicos, acabam ficando intimamente unidos. Embora coesas e, muitas vezes, duras, as rochas não são homogêneas. Elas não têm a continuidade física de um mineral e, portanto, podem ser subdivididas em todos os seus minerais constituintes (MADUREIRA et al. 2000). Rochas podem conter fases amorfas, como vidro vulcânico, por exemplo, e materiais orgânicos, como carvão.

De acordo com a origem, as rochas podem ser classificadas em três grandes grupos: rochas magmáticas ou ígneas, rochas sedimentares e rochas metamórficas.

\subsubsection{Rochas ígneas}

As rochas ígneas ou magmáticas são aquelas que resultam da solidificação de material rochoso parcial a totalmente fundido (denominado magma), gerado no interior da crosta terreste. Por isso se diz que este tipo de rocha tem origem primária. Delas se derivam, por vários processos, as rochas sedimentares e as metamórficas. Essas duas últimas 
categorias, por sua vez, através de processos ativos no interior da Terra, podem dar origem a novos mágmas: é o chamado Ciclo das Rochas.

Cerca de $95 \%$ do volume da crosta continental, ou seja, das áreas emersas, correspondem a rochas cristalinas, ígneas ou metamórficas, e os restantes $5 \%$ a rochas sedimentares. Por outro lado, $75 \%$ da superfície dos continentes são constituídos por rochas sedimentares, contra $25 \%$ constituídos por rochas ígneas ou metamórficas (LEINZ 1973). Ou seja, as rochas sedimentares constituem uma cobertura relativamente fina amplamente disposta sobre terrenos ígneos e metamórficos, que compõem o chamado embasamento cristalino continental, possuidor de algumas dezenas de km de espessura.

As rochas ígenas podem ser classificadas em função do local de sua formação: as plutônicas ou intrusivas são formadas em profundidade, no interior da crosta terreste, pelos lentos processos de resfriamento e solificação do magma, resultando em material cristalino, geralmente de granulação grossa e de formas definidas; as vulcânicas ou extrusivas, são formadas na superfície terreste, ou nas suas proximidades, pelo extravasamento, explosivo ou não, de lava por orifícios vulcânicos, do que resultam materiais vítreos ou cristalinos de granulação fina (FRASCÁ 2004).

Tradicionalmente rochas ígneas são consideradas ácidas quando possuem teores de $\mathrm{SiO}_{2}$ maiores que 66\%. Neste caso, a quantidade de $\mathrm{SiO}_{2}$ é tal que forma os silicatos e ainda sobra, sendo esta sobra cristalizada na forma de quartzo. É o caso dos granitos, por exemplo. São consideradas neutras quando o teor em $\mathrm{SiO}_{2}$ varia entre 65 e $52 \%$ (pouco ou nenhum quartzo), caso dos sienitos e outras rochas, e básicas quando o $\mathrm{SiO}_{2}$ ocorre na proporção de 52 a 45\% (com ausência de quartzo), a exemplo dos gabros e dioritos. Nessa classificação, os termos, ácido, neutro e básico, de uso clássico em petrografia, são incorretos do ponto de vista da Química. 
Em terrenos continentais granitos são relativamente comuns. São rochas que se consolidaram a partir de um magma resultante da diferenciação magmática em profundidade e, portanto têm granulação de média a grossa. Podem conter quartzo numa faixa entre 5 e $30 \%$.

Segundo a mineralogia, os granitos também podem ser classificados a partir do conteúdo de feldspato alcalino (em geral microclínio ou ortoclásio), de feldspato sódico (ou plagioclásio) e quartzo - granitos, monzogranitos, sienogranitos, etc. Podem conter biotita, acompanhada ou não de anfibólios ou muscovita. Como minerais acessórios, podem ser encontrados a zirconita, turmalina, fluorita, apatita, rutilo ou hematita.

Ocorrem em diversas cores, com predomínio para tons de rosa, vermelho ou cinza. Além disso, há os representantes amarronzados, esverdeados, amarelados ou brancos. Tais variações decorrem da cor e do teor relativo da assembléia mineral principal (especialmente dos feldspatos), e da cor e teor dos minerais, dentre os quais tendem a predominar tons mais escuros.

\subsubsection{Rochas sedimentares}

As rochas sedimentares (arenitos, argilitos e calcários, por exemplo) são formadas a partir do material originado da destruição erosiva de qualquer tipo de rocha préexistente, material esse que deverá ser transportado e posteriormente depositado ou precipitado em um dos muitos ambientes de sedimentação do globo terrestre (FRASCÁ 2004). A precipitação pode ser química ou biogênica (ex.: calcários).

Arenitos são constituídos predominantemente por quartzo.

Os argilitos podem conter mais do que $30 \%$ de quartzo.

Os calcários são compostos principalmente por carbonatos, mas podem conter quantidades substanciais de polimorfos de sílica. 


\subsubsection{Rochas metamórficas}

A rochas metamórficas são formadas a partir das rochas ígneas ou sedimentares que sofreram processos geológicos de transformação em diferentes condições de temperatura, pressão, presença de voláteis, etc. As principais rochas metamórficas são mármore, quartzito, ardósia, filito, xisto, gnaisse e migmatito.

A composição mineralógica das rochas metamórficas tende a refletir os materiais a partir dos quais se derivaram. Quartzitos, por exemplo, são produtos de recristalização de rochas sedimentares como arenitos e siltitos, predominando como constituinte mineral o quartzo.

Os mármores são compostos essencialmente por calcita ou dolomita, e derivam de metaformismo regional ou de contato (com rochas ígneas) sobre calcários e dolomitos.

Ardósias decorrem do metaformismo de argilitos e folhelhos. São rochas de granulação fina com clivagem característica, denominada clivagem ardosiana, resultante da orientação de minerais planares durante o evento de metamorfismo e deformação.

\subsubsection{Rochas Ornamentais e para Revestimento}

Rochas ornamentais e para revestimento são aquelas capazes de ser extraídas de pedreiras sob a forma de blocos ou placas, recortadas em formas diversas e beneficiadas através de esquadrejamento, polimento ou lustro, para emprego como revestimento ou estrutura de edificações - pisos, fachadas, paredes, soleiras e colunas, e peças decorativas ou funcionais - tampos e pés de mesa, balcões, pias, divisórias, esculturas, arte funerária, entre outras (modificado de CHIODI FILHO 1995).

O revestimento é a aplicação mais comum comum das rochas ornamentais (65\%), seguido pelo uso em arte funerária (15\%) e uso estrutural (10\%). Os demais 15\% correpondem a diversas outra formas de uso (MONTANI 2003). 
Em termos comerciais, as rochas ornamentais são classificadas de modo impreciso sob o ponto de vista geológico.

Nesse sentido, há duas principais categorias de rochas ornamentais: os granitos e os mármores. No entanto, granitos correspondem a toda rocha silicática, ígnea ou metamórfica, não possuidora de estrutura lamelar acentuada, ou seja, xistosa. Mármores, por sua vez, equivalem a toda rocha carbonática, metamórfica ou sedimentar.

Completam as principais categorias comerciais as ardósias, quartzitos e arenitos, tipos silicáticos mais próximos de sua definição geológica.

Em território brasileiro, por sua vez, estão expostas amplas áreas do embasamento cristalino, em parte cobertas por não menos extensas faixas sedimentares, Figura 3.4.

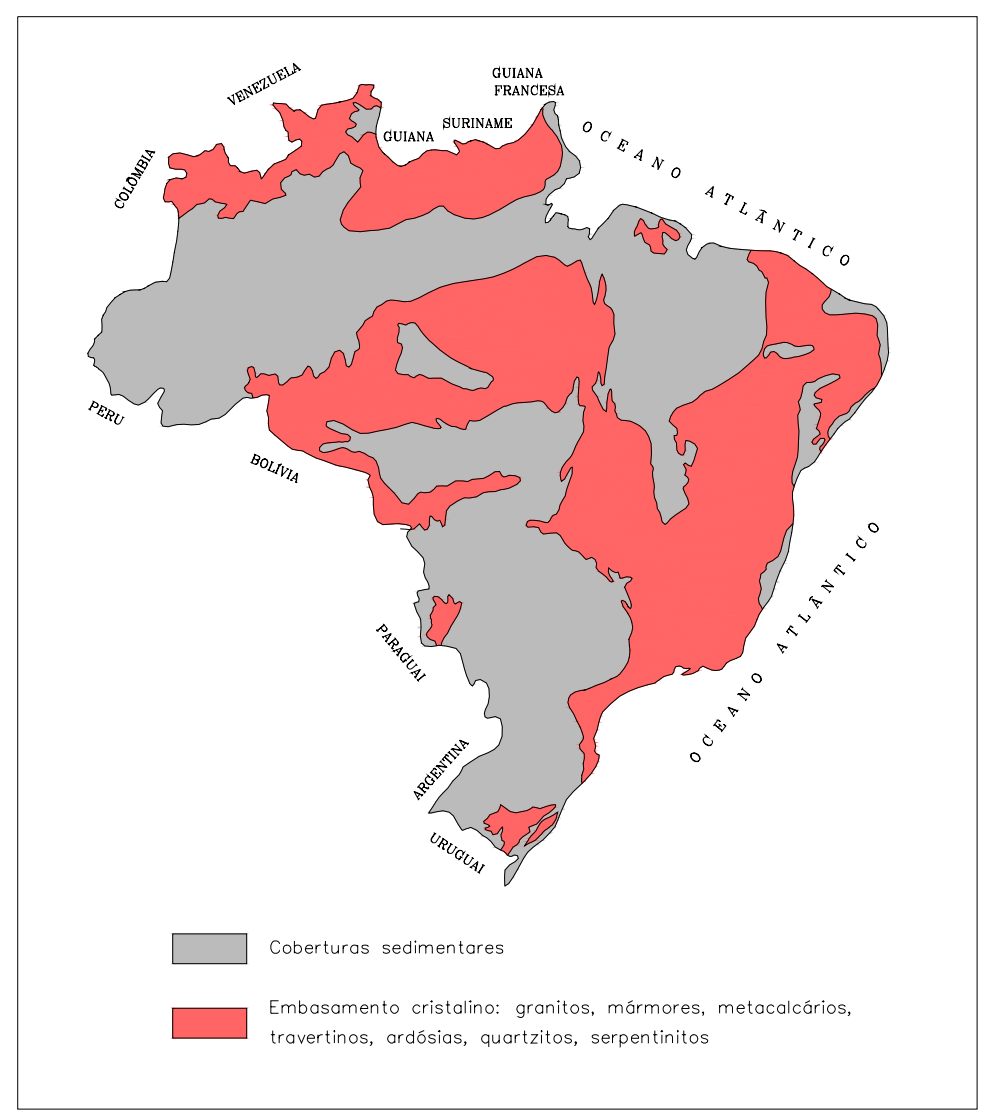

Figura 3.4 - Distribuição do embasamento cristalino no território brasileiro Fonte: (modificado de MELLO 2005) 
A grande maioria das rochas ornamentais e para revestimento extraídas no Brasil são provenientes das áreas do embasamento cristalino. Os centros de produção concentramse nas regiões sudeste e nordeste, havendo a participação também das regiões centrooeste e sul e, mais discretamente, da região amazônica (Rondônia e Pará). Em razão das características do embasamento, cerca de $60 \%$ das rochas produzidas são granitos, no sentido comercial do termo, Figura 3.5. Próximo a $80 \%$ da produção correspondem a rochas silicáticas.

No Brasil, segundo catálogo do CETEM, 2002, existem mais de 500 variedades comerciais de rochas, entre granitos, mármores, ardósias, quartzitos, travertinos, pedrasabão, basaltos, serpentinitos, conglomerados, pedra talco e materiais do tipo Miracema, pedra Cariri e pedra Morisca.

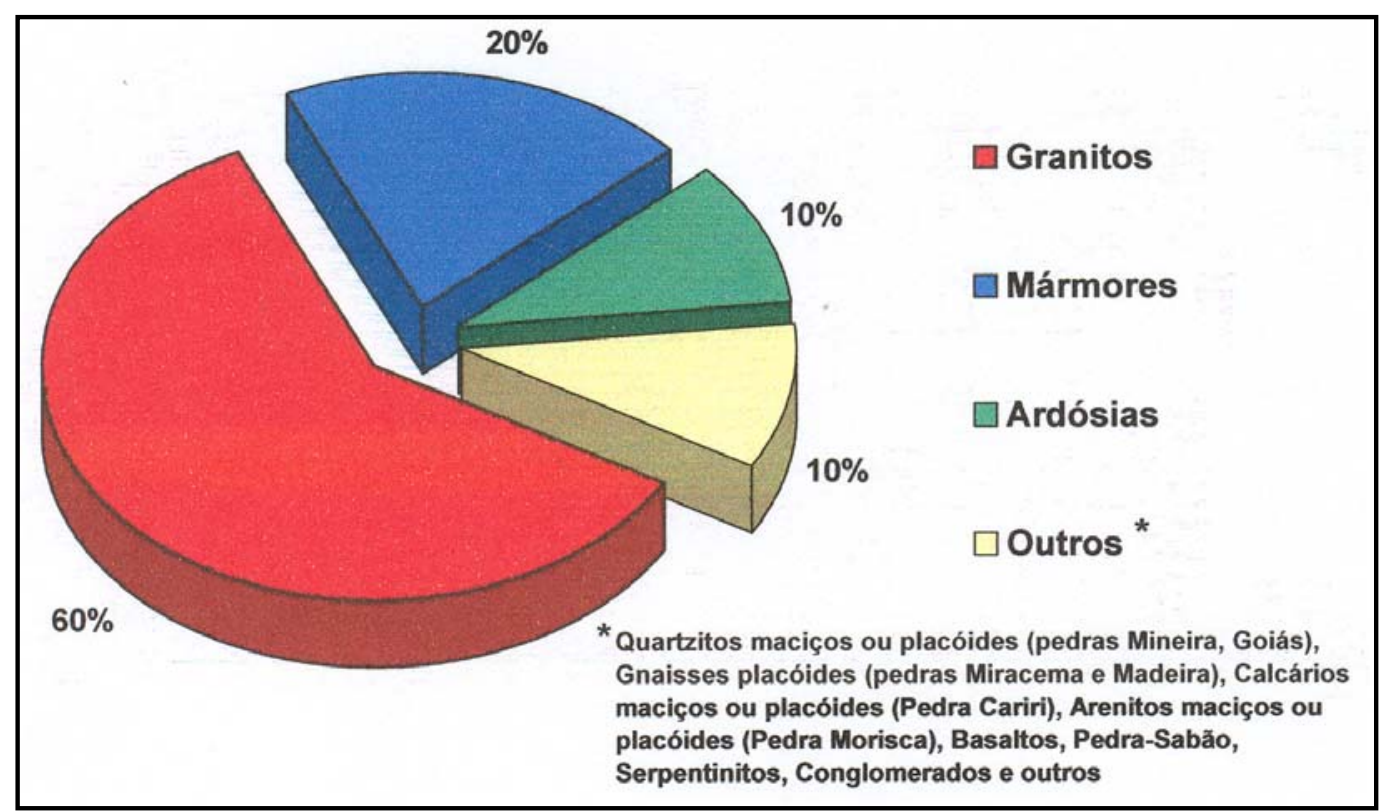

Figura 3.5 - Participação das várias categorias comerciais na mineração de rochas ornamentais e para revestimento no Brasil

Fonte: extraído de MELLO 2004. 
No catálogo citado acima, são apresentados 239 tipos comerciais de rochas ornamentais, sendo 2 arenitos, 1 calcário, 11 conglomerados, 3 gnaisses, 206 granitos, 1 metassiltito, 10 mármores e 5 quartzitos. Encontram-se informações sobre nome fantasia, localização de produção no território nacional, variedades, caracterização petrográfica, caracterização tecnológica, produtores e produtos.

A mineração e o beneficiamento de rochas ornamentais são atividades em expansão no Brasil, tanto para atender o mercado interno como o externo. Em estudo recente, MELLO, 2004, apresenta dados sobre o crescimento da produção de aproximadamente 2,0 em 1996 para 3,7 milhões de toneladas em 2002. O consumo interno cresceu de 1,4 para 2,5 milhões de toneladas no mesmo período.

No cenário produtivo brasileiro o Espírito Santo é o principal ator, responsável por mais de $40 \%$ da mineração brasileira de rochas ornamentais - pelo menos a metade da extração nacional de granitos e dois terços da extração de mármores, dois terços da serragem de blocos e metade das exportações brasileiras (MELLO 2004).

Segundo MELLO 2004, o Estado de São Paulo, respondia por uma produção mineira discreta neste mesmo período. No entanto, possui uma variedade de granitos com grande potencial para mineração e produção de rochas ornamentais em maior escala.

Em um estudo de caracterização tecnológica de rochas ornamentais e de revestimento, realizado pelo IPT e SCTDE, 2000, e descrito por FRASCÁ e QUITETE, 2000, pôdese cadastrar 37 ocorrências de granitos e um representante da classe dos mármores brancos. Estes se acham distribuídos por toda área relativa ao embasamento cristalino do território paulista. Como boa parte dessas ocorrências não eram exploradas, confirma-se o potencial para o aumento da produção do estado. 


\subsection{Beneficiamento de Rochas Ornamentais e para Revestimento em Marmorarias}

Os elos centrais da cadeia produtiva de rochas ornamentais e para revestimento são três: a extração, levada a cabo por mineradoras; a serragem de blocos, ou beneficiamento primário realizado nas chamadas serrarias; e o beneficiamento final, com a preparação de produtos acabados, objetivo das marmorarias.

A atividade de beneficiamento final realizada, pois, pelas marmorarias, encontra-se disseminada em praticamente todos os estados do Brasil, acentuando-se junto aos grandes centros de consumo de produtos acabados. Quanto a isso, destaca-se o Estado de São Paulo, onde estão aproximadamente 40\% das marmorarias brasileiras, cuja presença é condicionada por demanda que possivelmente corresponde à metade de todo o consumo nacional de produtos pétreos acabados (MELLO 2004).

As marmorarias são classificadas segundo o Código Nacional de Atividade Econômica (CNAE), 2005, com o código 2691-3/03. A descrição completa da classificação é apresentada na Tabela 3.4.

Tabela 3.4 - Classificação do CNAE para Marmorarias

\begin{tabular}{lll}
\hline Hierarquia & & \\
\hline Seção: & $\mathrm{D}$ & Indústrias de transformação \\
Divisão: & 26 & Fabricação de produtos de minerais não-metálicos \\
Grupo: & 269 & $\begin{array}{l}\text { Aparelhamento de pedras e fabricação de cal e de } \\
\text { outros produtos não-metálicos }\end{array}$ \\
& & Britamento, aparelhamento e outros trabalhos em \\
Classe & $2691-3$ & pedras (não associados a extração)
\end{tabular}

Subclasse

CNAE-Fiscal 2691-3/03 Produtos de marmoraria, Fabricação de

Fonte: CNAE, 2005. 
$\mathrm{Na}$ marmoraria os processos industriais mais comuns envolvem o corte, polimento e o acabamento (lustro) de produtos de rochas ornamentais como granitos, quartzitos, mármores, ardósia, arenitos, entre outras.

Estes processos envolvem a utilização de máquinas, ferramentas e matérias-primas que geram agentes ambientais com riscos à saúde, como a poeira contendo sílica e o ruído. Devido às características do processo, existe risco do trabalhador adquirir silicose, pois todas geram poeira que pode conter sílica cristalina (WHO 1999). Quanto a isso, destacam-se entre as matérias-primas processadas os granitos, rochas essencialmente silicáticas, que podem conter mais de $25 \%$ de quartzo na composição mineralógica AZAMBUJA, 1975; KOSKELA et al., 1994, e quartzito e arenitos, que são majoritariamente compostos por quartzo.

No Brasil, existem indicativos de que o número de trabalhadores com potencial de desenvolver silicose em atividades de mineração e beneficiamento de minerais nãometálicos é grande. Segundo dados da RAIS, 2001, (onde os estabelecimentos encontram-se classificados segundo o sub-setor de atividade econômica), existem 16.746 estabelecimentos nas atividades de mineração não-metálica e dentre esses 14.076 são estabelecimentos com até 19 empregados. No Espírito Santo, o sub-setor possui aproximadamente 650 empresas empregando 15000 trabalhadores (AGUIAR 1995).

Segundo dados do Projeto Marmoristas, no município de São Paulo, existiriam aproximadamente 450 empresas formais, no ramo marmorarias com 2500 trabalhadores. No entanto, este número de empresas não se confirmou no trabalho de vistoria, pois 150 empresas haviam fechado no período de realização deste projeto (MPESP, 2001).

O mercado trabalha com números informais bastante distintos. Desse modo, operariam no Estado de São Paulo mais de 3.000 marmorarias, mais de 1.000 delas situadas na Grande São Paulo. 
Os resultados preliminares encontrados no Projeto Marmoristas (MPESP, 2001) indicam que parte das atividades de beneficiamento final das rochas ornamentais é desenvolvida por um grande número de empresas de porte pequeno e micro com número reduzido de trabalhadores.

Estimativas semelhantes foram encontradas por MELLO, 2004, por diferente metodologia. Numa amostra de 304 empresas, 160 das quais localizadas na capital paulista e o restante em cidades do interior do Estado, 71\% empresas de micro porte, $26 \%$ de porte pequeno, e apenas $3 \%$ empresas médias. O número médio de empregados em cada uma dessas três categorias é respectivamente 5, 9 e 15 . O número total de trabalhadores empregados na produção das marmorarias é estimado na casa dos 20.000 a 30.000 .

As empresas maiores respondem por uma produção de aproximadamente 5 vezes a das empresas menores (MELLO 2004).

Segundo o Código Brasileiro de Ocupações (CBO), MTE, 2002, a classificação para os profissionais que trabalham em marmorarias é a de número 7122, Trabalhadores de beneficiamento de pedras ornamentais, cuja descrição está reproduzida no Anexo 4.

O Código Intenacional de Ocupação (CIOU 88) correpondente é o 7133-Tronzadores, labrantes y grabadores de piedra (MTE 2002). 


\section{MATERIAIS E MÉTODOS}

Os materiais e métodos utilizados para caracterizar a exposição ocupacional a poeira e a sílica cristalina respirável em marmorarias, as alternativas de controle da poeira, as matérias-primas, a população e a avaliação médica serão apresentados a seguir.

Neste item também serão descritos os materiais e métodos utilizados na obtenção da exposição acumulada à sílica cristalina e aqueles utilizados para correlacionar a exposição ocupacional com os achados clínicos e radiológicos.

\subsection{Seleção das Marmorarias}

Um estudo transversal analítico foi realizado em 27 marmorarias do Município de São Paulo com a seleção das marmorarias baseada em dois critérios. No primeiro critério foram sorteadas 22 marmorarias para desenvolvimento de estudo de exposição à poeira e à sílica cristalina e estimativa de risco de silicose entre os trabalhadores de marmorarias. No segundo, para o estudo de alternativas de controle, foram selecionadas 5 marmorarias com diferentes tipos de instalações, e etapas de acabamento seco e a úmido.

\subsubsection{Estudo de exposição ocupacional à poeira e à sílica cristalina respirável e estimativa de risco de silicose}

As informações existentes na literatura com relação ao número de marmorarias e de trabalhadores empregados nesta atividade no Município de São Paulo eram desencontradas. Assim, a FUNDACENTRO solicitou à Secretaria de Saúde do Município de São Paulo o banco de dados de marmorarias e o banco de trabalhadores 
utilizados no Projeto Marmoristas que era coordenado por esta secretaria e pelo Ministério Público do Estado de São Paulo até 2002 (MPESP 2001).

Os bancos de dados da SSMSP de 2002 continham informações de empresas legalmente constituídas e de trabalhadores que possuíam registro em Carteira de Trabalho.

As empresas foram sorteadas tendo como base o banco de dados da SSMSP, no qual em outubro de 2002 encontravam-se ao todo 312 marmorarias, com aproximadamente 2440 trabalhadores cadastrados.

Durante o processo de consulta ao banco de dados foi verificado que algumas informações não poderiam ser utilizadas, devido a problemas de duplicação ou ausência de dados. Sendo assim, o universo para o estudo era de 284 marmorarias cadastradas e em funcionamento no final do ano de 2002 nas 5 regiões de abrangência dos Centros de Referência em Saúde do Trabalhador do Município de São Paulo. As cinco regiões eram: Sé, Moóca, Lapa, Freguesia do Ó e Santo Amaro. O Anexo 2 apresenta o mapa correspondente.

Foi utilizada a classificação das marmorarias quanto ao porte, em função do número de trabalhadores conforme o banco de dados da SSMSP de 2002: marmoraria de porte micro com até 5 empregados, pequeno de 6 a 10, médio de 11 a 20 e porte grande com mais de 20 empregados.

As marmorarias não foram enquadradas segundo Estatuto da Microempresa e da Empresa de Pequeno Porte, devido à falta de informação sobre o faturamento das empresas (SEBRAE 2001).

Foram sorteadas $10 \%$ das marmorarias com pelo menos 1 empresa para cada porte em cada região e buscando manter a proporcionalidade quanto ao porte. A amostra inicial foi composta de 29 marmorarias, segundo a distribuição apresentada na Tabela 4.1. 
Tabela 4.1 - Distribuição da amostra inicial por região e porte das marmorarias para estudo de exposição ocupacional a poeira e sílica cristalina respirável

\begin{tabular}{cccccc}
\hline \multirow{2}{*}{ Região } & \multicolumn{3}{c}{ Número de marmorarias segundo porte } & \multirow{2}{*}{ Total } \\
\cline { 2 - 5 } Sé & Grande & Médio & Pequeno & Micro & \\
Moóca & 1 & 1 & 1 & 3 & 6 \\
Lapa & 1 & 1 & 2 & 4 & 8 \\
Freg. do Ó & 1 & 1 & 1 & 2 & 5 \\
S. Amaro & 0 & 1 & 1 & 3 & 6 \\
\hline Total & 4 & 1 & 1 & 2 & 4 \\
\hline
\end{tabular}

No entanto, devido a algumas dificuldades surgidas durante a execução da etapa de coleta e análise de dados, não foi possível atingir a meta de estudar 29 empresas. As dificuldades aconteceram com relação às empresas de porte micro, pois muitas haviam fechado ou mudado. Foram necessários vários sorteios, busca de novos endereços e muita negociação com as empresas. O trabalho de campo foi dificultado também pelo fato de haver número reduzido de trabalhadores em cada empresa, associado com a necessidade de afastá-los da produção no momento da coleta de amostras de ar.

Assim, foram estudadas 22 empresas, distribuídas por região da cidade de São Paulo e porte da empresa conforme apresentado na Tabela 4.2. Como se pode observar por esta nova distribuição, foram realizadas avaliações ambientais de poeira e sílica cristalina respirável, e avaliações médicas dos trabalhadores em todas as empresas de porte grande, médio e pequeno, e em metade das empresas de porte micro que constavam da amostra inicial. 
Tabela 4.2 - Distribuição da amostra estudada por região e porte das marmorarias para estudo de exposição ocupacional a poeira e sílica cristalina respirável no Município de São Paulo, 2004-2005

\begin{tabular}{cccccc}
\hline \multirow{2}{*}{ Região } & \multicolumn{2}{c}{ Número de marmorarias estudadas segundo porte } & \multirow{2}{*}{ Total } \\
\cline { 2 - 5 } Sé & Grande & Médio & Pequeno & Micro & \\
Moóca & 1 & 1 & 1 & 2 & 5 \\
Lapa & 1 & 1 & 2 & 1 & 5 \\
Freg. do Ó & 1 & 1 & 1 & 1 & 4 \\
S. Amaro & 0 & 1 & 1 & 2 & 5 \\
\hline Total & 4 & 1 & 1 & 1 & 3 \\
\hline
\end{tabular}

\subsubsection{Estudo de alternativas de controle de poeira}

Foram selecionadas 5 empresas para o estudo comparativo de alternativas de medidas de controle de poeira e sílica cristalina respirável em marmorarias com base nas informações obtidas nas visitas preliminares. A seleção incluiu diferentes tipos de instalações e equipamentos para o controle da poeira gerada em processos com etapa de acabamento a seco, tipos de ferramentas pneumáticas que trabalhavam com água, politriz ou lixadeira com água na etapa de acabamento e processos sem qualquer tipo de medida de controle.

A Tabela 4.3 apresenta a distribuição das marmorarias selecionadas para o estudo, identificadas por códigos alfa-numéricos, segundo o tipo de processo de acabamento e controle de poeira implantado. 
Tabela 4.3 - Distribuição das marmorarias selecionadas para estudo de alternativas de controle de poeira segundo o tipo de processo de acabamento e controle implantado, Município de São Paulo, 2004-2005

\begin{tabular}{|c|c|c|c|c|}
\hline \multirow{2}{*}{$\begin{array}{l}\text { Código da } \\
\text { Marmoraria }\end{array}$} & \multicolumn{2}{|c|}{$\begin{array}{c}\text { Tipo de processo } \\
\text { de acabamento }\end{array}$} & \multicolumn{2}{|l|}{ Medidas de Controle } \\
\hline & Seco & Úmido & No ambiente de trabalho & Na ferramenta \\
\hline M1 & $\operatorname{Sim}$ & Não & $\begin{array}{l}\text { Capela de fluxo laminar com filtros tipo manga. } \\
\text { Sistema de ventilação local exaustora instalado sob } \\
\text { bancada de trabalho e filtros de tecido de fibras } \\
\text { removíveis e descartáveis }\end{array}$ & Não \\
\hline M3 & Sim & Não & $\begin{array}{l}\text { Mesa de trabalho com sistema de ventilação local } \\
\text { exaustora e captação da poeira em lamina de água }\end{array}$ & Não \\
\hline
\end{tabular}




\subsection{Matérias-primas}

Foram coletadas amostras de matérias-primas em todas as etapas do processo produtivo das 27 marmorarias estudadas. As amostras foram identificadas com o nome comercial declarado pelo trabalhador, encarregado ou dono da empresa, o nome da empresa, a data e ponto da coleta.

Nesta primeira etapa de identificação, com o nome da rocha conhecido comercialmente, as matérias-primas foram classificadas em grandes subdivisões. Como rochas silicáticas foram classificados os granitos, as chamadas rochas dimensionadas e aparelhadas, materiais apenas esquadrejados, comercializados com superfície rústica e granitos sintéticos. Como rochas carbonáticas foram considerados os mármores e mármores sintéticos. Completam o conjunto, representantes de ardósias, que embora também sejam rochas silicáticas, elas foram estudadas em separado, para se coonhecer a exposição dos trabalhadores à silica cristalina vinda destas rochas em marmorarias.

Os resultados obtidos de porcentagem de sílica cristalina na poeira respirável foram utilizados para identificar as matérias-primas de maior risco à saúde, assumindo que quanto maior a porcentagem de sílica cristalina na poeira maior a probabilidade do trabalhador adquirir silicose. O critério adotado foi selecionar os resultados de porcentagem de sílica de amostras de ar coletadas quando estava em uso somente um tipo de matéria-prima, submetido ao processo de acabamento a seco nas operações de desbaste com disco diamantado e lixamento. Foram escolhidas estas operações por serem as mais poeirentas e para limitar a operação quanto a geração de tamanhos de partículas mais uniformes, porque a porcentagem de sílica pode variar em função do tamanho da partícula e da massa de poeira respirável coletada. Para a seleção foram utilizados os resultados de análises das amostras coletadas para o estudo da exposição ocupacional, das amostras coletadas em ponto fixo, associados aos dados obtidos com o estudo de alternativas de controle. 


\subsection{Avaliação Ambiental de Poeira e Sílica Cristalina Respirável}

A avaliação da exposição ocupacional foi realizada no Laboratório de Microscopia, Gravimetria e Difratometria de Raios X e no Laboratório de Instrumentação da FUNDACENTRO.

Para avaliar a exposição ocupacional, bem como estimar o risco de silicose dos trabalhadores das marmorarias com alta confiabilidade nos resultados obtidos, foram utilizados métodos de coleta padronizados e com capacidade de obter amostras representativas da exposição numa jornada de trabalho. Os métodos de análise química foram validados e conduzidos com adoção de procedimentos de controle da qualidade.

A avaliação e a expressão das incertezas das medições foram feitas de acordo com as recomendações do NIOSH, 1977, e AIHA, 1997, que são compatíveis com o Guia para a Expressão da Incerteza de Medição (ISO 2003).

Os resultados obtidos foram expressos em concentração de poeira na fração respirável e em concentração de sílica cristalina no ar, dadas em mg/m³.

\subsubsection{Coleta das amostras de ar}

A amostragem de partículas na fração respirável suspensa no ar dos ambientes de trabalho das marmorarias foi realizada utilizando os fundamentos teóricos e técnicos do manual de estratégia de amostragem para avaliação da exposição ocupacional elaborado por LEIDEL et al., 1977, e AIHA, 1998, no procedimento de coleta de material particulado sólido suspenso no ar de ambientes de trabalho da FUNDACENTRO, 2006, na norma de agentes químicos no ar - coleta de aerodispersóides por filtração da ABNT, 1991, e em procedimentos anteriormente adotados em avaliações da exposição ocupacional (BON 1998). 
A estratégia de amostragem estabelecida para as marmorarias visou atender dois objetivos principais: avaliar a exposição ocupacional a poeira respirável contendo sílica dos trabalhadores das marmorarias e verificar a eficiência das medidas de controle nas fontes de geração da poeira ou no ambiente de trabalho, quando existentes.

Foi escolhido o tipo de amostra parcial consecutiva para jornada de 8 horas, devido às altas concentrações de poeira respirável obtidas nas avaliações preliminares com amostras únicas para 8 horas. Além disto, a amostragem parcial consecutiva possibilita verificar a variabilidade da concentração ambiental no mesmo dia e a presença de possíveis picos de concentração.

Para dar representatividade às amostras, foi estabelecido fazer a coleta por um período de no mínimo $70 \%$ da jornada de trabalho de 8 horas e em 3 dias alternados de uma semana, visando à obtenção de resultados que contemplem a variabilidade entre dias.

\subsubsection{Tipo de coleta de amostras de ar}

Para atender os objetivos da estratégia de amostragem e com base nas informações obtidas durante as visitas preliminares, foi decidido utilizar dois tipos de coleta de amostras: a pessoal e a de área (ponto fixo).

A coleta do tipo pessoal (individual) foi feita para avaliar a exposição ocupacional dos trabalhadores à poeira respirável contendo sílica nas funções de acabador, cortador, polidor, ajudante geral e encarregado. O dispositivo de coleta foi colocado na vestimenta dos trabalhadores na altura da zona respiratória, definida como a região hemisférica com um raio de aproximadamente $150 \pm 50 \mathrm{~mm}$ das narinas. 
$\mathrm{Na}$ coleta do tipo área, para verificar a eficiência das medidas de controle e dispersão da poeira, o dispositivo foi colocado em um ponto fixo na altura da zona respiratória no ambiente do trabalho, simulando a presença de um trabalhador no local durante todo o período de coleta.

Para as marmorarias sem divisões físicas de ambiente para o desenvolvimento integral do processo de produção, o dispositivo de coleta foi colocado entre o setor de acabamento e o de corte com distância aproximada de 2 metros de alguma fonte geradora de poeira. $\mathrm{O}$ objetivo foi verificar se havia dispersão da poeira para os outros setores, onde as operações são realizadas a úmido.

Para as marmorarias com ambiente de trabalho fisicamente dividido os dispositivos foram colocados nos setores de acabamento e de corte.

\subsubsection{Seleção dos trabalhadores}

A seleção dos trabalhadores para a coleta das amostras de ar, utilizadas no estudo de exposição ocupacional das 22 marmorarias sorteadas, foi realizada com base no número de trabalhadores da empresa e no exercício das funções de acabador, cortador, polidor, ajudante geral e encarregado.

Para as empresas com número de trabalhadores menor que 8 , todos foram escalados para participar da amostragem. Para as empresas com 8 ou mais trabalhadores foram estabelecidos subgrupos de exposição similar por meio de amostragem aleatória, quando possível. Foi utilizada a Tabela do Anexo 3 para o estabelecimento do número de trabalhadores pertencentes ao subgrupo. O subgrupo foi formado por sorteio do nome do trabalhador contido na lista por empresa do banco de dados da SSMSP cedido para a Fundacentro.

A lista continha o nome, a função e o número de trabalhadores. Ela era verificada junto à empresa e as diferenças eram ajustadas antes da coleta das amostras. 
No entanto, na estratégia de amostragem estabelecida ficou em aberto a possibilidade de todos os trabalhadores serem envolvidos, devido à diversidade muito grande de arranjos físicos e formas de construção das marmorarias, tipos de máquinas, de ferramentas e de matérias-primas. Esta diversidade poderia se refletir no número de trabalhadores em cada função. Por exemplo, uma determinada marmoraria que possuía uma serra do tipo serra-ponte poderia fornecer trabalho para 4 acabadores, enquanto uma outra que possuía serra convencional poderia fornecer trabalho para 1 acabador.

No processo produtivo as funções de ajudante geral (Aj), polidor, (Pol), cortador (Co), acabador (Ac), encarregado (Enc) foram as que se apresentaram como geradoras de poeira e por este motivo escolhidas para caracterizar a exposição ocupacional a poeira na fração respirável e sílica cristalina.

As denominações e descrições de atividade da CBO sob o número 7122, trabalhadores de beneficiamento de pedras ornamentais, conforme Anexo 4, não foram utilizadas, pois não existia correspondência com todas as atividades realizadas nas marmorarias e neste estudo buscou-se a especificidade da função para relacionálas ao risco.

\subsubsection{Seleção dos materiais e equipamentos}

Os materiais para coleta foram escolhidos por indicação de métodos de análise de sílica cristalina reconhecidos e validados (NIOSH 2003; OSHA 1996; SANTOS 1989).

O dispositivo de coleta de poeira respirável foi composto por:

a) porta-filtro de poliestireno de três corpos, com $37 \mathrm{~mm}$ de diâmetro, do tipo $\mathrm{SKC}^{\circledR}$, conforme apresentado na Figura 4.1; 
b) filtro do tipo membrana de PVC com poro de $5 \mu \mathrm{m}$, da marca MSA ${ }^{\circledR}$, para retenção das partículas. Como este filtro é muito delicado, o método recomenda a utilização de um suporte de celulose. Todos os filtros utilizados foram pré-pesados em ambiente com temperatura e umidade controlada conforme a NHO-03 (FUNDACENTRO 2001). Na Figura 4.1 o filtro aparece como a parte mais clara;

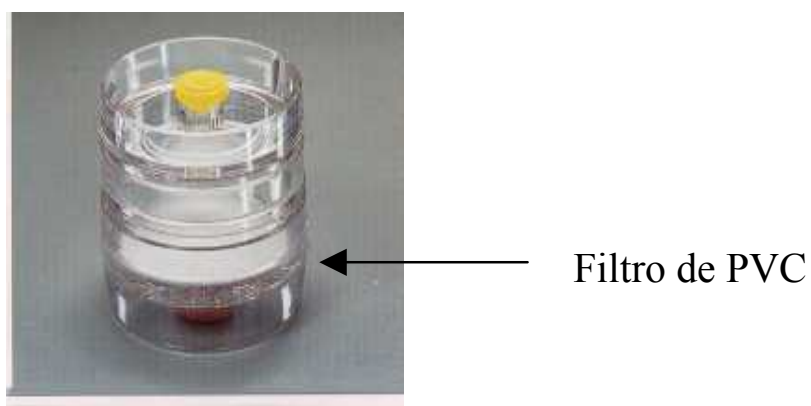

Figura 4.1 - Porta-filtro de poliestireno carregado com filtro do tipo membrana e suporte de celulose, usado para coleta de poeira

c) ciclone separador de partículas para a fração respirável, do tipo Dorr-Oliver com $10 \mathrm{~mm}$ de diâmetro, fabricado em nylon, com curva de eficiência de coleta de acordo com os métodos analíticos citados, e com a NR15 Anexo 12. Na Figura 4.2 o ciclone aparece em duas posições. Na posição a) o ciclone encontra-se desmontado e na b) acoplado ao porta-filtro de três corpos formando o dispositivo de coleta de poeira na fração respirável.

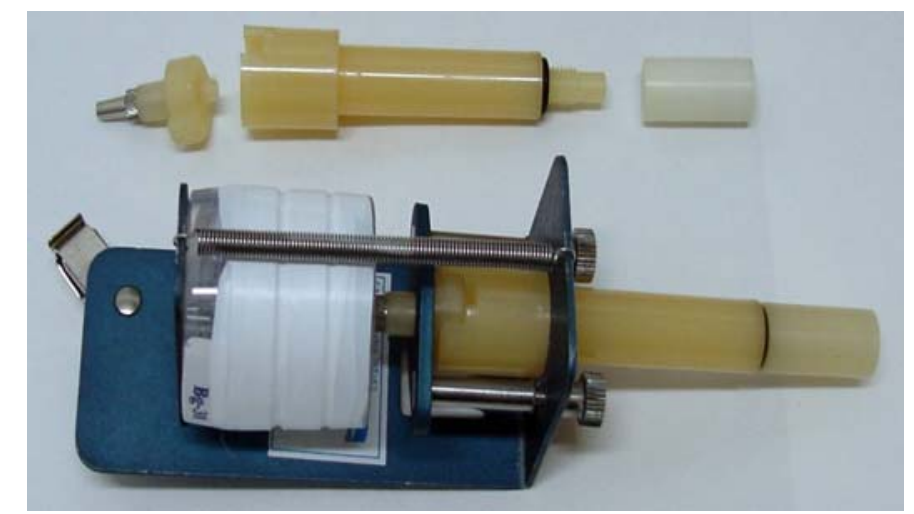

a)

b)

Figura 4.2 - a) Ciclone separador de partícula do tipo Dorr-Oliver desmontado. b) Dispositivo de coleta para a fração respirável de poeira 
O sistema de amostragem utilizado foi composto pelo dispositivo de coleta acoplado a uma bomba de amostragem de ar do tipo BUCK ${ }^{\circledR}$-modelo VSS-05. Todas as bombas utilizadas foram calibradas segundo a NHO-07, FUNDACENTRO, 2002, com fluxo de ar de 1,7 1/min e variação de $\pm 5 \%$. A Figura 4.3 apresenta o sistema de amostragem.

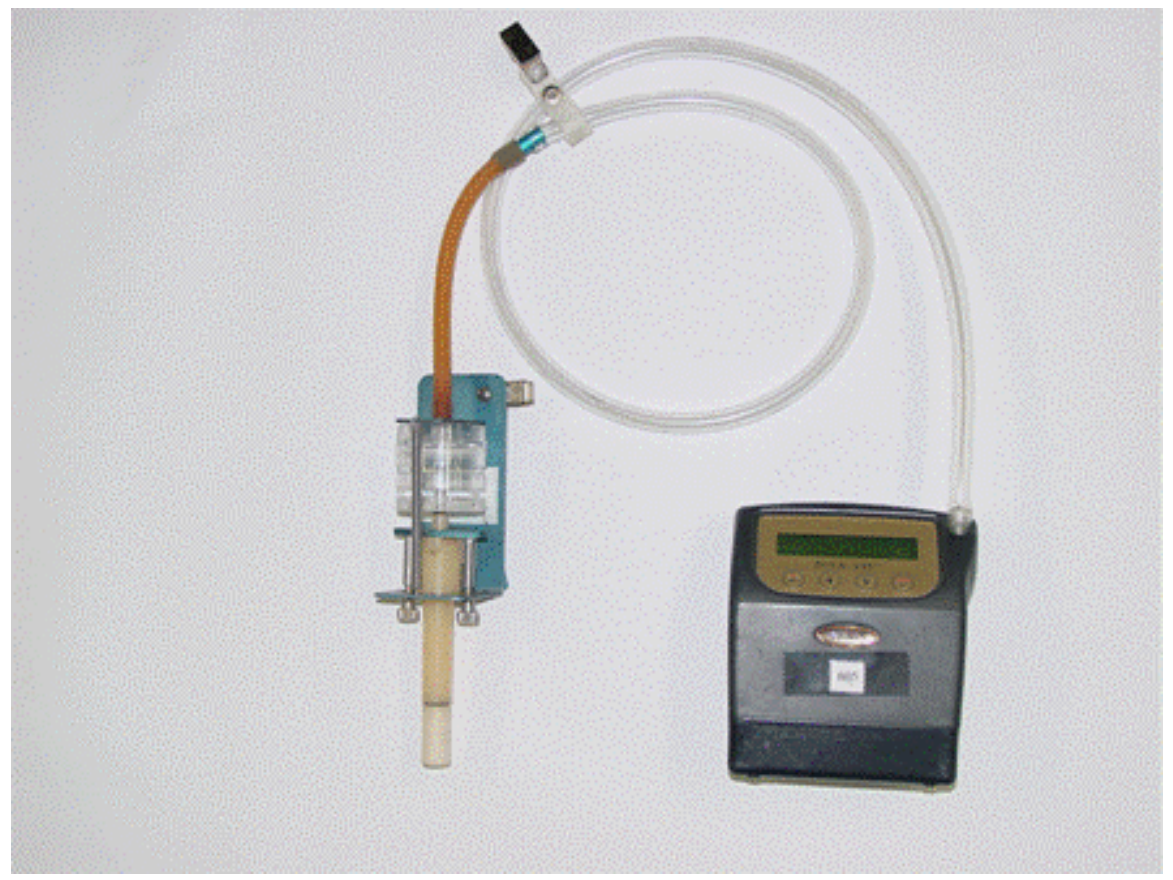

Figura 4.3 - Sistema de amostragem utilizado, mostrando o dispositivo de coleta para a fração respirável de poeira acoplado à bomba de ar

\subsubsection{Número de amostras coletadas}

Foram coletadas 762 amostras de ar de poeira respirável nas 27 marmorarias estudadas. Para o estudo de exposição ocupacional e estimativa de risco de silicose foram coletadas 577 amostras em 22 marmorarias. A Tabela 4.4 apresenta a distribuição do número de amostras coletadas e o número de jornadas diárias de trabalho correspondentes por função. 
Tabela 4.4 - Distribuição do número de amostras e jornadas de trabalho por função do estudo de exposição ocupacional à poeira nas 22 marmorarias estudadas, no Município de São Paulo 2004 -2005

\begin{tabular}{cccccc}
\hline \multirow{2}{*}{ Função } & \multirow{2}{*}{ Sigla } & \multicolumn{2}{c}{ Amostras } & \multicolumn{2}{c}{ Jornadas } \\
\cline { 3 - 6 } & & $\mathbf{n}^{\mathbf{0}}$ & $\mathbf{( \% )}$ & $\mathbf{n}^{\mathbf{0}}$ & $\mathbf{( \% )}$ \\
\hline Acabador & $\mathrm{Ac}$ & 310 & 53,7 & 258 & 49,8 \\
\hline Ajudante & $\mathrm{Aj}$ & 51 & 8,8 & 50 & 9,7 \\
\hline Cortador & $\mathrm{Co}$ & 109 & 18,9 & 109 & 21,0 \\
\hline Polidor & $\mathrm{Pol}$ & 19 & 3,3 & 19 & 3,7 \\
\hline Encarregado & $\mathrm{Enc}$ & 12 & 2,1 & 12 & 2,3 \\
\hline Área & $\mathrm{Ar}$ & 76 & 13,2 & 70 & 13,5 \\
\hline Total & & 577 & 100,0 & 518 & 100,0 \\
\hline
\end{tabular}

Para o estudo de alternativas de controle foram coletadas 185 amostras em 5 marmorarias. A Tabela 4.5 apresenta a distribuição do número de amostras coletadas e o número de jornadas diárias de trabalho correspondentes por função.

Tabela 4.5 - Distribuição do número de amostras e jornadas de trabalho por função do estudo de alternativas de controle da poeira nas 5 marmorarias estudadas, no Município de São Paulo 2004 -2005

\begin{tabular}{cccccc}
\hline \multirow{2}{*}{ Função } & \multirow{2}{*}{ Sigla } & \multicolumn{2}{c}{ Amostras } & \multicolumn{2}{c}{ Jornadas } \\
\cline { 3 - 6 } & & $\mathbf{n}^{\mathbf{0}}$ & $\mathbf{( \% )}$ & $\mathbf{n}^{\mathbf{0}}$ & $\mathbf{( \% )}$ \\
\hline Acabador & $\mathrm{Ac}$ & 92 & 49,7 & 77 & 47,2 \\
\hline Ajudante & $\mathrm{Aj}$ & 5 & 2,7 & 5 & 3,1 \\
\hline Cortador & $\mathrm{Co}$ & 33 & 17,8 & 33 & 20,2 \\
\hline Polidor & $\mathrm{Pol}$ & 4 & 2,2 & 4 & 2,5 \\
\hline Encarregado & $\mathrm{Enc}$ & 0 & 0,0 & 0 & 0,0 \\
\hline Área & $\mathrm{Ar}$ & 51 & 27,6 & 44 & 27,0 \\
\hline Total & & 185 & 100,0 & 163 & 100,0 \\
\hline
\end{tabular}


No estudo das matérias-primas para verificar a percentagem de sílica cristalina respirável foram utilizadas 519 amostras. A Tabela 4.6 apresenta a distribuição do número de amostras.

Tabela 4.6 - Distribuição do número de amostras por tipo de matéria-prima segundo a função para as 27 marmorarias estudadas, no Município de São Paulo, 2004 -2005

\begin{tabular}{ccccccc}
\hline \multirow{2}{*}{ Função } & \multicolumn{7}{c}{ Amostras } \\
\cline { 2 - 7 } & \multicolumn{2}{c}{ Ardósia } & \multicolumn{2}{c}{ Granito } & \multicolumn{2}{c}{ Mármore } \\
\cline { 2 - 7 } & $\mathbf{n}^{\mathbf{0}}$ & $\mathbf{( \% )}$ & $\mathbf{n}^{\mathbf{0}}$ & $\mathbf{( \% )}$ & $\mathbf{n}^{\mathbf{0}}$ & $\mathbf{( \% )}$ \\
\hline Acabador & 6 & 54,5 & 205 & 57,9 & 98 & 63,6 \\
\hline Ajudante & 3 & 27,3 & 23 & 6,5 & 7 & 4,5 \\
\hline Cortador & 2 & 18,2 & 55 & 15,5 & 20 & 13,0 \\
\hline Polidor & 0 & 0,0 & 7 & 2,0 & 9 & 5,8 \\
\hline Encarregado & 0 & 0,0 & 7 & 2,0 & 2 & 1,3 \\
\hline Área & 0 & 0,0 & 57 & 16,1 & 18 & 11,7 \\
\hline Total & 11 & 100,0 & 354 & 100,0 & 154 & 100,0 \\
\hline
\end{tabular}

\subsubsection{Análise das amostras}

Os métodos utilizados para análise gravimétrica de poeira respirável e para análise de sílica cristalina nas amostras coletadas foram ambos validados no Laboratório de Microscopia Gravimetria e Difratometria de Raios X da FUNDACENTRO.

\subsubsection{Análise gravimétrica de poeira respirável}

Para determinação da massa de partículas de poeira respirável encontradas nas amostras de ar coletadas em ambientes de trabalho de marmorarias foi utilizado o método de análise gravimétrica descrito na NHO-03 (FUNDACENTRO 2001).

O método tem como princípio a pesagem do filtro de membrana antes e depois da coleta, sob condições ambientais controladas. A massa da amostra foi determinada por diferença entre os valores obtidos, considerando possíveis variações da massa do filtro ocorridas entre as duas pesagens. Tais variações foram eventualmente 
detectadas por meio da utilização de controles de análise, denominados filtros testemunhos.

Foram utilizadas balanças da marca Metler ${ }^{\circledR}$ modelo H54AR com sensibilidade de 0,01 mg. As balanças foram calibradas utilizando padrões com massas rastreáveis na faixa de interesse analítico.

\subsubsection{Análise de sílica cristalina por difração de raios $X$}

Para a análise qualitativa e quantitativa de sílica cristalina contida na fração respirável da poeira foi utilizado o método "Determinação quantitativa de sílica livre cristalizada por difração de raios X”, desenvolvido por SANTOS, 1989.

O método se aplica a análise de amostras com massa entre 0,10 e 2,00 mg. A faixa de trabalho do método analítico encontra-se entre 0,01 a $0,50^{\circ} \mathrm{mg}$ para amostras de quartzo. O filtro de PVC é colocado num cadinho de porcelana e submetido a um processo de calcinação lento, para não ocorrer perda de material, até atingir $800^{\circ} \mathrm{C}$, permanecendo nesta temperatura por 2 horas. Depois disso, o material é resfriado até a temperatura ambiente. O material calcinado é disperso em água destilada e, por meio de um processo de filtração, é redepositado num filtro da marca Gelman ${ }^{\circledR}$, tipo PVC-copolímero de acrilonitrila, com $25 \mathrm{~mm}$ de diâmetro e $0,45 \mu \mathrm{m}$ de poro. $\mathrm{O}$ padrão interno, uma dispersão de fluorita $\left(\mathrm{CaF}_{2}\right)$, é adicionado durante o processo de filtração. Após secagem, o filtro é introduzido no difratômetro de raios $\mathrm{X}$, marca PHILIPS modelo 1710, para varredura e análise qualitativa. A massa de sílica cristalina correspondente é determinada por método de padronização interna, com curva de calibração composta de padrões de concentração conhecida de material de referência. O material de referência de sílica cristalina (quartzo) utilizado é o padrão do NIST ${ }^{\circledR}$ SRM $1878^{a}$, composto somente por partículas de diâmetro aerodinâmico menor que $10 \mu \mathrm{m}$, e com distribuição de tamanho de partículas de acordo com a curva de eficiência para a fração respirável. 
O método utilizado encontrava-se sob controle da qualidade dos resultados e o laboratório da Fundacentro era participante do Programa de Proficiência Analítica da AIHA, considerado proficiente durante todo o período de realização das análises.

\subsubsection{Concentração média ponderada pelo tempo}

A exposição à poeira e a sílica cristalina respirável dos trabalhadores das marmorarias e a eficiência das medidas de controle de exposição nelas existentes foram avaliadas por meio da estimativa da concentração média ponderada pelo tempo.

Para as situações nas quais foi possível coletar uma única amostra, a concentração de poeira dessa amostra é a estimativa de concentração média ponderada no tempo para a jornada diária de $8 \mathrm{hs}$.

Para esses casos, foi aplicada a expressão geral (2), obtendo-se a concentração de poeira respirável e a concentração de sílica cristalina dividindo-se suas respectivas massas pelo volume de ar amostrado corrigido para $1,0 \mathrm{~m}^{3}$ a $25^{\circ} \mathrm{C}$ e $760 \mathrm{~mm} \mathrm{Hg}$.

$$
\mathrm{C}=\frac{\mathrm{M}}{\mathrm{V}}
$$

onde:

$\mathrm{C}=$ concentração do componente na amostra, em $\mathrm{mg} / \mathrm{m}^{3}$

$\mathrm{M}=$ massa do componente na amostra, em mg.

$\mathrm{V}=$ volume de ar amostrado, $\mathrm{em}^{3}$ 
Para as situações em que a concentração de material suspenso no ar era muito alta, tornando necessário coletar mais de uma amostra, a concentração média ponderada pelo tempo foi calculada considerando os resultados de concentração em cada uma das amostras e os respectivos períodos de amostragem, conforme a equação (3):

$$
C_{M P T}=\frac{C_{1} t_{1}+C_{2} t_{2}+\ldots+C_{n} t_{n}}{t_{\text {total }}}
$$

onde:

$\mathrm{C}_{\mathrm{MPT}}=$ concentração média ponderada no tempo

$\mathrm{C}_{\mathrm{n}}=$ concentração do componente na amostra $n$

$\mathrm{t}_{\mathrm{n}}=$ tempo de coleta da amostra $n$

$\mathrm{t}_{\text {total }}=$ tempo total de coleta $=\mathrm{t}_{1}+\mathrm{t}_{2}+\ldots+\mathrm{t}_{n}$

\subsubsection{Incertezas analíticas}

As incertezas dos resultados de concentração de poeira respirável e de sílica cristalina foram calculadas com base na teoria de propagação de erros relativos indeterminados, utilizando como parâmetro de precisão o desvio padrão relativo (coeficiente de variação) conforme a expressão número 4:

$$
\overline{\mathrm{S}}_{\mathrm{r}}=\overline{\mathrm{CV}}_{\mathrm{ab}}=\sqrt{\mathrm{CV}_{\mathrm{a}}^{2}+\mathrm{CV}_{\mathrm{b}}^{2}}
$$

Onde :

$\overline{\mathrm{CV}}_{\mathrm{ab}}=$ coeficiente de variação médio de uma grandeza resultante da divisão das grandezas a e b

Para o método de análise gravimétrica o coeficiente de variação médio ficou entre 5

e $10 \%$ e para a amostragem adotou-se o valor máximo de variação da vazão da bomba que era de $5 \%$. 
Para o método de análise de sílica cristalina por Difração de Raios X o coeficiente de variação médio determinado em laboratório para o método analítico foi igual a $8 \% \mathrm{e}$ este valor foi utilizado nas estimativas de incerteza dos resultados. Para amostragem adotou-se o valor máximo de variação da vazão da bomba que era de 5\%. Os cálculos de incerteza foram realizados conforme expressão 4.

\subsection{Caracterização da Exposição Ocupacional}

Para a caracterização da exposição dos trabalhadores foram estimados os parâmetros média aritmética, desvio padrão e limites de confiança de $95 \%$ da média utilizando os valores de concentração de poeira e sílica cristalina respirável obtidos nas amostras de ar coletadas.

Para selecionar os parâmetros estatísticos a serem utilizados, foi considerado que as distribuições de dados mais importantes para caracterizar as exposições ocupacionais são a normal e a lognormal. Presume-se que a amostragem aleatória e os erros analíticos usualmente assumem uma distribuição normal. As flutuações aleatórias das exposições, jornada a jornada ou até mesmo dentro de uma mesma jornada, tendem a possuir uma distribuição lognormal (LEIDEL 1977).

A exposição ocupacional a agentes químicos com efeitos crônicos à saúde, como é o caso da sílica cristalina, é melhor caracterizada por meio da média de exposição em semanas, meses ou anos, do que pela média em uma simples jornada de 8horas. Por isso, é preciso buscar um parâmetro útil que represente a dose ou efeito acumulativo.

A média aritmética de uma distribuição lognormal é o melhor descritor da exposição média, e por esta razão é o melhor parâmetro para estimar a dose média (exposição média) e a dose acumulada (exposição acumulada). Numa distribuição de dados lognormal a média geométrica é igual ao centro da distribuição. Devido à média geométrica ser menor do que a média aritmética numa distribuição lognormal, o uso da média geométrica irá subestimar a exposição média (AIHA1998). 
Desta forma, julgou-se mais adequado estimar a média aritmética da distribuição lognormal dos dados de exposição à poeira e a sílica cristalina respirável. Existem vários métodos para estimar média aritmética de uma distribuição lognormal baseada em uma amostra estatística aleatória (AIHA 1998). Foi utilizado o procedimento simples descrito no item 4.4.1.

Foi desenvolvido banco de dados em Microsoft-ACCESS ${ }^{\circledR}$ versão 2003 para armazenar e gerenciar os resultados.

Os cálculos foram realizados utilizando-se uma planilha eletrônica MicrosoftEXCEL $^{\circledR}$, versão 2003.

\subsubsection{Estimativa da média aritmética de uma distribuição lognormal}

As estimativas de média aritmética, desvio padrão e intervalos com confiança de 95\% para cada função estudada dos trabalhadores foram obtidas utilizando-se método estatístico e a distribuição t'Student conforme apêndice VI, AIHA,1998. O procedimento se encontra no Anexo 5.

\subsubsection{Valores de referência}

Foram utilizados os valores de referência para julgar se as exposições ocupacionais a poeira e a sílica cristalina respirável poderiam ser consideradas aceitáveis ou se ofereceriam risco à saúde dos trabalhadores.

Adotou-se para poeira respirável o limite da Legislação Brasileira conforme expressão apresentada na Tabela 3.1. 
Para a sílica cristalina respirável foi adotado o limite do NIOSH de $0,05 \mathrm{mg} / \mathrm{m}^{3}$ por este limite de exposição ocupacional ser mais rigoroso que o limite da legislação brasileira e, portanto oferecer maior proteção para a saúde do trabalhador.

Nos cálculos de índice de exposição e de probabilidade dos valores obtidos ultrapassarem o limite de exposição ocupacional o valor de referência utilizado foi REL do NIOSH de $0,05 \mathrm{mg} / \mathrm{m}^{3}$ de sílica cristalina respirável da poeira conforme descritos no item 4.4.3.

\subsubsection{Porcentagem de resultados acima do Limite de Exposição Ocupacional}

Este foi um dos parâmetros utilizados para verificar a ocorrência de exposição excessiva dos trabalhadores e a eficiência das medidas de controle.

A probabilidade $\mathbf{P}$ dos resultados ultrapassarem o Limite de Exposição Ocupacional foi obtida a partir do procedimento descrito a seguir(LEIDEL 1977):

\section{Cálculo da probabilidade $\mathbf{P}$}

Quando $\mathrm{Y}<0 \Rightarrow \mathbf{P}=1$ - (valor da Tabela do Anexo 6, equivalente ao valor de $\mathrm{Z}$ ).

Quando $\mathrm{Y} \geq 0 \Rightarrow \mathbf{P}=$ (valor da Tabela do Anexo 6, equivalente ao valor de $\mathrm{Z}$ ).

Cálculo de $\mathbf{Y}$ (denominado por alguns autores índice de exposição) conforme expressão (5).

$$
\mathrm{Y}=\mathrm{C}_{\mathrm{MPT}} / \mathrm{LEO}
$$

Onde:

$\mathrm{C}_{\mathrm{MPT}}=$ Concentração média ponderada pelo tempo

LEO= Limite de Exposição Ocupacional 
Cálculo de $\mathbf{Z}$ conforme expressão (6).

$$
\mathrm{Z}=\mathrm{Y} / \mathrm{s}
$$

Onde:

$\mathrm{s}=$ desvio padrão

Segundo LEIDEL, 1977, o valor obtido para $\mathbf{P}$ é a probabilidade de o trabalhador estar exposto a valores superiores ao LEO, e quando $\mathbf{P}$ excede 0,05 (5\%) é recomendada introdução de medidas de controle para prevenir danos à saúde.

\subsubsection{Cálculo da exposição acumulada à sílica cristalina}

Para os cálculos da exposição acumulada à sílica cristalina respirável foram utilizados os dados referentes aos anos de exposição levantados no Histórico Ocupacional, descrito no item 4.5.1 a seguir.

As exposições acumuladas à sílica cristalina foram estimadas para cada função exercida, segundo relato dos trabalhadores, e feita a devida ponderação no tempo, em anos. Três modelos foram utilizados para estimar estes valores, que posteriormente foram usados nas correlações de risco de silicose.

Para funções existentes nas marmorarias, para as quais não existiam condições de realizar a coleta de amostras, como foi o caso dos colocadores estimou-se uma exposição equivalente a $10 \%$ da função de acabador. Esta porcentagem foi estipulada com base na experiência profissional da pesquisadora; na similaridade de algumas atividades realizadas por acabadores e colocadores e nos relatos dos próprios trabalhadores com função de colocador que indicavam que eles poderiam estar expostos em vários tipos de ambientes, inclusive fechados. Para funções não identificadas como poeirentas, como é o caso dos motoristas, as estimativas destas exposições foram realizadas com base em resultados de área (ponto fixo) ou situação similar, como a de alguns ajudantes de expedição, por exemplo. 


\section{Modelo 1}

No Modelo1 a exposição acumulada foi estimada para cada função utilizando os resultados de concentração média de sílica cristalina respirável e o tempo de trabalho na empresa atual. Para o tempo de trabalho em outras marmorarias (histórico ocupacional) foram utilizadas as concentrações médias por função e com etapa de acabamento a seco para o Município de São Paulo, pois os dados levantados indicavam que antes do ano de 2002 praticamente não existiam controles a úmido. Quando o processo havia sofrido algum tipo de intervenção o tempo de trabalho na empresa atual foi dividido em tempo com controle e sem controle. Ao tempo com controle foram associadas as médias das respectivas empresas e para o tempo sem controle, como não se tinha informação, a estimativa foi feita da mesma forma que o histórico ocupacional conforme citado acima.

Exemplo: Um trabalhador com história ocupacional com 2 anos na função de cortador na Empresa 1 e 2 anos de acabador a úmido na Empresa 2, que havia instalado este tipo de sistema de controle de poeira há 6 meses. Ele foi entrevistado na Empresa 2 e foram estimadas as médias da sua exposição, obtendo-se uma concentração de sílica cristalina igual a $0,05 \mathrm{mg} / \mathrm{m}^{3}$. No entanto este resultado somente foi considerado para os 6 últimos meses de trabalho (0,5 anos), pois para os 18 meses anteriores (1,5 anos) não existiam informações a respeito. Assim foi utilizada a média para os acabadores com etapa de acabamento a seco para matériasprimas mistas estimada para o Município de São Paulo, $0,19 \mathrm{mg} / \mathrm{m}^{3}$, Tabela 5.7. Para a função de cortador da Empresa 1, como não existem dados históricos da exposição, foram utilizados os valores estimados para a função de cortador com exposição ao material misto do Município de São Paulo, $0,04 \mathrm{mg} / \mathrm{m}^{3}$ para sílica cristalina, obtendo-se assim os seguintes valores:

\section{Sílica Cristalina Acumulada $=$ SCA}

$\mathrm{SCA}=0,05 \times 0,5+0,19 \times 1,5+0,04 \times 2=0,39 \mathrm{mg} / \mathrm{m}^{3}$-anos (em 4 anos) equivalente a aproximadamente uma concentração média de sílica cristalina de $0,11 \mathrm{mg} / \mathrm{m}^{3}$ por ano de trabalho. 


\section{Modelo 2}

O Modelo 2 foi elaborado como alternativa para situações nas quais não são possíveis coletas de amostras de ar e existem informações levantadas sobre a história do trabalhador e a história da empresa em um instrumento de avaliação conforme o proposto nesta tese. Assim, admitiu-se que a variabilidade das exposições das funções de ajudante, polidor, cortador e acabador entre as marmorarias durante os anos seria baixa desde que a variável tipo de etapa de acabamento, seco ou úmido fosse controlada e considerada no cálculo de exposição acumulada.. Para isto, os dados de concentração de sílica cristalina foram estratificados para as atividades realizadas a seco e a úmido. Neste modelo utilizou-se a concentração de sílica para a mistura das matérias-primas, isto é, não foi feita estratificação dos dados para os tipos de rochas ornamentais, granitos, ardósias e mármores.

Desta forma, a exposição acumulada para os trabalhadores segundo Modelo 2 foi calculada com as médias de exposição estimadas para as funções de ajudante, polidor, cortador e acabador com matéria-prima mista e levando em consideração o tipo de processo de acabamento a seco ou a úmido das 22 empresas avaliadas no MSP, Tabela 5.7.

\section{Modelo 3}

O Modelo 3, também foi proposto como alternativa quando não são possíveis as coletas de amostras de ar e existem informações levantadas em um instrumento de avaliação conforme o proposto nesta tese. Assim, admitiu-se que a variabilidade das exposições para as funções de ajudante, polidor, cortador, acabador e encarregado entre as marmorarias seria baixa, desde que as variáveis tipo de etapa de acabamento, seco ou úmido e tipo de matéria-prima granito, ardósia e mármores, fossem controladas e consideradas no cálculo de exposição acumulada. 
Assim, a exposição acumulada dos trabalhadores segundo Modelo 3 foi calculada com as médias de exposição estimadas para as funções de ajudante, polidor, cortador e acabador considerando o tipo de acabamento, a seco e a úmido e o tipo de matériaprima granitos, ardósias e mármores das 22 empresas avaliadas no MSP, Tabela 5.9.

\subsection{Avaliação Médica}

A avaliação médica foi realizada no Laboratório de Avaliação Clínica, Radiológica e Funcional em Doenças Ocupacionais da Fundacentro, com base nos instrumentos descritos a seguir.

\subsubsection{População de Estudo e Instrumentos de Avaliação}

A população do estudo foi formada por 267 trabalhadores empregados nas 22 marmorarias sorteadas, conforme descrito no item 4.1.1.

As informações necessárias para caracterização da população de estudo foram levantadas por meio de instrumentos de coleta integrados em um questionário denominado "Questionário sobre a atividade de marmorista e exposições inalatórias ocupacionais". A seguir são apresentados de forma resumida os conteúdos dos questionários.

\subsubsection{Questionário de histórico ocupacional}

Este instrumento, cujo modelo se encontra no Anexo 8, foi elaborado tomando como base o questionário desenvolvido por MAÇÃIRA, 2004. Foram formuladas questões para obter dados cadastrais do trabalhador, e fazer a sua caracterização demográfica e antropométrica. 
Foram introduzidas questões referentes às funções exercidas pelo trabalhador, aos tipos de matérias-primas, de máquinas e de ferramentas mais utilizadas e medidas de controle ambientais e pessoais adotadas em cada marmoraria.

Para este estudo foram priorizadas as funções de trabalhadores envolvidos diretamente com o processo de produção, ou seja: acabador, cortador, polidor e ajudante geral. Foi deixado um item em aberto para as outras funções, como encarregado, colocador, motorista e pedreiro, pois dependendo da característica da empresa estas funções poderiam existir ou ainda abrigar trabalhadores com história anterior na produção.

Procurou-se buscar informações sobre as atividades atuais desenvolvidas pelo trabalhador e sobre as desenvolvidas em empresas nas quais eventualmente estivesse empregado anteriormente. Para obter indícios de eventual exposição a poeira contendo sílica em outros tipos de trabalho anteriores, foi introduzida no questionário uma pergunta com referência aos ramos de atividade onde a sílica aparece com maior freqüência.Quando o trabalhador relatava já ter trabalhado no ramo de marmoraria, foi aplicado também o questionário complementar denominado "Descrição das atividades desenvolvidas em outras marmorarias".

\subsubsection{Questionário de sintomas respiratórios}

Neste estudo foi utilizado o questionário padronizado de sintomas respiratórios do British Medical Research Council - MRC 1976 Respiratory Questionnaire, (FLOREY e LEEDER 1982), traduzido para o português pela equipe do Ambulatório de Pneumologia da Fundacentro (ALGRANTI 1991), e incluído no Anexo 8 
O questionário traz questões referentes ao hábito de fumar e ao consumo de cigarros e foi incluída uma medida quantitativa para expressar este consumo denominada anos/maço, calculada para cada trabalhador fumante e ex-fumante conforme a expressão 7 .

$$
\text { Anos } / \text { maço }=\mathrm{t}(\text { anos }) \times \frac{n^{\circ} \text { de cigarros } / \text { dia }}{20}
$$

Foram considerados fumantes todos os trabalhadores que declararam ter fumado pelo menos um cigarro por dia por pelo menos um ano, e que continuavam a fumar na época da entrevista, e aqueles que haviam parado de fumar nos seis meses anteriores.

Foram considerados ex-fumantes os trabalhadores que deixaram de fumar há mais de seis meses.

Foram estimadas as freqüências dos sintomas dispnéia, chiado e bronquite crônica a partir dos dados levantados com aplicação do questionário do MRC adaptado, conforme descrito no item 4.6.3. Os sintomas foram classificados de acordo com os critérios descritos nos itens a seguir.

\section{Dispnéia grau 3}

Considerada presente somente quando os indivíduos responderam negativamente a questão D2: Você consegue acompanhar o passo de pessoas de sua idade, andando no plano?

\section{Chiado}

Considerado presente somente quando os indivíduos responderam positivamente a questão CH2: Você já apresentou algum episódio de chiado com falta de ar? 


\section{Bronquite crônica}

Considerada sua ocorrência quando presentes a tosse e o catarro matinais por pelo menos 3 meses por ano, nos dois últimos anos ou mais (Questão TC).

\subsubsection{Avaliação da função pulmonar - espirometria}

A espirometria foi utilizada para a obtenção de volumes e fluxos respiratórios forçados utilizando-se o espirômetro eletrônico (pneumotacógrafo) (Koko pnemotach spirometer PDS Medical Instruments, Louisville, EUA);

As espirometrias foram realizadas e interpretadas por pneumologistas, de acordo com os critérios técnicos do I CONSENSO BRASILEIRO SOBRE ESPIROMETRIA (SBPT 1996). As medidas obtidas foram:

1 Capacidade Vital Forçada (CVF);

2 Volume Expiratório Forçado no primeiro segundo $\left(\mathrm{VEF}_{1}\right)$;

3 Fluxo Expiratório Forçado médio entre 25 e 75\%da $\mathrm{CVF}\left(\mathrm{FEF}_{25-75 \%}\right)$;

4 Índice de Tiffeneau $=\mathrm{IT}=\mathrm{VEF}_{1} / \mathrm{CVF}$

Os parâmetros espirométricos obtidos foram expressos em percentuais frente aos valores de referência previstos para a população brasileira (PEREIRA et al. 1992).

\subsubsection{Radiografia de tórax}

Os trabalhadores foram submetidos à radiografia de tórax póstero-anterior (PA) e, quando necessário, em outras incidências. A leitura das radiografias foi realizada segundo classificação da OIT (ILO 2000). 
As radiografias foram interpretadas por 3 leitores independentes, sendo 2 certificados B (B Readers-NIOSH) e um terceiro leitor experiente (WAGNER 1992).

Os resultados para a profusão de pequenas opacidades e para a presença e tipo de espessamento pleural foram obtidos a partir da mediana das leituras.

Segundo a classificação da OIT, considera-se normal (sem doença) aquele trabalhador exposto cuja classificação radiológica for $0 /-$ ou $0 / 0$. Admite-se como “suspeito" o caso com classificação $0 / 1$.

No Brasil, para fins previdenciários, a definição técnica de "caso de pneumoconiose" consiste do trabalhador exposto, com história clínica e ocupacional compatíveis, cuja radiografia foi classificada a partir de 1/0, por 2 leitores experientes e qualificados (INSS 1998).

\subsection{Análises Estatísticas.}

Foram realizadas análises descritivas para os dados demográficos, tempo de exposição, sintomas respiratórios, fumantes e não-fumantes e classificação radiológica.

Para verificar relações entre as variáveis foi utilizado o teste de associação Qui Quadrado.

Os testes de comparação de médias t'Student ou teste não paramétrico de Savage foram utilizados para verificar se haveria diferenças nas médias das variáveis independentes em relação a variável dependente profusão com pequenas opacidades ou sem pequenas opacidades: a) exposição acumulada à sílica cristalina em $\mathrm{mg} / \mathrm{m}^{3}$ anos para os Modelos 1, 2 e 3; b) para tempo de exposição em anos. 
O teste de Cochran Armitage foi utilizado para verificar existência ou não de tendência linear nos quartis das variáveis independentes com a variável dependente.

A técnica da regressão logística univariada não condicional foi utilizada para verificar a intensidade de cada variável independente na variável dependente.

A técnica da regressão logística multivariada não condicional, com opção stepwise, foi utilizada quando havia mais de uma variável independente.

As análises dos dados foram realizadas no programa estatístico SAS versão 9.1 (SAS Institute 2004).

Adotou-se o nível de significância de $5 \%(\mathrm{p} \leq 0,05)$ para os testes estatísticos.

\subsection{Aspectos Éticos}

O presente estudo e seus instrumentos de coleta foram submetidos ao Comitê de Ética da Faculdade de Saúde Pública conforme norma do Ministério da Saúde, com a concordância e co-responsabilidade da Direção Técnica da FUNDACENTRO.

Todos os trabalhadores foram convidados, informados dos objetivos do estudo, receberam e assinaram o Termo de Consentimento Livre e Esclarecido (Anexo 9) previamente à aplicação dos instrumentos de coleta. Não houve recusas em participar da pesquisa.

Todas as empresas foram convidadas, informadas dos objetivos do estudo e receberam o Termo de Responsabilidade (Anexo 10) previamente à avaliação ambiental. Duas empresas declararam não poder participar da pesquisa, foram excluídas do estudo e um novo sorteio incluiu outras empresas com as mesmas características. 


\section{RESULTADOS}

Apresentam-se primeiramente os resultados dos levantamentos feitos para caracterização das marmorarias e de medida de concentração de poeira e sílica cristalina respirável utilizados no estudo de exposição ocupacional, no estudo de alternativas de controle para a poeira e para estimar a porcentagem de sílica cristalina respirável para determinadas matérias-primas. Na seqüência apresentam-se os resultados de caracterização da população, de avaliação médica e o cruzamento das informações de história ocupacional, avaliação médica e exposição acumulada à sílica cristalina.

\subsection{Caracterização das Marmorarias}

As informações foram obtidas durante as visitas realizadas nas 27 empresas e por meio do instrumento de coleta de dados (questionário) apresentado no Anexo 8.

\subsubsection{Instalações}

As marmorarias eram instaladas em um ou mais galpões contíguos de vários tipos, assumindo na maioria dos casos características de um local semi-aberto, construção com até 3 paredes, com pé direito de aproximadamente $5 \mathrm{~m}$ com cobertura. Foram encontrados galpões com cobertura de estrutura metálica, lage de concreto ou telhado de fibrocimento. As marmorarias eram da área urbana do município e 6 empresas (27\%) tinham galpões fechados por determinação do órgão ambiental estadual.

Em marmorarias com um único galpão, a poeira gerada ficava suspensa no ar, se dispersava no ambiente como um todo e posteriormente se depositava, produzindo acúmulo de poeira nas instalações e no maquinário. Isto foi observado para a maioria das marmorarias instaladas em locais semi-abertos ou fechados e onde não existiam medidas de controle adequadas. 
Os refeitórios, vestiários e instalações sanitárias na grande maioria dos casos eram inadequados em comparação com as Normas Regulamentadoras do Ministério do Trabalho e Emprego.

\subsubsection{Processo de produção}

O processo básico de produção em marmorarias era praticamente o mesmo em todas elas, com exceção da empresa número 2 que era uma empresa só de polimento de chapas de rochas. As etapas do processo envolviam corte, polimento e acabamento (lixamento, colagem e lustro) de rochas para produção de pisos e outros revestimentos, tampos de pias, mesas, escadas, túmulos, etc. Algumas eram praticamente especializadas em trabalhos com um determinado tipo de matériaprima, enquanto outras utilizavam diversos tipos. A maioria das marmorarias produzia peças projetadas com grande complexidade na fase do acabamento e vários tipos de bordas.

A produção se iniciava com o recebimento da matéria-prima em blocos ou chapas polidas. Das 22 empresas 4 realizam processo de jateamento de chapas a úmido e 2 realizam o processo de flameamento. A movimentação de blocos e de chapas era realizada com equipamentos pneumáticos, pontes rolantes, carrinhos, entre outros meios. Na grande maioria das marmorarias, as chapas eram movimentadas pelos próprios trabalhadores com o auxílio de um carrinho (comumente um trilho de metal com duas rodas). Em marmorarias de porte grande, empresas que cortavam blocos e empresa de polimento de chapas a movimentação do material era realizada por meio de ponte rolante ou talhas.

O polimento da chapa era realizado a úmido em politriz manual ou automática, utilizando abrasivos sintéticos colocados nos satélites da máquina. Entre as 22 empresas, 7 realizavam polimento, as empresas números $1,2,5,9,10,17$ e 18, e somente as empresas 2 e 18 possuíam politriz automática. Os abrasivos eram passados na chapa em uma seqüência que ia da maior para a menor granulometria até obter-se o brilho desejado. A etapa de polimento é realizada por aproximadamente 
$32 \%$ das marmorarias. A maioria delas adquire as chapas já polidas. Os abrasivos podem ser outras fontes de exposição a agentes químicos, nesta etapa do processo de produção. Foram encontrados abrasivos a base de chumbo, por exemplo.

O corte de blocos e de chapas era realizado a úmido por meio de cortadeira denominada serra convencional ou serra-ponte. As empresas números 7, 10, 15, 17 e 18, aproximadamente $23 \%$, possuíam serra-ponte e serra convencional. Os vários tipos de discos para as serras existentes eram trocados, dependendo do tipo de matéria-prima que seria cortada. Na operação de corte a exposição à poeira respirável pode ocorrer por projeção de partículas na direção do trabalhador devido à alta rotação do disco de corte.

O acabamento das peças era geralmente realizado a seco, com utilização de serras, politrizes e furadeiras manuais. O uso de politrez manual (lixadeira) a seco era a mais importante fonte de risco de exposição às poeiras. $O$ trabalhador que operava a politriz a seco produzia nuvens de poeira que eram projetadas na sua direção e na de outros trabalhadores. Isto ocorria devido à necessidade de movimentar a ferramenta em várias direções. Além dos acabadores, circulavam entre as bancadas, expondo-se a poeira gerada, trabalhadores de outras funções que entravam no setor. Somente a empresa número 15 havia introduzido a etapa de acabamento a úmido (desbaste, lixamento e lustro) no processo de produção. As outras empresas, números 1, 5, 6, 9, $10,12,14,16,17,18$ e 21 que possuíam 1 lixadeira a úmido para uso em todo o setor de acabamento, realizavam parcialmente o acabamento a úmido, reservando a ferramenta para o lustro.

A montagem de um conjunto de peças era realizada por meio de colagem com massas plásticas. Com exceção da empresa 15, todas as operações de pré-colagem eram realizadas a seco com geração de nuvens de poeira. 
O lustro era realizado aplicando-se sobre a peça uma camada de cera, produtos impermeabilizantes para corrigir pequenas trincas da rocha ou para realçar a cor. A lixadeira com feltro a seco ou a lixadeira com água eram utilizadas para fornecer alto-brilho e embelezar as peças.

Nas etapas de colagem e lustro os trabalhadores eram expostos a outros agentes químicos que não fizeram parte deste estudo, como, por exemplo, solventes e catalizadores.

As atividades de manutenção e limpeza eram realizadas pelos próprios trabalhadores das marmorarias. Entre os recursos utilizados para a limpeza as marmorarias utilizavam lavagem, aspiração, varrição entre outros. No setor de acabamento, por exemplo, a lavagem semanal era realizada por $68 \%$ das empresas. Nas limpezas diárias, grande parte utilizava a varrição ou ainda ar comprimido para limpeza de peças, bancadas e uniformes, causando a suspensão da poeira já depositada.

Medidas alternativas para a captação e controle da poeira gerada no processo existiam nas empresas números $5,6,7,8,11,12,13,14,15$ e 16, representando aproximadamente $45 \%$ das empresas estudadas. Os resultados do estudo para caracterização dessas medidas encontram-se no item 5.3.

Equipamentos de proteção individual eram fornecidos por todas as empresas.Uniformes eram fornecidos por 19 das 22 empresas. Os protetores faciais mais utilizados eram do tipo Peça Facial Filtrante com fator de proteção 1 e 2, PFF1 e PFF2 respectivamente. Os protetores com fator de proteção 3, PFF3, seriam mais adequados. Além disso, em nenhuma empresa existia um programa de proteção respiratória com treinamento adequado dos trabalhadores quanto ao uso e manutenção destes equipamentos. Os protetores auditivos tipo concha e de inserção também eram fornecidos, devido à geração de ruído proveniente de máquinas e ferramentas. Os equipamentos como botas, óculos, luvas, entre outros eram fornecidos ao trabalhador dependendo da sua função. 
As marmorarias visitadas eram empresas formalmente constituídas, algumas como micro empresas. Quanto ao número do CNAE, nem sempre correspondiam ao citado no item 3.7 .

\subsubsection{Funções}

A seguir são apresentadas as descrições das principais funções encontradas nas marmorarias estudadas.

\section{Ajudante geral}

A função de ajudante geral (Aj), algumas vezes denominada somente de auxiliar, abriga trabalhadores que realizam tarefas e desempenham talvez a maior variedade de atribuições nas marmorarias.

O ajudante geral realiza todas as atividades em pé, com grande esforço físico. Em empresas de grande porte ele faz o transporte das chapas e peças com auxílio de ponte rolante, com sistemas de ventosa. Nas outras, na maioria dos casos ele utiliza um carrinho de ferro já descrito. Devido ao peso, sempre recebe ajuda de um outro auxiliar ou do cortador, no caso de chapas que serão cortadas ou do acabador, quando da expedição de produtos acabados.

A função de ajudante geral é a primeira que um trabalhador executa quando começa sua vida profissional na marmoraria. Sempre que tem tempo, ele é requisitado como auxiliar de polimento, de corte, de furação ou de acabamento.

Em algumas empresas a atividade de limpeza dos sistemas de exaustão é realizada pelo ajudante geral. Além disso, quando não existe no quadro da empresa a função de faxineiro ou limpador, o ajudante geral também executa estas atividades. 


\section{Polidor}

A função de polidor é exercida por um trabalhador mais especializado que o auxiliar. Ele pode operar máquinas de grande porte, manuais ou automáticas (computadorizadas ou não), que trabalham com água, para resfriamento das sapatas, em posições fixas dentro da marmoraria, demarcando um espaço denominado setor de polimento.

O polidor faz a leitura e interpretação das ordens de serviço que especificam tipo de matéria-prima, tipo de polimento e número de chapas a produzir, e seleciona recursos necessários, tipos de abrasivos, número de abrasões, etc. Nas empresas com máquinas automáticas e materiais padronizados o controle da qualidade é preestabelecido. Nas empresas pequenas, fazer esse controle é atribuição do polidor, utilizando o processo visual e o toque das mãos.

A função de polidor também é exercida em pé e requer esforço físico intenso.

\section{Cortador}

A função de cortador é exercida por um trabalhador que pode operar máquina de corte automática (serra-ponte) ou convencional (serra) (que trabalha com água para resfriamento do disco), em um espaço na marmoraria denominado de setor de corte.

O cortador precisa ler as ordens de serviço, que trazem desenhos e projetos dos produtos a serem fabricados, conhecer as matérias-primas, as dimensões das chapas, os processos e instrumentos de medição, os tipos de disco de corte, entre outros assuntos pertinentes ao seu trabalho. Pode fazer uso de esquadros e moldes de peças já padronizados. 
O cortador também pode realizar atividades utilizando a serra manual, ou serramármore, em especial quando a peça a ser produzida tem pequenas dimensões. Nestes casos, o cortador vai até o pátio ou o depósito das chapas e realiza um corte longitudinal na chapa com a serra-mármore, expondo-se a nuvens de poeira geradas pela ferramenta. Enquanto o cortador está realizando o corte, o ajudante espirra a água contida numa garrafa de plástico do tipo "pet”, para resfriar o disco diamantado da ferramenta e para diminuir a poeira. Esse procedimento é comum a quase todas as marmorarias. Foi encontrada somente uma que utilizava o dispositivo da ferramenta com encaixe da mangueira para entrada de água, conforme recomendado pelo fabricante da ferramenta.

Quando o produto é diferenciado, o cortador pode utilizar diferentes tipos de fresas na serra, de modo a produzir diversos tipos de boleado (como o simples, o duplo ou o peito de pombo).

Em empresas que não dispõem de fresas ou com alta produtividade, o cortador deixa a borda reta e realiza as marcações das peças com giz de cera, codificando-as e indicando o tipo de processo de acabamento (por exemplo, reto ou boleado).

A função de cortador também é exercida em pé e requer esforço físico intenso. Além disto, nesta função existe a presença de outro agente ambiental de risco à saúde que é o ruído.

\section{Acabador}

A função de acabador é exercida por um trabalhador que pode operar ferramentas elétricas manuais de corte (serras-mármores) e de polimento a seco ou a úmido denominadas politrizes, ou simplesmente lixadeiras. Os acabadores demarcam um espaço na marmoraria denominado setor de acabamento. 
O acabador precisa ler instruções apresentadas em ordens de serviço, que costumam conter desenhos e projetos de produtos a serem fabricados, conhecer as matériasprimas, interpretar os códigos de tipos de acabamento enviados pelo setor de corte e verificar se eles estão corretos antes da execução do serviço.

Toda a fase final da produção acontece no setor de acabamento, onde são realizadas várias atividades. As mais importantes, do ponto de vista da exposição ocupacional a poeiras contendo sílica, estão descritas a seguir.

O acabador realiza cortes a seco ou a úmido com serra-mármore de determinada parte da peça (por exemplo: boca de pia). Quando o corte é a úmido, o acabador o faz de maneira semelhante à descrita anteriormente para o corte de chapas feito pelo cortador, com o ajudante espirrando água no disco por meio de uma garrafa.

O desbaste a seco é a operação mais comum para transformar as bordas das peças que são retas em arredondadas (boleadas). É realizado com politriz dotada de um disco diamantado ou com abrasivo do tipo rebolo acoplado à politriz. Em alguns casos esta operação pode ser realizada usando-se uma ferramenta denominada chicote. Também pode ser realizado com serra-mármore, posicionando-se a parte diamantada do disco sobre a peça.

O lixamento a seco é realizado para transformar a superfície da borda de rugosa em lustrada. É realizado com politriz e uma série de lixas de várias granulometrias. $\mathrm{O}$ processo começa com o uso da lixa mais grossa, prossegue até que se use uma lixa bem fina, e termina no lustro com feltro.

Na produção de peças de mármore em alguns casos é feito um polimento manual especial de alto brilho com sal e água.

O acabamento úmido é realizado por meio de uma politriz pneumática com disco diamantado para o desbaste, e discos cerâmicos para o acabamento e brilho. 


\section{Encarregado}

A função de encarregado (Enc) é exercida por trabalhador com experiência profissional sobre as etapas do processo produtivo de uma marmoraria. Ele é o profissional que recebe as encomendas vindas do setor administrativo e repassa para a produção. Recebe as matérias-primas e faz a expedição dos produtos acabados. Em geral em empresas de porte grande esta função tem caráter administrativo. Em empresas de alta produtividade ou de porque pequeno e micro os encarregados assumem funções múltiplas, inclusive como acabador, cortador, ou ambas.

\subsection{Caracterização da exposição ocupacional à poeira e à sílica cristalina respirável e estimativa de risco de silicose}

Entre fevereiro de 2004 e junho de 2005 foram coletadas 577 amostras de ar para determinação da concentração de poeira e sílica cristalina respirável a que estariam expostos trabalhadores das 22 marmorarias sorteadas do Município de São Paulo.

\subsubsection{Resultados de análise de poeira e sílica cristalina respirável por jornada de trabalho.}

Para os cálculos de concentração de poeira respirável (CPR) foram excluídas 11 amostras cujas atividades realizadas durante a amostragem eram totalmente incompatíveis com as funções. Com os resultados de 566 amostras foram calculadas as médias ponderadas de poeira respirável correspondentes a 507 jornadas de trabalho conforme item 4.3.3.

Para os cálculos de concentração de sílica cristalina respirável foram excluídas 21 amostras com Filtro Saturado (com massa superior a $2 \mathrm{mg}$ ) e 59 amostras com Massa Insuficiente para análise química (com massa inferior a $0,10 \mathrm{mg}$ ). Com os resultados 
de 486 amostras foram calculadas as médias ponderadas de sílica cristalina correspondentes a 430 jornadas de trabalho conforme item 4.3.3.

A sílica cristalina foi identificada em 337 amostras das 486 analisadas. Para as amostras nas quais a sílica cristalina não foi detectada (ND), foi utilizado o valor 0,0025 mg para a massa de sílica, correspondente a metade do limite de detecção do método analítico, nos cálculos de média ponderada (AIHA 1998).

Os resultados das análises foram organizados para cada empresa na forma de tabelas e gráficos. Nas Tabelas do Anexo 11 são apresentados os resultados das concentrações de poeira e sílica cristalina respirável para todas as amostras coletadas; as médias ponderadas para jornadas de trabalho com mais de uma amostra; as análises comparativas com os valores de referência apresentados no item 4.4 .2 e de um detalhamento sobre o tipo de operação a seco ou a úmido, matérias-primas utilizadas e medidas de controle ambiental de poeira em funcionamento no momento da coleta.

A Tabela 5.1 apresenta os resultados da Empresa 3, como exemplo.As Tabelas com os demais dados são apresentadas no Anexo 11. As médias ponderadas podem ser identificadas nas Tabelas pelos códigos das amostras apresentados de forma conjunta. Por exemplo, a média ponderada das amostras códigos Bo-67 e Bo-73 se encontra identificada pelo código Bo-67Bo-76.

Os resultados de médias ponderadas de concentração de poeira e sílica cristalina respirável para todas as funções foram organizados na forma de gráfico para melhor visualização da distribuição destes valores. No gráfico o valor de referência para sílica cristalina de $0,05 \mathrm{mg} / \mathrm{m}^{3}$ é apresentado como linha, orientando a comparação visual dos valores obtidos com o valor de referência.

A Figura 5.1 apresenta o gráfico com resultados da Empresa 3, como exemplo. Os gráficos com os resultados para as demais empresas são apresentados no Anexo 11. 
Tabela 5.1 - Concentração de poeira e de sílica cristalina respirável e informações complementares. Marmorarias, Município de São Paulo, 2004-2005

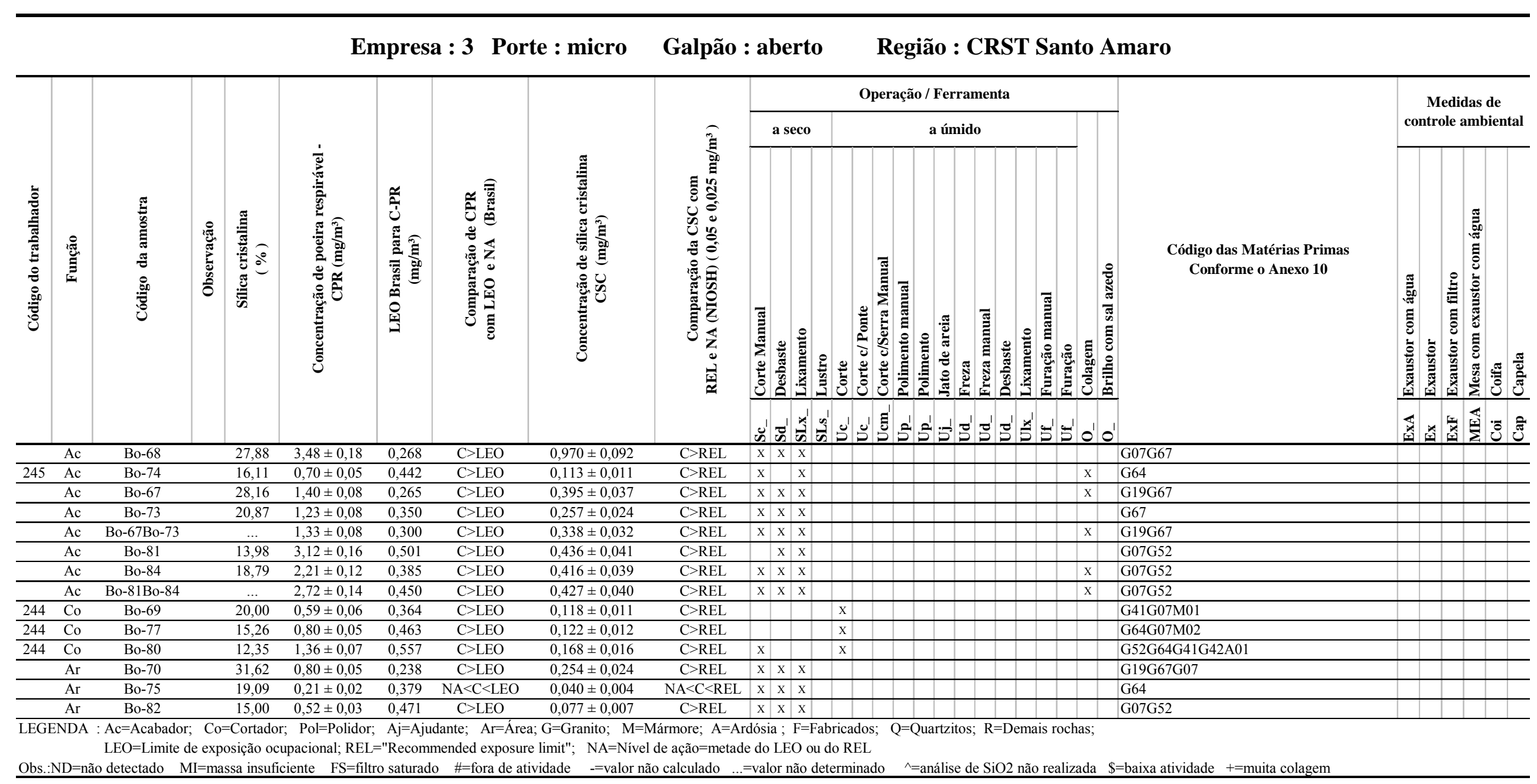


Empresa : 3 Porte : micro Galpão : aberto Região : CRST Santo Amaro

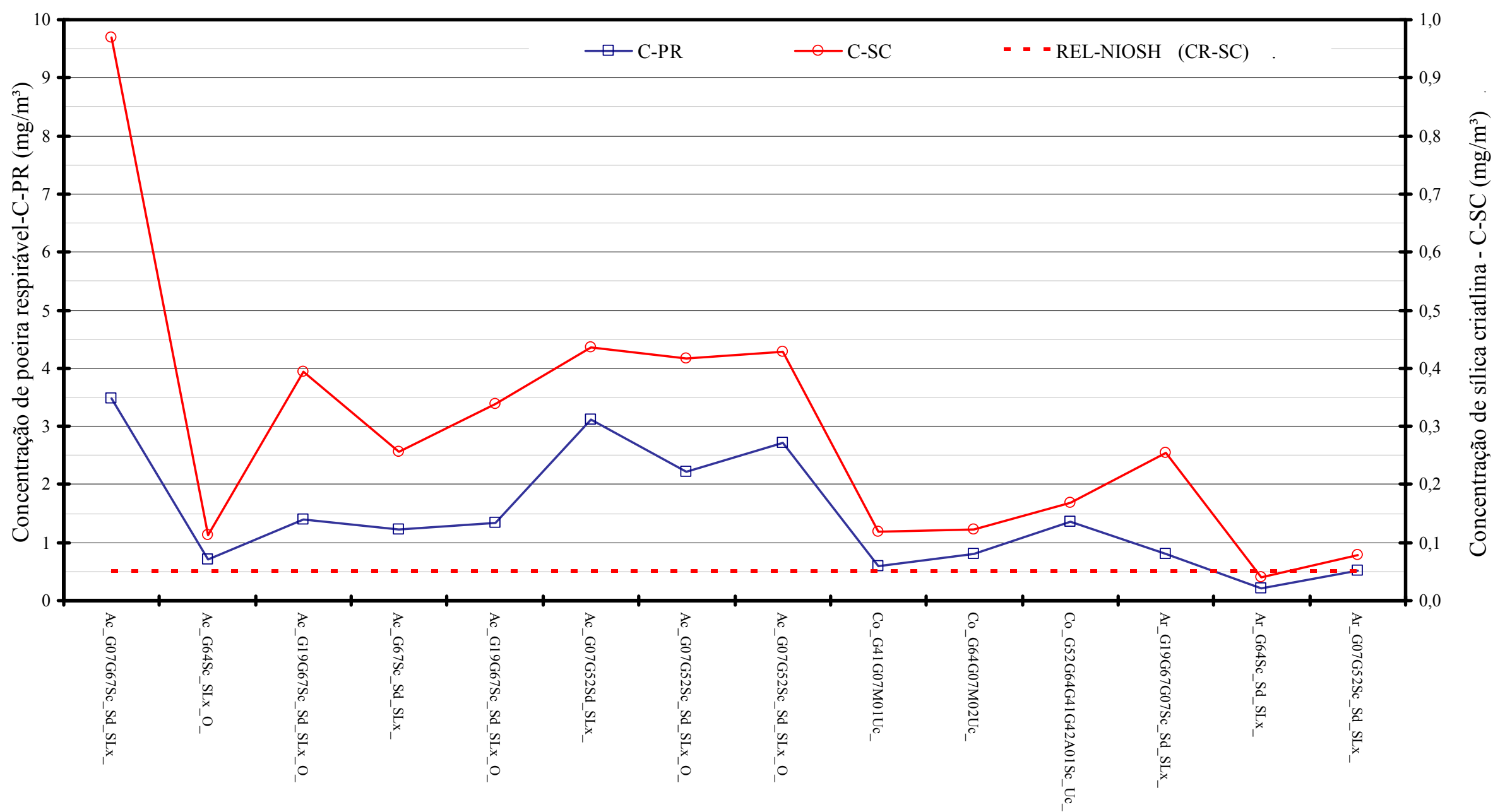

Figura 5.1 - Concentração de poeira e sílica cristalina respirável por amostra, respectivas matérias-primas e tipos de operação. Marmorarias, Município de São Paulo, 2004 -2005 
Para conhecer o perfil da exposição dos trabalhadores os resultados de concentração média ponderada de poeira e sílica cristalina respirável foram organizados por função para cada empresa e comparados com valores de referência apresentados no item 4.5.4. Esta comparação foi expressa em porcentagem de jornadas de trabalho com resultados acima do LEO, entre o LEO e o Nível de Ação (NA) e abaixo do NA.

A Figura 5.2 apresenta a porcentagem de resultados de concentração de poeira respirável contendo sílica cristalina por jornada de trabalho acima do LEO da legislação brasileira (LT-Brasil - Tabela 3.1), entre o LEO e NA e abaixo do NA para todas as funções.

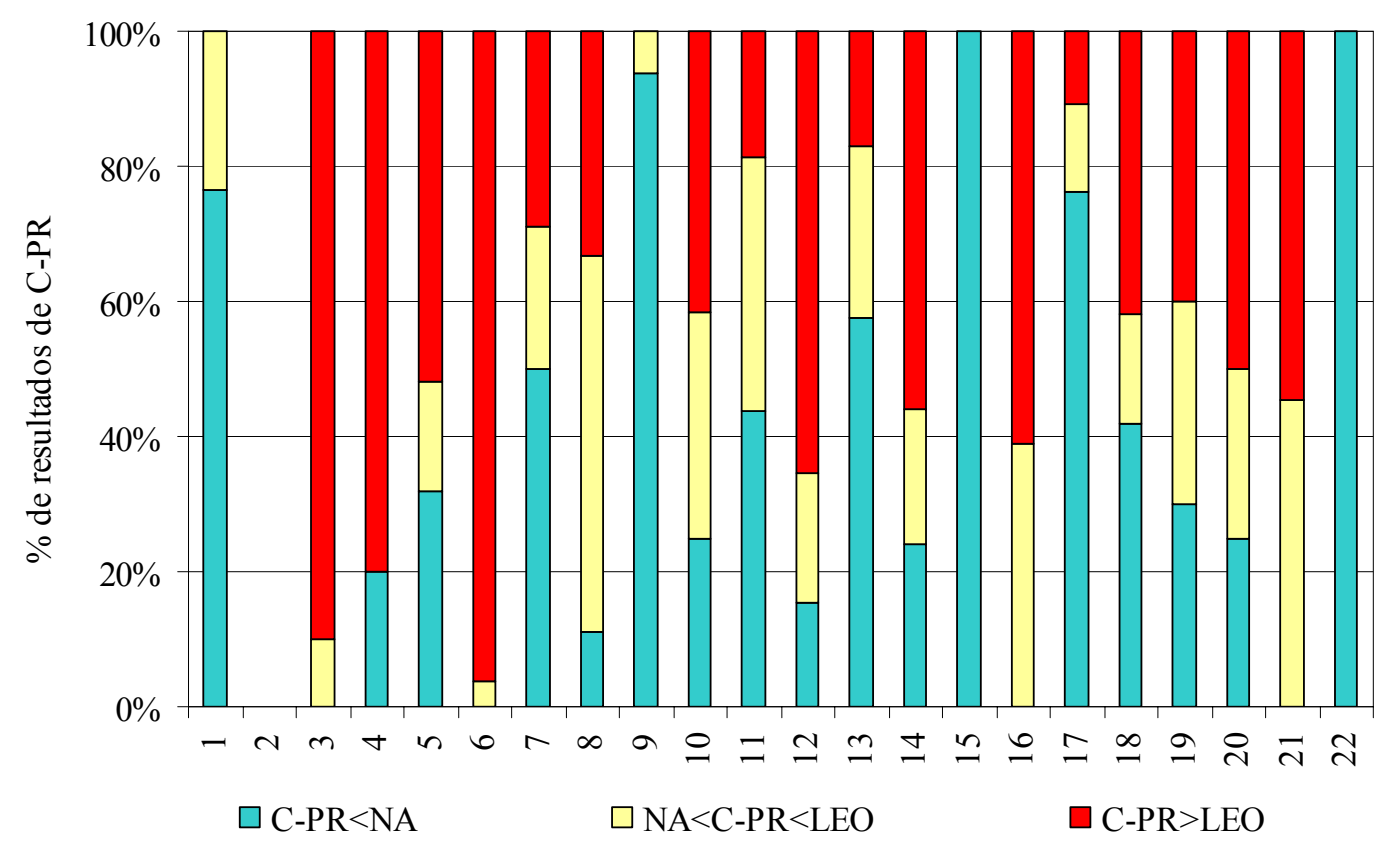

Figura 5.2 - Porcentagem de resultados de concentração de poeira respirável (C-PR) acima do LEO-Brasil, entre o LEO e NA e abaixo do NA nas marmorarias estudadas, Município de São Paulo, 2004 -2005

Na Figura 5.2 observa-se que nas empresas números, 3, 4, 5, 6, 7, 8, 10, 11, 12, 13 , $14,16,17,18,19,20,21(77 \%)$ foram encontrados valores maiores que 5\% de porcentagem de resultados de concentração de poeira respirável por jornada de trabalho acima do LEO, indicando a necessidade de implantação de medidas de controle da poeira. Todas estas empresas possuem processo com etapa de acabamento a seco. 
As empresas 1 e 9 realizavam a etapa de acabamento parcialmente a úmido. A empresa 15 realizava esta mesma etapa totalmente a úmido e seus resultados encontram-se abaixo do LEO. A empresa 2 não possui nenhum resultado na Figura 5.2 porque todas as amostras apresentaram massa insuficiente para análise química. A empresa 2 realizava somente o polimento de chapas, a úmido com pouca geração de poeira. A empresa 22 encontrava-se com a produção reduzida.

Nas empresas números 5, 6, 7, 8, 11, 12, 13, 14 e 16 (41\%) já existiam medidas de controle no ambiente, que porém mostraram-se insuficientes para captar a poeira respirável gerada em altas concentrações.

A Figura 5.3 apresenta a porcentagem de resultados de concentração de sílica cristalina respirável por jornada de trabalho acima do valor de referência de $0,05 \mathrm{mg} / \mathrm{m}^{3}$ (REL-NIOSH), entre o REL e Nível de Ação (NA) e abaixo do NA, por empresa.

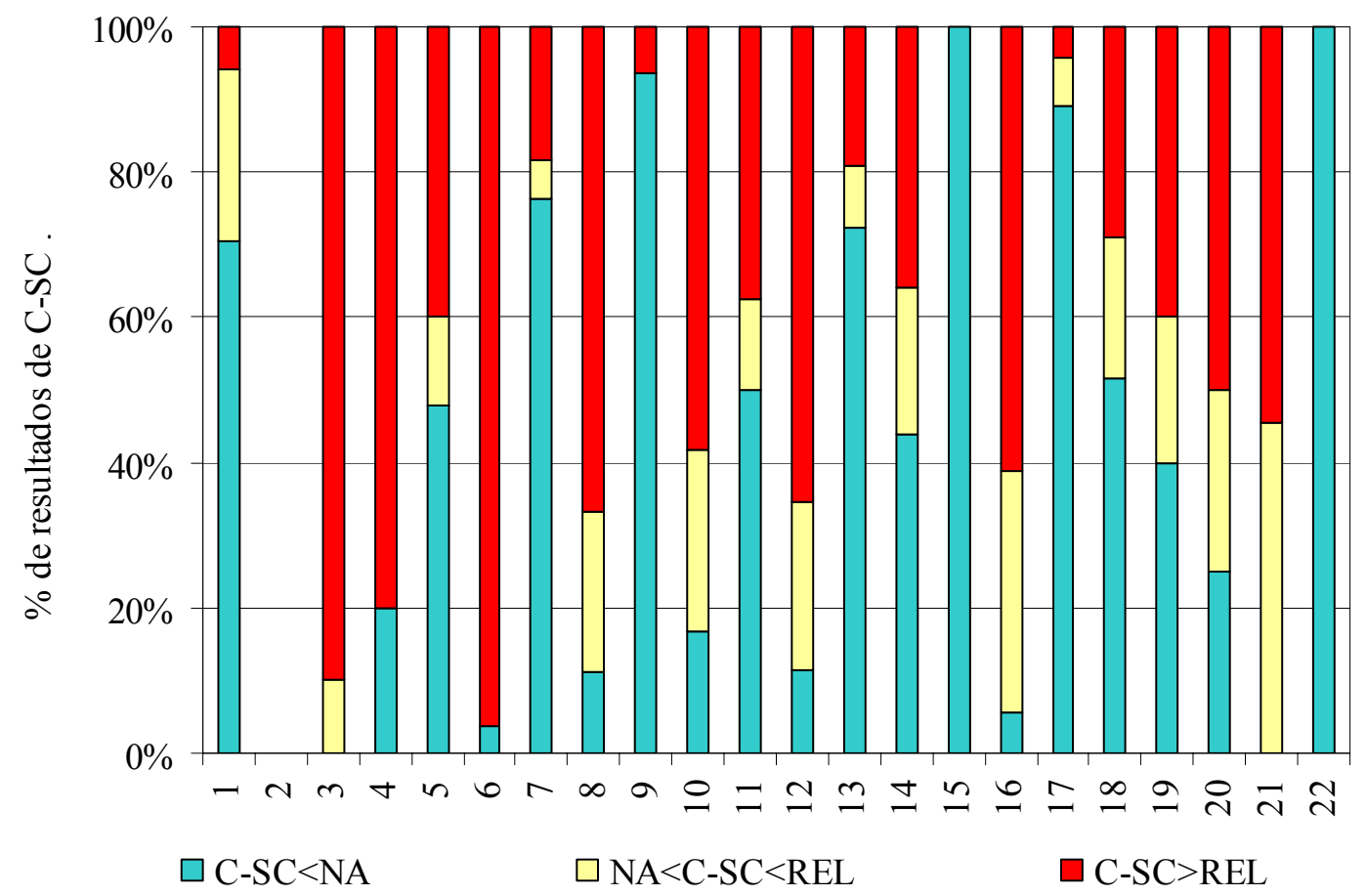

Figura 5.3 - Porcentagem de resultados de concentração de sílica cristalina respirável (C-SC) acima do REL-NIOSH, entre o REL e NA e abaixo do NA nas marmorarias estudadas, Município de São Paulo, 2004 -2005 
Na Figura 5.3 observa-se que nas empresas números1, 3, 4, 5, 6, 7, 8, 9, 10, 11, 12 , $13,14,16,17,18,19,20,21,(86 \%)$ foram encontrados valores maiores que $5 \%$ de porcentagem de resultados de concentração de poeira respirável por jornada de trabalho acima do REL-NIOSH.

Comparando-se as Figuras 5.2 e 5.3, verifica-se que as empresas números 1 e 9 apresentaram piores condições de exposição ocupacional para SC do que para PR. Isto ocorreu em parte porque o valor de referência para $\mathrm{SC}$ adotado é aproximadamente a metade do valor obtido utilizando a fórmula da legislação brasileira.

\subsubsection{Resultados por função para as empresas}

As concentrações médias de poeira respirável por função de cada empresa foram calculadas, conforme o item 4.4.1, a partir dos resultados das 566 amostras de poeira respirável no ar, correspondentes a 507 jornadas de trabalho.

A Tabela 5.2 apresenta os resultados de concentração média de poeira respirável no ar por função (amostras pessoais), e para área (amostras em ponto fixo), para cada empresa, com os respectivos valores de desvio padrão, número de jornadas e limites de confiança de $95 \%$. 
Tabela 5.2 - Concentração média de poeira respirável $\left(\mathrm{mg} / \mathrm{m}^{3}\right)$ por função e para amostras de área nas marmorarias estudadas no Município de São Paulo, 2004-2005

\begin{tabular}{|c|c|c|c|c|c|c|c|c|c|c|c|c|c|c|c|c|c|c|c|c|c|c|c|}
\hline & \multirow{2}{*}{ Funções } & \multicolumn{22}{|c|}{ Empresas } \\
\hline & & 1 & 2 & 3 & 4 & 5 & 6 & 7 & 8 & 9 & 10 & 11 & 12 & 13 & 14 & 15 & 16 & 17 & 18 & 19 & 20 & 21 & 22 \\
\hline \multirow{6}{*}{ Média aritmética } & $\mathrm{Ac}$ & 1,08 & & 2,06 & 4,35 & 6,57 & 6,63 & 2,20 & 2,64 & 0,45 & 1,42 & 1,09 & 2,12 & 1,39 & 3,12 & 0,34 & 2,63 & 1,77 & 2,70 & 2,37 & 3,42 & 2,40 & 1,42 \\
\hline & $\mathrm{Aj}$ & 0,53 & & & & 0,94 & & 0,38 & & 0,32 & & 0,18 & 0,41 & 0,66 & & & 1,54 & 0,85 & 3,02 & & 0,37 & & \\
\hline & $\mathrm{Co}$ & 0,31 & & 0,92 & 0,39 & 0,80 & 3,29 & 0,40 & 0,64 & 0,49 & 0,16 & 0,26 & 0,48 & 0,49 & 0,74 & 0,34 & 1,80 & 0,22 & 0,78 & 0,29 & 0,28 & 0,63 & 0,81 \\
\hline & Pol & 0,41 & 0,10 & & & 0,39 & & & & 0,19 & 0,04 & & & & & & & 0,18 & 0,50 & & & & \\
\hline & Enc & & 0,11 & & & & & & & & 0,13 & & & 0,49 & 1,28 & & & & 0,87 & & & & \\
\hline & $\mathrm{Ar}$ & 0,16 & & 0,51 & 1,67 & 0,50 & 2,11 & 0,56 & 0,48 & 0,17 & 0,48 & 0,10 & 1,35 & 0,31 & 2,49 & 0,19 & 1,71 & 0,50 & 1,06 & 0,50 & 0,36 & 1,02 & 0,83 \\
\hline \multirow{6}{*}{ Desvio padrão } & Ac & 0,92 & & 1,27 & 3,83 & 6,57 & 5,65 & 1,21 & 0,61 & 0,36 & 0,64 & 0,64 & 1,07 & 0,99 & 1,49 & 0,12 & 0,95 & 1,85 & 1,92 & 1,85 & 2,25 & 1,23 & \\
\hline & $\mathrm{Aj}$ & 0,38 & & & & 0,70 & & 0,06 & & 0,00 & & 0,10 & 0,08 & 0,67 & & & 0,20 & 0,68 & 0,47 & & 0,20 & & \\
\hline & $\mathrm{Co}$ & 0,16 & & 0,40 & 0,27 & 0,31 & 2,19 & 0,14 & 0,13 & 0,24 & 0,14 & 0,11 & 0,17 & 0,25 & 0,73 & 0,11 & 0,20 & 0,14 & 1,04 & 0,21 & 0,18 & 0,21 & \\
\hline & Pol & 0,05 & 0,17 & & & 0,10 & & & & & 0,05 & & & & & & & 0,16 & 0,07 & & & & \\
\hline & Enc & & 0,06 & & & & & & & & 0,13 & & & 0,02 & 0,78 & & & & 0,28 & & & & \\
\hline & $\mathrm{Ar}$ & 0,19 & & 0,30 & 0,84 & 0,28 & 0,91 & 0,21 & 0,08 & 0,18 & 0,45 & 0,06 & 0,83 & 0,16 & 1,61 & 0,06 & 0,29 & 0,21 & 0,20 & 0,32 & 0,10 & 0,47 & \\
\hline \multirow{6}{*}{$\begin{array}{l}\text { Número de } \\
\text { jornadas }\end{array}$} & $\mathrm{Ac}$ & 5 & & 4 & 17 & 13 & 32 & 23 & 3 & 8 & 8 & 8 & 11 & 33 & 19 & 5 & 9 & 29 & 11 & 5 & 6 & 6 & 1 \\
\hline & $\mathrm{Aj}$ & 3 & 5 & & & 3 & & 3 & & 2 & & 8 & 4 & 3 & & & 3 & 8 & 3 & & 3 & & \\
\hline & $\mathrm{Co}$ & 6 & & 3 & 6 & 6 & 5 & 9 & 3 & 6 & 6 & 5 & 4 & 6 & 3 & 4 & 3 & 9 & 9 & 5 & 3 & 3 & 1 \\
\hline & Pol & 3 & 3 & & & 2 & & & & 1 & 3 & & & & & & & 2 & 2 & & & & \\
\hline & Enc & & 2 & & & & & & & & 3 & & & 2 & 2 & & & & 3 & & & & \\
\hline & $\mathrm{Ar}$ & 4 & 2 & 3 & 2 & 3 & 3 & 5 & 3 & 3 & 3 & 3 & 7 & 3 & 2 & 6 & 3 & 3 & 3 & 3 & 2 & 3 & 1 \\
\hline \multirow{6}{*}{$\begin{array}{l}\text { LCI }(95 \%) \text { da } \\
\text { média }\end{array}$} & $\mathrm{Ac}$ & 0,25 & & 0,71 & 2,73 & 3,34 & 4,94 & 1,77 & 1,81 & 0,21 & 1,00 & 0,67 & 1,53 & 1,10 & 2,53 & 0,24 & 2,04 & 1,18 & 1,66 & 0,70 & 1,64 & 1,43 & 1,42 \\
\hline & $\mathrm{Aj}$ & 0,01 & & & & & & 0,31 & & 0,31 & & 0,12 & 0,32 & & & & 1,26 & 0,40 & 2,38 & & 0,11 & & \\
\hline & $\mathrm{Co}$ & 0,19 & & 0,37 & 0,17 & 0,55 & 1,31 & 0,32 & 0,47 & 0,30 & 0,04 & 0,15 & 0,29 & 0,29 & & 0,22 & 1,53 & 0,13 & 0,15 & 0,10 & 0,04 & 0,35 & 0,81 \\
\hline & Pol & 0,34 & & & & 0,19 & & & & 0,19 & & & & & & & & & 0,35 & & & & \\
\hline & Enc & & & & & & & & & & & & & 0,45 & & & & & 0,49 & & & & \\
\hline & $\mathrm{Ar}$ & & & 0,11 & & 0,12 & 0,88 & 0,36 & 0,37 & & & 0,01 & 0,75 & 0,10 & & 0,15 & 1,32 & 0,21 & 0,79 & 0,06 & 0,15 & 0,38 & 0,83 \\
\hline \multirow{6}{*}{$\begin{array}{c}\operatorname{LCS}(95 \%) \text { da } \\
\text { média }\end{array}$} & $\mathrm{Ac}$ & 1,91 & & 3,41 & 5,96 & 9,80 & 8,32 & 2,63 & 3,46 & 0,69 & 1,84 & 1,51 & 2,70 & 1,68 & 3,71 & 0,45 & 3,21 & 2,35 & 3,74 & 4,03 & 5,21 & 3,38 & 1,42 \\
\hline & $\mathrm{Aj}$ & 1,05 & & & & 1,90 & & 0,46 & & 0,32 & & 0,24 & 0,49 & 1,57 & & & 1,81 & 1,30 & 3,66 & & 0,64 & & \\
\hline & Co & 0,43 & & 1,46 & 0,61 & 1,04 & 5,26 & 0,48 & 0,81 & 0,68 & 0,27 & 0,36 & 0,66 & 0,69 & 1,74 & 0,47 & 2,08 & 0,30 & 1,42 & 0,48 & 0,52 & 0,92 & 0,81 \\
\hline & Pol & 0,49 & 0,32 & & & 0,59 & & & & 0,19 & 0,11 & & & & & & & 0,51 & 0,65 & & & & \\
\hline & Enc & & 0,23 & & & & & & & & 0,31 & & & 0,54 & 2,89 & & & & 1,26 & & & & \\
\hline & $\mathrm{Ar}$ & 0,36 & & 0,91 & 3,41 & 0,89 & 3,35 & 0,75 & 0,59 & 0,41 & 1,09 & 0,18 & 1,94 & 0,53 & 5,81 & 0,24 & 2,10 & 0,78 & 1,32 & 0,93 & 0,56 & 1,66 & 0,83 \\
\hline
\end{tabular}


As concentrações médias de poeira respirável por função e por empresa refletem as exposições a poeiras minerais (mistura de matérias-primas) em suspensão no ar das marmorarias durante a amostragem, independente do tipo de operação realizada a seco ou a úmido.

A Figura 5.4 apresenta a concentração média de poeira respirável (CPR) e seu intervalo de confiança de $95 \%$ para a função de acabador por empresa. O maior intervalo de confiança encontrado é o da empresa 5 (igual a $6,5 \mathrm{mg} / \mathrm{m}^{3}$ ), aproximadamente o dobro do verificado para a empresa 6 (igual a $3,4 \mathrm{mg} / \mathrm{m}^{3}$ ), empresa que também apresentou alta exposição à poeira respirável. Isso pode ser devido ao uso na empresa 5 de politrizes (lixadeiras) de alta rotação com diferentes tipos de abrasivos (rebolos, lixas) para as operações de desbaste e lixamento a seco com geração de teores maiores de poeira.

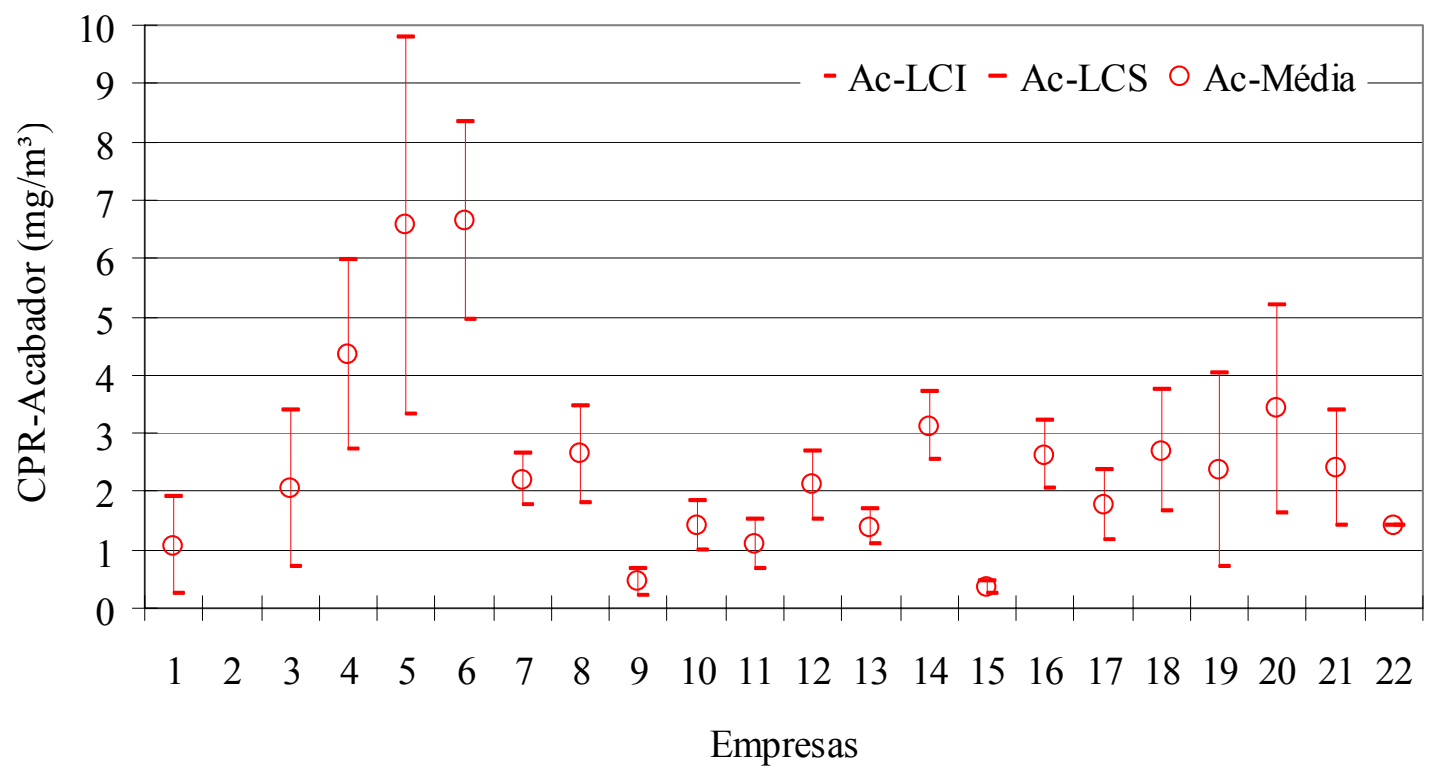

LCI $=$ Limite de confiança inferior

LCS $=$ Limite de confiança superior

Figura 5.4 - Médias e intervalos de confiança (95\%) da concentração de poeira respirável para a função de acabador nas marmorarias estudadas no Município de São Paulo, 2004 -2005 
A Tabela 5.3 apresenta os resultados de concentração média de sílica cristalina respirável por função e por área (ponto fixo), para cada empresa com os respectivos valores de desvio padrão, número de jornadas, limites de confiança de 95\%, índice de exposição e probabilidade do valor ultrapassar o valor de referência de $0,05 \mathrm{mg} / \mathrm{m}^{3}$.

As concentrações médias de sílica cristalina por função de cada empresa foram calculadas, conforme o tem 4.4.1, a partir dos resultados das 486 amostras coletadas, correspondentes a 430 jornadas de trabalho.

O índice de exposição e a probabilidade dos valores de concentração ultrapassar o REL-NIOSH em percentagem foram calculados conforme item 4.4.3.

Estas médias refletem as exposições à silica cristalina contida na poeira (mistura de matérias-primas) das marmorarias durante a amostragem, independente do tipo de operação realizada a seco ou a úmido.

Pode-se observar que a intensidade da exposição à sílica cristalina medida pelo índice de exposição foi alta para a função de acabador. Nas empresas 3, 6, 14 e 20 foram encontrados os maiores índices médios de exposição, indicando que em média os trabalhadores estão expostos a valores de concentração até 9 vezes superiores ao do valor de referência de $0,05 \mathrm{mg} / \mathrm{m}^{3}$. Para as outras empresas foi acima de $1 \mathrm{com}$ exceção das empresas $1,9,15,17$, e 22 .

Entre os cortadores, os índices de exposição mais elevados foram encontrados nas empresas 3, 6 e 14. Estes índices, entre 2,4 e 2,7, podem ser explicados em parte pela utilização mais frequente de rochas silicáticas, com altos teores de quartzo, por estas empresas.

Para as funções de ajudante, polidor e encarregado, a maioria dos índices de exposição se encontravam abaixo de 1 , com exceção do ajudante das empresas 5, 11, 18 e 20 e encarregado da empresa 14. 
Tabela 5.3 - Concentração média de sílica cristalina respirável $\left(\mathrm{mg} / \mathrm{m}^{3}\right)$ por função e para amostras de área nas marmorarias estudadas no Município de São Paulo, 2004-2005

\begin{tabular}{|c|c|c|c|c|c|c|c|c|c|c|c|c|c|c|c|c|c|c|c|c|c|c|c|}
\hline & \multirow{2}{*}{ inções } & \multicolumn{22}{|c|}{ Empresas } \\
\hline & & 1 & 2 & 3 & 4 & 5 & 6 & 7 & 8 & 9 & 10 & 11 & 12 & 13 & 14 & 15 & 16 & 17 & 18 & 19 & 20 & 21 & 22 \\
\hline \multirow{6}{*}{ Média aritmética } & $\mathrm{Ac}$ & 0,019 & & 0,462 & 0,214 & 0,174 & 0,437 & 0,082 & 0,259 & 0,012 & 0,133 & 0,057 & 0,247 & 0,069 & 0,412 & 0,008 & 0,089 & 0,024 & 0,109 & 0,276 & 0,435 & 0,257 & 0,007 \\
\hline & $\mathrm{Aj}$ & 0,024 & & & & 0,092 & & 0,008 & & 0,004 & & 0,071 & 0,036 & 0,020 & & & 0,048 & 0,015 & 0,127 & & 0,060 & & \\
\hline & Co & 0,015 & & 0,136 & 0,041 & 0,070 & 0,116 & 0,012 & 0,047 & 0,005 & 0,041 & 0,047 & 0,044 & 0,007 & 0,123 & 0,004 & 0,047 & 0,006 & 0,052 & 0,034 & 0,041 & 0,043 & 0,017 \\
\hline & Pol & 0,022 & & & & 0,013 & & & & 0,005 & & & & & & & & 0,004 & 0,019 & & & & \\
\hline & Enc & & & & & & & & & & & & & 0,005 & 0,199 & & & & 0,047 & & & & \\
\hline & $\mathrm{Ar}$ & 0,012 & & 0,124 & 0,149 & 0,024 & 0,258 & 0,028 & 0,036 & 0,018 & 0,082 & 0,032 & 0,115 & 0,007 & 0,722 & 0,004 & 0,072 & 0,005 & 0,077 & 0,042 & 0,036 & 0,136 & 0,004 \\
\hline \multirow{6}{*}{ Desvio padrão } & $\mathrm{Ac}$ & 0,009 & & 0,363 & 0,199 & 0,325 & 0,246 & 0,137 & 0,075 & 0,019 & 0,114 & 0,105 & 0,182 & 0,156 & 0,678 & 0,006 & 0,035 & 0,071 & 0,176 & 0,375 & 0,299 & 0,170 & \\
\hline & $\mathrm{Aj}$ & 0,004 & & & & 0,086 & & 0,007 & & 0,000 & & 0,067 & 0,016 & 0,013 & & & 0,039 & 0,015 & 0,181 & & 0,061 & & \\
\hline & Co & 0,019 & & 0,028 & 0,050 & 0,087 & 0,134 & 0,014 & 0,010 & 0,001 & 0,015 & 0,049 & 0,025 & 0,006 & 0,201 & 0,000 & 0,023 & 0,002 & 0,078 & 0,032 & 0,008 & 0,005 & \\
\hline & Pol & 0,004 & & & & 0,003 & & & & & & & & & & & & & 0,011 & & & & \\
\hline & Enc & & & & & & & & & & & & & 0,001 & 0,277 & & & & 0,060 & & & & \\
\hline & $\mathrm{Ar}$ & & & 0,114 & 0,098 & 0,026 & 0,164 & 0,036 & 0,017 & & 0,092 & & 0,107 & 0,002 & 0,965 & 0,002 & $\overline{0,071}$ & 0,001 & 0,063 & 0,048 & 0,016 & 0,091 & \\
\hline \multirow{6}{*}{$\begin{array}{l}\text { Número de } \\
\text { jornadas }\end{array}$} & $\mathrm{Ac}$ & 5 & & 4 & 15 & 11 & 20 & 21 & 3 & 6 & 8 & 8 & 11 & 33 & 18 & 5 & 9 & 28 & 11 & 5 & 6 & 5 & 1 \\
\hline & $\mathrm{Aj}$ & 2 & & & & 3 & & 3 & & 2 & & 3 & 4 & 3 & & & 3 & 8 & 3 & & 2 & & \\
\hline & Co & 6 & & 3 & 3 & 6 & 3 & 8 & 3 & 6 & 2 & 4 & 4 & 6 & 3 & 4 & 3 & 6 & 9 & 3 & 2 & 3 & 1 \\
\hline & Pol & 3 & & & & 2 & & & & 1 & & & & & & & & 1 & 2 & & & & \\
\hline & Enc & & & & & & & & & & & & & 2 & 2 & & & & 3 & & & & \\
\hline & $\mathrm{Ar}$ & 1 & & 3 & 2 & 3 & 3 & 5 & 3 & 1 & 2 & 1 & 7 & 3 & 2 & 4 & 3 & 3 & 3 & 2 & 2 & 3 & 1 \\
\hline \multirow{6}{*}{$\begin{array}{l}\text { LCI }(95 \%) \text { da } \\
\text { média }\end{array}$} & $\mathrm{Ac}$ & 0,011 & & 0,075 & 0,124 & & 0,343 & 0,031 & 0,157 & & 0,058 & & 0,148 & 0,023 & 0,135 & 0,003 & 0,067 & 0,001 & 0,014 & & 0,197 & 0,103 & 0,007 \\
\hline & $\mathrm{Aj}$ & 0,015 & & & & & & & & 0,004 & & & 0,019 & 0,002 & & & & 0,005 & & & & & \\
\hline & Co & & & 0,098 & & 0,001 & & 0,002 & 0,034 & 0,004 & 0,011 & & 0,017 & 0,003 & & 0,004 & 0,016 & 0,004 & 0,004 & & 0,023 & 0,036 & 0,017 \\
\hline & Pol & 0,017 & & & & 0,008 & & & & 0,005 & & & & & & & & 0,004 & & & & & \\
\hline & Enc & & & & & & & & & & & & & 0,003 & & & & & & & & & \\
\hline & $\mathrm{Ar}$ & 0,012 & & & & & 0,035 & & 0,013 & 0,018 & & 0,032 & 0,038 & 0,004 & & 0,002 & & 0,003 & & & 0,002 & 0,012 & 0,004 \\
\hline \multirow{6}{*}{$\begin{array}{l}\text { LCS }(95 \%) \text { da } \\
\text { média }\end{array}$} & $\overline{A c}$ & 0,027 & & 0,850 & 0,304 & 0,349 & 0,532 & 0,133 & 0,361 & 0,027 & 0,208 & 0,126 & 0,345 & 0,115 & 0,690 & 0,013 & 0,110 & 0,047 & 0,204 & 0,614 & 0,672 & 0,410 & 0,007 \\
\hline & $\mathrm{Aj}$ & 0,033 & & & & 0,208 & & 0,017 & & 0,004 & & 0,162 & 0,053 & 0,038 & & & 0,102 & 0,024 & 0,373 & & 0,187 & & \\
\hline & Co & 0,030 & & 0,174 & 0,109 & 0,139 & 0,298 & 0,021 & 0,061 & 0,006 & 0,072 & 0,099 & 0,071 & 0,012 & 0,396 & 0,004 & 0,078 & 0,007 & 0,099 & 0,078 & 0,058 & 0,050 & 0,017 \\
\hline & Pol & 0,028 & & & & 0,018 & & & & 0,005 & & & & & & & & 0,004 & 0,041 & & & & \\
\hline & Enc & & & & & & & & & & & & & 0,007 & 0,771 & & & & 0,128 & & & & \\
\hline & $\mathrm{Ar}$ & 0,012 & & 0,279 & 0,352 & 0,060 & 0,480 & 0,060 & 0,059 & 0,018 & 0,271 & 0,032 & 0,191 & 0,010 & 2,715 & 0,006 & 0,169 & 0,006 & 0,163 & 0,141 & 0,070 & 0,259 & 0,004 \\
\hline \multirow{6}{*}{$\begin{array}{c}\text { Probabilidade de } \\
\text { ultrapassar o } \\
\text { REL-NIOSH }\end{array}$} & $\mathrm{Ac}$ & 0,0 & & 87,2 & $\begin{array}{l}79,6 \\
\end{array}$ & 64,8 & 94,2 & \begin{tabular}{|l}
59,3 \\
\end{tabular} & 99,7 & 2,1 & 76,5 & \begin{tabular}{|l|l}
52,8 \\
\end{tabular} & 86,0 & \begin{tabular}{|l|l}
54,9 \\
\end{tabular} & 70,3 & 0,0 & 86,4 & $\begin{array}{l}35,9 \\
\end{array}$ & 63,2 & 72,7 & 90,1 & 88,8 & \\
\hline & $\mathrm{Aj}$ & 0,0 & & & & $\begin{array}{ll}68,8 \\
\end{array}$ & & 0,0 & & & & 62,3 & 19,6 & 1,2 & & & 488,2 & 0,8 & 666,6 & & 56,7 & & \\
\hline & Co & 3,6 & & 99,9 & 43,0 & 59,1 & 68,8 & 0,4 & 38,8 & & 27,8 & 47,5 & 40,4 & 0,0 & $\begin{array}{ll}64,1 \\
\end{array}$ & & 44,4 & & 50,9 & 30,6 & 13,2 & 8,1 & \\
\hline & Pol & 0,0 & & & & & & & & & & & & & & & & & 0,2 & & & & \\
\hline & Enc & & & & & & & & & & & & & & 70,5 & & & & 47,9 & & & & \\
\hline & $\mathrm{Ar}$ & & & 74,1 & 84,3 & 16,3 & 89,8 & 27,1 & 19,9 & & 63,5 & & 72,8 & & 75,7 & & 62,2 & & 66,7 & 43,5 & 19,4 & 82,7 & \\
\hline \multirow{6}{*}{$\begin{array}{l}\text { Índice de } \\
\text { exposição }\end{array}$} & $\mathrm{Ac}$ & 0,4 & & 9,2 & 4,3 & 3,5 & 8,7 & 1,6 & 5,2 & 0,2 & 2,7 & 1,1 & 4,9 & 1,4 & 8,2 & 0,2 & 1,8 & 0,5 & 2,2 & 5,5 & 8,7 & 5,1 & $\overline{0,1}$ \\
\hline & $\mathrm{Aj}$ & 0,5 & & & & 1,8 & & 0,2 & & 0,1 & & 1,4 & 0,7 & 0,4 & & & 1,0 & 0,3 & 2,5 & & 1,2 & & \\
\hline & $\begin{array}{ll}\text { Co } \\
\end{array}$ & 0,3 & & 2,7 & 0,8 & 1,4 & 2,3 & 0,2 & 0,9 & 0,1 & 0,8 & 0,9 & 0,9 & 0,1 & 2,5 & 0,1 & 0,9 & 0,1 & 1,0 & 0,7 & 0,8 & 0,9 & $\overline{0,3}$ \\
\hline & Pol & 0,4 & & & & 0,3 & & & & 0,1 & & & & & & & & 0,1 & 0,4 & & & & \\
\hline & Enc & & & & & & & & & & & & & 0,1 & 4,0 & & & & 0,9 & & & & \\
\hline & $\mathrm{Ar}$ & 0,2 & & 2,5 & 3,0 & 0,5 & 5,2 & 0,6 & 0,7 & 0,4 & 1,6 & 0,6 & 2,3 & 0,1 & 14,4 & 0,1 & 1,4 & 0,1 & 1,5 & 0,8 & 0,7 & 2,7 & $\overline{0,1}$ \\
\hline
\end{tabular}


A Figura 5.5 apresenta a probabilidade da concentração média de sílica cristalina ultrapassar o valor de referência $\left(0,05 \mathrm{mg} / \mathrm{m}^{3}\right)$ para as funções de acabador e de cortador. Essa probabilidade para as empresas números 3, 4, 5, 6, 7, 8, 10, 11, 12, 13 , $14,16,17,18,19,20,21$, para a função de acabador, em porcentagem, foi muito superior a 5\%, representando $81 \%$ das marmorarias estudadas para as quais havia a função. Isto demonstra a ocorrência de exposição excessiva dos acabadores.

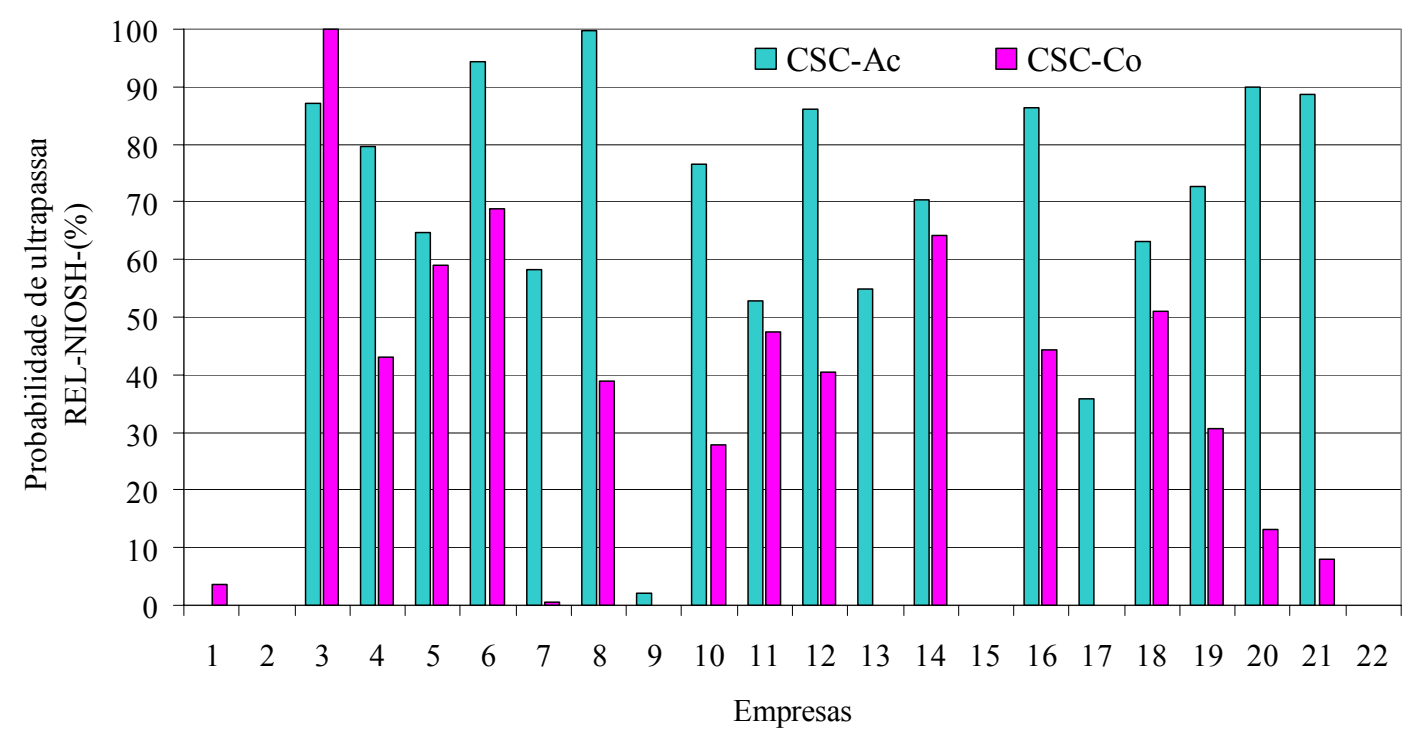

Figura 5.5 - Probabilidade da concentração de sílica cristalina na fração respirável (C-SC) ultrapassar o valor do REL-NIOSH para as funções de acabador e cortador nas 22 marmorarias estudadas no Município de São Paulo, 2004- 2005

Ainda com relação à função de acabador, nas empresas 1,9 e 15 se observa que os resultados encontrados de concentração média de sílica cristalina respirável apresentaram probabilidade menor que 5\% de ultrapassar o valor de referência. Estas empresas realizaram parcialmente a etapa de acabamento a úmido, no entanto, foram processados mármores ou granitos com baixo teor de sílica cristalina, e a mudança de matéria-prima para outra, com altos teores de sílica, poderá alterar este panorama. É o caso da empresa número 17 , que processou muito mármore durante a amostragem e num dos dias que processou granito o valor de referência foi ultrapassado. 
Existe probabilidade superior a $5 \%$ da concentração média de sílica cristalina respirável ultrapassar o valor de referência nas empresas números $3,4,5,6,8,10$, $11,12,14,16,18,19,20$ e 21 para a função de cortador, representando $67 \%$ das empresas estudadas para as quais havia a função. Comparando-se estes dados com o índice de exposição, verifica-se que nas empresas números 3, 6, e 14 a severidade da exposição é maior. Nestas empresas foram cortadas matérias-primas com altos teores de sílica, por exemplo, na empresa 3 o Amarelo Ornamental, na empresa 5 o Branco Ituanas, na empresa 6 o Cinza Corumbá e na empresa 14 o Branco Aqualux. $\mathrm{Na}$ empresa 7 foram cortados vários tipos de mármores e granitos com serra convencional e serra ponte. $\mathrm{Na}$ empresa 13 foram cortadas matérias-primas com baixos teores de sílica cristalina como, por exemplo, o mármore Branco Tasso usinado. Embora a etapa de corte no processo de produção seja a úmido, é provável que o tipo de máquina de corte tenha influência na exposição. Na operação da serra convencional o trabalhador ficava muito próximo ao disco de corte enquanto que a operação da serra-ponte era realizada a distância do disco.

A Figura 5.6 apresenta a probabilidade da concentração de sílica cristalina respirável ultrapassar o valor de referência de $0,05 \mathrm{mg} / \mathrm{m}^{3}$ por empresa para as funções de polidor, ajudante e encarregado e para amostras de área.

Existe probabilidade maior que $5 \%$ da concentração média de sílica cristalina ultrapassar o valor de referência para as amostras de área (ponto fixo) nas empresas $3,4,5,6,7,8,10,12,14,16,18,19,20$ e 21 , representando $67 \%$ das marmorarias. Estes resultados demonstram claramente que existia poeira excessiva nos ambientes de trabalho das marmorarias. Todas estas empresas realizavam a etapa de acabamento a seco e como os dispositivos de amostragem foram posicionados em um ponto fixo entre o setor de acabamento e o setor de corte, estes resultados explicam em parte a exposição das funções de cortador e de ajudante devido à dispersão da poeira de um setor para o outro. 


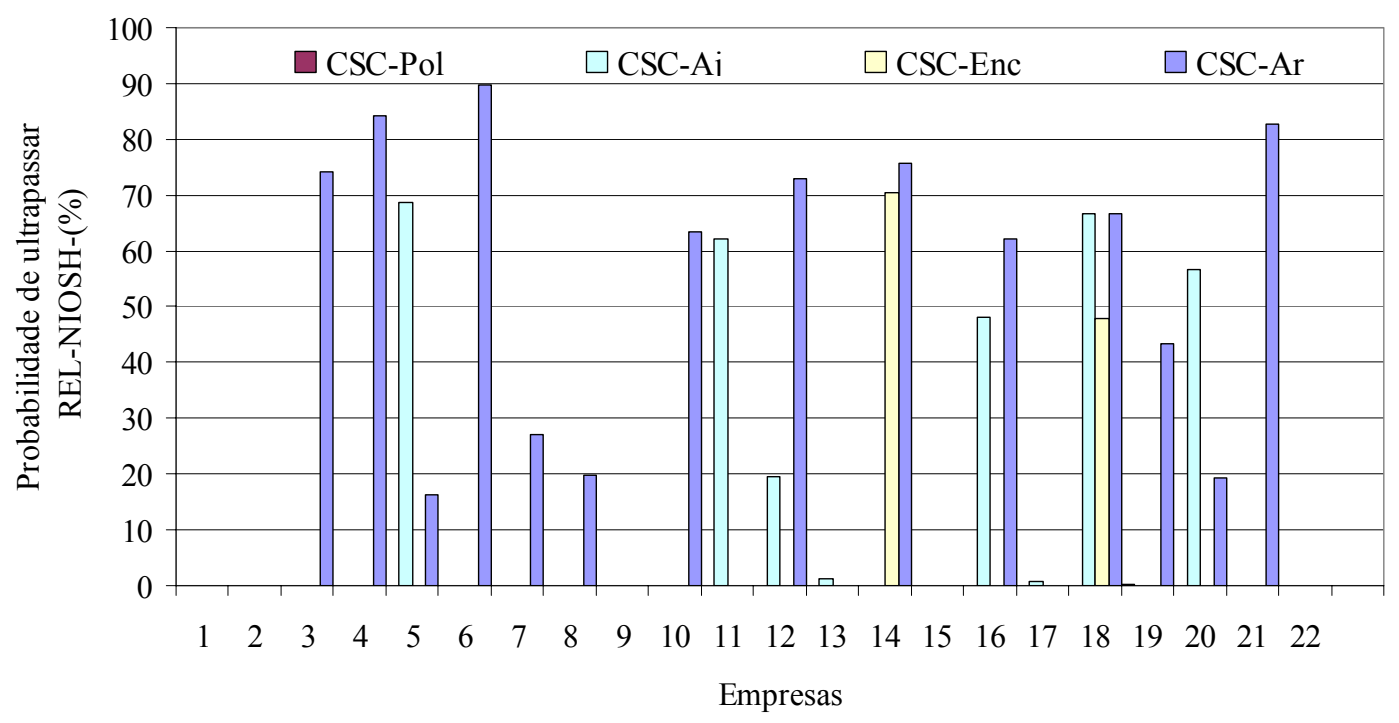

Figura 5.6 - Probabilidade da concentração de sílica cristalina respirável (C-SC) ultrapassar o valor do REL-NIOSH nas funções de polidor, ajudante e encarregado e para amostras de área nas marmorarias estudadas no Município de São Paulo, 2004 - 2005

Existe probabilidade superior a $5 \%$ da concentração de sílica cristalina respirável ultrapassar o valor de referência nas empresas números $5,11,12,16,18$ e 20 para a função de ajudante, representando $55 \%$ das marmorarias para as quais havia a função. Na empresa 5, o ajudante estava em treinamento para a função de acabador, nas empresas 11, 16 e 18 os ajudantes auxiliavam no setor de corte e estavam em treinamento para exercer a função de cortador. Nestas empresas as cortadeiras eram do tipo convencional. Na empresa 5, o ajudante realizou a etapa de acabamento com ferramentas que funcionavam a seco e outras a úmido, no entanto, processou vários tipos de granitos e mármores, sendo alguns granitos com altos teores de sílica cristalina, como Branco Itaúnas. Na empresa 11 as matérias-primas cortadas tinham altos teores de sílica cristalina - eram na maioria arenitos. Na empresa 12 o ajudante tinha como atividade principal o lixamento e brilho com água e auxiliava o cortador. Nas empresas 12, 16 e 18 foram cortados vários tipos de matérias-primas, com predominância para o granito. 
Para os polidores os valores encontrados não ultrapassaram os valores de referência, enquanto para os encarregados, em $67 \%$ das empresas onde existia a função os valores ultrapassaram o valor de referência.

A Figura 5.7 apresenta a representação gráfica da concentração média de sílica cristalina respirável e seu o intervalo de confiança para a função de acabador por empresa.

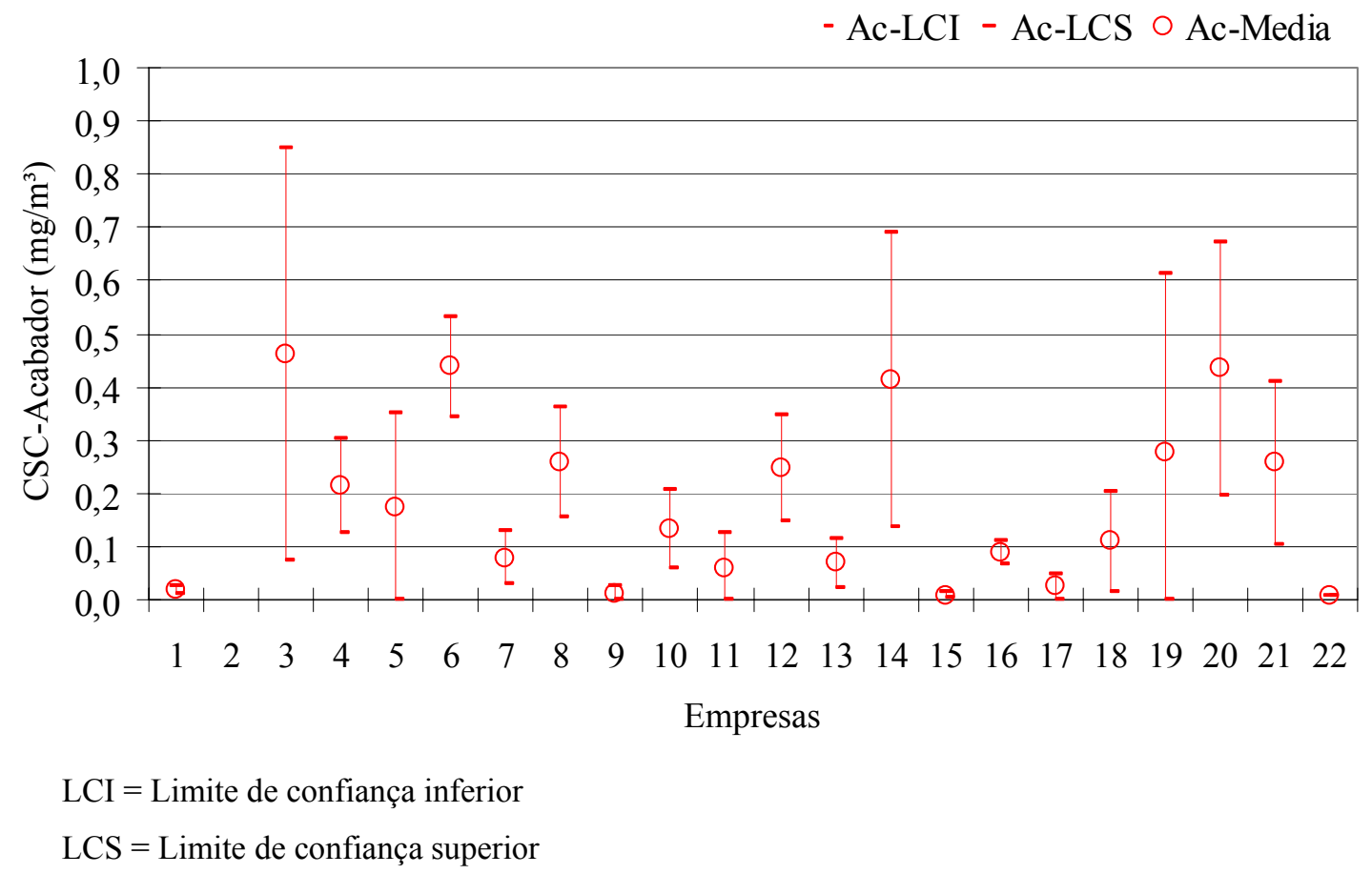

Figura 5.7 - Média e intervalo de confiança de 95\% da concentração de sílica cristalina respirável, para a função de acabador nas marmorarias estudadas, no Município de São Paulo, 2004 - 2005

A maior variabilidade para a concentração média de sílica cristalina respirável foi encontrada para os acabadores das empresas 3,14, 19 e 20 devido principalmente à utilização de vários tipos de tipos de matérias-primas, por não existirem medidas de controle de poeira adequadas ou por estas medidas serem insuficientes. 
Os resultados obtidos para as concentrações médias de sílica cristalina respirável por função e por empresa foram utilizados nos cálculos de exposição acumulada do Modelo 1, conforme descrito no item 4.4.4.

\subsubsection{Resultados for função para o Município de São Paulo}

As concentrações médias de poeira e sílica cristalina respirável por função para o Município de São Paulo foram calculadas a partir das 566 amostras de PR (507 jornadas) e das 486 amostras de SC (430 jornadas) conforme os itens de 4.4.1. As probabilidades dos valores de concentração média de sílica ultrapassar o valor de referência foram calculadas conforme item 4.4.3 e expressas em porcentagem. As Tabelas 5.4 e 5.5 apresentam os resultados encontrados para estas concentrações e seus respectivos parâmetros estatísticos.

Tabela 5.4 - Concentração média de poeira respirável por função e para amostras de área nas 22 marmorarias estudadas, no Município de São Paulo, 2004 - 2005

\begin{tabular}{|c|c|c|c|c|c|}
\hline \multicolumn{6}{|c|}{ CPR-SP (f) ( $\left.\mathrm{mg}^{\prime} \mathrm{m}^{3}\right)$} \\
\hline & LCI & Média & $\mathrm{LCS}$ & $D P$ & $n j$ \\
\hline $\mathrm{Ac}$ & 2,58 & 2,93 & 3,28 & 3,43 & 256 \\
\hline $\mathrm{Aj}$ & 0,49 & 0,68 & 0,88 & 0,81 & 48 \\
\hline Co & 0,49 & 0,64 & 0,78 & 0,87 & 105 \\
\hline Pol & 0,16 & 0,25 & 0,33 & 0,19 & 16 \\
\hline Enc & 0,29 & 0,57 & 0,84 & 0,53 & 12 \\
\hline \multirow[t]{2}{*}{ Ar } & 0,60 & 0,75 & 0,90 & 0,75 & 70 \\
\hline & & & & & 507 \\
\hline \multicolumn{6}{|c|}{ LCI = Limite inferior de confiança ( $95 \%$ - distribuição t) } \\
\hline \multicolumn{6}{|c|}{ Média = Média aritmética } \\
\hline \multicolumn{6}{|c|}{ LCS = Limite superior de confiança ( $95 \%$ - distribuição t) } \\
\hline \multicolumn{6}{|c|}{$\mathrm{DP}=$ Deswio padrão aritmético } \\
\hline \multicolumn{6}{|c|}{$\mathrm{nj}=$ número de jornadas } \\
\hline
\end{tabular}


Tabela 5.5 - Concentração média de sílica cristalina respirável por função e para amostras de área, nas 22 marmorarias estudadas, no Município de São Paulo, 2004 -2005

\begin{tabular}{|c|c|c|c|c|c|c|c|}
\hline \multicolumn{8}{|c|}{ CSC-SP (f) $\quad\left(\mathrm{mg} / \mathrm{m}^{3}\right)$} \\
\hline & LCI & Média & LCS & $D P$ & $\%>R E L$ & $I E$ & $n i$ \\
\hline $\mathrm{Ac}$ & 0,142 & 0,173 & 0,204 & 0,289 & 66,5 & 3,5 & 233 \\
\hline $\mathrm{Aj}$ & 0,025 & 0,043 & 0,061 & 0,064 & 45,6 & 0,9 & 36 \\
\hline $\mathrm{Co}$ & 0,029 & 0,040 & 0,051 & 0,062 & 43,4 & 0,8 & 88 \\
\hline Pol & 0,010 & 0,016 & 0,021 & 0,008 & 0,0 & 0,3 & 9 \\
\hline Enc & & 0,079 & 0,183 & 0,145 & 57,8 & 1,6 & 7 \\
\hline \multirow[t]{2}{*}{ Ar } & 0,049 & 0,093 & 0,137 & 0,198 & 58,6 & 1,9 & 57 \\
\hline & & & & & & & 430 \\
\hline \multicolumn{8}{|c|}{ LCI $=$ Limite inferior de confiança (95\% - distribuição $\mathrm{t}$ ) } \\
\hline \multicolumn{8}{|c|}{ Média = Média aritmética } \\
\hline \multicolumn{8}{|c|}{ LCS $=$ Limite superior de confiança $(95 \%$ - distribuição $t)$} \\
\hline \multicolumn{8}{|c|}{$\mathrm{DP}=\mathrm{Desuro}$ padrão aritmético } \\
\hline \multicolumn{8}{|c|}{$\mathrm{nj}=$ número de jornadas } \\
\hline \multicolumn{8}{|c|}{$\% \gg \mathrm{REL}=$ Probabilidade de ultrapassar $\circ$ valor de referência } \\
\hline \multicolumn{8}{|c|}{$\mathbb{E}=$ Indice de Exposição } \\
\hline
\end{tabular}

A Figura 5.8 apresenta as concentrações médias de sílica cristalina respirável e seus intervalos de confiança de 95\% por função e para as amostras de área. Estas médias correspondem às misturas de poeiras minerais, em suspensão no ar das marmorarias durante a amostragem, independente do tipo de matéria-prima e de operação realizada, a seco ou a úmido. A função de acabador apresentou a maior média.

A maior variabilidade encontra-se na média da função de encarregado, pois os trabalhadores que possuíam esta função realizavam diversas atividades ao mesmo tempo. A coleta de amostras de ar e número reduzido de jornadas de trabalho estudadas são fatores que contribuíram para esta dispersão. 


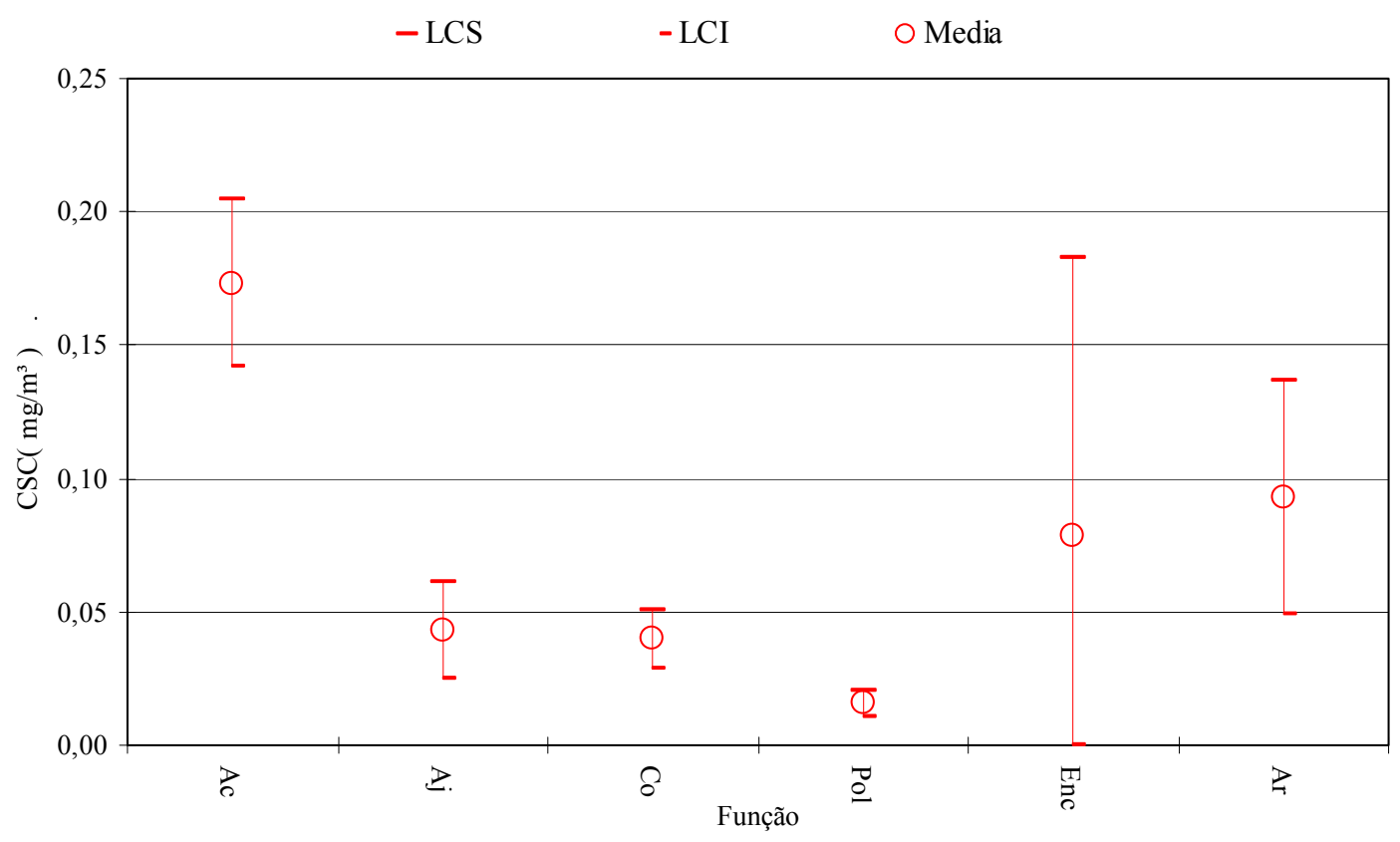

Figura 5.8 - Média e intervalo de confiança de 95\% da concentração de sílica cristalina respirável segundo a função dos trabalhadores nas 22 marmorarias estudadas, no Município de São Paulo, 2004 -2005

\subsubsection{Resultados for função e tipo de operação para o Município de São Paulo}

As concentrações médias de poeira e de sílica cristalina respirável por função e por tipo de operação para o Município de São Paulo foram obtidas por estratificação das amostras, utilizando banco de dados e planilha eletrônica, conforme descrito no item 4.4, e calculadas conforme apresentado no item 4.4.1. As Tabelas 5.6 e 5.7 apresentam os resultados encontrados para estas concentrações e seus respectivos parâmetros estatísticos. 
Tabela 5.6 - Concentração média de poeira respirável por função e para amostras de área, por tipo de operação, nas 22 marmorarias estudadas, no Município de São Paulo, 2004 - 2005

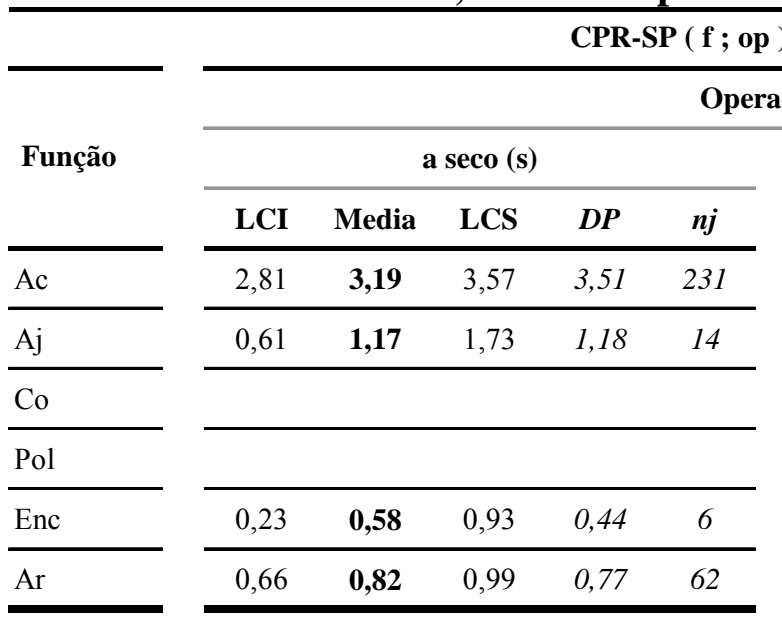

LCI $=$ Limite inferior de confiança ( $95 \%$ - distribuição t ) Media $=$ Média aritmética

LCS = Limite superior de confiança ( $95 \%$ - distribuição t )

$\mathrm{DP}=$ Desvio padrão aritmético

$\mathrm{nj}=$ número de jornadas

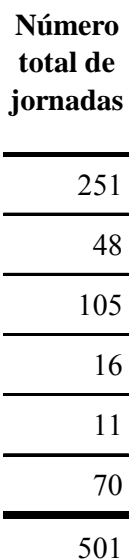

Tabela 5.7 - Concentração média de sílica cristalina respirável por função e para amostras de área, por tipo de operação, nas 22 marmorarias estudadas, no Município de São Paulo, 20042005

\begin{tabular}{|c|c|c|c|c|c|c|c|c|c|c|c|c|c|c|c|}
\hline \multicolumn{16}{|c|}{ CSC-SP ( f ; op ) $\left(\mathrm{mg} / \mathrm{m}^{3}\right)$} \\
\hline \multirow{3}{*}{ Função } & \multicolumn{14}{|c|}{ Operação } & \multirow{3}{*}{$\begin{array}{c}\text { Número } \\
\text { total de } \\
\text { jornadas }\end{array}$} \\
\hline & \multicolumn{7}{|c|}{ a seco (s) } & \multicolumn{7}{|c|}{ a úmido (u) } & \\
\hline & LCI & Média & LCS & $D P$ & $\%>R E L$ & $I E$ & $n j$ & LCI & Média & LCS & $D P$ & $\%>R E L$ & $I E$ & $n j$ & \\
\hline Ac & 0,158 & 0,192 & 0,226 & 0,300 & 68,2 & 3,8 & 209 & 0,007 & 0,010 & 0,013 & 0,008 & 0,0 & 0,2 & 19 & 228 \\
\hline $\mathrm{Aj}$ & & 0,048 & 0,096 & 0,094 & 49,1 & 1,0 & 12 & 0,024 & 0,040 & 0,056 & 0,045 & 41,5 & 0,8 & 24 & 36 \\
\hline Co & & & & & & & & 0,029 & 0,040 & 0,051 & 0,062 & 43,4 & 0,8 & 88 & 88 \\
\hline Pol & & & & & & & & 0,010 & 0,016 & 0,021 & 0,008 & 0,0 & 0,3 & 9 & 9 \\
\hline Enc & & 0,108 & 0,258 & 0,167 & 63,6 & 2,2 & 5 & 0,003 & 0,005 & 0,007 & 0,001 & & 0,1 & 2 & 7 \\
\hline $\mathrm{Ar}$ & 0,053 & $\mathbf{0 , 1 0 0}$ & 0,147 & 0,204 & 59,6 & & 53 & 0,002 & 0,004 & 0,006 & 0,002 & & 0,1 & 4 & 57 \\
\hline
\end{tabular}

LCI = Limite inferior de confiança ( $95 \%$ - distribuição t )

$\mathrm{DP}=$ Desvio padrão aritmético

Média $=$ Média aritmética

$\mathrm{nj}=$ número de jornadas

LCS $=$ Limite superior de confiança ( $95 \%$ - distribuição $\mathrm{t}$ )

$\%>\mathrm{REL}=$ Probabilidade de ultrapassar $\mathrm{o}$ valor de Referência

$\mathrm{IE}=$ Índice de Exposição 
As diferenças entre as concentrações médias de poeira respirável de operações a seco e operações a úmido, apresentadas na Tabela 5.6, foram significativas. Para a função de acabador, por exemplo, a diferença foi de aproximadamente 7 vezes (a seco a concentração era de $3,2 \mathrm{mg} / 3$ e a úmido era $0,49 \mathrm{mg} / \mathrm{m}^{3}$. A diferença na concentração de poeira respirável foi verificada para todas as funções que tinham operações a seco e para as amostras de área.

Os resultados de concentração média de sílica cristalina respirável, para o Município de São Paulo, obtidos nas operações realizadas a úmido apresentados na Tabela 5.7 encontram-se todos abaixo do valor de referência. Existe probabilidade em torno de $50 \%$ do valor de referência ser ultrapassado nas funções de ajudante e cortador. No entanto, os índices de exposição encontram-se abaixo de 1, demonstrando que a intensidade de exposição apresenta-se bem reduzida em relação às operações a seco.

A maior diferença da concentração média de sílica cristalina respirável foi para a função de acabador. A concentração a seco era de $0,19 \mathrm{mg} / \mathrm{m}^{3}$ e a úmido, $0,01 \mathrm{mg} / \mathrm{m}^{3}$, uma diferença de 19 vezes. Um outro indicador importante é o índice de exposição, que nas operações a seco apresentou valor 3,8 vezes maior que o valor de referência, e nas operações a úmido o valor era 0,2 vezes o valor de referência. Os resultados de operações a seco e a úmido serão discutidos com maiores detalhes no item 5.3.

A Figura 5.9 apresenta as concentrações médias de sílica cristalina respirável e seus intervalos de confiança de $95 \%$ por função e para as amostras de área. Estes resultados correspondem ao tipo de operação a seco ou a úmido, independentemente das matérias-primas.

A função de acabador com as operações a seco apresenta a maior média, seguida pela média das amostras de área. As amostras de área representam a dispersão da poeira vinda do setor de acabamento e, portanto, a média obtida revela que existe alta concentração de sílica cristalina respirável nos ambientes das marmorarias com processamento a seco. 


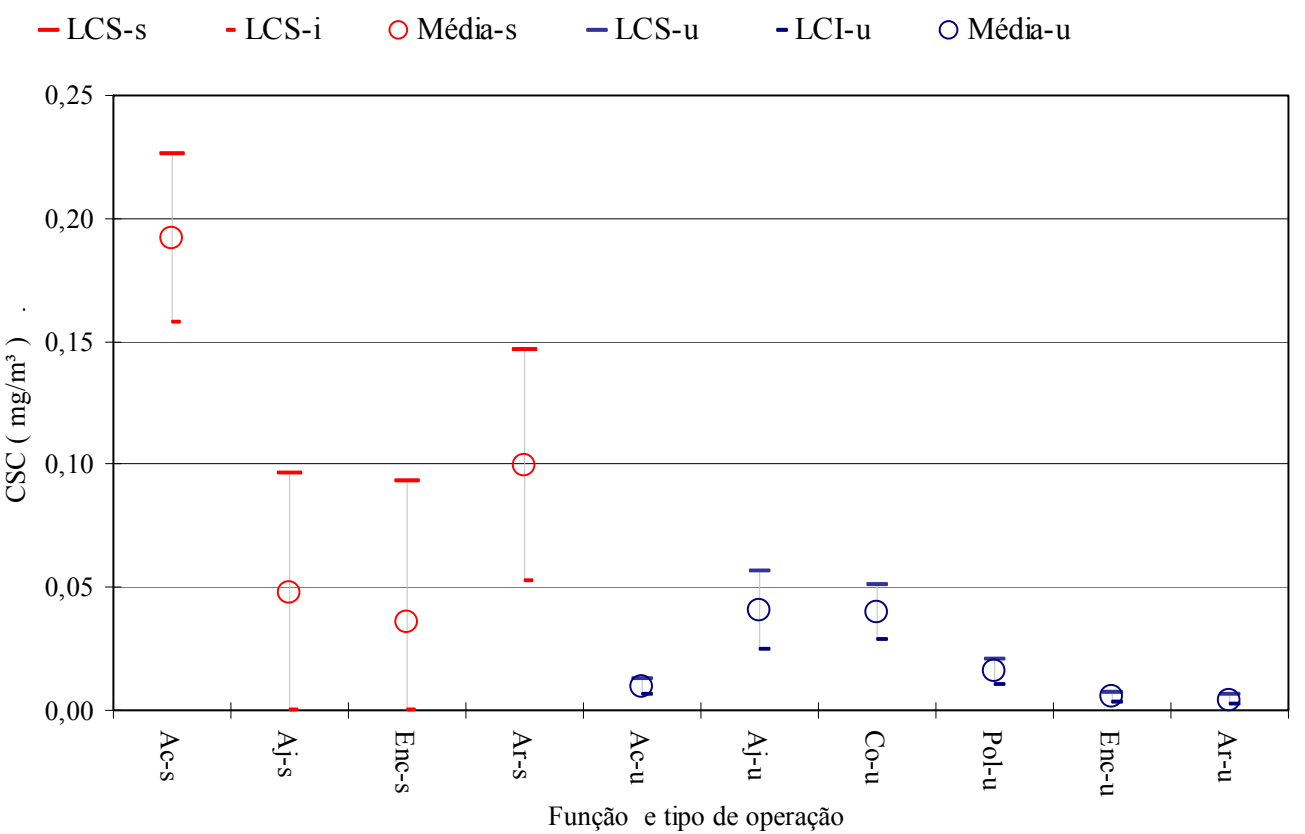

Figura 5.9 - Média e intervalo de confiança de 95\% para concentração de sílica cristalina respirável segundo a função e o tipo de operação (a seco e a úmido) nas 22 marmorarias estudadas, no Município de São Paulo, 2004 - 2005

As médias apresentadas na Tabela 5.7 foram utilizadas nos modelos de exposição acumulada à sílica cristalina para estimativa de risco de silicose. No Modelo 1 estas médias foram utilizadas nas funções referidas no histórico ocupacional. No Modelo 2 foram aplicadas para todas as funções em todo tempo de trabalho em marmorarias.

\subsubsection{Resultados por função, matéria-prima e tipo de operação para o Município} de São Paulo

As concentrações médias de poeira e de sílica cristalina respirável por função, matéria-prima e tipo de operação para o Município de São Paulo foram obtidas a partir de amostras de ar coletadas com somente um tipo de matéria-prima. A seleção 
destas amostras foi realizada por meio de consulta ao banco de dados conforme descrito no item 4.4 e calculadas 4.4.1. As Tabelas 5.8 e 5.9 apresentam respectivamente as médias de poeira e sílica cristalina respirável e seus parâmetros estatísticos.

Tabela 5.8 - Concentração média de poeira respirável por função e para amostras de área, por tipo de operação e de matéria-prima, nas 22 marmorarias estudadas, no Município de São Paulo, 20042005

\begin{tabular}{|c|c|c|c|c|c|c|c|c|c|c|}
\hline & \multirow{4}{*}{ Função } & \multirow{2}{*}{\multicolumn{3}{|c|}{ CPR-SP ( f ; mat ) }} & \multicolumn{6}{|c|}{ CPR-SP ( f ; mat ; op ) } \\
\hline & & & & & \multicolumn{6}{|c|}{ Operação } \\
\hline & & \multirow{2}{*}{ Granito } & \multirow{2}{*}{ Ardósia } & \multirow{2}{*}{ Mármore } & & a seco (s) & & & úmido (u & \\
\hline & & & & & Granito & Ardósia & Mármore & Granito & Ardósia & Mármore \\
\hline \multirow{6}{*}{$\begin{array}{l}\text { Média aritmética } \\
\left(\mathrm{mg} / \mathrm{m}^{3}\right)\end{array}$} & Ac & 3,93 & 3,22 & 1,92 & 4,25 & 3,22 & 2,10 & 0,50 & & $\overline{0,49}$ \\
\hline & $\mathrm{Aj}$ & 0,62 & 0,37 & 1,18 & 1,07 & & 1,18 & 0,49 & 0,37 & \\
\hline & Co & 0,71 & 0,38 & 0,43 & & & & 0,71 & 0,38 & 0,43 \\
\hline & Pol & 0,25 & & 0,18 & & & & 0,25 & & 0,18 \\
\hline & Enc & 0,64 & & 0,49 & 1,00 & & & 0,17 & & 0,49 \\
\hline & $\mathrm{Ar}$ & 1,00 & & 0,28 & 1,05 & & 0,30 & 0,06 & & 0,23 \\
\hline \multirow{6}{*}{ Desvio Padrão } & $\overline{\mathrm{Ac}}$ & 5,48 & 2,20 & 1,95 & 5,62 & 2,20 & 2,01 & 0,45 & & 0,46 \\
\hline & $\mathrm{Aj}$ & 0,65 & 0,20 & 1,56 & 0,89 & & 1,56 & 0,52 & 0,20 & \\
\hline & $\mathrm{Co}$ & 1,11 & 0,01 & 0,31 & & & & 1,11 & 0,01 & 0,31 \\
\hline & Pol & 0,21 & & 0,19 & & & & 0,21 & & 0,19 \\
\hline & Enc & 0,60 & & 0,02 & 0,56 & & & 0,11 & & 0,02 \\
\hline & $\mathrm{Ar}$ & 0,98 & & 0,18 & 0,98 & & $\overline{0,21}$ & 0,08 & & 0,03 \\
\hline \multirow{6}{*}{ Número de amostras } & $\mathrm{Ac}$ & 165 & 5 & 77 & 151 & 5 & 68 & 11 & & 7 \\
\hline & $\mathrm{Aj}$ & 22 & 3 & 4 & 5 & & 4 & 17 & 3 & \\
\hline & $\mathrm{Co}$ & 42 & 2 & 18 & & & & 42 & 2 & 18 \\
\hline & Pol & 6 & & 7 & & & & 6 & & 7 \\
\hline & Enc & 7 & & 2 & 4 & & & 3 & & 2 \\
\hline & $\mathrm{Ar}$ & 38 & & 7 & 36 & & 5 & 2 & & 2 \\
\hline \multirow{6}{*}{$\begin{array}{c}\text { LCI } \\
(95 \% \text { da média })\end{array}$} & Ac & 3,23 & 1,23 & 1,55 & 3,49 & 1,23 & 1,69 & 0,26 & & 0,17 \\
\hline & $\mathrm{Aj}$ & 0,38 & 0,11 & & 0,26 & & & 0,27 & 0,11 & \\
\hline & $\mathrm{Co}$ & 0,43 & 0,37 & 0,31 & & & & 0,43 & 0,37 & 0,31 \\
\hline & Pol & 0,09 & & 0,04 & & & & 0,09 & & 0,04 \\
\hline & Enc & 0,21 & & 0,45 & 0,40 & & & 0,02 & & 0,45 \\
\hline & $\mathrm{Ar}$ & 0,73 & & 0,15 & 0,78 & & 0,11 & & & 0,18 \\
\hline \multirow{6}{*}{$\begin{array}{c}\text { LCS } \\
(95 \% \text { da média })\end{array}$} & $\mathrm{Ac}$ & 4,64 & 5,20 & 2,29 & 5,01 & 5,20 & 2,51 & 0,75 & & 0,82 \\
\hline & $\mathrm{Aj}$ & 0,86 & 0,64 & 2,84 & 1,87 & & 2,84 & 0,71 & 0,64 & \\
\hline & $\mathrm{Co}$ & 1,00 & 0,39 & 0,56 & & & & 1,00 & 0,39 & 0,56 \\
\hline & Pol & 0,42 & & 0,31 & & & & 0,42 & & 0,31 \\
\hline & Enc & 1,07 & & 0,54 & 1,59 & & & 0,31 & & 0,54 \\
\hline & $\mathrm{Ar}$ & 1,27 & & 0,41 & 1,33 & & 0,49 & 0,23 & & 0,29 \\
\hline
\end{tabular}

Os maiores valores de concentrações médias de poeira respirável foram encontradas para a função de acabador nas operações realizadas a seco e com granito (rochas silicáticas) como matéria-prima. Foi encontrada uma concentração de poeira respirável igual a $4,25 \mathrm{mg} / \mathrm{m}^{3}$ para o granito, $3,22 \mathrm{mg} / \mathrm{m}^{3}$ para a ardósia e $2,10 \mathrm{mg} / \mathrm{m}^{3}$ para o mármore. 
As operações a seco realizadas pelo acabador envolviam a utilização de ferramentas de corte, desbaste e lixamento. $\mathrm{O}$ granito era a rocha mais dura, entre as três, e era necessária a utilização intensa das ferramentas, em especial da lixadeira com disco diamantado, para o desbaste das peças, com geração de altas concentrações de poeira.

Tabela 5.9 - Concentração média de sílica cristalina respirável por função e para amostras de área, por tipo de operação e de matéria-prima, nas 22 marmorarias estudadas, no Município de São Paulo, 20042005

\begin{tabular}{|c|c|c|c|c|}
\hline & \multirow{2}{*}{ Função } & \multicolumn{3}{|c|}{ CSC-SP ( f ; mat ) } \\
\hline & & Granito & Ardósia & Mármore \\
\hline \multirow{6}{*}{$\begin{array}{l}\text { Média aritmética } \\
\qquad\left(\mathrm{mg} / \mathrm{m}^{3}\right)\end{array}$} & Ac & 0,324 & 0,473 & 0,019 \\
\hline & $\mathrm{Aj}$ & 0,043 & 0,060 & 0,005 \\
\hline & $\mathrm{Co}$ & 0,058 & 0,041 & 0,006 \\
\hline & Pol & 0,022 & & 0,007 \\
\hline & Enc & 0,106 & & 0,005 \\
\hline & $\mathrm{Ar}$ & 0,183 & & 0,006 \\
\hline \multirow{6}{*}{ Desvio Padrão } & $\mathrm{Ac}$ & 0,428 & 0,347 & 0,047 \\
\hline & $\mathrm{Aj}$ & 0,035 & 0,061 & 0,001 \\
\hline & $\mathrm{Co}$ & 0,088 & 0,008 & 0,005 \\
\hline & Pol & 0,004 & & 0,004 \\
\hline & Enc & 0,193 & & 0,001 \\
\hline & $\mathrm{Ar}$ & 0,439 & & 0,003 \\
\hline \multirow{6}{*}{ Número de amostras } & Ac & 149 & 5 & 72 \\
\hline & $\mathrm{Aj}$ & 15 & 2 & 4 \\
\hline & $\mathrm{Co}$ & 33 & 2 & 15 \\
\hline & Pol & 3 & & 3 \\
\hline & Enc & 4 & & 2 \\
\hline & $\mathrm{Ar}$ & 33 & & 5 \\
\hline \multirow{6}{*}{$\begin{array}{c}\text { LCI } \\
(95 \% \text { da média })\end{array}$} & Ac & 0,266 & 0,160 & 0,010 \\
\hline & $\mathrm{Aj}$ & 0,027 & & 0,004 \\
\hline & $\mathrm{Co}$ & 0,032 & 0,023 & 0,004 \\
\hline & Pol & 0,017 & & 0,001 \\
\hline & Enc & & & 0,003 \\
\hline & $\mathrm{Ar}$ & 0,053 & & 0,003 \\
\hline \multirow{6}{*}{$\begin{array}{c}\text { LCS } \\
(95 \% \text { da média })\end{array}$} & Ac & 0,382 & 0,786 & 0,028 \\
\hline & $\mathrm{Aj}$ & 0,058 & 0,187 & 0,006 \\
\hline & Co & 0,084 & 0,058 & 0,009 \\
\hline & Pol & 0,028 & & 0,012 \\
\hline & Enc & 0,311 & & 0,007 \\
\hline & $\mathrm{Ar}$ & 0,312 & & 0,008 \\
\hline \multirow{6}{*}{$\begin{array}{c}\text { Probabilidade de } \\
\text { ultrapassar o } \\
\text { REL-NIOSH }\end{array}$} & Ac & 73,9 & 88,8 & 25,2 \\
\hline & $\mathrm{Aj}$ & 41,7 & 56,7 & \\
\hline & $\mathrm{Co}$ & 53,6 & 13,2 & \\
\hline & Pol & 0,0 & & \\
\hline & Enc & 61,4 & & \\
\hline & $\mathrm{Ar}$ & 61,9 & & \\
\hline \multirow{6}{*}{ Índice de Exposição } & Ac & 6,5 & 9,5 & 0,4 \\
\hline & $\mathrm{Aj}$ & 0,9 & 1,2 & 0,1 \\
\hline & Co & 1,2 & 0,8 & 0,1 \\
\hline & Pol & 0,4 & & 0,1 \\
\hline & Enc & 2,1 & & 0,1 \\
\hline & $\mathrm{Ar}$ & 3,7 & & 0,1 \\
\hline
\end{tabular}

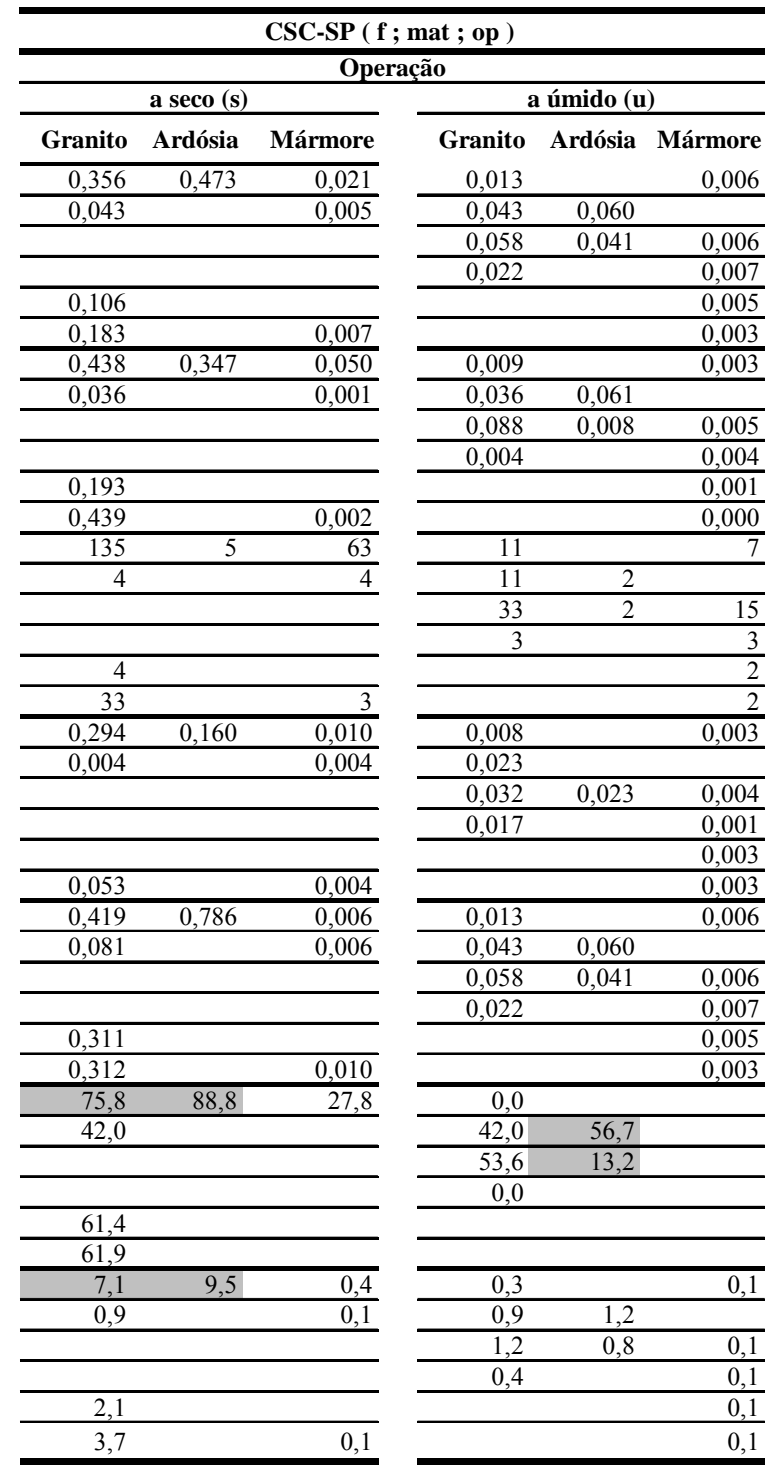

A função de acabador apresentou os maiores valores de concentrações médias de sílica cristalina respirável nas operações realizadas a seco. O maior valor foi 
encontrado para a ardósia, $0,473 \mathrm{mg} / \mathrm{m}^{3}$. A concentração para os granitos (rochas silicáticas) foi igual a $0,356 \mathrm{mg} / \mathrm{m}^{3}$ e para o mármore foi igual a $0,021 \mathrm{mg} / \mathrm{m}^{3}$. A probabilidade do valor de referência ser ultrapassado foi igual 88,8\% para a ardósia e de 75,8\% para o granito. O índice de exposição médio foi igual a 9,5 para a ardósia e 7,1 para o granito.

Nas análises dos resultados por amostra para as rochas silicáticas foram encontrados valores de índice de exposição 70 vezes maior que o valor de referência (VR) para os materiais sintéticos como Silestone ${ }^{\circledR}$ na empresa 14 (amostra código Bo-54, Tabela A11.13), o índice de exposição médio no dia foi de 54 vezes o VR (amostras códigos Bo-4 Bo-65, Tabela A11.13). Para amostras de granitos naturais o índice de exposição máximo foi igual a 23 vezes o VR, na empresa 6 granito cinza Corumbá (amostra código Bq-03, Tabela A11.5).

Na Figura 5.10 encontram-se as concentrações médias de sílica cristalina respirável por tipo de matéria-prima.

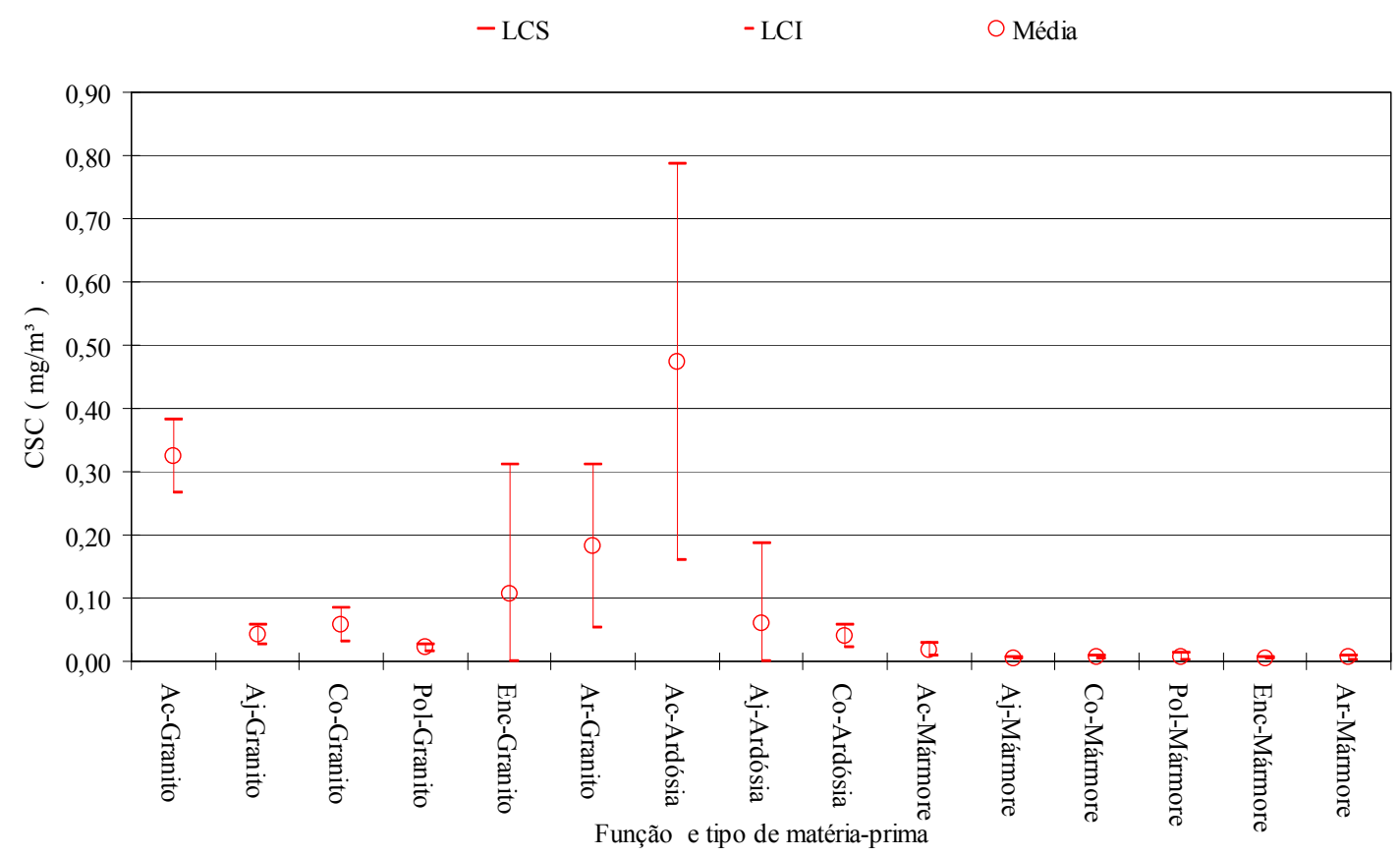

Figura 5.10 - Média e intervalo de confiança de 95\% para concentração de sílica cristalina segundo a função e o tipo de matéria-prima nas 22 marmorarias estudadas, no Município de São Paulo, 2004 - 2005 
Nas amostras de ar referentes ao trabalho feito somente com ardósia, coletadas em sua maioria na empresa 20, e para a função de acabador com operações de desbaste e lixamento a seco, foi encontrada uma faixa de concentração muito ampla. Possivelmente, esta variabilidade deveu-se ao número reduzido de amostras para o cálculo de média, pois a composição da ardósia não varia muito.

Os granitos e ardósias são rochas silicáticas, e embora os granitos tenham composição variável e com diferentes teores de sílica cristalina, a variabilidade da média para os granitos foi bem menor que para as ardósias. Provavelmente o elevado número de amostras levou à diminuição da variabilidade na média para os granitos.

Os mármores são rochas carbonáticas com baixos teores de sílica cristalina e a média não apresentou alta variabilidade.

A Figura 5.11 apresenta as concentrações médias de sílica cristalina respirável para o Município de São Paulo por função, matéria-prima e tipo de operação.

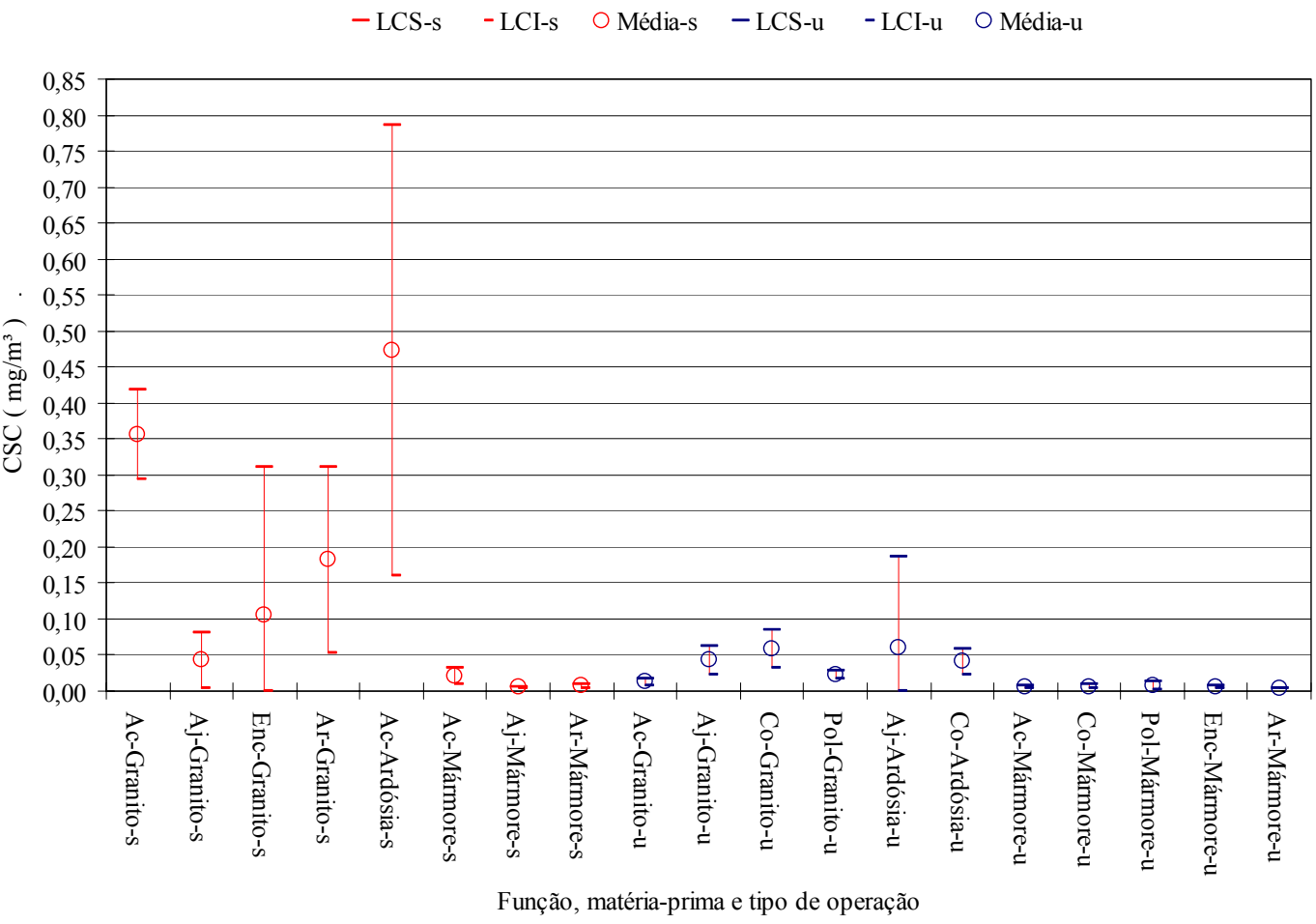

Figura 5.11 - Média e intervalo de confiança de 95\% para concentração de sílica cristalina respirável segundo a função, matéria-prima e tipo de operação nas 22 marmorarias estudadas, no Município de São Paulo, 2004 - 2005 
Os valores de concentração média de sílica cristalina para todas as funções e tipos de matéria-prima nas operações a úmido são significativamente menores que os correspondentes para operação a seco.

\subsection{Caracterização das alternativas de controle de poeira}

Para caracterizar as alternativas de controle da poeira em marmorarias foram estudadas 5 empresas com diferentes tipos de sistemas de ventilação local exaustora, máquinas e ferramentas, conforme apresentado no item 4.1.2. Foram coletadas amostras, analisadas e os resultados estão apresentados nas Tabelas de números 5.10 a 5.11 a seguir. Foi realizada uma análise comparativa dos resultados obtidos neste estudo para a função de acabador com os resultados de alternativas de controle encontradas no estudo de exposição ocupacional.

\subsubsection{Resultados por função e por empresas}

A Tabela 5.10 apresenta os resultados de concentração média de poeira respirável por função e por empresa. A função de acabador apresentou as maiores concentrações médias.

A empresa M1 possuía dois tipos de controle no ambiente para captar a poeira, uma capela e um sistema de ventilação local exaustora (SVLE) com filtros descartáveis, e apresentou concentração média de poeira respirável igual a $2,26 \mathrm{mg} / \mathrm{m}^{3}$.

A empresa M2 possuía um SVLE com coifa e filtros tipo manga para o controle no ambiente da poeira gerada. No momento da coleta das amostras de ar o sistema estava quebrado, o que explica o alto valor de concentração média de poeira respirável encontrado, $4,07 \mathrm{mg} / \mathrm{m}^{3}$.

Na empresa M3 havia uma Mesa com SVLE e sistema com lâmina de água para captação da poeira, e a concentração média de poeira respirável encontrada foi igual a $0,55 \mathrm{mg} / \mathrm{m}^{3}$. 
A empresa M4 possuía politrizes manuais pneumáticas com água, e ali a concentração média de poeira respirável encontrada foi igual a $0,50 \mathrm{mg} / \mathrm{m}^{3}$.

A empresa M5 possuía politrizes pneumáticas com água e uma sala enclausurada com sistema de insuflamento de ar na qual se encontrava instalada uma Mesa com SVLE e sistema de lâmina de água para captação da poeira. Ali a concentração média de poeira respirável encontrada foi igual a $1,0 \mathrm{mg} / \mathrm{m}^{3}$.

Tabela 5.10 - Concentração média de poeira respirável por função e para amostras de área em cada empresa do estudo de alternativas de controle de poeira. Município de São Paulo, 2003 - 2005

\begin{tabular}{|c|c|c|c|c|c|c|}
\hline & \multirow{2}{*}{ Funções } & \multicolumn{5}{|c|}{ Empresas } \\
\hline & & M1 & M2 & M3 & M4 & M5 \\
\hline \multirow{6}{*}{ Média aritmética } & $\mathrm{Ac}$ & 2,26 & 4,07 & 0,55 & 0,50 & 1,00 \\
\hline & $\overline{\mathrm{Aj}}$ & 0,77 & & 0,44 & & \\
\hline & Co & 0,65 & 0,41 & 0,44 & 0,31 & \\
\hline & Pol & & & 0,74 & & $\overline{0,08}$ \\
\hline & Enc & & & & & \\
\hline & $\mathrm{Ar}$ & 1,22 & 1,11 & 0,31 & 0,29 & $\overline{2,16}$ \\
\hline \multirow{6}{*}{ Desvio padrão } & Ac & 1,24 & 2,27 & 0,21 & 0,17 & 0,83 \\
\hline & $\mathrm{Aj}$ & 0,41 & & 0,03 & & \\
\hline & $\mathrm{Co}$ & 0,31 & 0,17 & 0,27 & 0,17 & \\
\hline & Pol & & & 0,23 & & \\
\hline & Enc & & & & & \\
\hline & $\mathrm{Ar}$ & 0,63 & 1,00 & 0,18 & 0,09 & 1,37 \\
\hline \multirow{6}{*}{$\begin{array}{l}\text { Número de } \\
\text { jornadas }\end{array}$} & $\mathrm{Ac}$ & 23 & 19 & 8 & 6 & 6 \\
\hline & $\mathrm{Aj}$ & 2 & & 2 & & \\
\hline & $\mathrm{Co}$ & 4 & 9 & 9 & 5 & \\
\hline & Pol & & & 3 & & 1 \\
\hline & Enc & & & & & \\
\hline & $\mathrm{Ar}$ & 12 & 9 & 9 & 3 & 2 \\
\hline \multirow{6}{*}{$\begin{array}{l}\text { LCI }(95 \%) \mathrm{da} \\
\text { média }\end{array}$} & $\mathrm{Ac}$ & 1,82 & 3,17 & 0,41 & 0,36 & $\overline{0,34}$ \\
\hline & $\mathrm{Aj}$ & & & 0,38 & & \\
\hline & $\mathrm{Co}$ & 0,32 & 0,31 & 0,27 & 0,16 & \\
\hline & Pol & & & 0,43 & & $\overline{0,08}$ \\
\hline & Enc & & & & & \\
\hline & $\mathrm{Ar}$ & 0,90 & 0,49 & 0,20 & 0,18 & \\
\hline \multirow{6}{*}{$\begin{array}{c}\text { LCS }(95 \%) \text { da } \\
\text { média }\end{array}$} & $\overline{A c}$ & 2,70 & 4,98 & 0,69 & 0,63 & $\overline{1,66}$ \\
\hline & $\mathrm{Aj}$ & 1,61 & & 0,49 & & \\
\hline & $\mathrm{Co}$ & 0,99 & 0,52 & 0,60 & 0,46 & \\
\hline & Pol & & & 1,05 & & $\overline{0,08}$ \\
\hline & Enc & & & & & \\
\hline & $\mathrm{Ar}$ & 1,54 & 1,72 & 0,42 & 0,41 & $\overline{4,98}$ \\
\hline
\end{tabular}


A Tabela 5.11 apresenta os resultados de concentração média de sílica cristalina por função e por empresa. Nas empresas M1, M3 e M4 os resultados para a função de acabador eram respectivamente $0,024,0,031$ e $0,041 \mathrm{mg} / \mathrm{m}^{3}$ e encontravam-se abaixo do valor de referência. As probabilidades de estes resultados ultrapassarem o valor de referência foram de $26,0 \%, 12,1 \%$ e $32,5 \%$ respectivamente, valores bem menores que de uma empresa sem controle como, por exemplo, a M2, cuja probabilidade é de 93,4\%. Os índices de exposição encontravam-se abaixo de 1 nestas empresas, indicando que a exposição à sílica cristalina era menos intensa que em ambientes sem controle como, por exemplo, o da empresa M2, que apresentou índice de exposição igual a 7,4 .

A empresa M5 apresentou resultado de concentração média de sílica cristalina para a função de acabador igual a $0,07 \mathrm{mg} / \mathrm{m}^{3}$. A probabilidade de o valor de referência ser ultrapassado foi igual a 69,9\% e o índice de exposição igual a 1,4.

Estas diferenças podem ter sido encontradas devido a diferentes eficiências dos sistemas de controle de poeira das empresas e diferentes matérias-primas processadas. 
Tabela 5.11 - Concentração média de sílica cristalina respirável por função e para amostras de área em cada empresa do estudo de alternativas de controle de poeira. Município de São Paulo, 20032005

\begin{tabular}{|c|c|c|c|c|c|c|}
\hline & \multirow{2}{*}{ Funções } & \multicolumn{5}{|c|}{ Empresas } \\
\hline & & M1 & M2 & M3 & M4 & M5 \\
\hline \multirow{6}{*}{ Média aritmética } & $\overline{\mathrm{Ac}}$ & 0,024 & 0,372 & 0,031 & 0,041 & $\overline{0,070}$ \\
\hline & $\overline{\mathrm{Aj}}$ & 0,008 & & 0,020 & & \\
\hline & $\mathrm{Co}$ & 0,009 & 0,051 & 0,038 & 0,021 & \\
\hline & $\overline{\text { Pol }}$ & & & 0,017 & & \\
\hline & Enc & & & & & \\
\hline & $\mathrm{Ar}$ & 0,023 & 0,132 & 0,010 & 0,012 & $\overline{0,144}$ \\
\hline \multirow{6}{*}{ Desvio padrão } & $\mathrm{Ac}$ & 0,041 & 0,214 & 0,016 & 0,021 & 0,038 \\
\hline & $\mathrm{Aj}$ & 0,000 & & 0,008 & & \\
\hline & Co & 0,002 & 0,020 & 0,025 & 0,009 & \\
\hline & Pol & & & 0,005 & & \\
\hline & Enc & & & & & \\
\hline & $\mathrm{Ar}$ & 0,021 & 0,117 & 0,004 & 0,007 & $\overline{0,035}$ \\
\hline \multirow{6}{*}{$\begin{array}{l}\text { Número de } \\
\text { jornadas }\end{array}$} & Ac & 22 & 16 & 8 & 6 & 5 \\
\hline & $\mathrm{Aj}$ & 2 & & 2 & & \\
\hline & $\mathrm{Co}$ & 4 & 8 & 9 & 4 & \\
\hline & Pol & & & 3 & & \\
\hline & Enc & & & & & \\
\hline & $\mathrm{Ar}$ & 12 & 8 & 8 & 3 & 2 \\
\hline \multirow{6}{*}{$\begin{array}{l}\text { LCI }(95 \%) \text { da } \\
\text { média }\end{array}$} & $\mathrm{Ac}$ & 0,008 & 0,278 & 0,021 & 0,024 & $\overline{0,036}$ \\
\hline & $\mathrm{Aj}$ & 0,008 & & 0,003 & & \\
\hline & Co & 0,007 & 0,038 & 0,022 & 0,011 & \\
\hline & Pol & & & 0,011 & & \\
\hline & Enc & & & & & \\
\hline & $\mathrm{Ar}$ & 0,012 & 0,054 & 0,007 & 0,003 & $\overline{0,072}$ \\
\hline \multirow{6}{*}{$\begin{array}{l}\text { LCS }(95 \%) \text { da } \\
\text { média }\end{array}$} & $\mathrm{Ac}$ & 0,039 & 0,465 & 0,042 & 0,057 & 0,104 \\
\hline & $\mathrm{Aj}$ & 0,008 & & 0,038 & & \\
\hline & Co & 0,012 & 0,064 & 0,053 & 0,031 & \\
\hline & Pol & & & 0,024 & & \\
\hline & Enc & & & & & \\
\hline & $\mathrm{Ar}$ & 0,034 & 0,209 & 0,012 & 0,021 & 0,216 \\
\hline \multirow{6}{*}{$\begin{array}{c}\text { Probabilidade de } \\
\text { ultrapassar o } \\
\text { REL-NIOSH }\end{array}$} & $\mathrm{Ac}$ & 26,0 & 93,4 & 12,1 & 32,5 & 69,9 \\
\hline & $\mathrm{Aj}$ & & & 0,0 & & \\
\hline & Co & & 52,3 & 31,4 & 0,1 & \\
\hline & Pol & & & 0,0 & & \\
\hline & Enc & & & & & \\
\hline & $\mathrm{Ar}$ & 9,8 & 75,7 & & 0,0 & 99,7 \\
\hline \multirow{6}{*}{$\begin{array}{l}\text { Índice de } \\
\text { exposição }\end{array}$} & $\mathrm{Ac}$ & 0,5 & 7,4 & 0,6 & 0,8 & 1,4 \\
\hline & $\mathrm{Aj}$ & 0,2 & & 0,4 & & \\
\hline & Co & 0,2 & 1,0 & 0,8 & 0,4 & \\
\hline & Pol & & & 0,3 & & \\
\hline & Enc & & & & & \\
\hline & $\mathrm{Ar}$ & 0,5 & 2,6 & 0,2 & 0,2 & 2,9 \\
\hline
\end{tabular}




\subsubsection{Resultados por função e por tipo de operação}

Os cálculos das concentrações médias por função foram realizados com os resultados das empresas nas quais as medidas de controle estavam em funcionamento. A empresa M2 foi excluída. As Tabelas 5.12 e 5.13 apresentam respectivamente os resultados de concentração média de poeira e sílica cristalina respirável por função para as empresas estudadas.

Tabela 5.12 - Concentração média de poeira respirável por função e para amostras de área das empresas do estudo de alternativas de controle de poeira. Município de São Paulo, 2003 - 2005

\begin{tabular}{|c|c|c|c|c|c|}
\hline \multicolumn{6}{|c|}{ CPR ( f ) ( $\left.\mathrm{mg} / \mathrm{m}^{3}\right)$} \\
\hline & LCI & Média & LCS & $D P$ & $n j$ \\
\hline Ac & 1,20 & 1,52 & 1,84 & 1,25 & 43 \\
\hline $\mathrm{Aj}$ & 0,28 & 0,60 & 0,93 & 0,30 & 4 \\
\hline $\mathrm{Co}$ & 0,34 & 0,45 & 0,56 & 0,27 & 18 \\
\hline Pol & 0,17 & 0,58 & 0,98 & 0,38 & 4 \\
\hline Enc & & & & & \\
\hline $\mathrm{Ar}$ & 0,61 & 0,87 & 1,13 & 0,78 & 26 \\
\hline
\end{tabular}

LCI = Limite inferior de confiança ( 95\% - distribuição t )

Média $=$ Média aritmética

LCS $=$ Limite superior de confiança ( $95 \%$ - distribuição $t$ )

$\mathrm{DP}=$ Desvio padrão aritmético

$\mathrm{nj}=$ número de jornadas 
Tabela 5.13 - Concentração média de sílica cristalina respirável por função e para amostras de área das empresas do estudo de alternativas de controle de poeira. Município de São Paulo, 2003 - 2005

\begin{tabular}{|c|c|c|c|c|c|c|c|}
\hline \multicolumn{8}{|c|}{$\operatorname{CSC}(\mathrm{f}) \quad\left(\mathrm{mg} / \mathrm{m}^{3}\right)$} \\
\hline & LCI & Média & LCS & $D P$ & $\%>R E L$ & $I E$ & nj \\
\hline Ac & 0,024 & 0,033 & 0,043 & 0,037 & 32,4 & 0,7 & 41 \\
\hline $\mathrm{Aj}$ & 0,005 & 0,014 & 0,023 & 0,009 & 0,0 & 0,3 & 4 \\
\hline $\mathrm{Co}$ & 0,018 & $\mathbf{0 , 0 2 7}$ & 0,036 & 0,022 & 15,0 & 0,5 & 17 \\
\hline Pol & 0,011 & 0,017 & 0,024 & 0,005 & 0,0 & 0,3 & 3 \\
\hline \multicolumn{8}{|l|}{ Enc } \\
\hline $\mathrm{Ar}$ & 0,014 & 0,027 & 0,040 & 0,039 & 27,8 & 0,5 & 25 \\
\hline
\end{tabular}

LCI = Limite inferior de confiança ( 95\% - distribuição $\mathrm{t}$ )

Média $=$ Média aritmética

LCS = Limite superior de confiança ( 95\% - distribuição $t$ )

$\mathrm{DP}=$ Desvio padrão aritmético

$\mathrm{nj}=$ número de jornadas

$\%>\mathrm{REL}=$ Probabilidade de ultrapassar o valor de referência

$\mathrm{IE}=$ Índice de Exposição

Os resultados apresentados nas Tabelas 5.12 e 5.13 indicam uma diferença significativa nas concentrações médias da poeira e de sílica cristalina respirável, sendo que para sílica cristalina todos os valores encontravam-se abaixo do valor de referência.

As Tabelas 5.14 e 5.15 apresentam respectivamente os resultados de concentração de poeira e sílica cristalina respirável por função e tipo de operação, a seco ou a úmido, para a mistura de poeiras minerais dos ambientes das marmorarias com controle nas visitas preliminares. Os resultados indicam que a exposição à poeira respirável é mais baixa para as operações a úmido, e que as concentrações médias de sílica cristalina apresentaram-se abaixo do valor de referência para ambos os tipos de operação, para todas as funções e amostras de área. 
Tabela 5.14 - Concentração média de poeira respirável por função e para amostras de área, por tipo de operação das empresas do estudo de alternativas de controle de poeira. Município de São Paulo, 20032005

\begin{tabular}{|c|c|c|c|c|c|c|c|c|c|c|c|}
\hline \multirow{4}{*}{ Função } & \multicolumn{10}{|c|}{ CPR (f ; op ) $\left(\mathrm{mg} / \mathrm{m}^{3}\right)$} & \multirow{4}{*}{$\begin{array}{c}\text { Número } \\
\text { total de } \\
\text { jornadas }\end{array}$} \\
\hline & \multicolumn{10}{|c|}{ Operação } & \\
\hline & \multicolumn{5}{|c|}{ a seco (s) } & \multicolumn{5}{|c|}{ a úmido (u) } & \\
\hline & LCI & Media & LCS & $D P$ & nj & LCI & Media & LCS & $D P$ & $n j$ & \\
\hline$\overline{\mathrm{Ac}}$ & 1,44 & 1,82 & 2,20 & 1,28 & 33 & 0,42 & 0,55 & 0,67 & 0,21 & 10 & 43 \\
\hline $\mathrm{Aj}$ & 1,06 & 1,06 & 1,06 & & 1 & 0,41 & 0,45 & 0,50 & 0,03 & 3 & 4 \\
\hline $\mathrm{Co}$ & & & & & & 0,34 & 0,45 & 0,56 & 0,27 & 18 & 18 \\
\hline Pol & & & & & & 0,17 & 0,58 & 0,98 & 0,38 & 4 & 4 \\
\hline \multicolumn{12}{|l|}{ Enc } \\
\hline $\mathrm{Ar}$ & 0,68 & 0,97 & 1,26 & 0,80 & 22 & 0,07 & 0,32 & 0,57 & 0,23 & 4 & 26 \\
\hline
\end{tabular}

LCI = Limite inferior de confiança ( 95\% - distribuição t ) DP = Desvio padrão aritmético Media $=$ Média aritmética $\quad n j=$ número de jornadas

LCS = Limite superior de confiança ( $95 \%$ - distribuição t )

Tabela 5.15 - Concentração média de sílica cristalina respirável por função e para amostras de área, por tipo de operação das empresas do estudo de alternativas de controle de poeira. Município de São Paulo, 2003 -2005

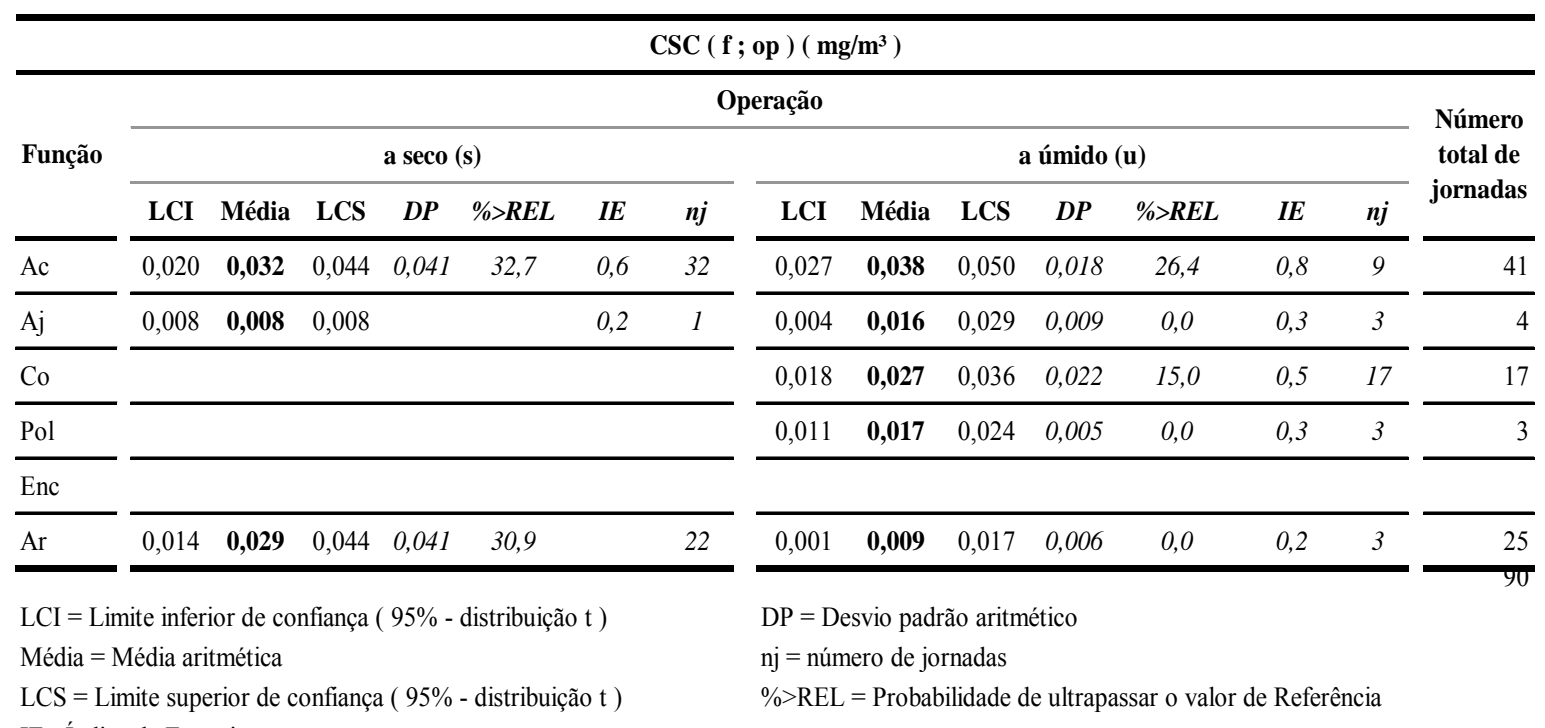




\subsubsection{Resultados por função, matéria-prima e tipo de operação}

Os cálculos das concentrações médias por função, matéria-prima e operação foram realizados com os resultados das empresas nas quais as medidas de controle estavam em funcionamento. A empresa M2 foi excluída. Não foram encontradas situações de trabalho nas quais as ardósias estivessem presentes sem a presença de outras matérias-primas. As Tabelas 5.16 e 5.17 apresentam respectivamente os resultados de concentração média de poeira e sílica cristalina respirável.

Os resultados da Tabela 5.16 indicam que a função de acabador apresentou as maiores concentrações médias de poeira respirável e, neste caso, a concentração para o mármore apresentou o maior valor, independentemente do tipo de operação.

Os resultados de concentração média para sílica cristalina apresentados na Tabela 5.17 indicam o que a função de acabador de granito com as operações a seco era a de maior exposição.

A Figura 5.12 apresenta as concentrações médias para sílica cristalina e seu intervalo de confiança de 95\%. As únicas situações em que se verificou valor de referência ultrapassado foram: acabador de granito trabalhando a seco e área com granito sendo trabalhado a seco, indicando que as atividades na etapa de acabamento eram realizadas sem controle e contaminavam a área de trabalho. 
Tabela 5.16 - Concentração média de poeira respirável por função e para amostras de área, por tipo matéria-prima e operação das empresas do estudo de alternativas de controle de poeira. Município de São Paulo, 2003 - 2005

\begin{tabular}{|c|c|c|c|c|c|c|c|}
\hline \multirow{4}{*}{ Variável } & \multirow{4}{*}{ Função } & \multirow{2}{*}{\multicolumn{2}{|c|}{ CPR ( f ; mat ) }} & \multicolumn{4}{|c|}{ CPR ( f ; mat ; op ) } \\
\hline & & & & \multicolumn{4}{|c|}{ Operação } \\
\hline & & \multirow{2}{*}{ Granito } & \multirow{2}{*}{ Mármore } & \multicolumn{2}{|c|}{ a seco (s) } & \multicolumn{2}{|c|}{ a úmido (u) } \\
\hline & & & & Granito & Mármore & Granito & Mármore \\
\hline \multirow{6}{*}{$\begin{array}{l}\text { Média aritmética } \\
\left(\mathrm{mg} / \mathrm{m}^{3}\right)\end{array}$} & Ac & 1,32 & 2,05 & 1,95 & 2,13 & 0,53 & 0,62 \\
\hline & $\mathrm{Aj}$ & 0,42 & 0,67 & & 1,06 & 0,42 & 0,47 \\
\hline & $\mathrm{Co}$ & 0,29 & 0,82 & & & 0,29 & 0,82 \\
\hline & Pol & 0,93 & 0,65 & & & 0,93 & 0,65 \\
\hline & Enc & & & & & & \\
\hline & $\mathrm{Ar}$ & 1,16 & 0,99 & 1,30 & 1,19 & 0,45 & 0,19 \\
\hline \multirow{6}{*}{ Desvio Padrão } & Ac & 1,61 & 0,96 & 1,97 & 0,92 & 0,24 & \\
\hline & $\mathrm{Aj}$ & & $\overline{0,34}$ & & & & 0,02 \\
\hline & $\mathrm{Co}$ & 0,09 & 0,40 & & & 0,09 & 0,40 \\
\hline & Pol & & 0,23 & & & & 0,23 \\
\hline & Enc & & & & & & \\
\hline & $\mathrm{Ar}$ & 1,20 & 0,63 & 1,27 & 0,53 & 0,30 & 0,10 \\
\hline \multirow{6}{*}{ Número de amostras } & Ac & 18 & 19 & 10 & 18 & 8 & 1 \\
\hline & $\mathrm{Aj}$ & 1 & 3 & & 1 & 1 & 2 \\
\hline & $\mathrm{Co}$ & 8 & 2 & & & 8 & 2 \\
\hline & Pol & 1 & 2 & & & 1 & 2 \\
\hline & Enc & & & & & & \\
\hline & $\mathrm{Ar}$ & 12 & 10 & 10 & 8 & 2 & 2 \\
\hline \multirow{6}{*}{$\begin{array}{c}\text { LCI } \\
(95 \% \text { da média })\end{array}$} & Ac & 0,66 & 1,67 & 0,82 & 1,76 & 0,38 & 0,62 \\
\hline & $\mathrm{Aj}$ & 0,42 & 0,20 & & 1,06 & 0,42 & 0,43 \\
\hline & $\mathrm{Co}$ & 0,23 & & & & 0,23 & \\
\hline & Pol & 0,93 & 0,17 & & & 0,93 & 0,17 \\
\hline & Enc & & & & & & \\
\hline & $\mathrm{Ar}$ & 0,54 & 0,63 & 0,57 & 0,85 & & \\
\hline \multirow{6}{*}{$\begin{array}{c}\text { LCS } \\
(95 \% \text { da média })\end{array}$} & Ac & 1,98 & 2,43 & 3,07 & 2,50 & 0,69 & 0,62 \\
\hline & $\mathrm{Aj}$ & 0,42 & 1,13 & & 1,06 & 0,42 & 0,51 \\
\hline & $\mathrm{Co}$ & 0,35 & 1,63 & & & 0,35 & 1,63 \\
\hline & Pol & 0,93 & 1,13 & & & 0,93 & 1,13 \\
\hline & Enc & & & & & & \\
\hline & $\mathrm{Ar}$ & 1,77 & 1,35 & 2,03 & 1,54 & 1,06 & 0,40 \\
\hline \multirow{6}{*}{$\begin{array}{c}\text { Probabilidade de } \\
\text { ultrapassar o REL- } \\
\text { NIOSH }\end{array}$} & Ac & 78,5 & 98,2 & 83,3 & 98,8 & 98,0 & \\
\hline & $\mathrm{Aj}$ & & 96,5 & & & & 100,0 \\
\hline & $\mathrm{Co}$ & 99,6 & 97,4 & & & 99,6 & 97,4 \\
\hline & Pol & & 99,5 & & & & 99,5 \\
\hline & Enc & & & & & & \\
\hline & $\mathrm{Ar}$ & 82,3 & 93,3 & 83,8 & 98,5 & 91,0 & 91,7 \\
\hline \multirow{6}{*}{ Índice de exposição } & Ac & 26,4 & 41,0 & 39,0 & 42,6 & 10,7 & 12,3 \\
\hline & $\mathrm{Aj}$ & 8,3 & 13,3 & & 21,1 & 8,3 & 9,4 \\
\hline & $\mathrm{Co}$ & 5,8 & 16,3 & & & 5,8 & 16,3 \\
\hline & Pol & 18,6 & 13,0 & & & 18,6 & 13,0 \\
\hline & Enc & & & & & & \\
\hline & $\mathrm{Ar}$ & 23,2 & 19,9 & 26,0 & 23,9 & 9,0 & 3,8 \\
\hline
\end{tabular}


Tabela 5.17 - Concentração média de sílica cristalina respirável por função e para amostras de área, por tipo de matéria-prima e operação das empresas do estudo de alternativas de controle de poeira. Município de São Paulo, 2003 - 2005

\begin{tabular}{|c|c|c|c|c|c|c|c|}
\hline \multirow{4}{*}{ Variável } & \multirow{4}{*}{ Função } & \multirow{2}{*}{\multicolumn{2}{|c|}{ CSC ( f ; mat ) }} & \multicolumn{4}{|c|}{ CSC ( f ; mat ; op ) } \\
\hline & & & & \multicolumn{4}{|c|}{ Operação } \\
\hline & & \multirow{2}{*}{ Granito } & \multirow{2}{*}{ Mármore } & \multicolumn{2}{|c|}{ a seco (s) } & \multicolumn{2}{|c|}{ a úmido (u) } \\
\hline & & & & Granito & Mármore & Granito & Mármore \\
\hline \multirow{6}{*}{$\begin{array}{l}\text { Média aritmética } \\
\qquad\left(\mathrm{mg} / \mathrm{m}^{3}\right)\end{array}$} & $\mathrm{Ac}$ & 0,058 & 0,009 & 0,073 & 0,009 & 0,038 & 0,017 \\
\hline & $\mathrm{Aj}$ & 0,026 & 0,010 & & 0,008 & 0,026 & 0,011 \\
\hline & $\mathrm{Co}$ & 0,020 & 0,009 & & & 0,020 & 0,009 \\
\hline & Pol & 0,022 & 0,015 & & & 0,022 & 0,015 \\
\hline & Enc & & & & & & \\
\hline & $\mathrm{Ar}$ & 0,048 & 0,014 & 0,056 & 0,015 & 0,010 & 0,007 \\
\hline \multirow{6}{*}{ Desvio Padrão } & $\mathrm{Ac}$ & 0,045 & 0,004 & 0,055 & 0,004 & 0,016 & \\
\hline & $\mathrm{Aj}$ & & 0,004 & & & & 0,004 \\
\hline & $\mathrm{Co}$ & 0,010 & 0,001 & & & 0,010 & $\overline{0,001}$ \\
\hline & Pol & & 0,004 & & & & 0,004 \\
\hline & Enc & & & & & & \\
\hline & $\mathrm{Ar}$ & 0,065 & 0,019 & 0,069 & 0,020 & 0,008 & \\
\hline \multirow{6}{*}{ Número de amostras } & $\mathrm{Ac}$ & 16 & 19 & 9 & 18 & 7 & 1 \\
\hline & $\mathrm{Aj}$ & 1 & 3 & & 1 & 1 & 2 \\
\hline & $\mathrm{Co}$ & 7 & 2 & & & 7 & 2 \\
\hline & Pol & 1 & 2 & & & 1 & 2 \\
\hline & Enc & & & & & & \\
\hline & $\mathrm{Ar}$ & 12 & 9 & 10 & 8 & 2 & 1 \\
\hline \multirow{6}{*}{$\begin{array}{c}\text { LCI } \\
(95 \% \text { da média })\end{array}$} & $\mathrm{Ac}$ & 0,038 & 0,007 & 0,040 & 0,007 & 0,026 & 0,017 \\
\hline & $\mathrm{Aj}$ & 0,026 & 0,005 & & 0,008 & 0,026 & 0,002 \\
\hline & Co & 0,012 & 0,007 & & & 0,012 & 0,007 \\
\hline & Pol & 0,022 & 0,007 & & & 0,022 & 0,007 \\
\hline & Enc & & & & & & \\
\hline & $\mathrm{Ar}$ & 0,015 & 0,003 & 0,017 & 0,002 & & 0,007 \\
\hline \multirow{6}{*}{$\begin{array}{c}\text { LCS } \\
(95 \% \text { da média })\end{array}$} & $\overline{A c}$ & 0,078 & 0,011 & 0,107 & 0,030 & 0,049 & 0,017 \\
\hline & $\mathrm{Aj}$ & 0,026 & 0,015 & & 0,028 & 0,026 & 0,020 \\
\hline & Co & 0,027 & 0,010 & & 0,028 & 0,027 & 0,010 \\
\hline & Pol & 0,022 & 0,022 & & 0,028 & 0,022 & 0,022 \\
\hline & Enc & & & & 0,028 & & \\
\hline & $\mathrm{Ar}$ & 0,082 & 0,026 & 0,096 & 0,028 & 0,027 & 0,007 \\
\hline \multirow{6}{*}{$\begin{array}{c}\text { Probabilidade de } \\
\text { ultrapassar o REL- } \\
\text { NIOSH }\end{array}$} & Ac & 56,9 & & 66,4 & & 22,3 & \\
\hline & $\mathrm{Aj}$ & & & & & & \\
\hline & $\mathrm{Co}$ & 0,2 & & & & 0,2 & \\
\hline & Pol & & & & & & \\
\hline & Enc & & & & & & \\
\hline & $\mathrm{Ar}$ & 49,0 & 2,8 & 53,5 & 3,9 & 0,0 & \\
\hline \multirow{6}{*}{ Índice de exposição } & $\mathrm{Ac}$ & 1,2 & 0,2 & 1,5 & 0,2 & 0,8 & $\overline{0,3}$ \\
\hline & $\mathrm{Aj}$ & 0,5 & 0,2 & & 0,2 & 0,5 & 0,2 \\
\hline & $\mathrm{Co}$ & 0,4 & 0,2 & & & 0,4 & $\overline{0,2}$ \\
\hline & Pol & 0,4 & 0,3 & & & 0,4 & 0,3 \\
\hline & Enc & & & & & & \\
\hline & $\mathrm{Ar}$ & 1,0 & 0,3 & 1,1 & 0,3 & 0,2 & 0,1 \\
\hline
\end{tabular}




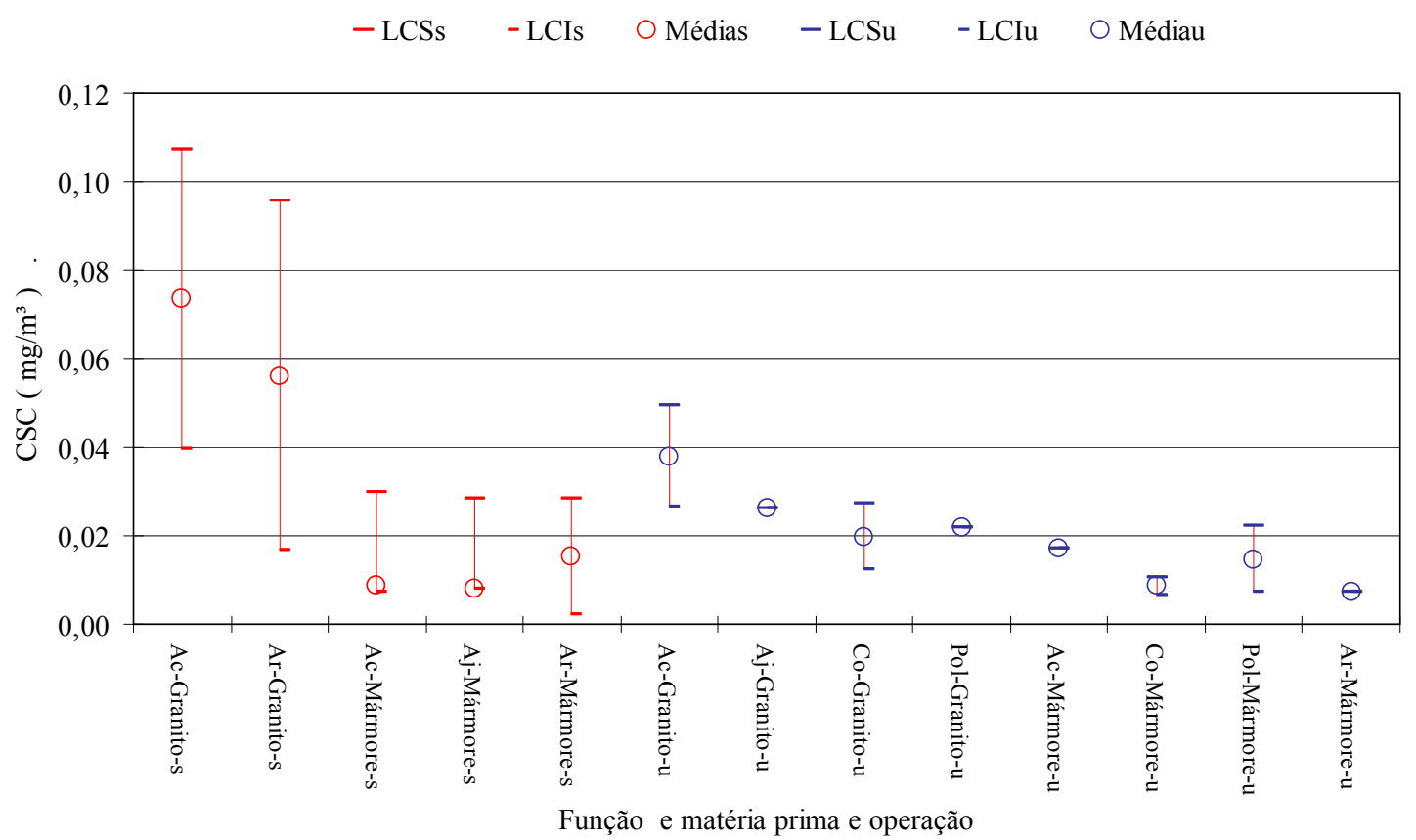

Figura 5.12 - Média e intervalo de confiança de 95\% para concentração de sílica cristalina respirável segundo a função e para amostras de área, por tipo de matéria-prima e tipo de operação das empresas do estudo de alternativas de controle de poeira. Município de São Paulo, 2003- 2005

\subsubsection{Análise dos resultados}

A análise dos resultados para as alternativas de controle das poeiras minerais geradas em marmorarias foi realizada com base nos resultados de concentração de sílica cristalina respirável das 27 marmorarias estudadas. Esta comparação justifica-se, pois foram identificados diferentes tipos de controle ambiental da poeira durante a realização do estudo de exposição ocupacional.

Os resultados da função de acabador foram utilizados nas análises comparativas por ser esta a função sujeita a maior risco de exposição às poeiras minerais nas marmorarias e para a qual as alternativas de controle podem ter maior impacto de redução das concentrações de poeira e de sílica cristalina na fração respirável. 
Os resultados para as funções de cortador e de ajudante geral encontrados e apresentados na Tabela 5.3 e Figuras 5.5 e 5.6, indicam também para estas funções o controle da poeira necessita ser melhorado.

A Tabela 5.18 apresenta por empresa o rol de alternativas de controle no ambiente, nas máquinas e ferramentas quando existiam e as ferramentas utilizadas na etapa de acabamento a seco.

No Anexo 13 são apresentadas fotos de algumas alternativas de controle a úmido nas máquinas e ferramentas.

Na Tabela 5.19 são apresentados os resultados de concentração média de sílica cristalina para a função de acabador segundo a alternativa de controle presente no ambiente de trabalho. 
Tabela 5.18 - Distribuição das marmorarias segundo as alternativas de controle da poeira no ambiente, nas máquinas e ferramentas quando existiam, e ferramentas utilizadas na etapa de acabamento a seco. Município de São Paulo, 2003- 2005

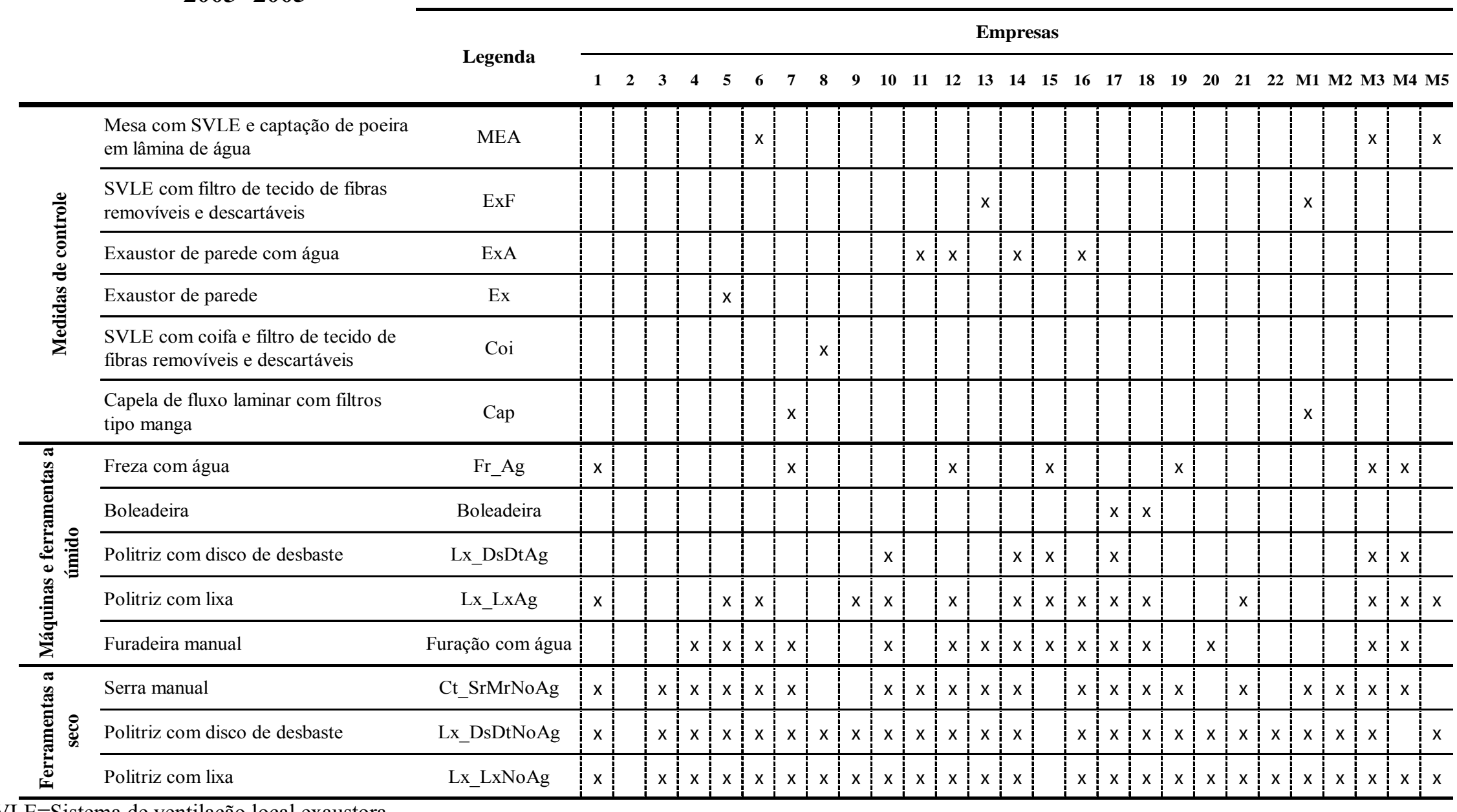

SVLE=Sistema de ventilação local exaustora 
Tabela 5.19 - Concentração média de sílica cristalina respirável para a função de acabador, segundo as alternativas de controle da poeira existentes no ambiente das marmorarias estudadas. Município de São Paulo, 2003 - 2005

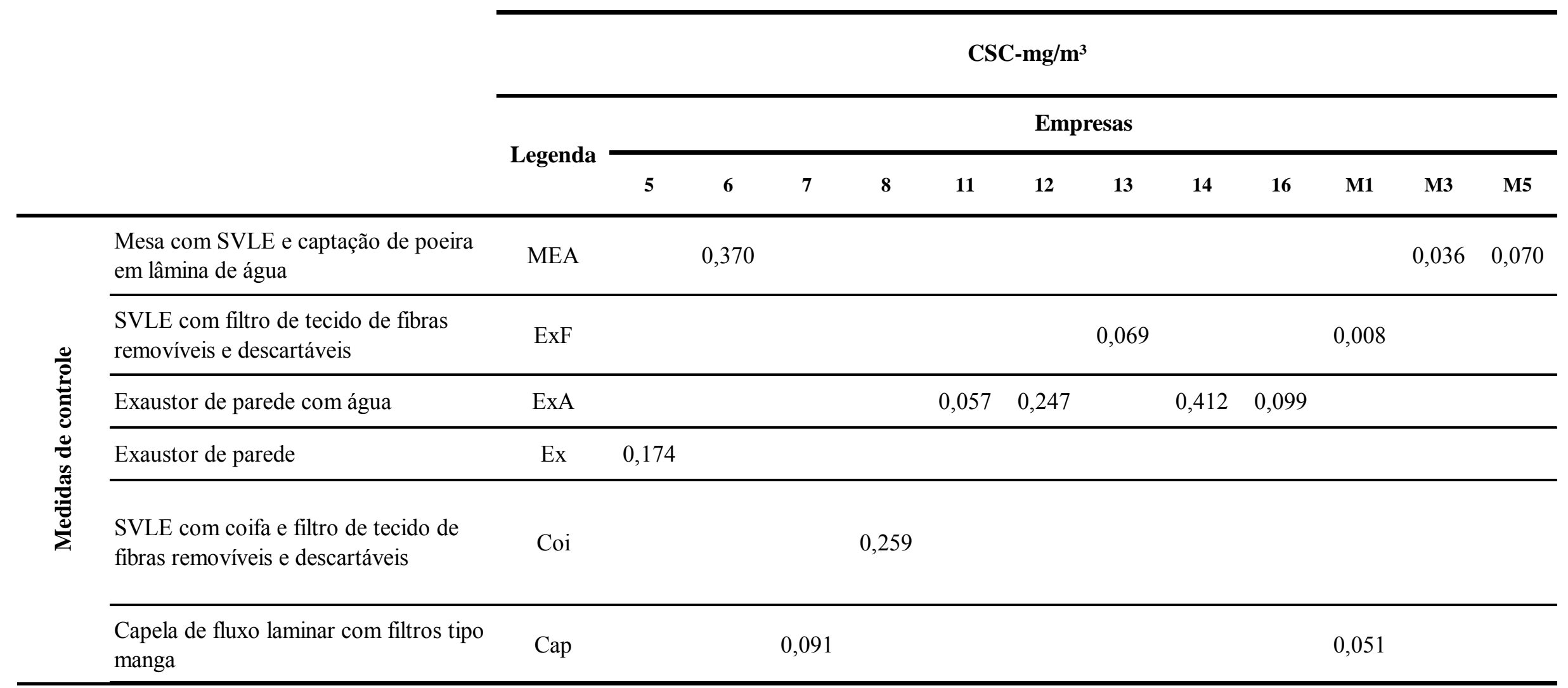


Os resultados para os seguintes tipos de controle de poeira encontravam-se acima do valor de referência: a) exaustor de parede na empresa 5 ; b) exaustor de parede com split de água nas empresas 11,12, 14, e 16; c) Sistema de Ventilação Local Exaustora (SVLE) com coifa da empresa 8; d) Capela das empresas 7 e M1; e) Mesa com SVLE e lâmina de água da empresa 6 e M5; f) SVLE com filtro da empresa 13.

Por outro lado, obtiveram-se resultados com valor igual ou abaixo do Limite de Exposição Ocupacional para: a) SVLE com filtro da empresa da M1; b) Mesa com SVLE e lâmina de água da M3.

As diferenças encontradas entre os resultados da empresa 11 em relação aos das 12, 14 e 16, que possuíam tipos de controle semelhantes, são possivelmente devidas a: a) instalações - a empresa 11 era instalada em galpão mais aberto que a empresa 12, enquanto as empresas 14 e 16 eram instaladas em galpões fechados; b) matériasprimas - as empresas 12, 14 e 16 utilizaram mais os granitos, sendo que a empresa 14 utilizou matérias-primas sintéticas com alto teor de sílica cristalina; c) porte eram empresas com diferentes portes; d) projetos - sistemas com projetos e procedimentos de manutenção distintos.

Quanto às Mesas com SVLE e lâmina de água das empresas M3 e 6, as possíveis diferenças são: a) instalações - a empresa M3 era instalada num galpão semi-aberto, e a 6 em galpão fechado; b) volume de produção - a M3 e a 6 eram empresas de porte grande. No entanto, na empresa 6 a produção era muito maior, e realizada em ritmo mais intenso que na $\mathrm{M} 3$; c) diferenças de projeto de construção da mesa e manutenção dos sistemas.

Para a Mesa com SVLE e lâmina de água instalada em sala com insuflamento de ar da empresa M5 foi encontrada concentração média de sílica cristalina igual a $0,07 \mathrm{mg} / \mathrm{m}^{3}$ para a função de acabador, resultado um pouco acima do valor de referência. Este resultado, quando comparado com o da empresa 6, que também possuía a Mesa com SVLE fornecida pelo mesmo fabricante e instalada em ambiente 
fechado, demonstra que o sistema de insuflamento de ar foi determinante para diminuir a concentração.

Quanto aos SVLE com filtro das empresas M1 e 13 as possíveis diferenças são: a) instalações - a empresa M1 era instalada num galpão semi-aberto e a 13 em galpão fechado; b) matérias-primas - a empresa M1 utilizou praticamente mármore, e ao realizar trabalhos com granito o resultado de concentração de sílica do acabador apresentou-se acima do LEO; c) diferenças de projeto e manutenção dos sistemas.

As capelas das empresas M1 e 7 apresentaram resultados acima do LEO. Entre as suas características limitantes pode-se mencionar, por exemplo, o tamanho das peças. Muitas peças grandes em produção não cabiam na capela.

A Figura 5.13 apresenta todos os resultados de concentração de sílica cristalina respirável para a função de acabador, representados pelos pontos, e as concentrações médias para função de acabador das empresas para as operações a seco e a úmido, representadas pelas barras. As barras na cor azul marinho representam as operações a seco, e as barras na cor azul claro as operações a úmido.

As empresas números 3, 4, 10,19, 2021 e M2 não possuíam nenhum tipo de controle para a poeira. Pode-se observar a ocorrência de exposição excessiva dos trabalhadores na função de acabador, com concentrações médias variando entre 0,14 a $0,47 \mathrm{mg} / \mathrm{m}^{3}$ de sílica cristalina, praticamente de 3 a 10 vezes o valor de referência. 


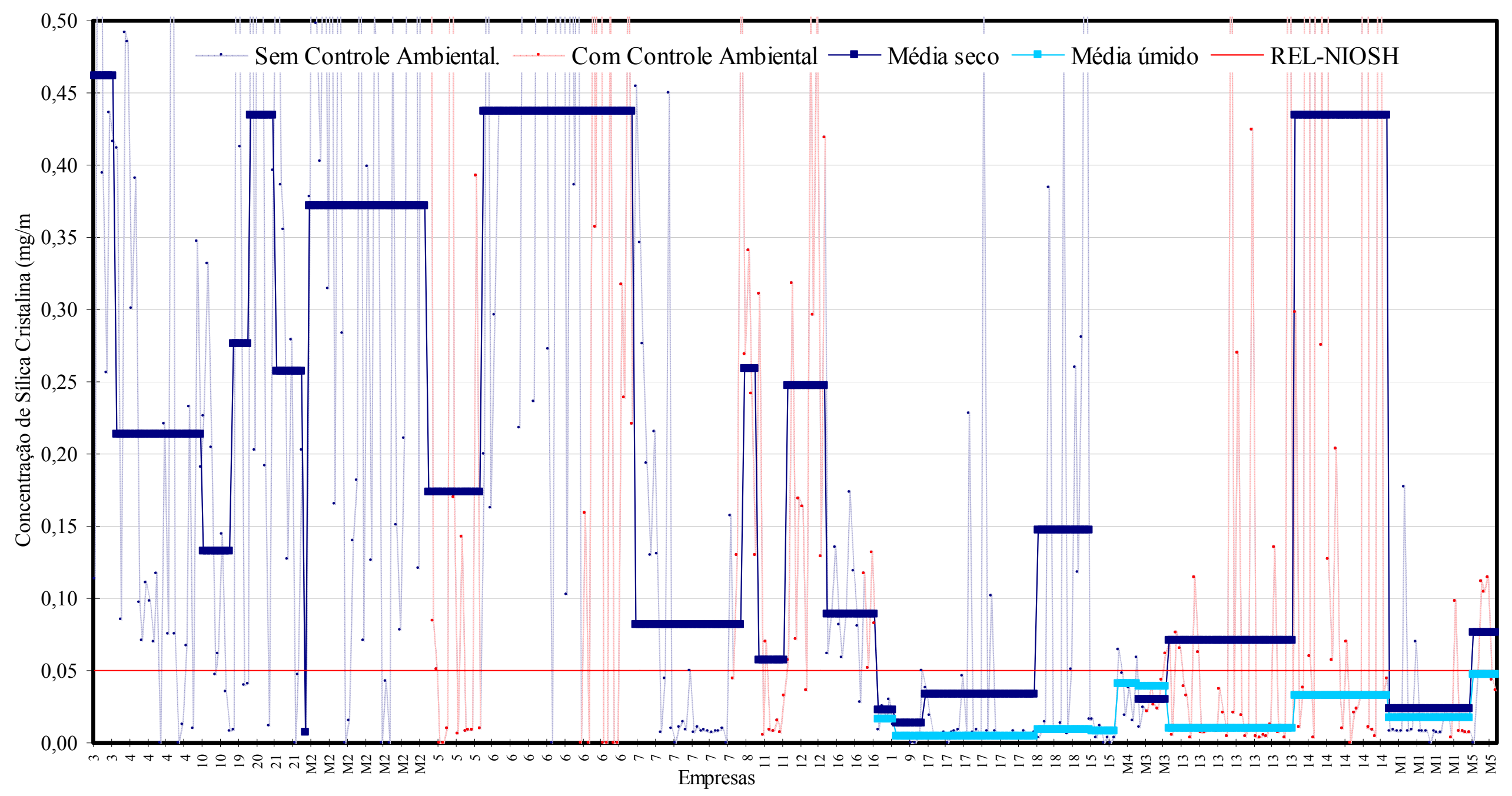

Figura 5.13 - Concentração de sílica cristalina respirável para a função de acabador segundo os tipos controle da poeira existentes nas 27 marmorarias estudadas. Município de São Paulo, 20032005 
Nas empresas de códigos 1, 9, 17, 15, M3, 14 e M5 os acabadores realizavam todas as operações a úmido, com politrizes que trabalhavam com água, com furadeiras e fresas, e por isso foram caracterizadas como operações à úmido. Estas apresentaram resultados de concentração média de sílica cristalina para a função de acabador abaixo do valor de referência, para as várias matérias-primas, com exceção das matérias-primas sintéticas. Nas empresas M3, M4, M5 e 14, as matérias-primas eram em sua maioria granitos com altos teores de sílica. Na empresa 1, eram granitos pretos com teores mais baixos. Nas empresas 9 e 17, eram mármores, e a sílica cristalina foi detectada em um número reduzido de amostras.

Os resultados de concentração média de sílica cristalina encontrados para as politrizes com água com sistema elétrico das empresas $1,9,14$ e 18 ou pneumático das empresas 17, 15, M4, M3 e M5, foram semelhantes. As maiores concentrações foram das M4, M3, 14 e M5 que realizaram trabalhos com granitos.

As empresas de números 17 e 18, que possuíam Boleadeira, apresentaram resultados de concentração média de sílica cristalina para a função de acabador abaixo do valor de referência.

Nas empresas M1 e 13, foram realizadas atividades de acabamento de mármore com água e sal de forma manual.

As Figuras 5.14 e 5.15 são situações de trabalho para a função de acabador que realizavam desbaste com rebolo a seco e a úmido, respectivamente.

As Figuras 5.16 e 5.17 são situações de trabalho para a função de acabador que realizavam desbaste com disco diamantado a seco e a úmido, respectivamente.

As Figuras 5.18 e 5.19 são vistas gerais para uma empresa de com a etapa de acabamento a seco, e outra a úmido, respectivamente. 


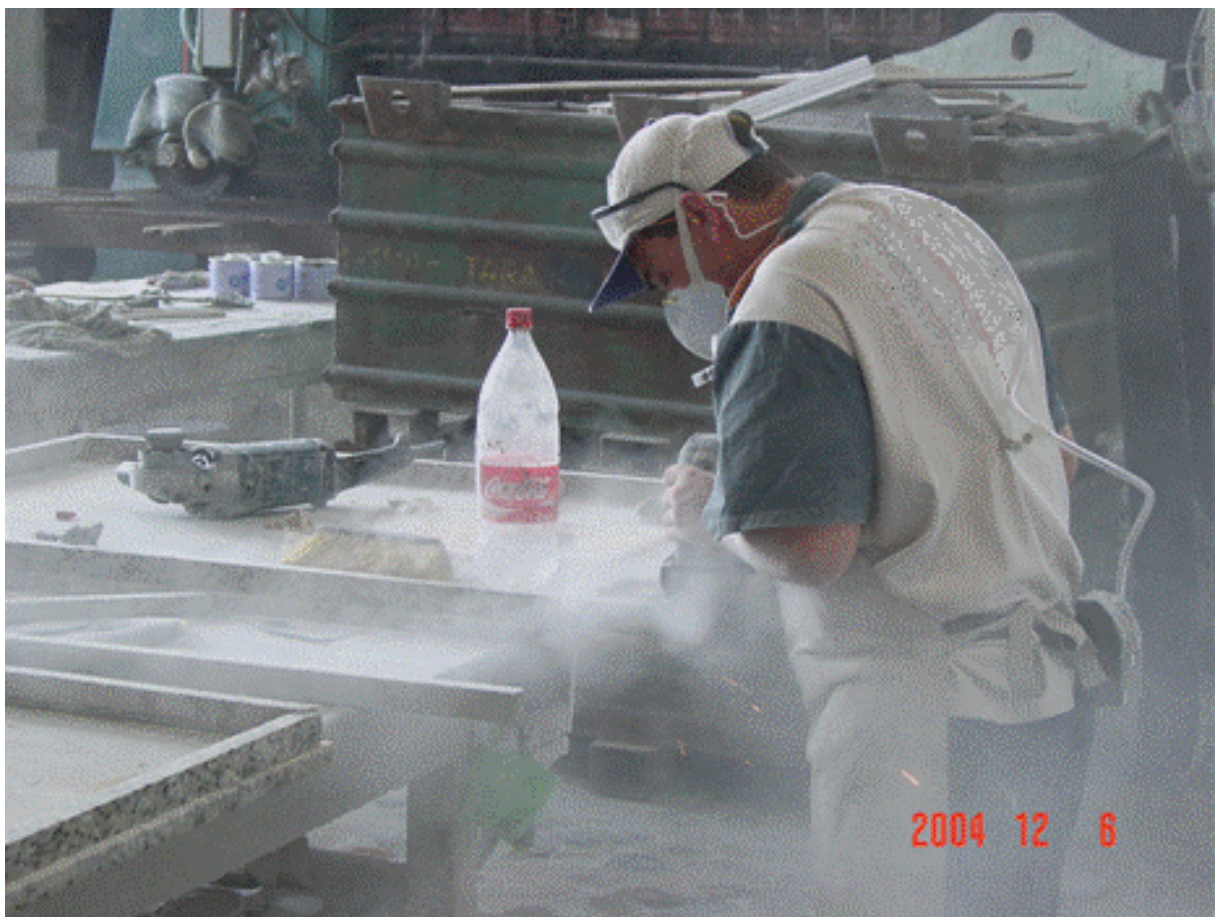

Figura 5.14 - Atividade de desbaste com politriz manual e rebolo para processo com a etapa de acabamento a seco em marmorarias. Município de São Paulo, 2003-2005

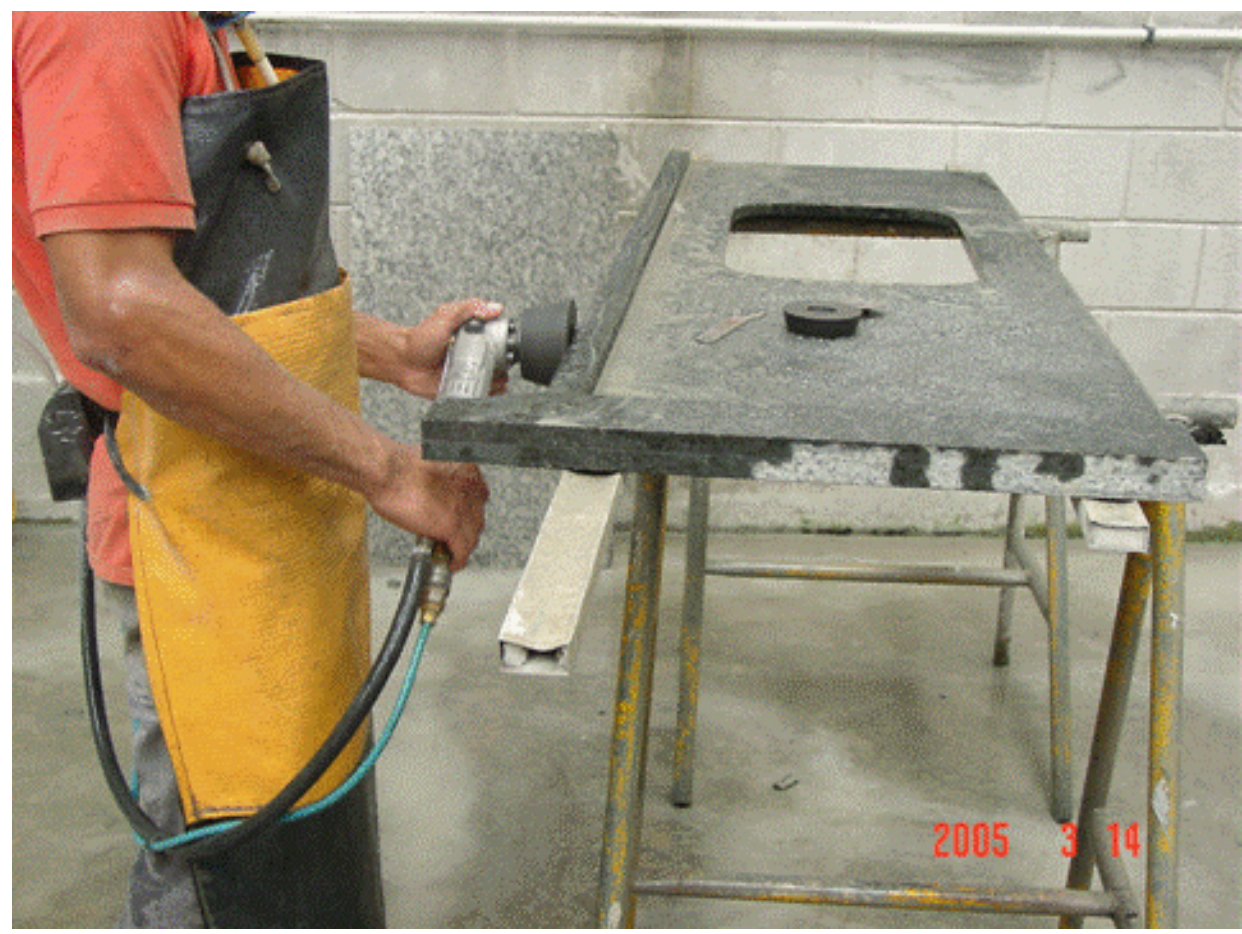

Figura 5.15 - Atividade de desbaste com politriz manual e rebolo para processo com a etapa de acabamento a úmido em marmorarias. Município de São Paulo, 2003-2005 


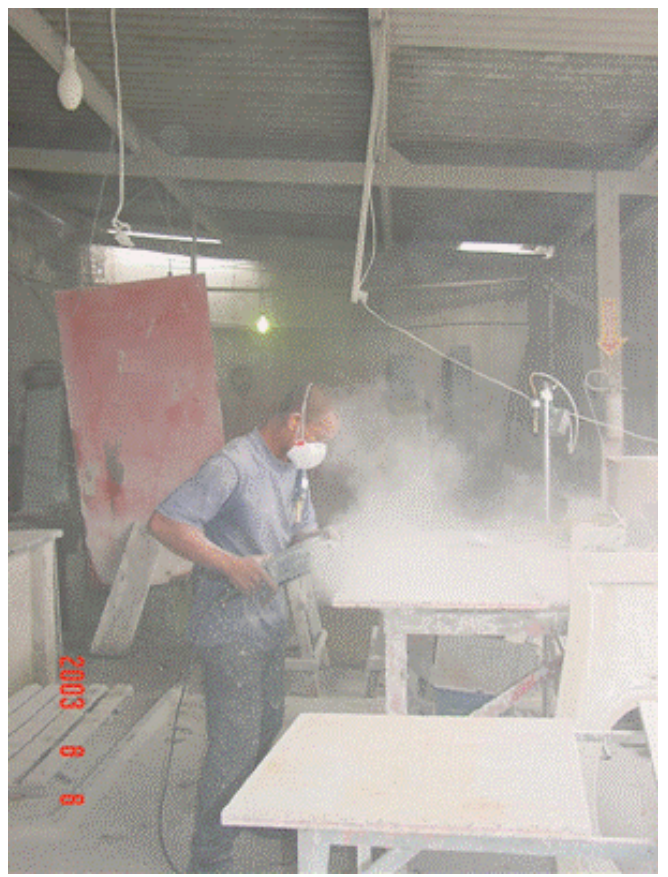

Figura 5.16 - Atividade de desbaste com politriz manual e disco diamantado para processo com a etapa de acabamento a seco em marmorarias. Município de São Paulo, 2003-2005

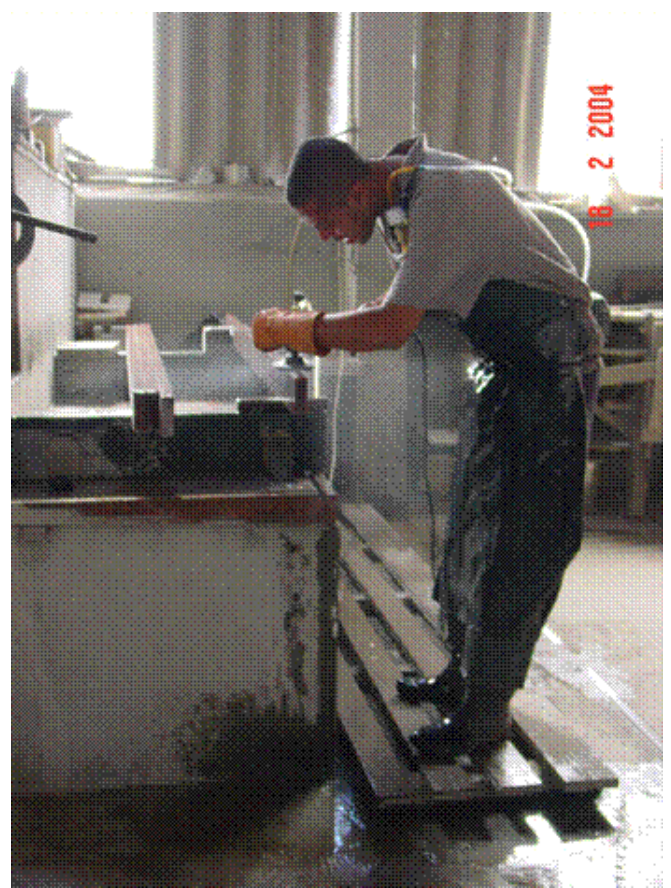

Figura 5.17 - Atividade de desbaste com politriz manual e disco diamantado para processo com a etapa de acabamento a úmido em marmorarias. Município de São Paulo, 2003-2005 


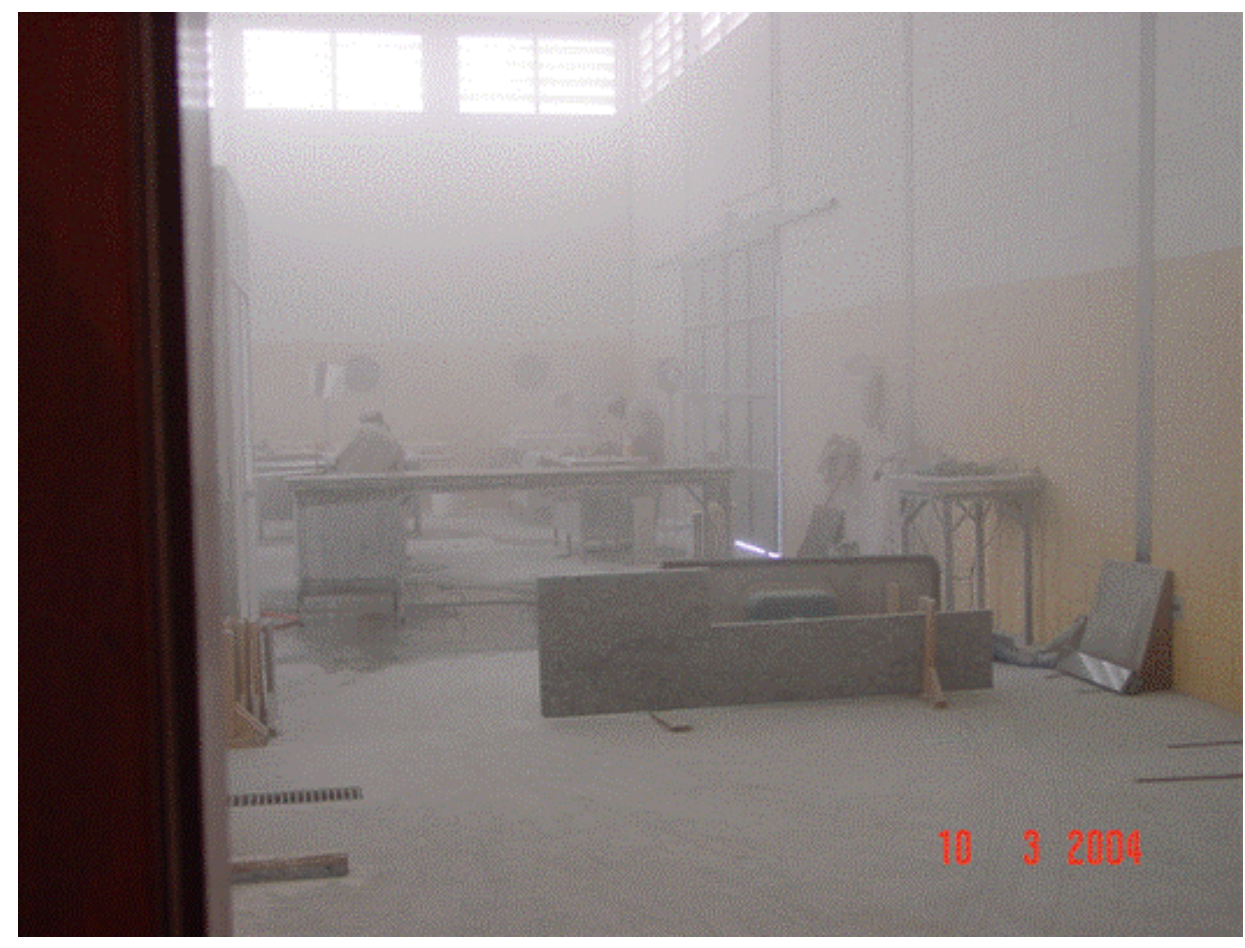

Figura 5.18 - Vista geral de marmoraria que utilizava processo com a etapa de acabamento a seco. Município de São Paulo, 2003-2005

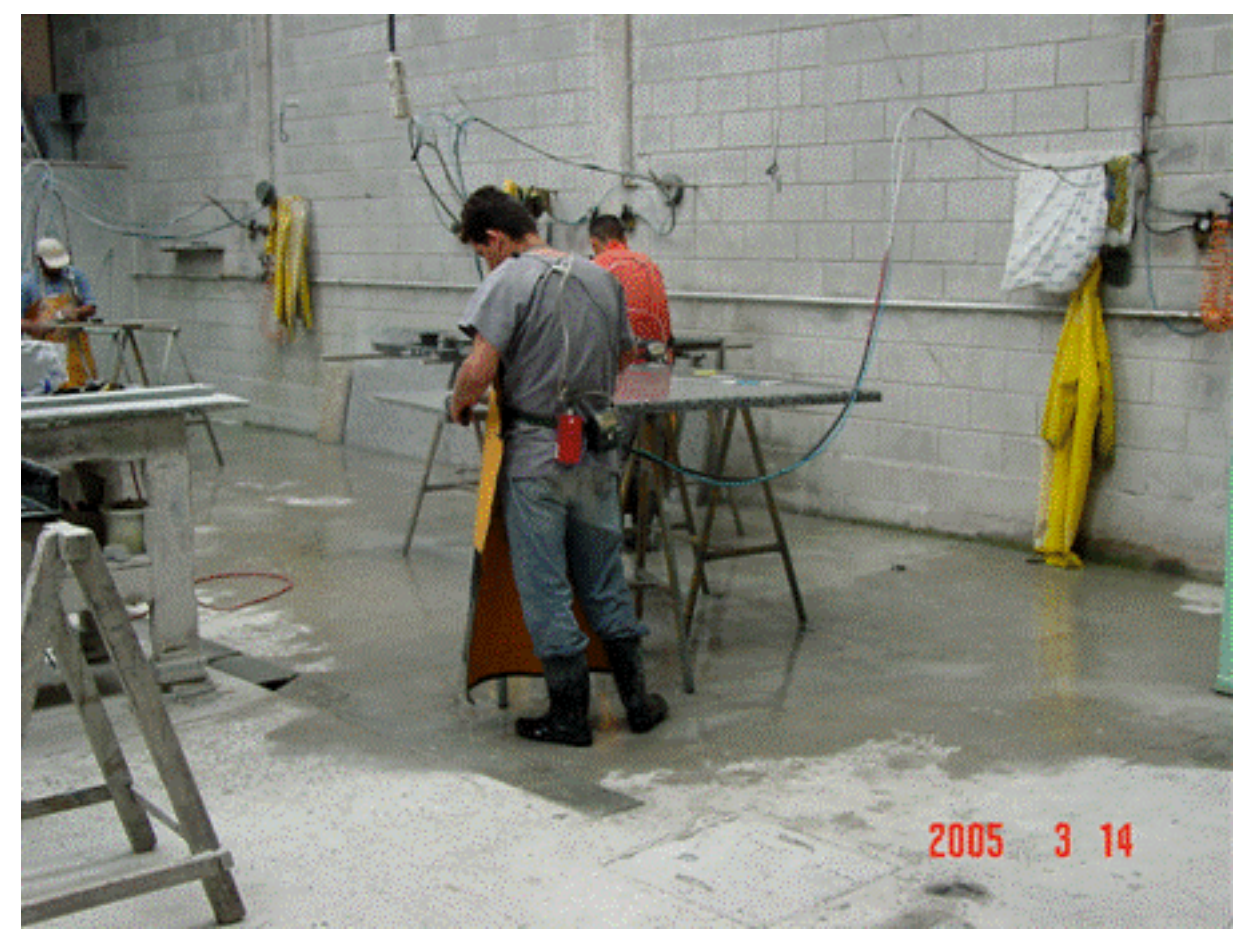

Figura 5.19 - Vista geral de marmoraria que utilizava processo com a etapa de acabamento a úmido. Município de São Paulo, 2003- 2005 


\subsection{Caracterização das matérias-primas}

As matérias-primas encontradas com maior freqüência nas marmorarias eram de origem natural, comercialmente conhecidas como rochas ornamentais e de revestimento. Matérias-primas sintéticas foram encontradas em pequenas quantidades.

Foram coletadas 122 amostras de matérias-primas, sendo 80 de granitos, 26 de mármores, 10 de rochas aparelhadas e dimensionadas (arenitos, mineiras, entre outras), 4 de produtos sintéticos, 1 de ardósia e 1 de quartzito. A Figura 5.20 apresenta a distribuição porcentual das matérias-primas.

A Tabela com a classificação em grandes grupos das rochas ornamentais, conforme descrito no item 3.6.4 é apresentada no Anexo 14.

$\square$ Granitos

Mármores

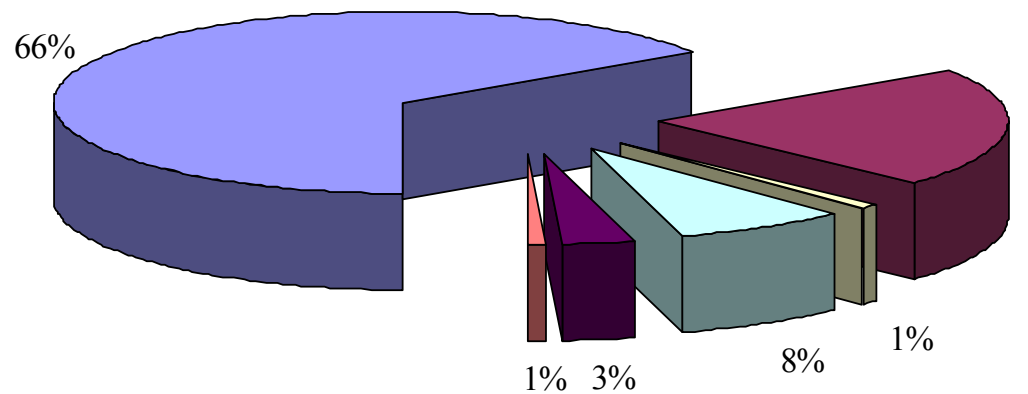

$\square$ Ardósia

$\square$ Rochas aparelhadas (arenito, mineira, outras)

$\square$ Produtos sintéticos

$1 \% \quad 3 \%$

$\square$ Quartzito

Figura 5.20 - Distribuição porcentual das matérias-primas encontradas nas 27 marmorarias estudadas. Município de São Paulo, 2003 - 2005 
Buscou-se traçar um perfil para os granitos, encontrados em maior proporção, 66\%, utilizando a porcentagem de sílica cristalina presente na fração respirável, conforme critério e procedimento no item 4.2. Apresentam-se na Figura 5.20 os resultados de porcentagem de sílica cristalina obtidos para os granitos utilizados nas 27 marmorarias estudadas.

Os granitos podem contem teores variáveis de sílica cristalina enquanto rocha bruta. Foi encontrado uma faixa ampla de porcentagem de sílica cristalina respirável nos resultados individuais para amostras de ar coletadas durante trabalho feito exclusivamente com granito. 


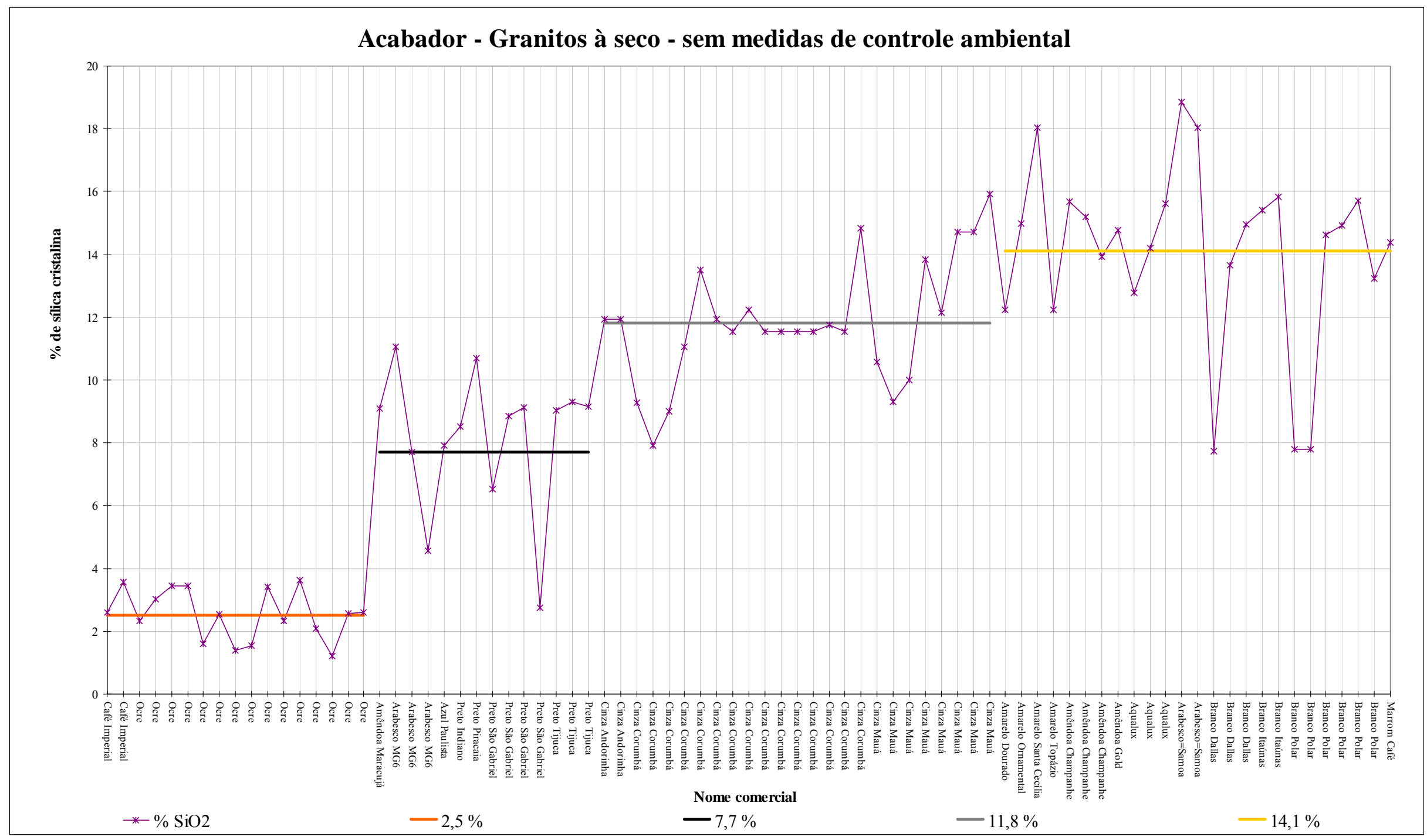

Figura 5. 21 - Porcentagem de sílica cristalina encontrada na fração respirável de poeira gerada nas atividades de desbaste, com disco diamantado, para os diversos tipos de granitos utilizados nas 27 marmorarias estudadas. Município de São Paulo, 20032005 
A exposição ocupacional a sílica cristalina respirável está relacionada com risco de silicose especialmente se a porcentagem desta for superior a $10 \%$ na fração respirável da poeira (ALGRANTI et al. 2003). Tomando como base este valor, os granitos foram classificados em 2, grupos com 2 subdivisões segundo a porcentagem de sílica cristalina presente na fração respirável: a) Grupo 1 - granitos com mais de $10 \%$, b) granitos com menos de $10 \%$.

No grupo 1, sub-grupo $1^{\text {a }}$, foram enquadrados os granitos brancos e amarelos, os mais perigosos, com aproximadamente $14 \%$ de sílica cristalina (quartzo). Os granitos cinza tinham aproximadamente $12 \%$ de sílica cristalina (quartzo), e foram enquadrados grupo 1B.

No grupo 2, sub-grupo $2^{\mathrm{a}}$, foram enquadrados a maioria dos granitos pretos, arabesco MG6 e Amêndoa Maracujá, com aproximadamente 8,0\% de quartzo, em média. No último grupo, sub-grupo 2B, foram colocados granitos Ocre e Café Imperial, com aproximadamente $2,5 \%$ de quartzo, considerados os menos perigosos.

Neste estudo deve ser destacada a ocorrência de matérias-primas de composição mineralógica ou de fabricação com alta concentração de sílica como, por exemplo, as rochas brutas com vários tipos de arenitos e o Silestone ${ }^{\circledR}$, com $95 \%$ de sílica cristalina (quartzo) em sua composição.

Para o Silestone ${ }^{\circledR}$ foi encontrada faixa de 16 a $52 \%$ de sílica cristalina na fração respirável.

Para os quartzitos e arenitos foi encontrada faixa de 7 a $38 \%$ de sílica na fração respirável.

Para a ardósia, foi obtida uma faixa entre 6 e 18,2\% de sílica cristalina respirável. 
A sílica cristalina não foi identificada na maioria das amostras de ar coletadas durante trabalho usando matéria-prima mármore como, por exemplo, Branco Espírito Santo. Usando travertino brasileiro, médio baiano, foi encontrado teor de aproximadamente $2,0 \%$ de sílica cristalina respirável. No caso do Ônix, o valor encontrado foi aproximadamente $9 \%$.

\subsection{Caracterização da População do Estudo e Avaliação Médica}

A população do estudo foi composta por 267 trabalhadores do sexo masculino de 22 marmorarias do Município de São Paulo. A população era inicialmente composta por 279 trabalhadores que poderiam estar expostos à poeira. Foram excluídos 7 homens e 5 mulheres após observações de campo e análise dos dados dos instrumentos de avaliação. A coleta de dados foi realizada de fevereiro de 2004 a maio de 2005, conforme itens 4.5.1 e 4.5.2.

\subsubsection{Caracterização demográfica, antropométrica e sócio-econômica}

Na Tabela 5.20 são apresentados os resultados das análises descritivas com as características gerais da população de estudo, idade, índice de massa corpórea, hábito de fumar, escolaridade, renda familiar e número de habitantes por domicílio.

Com base nos dados da Tabela 5.20, verifica-se que: a população era formada por trabalhadores com média de idade 35,8 anos; Índice de Massa Corporal médio de 25,8; não fumantes eram 54,7\%; cerca de 70\% dos trabalhadores não concluíram o ensino fundamental; $60 \%$ da população possuíam renda familiar de até 4 salários mínimos e $80 \%$ da população residiam com no máximo 4 pessoas. 
Tabela 5.20 - Características demográficas, antropométricas e sócio-econômicas dos trabalhadores estudados em marmorarias, no Município de São Paulo, 2004 - 2005

\begin{tabular}{|c|c|}
\hline \multirow[t]{2}{*}{ Característica } & Homens \\
\hline & $\mathrm{n}(\%)$ \\
\hline Número & $267 \quad(100)$ \\
\hline Idade (anos) (média dp) ${ }^{(1)}$ & $35,8 \pm(11,6)$ \\
\hline IMC $\left(\mathrm{kg} / \mathrm{m}^{2}\right)^{(2)}(\text { média dp })^{(3)}$ & $25,8 \pm(3,9)$ \\
\hline \multicolumn{2}{|l|}{ Tabagismo } \\
\hline Fumantes & $58 \quad(21,7)$ \\
\hline Ex-fumantes & $63 \quad(23,6)$ \\
\hline Não fumantes & $146 \quad(54,7)$ \\
\hline \multicolumn{2}{|l|}{ Escolaridade } \\
\hline Nunca freqüentou a escola & $(4,1)$ \\
\hline Fundamental incompleto & $177 \quad(66,3)$ \\
\hline Fundamental completo & $39 \quad(14,6)$ \\
\hline Segundo grau incompleto & $15 \quad(5,6)$ \\
\hline Segundo grau completo & $20 \quad(7,5)$ \\
\hline Superior incompleto & $2 \quad(0,8)$ \\
\hline Superior completo & $(1,1)$ \\
\hline \multicolumn{2}{|l|}{ Renda Familiar } \\
\hline Até $1 \mathrm{SM}^{(3)}$ & $(0,4)$ \\
\hline$>1 \mathrm{SM}$ até $2 \mathrm{SM}$ & $32(12,0)$ \\
\hline$>2 \mathrm{SM}$ até $3 \mathrm{SM}$ & $91 \quad(34,1)$ \\
\hline$>3 \mathrm{SM}$ até $4 \mathrm{SM}$ & $30 \quad(11,2)$ \\
\hline$>4 \mathrm{SM}$ até $5 \mathrm{SM}$ & $19 \quad(7,1)$ \\
\hline$>5 \mathrm{SM}$ até $10 \mathrm{SM}$ & $80 \quad(30,0)$ \\
\hline$>10 \mathrm{SM}$ & $14 \quad(5,2)$ \\
\hline \multicolumn{2}{|l|}{ Número de habitantes por domicílio } \\
\hline 1 & $(8,2)$ \\
\hline 2 & $50 \quad(18,7)$ \\
\hline 3 & $66 \quad(24,7)$ \\
\hline 4 & $72(27,0)$ \\
\hline 5 & $40 \quad(15,0)$ \\
\hline 6 & $11 \quad(4,1)$ \\
\hline 7 & $(0,8)$ \\
\hline 8 & $4 \quad(1,5)$ \\
\hline
\end{tabular}

(1)Média = Média artimética; $\mathrm{DP}=$ Desvio padrão

(2)IMC=Índice de Massa Corporal

(3)SM=Salário Mínimo 
Foi utilizado o teste paramétrico t'Student, para comparar a média de idade dos trabalhadores da função de acabador e a média de idade dos trabalhadores de outras funções. A Tabela 5.21 apresenta os resultados encontrados.

Tabela 5.21 - Número, média e desvio padrão para idade em anos segundo a função, entre os trabalhadores de marmorarias, no Município de São Paulo, 2004 -2005

\begin{tabular}{cccc}
\hline \multirow{2}{*}{ Função } & \multicolumn{3}{c}{ Idade } \\
\cline { 2 - 4 } & $\begin{array}{c}\text { Número de } \\
\text { trabalhadores }\end{array}$ & $\begin{array}{c}\text { Média } \\
(\text { anos })\end{array}$ & $\begin{array}{c}\text { DP } \\
(\text { anos })\end{array}$ \\
\hline Acabador & 97 & 33,3 & 9,7 \\
\hline Outras & 170 & 37,1 & 12,3 \\
\hline TOTAL & 250 & &
\end{tabular}

$\mathrm{t}=-2,80 ; \mathrm{p}=0,0055$

Existe diferença estatisticamente significante entre a média de idade para os trabalhadores da função de acabador e os trabalhadores de outras funções.

\subsubsection{Caracterização da população por função}

Na Tabela 5.22 apresentam-se os dados das análises descritivas da população por função na empresa atual. Pode-se observar que os trabalhadores apresentavam pouco tempo nas funções. A função de polidor foi a que apresentou o maior tempo médio, 12,5 anos. A função de acabador, por exemplo, apresentou um tempo médio de 5,8 anos. O tempo de permanência dos trabalhadores na mesma função foi em média 6,5 anos. 
Tabela 5.22 - Distribuição do número de trabalhadores, tempo médio de trabalho na marmoraria atual, tempo médio total de trabalho em marmorarias segundo a função, no Município de São Paulo, $2004-2005$

\begin{tabular}{|c|c|c|c|c|}
\hline \multirow[b]{2}{*}{$\begin{array}{l}\text { Função ou } \\
\text { atividades em } \\
\text { setores específicos }\end{array}$} & \multicolumn{4}{|c|}{ Trabalhadores } \\
\hline & $\mathrm{n}$ & $\%$ & $\begin{array}{l}\text { Tempo médio na } \\
\text { marmoraria atual } \\
\text { (anos) }\end{array}$ & $\begin{array}{c}\text { Tempo médio total } \\
\text { em marmorarias } \\
\text { (anos) }\end{array}$ \\
\hline Acabador & 97 & 36,3 & $5,8 \pm 5,7$ & $10,3 \pm 7,8$ \\
\hline Ajudante & 52 & 19,5 & $3,7 \pm 3,8$ & $3,9 \pm 4,4$ \\
\hline Cortador & 50 & 18,8 & $7,5 \pm 7,3$ & $13,6 \pm 10,8$ \\
\hline Colocador & 22 & 8,2 & $5,5 \pm 4,9$ & $16,7 \pm 12,4$ \\
\hline $\begin{array}{l}\text { Administrativos } \\
\text { (arquiteto, medidor) }\end{array}$ & 11 & 4,1 & $6,2 \pm 6,6$ & $12,2 \pm 12,5$ \\
\hline Polidor & 10 & 3,8 & $12,5 \pm 7,7$ & $12,4 \pm 5,9$ \\
\hline Encarregado & 9 & 3,4 & $10,5 \pm 7,7$ & $12,2 \pm 8,3$ \\
\hline Motorista & 5 & 1,9 & $9,8 \pm 4,1$ & $9,8 \pm 4,2$ \\
\hline Manutenção & 4 & 1,5 & $9,0 \pm 6,3$ & $15,8 \pm 11,3$ \\
\hline Proprietário & 3 & 1,1 & $10,3 \pm 8,0$ & $12,3 \pm 9,1$ \\
\hline Gravador & 2 & 0,7 & $9,0 \pm 4,2$ & $12,0 \pm 5,7$ \\
\hline Canteiro & 2 & 0,7 & $27,7 \pm 24,5$ & $27,7 \pm 24,5$ \\
\hline TOTAL & 267 & 100,0 & $6,5 \pm 6,5$ & $10,65 \pm 9,4$ \\
\hline
\end{tabular}

A Tabela 5.23 apresenta a distribuição de trabalhadores por número de marmorarias em que estes já haviam trabalhado.

Tabela 5.23 - Distribuição dos trabalhadores segundo número referido de marmorarias em que haviam trabalhado anteriormente. Município de São Paulo, 2004 -2005

\begin{tabular}{ccc}
\hline \multirow{2}{*}{$\begin{array}{c}\text { Número de marmorarias } \\
\text { anteriores }\end{array}$} & \multicolumn{2}{c}{ Trabalhadores } \\
\cline { 2 - 3 } & Número & Porcentagem \\
\hline 0 & 137 & 51,3 \\
1 & 38 & 14,2 \\
2 & 35 & 13,1 \\
3 & 21 & 7,8 \\
4 & 15 & 5,6 \\
5 & 8 & 3,0 \\
6 & 7 & 2,6 \\
7 & 2 & 0,8 \\
8 & 1 & 0,4 \\
9 & 1 & 0,4 \\
10 & 1 & 0,4 \\
"não respondeu” & 1 & 0,4 \\
\hline TOTAL & 267 & 100,0 \\
\hline
\end{tabular}


Entre os 267 trabalhadores, 130 (aproximadamente 50,0\%) referiram já ter trabalhado em outras marmorarias.

\subsubsection{Sintomas respiratórios referidos}

A Tabela 5.24 apresenta a distribuição e prevalência dos sintomas respiratórios referidos na população estudada. $24 \%$ dos trabalhadores mostraram algum tipo de sintoma respiratório.

Tabela 5.24 - Prevalência de sintomas respiratórios referidos em trabalhadores de marmorarias $(n=267)$ no Município de São Paulo, em 20042005

\begin{tabular}{ccc}
\hline \multirow{2}{*}{ Sintoma respiratório } & \multicolumn{3}{c}{ Trabalhadores } \\
\cline { 2 - 3 } & Número & Percentagem \\
\hline Chiado com Dispnéia & 48 & 18,0 \\
Bronquite crônica & 11 & 4,1 \\
Dispnéia grau 3 & 5 & 1,9 \\
\hline Total & 64 & 24,0 \\
\hline
\end{tabular}

\subsubsection{Avaliação da função pulmonar}

Dos 267 trabalhadores, 261 realizaram provas de função pulmonar, conforme descrito no item 4.5.4. Quatro trabalhadores não realizaram os exames, 1 por possuir aneurisma de aorta, e 3 por motivos desconhecidos. Dois realizaram os exames após análises dos dados, e não puderam ser incluídos neste estudo. A Tabela 5.25 apresenta os resultados obtidos.

Tabela 5.25 - Prevalência de $C V F$, $\mathrm{VEF}_{1}$, e a relação $\mathrm{VEF}_{1} / \mathrm{CVF}$ reduzidos em trabalhadores de marmorarias $(n=261)$, no Município de São Paulo, 2004 -2005

\begin{tabular}{ccc}
\hline \multirow{2}{*}{ Parâmetro } & \multicolumn{2}{c}{ Trabalhadores } \\
\cline { 2 - 3 } & Número & Porcentagem \\
\hline CVF (L) & 9 & 3,4 \\
$\mathrm{VEF}_{1}(\mathrm{~L})$ & 14 & 5,2 \\
$\mathrm{VEF}_{1} / \mathrm{CVF}(\%)$ & 37 & 13,9 \\
\hline
\end{tabular}


Houve uma tendência dos exames de espirometria dos trabalhadores das marmorarias estudadas apresentarem-se com relação $\mathrm{VEF}_{1} / \mathrm{CVF}$ reduzida.

A Tabela 5.26 apresenta o número de trabalhadores que realizaram provas de função pulmonar (espirometria) segundo diagnóstico do tipo de alteração encontrada.

Tabela 5.26 - Número de trabalhadores segundo diagnóstico do tipo de alteração encontrada nas marmorarias estudadas, no Município de São Paulo, 2004 -2005

\begin{tabular}{ccc}
\hline \multirow{2}{*}{ Diagnóstico } & \multicolumn{2}{c}{ Trabalhadores } \\
\cline { 2 - 3 } & Número & Porcentagem \\
\hline Distúrbios Ventilatórios Obstrutivos & 34 & 13,0 \\
Distúrbios Ventilatórios Restritivos & 3 & 1,1 \\
Normal & 224 & 85,9 \\
TOTAL & 261 & 100,0 \\
\hline
\end{tabular}

Os resultados indicam um excesso de distúrbios ventilatórios obstrutivos.

\subsubsection{Radiografia de tórax}

Da população formada por 267 trabalhadores, as radiografias de tórax de 9 trabalhadores apresentaram qualidade $4 \mathrm{e}$, portanto, não puderam ser interpretadas, 5 trabalhadores haviam sido demitidos e 3 trabalhadores com função administrativa recusaram-se a fazer o exame. Sendo assim, foram interpretadas 250 radiografias de tórax conforme item 4.5.5. Os resultados obtidos estão apresentados na Tabela 5.27.

Tabela 5.27 - Resultados da classificação radiológica, segundo a profusão em trabalhadores de marmorarias $(n=250)$, no Município de São Paulo, 2004 -2005

\begin{tabular}{ccc}
\hline \multirow{2}{*}{ Profusão } & \multicolumn{2}{c}{ Trabalhadores } \\
\cline { 2 - 3 } & Número & Prevalência (\%) \\
\hline $0 / 0$ & 223 & 89,2 \\
$0 / 1$ & 25 & 10,0 \\
$1 / 0$ & 1 & 0,4 \\
$1 / 1$ & 1 & 0,4 \\
\hline TOTAL & 250 & 100,0 \\
\hline
\end{tabular}


Os resultados indicam que 27 trabalhadores, 10,8\% da população estudada, possuem exames com alterações nas radiografias de tórax com a presença de pequenas opacidades, profusão $\geq 0 / 1$. Dois trabalhadores, $0,8 \%$ da população apresentaram leituras com pequenas opacidades compatíveis com pneumoconiose. 


\subsection{Correlações entre Exposição Ocupacional e Avaliação Médica}

Os resultados de exposição ocupacional a poeira e a sílica cristalina respirável foram comparados com os achados clínicos, radiológicos e de história ocupacional da população estudada.

\subsubsection{Exposição acumulada à sílica cristalina e classificação radiológica}

Foram correlacionados os dados de exposição acumulada à sílica cristalina dos modelos 1, 2 e 3 com os achados de alterações radiológicas.

A Tabela 5.28 apresenta os dados de história ocupacional para os 27 trabalhadores cuja radiografia de tórax mostrou a presença de pequenas opacidades e a Tabela 5.29 apresenta a comparação entre história ocupacional em marmorarias, profusão $\geq 0 / 1 \mathrm{e}$ exposição acumulada.

No Modelo 1 foram utilizados os valores de concentração média de sílica cristalina por função na empresa atual conforme apresentadas na Tabela 5.3. Para o tempo de serviço em outras marmorarias e outras funções declaradas no histórico ocupacional, foram utilizadas as concentrações médias por função para o material misto, considerando tipo de processo conforme apresentadas nas Tabelas 5.7. Os cálculos de exposição acumulada foram realizados conforme descrito no item 4.4.4.

No Modelo 2 foram utilizados os valores de concentração média de sílica cristalina respirável apresentados na Tabela 5.7 para material misto e considerando o tipo de processo. Estes valores foram acumulados conforme descrito no item 4.4.4.

No Modelo 3 foram utilizados os valores de concentração média de sílica cristalina respirável apresentados na Tabela 5.9 para granito, ardósia e mármore considerando o tipo de processo seco ou úmido. Estes valores foram acumulados conforme descrito no item 4.4.4. 
Tabela 5.28 - História ocupacional resumida dos 27 trabalhadores que apresentaram resultados de classificação radiológica com profusão $\geq 0 / 1$ com pequenas opacidades nas marmorarias estudadas no município de São Paulo, 2004 -2005.

\begin{tabular}{|c|c|c|c|c|c|c|c|c|c|c|c|}
\hline \multicolumn{12}{|c|}{ Histórico ocupacional } \\
\hline \multirow{4}{*}{ 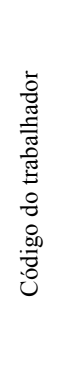 } & \multirow[b]{3}{*}{ 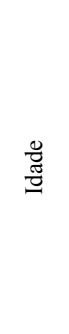 } & \multicolumn{7}{|c|}{ Marmorarias } & \multirow[b]{3}{*}{ 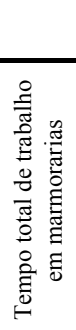 } & \multicolumn{2}{|l|}{ Outros ramos de atividade } \\
\hline & & \multicolumn{4}{|c|}{ Empresa atual } & \multicolumn{3}{|r|}{ Empresas anteriores } & & \multirow{3}{*}{ Atividades } & \multirow[b]{2}{*}{ 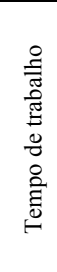 } \\
\hline & & 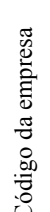 & 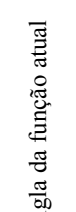 & $\begin{array}{l}\text { Sigla das funções } \\
\text { exercidas associadas às } \\
\text { materias primas } \\
\text { utilizadas }\end{array}$ & 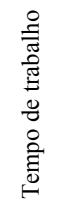 & 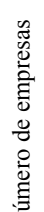 & 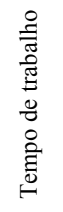 & Sigla das funções exercidas assoiadas às materias primas utilizadas & & & \\
\hline & anos & & & & anos & & anos & & anos & & anos \\
\hline 48 & 35,3 & 6 & Ac & AcG-AcM- & 6,5 & 0 & 0,0 & - & 6,5 & outras & 1,3 \\
\hline 270 & 54,8 & 17 & Co & CoG-CoM- & 23,0 & 5 & 19,0 & CoA-CoM-AcG & 39,0 & - & 0,0 \\
\hline 2 & 69,4 & 1 & $\mathrm{Ac}$ & AcG-AcM- & 25,0 & 1 & 17,6 & AcA & 42,6 & - & - \\
\hline 136 & 53,9 & 15 & Co & CoG-CoA-CoM- & 9,3 & 7 & 26,9 & CoA-CoM-AcG-AcA-AcM & 35,6 & Construção civil & 0,5 \\
\hline 170 & 54,9 & 13 & Ac & AcG-AcM- & 14,0 & 2 & 19,0 & AcAAcM & 33,0 & Construção civil + Agricultura & 6,0 \\
\hline 272 & 62,7 & 17 & Co & CoG-CoM- & 34,0 & 0 & - & - & 31,0 & Construção civil + Agricultura & 16,0 \\
\hline 90 & 54,0 & 11 & Adm & ColA-OF & 26,2 & 2 & 7,0 & OF-ColG & 30,0 & Tecelagem algodão & 1,0 \\
\hline 70 & 53,6 & 6 & Co & CoG-CoA-CoM- & 8,9 & 3 & 22,0 & AjA-AjM-PolG-PolA-PolM-CoG-CoA-CoM-AcG-AcA-AcM & 30,0 & Agricultura & 10,0 \\
\hline 212 & 50,6 & 19 & $\mathrm{Col}$ & ColG-ColM- & 20,0 & 3 & 9,0 & OF-ColG-ColA-AjG & 29,0 & - & - \\
\hline 148 & 54,5 & 18 & Man & OF & 3,5 & 3 & 23,8 & OF-ColG-ColA-ColM-AjG-CoA-AcG-AcA & 27,3 & Construção civil & 3,7 \\
\hline 158 & 42,9 & 13 & Ac & AcG-AcM- & 20,0 & 2 & 5,0 & AcA & 25,0 & - & - \\
\hline 153 & 59,2 & 13 & Ac & AcG-AcM- & 19,0 & 2 & 5,0 & AcA-AcM & 24,0 & - & - \\
\hline 157 & 44,0 & 13 & Co & CoG-CoM- & 2,0 & 6 & 17,5 & OF-ColG-ColA-AjG-PolG-PolA-PolM-CoG-CoA-CoM-AcG-AcA & 18,5 & Agricultura & 14,0 \\
\hline 19 & 71,1 & 20 & Prp & AcG-AcA-AcM-OF & 18,0 & 0 & - & - & 18,0 & - & - \\
\hline 8 & 55,7 & 1 & Man & $\mathrm{OF}$ & 17,0 & 0 & - & - & 17,0 & Metalúrgica-Soldador & 15,0 \\
\hline 85 & 33,9 & 11 & $\mathrm{Col}$ & ColG-ColM- & 11,2 & 3 & 4,0 & OF-ColG-ColA-ColM-AjG & 12,0 & Construção civil & 1,0 \\
\hline 53 & 32,7 & 6 & Co & CoG-CoM- & 8,1 & 2 & 3,8 & AjA-CoA-CoM-AcG & 11,0 & Não declarado & 2,8 \\
\hline 33 & 42,2 & 4 & $\mathrm{Co}$ & CoG-CoM- & 11,0 & 0 & - & - & 11,0 & Não declarado & 0,5 \\
\hline 3 & 34,2 & 1 & Co & CoG-CoM- & 4,0 & 3 & 6,7 & CoA-CoM-AcG-AcA-AcM & 10,7 & Construção civil & 0,4 \\
\hline 9 & 47,7 & 1 & Can & $\mathrm{OF}$ & 10,3 & 0 & - & - & 10,3 & Mecânica & 9,0 \\
\hline 247 & 51,2 & 8 & Ac & AcG-AcA-AcM- & 6,0 & 1 & 2,0 & AjA-AjM & 8,0 & Carvoaria & 18,0 \\
\hline 72 & 44,6 & 6 & Adm & $\mathrm{OF}$ & 5,4 & 4 & - & - & 4,5 & - & - \\
\hline 184 & 47,7 & 7 & Mot & OF & 4,0 & 0 & - & - & 4,0 & Não declarado & 10,0 \\
\hline 150 & 31,9 & 18 & Adm & OF & 4,0 & 0 & - & - & 4,0 & - & - \\
\hline 56 & 30,2 & 6 & $\mathrm{Co}$ & CoG-CoA-CoM-OF & 4,6 & 0 & - & - & 3,7 & Agricultura & 4,0 \\
\hline 257 & 22,4 & 17 & $\mathrm{Aj}$ & AjG-AjM-OF & 2,7 & 0 & - & - & 2,7 & Agricultura & 10,0 \\
\hline 267 & 23,1 & 17 & Co & CoG-CoM- & 3,5 & 0 & - & - & 1,8 & - & - \\
\hline
\end{tabular}

$\mathrm{Ac}=$ acabador; $\mathrm{Co}=$ cortador; $\mathrm{Man}=$ manutenção; $\mathrm{Can}=$ canteiro; $\mathrm{Adm}=$ administrativo; $\mathrm{Mot}=$ morista; $\mathrm{Col}=$ colocador; $\mathrm{Aj}=$ ajudante Prp=proprietário $\mathrm{A}=$ ardósia; $\mathrm{G}=$ granito; $\mathrm{M}=$ mármore; 
Tabela 5.29 - Comparação entre história ocupacional, achados de alterações radiológicas - profusão $\geq 0 / 1$, e os resultados de exposição acumulada à sílica cristalina entre os trabalhadores das marmorarias estudadas. Município de São Paulo $2004-2005$

\begin{tabular}{|c|c|c|c|c|c|c|c|c|c|c|c|c|c|c|c|c|}
\hline \multirow{5}{*}{ 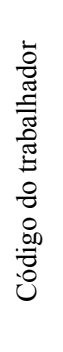 } & \multirow{5}{*}{ 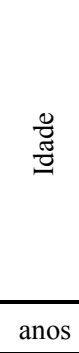 } & \multicolumn{8}{|c|}{ Marmorarias } & \multirow{5}{*}{ 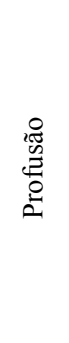 } & \multicolumn{6}{|c|}{ Exposição acumulada de sílica cristalina } \\
\hline & & \multicolumn{5}{|c|}{ Empresa atual } & \multicolumn{2}{|c|}{$\begin{array}{l}\text { Empresas } \\
\text { anteriores }\end{array}$} & \multirow{3}{*}{ 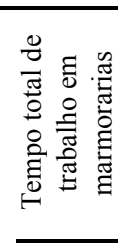 } & & & rabalh & & $\begin{array}{r}\text { médic } \\
\text { com }\end{array}$ & $\begin{array}{l}\text { s traba } \\
\text { esma p }\end{array}$ & $\begin{array}{l}\text { Adores } \\
\text { usão }\end{array}$ \\
\hline & & \multirow{3}{*}{ 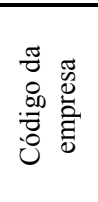 } & \multirow{3}{*}{ 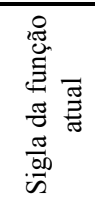 } & \multicolumn{3}{|c|}{ Tempo de trabalho } & \multirow{3}{*}{ 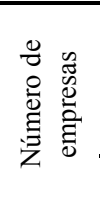 } & \multirow{2}{*}{ 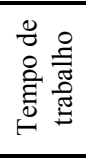 } & & & \multicolumn{6}{|c|}{ Modelos de acumulação } \\
\hline & & & & Total & $\begin{array}{c}\text { Com } \\
\text { controle }\end{array}$ & $\begin{array}{c}\text { Sem } \\
\text { controle }\end{array}$ & & & & & 1 & 2 & 3 & 1 & 2 & 3 \\
\hline & & & & & anos & & & anos & anos & & \multicolumn{6}{|c|}{$\mathrm{mg} / \mathrm{m}^{3}$-anos } \\
\hline 48 & 35,3 & 6 & $\overline{A c}$ & 6,5 & 0,9 & 5,6 & & & 6,5 & $1 / 1$ & 2,84 & 1,25 & 1,66 & 2,84 & 1,25 & 1,66 \\
\hline 270 & 54,8 & 17 & Co & 23,0 & 3,0 & 20,0 & 5 & 19,0 & 39,0 & $1 / 0$ & 1,48 & 1,56 & 1,25 & 1,48 & 1,56 & 1,25 \\
\hline 2 & 69,4 & 1 & $\overline{\mathrm{Ac}}$ & 25,0 & & 25,0 & 1 & 17,6 & 42,6 & $0 / 1$ & 3,95 & 8,18 & 9,20 & & & \\
\hline 136 & 53,9 & 15 & Co & 9,3 & 0,6 & 8,7 & 7 & 26,9 & 35,6 & $0 / 1$ & 2,94 & 2,94 & 2,58 & & & \\
\hline 170 & 54,9 & 13 & Ac & 14,0 & 2,9 & 11,1 & 2 & 19,0 & 33,0 & $0 / 1$ & 6,34 & 6,34 & 7,08 & & & \\
\hline 272 & 62,7 & 17 & Co & 34,0 & 3,0 & 31,0 & & & 31,0 & $0 / 1$ & 1,24 & 1,24 & 0,99 & & & \\
\hline 90 & 54,0 & 11 & $\mathrm{Adm}$ & 26,2 & 3,2 & 23,0 & 2 & 7,0 & 30,0 & $0 / 1$ & 3,08 & 2,47 & 2,37 & & & \\
\hline 70 & 53,6 & 6 & Co & 8,9 & 0,9 & 8,0 & 3 & 22,0 & 30,0 & $0 / 1$ & 0,69 & 0,69 & 0,36 & & & \\
\hline 212 & 50,6 & 19 & Col & 20,0 & & 20,0 & 3 & 9,0 & 29,0 & $0 / 1$ & 0,78 & 0,61 & 0,17 & & & \\
\hline 148 & 54,5 & 18 & Man & 3,5 & & 3,5 & 3 & 23,8 & 27,3 & $0 / 1$ & 1,84 & 1,84 & 2,30 & & & \\
\hline 158 & 42,9 & 13 & $\mathrm{Ac}$ & 20,0 & 2,9 & 17,1 & 2 & 5,0 & 25,0 & $0 / 1$ & 4,43 & 4,80 & 2,87 & & & \\
\hline 153 & 59,2 & 13 & $\mathrm{Ac}$ & 19,0 & 2,9 & 16,1 & 2 & 5,0 & 24,0 & $0 / 1$ & 4,08 & 4,61 & 4,61 & & & \\
\hline 157 & 44,0 & 13 & Co & 2,0 & 1,0 & 1,0 & 6 & 17,5 & 18,5 & $0 / 1$ & 1,33 & 1,33 & 1,21 & & & \\
\hline 19 & 71,1 & 20 & Prp & 18,0 & & 18,0 & & & 18,0 & $0 / 1$ & 0,59 & 0,62 & 0,77 & & & \\
\hline 8 & 55,7 & 1 & Man & 17,0 & & 17,0 & & & 17,0 & $0 / 1$ & 0,10 & 0,85 & 0,33 & 1,46 & 1,65 & 1,55 \\
\hline 85 & 33,9 & 11 & $\mathrm{Col}$ & 11,2 & 3,2 & 8,0 & 3 & 4,0 & 12,0 & $0 / 1$ & 0,25 & 0,25 & 0,08 & & & \\
\hline 53 & 32,7 & 6 & Co & 8,1 & 0,9 & 7,2 & 2 & 3,8 & 11,0 & $0 / 1$ & 0,99 & 0,45 & 0,61 & & & \\
\hline 33 & 42,2 & 4 & Co & 11,0 & & 11,0 & & & 11,0 & $0 / 1$ & 0,53 & 0,44 & 0,46 & & & \\
\hline 3 & 34,2 & 1 & Co & 4,0 & & 4,0 & 3 & 6,7 & 10,7 & $0 / 1$ & 0,56 & 0,69 & 0,83 & & & \\
\hline 9 & 47,7 & 1 & Can & 10,3 & & 10,3 & & & 10,3 & $0 / 1$ & 0,12 & 1,03 & 0,20 & & & \\
\hline 247 & 51,2 & 8 & $\mathrm{Ac}$ & 6,0 & 2,7 & 3,3 & 1 & 2,0 & 8,0 & $0 / 1$ & 1,61 & 1,25 & 1,24 & & & \\
\hline 72 & 44,6 & 6 & $\mathrm{Adm}$ & 5,4 & 0,9 & 4,5 & 4 & & 4,5 & $0 / 1$ & 0,29 & 0,11 & 0,09 & & & \\
\hline 184 & 47,7 & 7 & Mot & 4,0 & & 4,0 & & & 4,0 & $0 / 1$ & 0,10 & 0,10 & 0,08 & & & \\
\hline 150 & 31,9 & 18 & $\mathrm{Adm}$ & 4,0 & & 4,0 & & & 4,0 & $0 / 1$ & 0,03 & 0,10 & 0,08 & & & \\
\hline 56 & 30,2 & 6 & Co & 4,6 & 0,9 & 3,7 & & & 3,7 & $0 / 1$ & 0,31 & 0,16 & 0,12 & & & \\
\hline 257 & 22,4 & 17 & $\mathrm{Aj}$ & 2,7 & 2,7 & & & & 2,7 & $0 / 1$ & 0,13 & 0,13 & 0,07 & & & \\
\hline 267 & 23,1 & 17 & Co & 3,5 & 1,8 & 1,8 & & & 1,8 & $0 / 1$ & 0,07 & 0,07 & 0,04 & & & \\
\hline
\end{tabular}

$\mathrm{Ac}=$ acabador; $\mathrm{Co}=$ cortador; $\mathrm{Man}=$ manutenção; $\mathrm{Can}=$ canteiro; $\mathrm{Adm}=$ administrativo; $\mathrm{Mot}=$ morista; $\mathrm{Col}=$ colocador; $\mathrm{Aj}=$ ajudante $\operatorname{Prp}=$ proprietário $\mathrm{A}=$ ardósia; $\mathrm{G}=$ granito; $\mathrm{M}=$ mármore; 
$\mathrm{Na}$ Figura 5.22 apresentam-se as médias para a exposição acumulada à sílica cristalina em $\mathrm{mg} / \mathrm{m}^{3}$-anos (SCA) e os intervalos de confiança de $95 \%$ para cada modelo e cada categoria de profusão, $0 / 0 ; 0 / 1 ; 1 / 0$ e $1 / 1$.

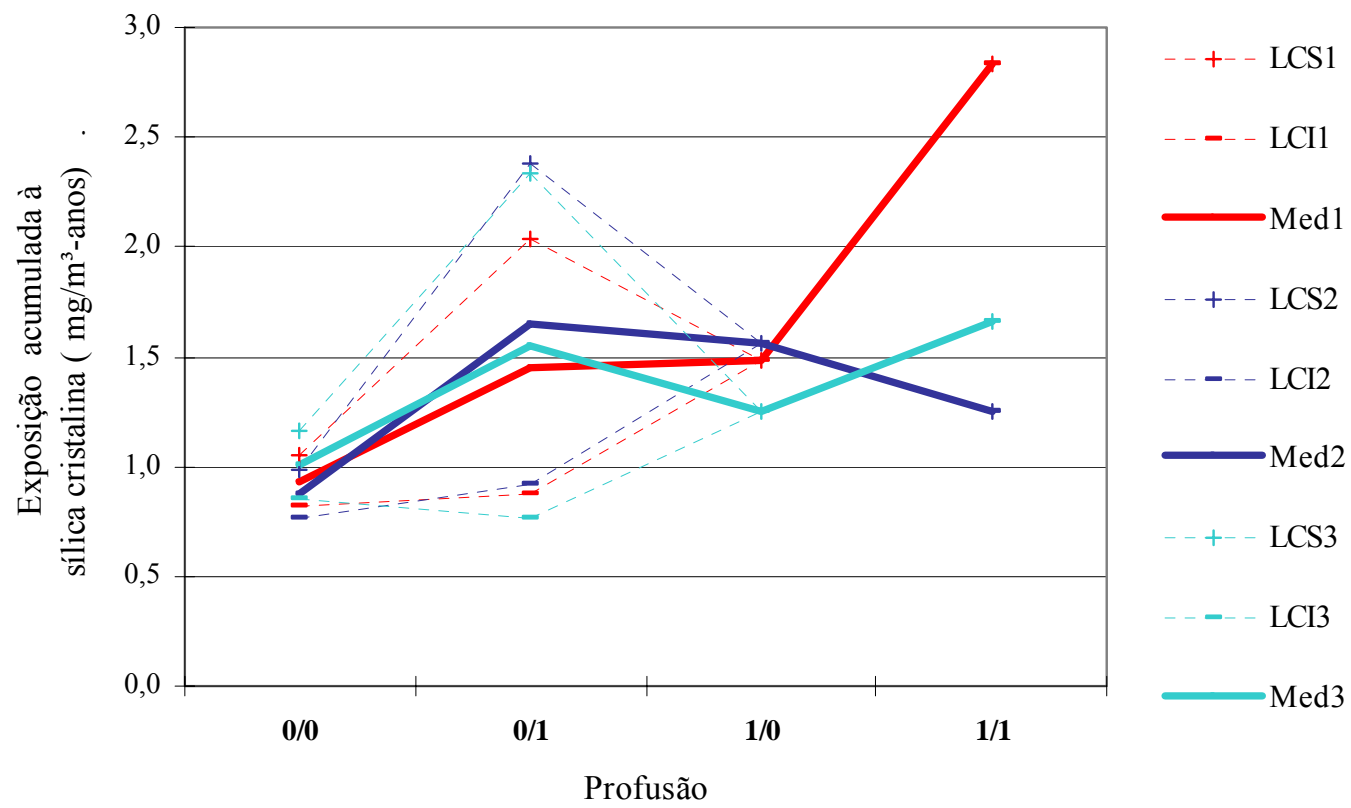

Profusão $=$ Resultado de classificação radiológica segundo OIT-2000

Figura 5.22 - Médias de exposição acumulada à sílica cristalina em $\mathrm{mg} / \mathrm{m}^{3}$-anos e intervalos de confiança de $\mathbf{9 5 \%}$ em função dos resultados obtidos de radiografia de tórax, segundo a profusão, para os trabalhadores de marmorarias, no Município de São Paulo, 2004 -2005

As análises estatísticas foram realizadas com os dados agrupados, considerando os 223 trabalhadores com resultados de radiografia normais (profusão $=0 / 0$ e sem pequenas opacidades) e 27 trabalhadores com radiografias com alterações (profusão $\geq 0 / 1$ e com pequenas opacidades). 
Os testes estatísticos utilizados para os Modelos 1, 2 e 3 de concentrações médias de exposição acumulada à sílica cristalina e resultados de radiografias normais e com alterações foram aplicados na seguinte seqüência:

\section{1) Comparação de Médias}

Na comparação de concentrações médias de exposição acumulada à sílica cristalina dos Modelos 1, 2 e 3 com os resultados da classificação radiológica com pequenas opacidades (com alterações) e sem opacidades, utilizou-se o teste não paramétrico Savage, uma vez que as distribuições de freqüência destas concentrações foram heterogêneas (não normais) (SAS 2004). As Tabelas 5.30, 5.31 e 5.32 apresentam os resultados deste teste aplicado para os Modelos 1, 2 e 3 respectivamente.

Os resultados indicam que existe diferença estatística significante entre as médias de exposição acumulada à sílica cristalina para os trabalhadores com a presença de pequenas opacidades (com alterações) e os normais quando são utilizados os Modelos 1 e 2 . O Modelo 3 não apresentou diferença entre as médias.

Tabela 5.30 - Resultado do teste de Savage de comparação de médias de exposição acumulada à sílica cristalina para o Modelo 1 , segundo resultados da classificação radiológica, entre os trabalhadores de marmorarias, no Município de São Paulo, 2004 -2005

\begin{tabular}{ccc}
\hline \multirow{2}{*}{$\begin{array}{c}\text { Presença de pequenas } \\
\text { opacidades }\end{array}$} & \multicolumn{3}{c}{ Modelo 1 } \\
\cline { 2 - 3 }$\left(\mathrm{mg} / \mathrm{m}^{3}\right.$-anos $)$ & $\begin{array}{c}\mathrm{DP} \\
\left(\mathrm{mg} / \mathrm{m}^{3} \text {-anos }\right)\end{array}$ \\
\hline Sim & 1,51 & 1,30 \\
\hline Não & 0,96 & 0,97 \\
\hline$Z=2,25 ; \mathrm{p}=0,0243$ (significativo) & &
\end{tabular}

$\mathrm{Z}=2,25 ; \mathrm{p}=0,0243$ (significativo) 
Tabela 5.31 - Resultado do teste de Savage de comparação de médias de exposição acumulada à sílica cristalina para o Modelo 2, segundo resultados da classificação radiológica, entre os trabalhadores de marmorarias, no Município de São Paulo, 2004 -2005

\begin{tabular}{ccc}
\hline \multirow{2}{*}{$\begin{array}{c}\text { Presença de pequenas } \\
\text { opacidades }\end{array}$} & \multicolumn{3}{c}{ Modelo 2} \\
\cline { 2 - 3 } & $\begin{array}{c}\text { SCA } \\
\left(\mathrm{mg} / \mathrm{m}^{3} \text {-anos }\right)\end{array}$ & $\begin{array}{c}\mathrm{DP} \\
\left(\mathrm{mg} / \mathrm{m}^{3} \text {-anos }\right)\end{array}$ \\
\hline Sim & 1,63 & 1,62 \\
\hline Não & 0,90 & 0,94 \\
\hline$Z$
\end{tabular}

$\mathrm{Z}=2,64 ; \mathrm{p}=0,0082$ (significativo)

Tabela 5.32 - Resultado do teste de Savage de comparação de médias de exposição acumulada à sílica cristalina para o Modelo 3, segundo resultados da classificação radiológica, entre os trabalhadores de marmorarias, no Município de São Paulo, 2004 -2005

\begin{tabular}{ccc}
\hline \multirow{2}{*}{$\begin{array}{c}\text { Presença de pequenas } \\
\text { opacidades }\end{array}$} & \multicolumn{3}{c}{ Modelo 3 } \\
\cline { 2 - 3 }$\left(\mathrm{mg} / \mathrm{m}^{3}\right.$-anos $)$ & $\begin{array}{c}\mathrm{DP} \\
\left(\mathrm{mg} / \mathrm{m}^{3} \text {-anos }\right)\end{array}$ \\
\hline Sim & 1,54 & 1,29 \\
\hline Não & 1,03 & 1,75 \\
\hline
\end{tabular}

$\mathrm{Z}=1,48 ; \mathrm{p}=0,1397$ (não significativo)

2) Teste de tendência - Cochran-Armitage Trend Test

Foi aplicado o Cochran-Armitage Trend Test para verificar tendência de aumento da prevalência de trabalhadores com classificação radiológica com alterações (presença de pequenas opacidades na radiografia de tórax- profusão $\geq 0 / 1$ ) à proporção que aumenta a exposição acumulada à sílica cristalina. O teste foi aplicado para os Modelos 1, 2 e 3. Os resultados indicam que não houve tendência linear em nenhum dos Modelos. 


\section{3) Regressão Logística}

Foi utilizado o modelo de regressão logística univariada na qual a variável dependente era a classificação radiológica, sendo que para os exames com alterações foi adotado valor 1 e para os normais o valor 0 . As variáveis independentes foram os Modelos 1,2 e 3 de exposição acumulada à sílica cristalina, analisados separadamente.

Para medir o risco (Odds Ratio) foi adotado o valor mediano de exposição acumulada à sílica cristalina. No Modelo $1 \mathrm{o}$ valor mediano de exposição acumulada à sílica cristalina foi $0,56 \mathrm{mg} / \mathrm{m}^{3}$-anos, o Odds Ratio foi igual a 1,20 com intervalo de confiança de $95 \%$ entre 1,02 a 1,40. Este resultado indica que a cada $0,56^{\circ} \mathrm{mg} / \mathrm{m}^{3}$-anos o risco de ter classificação radiológica com alterações é de $20 \%$.

No Modelo 2 o valor mediano foi de $0,46 \mathrm{mg} / \mathrm{m}^{3}$-anos, o Odds Ratio foi igual a 1,18, com intervalo de confiança de $95 \%$ entre 1,05 a 1,33 . Este resultado indica que a cada $0,46 \mathrm{mg} / \mathrm{m}^{3}$-anos o risco de ter classificação radiológica com alterações é de $18 \%$.

No Modelo 3 o valor mediano foi de $0,43 \mathrm{mg} / \mathrm{m}^{3}$-anos, o Odds Ratio foi igual a 1,08, com intervalo de confiança de $95 \%$ entre 0,98 a 1,17 . A regressão ficou no borderline.

\subsubsection{Classificação radiológica e tabagismo}

O teste Qui-Quadrado foi aplicado para verificar associação entre as variáveis fumar (fumantes e ex-fumantes) e não fumar (não fumante) em relação aos resultados da classificação radiológica, presença ou não de pequenas opacidades. Os resultados encontram-se na Tabela 5.33. 
Tabela 5.33 - Resultado do teste de Qui-Quadrado para tabagismo, segundo resultados da classificação radiológica, entre os trabalhadores de marmorarias, no Município de São Paulo, 2004 -2005

\begin{tabular}{cccc}
\hline \multirow{2}{*}{$\begin{array}{c}\text { Presença de } \\
\text { pequenas } \\
\text { opacidades }\end{array}$} & $\begin{array}{c}\text { Túmero de } \\
\text { trabalhadores }\end{array}$ & $\begin{array}{c}\text { Fumantes e } \\
\text { ex-fumantes } \\
\mathrm{n}(\%)\end{array}$ & $\begin{array}{c}\text { Não fumantes } \\
\mathrm{n}(\%)\end{array}$ \\
\hline Sim & 27 & $18(15,4)$ & $9(6,8)$ \\
\hline Não & 223 & $99(84,6)$ & $124(93,2)$ \\
\hline TOTAL & 250 & $117(100)$ & $133(100)$ \\
\hline$\chi^{2}=4,80$ e $\mathrm{p}=0,0285$ (significante)
\end{tabular}

Houve associação (Qui-Quadrado) entre fumar (fumantes e ex-fumantes) e não fumar (não fumantes), com $\chi^{2}=4,80$ e $p=0,0285$. Isto significa que, $15,4 \%$ dos fumantes têm radiografias de tórax com presença de pequenas opacidades, contra $6,8 \%$ dos não fumantes.

Foi utilizada a regressão logística univariada na qual a variável dependente era a classificação radiológica, sendo que, para os exames com alterações foi adotado valor 1 e para os normais o valor 0 . A variável independente foi fumar ou não fumar. $\mathrm{O}$ risco encontrado foi significativo, com um Odds Ratio $=2,50$ e intervalo de confiança de $95 \%$ de 1,10 a 6,07 .

\subsubsection{Exposição acumulada à sílica cristalina, classificação radiológica, e tabagismo}

Foi utilizada a regressão logística multivariada com a opção "stepwise", na qual a variável dependente foi a classificação radiológica, exames com alterações e normais e as variáveis independentes foram as concentrações de exposição acumulada à sílica cristalina (Modelos 1, 2 e 3) e o tabagismo. Foi adotado valor 1 para fumar (fumantes e ex-fumantes), e o valor 0 para não fumar. As análises foram realizadas separadamente. 
Havendo associação entre o tabagismo e classificação radiológica com presença de pequenas opacidades, e um Odds Ratio de 2,50 para o tabagismo, foram realizadas análises estatísticas de regressão logística multivariada para a classificação radiológica com exposição acumulada e tabagismo. Os resultados apresentaram-se estatisticamente significantes para o Modelo 1 e tabagismo e para o Modelo 2 e tabagismo. Considerando o Modelo 3, somente a variável tabagismo foi estatisticamente significante. Tabelas 5.34, 5.35, 5.36 respectivamente.

Tabela 5.34 - Resultados da regressão logística multivariada opção “stepwise”, da classificação radiológica, para a exposição acumulada à sílica cristalina - Modelo 1, e tabagismo entre os trabalhadores de marmorarias, no Município de São Paulo, 2004 -2005

\begin{tabular}{cccc}
\hline \multirow{2}{*}{ Variável } & \multicolumn{3}{c}{ Presença de pequenas opacidades } \\
\cline { 2 - 4 } & $\begin{array}{c}\text { Razão de chance } \\
\text { (Odds Ratio) }\end{array}$ & IC 95\% & Significância \\
\hline Modelo 1 (SCA) & 1,38 & $1,04-1,84$ & Significante \\
\hline Tabagismo & 2,49 & $1,06-5,83$ & Significante \\
\hline
\end{tabular}

Tabela 5.35 - Resultados da regressão logística multivariada opção “stepwise”, da classificação radiológica, para a exposição acumulada à sílica cristalina - Modelo 2, e tabagismo entre os trabalhadores de marmorarias, no Município de São Paulo, 2004 -2005

\begin{tabular}{cccc}
\hline \multirow{2}{*}{ Variável } & \multicolumn{3}{c}{ Presença de pequenas opacidades } \\
\cline { 2 - 4 } & $\begin{array}{c}\text { Razão de chance } \\
\text { (Odds Ratio) }\end{array}$ & IC 95\% & Significância \\
\hline Modelo 2 (SCA) & 1,44 & $1,09-1,86$ & Significante \\
\hline Tabagismo & 2,53 & $1,07-5,98$ & Significante \\
\hline
\end{tabular}


Tabela 5.36 - Resultados da regressão logística multivariada opção “stepwise”, da classificação radiológica, para a exposição acumulada à sílica cristalina - Modelo 3, e tabagismo entre os trabalhadores de marmorarias, no Município de São Paulo, 2004 -2005

\begin{tabular}{cccc}
\hline \multirow{2}{*}{ Variável } & \multicolumn{3}{c}{ Presença de pequenas opacidades } \\
\cline { 2 - 4 } & $\begin{array}{c}\text { Razão de chance } \\
\text { (Odds Ratio) }\end{array}$ & IC 95\% & Significância \\
\hline Tabagismo & 2,50 & $1,10-6,07$ & Significante \\
\hline
\end{tabular}

\subsubsection{Classificação radiológica e tempo de exposição}

Os testes estatísticos utilizados para a variável de tempo de exposição e resultados de classificação radiológica, exames com alterações e normais foram aplicados na seguinte seqüência:

\section{1) Comparação de Médias}

A variabilidade foi testada inicialmente por meio do teste F'Snedecor e resultou em valor de $F=2,35$, indicando que as variâncias eram diferentes com $p=0,0009$. $\mathrm{Na}$ seqüência, o teste paramétrico t'Student para variâncias diferentes foi aplicado para comparar as médias de tempo de trabalho com os resultados de radiografias de tórax com presença ou não de pequenas opacidades. A Tabela 5.37 apresenta os resultados encontrados.

Tabela 5.37 Número de trabalhadores, média e desvio padrão para tempo de exposição em anos segundo resultados da classificação radiológica, entre os trabalhadores de marmorarias, no Município de São Paulo, 20042005

\begin{tabular}{cccc}
\hline \multirow{2}{*}{$\begin{array}{c}\text { Presença de } \\
\text { pequenas } \\
\text { opacidades }\end{array}$} & $\begin{array}{c}\text { Número de } \\
\text { trabalhadores }\end{array}$ & $\begin{array}{c}\text { Média } \\
\text { (anos) }\end{array}$ & $\begin{array}{c}\text { DP } \\
\text { (anos) }\end{array}$ \\
\hline Sim & 27 & 19,9 & 13,0 \\
\hline Não & 223 & 9,9 & 8,4 \\
\hline TOTAL & 250 & & \\
$\mathrm{t}=-3,94 ; \mathrm{p}=0,0005$ & & &
\end{tabular}




\section{2) Teste de tendência}

Foi aplicado o Cochran-Armitage Trend Test para verificar tendência de aumento da prevalência de trabalhadores com classificação radiológica com alterações (presença de pequenas opacidades na radiografia de tórax - profusão $\geq 1$ ) à proporção que aumenta o tempo de trabalho com exposição à sílica cristalina em marmorarias.

A Figura 5.23 apresenta o gráfico da distribuição das prevalências de classificação radiológica com alterações segundo tempo de trabalho por quartis $\left(1^{\circ}\right.$ quartil: $\mathrm{t} \leq 4$ anos; $2^{\circ}$ quartil: $4<\mathrm{t} \leq 8$ anos; $3^{\circ}$ quartil: $8<\mathrm{t} \leq 13,5 ; 4^{\circ}$ quartil; $\mathrm{t}>13,5$ ). A tendência foi significativa $(Z=-3,08 ; p \leq 0,0021)$.

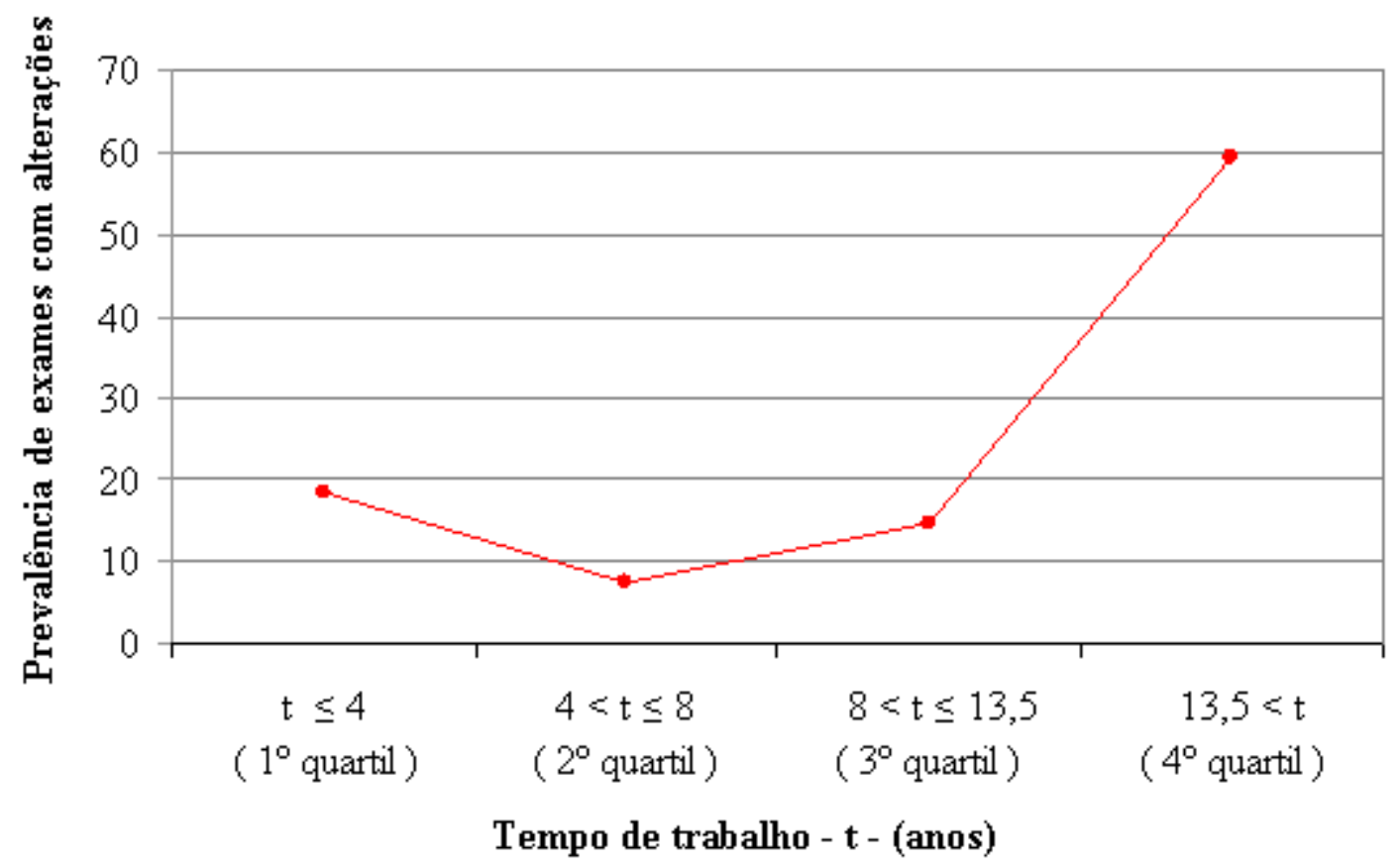

Figura 5.23 - Prevalência de resultados de radiografia de tórax com presença de pequenas opacidades (exames com alterações) por quartis de tempo de trabalho com exposição à sílica em marmorarias, na população estudada, Município de São Paulo, 2004 -2005 


\section{3) Regressão Logística}

Foi utilizado o modelo de regressão logística univariada na qual a variável dependente era a classificação radiológica, sendo que para a presença de pequenas opacidades (exame alterado) foi adotado valor 1, e para a ausência o valor 0 . A variável independente foi tempo de exposição em anos.

Para um tempo de exposição à sílica cristalina respirável igual a 4 anos obteve-se um Odds Ratio igual a 1,39 com intervalo confiança de 95\% de 1,21 a 1,62. Isto significa que o risco de ter classificação radiológica com pequenas opacidades a cada 4 anos é de $39 \%$ para o trabalhador exposto em relação ao trabalhador não exposto.

Com um tempo de exposição igual há 8 anos obteve-se um Odds Ratio igual a 1,94 com intervalo confiança de $95 \%$ de 1,47 a 2,62. Isto significa que o risco de ter classificação radiológica com pequenas opacidades a cada 8 anos é de $94 \%$ para o trabalhador exposto em relação ao trabalhador não exposto.

\subsubsection{Classificação radiológica, tempo de exposição e tabagismo}

Foi utilizada a regressão logística multivariada com a opção "stepwise", na qual a variável dependente foi o resultado da classificação radiológica, presença de pequenas opacidades (exames com alterações) ou não, e as variáveis independentes foram o tempo de exposição em anos e o tabagismo. Foi adotado valor 1 e para fumar (fumantes e ex-fumantes), e o valor 0 não fumar. A Tabela 5.38 apresenta os resultados. 
Tabela 5.38 - Resultados da regressão logística multivariada opção “stepwise”, da classificação radiológica, por tempo de exposição e tabagismo entre os trabalhadores de marmorarias, no Município de São Paulo, 20042005

\begin{tabular}{cccc}
\hline \multirow{2}{*}{ Variável } & \multicolumn{2}{c}{ Presença de pequenas opacidades } & \\
\cline { 2 - 4 } & $\begin{array}{c}\text { Razão de chance } \\
\text { (Odds Ratio) }\end{array}$ & IC 95\% & Significância \\
\hline $\begin{array}{c}\text { Tempo de exposição } \\
\text { (anos) }\end{array}$ & 1,39 & $1,21-1,62$ & Significante \\
\hline
\end{tabular}

\subsubsection{Correlação entre Exposição Ocupacional e Avaliação Médica para a Função Acabador}

Os resultados obtidos indicavam que a exposição de maior intensidade era da função de acabador. Assim, foram realizadas análises estatísticas específicas para esta função.

O teste Qui-Quadrado foi utilizado para verificar associação entre as variáveis acabadores e outras funções em relação aos resultados de provas de função pulmonar com a razão $\mathrm{VEF}_{1} / \mathrm{CVF}$ reduzida. Os resultados encontram-se na Tabela 5.39.

Tabela 5.39 - Resultado do teste de Qui-Quadrado para a razão $\mathrm{VEF}_{1} / \mathrm{CVF}$, segundo a função atual dos trabalhadores das marmorarias estudadas, no Município de São Paulo, 2004 -2005

\begin{tabular}{cccc}
\hline \multirow{2}{*}{ Função atual } & \multicolumn{3}{c}{$\mathbf{V E F}_{\mathbf{1}} / \mathbf{C V F}$} \\
\cline { 2 - 4 } & $\begin{array}{c}\text { Número de } \\
\text { trabalhadores }\end{array}$ & $\begin{array}{c}\text { Reduzido } \\
\mathrm{n}(\%)\end{array}$ & $\begin{array}{c}\text { Normal } \\
\mathrm{n}(\%)\end{array}$ \\
\hline Acabadores & 97 & $19(19,6)$ & $78(80,4)$ \\
\hline Outras funções & 170 & $18(10,6)$ & $152(89,4)$ \\
\hline TOTAL & 267 & $37(13,9)$ & $230(86,1)$ \\
\hline$\chi^{2}=4,19$ e $\mathrm{p}=0,0407$ (significante) & &
\end{tabular}


O teste Qui-Quadrado foi estatisticamente significante. Portanto existe uma associação entre a razão $\mathrm{VEF}_{1} / \mathrm{CVF}$ apresentar-se reduzida e o trabalhador ter a função atual de acabador.

Foi utilizada a regressão logística multivariada com a opção "stepwise", na qual a variável dependente foi a razão $\mathrm{VEF}_{1} / \mathrm{CVF}$ reduzida, e as variáveis independentes foram: a função, o tempo de exposição e o tabagismo. Para a função de acabador foi adotado o valor 1 e para as outras funções o valor 0 . Para o tabagismo valor 1 para fumar (fumantes e ex-fumantes) e o valor 0 não fumar. A Tabela 5.40 apresenta os resultados obtidos.

Tabela 5.40 - Resultados da regressão logística multivariada opção "stepwise” para razão $\mathrm{VEF}_{1} / \mathrm{CVF}$ reduzida, segundo função, tempo de exposição e tabagismo, entre trabalhadores de marmorarias, no Município de São Paulo, 2004 -2005

$\mathrm{VEF}_{1} / \mathrm{CVF}$ reduzida

\begin{tabular}{llll}
\cline { 3 - 3 } Variável & Razão de chance & IC 95\% & Significância
\end{tabular}

(Odds Ratio)

\begin{tabular}{cccc}
\hline Acabador & 2,07 & $1,02-4,20$ & Significante \\
\hline $\begin{array}{c}\text { Tempo de exposição } \\
\text { (anos) }\end{array}$ & 1,04 & $0,89-1,20$ & Não significante \\
\hline Tabagismo & 1,11 & $0,54-2,27$ & Não significante \\
\hline
\end{tabular}

Com objetivo de verificar se presença de pequenas opacidades estava relacionada ao trabalhador ter a função de acabador foi realizada a análise de regressão logística multivariada com a opção "stepwise", na qual a variável dependente foi a classificação radiológica com presença de pequenas opacidades, valor 1 , e sem opacidades valor 0 . As variáveis independentes foram: a exposição acumulada à sílica cristalina (modelos 1 e 2), a função e o tabagismo. Para a função de acabador foi adotado o valor 1, e para as outras funções o valor 0. Para o tabagismo, valor 1 para fumar (fumantes e ex-fumantes), e o valor 0 não fumar. As Tabelas 5.41 e 5.42 apresentam os resultados dos modelos 1 e 2 respectivamente. 
Tabela 5.41 - Resultados da regressão logística multivariada opção "stepwise” da classificação radiológica, segundo exposição acumulada à sílica cristalina Modelo 1, função de acabador e tabagismo entre trabalhadores de marmorarias, no Município de São Paulo, $2004-2005$

\begin{tabular}{cccc}
\hline \multirow{2}{*}{ Variável } & \multicolumn{2}{c}{ Presença de pequenas opacidades } & \\
\cline { 2 - 4 } & $\begin{array}{c}\text { Razão de chance } \\
\text { (Odds Ratio) }\end{array}$ & IC 95\% & Significância \\
\hline Tabagismo & 2,75 & $1,17-6,94$ & Significante \\
\hline $\begin{array}{c}\text { Modelo 1-SCA } \\
\left(\mathrm{mg} / \mathrm{m}^{3} \text {-anos }\right)\end{array}$ & 1,50 & $1,21-1,87$ & Significante \\
\hline Acabador & 0,13 & $0,03-0,44$ & Não significante \\
\hline
\end{tabular}

Tabela 5.42 -Resultados da regressão logística multivariada opção “stepwise” da classificação radiológica, segundo exposição acumulada à sílica cristalina, Modelo 2, função de acabador e tabagismo entre trabalhadores de marmorarias, no Município de São Paulo, $2004-2005$

\begin{tabular}{cccc}
\hline \multirow{2}{*}{ Variável } & \multicolumn{2}{c}{ Presença de pequenas opacidades } & \\
\cline { 2 - 4 } & $\begin{array}{c}\text { Razão de chance } \\
\text { (Odds Ratio) }\end{array}$ & IC 95\% & Significância \\
\hline Tabagismo & 2,90 & $1,21-7,53$ & Significante \\
\hline $\begin{array}{c}\text { Modelo 2-SCA } \\
\text { (mg/m³-anos) }\end{array}$ & 1,41 & $1,20-1,68$ & Significante \\
\hline Acabador & 0,10 & $0,02-0,38$ & Não significante \\
\hline
\end{tabular}

Os resultados indicam que apenas duas variáveis independentes tabagismo e exposição acumulada à sílica cristalina foram significativas para explicar a variável dependente, exames de radiografia de tórax com presença de pequenas ocupacidades. A variável função não tem razão de chance significativa $(<1)$, embora tenha entrado no modelo pelo teste Wald $(\mathrm{p}=0,0020)$. 


\subsubsection{Câncer}

Foi encontrado 1 caso de trabalhador com câncer ocupacional. Trata-se do trabalhador $n^{\circ} 83$ da empresa 11, com 55 anos de idade, ex-tabagista de 31 anosmaço, que trabalhou por 8 anos na quebra e assentamento de pedras (mosaico português) em praças e calçadas e, nos últimos 34 anos, exercia a função de colocador em marmorarias com destaque para a colocação de rochas aparelhadas como quartzitos e arenitos. À radiografia de tórax, foi evidenciado nódulo pulmonar na região superior do hemitórax direito. $\mathrm{O}$ trabalhador foi submetido à toracotomia, com retirada do lobo superior direito e linfonodos mediastinais. O exame anátomopatológico da peça retirada revelou adenocarcinoma moderadamente diferenciado e parênquima pulmonar com presença de fibrose axial e partículas de poeira, que também foram encontradas nos linfonodos analisados. Concluiu-se pelo diagnóstico de pneumoconiose e neoplasia maligna do pulmão pelo efeito do tabagismo em associação à exposição à poeira de sílica. 


\section{DISCUSSÃO}

Foi desenvolvido estudo transversal analítico para investigar a exposição ocupacional as poeiras minerais e a prevalência de silicose em marmorarias no Município de São Paulo. A investigação foi iniciada em 2003 com estudo das alternativas de controle da poeira, pois neste ano algumas marmorarias implantaram operações a úmido na etapa de acabamento. $\mathrm{O}$ estudo de exposição ocupacional a poeira, a estimativa de risco de silicose e a avaliação médica dos trabalhadores foram realizados simultaneamente entre 2004 e 2005.

\subsection{Avaliação da exposição ocupacional, alternativas de controle para poeira em marmorarias e matérias-primas}

\subsubsection{Exposição ocupacional à poeira, à sílica cristalina respirável e estimativa de risco de silicose}

Os trabalhadores de marmorarias estavam expostos a altas concentrações de poeiras minerais contendo sílica, sendo que $86 \%$ das empresas, Figura 5.3, apresentaram resultados de concentração de sílica cristalina acima do valor de referencia (VR) de $0,05 \mathrm{mg} / \mathrm{m}^{3}$.

Para a função de acabador, $81 \%$ das empresas apresentavam probabilidade acima de $5 \%$ dos resultados de concentração de sílica cristalina ultrapassar o valor de referência, indicando a necessidade de introdução de medidas de controle de poeira (Figura 5.5), conforme critério apresentado no item 4.4.3. Nesta mesma figura, observa-se que $67 \%$ das empresas onde havia a função de cortador, apresentaram probabilidade de ultrapassar o VR. Na Figura 5.6, 67\% das empresas onde havia a função de encarregado e $55 \%$ das empresas onde havia encarregado apresentaram probabilidade de ultrapassar o VR, segundo o mesmo critério. A função de polidor caracterizou-se por apresentar resultados abaixo do VR. 
A exposição a poeira respirável de diversas matérias-primas em operações a seco estimada para a função de acabador no Município de São Paulo foi igual a $3,19 \mathrm{mg} / \mathrm{m}^{3}$, com intervalo de confiança de $95 \%$ entre 2,81 e $3,57 \mathrm{mg} / \mathrm{m}^{3}$, Tabela 5.6 . O valor mínimo encontrado foi igual a $0,06 \mathrm{mg} / \mathrm{m}^{3}$, Tabela A11.5 registro da amostra código $\mathrm{Bp} 81$, e o máximo igual a $31,6 \mathrm{mg} / \mathrm{m}^{3}$, registro das amostras $\mathrm{Bq} 02-\mathrm{Bq} 19$ apresentado na Tabela A11.5.

A exposição a poeira respirável de diversas matérias-primas em operações a úmido para a função de cortador no Município de São Paulo, foi igual a $0,64 \mathrm{mg} / \mathrm{m}^{3}$, com intervalo de confiança de $95 \%$ entre 0,49 e $0,78 \mathrm{mg} / \mathrm{m}^{3}$, Tabela 5.6 . O valor mínimo encontrado foi igual a $0,02 \mathrm{mg} / \mathrm{m}^{3}$, Tabela A11.16 registros das amostras códigos Bt75 e Bt-77, e o valor máximo igual a $6,33 \mathrm{mg} / \mathrm{m}^{3}$, registro das amostra Bp-68 apresentado na Tabela A11.5.

Comparando-se os resultados de exposição a poeira respirável deste estudo com os obtidos por GUENÈL et al., 1989, na indústria de corte de pedra na Dinamarca, média geométrica de $0,7 \mathrm{mg} / \mathrm{m}^{3}$ com faixa entre 0,2 e $5,4 \mathrm{mg} / \mathrm{m}^{3}$, verifica-se que a exposição à poeira respirável para a função de acabador a seco em marmorarias foi maior, enquanto que, a exposição à poeira respirável para a função de cortador a úmido em marmorarias encontra-se muito próxima da encontrada por GUENÉL.

Os resultados de exposição a poeira respirável do acabador a seco em marmorarias encontram-se mais próximos dos resultados de exposição obtidos por GUENÈL et al, 1989, na indústria de materiais de construção e de estradas, média geométrica de $1,1 \mathrm{mg} / \mathrm{m}^{3}$ com faixa de 0,1 a $39,7 \mathrm{mg} / \mathrm{m}^{3}$. Isto deve-se possivelmente ao fato de que as operações em na indústria de materiais de construção e de estradas também eram realizadas a seco. 
A concentração média estimada para sílica cristalina de diversas matérias-primas em operações a seco para a função de acabador no Município de São Paulo foi igual a $0,19 \mathrm{mg} / \mathrm{m}^{3}$, com intervalo de confiança de $95 \%$ entre 0,16 e $0,22 \mathrm{mg} / \mathrm{m}^{3}$, e a probabilidade dos resultados apresentaram-se acima do valor de referência de $0,05 \mathrm{mg} / \mathrm{m}^{3}$ foi de $68,2 \%$, Tabela 5.7 . A faixa de concentração ficou entre Não Detectado (ND) e 2,10mg/m³ , registro das amostras Bo54-Bo65 apresentado na Tabela A11.13.

Para a função de cortador a úmido concentração média estimada de sílica cristalina foi igual a $0,04 \mathrm{mg} / \mathrm{m}^{3}$ com intervalo de confiança de 0,03 a $0,05 \mathrm{mg} / \mathrm{m}^{3}$, e a probabilidade dos resultados apresentarem-se acima do valor de referência de $0,05 \mathrm{mg} / \mathrm{m}^{3}$ foi de $43,4 \%$, Tabela 5.7. A faixa de concentração ficou entre ND e $0,54 \mathrm{mg} / \mathrm{m}^{3}$ registro das amostra Bp-67 apresentado na Tabela A11.5.

Quanto à exposição ocupacional à sílica cristalina os resultados de concentração média estimada para a função de acabador a seco em marmorarias encontram-se acima dos valores obtidos por GUENÈL et al 1989. Na indústria de corte de pedra na Dinamarca, que obteve média geométrica sílica respirável igual a $0,05 \mathrm{mg} / \mathrm{m}^{3} \mathrm{com}$ faixa de 0,02 a $0,57 \mathrm{mg} / \mathrm{m}^{3}$, e $45 \%$ dos resultados se encontravam acima do limite de exposição ocupacional. Para a função de cortador a úmido em marmorarias os resultados de concentração média estimada de sílica cristalina são praticamente da mesma ordem de grandeza, considerando que a média aritmética fornece estimativas com valores mais altos que a média geométrica

$\mathrm{Na}$ indústria de materiais de construção e estradas na Dinamarca a média geométrica para sílica cristalina respirável era igual a $0,16 \mathrm{mg} / \mathrm{m}^{3}$ com faixa de 0,02 a $12,7^{\circ} \mathrm{mg} / \mathrm{m}^{3}$, e $75 \%$ dos resultados se encontravam acima do limite de exposição ocupacional (GUENÈL et al. 1989). Esta média é comparável ao resultado da função de acabador a seco com matéria-prima mista com média igual a $0,19 \mathrm{mg} / \mathrm{m}^{3}$, Tabela 5.7 . 
A exposição à poeira respirável de granitos em operações a seco estimada para a função de acabador no Município de São Paulo, Tabela 5.8, foi igual a 4,25 mg/m com intervalo de confiança de $95 \%$ entre 3,49 e $5,01 \mathrm{mg} / \mathrm{m}^{3}$. A faixa de valores ficou entre $0,06 \mathrm{mg} / \mathrm{m}^{3}$, Tabela A11.5 registro da amostra código Bp81, e o máximo igual a $31,6 \mathrm{mg} / \mathrm{m}^{3}$, registro das amostras $\mathrm{Bq} 02-\mathrm{Bq} 19$ apresentado na Tabela A11.5. A média estimada para sílica cristalina respirável foi igual a $0,36 \mathrm{mg} / \mathrm{m}^{3}$, com intervalo de confiança de $95 \%$ entre 0,29 e $0,42 \mathrm{mg} / \mathrm{m}^{3}$, Tabela 5.9 . O valor da média estimada para sílica cristalina encontrava-se 7 vezes acima do VR. A faixa de concentração ficou entre Não Detectado (ND) a 3,55 mg/m³ registro da amostra Bo-54 apresentado na Tabela A11.13. O valor máximo ultrapassou 70 vezes o VR, caso em que a matéria-prima era um material sintético - Silestone ${ }^{\circledR}$. Para os granitos naturais o valor máximo ultrapassou 23 vezes o $\mathrm{VR}, 1,16 \mathrm{mg} / \mathrm{m}^{3}$ registro da amostra $\mathrm{Bq}-03$ apresentado na Tabela A11.5 para o granito cinza Corumbá.

Para determinadas atividades os trabalhadores das marmorarias na função de acabador encontravam-se expostos a picos de concentração de sílica cristalina respirável. No Brasil, os valores de exposição altos que constam da literatura, foram encontrados: entre os trabalhadores na escavação de poços em rocha de arenito no Estado do Ceará e na mineração e beneficiamento de arenito do estado de Goiás. Os valores ultrapassavam aproximadamente 30 vezes o limite da legislação brasileira, o equivalente a aproximadamente 60 vezes o VR para este estudo (HATTEN e CAVALCANTI 1988); e entre os trabalhadores da mineração e beneficiamento de rochas ornamentais em Pirenópolis no Estado de Goiás, com 88\% dos resultados acima do limite da legislação brasileira e faixa de concentração de 0,02 a 4,64 mg/m³ de sílica cristalina (SILVA 1998).

O resultado de concentração média de sílica cristalina respirável para função de acabador de granito, $0,36 \mathrm{mg} / \mathrm{m}^{3}$, Tabela 5.9 é comparável aos encontrados por DAVIS et al. 1983; COSTELLO e GRAHAM 1988, no beneficiamento de granito em Vermont em1940, antes da introdução das medidas de controle. Segundo estes autores, a concentração média de sílica cristalina para a função de cortador (maior exposição) era de $0,366 \mathrm{mg} / \mathrm{m}^{3}$ e para o nivelador (surfacer) era de $0,266 \mathrm{mg} / \mathrm{m}^{3}$. 
Após a introdução do controle a média do cortador era $0,066 \mathrm{mg} / \mathrm{m}^{3}$ e do surfacer era $0,069 \mathrm{mg} / \mathrm{m}^{3}$, praticamente iguais.

O resultado de concentração média de sílica cristalina respirável para função de acabador de granito, $0,36 \mathrm{mg} / \mathrm{m}^{3}$ é aproximadamente 4 vezes menor que os resultados encontrados na mineração de granito da Finlândia, para o período de 1970 a 1972, KOSKELA et al., 1994, cuja média geométrica de sílica cristalina respirável estava na faixa entre 1,0 e $1,5 \mathrm{mg} / \mathrm{m}^{3}$ para a função de perfurador, sujeita a maior exposição.

Em estudo de KULMAN et al.,1995, sobre mineração e beneficiamento de calcário, granito e arenito nos EUA entre 1979 e 1982, os resultados para poeira respirável de granito tinham média igual a $0,17 \mathrm{mg} / \mathrm{m}^{3}$ e uma faixa entre $\mathrm{ND}$ e $1,46 \mathrm{mg} / \mathrm{m}^{3}$. Na Tabela 5.8 todas as funções apresentaram valores de média de concentração de poeira respirável superiores, com exceção para amostras de área a úmido para o granito.

Em se tratando da sílica cristalina respirável os dados de exposição apresentados por KULMAN et al.,1995, média geométrica de $0,06 \mathrm{mg} / \mathrm{m}^{3}$, e faixa entre $\mathrm{ND}$ e $0,28 \mathrm{mg} / \mathrm{m}^{3}$, o resultado de média para a função de acabador de granito a seco nas marmorarias foi igual $0,36 \mathrm{mg} / \mathrm{m}^{3}$, valor acima do resultado mais alto encontrado por KULMAN et al.,1995. Para a função de encarregado e as amostras de área os valores encontravam-se acima da média, o cortador apresentou média aritmética de $0,06 \mathrm{mg} / \mathrm{m}^{3}$ e ajudante e polidor médias abaixo Tabela 5.9.

Para a função de polidor, cortador e de ajudante geral os resultados apresentaram-se comparáveis aos dos outros estudos, com exceção dos obtidos nos estudos relacionados à mineração e beneficiamento em Vermont antes da adoção de medidas de controle, que eram muito altos. 
Os resultados de exposição ocupacional a poeiras minerais de rochas ornamentais em marmorarias encontrados neste estudo são compatíveis com os dados existentes na literatura internacional sobre a exposição ocupacional a poeiras na mineração e no beneficiamento de minerais, em especial às poeiras de granito. Estes resultados vêm preencher uma lacuna na literatura sobre exposição ocupacional a poeiras minerais e a sílica cristalina respirável em marmorarias. Assim, os resultados das médias estimadas foram utilizados no cálculo de exposição acumulada à sílica cristalina respirável com base no histórico ocupacional para estimar o de risco de silicose em marmorarias no Município de São Paulo.

\subsubsection{Alternativas de controle para poeira em marmorarias}

Foram identificados 6 tipos distintos de controle da poeira no ambiente com etapa de acabamento a seco, conforme apresentado na Tabela 5.18.

Os resultados indicam uma forte diminuição na concentração média de poeira respirável com a introdução dos controles em marmorarias. Comparando-se os resultados médios, por exemplo, para a função de acabador das Tabelas 5.6 e 5.14, pode-se observar que: a concentração média de poeira respirável para o acabador a seco foi igual a $3,19 \mathrm{mg} / \mathrm{m}^{3}$; com os controles no ambiente, o resultado foi igual a $1,82 \mathrm{mg} / \mathrm{m}^{3}$, e com os controles a úmido nas máquinas e ferramentas foi igual a $0,48 \mathrm{mg} / \mathrm{m}^{3}$ no estudo de exposição, e $0,55 \mathrm{mg} / \mathrm{m}^{3}$ no estudo de alternativas de controle.

Comparando-se os resultados de concentração de sílica respirável para a função de acabador a seco por tipo de controle no ambiente (Tabela 5.19) observa-se que os melhores resultados foram para:

a) a Mesa com SVLE na empresa M3, $0,036 \mathrm{mg} / \mathrm{m}^{3}$;

b) o SVLE com filtros de tecido de fibra da empresa M1, 0,008 mg/m³

c) o exaustor com água da empresa $11,0,057 \mathrm{mg} / \mathrm{m}^{3} \mathrm{e}$

d) a capela de fluxo laminar da empresa $\mathrm{M} 1,0,051 \mathrm{mg} / \mathrm{m}^{3}$. 
Todos os resultados encontravam-se abaixo ou próximos do VR. No entanto, estes mesmos tipos de controle, ao serem solicitados em função de uma demanda maior de produção, tipos de matérias-primas com maior teor de sílica cristalina, variações no padrão de dispersão da poeira em função de ambientes abertos ou fechados, máquinas de diferentes fabricações e procedimentos de manutenção inadequados, os resultados poderiam ser outros. Observando-se, por exemplo, os resultados da Tabela 5.19, para a Mesa com SVLE na empresa 6 o resultados de concentração de sílica cristalina foi de $0,370 \mathrm{mg} / \mathrm{m}^{3}$, para o SVLE com água na empresa $14,0,412 \mathrm{mg} / \mathrm{m}^{3}$, aproximadamente 7 e 8 vezes o VR respectivamente.

Para as operações com máquinas e ferramentas a úmido, o resultado de concentração média de sílica cristalina para a função de acabador foi igual a $0,038 \mathrm{mg} / \mathrm{m}^{3} \mathrm{com}$ intervalo de confiança de $95 \%$ entre 0,026 e $0,049 \mathrm{mg} / \mathrm{m}^{3}$, Tabela 5.17 , valores abaixo do VR. A faixa de resultados ficou entre ND e $1,010 \mathrm{mg} / \mathrm{m}^{3}$, registro da amostra código Bo-60 na Tabela A11.13, para uma mistura de granito Branco Polar com Silestone Branco. Assim, deve-se ressaltar a possibilidade de haver exposição acima do VR em situações em que a matéria-prima apresente alto teor de sílica, como os granitos sintéticos, quartzitos, arenitos e outras. Esta observação é valida para as funções de acabador e ajudante geral, cujas médias a úmido encontravam-se muito próximas ao VR e acima do nível de ação.

Foram observadas vantagens na utilização das politrizes manuais com sistema pneumático e água em relação à politriz a seco. Além de elas serem mais leves e de fácil utilização, segundo informações levantadas junto aos usuários, os investimentos para aquisição, mais altos, são compensados pelos custos mais baixos de manutenção.

Para as operações com máquinas e ferramentas a úmido, o resultado de concentração média de sílica cristalina para a função de cortador foi igual a $0,038 \mathrm{mg} / \mathrm{m}^{3} \mathrm{com}$ intervalo de confiança de $95 \%$ entre 0,026 e $0,049 \mathrm{mg} / \mathrm{m}^{3}$, Tabela 5.17 , 
As concentrações médias de sílica cristalina para os cortadores que trabalhavam a úmido apresentaram-se abaixo do valor de referência, com exceção para o granito que foi igual a $0,058 \mathrm{mg} / \mathrm{m}^{3}$, Tabela 5.9 .

As concentrações médias de sílica cristalina para os ajudantes gerais que trabalhavam a úmido apresentaram-se abaixo do valor de referência, com exceção para a ardósia que foi igual a $0,060 \mathrm{mg} / \mathrm{m}^{3}$, Tabela 5.9 .

A Organização Mundial da Saúde em seu manual Harzad Prevention and Control in the Work Environment: Airbone Dust (WHO/SDE/OEH/99.14 1999) recomenda diversas soluções para a eliminação ou redução das exposições ocupacionais a poeiras. Entre elas se encontram medidas relacionadas: ao processo de trabalho; aos métodos de engenharia; aos trabalhadores e às ações administrativas. Considerando os processos de trabalho, um dos focos principais deste estudo, além da eliminação ou redução do agente, são sugeridas a substituição e a umidificação do processo, com redução da poeira na fonte.

\subsubsection{Matérias-primas}

As rochas ornamentais e de revestimento possuem composição química e mineralógica variável, podendo apresentar teores diferentes de seus constituintes. O quartzo, por exemplo, pode estar presente em diferentes proporções nos granitos, mármores, arenitos, entre outras.

Os resultados obtidos no estudo das matérias-primas utilizadas nas marmorarias apresentados na Figura 5.20 refletem em parte os tipos de rochas mineradas no Brasil, conforme apresentado no item 3.6.4, particularmente na Figura 3.5. Os granitos correspondiam $66 \%$ das matérias-primas, os mármores $21 \%$, as rochas aparelhadas $8 \%$, os produtos sintéticos $3 \%$, ardósias e os quartzitos $1 \%$. Quando estes resultados foram agrupados em rochas silicáticas e rochas carbonáticas as rochas silicáticas correspondiam a aproximadamente a $78 \%$ das matérias-primas 
utilizadas nas marmorarias com procedência nacional. As rochas carbonáticas correspondiam a aproximadamente $22 \%$, no entanto, $19,5 \%$ de mármores importados e $2,5 \%$ de mármores nacionais.

Do ponto de vista da saúde ocupacional, as rochas silicáticas são as mais importantes devido à presença de sílica cristalina (quartzo) e outros possíveis silicatos compostos como feldspatos, piroxênios, anfibólios (asbesto), que não foram objeto deste estudo. No entanto, existe a possibilidade de exposição múltipla, e estes são outros agentes químicos que podem causar pneumoconioses ou câncer de pulmão.

Os granitos foram as rochas encontradas com maior freqüências nas marmorarias e para as quais foi possível coletar um maior número de amostras de ar sem contaminação de outros tipos de rochas. Os resultados obtidos para alguns tipos de granitos encontram-se na Figura 5.21. As médias de percentagem de sílica cristalina de acordo com o nome comercial do granito variaram de 2,5 a 14,1\% na fração respirável da poeira. A faixa encontrada para todos os tipos de granitos estudados ficou entre 1 a 19\% na fração respirável.

Existiram situações de trabalho com granito, para as quais as porcentagens de sílica apresentaram-se com valores superiores aos apresentados na Figura 5.21. Por exemplo, 32\% de sílica cristalina na amostra código Bp-55, Tabela A11.4, para uma mistura de granitos composta por Preto São Gabriel, Branco Polar e Branco Itaúnas, coletada em um trabalhador com a função de cortador. Este resultado se diferencia da maioria dos resultados de cortadores de granito, possivelmente devido a mistura de granitos com alto teor de quartzo, e da solução improvisada de jogar água no disco da serra mármore que não diminuiu a exposição a poeira.

A classificação dos granitos em faixas como foi apresentado no item 5.4 é um indicativo da porcentagem de sílica cristalina segundo o nome comercial da rocha. A literatura apresenta os granitos brancos (em geral) com altos teores de quartzo. Neste estudo os granitos brancos e amarelos apresentaram teores superiores aos cinzas, pretos e marrons. As principais dificuldades para realizar esta classificação foram: as 
situações reais de trabalho que limitaram o número de amostras; o mesmo nome comercial para rochas vindas de diversas origens. Para obtenção de resultados mais exatos sobre a toxicidade das poeiras respiráveis de rochas ornamentais são necessários estudos de laboratório mais controlados, do ponto de vista das operações, da procedência exata da rocha (mina) e estudos citotóxicos.

GUENÈL et al., 1989, obtiveram valores médios de percentagem de sílica cristalina na fração respirável da poeira de granito igual a13\% com faixa entre 3 e 35\% para as indústrias de materiais construção civil de estradas e para a indústria de corte de pedras a porcentagem de sílica cristalina foi de $9 \%$ com faixa entre 3 e $30 \%$.

KULMAN et al.,1995, encontraram 37\% de sílica cristalina na poeira respirável na indústria da mineração de granito nos EUA entre 1978 e 1982.

THERIAULT et al., 1974, encontraram 9\% de sílica cristalina na poeira respirável nas minas de granito de Vermont nos EUA em 1972. Em estudos anteriores, amostras de rochas de Vermont foram analisadas por meio de análise petrográfica e $30 \%$ de sílica cristalina na forma de quartzo estava presente na rocha.

\subsection{População de estudo e avaliação médica}

A população estudada foi composta por 267 homens trabalhadores de marmorarias com atividades ligadas a produção. Foi caracterizada como uma população de baixo nível de escolaridade e de renda familiar, sendo que $70 \%$ não haviam concluído o ensino fundamental, e 40\% possuíam renda familiar inferior a 3 salários mínimos, Tabela 5.20.

A freqüência de não fumantes foi de aproximadamente $55 \%$, e $24 \%$ eram exfumantes, perfazendo um total de aproximadamente $79 \%$ da população. No entanto, o tabagismo em anos-maço (fumantes e ex-fumantes) apresentou-se como variável 
importante nas análises de regressão logística para a presença de pequenas opacidades.

A média de idade da população estudada era de 35,8 anos e observou-se diferença estatisticamente significante entre a média de idade dos acabadores e a média de idade dos trabalhadores de outras funções, podendo-se caracterizar que a população de acabadores era mais jovem. A função de acabador apresentou média de idade de 33 anos, contra 37 anos dos trabalhadores de outras funções, Tabela 5.21.

O tempo médio de permanência na função na empresa atual foi de 6,5 anos, Tabela 5.22, e com exceção da função de canteiro com 27,7 anos, as outras funções apresentaram tempo médio na empresa atual abaixo de 10 anos. $\mathrm{O}$ tempo médio de 3,9 anos para a função de ajudante geral, se explica, pois esta função representa o início da carreira de marmorista. Na mesma tabela, apresenta-se o tempo médio total de trabalho em marmorarias que foi de 10,6 anos. Estes resultados, associados à informação de que 50\% desta população já haviam trabalhado em outras marmorarias, Tabela 5.23, pode-se caracterizar rotatividade desta população entre as marmorarias.

A população deste estudo, era formada por 267 trabalhadores, no entanto, devido à ausência de trabalhadores, alguns casos de demissão ou por eles não poderem comparecer na data do exame, 250 realizaram a radiografia de tórax. Destes 250 trabalhadores, $223(89,2 \%)$ apresentaram radiografias de tórax consideradas normais, profusão 0/0, e 27 trabalhadores (10,8\%) apresentaram alterações nas radiografias com presença de pequenas opacidades, profusão $\geq 0 / 1$, Tabela 5.27.

Os dois casos com leitura compatíveis com pneumoconioses apresentaram história com exposição ocupacional a poeiras minerais de rochas ornamentais que contem altos teores de sílica cristalina respirável, sendo, portanto possíveis casos de silicose resultando numa prevalência de $0,8 \%$. 
Esta prevalência é semelhante ao resultado do Projeto Marmoristas de 2001, existia uma prevalência de silicose igual a 0,9\% numa população inicial formada por 954 trabalhadores. Os dados indicavam ainda perspectiva de um aumento desta prevalência, pois, $16,6 \%$ dos trabalhadores haviam apresentado alterações nas radiografias de tórax e estavam sob investigação.

FREITAS, 2004, em comunicação oral no Simpósio da SIMBRAVISA ${ }^{1}$ atualizou os dados do Projeto Marmoristas até de outubro de 2002, e encontrou prevalência de $3 \%$ de silicóticos entre os trabalhadores avaliados no Centro de Referência de Saúde do Trabalhador da Freguesia do Ó.

\subsection{Correlações entre Exposição Ocupacional e Avaliação Médica}

\subsubsection{Exposição acumulada à sílica cristalina}

Pode-se observar na primeira linha da Tabela 5.29, que o trabalhador código 48 que apresentou profusão de $1 / 1$ à radiografia de tórax e não teve emprego anterior em outras marmorarias, possuía exposição acumulada de sílica cristalina respirável, segundo o Modelo 1, de 2,8 mg/m³-anos em 6,5 anos de trabalho, representando uma média de acumulação igual $0,43 \mathrm{mg} / \mathrm{m}^{3}$ por ano. A empresa onde se deu esta exposição é a de número 6, onde o índice de exposição é igual a 8,7 (Tabela 5.3) isto é, a concentração média de sílica cristalina é 8,7 vezes o valor de referência.

Valores semelhantes foram encontrados por KREISS et al.,1996, em estudo transversal para exposições em minas, com o mesmo critério para a definição de silicose, pequenas opacidades com profusão $\geq 1 / 0$. Para exposições acumuladas superiores a 2,0 mg/m³ -anos com 40 anos de exposição a prevalência de silicóticos era $62,5 \%$, utilizando o modelo de regressão logística multivariada stepwise.

\footnotetext{
${ }^{1}$ SIMBRAVISA II Simpósio Brasileiro de Vigilância Sanitária e I Simpósio Pan-Americano de Vigilância Sanitária realizado de 21 a 24 de novembro de 2004 no Centro de Convenções Thermas Di Roma, Caldas Novas- Goiás -Brasil. Informações disponíveis em: http://www.abrasco.org.br/Eventos/simbravisa.htm
} 
Como o número de casos de exames com alterações radiológicas foi baixo, dois, não foi possível calcular a mediana por categoria de profusão. No entanto, os resultados de exposição acumulada obtidos neste estudo para os trabalhadores com exames com alterações radiológicas com a presença de pequenas opacidades (profusão $>1 / 0$ ) compatíveis com pneumoconiose (trabalhador código 48 e trabalhador código 270) Tabela 5.29, se encontram dentro da faixa de exposição acumulada encontrada por MANNETJE et al., 2002. Segundo MANNETJE et al., 2002, embora existam diferenças entre os modelos dos 10 estudos de coortes de diferentes ramos de atividade analisados, os valores de exposição acumulada com faixa entre 0,13 e $11,37 \mathrm{mg} / \mathrm{m}^{3}-^{\circ}$ anos e para a mediana da exposição acumulada com uma faixa entre 0,04 e $0,59 \mathrm{mg} / \mathrm{m}^{3}$ para a mediana de exposição à sílica cristalina, foram considerados válidos. As diferenças existentes entre os 10 estudos de coorte, não prejudicaram a tendência de linearidade entre o aumento de casos de silicose à medida do aumento da exposição acumulada na análise com regressão logística condicional para um $\mathrm{OR}=1,0$.

Comparando-se os resultados deste estudo, para os dois casos (trabalhador código 48 e trabalhador código 270), com os resultados do estudo de MANNETJE et al., 2002, para as atividades com granito, observa-se uma maior concordância com os resultados dos estudos de Vermont para o qual foi encontrada mediana da exposição acumulada de $0,71 \mathrm{mg} / \mathrm{m}^{3}$-anos. Em relação aos estudos da Finlândia, mediana de $4,65 \mathrm{mg} / \mathrm{m}^{3}$-anos, os resultados deste estudo se apresentam mais baixos.

O Modelo 1 sugerido neste estudo refletiu a exposição acumulada de acordo com as características da função e da empresa. Isto foi válido para empresas que tinham história de produção sem mudanças de processo e de tipos de matérias-primas. No entanto, verificaram-se mudanças em várias empresas com implantação de medidas de controle. Para estes casos foram utilizados os resultados de médias para o município de São Paulo conforme descrito item 4.4.4.

Os modelos de exposição acumulada à sílica cristalina apresentaram descontinuidade na tendência de aumento de sílica cristalina acumulada em relação à classificação 
radiológica para a profusão1/0, conforme apresentado na Figura 5.22. Esta descontinuidade pode ser devida: a) à falta de informação adequada sobre a história ocupacional; b) a exposição acumulada à sílica cristalina respirável ter sido superestimada ou subestimada em alguns casos; c) a exposição a poeiras minerais com outros agentes tóxicos; d) a diferenças em relação às leituras radiológicas; e) ao número reduzido de dados para as categorias de profusão mais altas; f) ou até mesmo uma combinação destas possibilidades. Assim, foram realizadas análises estatísticas de forma agrupada.

As análises de comparação de médias utilizando o teste não paramétrico de Savage indicaram que existe diferença estatisticamente significante entre as médias de exposição acumulada à sílica cristalina para os trabalhadores com a presença de pequenas opacidades (exames com alterações) e os trabalhadores com exames considerados normais para os modelos de exposição acumulada 1 e 2 Tabela 5.30 e 5.31 respectivamente. $\mathrm{O}$ modelo 3 não apresentou diferença estatisticamente significante entre as médias, Tabela 5.32 .

O teste de tendência - Cochran-Armitage Trend Test, indicou que não houve tendência linear em nenhum dos Modelos de exposição acumulada, confirmando a descontinuidade que havia sido observada na Figura 5.22.

As curvas de tendência da Figura 5.22 indicam que o Modelo 1 e 3 de exposição acumulada poderiam explicar a progressão do risco do que o Modelo 2. No entanto, provavelmente em função do baixo número de casos com classificação radiológica, com categorias de profusão igual ou maior que1/0, e falta de informação sobre os tipos de matérias-primas, conduziram os resultados da regressão logística univariada para a classificação radiológica com exposição acumulada a se apresentarem foram estatisticamente significantes para os Modelos 1 e 2, e o Modelo 3 ficou no borderline do teste.

Para o Modelo 1 o Odds Ratio (OR) foi igual a 1,20 com Intervalo de Confiança (IC) de $95 \%$ entre 1,02 a 1,40, indicando que os trabalhadores expostos a concentração 
acumulada de sílica cristalina com mediana igual a $0,56 \mathrm{mg} / \mathrm{m}^{3}$-anos tem $20 \%$ mais chance de ter classificação radiológica com alterações em relação a um trabalhador não exposto.

Para o Modelo 2 obteve-se um OR=1,18 com IC de 95\% entre 1,05 e 1,33, indicando que os trabalhadores expostos a concentração acumulada de sílica cristalina com mediana igual a $0,46 \mathrm{mg} / \mathrm{m}^{3}$-anos tem $18 \%$ mais chance de ter classificação radiológica com alterações em relação a um trabalhador não exposto.

Foram realizadas análises dos Modelos de exposição acumulada, classificação radiológica e tabagismo, pois houve uma associação entre tabagismo e classificação radiológica. O teste Qui-quadrado foi estatisticamente significante para a associação tabagismo e classificação radiológica - profusão. Houve associação entre fumar (fumantes e ex-fumantes) e não fumar (não fumantes) $\operatorname{com} \chi^{2}=4,80$ e $\mathrm{p}=0,0285$, Tabela 5.33. A regressão logística univariada foi estatisticamente significante para o tabagismo e a classificação radiológica, com um $\mathrm{OR}=2,50$ com IC de 95\% de 1,10 a 6,07 .

As regressões logísticas multivariadas para a classificação radiológica, modelos de exposição acumulada e tabagismo apresentaram os seguintes resultados:

a) Modelo 1 - para tabagismo foi encontrado um $\mathrm{OR}=2,49$ com IC de $95 \%$ entre 1,06 e 5,83 e para a exposição acumulada um $\mathrm{OR}=1,38$ com IC de $95 \%$ entre 1,04 e 1,84, Tabelas 5.28;

b) Modelo 2 -, para tabagismo foi encontrado um $\mathrm{OR}=2,53$ com IC de $95 \%$ entre 1,07 e 5,98 e para a exposição acumulada um $\mathrm{OR}=1,44$ com IC de 95\% entre 1,09 e 1,86, Tabela 5.29;

c) Modelo 3 - para tabagismo foi encontrado OR=2,50 com IC de 95\% de $1,10 \mathrm{a}$ 6,07, e para a exposição acumulada não foi significante. 
Estes resultados indicam que a variável independente fumar tinha força maior na variável dependente classificação radiológica que a variável independente exposição acumulada.

Em função dos resultados obtidos, o Modelo 1 poderia ser utilizado para situações nas quais estejam disponíveis resultados de exposição ocupacional à sílica cristalina confiáveis, informações da história ocupacional e das marmorarias. O Modelo 2 poderia ser utilizado para situações nas quais não existem resultados de exposição ocupacional e as informações sobre as funções e os tempos de exposição correspondentes em cada uma delas poderiam ser obtidos por meio de um instrumento de investigação do tipo questionário padronizado como, por exemplo, o utilizado neste estudo.

\subsubsection{Tempo de exposição em marmorarias}

A análise de comparação de médias para a variável tempo de exposição com os resultados de classificação radiológica foi realizada por meio do teste t'Student, Tabela 5.37. A média para o tempo de trabalho do exposto com classificação radiológica com alterações foi igual a 19,9 anos, enquanto o tempo de trabalho do exposto com classificação radiológica normal foi igual a 9,9 anos.

O Cochran-Armitage Trend Test foi aplicado e verificou-se uma tendência de aumento na prevalência de alterados à proporção que aumenta o tempo de exposição em marmorarias, Figura 5.23.

A regressão logística univariada para a classificação radiológica com tempo de exposição em marmorarias igual a 4 anos foi estatisticamente significante com $\mathrm{OR}=1,39$ e IC de $95 \%$ entre 1,21 e 1,62. Portanto, existem $40 \%$ de chance de um trabalhador exposto possuir classificação radiológica com alterações em relação ao trabalhador não exposto. 
A regressão logística multivariada para a classificação radiológica, tempo de exposição e tabagismo foi significativa somente para a variável anos de exposição com $\mathrm{OR}=1,39$ e IC de $95 \%$ entre 1,21 e 1,62, resultado igual ao da regressão univariada sem o tabagismo. Isto significa que a força da variável independente, anos de exposição, tem força na variável dependente classificação radiológica muito maior, tanto que a variável independente, tabagismo, não foi significativa, Tabela 5.38 .

\subsubsection{Considerações de possíveis vieses}

A partir do estudo transversal analítico se obteve as exposições acumuladas à sílica cristalina da população de trabalhadores de marmorarias e as prevalências quanto à classificação radiológica, sintomas respiratórios e função pulmonar. No entanto, com relação as correlações entre exposição acumulada à sílica cristalina e a classificação radiológica, considerações devem ser feitas sobre os possíveis vieses destes estudo. A idade é variável nos modelos de exposição acumulada, pois trabalhadores com maior tempo de exposição, latência e altas exposições são os trabalhadores mais velhos e estes poderão influenciar nos índices de morbidade e de mortalidade, (CONSONNI et al.1997). Ainda em relação à idade deve-se também considerar que, por outro lado, para os trabalhadores mais jovens e com pouco tempo de exposição os índices poderão refletir no estudo no que é conhecido como efeito do trabalhador sadio (CHOI 1992).

Fatores ainda a considerar são: o tabagismo, que teve forte influência nos modelos de exposição, diferenças nas leituras radiológicas, a ausência de resultados de avaliação da exposição para as funções de menor freqüência nas marmorarias e as próprias estimativas de exposição, que podem estar super ou subestimadas. 


\section{CONCLUSÕES}

A avaliação das condições de trabalho e saúde dos trabalhadores em decorrência da exposição ocupacional a poeiras minerais contendo sílica cristalina marmorarias no Município de São Paulo foi realizada. A correlação dos resultados da avaliação da exposição ocupacional à sílica cristalina na fração respirável de poeiras minerais com os achados de história ocupacional, clínicos e radiológicos dos trabalhadores foi realizada por meio de estudo transversal analítico. A caracterização dos processos de beneficiamento final de rochas ornamentais foi realizada por meio do estudo de alternativas de controle e do estudo de matérias-primas. As conclusões serão apresentadas a seguir.

1) A exposição ocupacional à poeira e à sílica cristalina respirável em marmorarias foi caracterizada para as funções de ajudante geral, polidor, cortador, acabador e encarregado e para amostras de área por empresa. Foram estimadas concentrações médias para as operações a seco, a úmido e para as matérias-primas, granitos, ardósias e mármores para o Município de São Paulo.

- Os resultados de exposição ocupacional a poeiras de rochas ornamentais em marmorarias encontrados neste estudo são compatíveis com dados existentes na literatura internacional sobre exposição ocupacional a poeiras e à sílica cristalina respirável na mineração e no beneficiamento destas matériasprimas, em especial às poeiras de granito, e foram utilizados:

o na estimativa de exposição acumulada à silica cristalina respirável com base no histórico ocupacional para estimar o de risco de silicose;

o na avaliação de alternativas de controle para poeiras;

o e na estimativa do percentual de sílica cristalina respirável gerada pelas matérias-primas estudadas. 
- Há exposição excessiva para a função de acabador. Foi encontrada concentração média de sílica cristalina com probabilidade superior a $5 \%$ de ultrapassar o valor de referência de $0,05 \mathrm{mg} / \mathrm{m}^{3}$ para $81 \%$ das empresas estudadas.

- A etapa de acabamento a seco para o granito revelou-se como situação de risco importante à saúde, principalmente devido à utilização de ferramentas de alta rotação para abrasão de matérias-primas com altos teores de sílica.

- Há exposição excessiva para a função de cortador. Em $67 \%$ das empresas foi encontrada concentração média de sílica cristalina com probabilidade superior a $5 \%$ de ultrapassar o valor de referência de $0,05 \mathrm{mg} / \mathrm{m}^{3}$, em especial em situações de trabalho para corte de matéria-prima das rochas silicáticas como, granitos arenitos e outras com alto teor de sílica cristalina.

- É grande a diversidade de atividades executadas pelos trabalhadores das funções de ajudante geral e de encarregado, para as quais foram detectadas exposições excessivas quando eles realizavam atividades típicas de acabador ou de cortador. Para o ajudante geral, em 55\% das empresas foi encontrada concentração média de sílica cristalina com probabilidade superior a $5 \%$ de ultrapassar o valor de referência de $0,05 \mathrm{mg} / \mathrm{m}^{3}$, e para o encarregado o valor de referência foi ultrapassado em $67 \%$ das empresas.

- A função de polidor é a que tem a menor exposição ocupacional.

2) A população estudada é constituída por trabalhadores como nível de escolaridade e de renda familiar baixo, com média de idade de 35,8 anos. O tempo médio na função na marmoraria atual foi de 6,5 anos e o tempo médio de trabalho em marmorarias foi de 10,7 anos e aproximadamente $50 \%$ da população havia trabalhado em outras marmorarias indicado uma alta rotatividade. 
3) A avaliação médica permite concluir que:

- Existe tendência significativa de aumento das alterações radiológicas com presença de pequenas opacidades, com o tempo de exposição.

- O fato das funções com exposição excessiva a poeiras contendo sílica cristalina se associarem a uma prevalência de distúrbio obstrutivo, leva a hipótese de provavelmente a exposição tenha uma participação na gênese destes achados.

4) Três modelos de exposição acumulada à sílica cristalina respirável foram propostos para estimar o risco de silicose.

- O Modelo 1 - Mostrou-se o mais indicado entre os três Modelos propostos. Foi elaborado com base nos resultados das avaliações das exposições dos trabalhadores à sílica cristalina caracterizadas por função e para cada empresa, e na composição da exposição acumulada foram consideradas as informações levantadas do histórico dos trabalhadores e das empresas. Ele possibilitou a obtenção de resultados mais representativos de exposição acumulada à sílica cristalina do que os Modelos 2 e 3, alternativos. Na análise estatística de regressão logística univariada para classificação radiológica com exposição acumulada conforme Modelo 1, apresentou resultados estatisticamente significantes.

- O Modelo 2 - Poderá ser utilizado como forma alternativa de obtenção da exposição acumulada à sílica cristalina, para situações onde não existem avaliações das exposições. A utilização das médias de exposições por função e estratificadas por tipo de operação (a seco ou a úmido), para o município de São Paulo, na composição da exposição acumulada à sílica, mostrou-se representativa. No entanto, pode-se observar que para alguns casos este modelo poderá subestimar ou superestimar as exposições acumuladas. Na análise estatística de regressão logística univariada para 
classificação radiológica com exposição acumulada conforme Modelo 2, apresentou resultados estatisticamente significantes.

- O Modelo 3 - Deverá ser aprimorado, pois não apresentou-se como alternativa de obtenção da exposição acumulada à sílica cristalina, para situações onde não existem avaliações das exposições. A análise estatística de regressão logística univariada para classificação radiológica com exposição acumulada conforme Modelo 3, não apresentou resultados estatisticamente significantes, embora o resultado do teste tenha ficado no borderline. A hipótese mais provável para este resultado está relacionada com a falta de informações confiáveis do histórico das matérias-primas utilizadas pelos trabalhadores. As médias estimadas de exposições por função e estratificadas por tipo de operação (a seco ou a úmido), e por tipo de matéria-prima (granito, ardósia e mármore), para o município de São Paulo, poderão ser utilizadas na composição da exposição acumulada à sílica, desde que o instrumento de avaliação (questionário) seja aperfeiçoado e uma nova análise de regressão seja realizada e apresente resultados estatisticamente significantes.

- Para os Modelos 1 e2 de exposição acumulada à sílica cristalina o tabagismo foi estatisticamente significante na regressão logística multivariada com Odds Ratio próximo a 2,5 e Intervalo de Confiança de 95\% entre 1,1 e 6,0.

5) O tempo de exposição à sílica cristalina em marmorarias também foi analisado neste estudo.

- $\quad$ O tempo médio de exposição para os trabalhadores de marmorarias com classificação radiológica com alterações (presença de pequenas capacidades - profusão $\geq 0 / 1$ ) foi de 19,9 anos enquanto o tempo médio de exposição para os trabalhadores sem alteração radiológica foi de 9,9 anos. 
- Há tendência linear de aumento nas prevalências de trabalhadores com classificação radiológica com alterações à proporção que aumenta o tempo de exposição nas marmorarias. Para um tempo de exposição de 4 anos, o Odds Ratio foi igual a 1,39 com intervalo confiança de 95\% de 1,21 e 1,62, significando que a cada 4 anos de exposição há chance igual a $40 \%$ de o trabalhador exposto ter classificação radiológica com alterações em relação ao não exposto.

6) Há exposição excessiva à poeira e à sílica cristalina respirável nas marmorarias e a forma de prevenir a silicose certamente passa pela implantação de medidas de controle para poeira. $\mathrm{O}$ estudo das alternativas de controle e tipos de matérias-primas permite tirar as seguintes conclusões:

- Houve diminuição considerável na concentração média de poeira respirável de $3,19 \mathrm{mg} / \mathrm{m}^{3}$ para situações sem controle, para $1,82 \mathrm{mg} / \mathrm{m}^{3}$ com controle no ambiente e $0,55 \mathrm{mg} / \mathrm{m}^{3}$ para máquinas e ferramentas a úmido. A diminuição da concentração de sílica cristalina respirável foi proporcional à redução da poeira respirável;

- Quando eram utilizadas máquinas, como boleadeiras, politrizes manuais com águas os resultados encontrados ficaram abaixo do valor de referência para a etapa de acabamento, com média de concentração de sílica cristalina de $0,038 \mathrm{mg} / \mathrm{m}^{3}$, indicando que são mais eficientes que os controles no ambiente para redução da exposição a poeira minerais e sílica cristalina respirável.

- Quer utilizando politrizes a úmido elétricas, quer pneumáticas, os resultados obtidos foram semelhantes, evidenciando que os dois sistemas de funcionamento da ferramenta, têm a mesma eficiência para o controle da poeiraelétrico ou pneumático. 
- Com quatro sistemas de controle da poeira no ambiente obtiveram-se resultados de concentração de sílica cristalina respirável abaixo do valor de referência, mostrando que eles podem ser eficientes desde que cuidados sejam tomados e procedimentos sejam seguidos com rigor em relação a: instalação em local apropriado; manutenção; adequação da sua capacidade ao volume de produção; vigilância constante com relação a concentrações de poeira e de sílica cristalina respirável presentes nos ambientes de trabalho.

- As rochas silicáticas foram responsáveis por $80 \%$ dos materiais processados. Os granitos geraram faixa entre 1 e $32 \%$ de sílica cristalina respirável, as ardósias entre 6 e 18\%, os arenitos e quartzitos entre 7 e $38 \%$ e os materiais sintéticos entre 16 a $52 \%$. Estas foram as matérias-primas mais perigosas encontradas do ponto de vista do risco à saúde, com aparecimento de silicose e de câncer. 


\section{RECOMENDAÇÕES}

Os resultados quantitativos obtidos neste estudo indicam que são necessárias diversas ações para reduzir a exposição ocupacional a poeiras minerais e à sílica cristalina respirável dos trabalhadores de marmorarias.

Recomendam-se:

- A implantação de processos com etapa de acabamento a úmido usando máquinas e ferramentas que controlam na fonte a emissão de partículas de poeira.

- A revisão e melhoria dos controles de poeira no ambiente já instalados nas empresas. Não sendo possível adequação técnica para obtenção de um nível de exposição dos trabalhadores abaixo do nível de ação dos Limites de Exposição Ocupacional, recomenda-se a mudança para processos com etapa de acabamento a úmido.

- A implantação de programa de proteção respiratória adequado em ambos os casos, pois mesmo a úmido pode ocorrer exposição devido à utilização de matérias-primas maisperigosas.

- A melhoria dos layouts e instalações das marmorarias. Em particular na área de produção faz-se necessário melhorar a organização; a limpeza a úmido, eliminando o processo de varrição, adequar bancadas, rearranjar áreas, criando acessos livres para circulação e instalar sistemas de transporte de chapas e de peças que não exijam o esforço físico, como exige o carrinho de trilho utilizado em muitas marmorarias. As instalações sanitárias, vestiários e refeitórios devem ser adequados à legislação. 
- O desencadeamento de ações políticas, administrativas e de financiamento por parte do Estado, a fim de incentivar a modernização das marmorarias, para adequação dos processos de produção com a implantação de tecnologias limpas, que diminuam a exposição dos trabalhadores a poeiras.

- Diante do baixo nível de escolaridade e de renda da população estudada, a busca de alternativas para melhoria desta condição por meio de cursos de formação e de especialização profisssional, com foco também na prevenção de riscos à saúde, considerando a silicose como risco importante no ramo de atividade. Ações dos serviços de aprendizagem profissional, assim como iniciativas de sindicatos de trabalhadores e de empregadores devem ser estimuladas e apoiadas neste sentido.

- O seguimento do estado de saúde dos trabalhadores de marmorarias com elaboração de cadastro de expostos, ações de vigilância à saúde e de fiscalização dos ambientes de trabalho pelo Estado, a fim prevenir o aparecimento de novos casos de silicose e de câncer.

- O aperfeiçoamento dos modelos de exposição acumulada à sílica cristalina para marmorarias, por ação conjunta de diversas instituições que atuam na área.

- O desenvolvimento de ações que estimulem a realização de estudos em marmorarias com objetivos de: melhorar o conhecimento sobre a toxicidade das rochas ornamentais; avaliar as exposições à poeira e à sílica respirável de trabalhadores em funções e atividades realizadas fora da área de produção das marmorarias, isto é, atividades como as realizadas pelos colocadores, que possuem interfaces com a construção civil; melhorar o processo produtivo das marmorarias levando em consideração aspectos ligados ao gerenciamento da qualidade dos produtos, à saúde e segurança dos trabalhadores e ao meio ambiente. 


\section{REFERÊNCIAS BIBLIGRÁFICAS}

1. [ABHO]. Associação Brasileira de Higienistas Ocupacionais. Limites de Exposição $\left(\operatorname{TLVs}^{\circledR}\right)$ para Substâncias Químicas e Agentes Físicos \& Índices Biológicos de Exposição (BEIs ${ }^{\circledR}$ ). São Paulo: ABHO; 2005.

2. [ABNT]. Associção Brasileira de Normas Técnicas - MB 3422 Agentes químicos no ar - Coleta de aerodispersóides por filtração - Método de ensaio. 1991.

3. [ACGIH]. American Conference of Governmental Industrial Hygienists. 2000 - Threshold Limit Values for Chemical Substances and Physical Agents and Biological Exposures Indices. Cincinnati: ACGIH, 2000.

4. [ACGIH] American Conference of Governmental Industrial Hygienists. 2005 - Threshold Limit Values for Chemical Substances and Physical Agents and Biological Exposures Indices. Cincinnati: ACGIH, 2005.

5. Aguiar JG, Garcia Junior AC, Kiefer C, Gusmão FA, Borges LH, Oliveira WRT. Estudo das condições de trabalho e saúde dos trabalhadores no processo de extração, transporte e beneficiamento do mármore e granito no estado do Espírito Santo. Vitória (ES); 1995. (FUNDACENTRO Centro Estadual do Espírito Santo - Relatório Técnico).

6. [AIHA]. American Industrial Hygiene Association. A Strategy for Assessing and Managing Occupational Exposures. $2^{\text {th }}$ ed. Fairfax: AIHA Press; 1998.

7. [AIHA]. American Industrial Hygiene Association. Laboratory Quality Assurance Manual $2^{\text {th }}$ ed. Fairfax: AIHA Press; 1997 
8. Algranti E, De Capitani EM, Carneiro APS, Saldiva PHN. Patologia Respiratória Relacionada com o Trabalho. In René Mendes editor: Patologia do Trabalho. $2^{\text {a }}$ ed. São Paulo; 2003. p.1330-97.

9. Algranti E, Handar Z, Ribeiro FSN, Bon AMT, Santos AM, Bedrikow B. Exposición a sílice y silicosis em el Programa Nacional de Eliminación de Silicosis en Brasil (PNES). Ciencia \& Trabajo 2004; 11: 1-13.

10. Algranti E. Doenças Respiratórias Associadas à Mineração de Carvão Estudo de Coorte de 5 anos. São Paulo; 1991. [Tese de Doutorado Universidade de São Paulo. Faculdade de Saúde Pública].

11. Algranti E. Occupational lung disease in Brazil. In: Daniel E. Banks and John E. Parker, editors. Occupational Lung Disease. London: UK Chapman \& Hall;1998. p. 105-15.

12. Araújo A. Determinants on silicosis in quarry workers - final report. Irwing Selikoff Fellowship Program, PAHO/Mount Sinai/ Queens College; 2001.

13. ATS. American Thoracic Society. Adverse Effects of Crystalline Sílica Exposure. Am J Respir Crit Care Med 1997; 155: 761-5.

14. Azambuja JC, Silva ZCG. Perfil analítico dos mármores e granitos Ministério das Minas e Energia. Departamento Nacional de Produção Mineral. Boletim, 38; 1975.

15. Bagatin E, Jardim JRB, Nery LE e col. Ocorrência de silicose pulmonar na região de Campinas-SP. J Pneumol 1995; 21 (1):17-26. 
16. Bagatin E. Avaliação clínica, radiológica e da função pulmonar em trabalhadores expostos à poeira de sílica. Campinas, 1988. [Tese de doutorado - Faculdade de Ciências Médicas - Universidade Estadual de Campinas].

17. Bégin R, Filion R, Ostiguy G. Emphysema in sílica and asbestos exposed workers seeking compensation. Chest 1995; 108:539-45.

18. Bolsaitis PP, Wallace WE. The struture of sílica surfaces in relation to cytotoxicity. In: Castranova V, Vallyathan V, Wallace WE, eds. Silica and silica-induced lung diseases. Boca Raton, FL: CRC Press Inc; 1996. p.79 89.

19. Bon AMT, Santos AMA, Amaral NC, Kulsar Neto F. Avaliação Ambiental de Sílica Livre Cristalizada Realizada no Laboratório de Classificação de Areia do Instituto de Pesquisas Tecnológicas do Estado de São Paulo S/A - IPT. São Paulo; 1998. (FUNDACENTRO- Relatório Técnico RT/02).

20. [BSI] British Standard Institute. BS 8800: Guide to Occupational health and safety management systems. London: 1996.

21. Carneiro APS, Campos LO, Gomes MFCF e col. Perfil de 300 trabalhadores expostos à sílica atendidos ambulatorialmente em Belo Horizonte. J Pneumol 2002; 28: 329-34.

22. Castranova V, Vallyathan V, Ramsey DM, McLaurin JL, Pack D, Leonard S, Barger MW, Ma JYC, Dalal NS, Teass. A. Augmentation of pulmonary reactions to quartz inhalation by trace amounts of iron-containing particles. Environ Health Perspect 1997; 105 (Suppl 5): 1319-24.

23. Castro HA, Bethlem EP. A silicose na indústria naval do Estado do Rio de Janeiro: análise parcial. Comissão Técnica Estadual de Pneumopatias Ocupacionais do Estado do Rio de Janeiro. J Pneumol 1995; 21: 13-16. 
24. Castro HA, Vicentin G, Pereira KCX. Mortalidade por pneumoconioses nas macrorregiões do Brasil no período de 1979-1988. J Pneumol 2003; 29(2): 82-8.

25. CETEM (Centro de Tecnologia Mineral) e ABIROCHAS (Associação Brasileira de Rochas Ornamentais). Catálogo de Rochas Ornamentais do Brasil [CD ROM]. Rio de Janeiro: CETEM; 2002.

26. Chechoway H, Pearce NE, Crawford-Brown DJ. Characterizing the Workplace Environment. In: Research Methods in Occupational Epidemiology. New York Oxford: Oxford University Press; 1989. p.18-45.

27. Chiodi Filho C. Aspectos técnicos e econômicos do setor de rochas ornamentais, Rio de Janeiro; CNPQ/CETEM. (Estudos e Documentos, 28).

28. Choi BCK. Definition, Sources, Magnitude, Effect Modifiers, and Strategies of Reduction of the Healthy Worker Effect. JOM 1992; 34(10): 979-88.

29. [CNAE]. Código Nacional de Atividade Econômica. Instituto Brasileiro de Geografia e Estatítica. IBGE. Disponível em http://www.cnae.ibeg.gov.br . $[18 / 10 / 2005]$.

30. Consonni D, Bertazzi PA, Zocchetti C. Why and how to control for age in occupational epidemiology. Occup Environ Med 1997; 54: 772-6.

31. Costello J, Castellan RM, Swecker GS e col. Mortality of U.S. Workers Employed in the Crushed Stone Idustry, 1940-1980. Am J Ind Med 1995; 27: 625-40.

32. Costello J, Graham WGB. Vermont granite worker's mortality study. Am J Ind Med 1988; 13: 483-97. 
33. Davis LK, Wegman DH, Monson RR, Froines J. Mortality Experience of Vermont Granite Workers. Am J Ind Med 1983; 4:705-23.

34. Donalson K, Borm PJA. The quartz hazard: A variable entity. Ann Occup Hyg 1998; 42(5): 287-94.

35. EPA. Environmental Protection Agency. Guidelines for Exposure Assessment. Washington: DC; 1992. (EPA/600/Z-92/001).

36. Ferreira AS. Silicose aguda. Pulmão RJ 1999; 8:349-58.

37. Florey CV, Leeder SR. Methods for cohort studies of chronic airflow limitation. WHO Regional Publications. Copenhagem; 1982. (European Series, 12).

38. Franco AR. Silicose pulmonar em trabalhadores de pedreiras. Res Bras Saúde Ocup 1978; 6: 21-59.

39. Frascá MHBO, Quitete EB. Rochas Ornamentais do Estado de São Paulo Características Tecnológicas. Rochas de Qualidade 2000; 154 (Set/Out): 154-71.

40. Frascá MHBO. Rochas Ornamentais e para Revestimento: Variedades, Propriedades, Usos e Conservação. In: A cadeia produtiva de Rochas Ornamentais e para Revestimento no Estado de São Paulo. São Paulo: IPT; 2004. p.153-91.

41. Freeman CS, Grossman EA. Sílica exposures in the United States between 1980 and 1992. Scand J Work Environ Health 1995; 21 (suppl. 2), 46-9.

42. Fubini B. Health effects of sílica. In: Legrand AP, ed. The Surfance Properties of Silicas. New York: John Wiley \& Sons; 1998a. p.415-64. 
43. Fubini B. Surface chemistry and quartz hazard. Ann Occup Hyg 1998b; 42 (8):521-30.

44. Fubini B. Surface reactivity in the pathogenic response to particulates. Environ Health Perspect 1997; 105 (5): 1013-20.

45. [FUNDACENTRO]. Fundação Jorge Duprat Figueiredo de Segurança e Medicina do Trabalho. Levantamentos Técnicos das Condições de Higiene realizado em Minas de Carvão. Porto Alegre;1985. (Relatório do Centro Regional do Rio Grande do Sul e Santa Catarina).

46. [FUNDACENTRO]. Fundação Jorge Duprat Figueiredo de Segurança e Medicina do Trabalho. Relatórios das condições de higiene do trabalho realizado em 30 empresas das indústrias cerâmicas no município de Pedreira. São Paulo; 1980. (Relatórios da Divisão de Higiene do Trabalho v.2, v.4, v.4, v.25, v.29, v.30, v.32).

47. [FUNDACENTRO]. Fundação Jorge Duprat Figueiredo de Segurança e Medicina do Trabalho. Relatórios do II Levantamento Técnico Quantitativo das Condições de Exposição nas Empresas de Cerâmica na Cidade de Pedreira. São Paulo, 1987; 1988; 1989. (Relatórios da Divisão de Higiene do Trabalho v.11, v.16, v.17, v.18, v.19, v.20, v.23).

48. [FUNDACENTRO]. Fundação Jorge Duprat Figueiredo de Segurança e Medicina do Trabalho. Introdução à Higiene Ocupacional. São Paulo (SP); 2001.

49. [FUNDACENTRO]. Fundação Jorge Duprat Figueiredo de Segurança e Medicina do Trabalho. Norma de Higiene Ocupacional - NHO 03. Análise gravimétrica de aerodispersóides sólidos coletados sobre filtro de membrana - Método de ensaio. São Paulo (SP); 2001. 
50. [FUNDACENTRO]. Fundação Jorge Duprat Figueiredo de Segurança e Medicina do Trabalho. Norma de Higiene Ocupacional - NHO-07. Calibração de bombas de coleta individual pelo método da bolha de sabão - Procedimento técnico.. São Paulo (SP); 2002.

51. [FUNDACENTRO]. Fundação Jorge Duprat Figueiredo de Segurança e Medicina do Trabalho. Norma de Higiene Ocupacional. Coleta de Material Particulado sólido suspenso no ar de ambientes de Trabalho Procedimento Técnico. 2006. Em Publicação.

52. [FUNDACENTRO]. Fundação Jorge Duprat Figueiredo de Segurança e Medicina do Trabalho. Programa Nacional de Eliminação da Silicose. Disponível em http://www.fundacentro.gov.br/SES/programas_apresentacao.asp?D=SES. [30/11/2005].

53. [FUNDACENTRO]. Fundação Jorge Duprat Figueiredo de Segurança e Medicina do Trabalho. Sílica e Silicose. Disponível em http://www.fundacentro.gov.br/SES/silica_base_2.asp?D=SES. [03/05/2003].

54. Goelzer BIF. Silicose. In: Seminário Internacional sobre Exposição à Sílica "Prevenção e Controle"; 6-10 de Novembro 2000; Curitiba, Brasil. Disponível http://www.fundacentro.gov.br/SES/seminario_1.asp?D=SES. [30/11/2005].

55. Gruenzner G. Avaliação da poeira da sílica: Um estudo de caso em uma pedreira na região metropolitana de São Paulo. São Paulo, 2003. [Dissertação de mestrado - Escola Politécnica da Universidade de São Paulo].

56. Guénel P, Hojberg G, Lynge E. Cancer incidence among Danish stone workers. Scand J Work Environ Health 1989; 15: 265-70. 
57. Guthrie Jr. GD. Mineralogical Factors Affect the Biological Activity of Crystalline Silica. Appl Occup Environ Hyg 1995; 10 (12): 1126-31.

58. Haten E, Cavalcanti FTB. Silicosis in pit diggers in Serra da Ibiapaba, Ceará Brazil. In: VII International Pneumoconiosis Conference; 1988 Pittsburgh PA. p. 316-19.

59. Hearl FJ. Identification monitoring and control of exposures. In: Daniel E. Banks and John E. Parker, editors. Occupational Lung Disease. London, UK Chapman \& Hall 1998. p. 35-52.

60. Hnizdo E. Loss of lung function associated with exposure to silica dust and with smoking and its relation to disability and mortality in South African gold miners. Brit J Ind Med 1992; 49: 472-9.

61. Hnizdo E, Murray J, Sluiss-Cremer GK, Thomas RG. Correlation between radiological and pathological diagnosis of silicosis: An autopsy population based study. Am J Ind Med 1993; 24: 427-45.

62. Hnizdo E, Sluis-Cremer GK. Risk of silicosis in a cohort of white South African gold miners. Am J Ind Med 1993; 24: 447-57.

63. Holanda MA, Martins MPS et al. Silicosis in Brazilian pit diggers: relationship between dust exposure and radiological findings. Am J Ind Méd 1995; $27: 367-78$.

64. [IARC]. Internacional Agency for Tesearch on Cancer. Silica Some Silicates Coal Dust and Para-Aramid Fibrils. IARC Monographs on the Evaluation of the Carcinogenic Risk of Chemicals to Humans. Lyon, France: IARC Press; 1997. v. 68 
65. [ISEGI]. Instituto Superior de Estatística e Gestão de Informação. Disponível em http://www.isegi.unl.pt/ensino/docentes/ccosta/aulas/tp_pdf/tabelas.pdf $[03 / 12 / 2005]$

66. [ILO]. International Labour Organization. Global Elimination of Silicosis: The ILO/WHO International Programme, by Igor A. Fedotov. Mineral dusts and prevention of silicosis. Asian-Pacific Newsletter on Occupational Health and Safety 1997; 4(2): 34-5.Disponível em<http://www.ilo.org/public/english/...aosh/newsletr/silicosi/asialtr.htm>.

67. [ILO]. International Labour Office. 2000. Guidelines for the use of ILO International Classification of Radiographs of Pneumoconiosis. Occupational Safety and Health Series n. 22. Geneva: ILO

68. [IPT]. Instituto de Pesquisas do Estado de São Paulo S/A. Secretaria da Ciência, Tecnologia e Desenvolvimento Econômico do Estado de São Paulo. Rochas Ornamentais e de Revestimento do Estado de São Paulo [CD ROM]. São Paulo: Publicação IPT 2651; 2000.

69. [INSS]. Instituto Nacional do Seguro Social. Ordem de Serviço Nº69, de 5 de agosto de 1988: Aprova Norma Técnica sobre Pneumoconioses. Diário Oficial da União, Brasília, 19 ago 1998. Seção I, p.53-60.

70. [ISO] International Organization for Standardization. Guia para a expressão de incerteza da medição. Terceira edição brasileira em língua portuguesa. Rio de Janeiro: ABNT, 2003.

71. Johnson D, Swift D. Sampling and Sizing Particles. In: Ed. Salvatore R. Dinard editor. The Occupational Environmet - Its Evaluation and Control. Fairfax: AIHA Press 1998. p 243-61. 
72. Kirk Otmer. Encyclopedia of Chemical Tecnology - Sílica. $4^{\text {th }}$ ed. A Willy Interscience Publication. John Wiley\&Sons. Inc; 1997. p. 977-1005.

73. Koskela RS, Klockars M, Laurent H, Holopainen M. Silica dust exposure and lung cancer. Scand J Work Environ Health 1994; 20: 407-16.

74. Kreiss K, Zhen B. Risk of silicosis in a Colorado mining community. Am J Ind Med 1996; 30:529-39.

75. Leidel NA, Bush KA e Lynch JA. Occupational Exposure Sampling Strategy Manual. Cincinnati: Ohio; National Institute for Occupational Safety and Health (NIOSH). 1977.

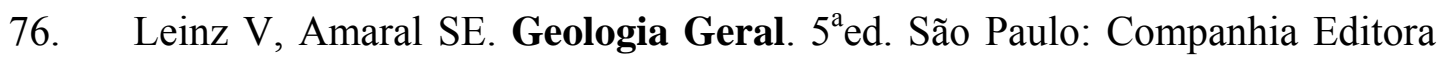
Nacional; 1973.

77. Lessa Davydoff. A Higiene do Trabalho e as Minas de Ouro do Brasil. In: Anais do I Congresso Brasileiro de Higiene e Segurança do Trabalho. Rio de Janeiro. 1949.

78. Lippmann M. Size-Selective Health Hazard Samplig. In: Air Sampling Instruments for evaluation of atmospheric contaminants. $7^{\text {ht }}$ ed. Cincinnati: Ohio; American Conference of Governmental Industrial Hygienists (ACGIH). 1989.

79. Maçãira EF. Morbidade respiratória em trabalhadores em limpeza interna da região metropolitana de São Paulo; 2004. [Dissertação de Mestrado - Universidade de São Paulo. Faculdade de Saúde Pública].

80. Madureira Filho JB, Atencio D, Mcreath I. Minerais e rochas: constituintes da terra sólida. In: Teixeira W, Toledo MCM, Fairchild TR, Taioli F. (org.). Decifrando a Terra. São Paulo: Oficina de textos; 2000. p.568. 
81. Mannetje A, Steenland K, Chechoway et al. Development of Quantitative Exposure Data For a Pooled Exposure-Response Analysis of 10 Silica Cohorts. American Journal of Industrial Medicine 2002; 42:73-86.

82. Mello ISC. Indicadores do Mercado Nacional e Internacional de Rochas Ornamentais e para revestimento. In: A cadeia produtiva de Rochas Ornamentais e para Revestimento no Estado de São Paulo. São Paulo: IPT; 2004.

83. Mello, ISC, Zanardo, A, Motta JFM, Navarro FC, Roldan AA. Condicionantes geológicos para a ocorrência de conglomerados ornamentais no Brasil. In: Anais do Simpósio de Geologia do Sudeste; 2005 set; Niterói: SBG; 2005. [1 CD-ROM].

84. Mendes R. Epidemiologia da silicose na região sudeste do Brasil. São Paulo, 1978. [Tese de doutorado - Faculdade de Saúde Pública da Universidade de São Paulo].

85. Minervino DM, Garrafa NM, De Stefano IJ. A silicose pulmonar nas indústrias de São Paulo. In: Anais do Congresso Americano de Medicina do Trabalho; 1964; São Paulo. p. 268-80.

86. [MPESP]. Ministério Público do Estado de São Paulo. Prefeitura do Município de São Paulo, Projeto Marmoristas. Relatório Elaborado pela Equipe Técnica do Projeto. Dezembro de 2001.

87. Montani C. Stone 2003 - Word Marketing Handbook. Faenza (ITA): Gruppo Editorial e Faenza Editrice; 2003. p. 237. 
88. Moreira CW, et al. Projeto Especial Marmorarias do Programa de Vigilância à Saúde dos Trabalhdores em Belo Horizonte. Belo Horizonte; 2003. (Secretaria Municipal de Saúde, Relatório Final).

89. Morrone LC. Epidemiologia da silicose no Estado de São Paulo. São Paulo, 1979. [Dissertação de mestrado - Faculdade de Saúde Pública da Universidade de São Paulo].

90. [MTE]. Ministério do Trabalho e Emprego. Classificação Brasileira de Ocupações, 2002. Disponível em http://www.mtecbo.gov.br/busca.asp .[08/11/2003]

91. [MTE]. Ministério do Trabalho e Emprego. Portaria $\mathbf{N}^{\circ} 3214$ de 08/06/1978. Norma Regulamentadora $N^{\circ} 15$, Atividades e Operações Insalubres, Anexo 12.

http://www.mte.gov.br/Empregador/segsau/Legislacao/Normas/Download/NR_15.pdf [18/01/2006].

92. [MTE] Ministério do Trabalho e Emprego. Secretaria de Segurança do Trabalho. Portaria $N^{\circ} .25$ de 29/12/1994. Norma Regulamentadora $N^{\circ}$ 9: Programas de Prevenção de Riscos Ambientais. Disponível em: http://www.mtb.gov.br/Temas/SegSau/Legislacao. Acesso em: 12 Abril 2004.

93. Muir DCF, Shannon HS, Julian JA, et al. Sílica exposure and silicosis among Ontario hardrock miners: I. Methodology. Am J Ind Med 1989a; 16: 5-11.

94. Muir DCF, Julian JA, Shannon HS et al. Silica exposure and silicosis among Ontario hardrock miners: III Analysis and risk estimatives. Am J Ind Med 1989b; 16: 29-43. 
95. Muir DCF. Correction in cumulative risk in silicosis exposure assessment. Am J Ind Med 1991; 19:555.

96. Murray J, Kielkowski D, Reid P. Occupational disease trends in black South African gold mines. Am J Respir Crit Care Med 1996; 153: 706-10.

97. [NIOSH]. National Institute for Occupational Safety and Health. Criteria for a recommended standard occupational exposure to crystalline silica. Washington (DC): NIOSH Publication n. 75-120; 1974.

98. [NIOSH]. National Institute for Occupational Safety and Health. Documentation of the NIOSH - Validation Tests. Cincinnati (Ohio): 1977.

99. [NIOSH]. National Institute for Occupational Safety and Health. NIOSH Hazard Review - Health Effects of Occupational Exposure to Respirable Crystalline Silica. Cincinnati (Ohio): DHHS (NIOSH) Publication n. 2002$129 ; 2002$.

100. [NIOSH]. National Institute for Occupational Safety and Health. Manual of Analytical Methods. Silica, crystalline by XRD (filter redeposition). Method: 7500, Issue 415 March 2003.

101. Oliveira JL. Prevalence of silicosis among ceramic industry workers in the city of Pedreira - Brazil. In: Abstracts of Communications VII International Pneumocnioses Conference, 1988. p.114.

102. [OSHA]. Occupational Safety and Health Administration. Quartz and cristobalite in workplace atmospheres. Method Number ID-142 (Revised in december 1996). Disponível em http://www.oshaslc.gov/dts/sltc/methods/inorganic/id142/id142.html [26/05/2002]. 
103. [OSHA]. Occupational Safety and Health Administration. U.S.Department of Labor. Regulations (Standards - 29 CFR). Table Z-3 Mineral Dusts 1910.1000. Disponível em: http://www.oshaslc.gov/pls/oshaweb/owadisp.show_document?p_table=STANDARDS\&p_id=9994 [6/07/2004].

104. Pereira CAC, Barreto SP, Simões JG, Pereira FWL, Gerstler JG, Nakatani J. Valores de referência para espirometria em uma amostra da população brasileira adulta. J Pneumol 1992; 18: 10-22

105. Pivetta ABDA. Prevalência de sintomas respiratórios em trabalhadores de marmorarias de Cuiabá e Vázea-Grande/MT. Cuiabá; 1996. [Dissertação de mestrado - Instituto de Saúde coletiva da Universidade Federal de Mato-Grosso].

106. [RAIS]. Relação Anual das Informações Socias. Ministério do Trabalho e Emprego. Estatísticas dos últimos três anos (1995-1997). Disponível em: http://www.mte.gov.br/sppe/rais/anuario/estrutu/estab/tab1_1.htm [04/06/2001].

107. [RAIS]. Relação Anual das Informações Socias. Ministério do Trabalho e Emprego. RAIS/RAISESTB [CD-ROM]. Departamento de emprego e salário. Coordenação Geral de Estatísticas do Trabalho. 2003.

108. Ribeiro FSN. Exposição ocupacional à sílica no Brasil: tendência temporal entre 1985 e 2001. São Paulo, 2004. [Tese de doutorado Faculdade de Saúde Pública da Universidade de São Paulo]

109. Rice FL, Stayner LT. Assessment of silicosis risk for occupational exposure to crystalline sílica. Scand J Work Environ Health 1995; 21 (Suppl 2):8790. 
110. Rodriques GL. Poeira e ruído na produção de brita a partir de basalto e gnaisse nas regiões de Londrina e Curitiba, Paraná: Incidência sobre os trabalhadores e Meio Ambiente. Curitiba, 2004. [Tese de doutorado - da Universidade Federal do Paraná].

111. Santos AMA. Determinação quantitativa de sílica livre cristalizada por difração de raios-X. Rev Bras Saúde Ocup 1989; 17 (65): 55-9.

112. Santos AMA. O tamanho das partículas de poeira suspensas no ar dos ambientes de trabalho. FUNDACENTRO, 2001.

113. [SAS]. SAS Institute INC; Cary: (NC USA), 2004.

114. [SBPT] Sociedade Brasileira de Pneumologia e Tisiologia. I Consenso Brasileiro Sobre Espirometria. J Pneumol 1996; 22 (3):105-64.

115. [SEBRAE]. Serviço Brasileiro de Apoio às Micro e Pequenas Empresas. Lei $\mathrm{N}^{\mathrm{o}} 9.841$ de 5 de outubro de 1999. Estatuto da Microempresa e da Empresa de Pequeno Porte. Disponível em http://www.sebrae.com.br [04/06/2001].

116. Silicosis and Silicate Disease Committee. Diseases associated with exposure to silica and nonfibrous silicate minerals. Arch Pathol Lab Med 1988; 112: 672-673.

117. Silva CRS, Moreira JC, GS Kuriyama et al. Occupational exposure to mineral dusts in an ornamental stone works in Brazil. In: Chiyotani K, Hosada Y e Aizawa Y.eds. Advances in the Prevention of Occupational Respiratory Diseases. Elsevier Science B.V. 1998. p. 1047-49.

118. Soto, JMG et al. Riscos Químicos. São Paulo: FUNDACENTRO; 1991. 
119. Souza Filho AJ, Alice SH. Pneumoconiose em borracheiros. J Pneumol 1992; 18 (Supl 2): 101-2.

120. Steenland K, Brown D. Silicosis among gold miners: Exposure-response analyses and risk assessment. Am J Public Health 1995; 85 (10): 1372-77.

121. Task Group on Lung Dynamics Committee II. International Commission on Radiological Protection. Deposition and retention models for internal dosimetry of the human respiratory tract. Health Phys 1966; 12:173-208.

122. Torloni M, Vieira AV. Manual de Proteção Respiratória. São Paulo: ABHO; 2003.

123. Tourmann JL, Kaufmann R. Laser microprobe mass spectrometric (LAMMS) study of quartz-related and non-quartz-related factors of the specific harmfulness of coal mine dusts. Ann Occup Hyg 1994; 38 (Suppl1): 455-67.

124. Vallyathan V, Shi X. The role of oxigen free radicals in occupational and environmental lung diseases. Environ Health Perspect 1997; 105 (Suppl 1): 165-77.

125. Verma DK, Sebestyen A, Julian JA, Muir DCF, Schimit H, Bernholz CD, et al. Silica exposure and silicosis among Ontario hardroch miners:II. Exposure estimativas. Am J Ind Med 1989; 16:13-28.

126. Wagner GR, Attfield MD, Kennedy RD e col. The NIOSH B Reader Certification Program. An Update Report. JOM 1992; 34 (9) Sep. 
127. Wallace WE, Chen J, Harrison J e col. Respirable silica particle occlusion by alumino-slicate: surface properties of dusts with disease risk anomalies. [abstract] La Medicina del Lavoro; 2002; 93 (Suppl 2002). p. S24. $3^{\text {RD }}$ International Symposium on Silica, Silicoses, Cancer and Other Diseases; 2002 oct 21-25; Santa Margherita Ligure, Italy.

128. Wallace WE, Harrison J, Keane MJ e col. Clay occlusion of respirable quartz particles detected by low voltage scanning electron microscopy - X-Ray Analysis. Ann Occup Hyg 1998; 34 (2):195-204.

129. Wallace WE, Keane JM, Harrison JC e col. Surface properties of silica in mixed dusts. In: Castranova V, Vallyathan V, Wallace WE, eds. Silica and silica-induced lung diseases. Boca Raton, FL: CRC, Press Inc; 1996. p.10717.

130. [WHO]. World Health Organization. Hazard Prevention and Control in the Work Environment: Airborne Dust. WHO/SDE/OEH/99.14. 1999. 


\section{TABELA DE ATIVIDADES ONDE HÁ PRESENÇA DE SÍLICA}

\begin{tabular}{|c|c|c|}
\hline Industria/atividade & Operação específica/tarefa & Fonte do material \\
\hline Agricultura & Aragem, colheita, uso de máquinas & Solos \\
\hline $\begin{array}{l}\text { Mineração e operações relacionadas ao } \\
\text { beneficiamento do minério }\end{array}$ & $\begin{array}{l}\text { A maioria das ocupações (subterrâneas, } \\
\text { superficiais, moinhos) e minas (metal, } \\
\text { não metal, carvão) }\end{array}$ & Minérios e rochas associadas \\
\hline $\begin{array}{l}\text { Lavra/extração e operações relacionadas } \\
\text { com o beneficiamento do minério }\end{array}$ & $\begin{array}{l}\text { Processo de trituração de pedra, areia e } \\
\text { pedregulho, corte de pedra, abrasivo } \\
\text { para jateamento, trabalho com ardósia, } \\
\text { calcinação da diatomita }\end{array}$ & $\begin{array}{l}\text { Arenito, granito, pedra, areia, } \\
\text { pedregulho, ardósia, terras diatomáceas, } \\
\text { pedra. }\end{array}$ \\
\hline Construção & $\begin{array}{l}\text { Jateamento de estruturas, edifícios, } \\
\text { construção de auto estrada e túneis, } \\
\text { escavação e movimentação de terra, } \\
\text { alvenaria, trabalho com concreto, } \\
\text { demolição. }\end{array}$ & $\begin{array}{l}\text { Areia, concreto, rocha-solo e rocha- } \\
\text { concreto, argamassas. }\end{array}$ \\
\hline Vidro e fibra de vidro & Vidro e fibra de vidro & $\begin{array}{l}\text { Areia, quartzo moído, material } \\
\text { refratário. }\end{array}$ \\
\hline Cimento & Processamento da matéria prima & $\begin{array}{l}\text { Argila, areia, pedra calcárea terras } \\
\text { diatomáceas. }\end{array}$ \\
\hline Abrasivos & $\begin{array}{l}\text { Produção de carbeto de } \\
\text { silícioFabricação de Produtos Abrasivos }\end{array}$ & Areia, tripoli e arenito \\
\hline $\begin{array}{l}\text { Cerâmicas, incluindo tijolos, telha, } \\
\text { porcelana sanitária, porcelana, olaria, } \\
\text { refratários, esmaltes vitrificados. }\end{array}$ & $\begin{array}{l}\text { Misturas, moldagem, Cobertura } \\
\text { vifriticada ou esmaltada, acabamento. }\end{array}$ & $\begin{array}{l}\text { Argila, pedra, areia "Shale"Quartzito, } \\
\text { terras diatomáceas. }\end{array}$ \\
\hline Fabricação de ferro e aço & $\begin{array}{l}\text { Fabricação (manipulação) de refratários } \\
\text { e reparos em fornos }\end{array}$ & Material refratário \\
\hline Silício e ferro-silício & Manuseio de matérias primas & Areia \\
\hline Fundições de ferrosos e não ferrosos & $\begin{array}{l}\text { Fundição da peças, choques para } \\
\text { retirada da peça do molde, limpeza da } \\
\text { peça que encontra-se com areia aderida } \\
\text { na superfície, uso de abrasivos, } \\
\text { operações de alisamento/aplainamento, } \\
\text { instalação e reparo de fornos. }\end{array}$ & Areia-Material refratário. \\
\hline $\begin{array}{l}\text { Produtos de metal, incluindo metal } \\
\text { estrutural, maquinaria, equipamento de } \\
\text { transporte. }\end{array}$ & Jateamento com abrasivos & Areia \\
\hline $\begin{array}{l}\text { Construção civil e manutenções } \\
\text { (reparos) }\end{array}$ & Jateamento com abrasivos & Areia \\
\hline Borrachas e plásticos & Manuseio de matéria prima & $\begin{array}{l}\text { Funis alimentadores (tripoli, terras } \\
\text { diatomáceas) }\end{array}$ \\
\hline Tintas & Manuseio de matéria prima & $\begin{array}{l}\text { Funis alimentadores (tripoli, terras } \\
\text { diatomáceas, sílica flour) }\end{array}$ \\
\hline Sabões e cosméticos & Sabões abrasivos, pós para arear & Sílica flour \\
\hline Asfalto e papelão alcatroado & $\begin{array}{l}\text { Aplicação como enchimento e } \\
\text { granulado }\end{array}$ & Areia e agregado, terra diatomáceas. \\
\hline Substâncias químicas para a agricultura & $\begin{array}{l}\text { Trituração e manuseio de matérias } \\
\text { primas. }\end{array}$ & Minérios e rochas fosfáticas \\
\hline Joalheria & $\begin{array}{l}\text { Corte, esmerilhaMENTO, polimento, } \\
\text { lustramento }\end{array}$ & $\begin{array}{l}\text { Gemas semi-preciosas ou pedras, } \\
\text { abrasivos }\end{array}$ \\
\hline Material dental & Polimento & Areia, abrasivos \\
\hline Reparos de automóveis & Jateamento & Areia \\
\hline Escamação de "boiler" & "Boiler" com queima de carvão & Cinzas e concreções. \\
\hline
\end{tabular}

Fonte: IARC 1997- World Health Organization - International Agency for Research on Cancer 
ANEXO 2

ÁREAS DE ABRANGÊNCIA DOS CENTROS DE REFERÊNCIA DE SAÚDE DO TRABALHADOR NO MUNICÍPIO DE SÃO PAULO EM OUTUBRO DE 2002.

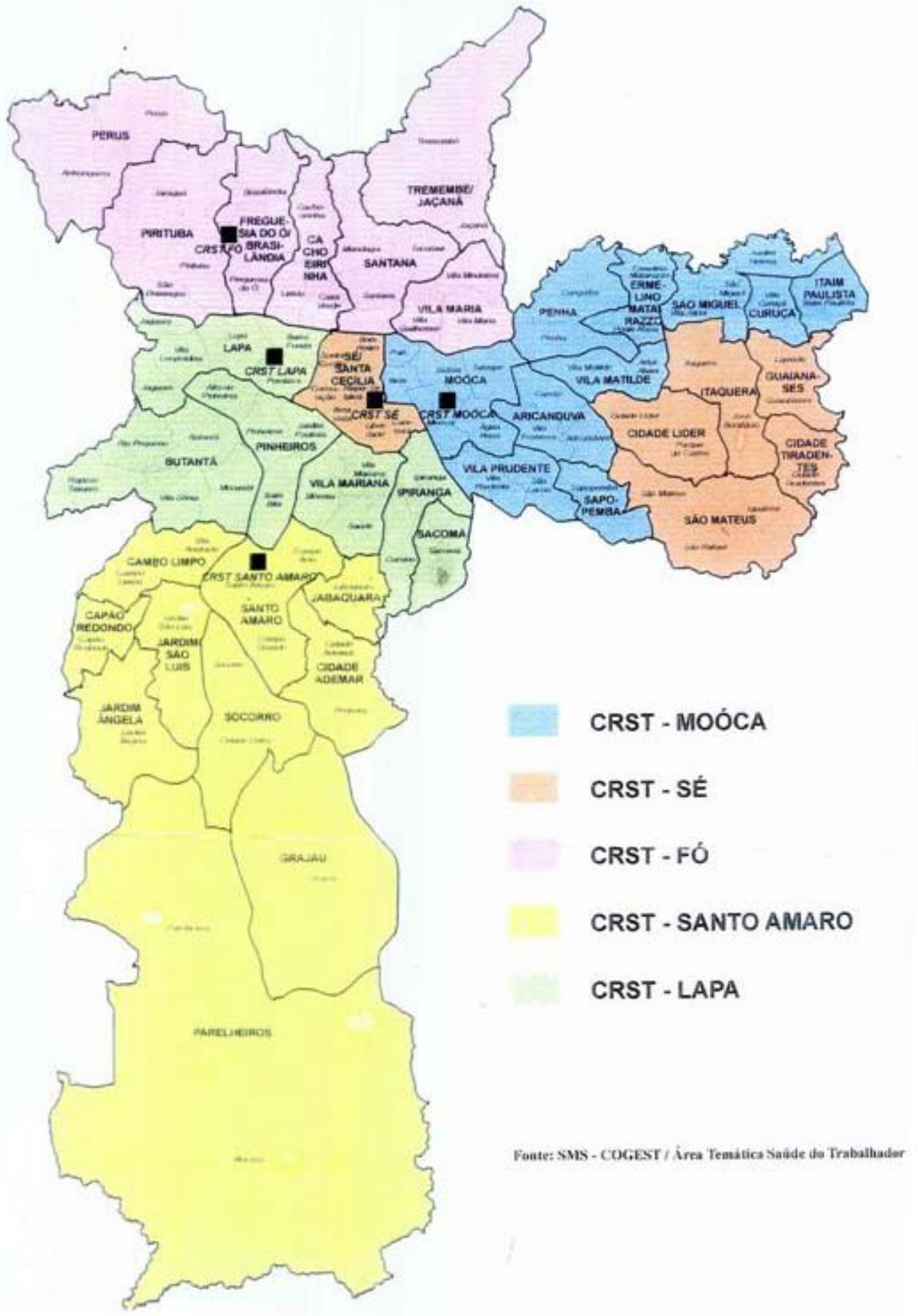


ANEXO 3

\section{TABELA PARA AMOSTRAGEM PARCIAL ALEATÓRIA PARA GRUPO DE EXPOSIÇÃO SIMILAR}

Tamanho mínimo de subgrupo para coleta de amostras com $90 \%$ de confiança de que pelos menos 1 trabalhador com alta exposição faça parte do subgrupo.

\begin{tabular}{cc}
\hline $\begin{array}{c}\text { Tamanho do Grupo } \\
\text { Original } \\
\mathrm{N}\end{array}$ & $\begin{array}{c}\text { Número de trabalhadores } \\
\text { requeridos } \\
\mathrm{n}\end{array}$ \\
\hline 8 & 7 \\
9 & 8 \\
10 & 9 \\
$11-12$ & 10 \\
$13-14$ & 11 \\
$15-17$ & 12 \\
$18-20$ & 13 \\
$21-24$ & 14 \\
$25-29$ & 15 \\
$30-37$ & 16 \\
$38-49$ & 17 \\
50 & 18 \\
\hline
\end{tabular}

$\mathrm{N}$ = Número igual ao tamanho do grupo de exposição similar. Se $\mathrm{N}<8$ coletar amostras para todos os trabalhadores.

$\mathrm{n}$ = tamanho da amostra ou tamanho do subgrupo

Fonte: Extraído de LEIDEL(1977) 


\section{ANEXO 4 \\ CLASSIFICAÇÃO BRASILEIRA DE OCUPAÇÕES PARA TRABALHADORES DE PEDRAS ORNAMENTAIS}

7122

Trabalhadores de beneficiamento de pedras ornamentais

Títulos

7122 - 05 Cortador de pedras - Aplainador de mármore, Cortador de mármore, Cortador de pedras - lavra de pedras, Marmorista - exclusive empregador em marmoraria, Montador de mármore, Operador de máquina de desdobramento de mármores, Serrador de mármore, Serrador de pedras (beneficiamento) 7122 - 10 Gravador de inscrições em pedra - Gravador de inscrições em mármore, Gravador de inscrições em mármore e em pedras, Trabalhador na colocação de inscrições em pedras 7122 - 15 Gravador de relevos em pedra - Ornamentador, Ornamentista de pedra

7122 - 20 Polidor de pedras - Acabador de pedras, Aparelhador de pedra (mármore), Polidor de granito, Polidor de mármore, Polidor de marmorite, Polidor de pedras, a mão, Polidor de pedras, a máquina 7122 - 25 Torneiro (lavra de pedra)

7122 - 30 Traçador de pedras

Descrição sumária

Realizam atividades de beneficiamento e ajustagem de pedras. Efetuam acabamento em superficies de pedra e constroem pisos de granitina. Podem planejar todas as fases do trabalho.

\section{Formação e experiência}

O exercício dessas ocupações requer quarta série do ensino fundamental e qualificação profissional adquirida em cursos básicos de até duzentas horas de duração. O pleno exercício das ocupações ocorre após experiência de um a dois anos na área de atuação.

Condições gerais de exercício

Atuam nas indústrias de construção e são assalariados com carteira assinada. Também podem atuar na fabricação de produtos de minerais não metálicos, comércio varejista e em serviços pessoais de outros tipos (exceto o Torneiro - lavra de pedra). Trabalham em equipe, com supervisão permanente. $\mathrm{O}$ ambiente de trabalho é fechado, exceto para o Torneiro (lavra de pedra) que desenvolve atividades a céu aberto. $O$ trabalho é realizado no periodo diurno. Também estão sujeitos a exposição de materiais tóxicos e ruído intenso e ao estresse.

\section{Código internacional CIUO 88:}

7113 - Tronzadores, labrantes y grabadores de piedra 
7122

\section{A - PLANEJAR OS TRABALHOS}

- Interpretar projetos arquitetônicos

- Identificar pedras

- Identificar máquinas conforme utilização

- Identificar acessórios das máquinas

- Consultar tabelas de preços e especificações

- Estabelecer cronograma de execução

- Elaborar orçamento

\section{B - BENEFICIAR PEDRAS}

- Descarregar chapas, blocos e ladrilhos

- Estocar chapas, blocos e ladrilhos

- Desdobrar blocos em chapas

- Selecionar pedras por cores e tamanhos

- Carregar chapas, blocos e ladrilhos seguindo

recomendações técnicas

- Identificar os grânulos dos abrasivos conforme

as etapas do polimento

- Regular quantidade de água no corte e

polimento de pedras

- Polir pedras utilizando politriz móvel ou fixa

- Substituir material abrasivo e cortante

- Substituir acessórios das máquinas

- Serrar pedras utilizando serra fixa ou móvel

- Levigar pedra

- Apicoar pedra e ladrilho

- Flamear pedra

- Cortar meio fios

- Quebrar pedras portuguesas com marreta

- Cortar paralelepípedos com talhadeira

mareta

- Triturar pedras

\section{C - EFETUAR ACABAMENTO EM SUPERFÍCIES}

DE PEDRA

- Resinar chapas, blocos e ladrilhos

- Impermeabilizar pedras e pisos de granitina

- Ranhurar pedras e ladrilhos

- Inscrever em blocos, chapas e ladrilhos

- Almofadar pedras

- Bizelar chapas e ladrilhos

- Efetuar molduras em pedras utilizando máquinas e acessórios

\section{D - AJUSTAR PEDRAS}

- Furar chapas

- Montar conjuntos de pedras

- Colar chapas, blocos e acessórios

- Encrostar pedras em chapas e ladrilhos

- Encrostar metais em chapas e ladrilhos

- Traçar os moldes para corte em folhas de

metal (gabarito)

- Numerar os moldes para identificação

- Definir o processo de corte para o máximo

aproveitamento dos blocos de pedra

- Desbastar as superfícies dos blocos ou

chapas usando máquinas aplainadoras

\section{E - CONSTRUIR PISOS DE GRANITINA}

- Nivelar o terreno da construção

- Compactar o solo

- Calcular quantidade de material (areia,

cimento, brita, caco de granito)

- Assentar juntas de dilatação no piso

- Classificar pedras granuladas

- Misturar os agregados para fundir a granitina

- Polir piso de granitina utilizando politriz móve

\section{Z - DEMONSTRAR COMPETÊNCIAS PESSOAIS}

- Realizar serviços com qualidade

- Demonstrar iniciativa

- Manter-se atualizado no trabalho

- Controlar o estresse

- Trabalhar em equipe

- Demonstrar sendo de responsabilidade

- Seguir orientações técnicas

- Reconhecer limitações pessoais

- Demonstrar criatividade 
7122

Recursos de Trabalho:

Escassilhador; Furadeira manual e fixa; Lixadeira fixa e manual; Martelete; Nível; Politriz fixa e manual; Serra mámore manual e bancada; Trena

\section{Participantes da Descrição}

\section{Especialistas}

Adelino Filho Carlos de Oliveira

Alípio Policarpo Martinhon

Arcelino Alencar de Souza

Carlos Henrique Ribeiro

Celino Manoel da Silva

Domingos Carlos de Oliveira

Edvard Carlos de Oliveira

Geraldo Pereira dos Santos

João Augusto Martinhom

Joaquim Ribeiro Varanda

José Ferreira Chaves

Nilson Sena

Paulo Carlos Afonso

Sônia Alves Florentino

Wagnozan Luiz de Carvalho

\section{Instituições}

Bueno e Teles, Projetos e Construções Ltda.

Construtora Maia e Borba Ltda.

Eletroenge Engenharia e Construcões Ltda.

Marmoraria Arte Final Pedras e Decorações Ltda.

Marmoraria JB Comércio e Serviços Ltda.

Marmoraria Santa Cruz Ltda.

Muralha Marmoraria Ltda.

Raspadora Brasil Ltda.

Raspadora Brasília Ltda.

Sousa Andrade Construtora e Incorporadora Ltda.

\section{Instituição conveniada responsável}

SENAI - Serviço Nacional de Aprendizagem Industrial - Senai

Fonte: MTE-CBO (2002) 
Média aritmética $\overline{\mathrm{x}}$

$$
\overline{\mathrm{x}}=\frac{\sum \mathrm{x}_{\mathrm{i}}}{\mathrm{n}}
$$

Desvio padrão s

$$
\mathrm{S}=\sqrt[2]{\frac{\sum\left(\mathrm{x}_{\mathrm{i}}-\overline{\mathrm{x}}\right)^{2}}{(\mathrm{n}-1)}}
$$

Limite de Confiança Superior

$$
\operatorname{LCS}_{1,95 \%}=\bar{x}+t_{0,95}\left(\frac{\mathrm{s}}{\sqrt{\mathrm{n}}}\right)
$$

Limite de Confiança Inferior

$$
\operatorname{LCS}_{1,95 \%}=\overline{\mathrm{x}}-\mathrm{t}_{0,95}\left(\frac{\mathrm{s}}{\sqrt{\mathrm{n}}}\right)
$$

Onde

$\mathrm{x}_{\mathrm{i}}=$ valores obtidos

$\overline{\mathrm{x}}=$ média aritmética

$\mathrm{s}$ = desvio padrão da media aritmética

$\mathrm{n}=$ número de amostras

$\mathrm{t}_{0,95 \%}=\mathrm{t}$ de Student para $\mathrm{q}=0,95 \%$ e $\mathrm{n}$ graus de liberdade de acordo com a tabela 1 
ANEXO 6

VALORES PERCENTUAIS DA DISTRIBUIÇÃO T DE STUDENT COM N GRAUS DE LIBERDADE.

\begin{tabular}{|c|c|c|c|c|c|c|c|c|c|c|}
\hline$n \backslash q$ & 0.6 & 0.7 & 0.8 & 0.9 & 0.95 & 0.975 & 0.99 & 0.995 & 0.999 & 0.9995 \\
\hline 1 & 0.325 & 0.727 & 1.376 & 3.078 & 6.314 & 12.706 & 31.821 & 63.656 & 318.289 & 636.578 \\
\hline 2 & 0.289 & 0.617 & 1.061 & 1.886 & 2.920 & 4.303 & 6.965 & 9.925 & 22.328 & 31.600 \\
\hline 3 & 0.277 & 0.584 & 0.978 & 1.638 & 2.353 & 3.182 & 4.541 & 5.841 & 10.214 & 12.924 \\
\hline 4 & 0.271 & 0.569 & 0.941 & 1.533 & 2.132 & 2.776 & 3.747 & 4.604 & 7.173 & 8.610 \\
\hline 5 & 0.267 & 0.559 & 0.920 & 1.476 & 2.015 & 2.571 & 3.365 & 4.032 & 5.894 & 6.869 \\
\hline 6 & 0.265 & 0.553 & 0.906 & 1.440 & 1.943 & 2.447 & 3.143 & 3.707 & 5.208 & 5.959 \\
\hline 7 & 0.263 & 0.549 & 0.896 & 1.415 & 1.895 & 2.365 & 2.998 & 3.499 & 4.785 & 5.408 \\
\hline 8 & 0.262 & 0.546 & 0.889 & 1.397 & 1.860 & 2.306 & 2.896 & 3.355 & 4.501 & 5.041 \\
\hline 9 & 0.261 & 0.543 & 0.883 & 1.383 & 1.833 & 2.262 & 2.821 & 3.250 & 4.297 & 4.781 \\
\hline 10 & 0.260 & 0.542 & 0.879 & 1.372 & 1.812 & 2.228 & 2.764 & 3.169 & 4.144 & 4.587 \\
\hline 11 & 0.260 & 0.540 & 0.876 & 1.363 & 1.796 & 2.201 & 2.718 & 3.106 & 4.025 & 4.437 \\
\hline 12 & 0.259 & 0.539 & 0.873 & 1.356 & 1.782 & 2.179 & 2.681 & 3.055 & 3.930 & 4.318 \\
\hline 13 & 0.259 & 0.538 & 0.870 & 1.350 & 1.771 & 2.160 & 2.650 & 3.012 & 3.852 & 4.221 \\
\hline 14 & 0.258 & 0.537 & 0.868 & 1.345 & 1.761 & 2.145 & 2.624 & 2.977 & 3.787 & 4.140 \\
\hline 15 & 0.258 & 0.536 & 0.866 & 1.341 & 1.753 & 2.131 & 2.602 & 2.947 & 3.733 & 4.073 \\
\hline 16 & 0.258 & 0.535 & 0.865 & 1.337 & 1.746 & 2.120 & 2.583 & 2.921 & 3.686 & 4.015 \\
\hline 17 & 0.257 & 0.534 & 0.863 & 1.333 & 1.740 & 2.110 & 2.567 & 2.898 & 3.646 & 3.965 \\
\hline 18 & 0.257 & 0.534 & 0.862 & 1.330 & 1.734 & 2.101 & 2.552 & 2.878 & 3.610 & 3.922 \\
\hline 19 & 0.257 & 0.533 & 0.861 & 1.328 & 1.729 & 2.093 & 2.539 & 2.861 & 3.579 & 3.883 \\
\hline 20 & 0.257 & 0.533 & 0.860 & 1.325 & 1.725 & 2.086 & 2.528 & 2.845 & 3.552 & 3.850 \\
\hline 21 & 0.257 & 0.532 & 0.859 & 1.323 & 1.721 & 2.080 & 2.518 & 2.831 & 3.527 & 3.819 \\
\hline 22 & 0.256 & 0.532 & 0.858 & 1.321 & 1.717 & 2.074 & 2.508 & 2.819 & 3.505 & 3.792 \\
\hline 23 & 0.256 & 0.532 & 0.858 & 1.319 & 1.714 & 2.069 & 2.500 & 2.807 & 3.485 & 3.768 \\
\hline 24 & 0.256 & 0.531 & 0.857 & 1.318 & 1.711 & 2.064 & 2.492 & 2.797 & 3.467 & 3.745 \\
\hline 25 & 0.256 & 0.531 & 0.856 & 1.316 & 1.708 & 2.060 & 2.485 & 2.787 & 3.450 & 3.725 \\
\hline 26 & 0.256 & 0.531 & 0.856 & 1.315 & 1.706 & 2.056 & 2.479 & 2.779 & 3.435 & 3.707 \\
\hline 27 & 0.256 & 0.531 & 0.855 & 1.314 & 1.703 & 2.052 & 2.473 & 2.771 & 3.421 & 3.689 \\
\hline 28 & 0.256 & 0.530 & 0.855 & 1.313 & 1.701 & 2.048 & 2.467 & 2.763 & 3.408 & 3.674 \\
\hline 29 & 0.256 & 0.530 & 0.854 & 1.311 & 1.699 & 2.045 & 2.462 & 2.756 & 3.396 & 3.660 \\
\hline 30 & 0.256 & 0.530 & 0.854 & 1.310 & 1.697 & 2.042 & 2.457 & 2.750 & 3.385 & 3.646 \\
\hline 40 & 0.255 & 0.529 & 0.851 & 1.303 & 1.684 & 2.021 & 2.423 & 2.704 & 3.307 & 3.551 \\
\hline 45 & 0.255 & 0.528 & 0.850 & 1.301 & 1.679 & 2.014 & 2.412 & 2.690 & 3.281 & 3.520 \\
\hline 50 & 0.255 & 0.528 & 0.849 & 1.299 & 1.676 & 2.009 & 2.403 & 2.678 & 3.261 & 3.496 \\
\hline 60 & 0.254 & 0.527 & 0.848 & 1.296 & 1.671 & 2.000 & 2.390 & 2.660 & 3.232 & 3.460 \\
\hline 70 & 0.254 & 0.527 & 0.847 & 1.294 & 1.667 & 1.994 & 2.381 & 2.648 & 3.211 & 3.435 \\
\hline 80 & 0.254 & 0.526 & 0.846 & 1.292 & 1.664 & 1.990 & 2.374 & 2.639 & 3.195 & 3.416 \\
\hline 90 & 0.254 & 0.526 & 0.846 & 1.291 & 1.662 & 1.987 & 2.368 & 2.632 & 3.183 & 3.402 \\
\hline 100 & 0.254 & 0.526 & 0.845 & 1.290 & 1.660 & 1.984 & 2.364 & 2.626 & 3.174 & 3.390 \\
\hline 120 & 0.254 & 0.526 & 0.845 & 1.289 & 1.658 & 1.980 & 2.358 & 2.617 & 3.160 & 3.373 \\
\hline 150 & 0.254 & 0.526 & 0.844 & 1.287 & 1.655 & 1.976 & 2.351 & 2.609 & 3.145 & 3.357 \\
\hline$\infty$ & 0.253 & 0.524 & 0.842 & 1.282 & 1.645 & 1.960 & 2.327 & 2.576 & 3.091 & 3.291 \\
\hline
\end{tabular}

Fonte: ISEGI, 2005 
ANEXO 7-

FUNÇÃO DA DISTRIBUIÇÃO NORMAL PADRÃO

\begin{tabular}{|c|c|c|c|c|c|c|c|c|c|c|}
\hline$x$ & 0.00 & 0.01 & 0.02 & 0.03 & 0.04 & 0.05 & 0.06 & 0.07 & 0.08 & 0.09 \\
\hline 0.0 & 0.5000 & 0.5040 & 0.5080 & 0.5120 & 0.5160 & 0.5199 & 0.5239 & 0.5279 & 0.5319 & 0.5359 \\
\hline 0.1 & 0.5398 & 0.5438 & 0.5478 & 0.5517 & 0.5557 & 0.5596 & 0.5636 & 0.5675 & 0.5714 & 0.5753 \\
\hline 0.2 & 0.5793 & 0.5832 & 0.5871 & 0.5910 & 0.5948 & 0.5987 & 0.6026 & 0.6064 & 0.6103 & 0.6141 \\
\hline 0.3 & 0.6179 & 0.6217 & 0.6255 & 0.6293 & 0.6331 & 0.6368 & 0.6406 & 0.6443 & 0.6480 & 0.6517 \\
\hline 0.4 & 0.6554 & 0.6591 & 0.6628 & 0.6664 & 0.6700 & 0.6736 & 0.6772 & 0.6808 & 0.6844 & 0.6879 \\
\hline 0.5 & 0.6915 & 0.6950 & 0.6985 & 0.7019 & 0.7054 & 0.7088 & 0.7123 & 0.7157 & 0.7190 & 0.7224 \\
\hline 0.6 & 0.7257 & 0.7291 & 0.7324 & 0.7357 & 0.7389 & 0.7422 & 0.7454 & 0.7486 & 0.7517 & 0.7549 \\
\hline 0.7 & 0.7580 & 0.7611 & 0.7642 & 0.7673 & 0.7704 & 0.7734 & 0.7764 & 0.7794 & 0.7823 & 0.7852 \\
\hline 0.8 & 0.7881 & 0.7910 & 0.7939 & 0.7967 & 0.7995 & 0.8023 & 0.8051 & 0.8078 & 0.8106 & 0.8133 \\
\hline 0.9 & 0.8159 & 0.8186 & 0.8212 & 0.8238 & 0.8264 & 0.8289 & 0.8315 & 0.8340 & 0.8365 & 0.8389 \\
\hline 1.0 & 0.8413 & 0.8438 & 0.8461 & 0.8485 & 0.8508 & 0.8531 & 0.8554 & 0.8577 & 0.8599 & 0.8621 \\
\hline 1.1 & 0.8643 & 0.8665 & 0.8686 & 0.8708 & 0.8729 & 0.8749 & 0.8770 & 0.8790 & 0.8810 & 0.8830 \\
\hline 1.2 & 0.8849 & 0.8869 & 0.8888 & 0.8907 & 0.8925 & 0.8944 & 0.8962 & 0.8980 & 0.8997 & 0.9015 \\
\hline 1.3 & 0.9032 & 0.9049 & 0.9066 & 0.9082 & 0.9099 & 0.9115 & 0.9131 & 0.9147 & 0.9162 & 0.9177 \\
\hline 1.4 & 0.9192 & 0.9207 & 0.9222 & 0.9236 & 0.9251 & 0.9265 & 0.9279 & 0.9292 & 0.9306 & 0.9319 \\
\hline 1.5 & 0.9332 & 0.9345 & 0.9357 & 0.9370 & 0.9382 & 0.9394 & 0.9406 & 0.9418 & 0.9429 & 0.9441 \\
\hline 1.6 & 0.9452 & 0.9463 & 0.9474 & 0.9484 & 0.9495 & 0.9505 & 0.9515 & 0.9525 & 0.9535 & 0.9545 \\
\hline 1.7 & 0.9554 & 0.9564 & 0.9573 & 0.9582 & 0.9591 & 0.9599 & 0.9608 & 0.9616 & 0.9625 & 0.9633 \\
\hline 1.8 & 0.9641 & 0.9649 & 0.9656 & 0.9664 & 0.9671 & 0.9678 & 0.9686 & 0.9693 & 0.9699 & 0.9706 \\
\hline 1.9 & 0.9713 & 0.9719 & 0.9726 & 0.9732 & 0.9738 & 0.9744 & 0.9750 & 0.9756 & 0.9761 & 0.9767 \\
\hline 2.0 & 0.9772 & 0.9778 & 0.9783 & 0.9788 & 0.9793 & 0.9798 & 0.9803 & 0.9808 & 0.9812 & 0.9817 \\
\hline 2.1 & 0.9821 & 0.9826 & 0.9830 & 0.9834 & 0.9838 & 0.9842 & 0.9846 & 0.9850 & 0.9854 & 0.9857 \\
\hline 2.2 & 0.9861 & 0.9864 & 0.9868 & 0.9871 & 0.9875 & 0.9878 & 0.9881 & 0.9884 & 0.9887 & 0.9890 \\
\hline 2.3 & 0.9893 & 0.9896 & 0.9898 & 0.9901 & 0.9904 & 0.9906 & 0.9909 & 0.9911 & 0.9913 & 0.9916 \\
\hline 2.4 & 0.9918 & 0.9920 & 0.9922 & 0.9925 & 0.9927 & 0.9929 & 0.9931 & 0.9932 & 0.9934 & 0.9936 \\
\hline 2.5 & 0.9938 & 0.9940 & 0.9941 & 0.9943 & 0.9945 & 0.9946 & 0.9948 & 0.9949 & 0.9951 & 0.9952 \\
\hline 2.6 & 0.9953 & 0.9955 & 0.9956 & 0.9957 & 0.9959 & 0.9960 & 0.9961 & 0.9962 & 0.9963 & 0.9964 \\
\hline 2.7 & 0.9965 & 0.9966 & 0.9967 & 0.9968 & 0.9969 & 0.9970 & 0.9971 & 0.9972 & 0.9973 & 0.9974 \\
\hline 2.8 & 0.9974 & 0.9975 & 0.9976 & 0.9977 & 0.9977 & 0.9978 & 0.9979 & 0.9979 & 0.9980 & 0.9981 \\
\hline 2.9 & 0.9981 & 0.9982 & 0.9982 & 0.9983 & 0.9984 & 0.9984 & 0.9985 & 0.9985 & 0.9986 & 0.9986 \\
\hline 3.0 & 0.998650 & 0.998694 & 0.998736 & 0.998777 & 0.998817 & 0.998856 & 0.998893 & 0.998930 & 0.998965 & 0.998999 \\
\hline 3.1 & 0.999032 & 0.999064 & 0.999096 & 0.999126 & 0.999155 & 0.999184 & 0.999211 & 0.999238 & 0.999264 & 0.999289 \\
\hline 3.2 & 0.999313 & 0.999336 & 0.999359 & 0.999381 & 0.999402 & 0.999423 & 0.999443 & 0.999462 & 0.999481 & 0.999499 \\
\hline 3.3 & 0.999517 & 0.999533 & 0.999550 & 0.999566 & 0.999581 & 0.999596 & 0.999610 & 0.999624 & 0.999638 & 0.999650 \\
\hline 3.4 & 0.999663 & 0.999675 & 0.999687 & 0.999698 & 0.999709 & 0.999720 & 0.999730 & 0.999740 & 0.999749 & 0.999758 \\
\hline 3.5 & 0.999767 & 0.999776 & 0.999784 & 0.999792 & 0.999800 & 0.999807 & 0.999815 & 0.999821 & 0.999828 & 0.999835 \\
\hline 3.6 & 0.999841 & 0.999847 & 0.999853 & 0.999858 & 0.999864 & 0.999869 & 0.999874 & 0.999879 & 0.999883 & 0.999888 \\
\hline 3.7 & 0.999892 & 0.999896 & 0.999900 & 0.999904 & 0.999908 & 0.999912 & 0.999915 & 0.999918 & 0.999922 & 0.999925 \\
\hline 3.8 & 0.999928 & 0.999930 & 0.999933 & 0.999936 & 0.999938 & 0.999941 & 0.999943 & 0.999946 & 0.999948 & 0.999950 \\
\hline 3.9 & 0.999952 & 0.999954 & 0.999956 & 0.999958 & 0.999959 & 0.999961 & 0.999963 & 0.999964 & 0.999966 & 0.999967 \\
\hline 4.0 & 0.999968 & 0.999970 & 0.999971 & 0.999972 & 0.999973 & 0.999974 & 0.999975 & 0.999976 & 0.999977 & 0.999978 \\
\hline
\end{tabular}

Fonte: ISEGI,2005 


\section{ANEXO 8 \\ INSTRUMENTOS DE AVALIAÇÃO \\ QUESTIONÁRIO SOBRE A ATIVIDADE DE “MARMORISTA” E EXPOSIÇÕES INALATÓRIAS OCUPACIONAIS}

Seu nome foi incluído para esta pesquisa e sua cooperação é muito importante para conhecermos os efeitos do seu trabalho sobre sua saúde e a de seus colegas de trabalho..

Obrigado(a) pela sua disposição em participar!

Data:

Entrevistador:

I1. Nome da Empresa:

I2.REG ${ }^{\circ}$ Marm

I3.Nome:

I4.RG:

I5.Endereço:

I6.CEP

I7. Telefone :

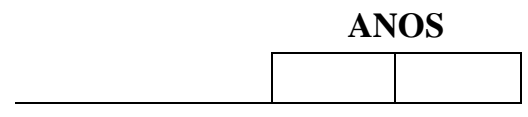

P2. Data de Nascimento

$1 /$

P3.Sexo:

P4.Peso:
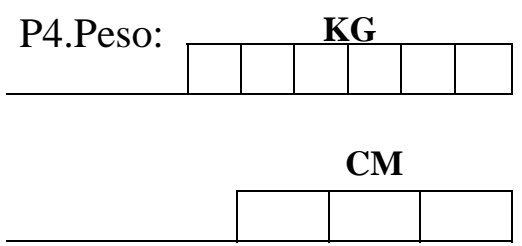

P6. Cor/Raça:

P7. Estado civil atual:

\begin{tabular}{|ll|} 
Solteiro & 1 \\
Casado & 2 \\
Viúvo & 3 \\
Outros & 4 \\
\hline
\end{tabular}

P8. Até que ano estudou?

Nunca freqüentou a escola

Fundamental incompleto

Fundamental completo

Segundo grau incompleto

Segundo grau completo

Superior incompleto

Superior completo

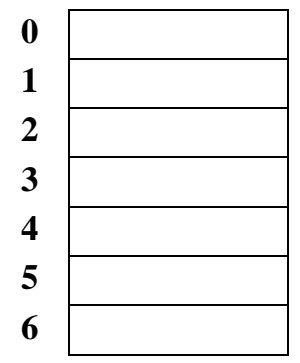

P9.Nível sócio-econômico (Renda familiar):

Até 1 salário mínimo

De 1 a 2 salários mínimos

De 2 a 3 salários mínimos

De 4 a 5 salários mínimos

De 5 a 10 salários mínimos

Mais de 10 salários mínimos

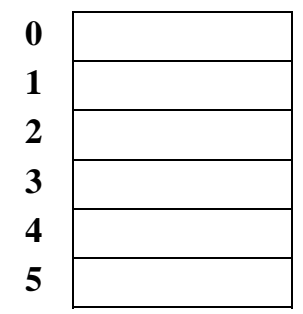

Valor do salário mínimo

P10.Quantas pessoas vivem na residência? 
A1. Há quanto tempo está empregado nesta empresa?

ANOS

A2. Qual (is) a (s) função (ões) em que você já trabalhou ou trabalha nesta empresa e por quanto tempo?

ANOS

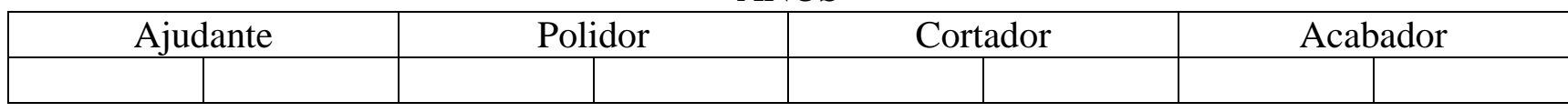

A3. Com quais matérias-primas e em quais funções já trabalhou ou trabalha nesta empresa e por quanto tempo?

ANOS

\begin{tabular}{|c|c|c|c|c|c|c|c|c|}
\hline & \multicolumn{2}{|c|}{ Ajudante } & \multicolumn{2}{c|}{ Polidor } & \multicolumn{2}{c|}{ Cortador } & \multicolumn{2}{c|}{ Acabador } \\
\hline Granito & & & & & & & & \\
\hline Ardósia & & & & & & & & \\
\hline Mármore & & & & & & & & \\
\hline
\end{tabular}

A4. Você já trabalhou com outras matérias-primas?

Quais?

A5. Com quais ferramentas e em quais funções você já trabalhou ou trabalha nesta empresa e por quanto tempo?

ANOS
\begin{tabular}{|l|l|l|l|l|l|l|l|l|}
\hline & Ajudante & \multicolumn{2}{c|}{ Polidor } & \multicolumn{2}{c|}{ Cortador } & \multicolumn{2}{c|}{ Acabador } \\
\hline Serra com água & & & & & & & & \\
\hline Serra sem água & & & & & & & & \\
\hline Serra mármore (Makita) com água & & & & & & & & \\
\hline Serra mármore (Makita) sem água & & & & & & & & \\
\hline Lixadeira manual com água & & & & & & & & \\
\hline Lixadeira manual sem água & & & & & & & & \\
\hline Lixadeira manual com exaustão & & & & & & & & \\
\hline Chicote & & & & & & & & \\
\hline
\end{tabular}

A6. Existem na empresa medidas ou equipamentos de proteção coletiva para o controle da poeira gerada?

A7. Quais as medidas ou equipamentos de proteção coletiva existem e em quais setores da empresa?

\begin{tabular}{|c|c|c|c|c|}
\hline & & Corte & Polimento & Acabamento \\
\hline \multirow[t]{3}{*}{ Ventilação natural } & Galpão aberto & & & \\
\hline & Galpão semi-aberto & & & \\
\hline & Galpão fechado & & & \\
\hline \multirow{3}{*}{$\begin{array}{l}\text { Ventilação local } \\
\text { exaustora }\end{array}$} & Sistema de exaustão & & & \\
\hline & $\begin{array}{l}\text { Mesas de trabalho } \\
\text { com exaustão }\end{array}$ & & & \\
\hline & Capela com exaustão & & & \\
\hline \multicolumn{2}{|l|}{ Piso adequado } & & & \\
\hline \multicolumn{2}{|l|}{ Lavagem semanal } & & & \\
\hline
\end{tabular}

A8. Existem outras medidas de controle?

Quais? 
A9. Existem na empresa equipamentos de proteção individual para o controle da poeira gerada e projeção de partículas?

A10. Quais equipamentos de proteção individual existem e em quais setores da empresa?

\begin{tabular}{|c|c|c|c|c|c|}
\hline & & & Corte & Polimento & Acabamento \\
\hline Uniforme & & & & & \\
\hline Peça facial & Tipo & & & & \\
\hline filtrante & Tipo F & & & & \\
\hline & Tipo F & & & & \\
\hline Peça semi-facial & Filtro & $\mathrm{P} 1$ & & & \\
\hline & único & $\mathrm{P} 2$ & & & \\
\hline & & P3 & & & \\
\hline & Filtro & $\mathrm{P} 1$ & & & \\
\hline & aos & $\mathrm{P} 2$ & & & \\
\hline & pares & P3 & & & \\
\hline Protetor facial & & & & & \\
\hline Óculos de segura & & & & & \\
\hline Luvas & & & & & \\
\hline Avental de plástic & & & & & \\
\hline Bota de seguranç & & & & & \\
\hline Protetor auditivo & Tipo c & & & & \\
\hline & Tipo i & ção & & & \\
\hline
\end{tabular}

A11. Existem outros EPIs?

Quais?

A12. Você trabalhou em outras marmorarias?

Caso SIM para A12.

A13. Em quantas marmorarias você já trabalhou?

Se trabalhou em outras marmorarias responder as questões do questionário "Descrição das atividades desenvolvidas em outras marmorarias”

A 14. Exceto marmorarias, você trabalhou em outra atividade com exposição à poeira?

A15. Em qual (is) ramo (s) de atividade(s) e por quanto tempo?

Mineração

Metalurgia

Fundição

Jateamento com areia

Construção civil

Agricultura

Outras

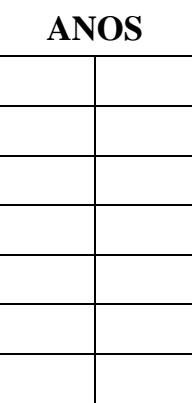




\section{QUESTIONÁRIO DE SINTOMAS RESPIRATÓRIOS (MRC/1976)*}

Eu vou fazer algumas perguntas sobre sua respiração. Sempre que possível, eu gostaria que você respondesse "SIM" ou "NÃO". Todas as suas respostas serão confidenciais e usadas somente para esta pesquisa

T1. Você geralmente tosse ao acordar?

T2. Você geralmente tosse durante o dia ou à noite?

\section{Caso SIM para T1 ou T2}

T3. Você tosse pelo menos 3 meses por ano ao acordar?

C1. Você geralmente escarra ao acordar?

C2. Você geralmente escarra durante o dia ou à noite?

\section{Caso SIM para C1 ou C2}

C3. Você escarra pelo menos 3 meses por ano ao acordar?

\section{Caso SIM para T3 e C3}

TC. Há quantos anos você apresenta tosse e catarro matinais?

ANOS

Caso o entrevistado tenha uma limitação à deambulação por problemas que não sejam de ordem pulmonar ou cardíaca, assinale "1" e omita as questões de $N^{\circ}$ s D1, D2 e D3

D1. Você sente falta de ar ao andar apressado no plano ou numa subida leve?

\section{Caso SIM para D1}

D2. Você consegue acompanhar o passo de pessoas de sua idade, andando no plano?

\section{Caso SIM para D1 ou D2}

D3. Você tem de parar para descansar quando anda no plano em passo normal?

\footnotetext{
* Adaptado do Questionário de Sintomas Respiratórios do Medical Research Council - Grã Bretanha 1976.
} 
CH1. Você já notou “chiado”, “apitos” ou “miados” no seu peito?

CH2. Você já apresentou algum episódio de chiado com falta de ar?

CH3. Você já teve algum diagnóstico de asma?

CH4. Você já teve algum diagnóstico de bronquite?

CH5. Você toma remédios para asma, bronquite ou tomou nos últimos doze meses?

F1. Você fuma?

F2. Você já fumou pelo menos 1 cigarro ao dia por 1 ano?

Se a resposta foi NÃO para F2, omita as questões restantes referentes ao fumo

F3.Com que idade começou a fumar?

ANOS

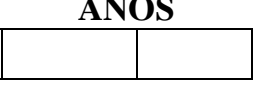

F4.Quantos cigarros por dia?

CIGARROS

F5.Tabagismo em anos/maço?

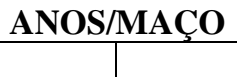

\section{Para ex-fumantes}

F6.Há quantos anos parou de fumar?

ANOS

Resultados da Radiografia de Tórax segundo padrão OIT

Número do RX

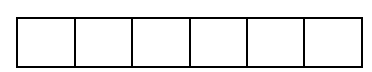

Data do RX

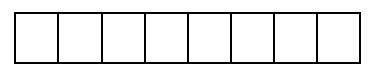

Qualidade

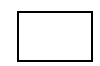

Profusão

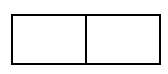

Tipo

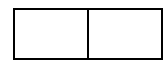

Pleura

Símbolos
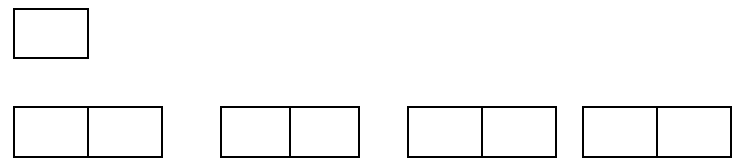

Resultados da Prova de Função Pulmonar

$\operatorname{VEF}_{1}(1)$

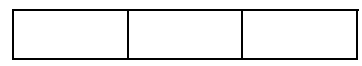

CVF (1)

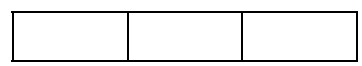

FEF (1/s)

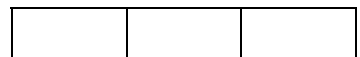




\section{“DESCRIÇÃO DAS ATIVIDADES DESENVOLVIDAS EM OUTRAS MARMORARIAS”}

\section{Agora eu vou fazer algumas perguntas sobre seu trabalho. Todas as suas respostas serão confidenciais e usadas somente para esta pesquisa.}

M1. Nome da Empresa:

M2.REG ${ }^{\circ}$ Marm

M3. Quanto tempo ficou empregado nesta empresa?

ANOS

M4. Qual (is) a (s) função (ões) em que você já trabalhou nesta empresa e por quanto tempo?

ANOS

\begin{tabular}{|c|}
\hline Ajudante \\
\hline
\end{tabular}

M5. Com quais matérias-primas e em quais funções já trabalhou nesta empresa e por quanto tempo?

ANOS

\begin{tabular}{|c|c|c|c|c|c|c|c|c|}
\hline & \multicolumn{2}{|c|}{ Ajudante } & \multicolumn{2}{c|}{ Polidor } & \multicolumn{2}{c|}{ Cortador } & \multicolumn{2}{c|}{ Acabador } \\
\hline Granito & & & & & & & & \\
\hline Ardósia & & & & & & & & \\
\hline Mármore & & & & & & & & \\
\hline
\end{tabular}

M6. Você já trabalhou com outras matérias-primas?

Quais?

M7. Com quais ferramentas e em quais funções você já trabalhou nesta empresa e por quanto tempo?

ANOS

\begin{tabular}{|l|l|l|l|l|l|l|l|l|}
\hline & Ajudante & \multicolumn{2}{c|}{ Polidor } & \multicolumn{2}{c|}{ Cortador } & \multicolumn{2}{c|}{ Acabador } \\
\hline Serra com água & & & & & & & & \\
\hline Serra sem água & & & & & & & & \\
\hline Serra mármore (Makita) com água & & & & & & & & \\
\hline Serra mármore (Makita) sem água & & & & & & & & \\
\hline Lixadeira manual com água & & & & & & & & \\
\hline Lixadeira manual sem água & & & & & & & & \\
\hline Lixadeira manual com exaustão & & & & & & & & \\
\hline Chicote & & & & & & & & \\
\hline
\end{tabular}

M8. Existiam na empresa medidas ou equipamentos de proteção coletiva para o controle da poeira gerada? 
M9. Quais as medidas ou equipamentos de proteção coletiva existem e em quais setores da empresa?

\begin{tabular}{|l|l|l|l|l|}
\hline \multirow{4}{*}{ Ventilação natural } & Galpão aberto & Corte & Polimento & Acabamento \\
\cline { 2 - 5 } & Galpão semi-aberto & & & \\
\cline { 2 - 5 } & Galpão fechado & & & \\
\hline \multirow{2}{*}{$\begin{array}{l}\text { Ventilação local } \\
\text { exaustora }\end{array}$} & Sistema de exaustão & & & \\
\cline { 2 - 5 } & $\begin{array}{c}\text { Mesas de trabalho } \\
\text { com exaustão }\end{array}$ & & & \\
\cline { 2 - 5 } & Capela com exaustão & & & \\
\hline \multicolumn{2}{|l|}{ Piso adequado } & & & \\
\hline \multicolumn{2}{|l|}{ Lavagem semanal } & & & \\
\hline
\end{tabular}

M10. Existem outras medidas?

Quais?

M11. Existiam na empresa equipamentos de proteção individual para o controle da poeira gerada e projeção de partículas?

M12. Quais equipamentos de proteção individual existem e em quais setores da empresa?

\begin{tabular}{|c|c|c|c|c|c|}
\hline & & & Corte & Polimento & Acabamento \\
\hline Uniforme & & & & & \\
\hline Peça facial & Tipo F & & & & \\
\hline filtrante & Tipo F & & & & \\
\hline & Tipo F & & & & \\
\hline Peça semi-facial & Filtro & $\mathrm{P} 1$ & & & \\
\hline & único & $\mathrm{P} 2$ & & & \\
\hline & & P3 & & & \\
\hline & Filtro & $\mathrm{P} 1$ & & & \\
\hline & aos & $\mathrm{P} 2$ & & & \\
\hline & pares & P3 & & & \\
\hline Protetor facial & & & & & \\
\hline Óculos de segura & & & & & \\
\hline Luvas & & & & & \\
\hline Avental de plástic & & & & & \\
\hline Bota de seguranç & & & & & \\
\hline Protetor auditivo & Tipo c & & & & \\
\hline & Tipo i & ção & & & \\
\hline
\end{tabular}

M13. Existiam outros EPIs?

Quais? 


\section{ANEXO 9 \\ TERMO DE CONSENTIMENTO LIVRE E ESCLARECIDO}

$\mathrm{Eu}$,

informado(a) que o estudo em desenvolvimento tem como objetivo saber se o meu trabalho está provocando problemas na minha respiração por causa do pó que eu respiro enquanto estou fazendo minhas atividades na marmoraria ou em outros trabalhos passados.

Fui informado(a) também que não sou obrigado(a) e não terei nenhum prejuízo se não quiser participar. Se eu decidir aceitar, minha participação será:

1. Responder as perguntas que a pesquisadora me fará, sobre alguns sintomas como tosse, falta de ar, etc. e sobre o meu trabalho;

2. Fazer um exame, onde vou soprar com força várias vezes em um tubo, para medir a minha respiração. Pode acontecer de eu me sentir um pouco cansado(a), mas fui informado(a) que isto passa em alguns minutos;

3. Realizar Raios X de Tórax, se necessário, na Fundacentro.

Serei informado sobre os resultados dos exames realizados, e em função do diagnóstico, receberei as recomendações e encaminhamentos apropriados. Por exemplo: em caso de pneumoconiose, será demandada à empresa empregadora a abertura de uma Comunicação de Acidentes de Trabalho (CAT); em caso de outra doença serei encaminhado para um serviço especializado para diagnóstico e tratamento quando for o caso.

Não terei nenhum gasto e também não receberei nada por isto.

Posso desistir de participar da pesquisa a qualquer momento.

Sei também que as minhas respostas e os resultados dos exames serão confidenciais e que qualquer dúvida que eu tiver sobre a minha participação nesta pesquisa posso procurar a pesquisadora para esclarecimento a qualquer momento.

Sendo assim, concordo em participar desta pesquisa e confirmo que recebi uma cópia deste termo.

Data:

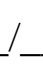

\section{Participante}

Pesquisadora Responsável: Ana Maria Tibiriçá Bon Telefone: (11) 3066-6211 


\section{ANEXO 10 \\ TERMO DE RESPONSABILIDADE}

Eu Ana Maria Tibiriçá Bon aluna da Universidade de São Paulo, Nº233 9526, na Faculdade de Saúde Pública no Departamento de Saúde Ambiental estou desenvolvendo um projeto de pesquisa intitulado "Caracterização da exposição ocupacional às poeiras minerais em especial a sílica cristalina, no beneficiamento de rochas ornamentais em marmorarias, na cidade de São Paulo”. Este projeto está sendo desenvolvido como parte do meu programa de doutorado na USP.

A execução deste projeto é conjunta com FUNDACENTRO, instituição onde trabalho como Tecnologista, sob o N SIAPE 876900. A FUNDACENTRO é uma instituição de pesquisa na área de saúde e segurança do trabalho e está financiando este projeto com recursos humanos e de laboratório.

É etapa deste projeto a avaliação ambiental em marmorarias. Esta etapa é de grande importância para a obtenção de dados visando à melhoria destes locais de trabalho e a prevenção de doenças ocupacionais.

Os dados encontrados nesta empresa serão utilizados para a conclusão deste projeto de pesquisa e me responsabilizo em manter sob sigilo os nomes tanto da empresa como dos trabalhadores.

Pesquisadora Responsável: Ana Maria Tibiriçá Bon

Telefone: (11) 3066-6211 
ANEXO 11

RESULTADOS DE ANÁLISE DE POEIRA E DE SÍLICA CRISTALINA RESPIRÁVEL E INFORMAÇÕES COMPLEMENTARES DO ESTUDO DE EXPOSIÇÃO OCUPACIONAL NAS MARMORARIAS ESTUDADAS 
Tabela A11.1 - Concentração de poeira e de sílica cristalina respirável e informações complementares da Empresa 1. Marmorarias, Município de São Paulo, 2004-2005

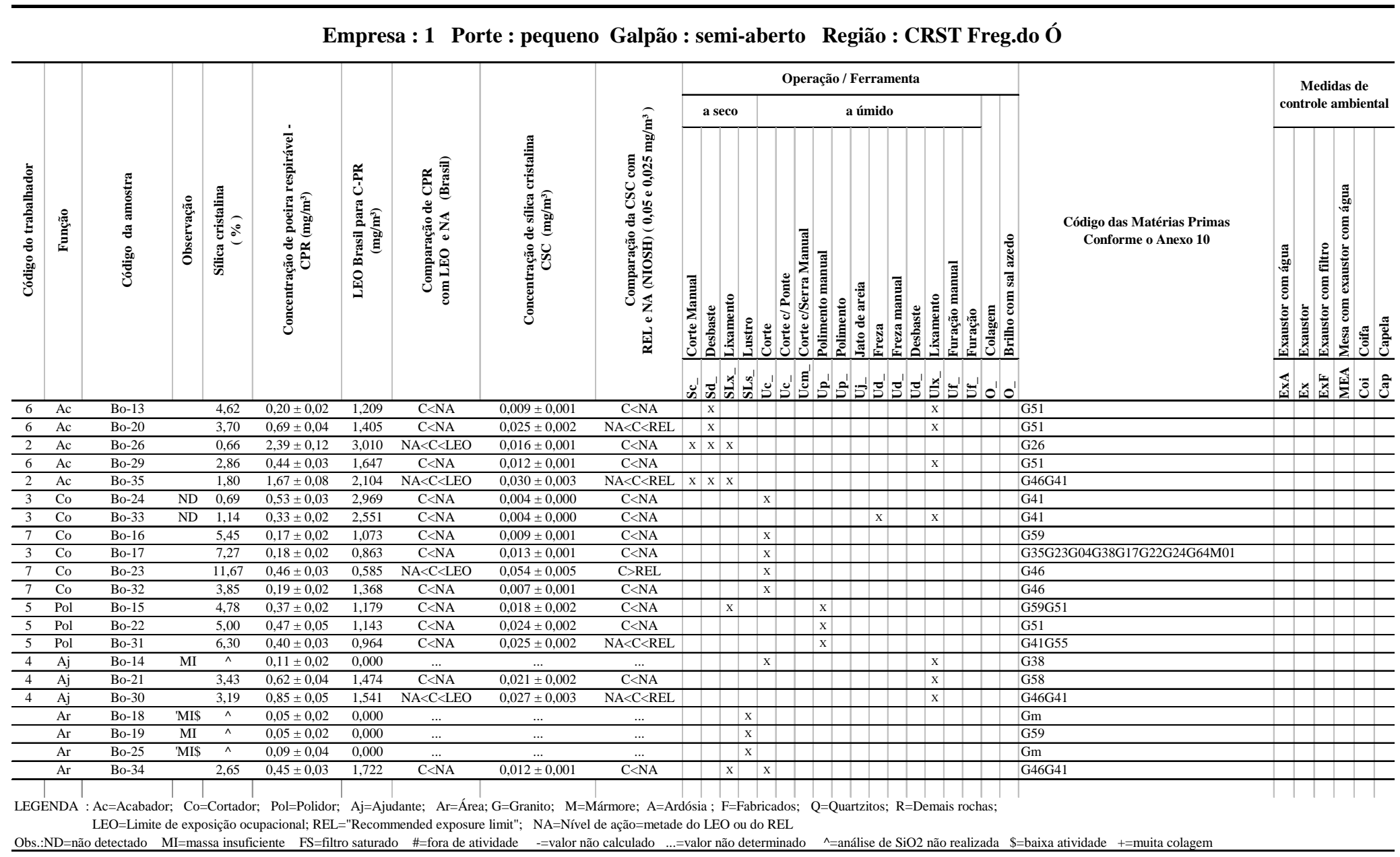


Empresa : 1 Porte : pequeno Galpão : semi-aberto Região : CRST Freg.do Ó

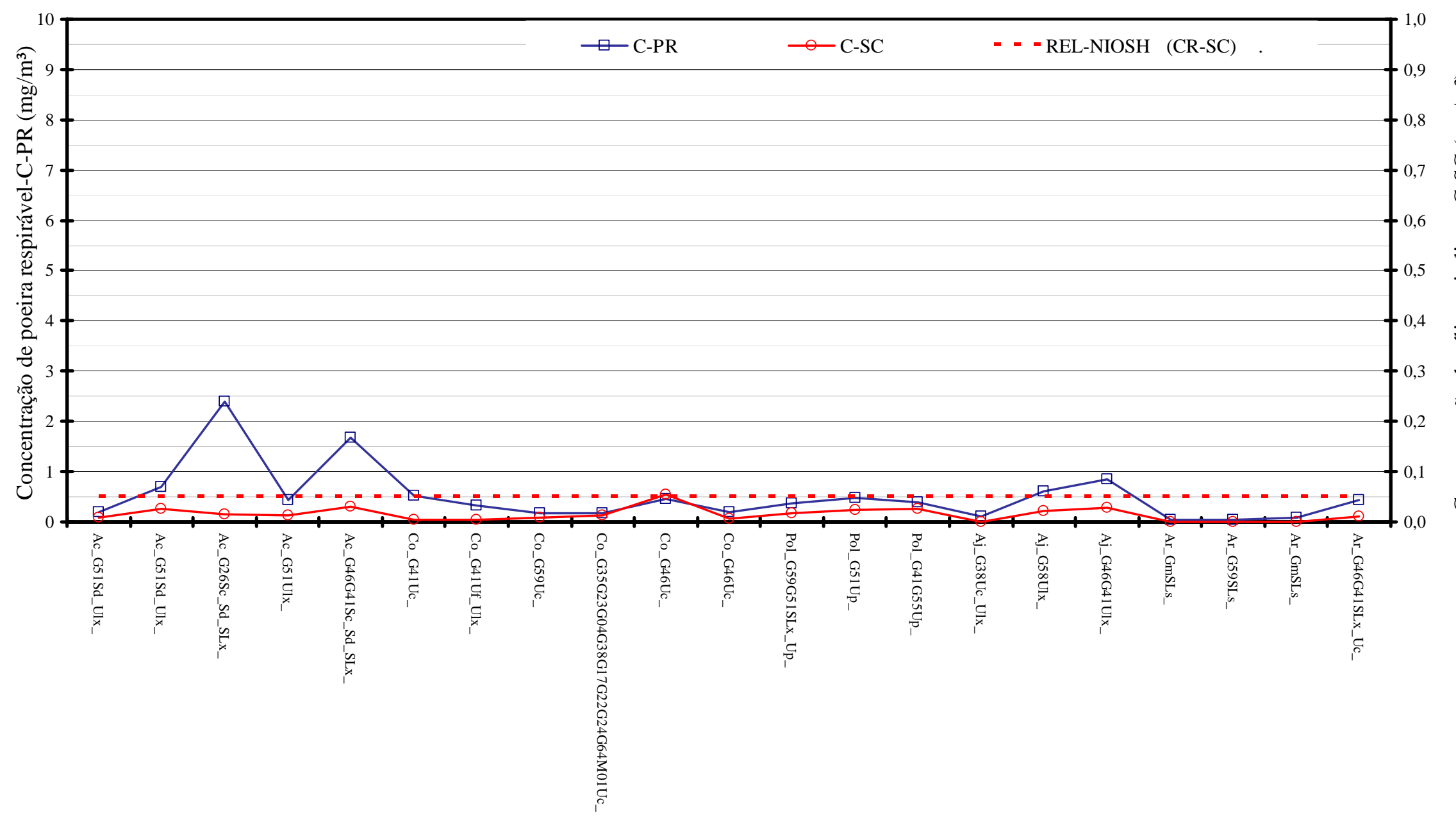

Figura A11.1 - Concentração de poeira respirável e sílica cristalina com respectiva etapa do processo (conf.Tabela A11.1) 
Tabela A11.2 - Concentração de poeira e de sílica cristalina respirável e informações complementares da Empresa 2. Marmorarias, Município de São Paulo, 2004-2005

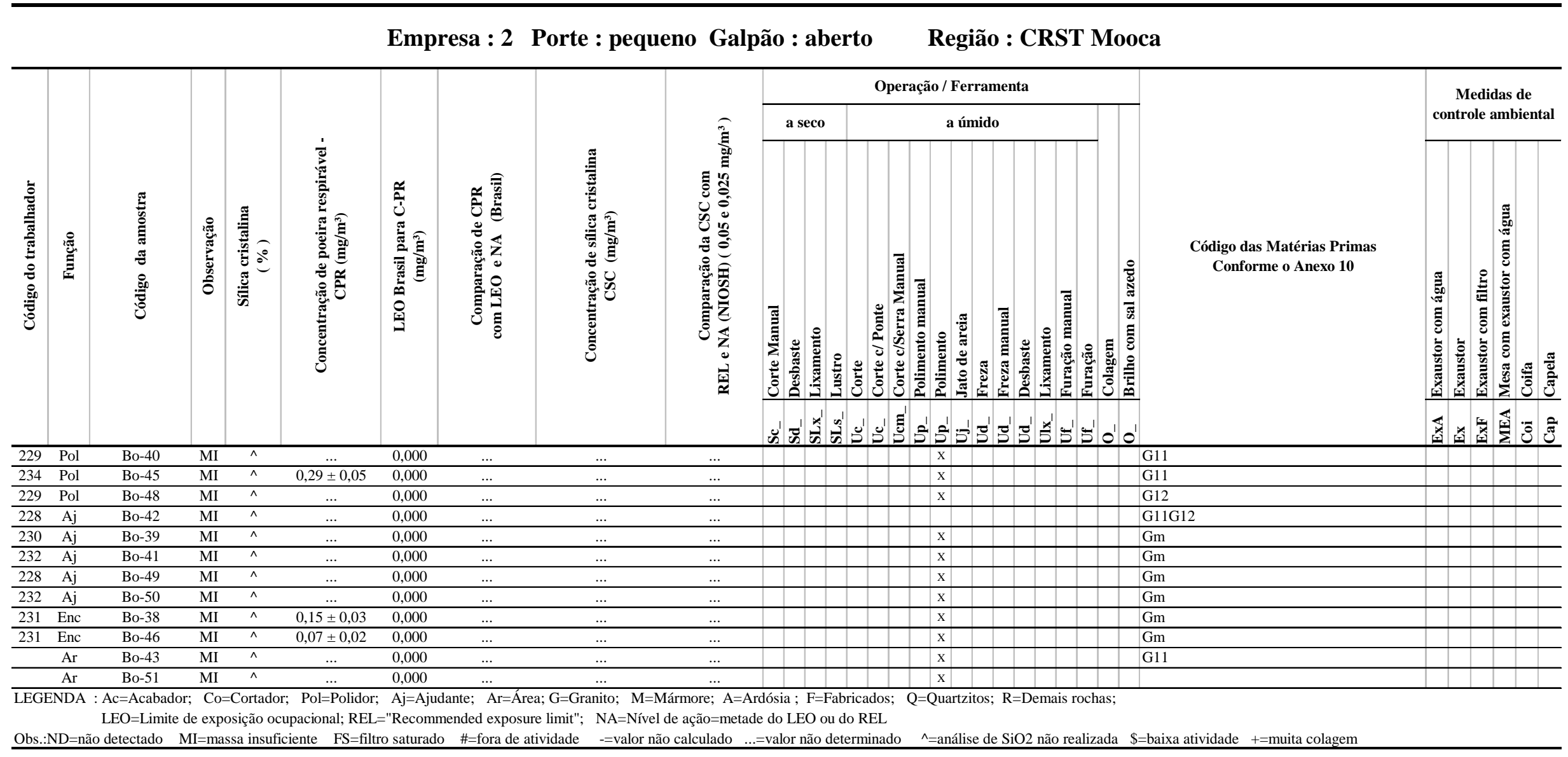


Empresa : 2 Porte : pequeno Galpão : aberto

Região : CRST Mooca

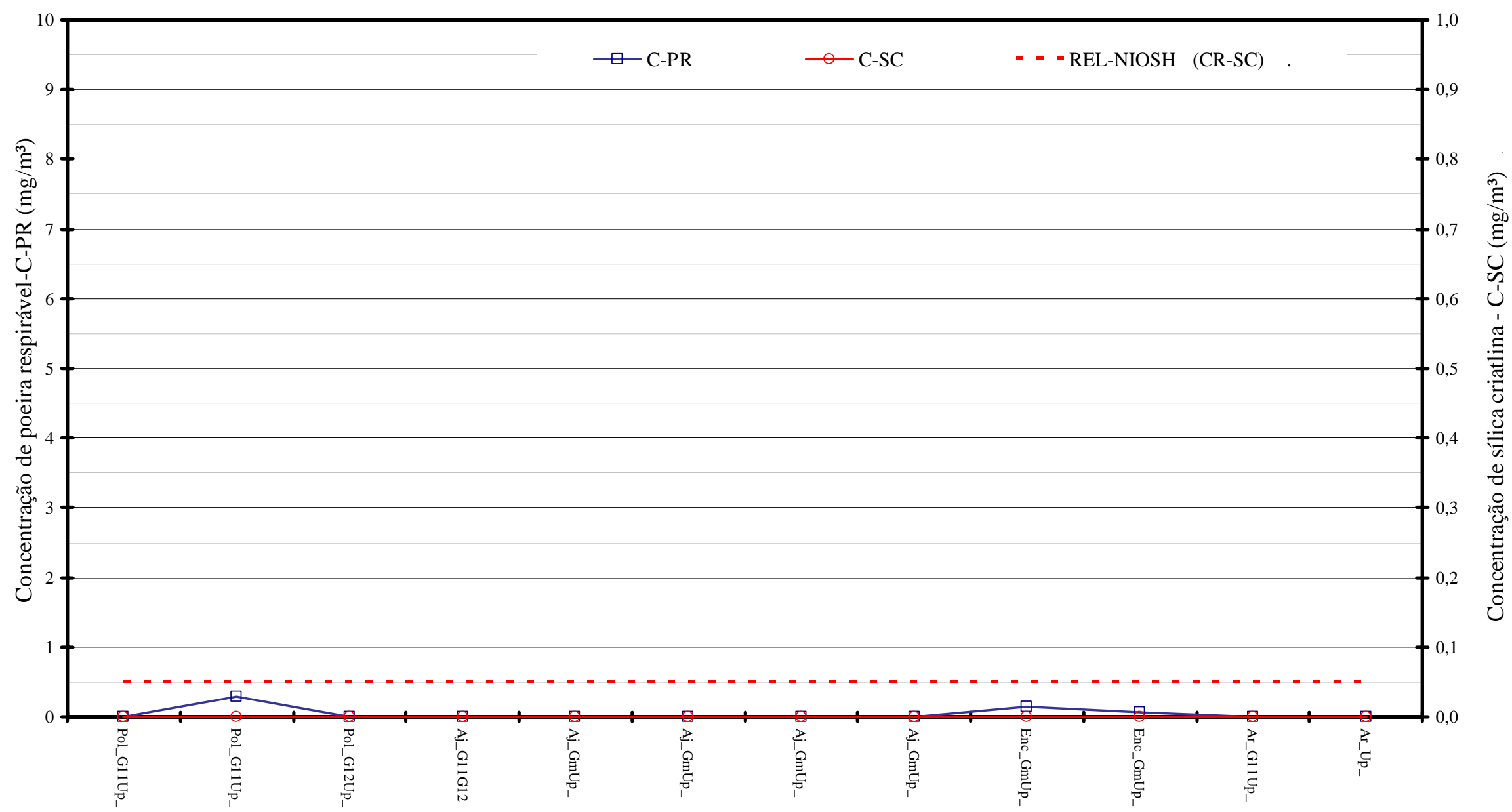

Figura A11.2 - Concentração de poeira e de sílica cristalina respirável com respectiva etapa do processo (conf.Tabela A11.2) 
Tabela A11.3 - Concentração de poeira e de sílica cristalina respirável e informações complementares da Empresa 4. Marmorarias, Município de São Paulo, 2004-2005

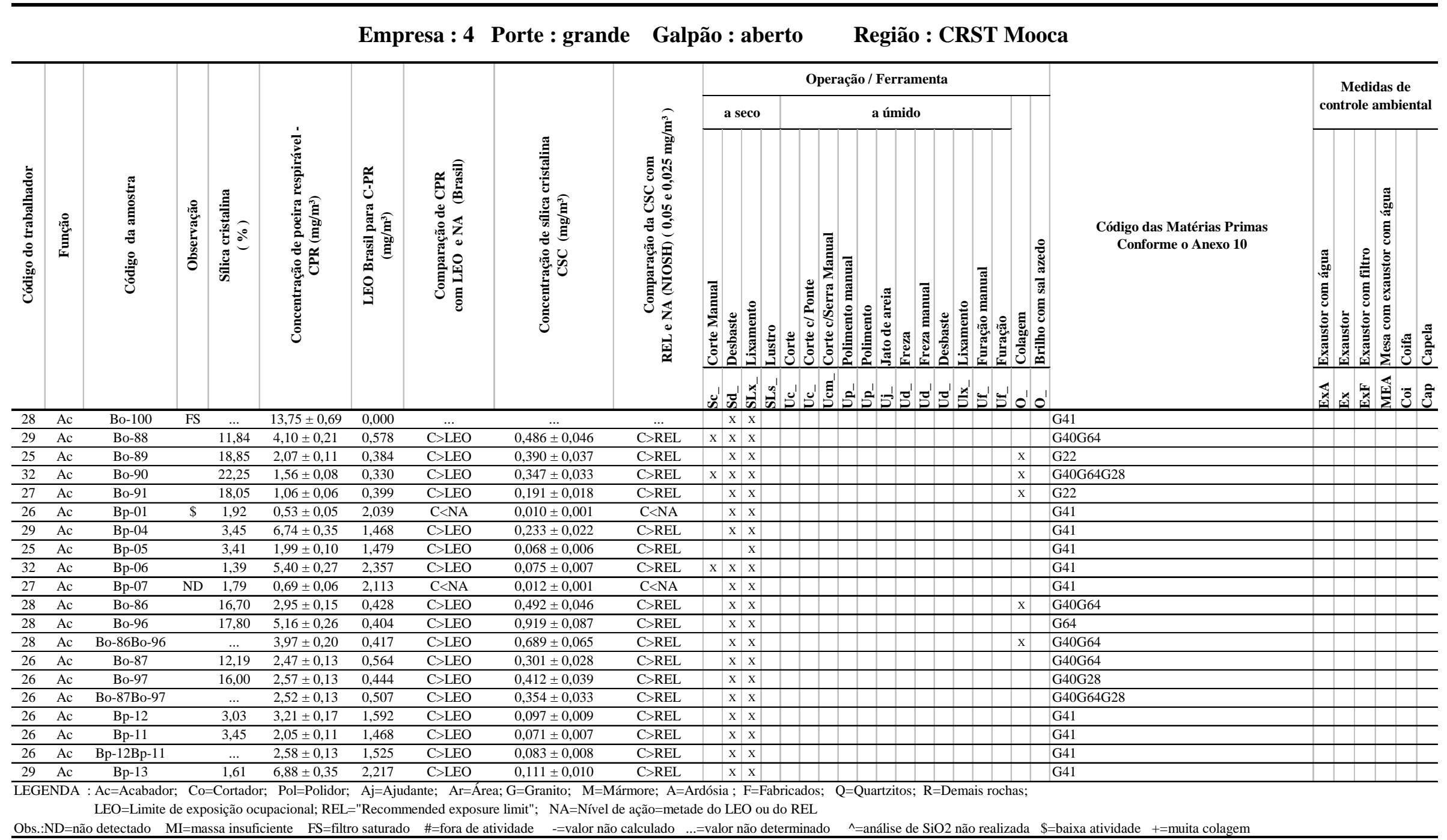

\section{Continua}


Tabela A11.3 - Concentração de poeira e de sílica cristalina respirável e informações complementares da Empresa 4

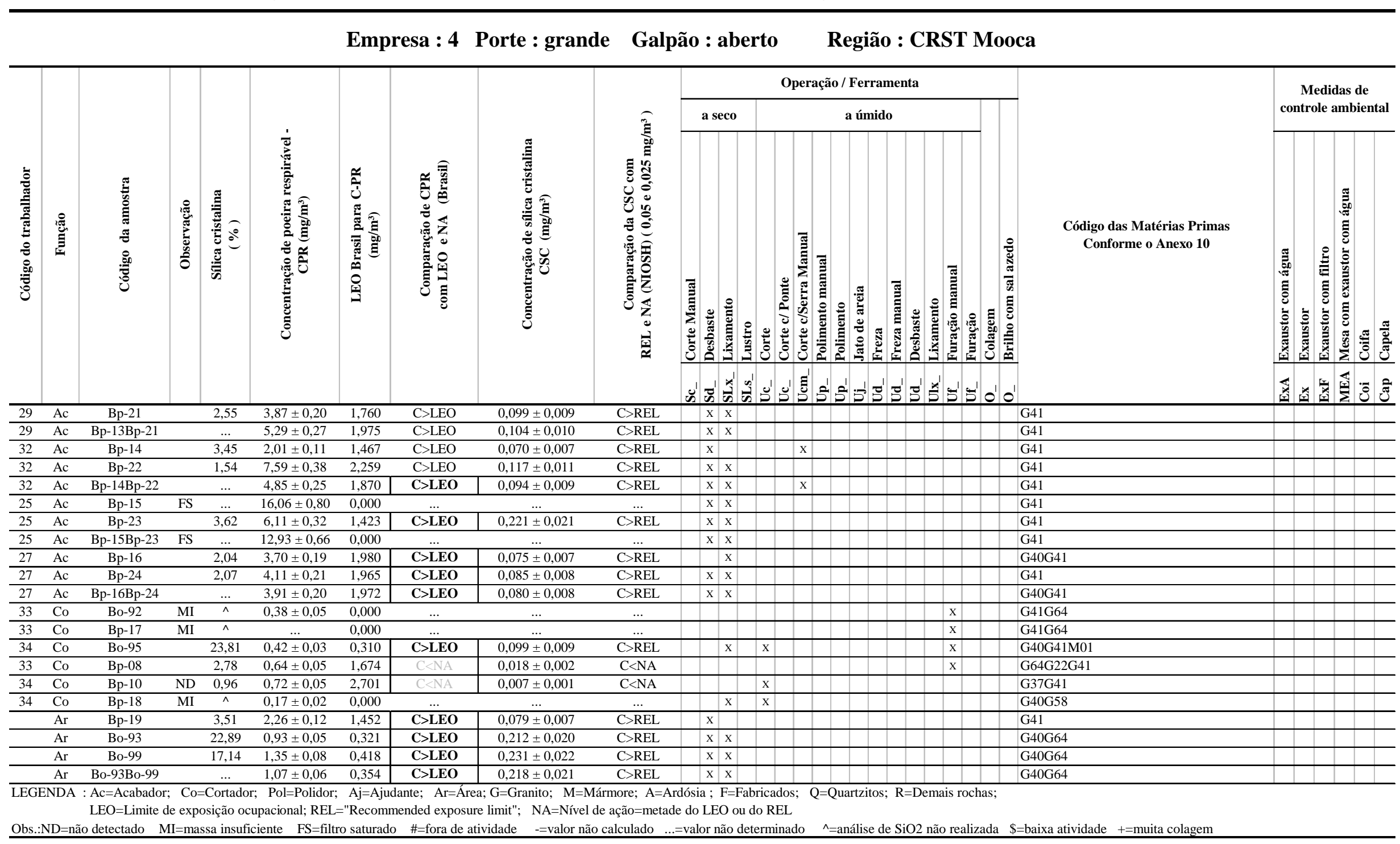


Empresa : 4 Porte : grande Galpão : aberto Região : CRST Mooca

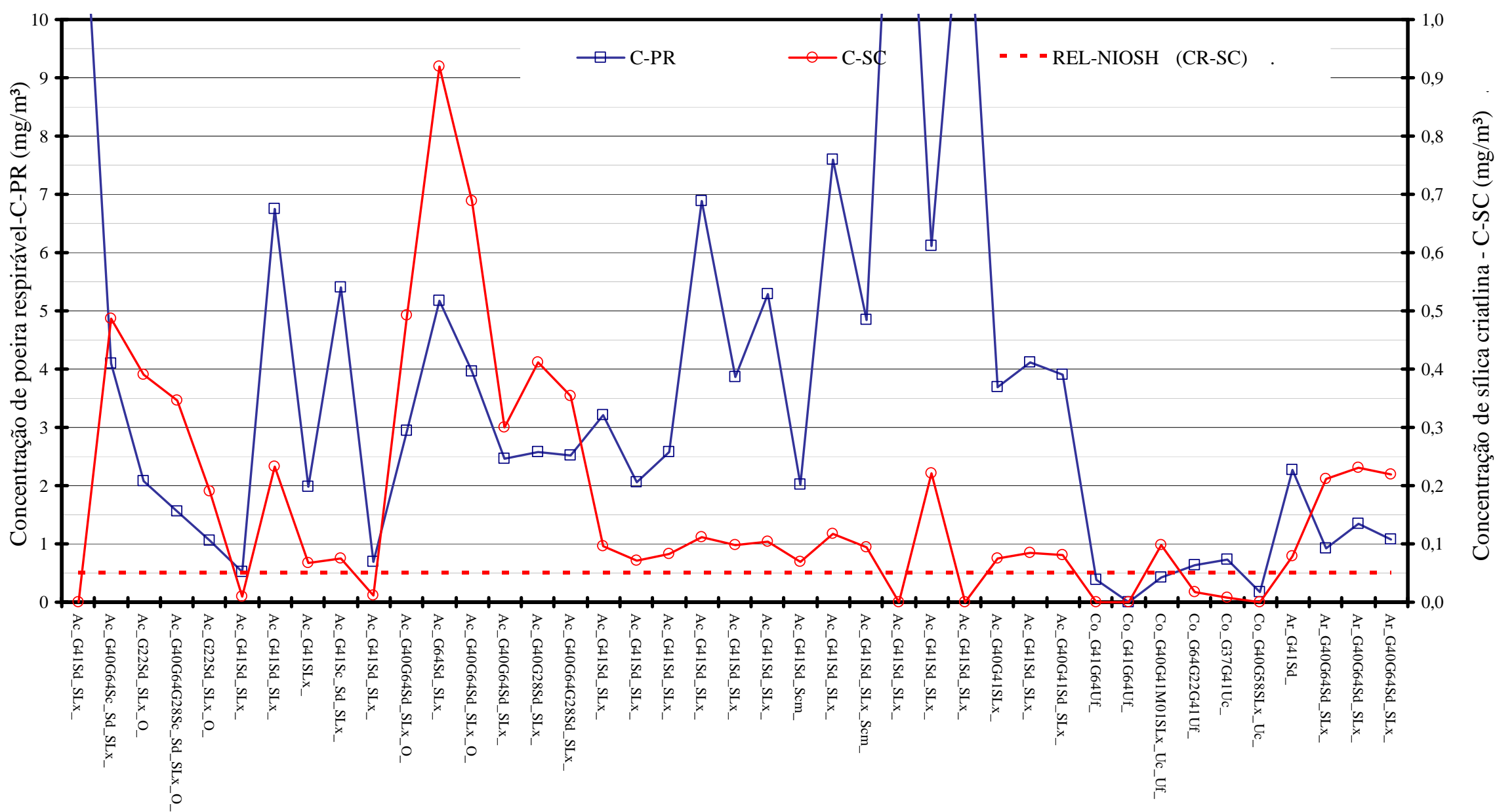

Figura A11.3 - Concentração de poeira e de sílica cristalina respirável com respectiva etapa do processo (conf.Tabela A11.3) 
Tabela A11.4 - Concentração de poeira e de sílica cristalina respirável e informações complementares da Empresa 5. Marmorarias, Município de São Paulo, 2004-2005

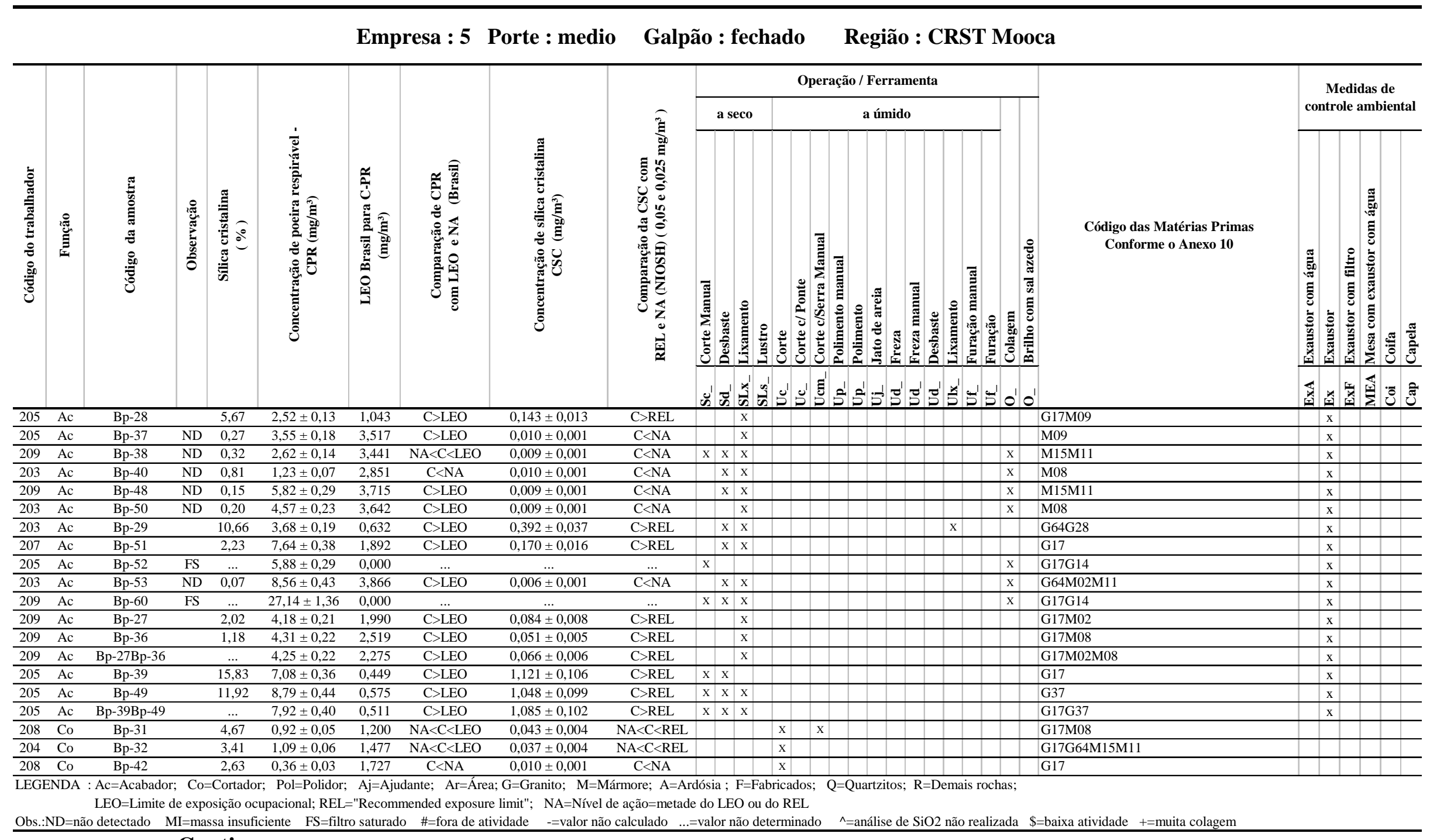

\section{Continua}


Tabela A11.4 - Concentração de poeira e de sílica cristalina respirável e informações complementares da Empresa 5

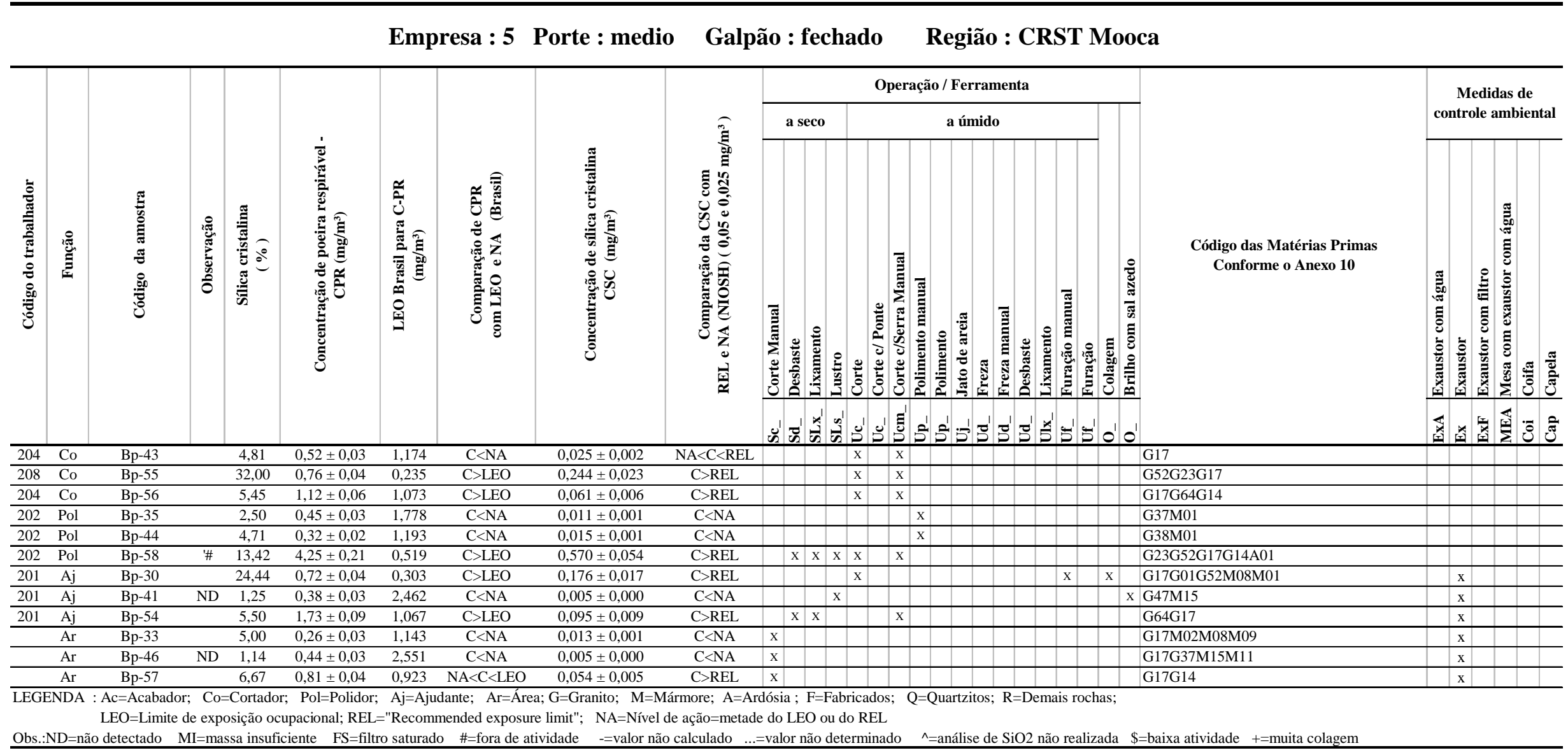


Empresa : 5 Porte : medio

Galpão : fechado

Região : CRST Mooca

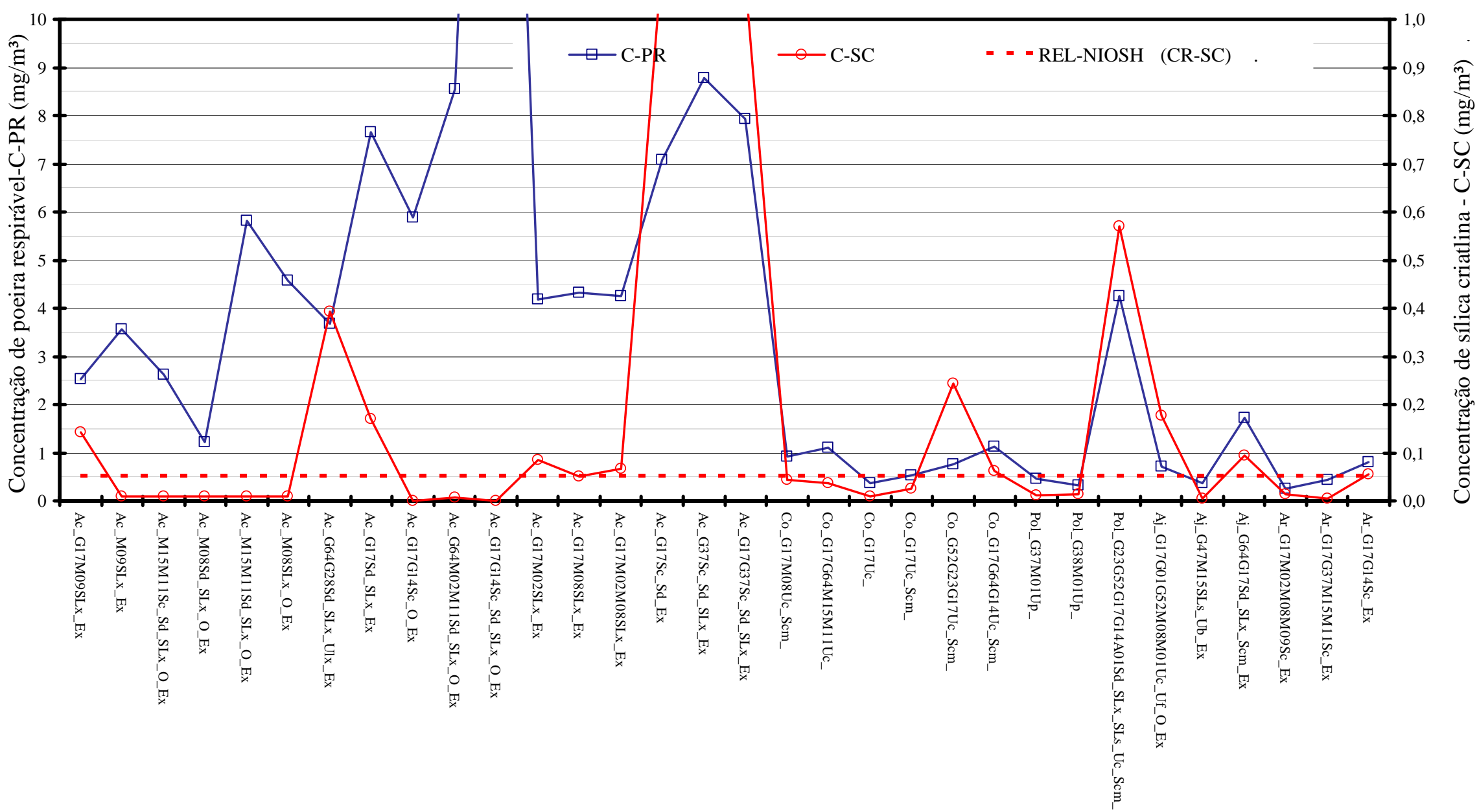

Figura A11. 4 - Concentração de poeira respirável e sílica cristalina com respectiva etapa do processo (conf.Tabela A11.4) 
Tabela A11.5 - Concentração de poeira e de sílica cristalina respirável e informações complementares da Empresa 6. Marmorarias, Município de São Paulo, 2004-2005

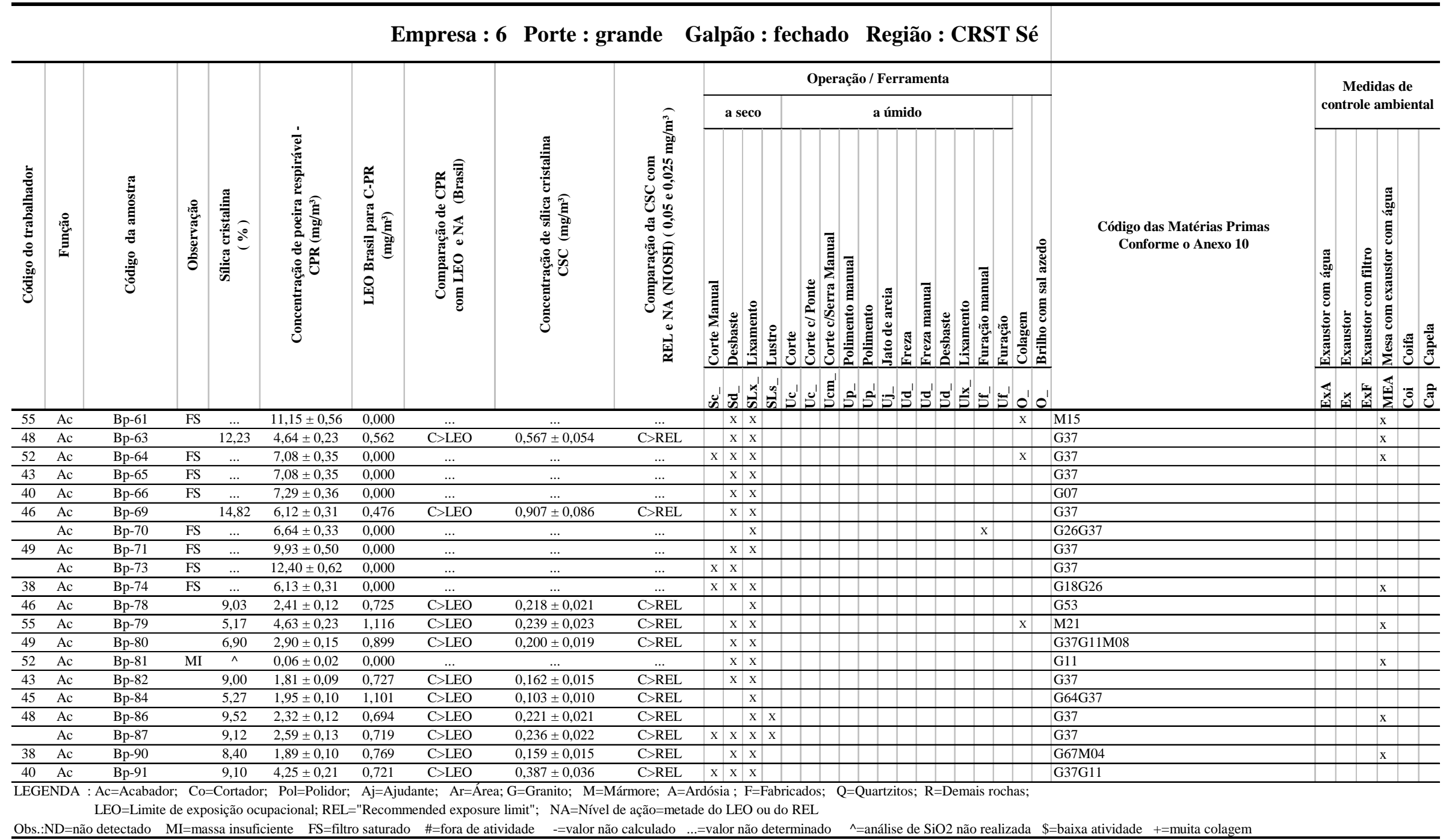

\section{Continua}


Tabela A11.5 - Concentração de poeira e de sílica cristalina respirável e informações complementares da Empresa 6

Empresa : 6 Porte : grande Galpão : fechado Região : CRST Sé

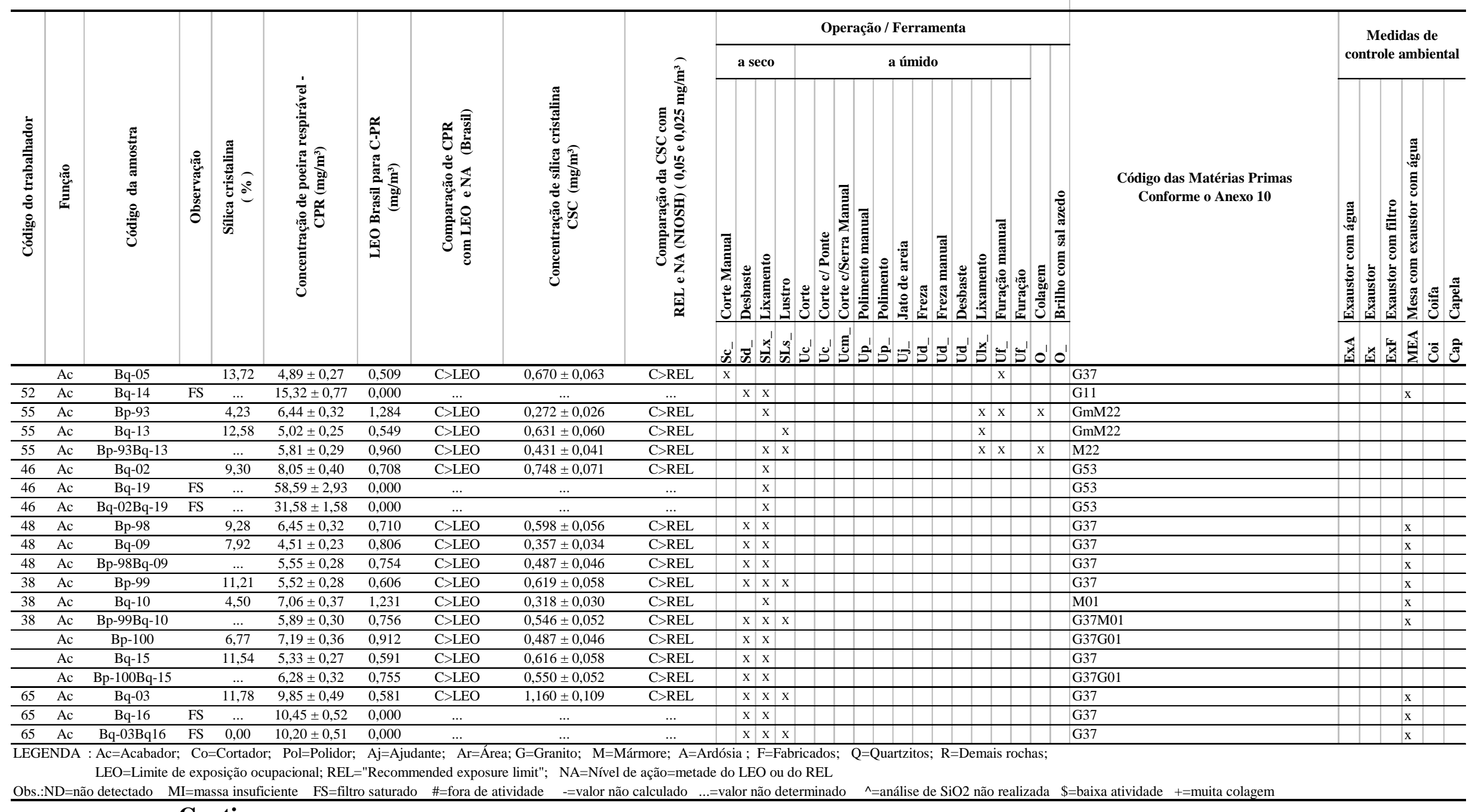

Continua 
Tabela A11.5 - Concentração de poeira e de sílica cristalina respirável e informações complementares da Empresa 6

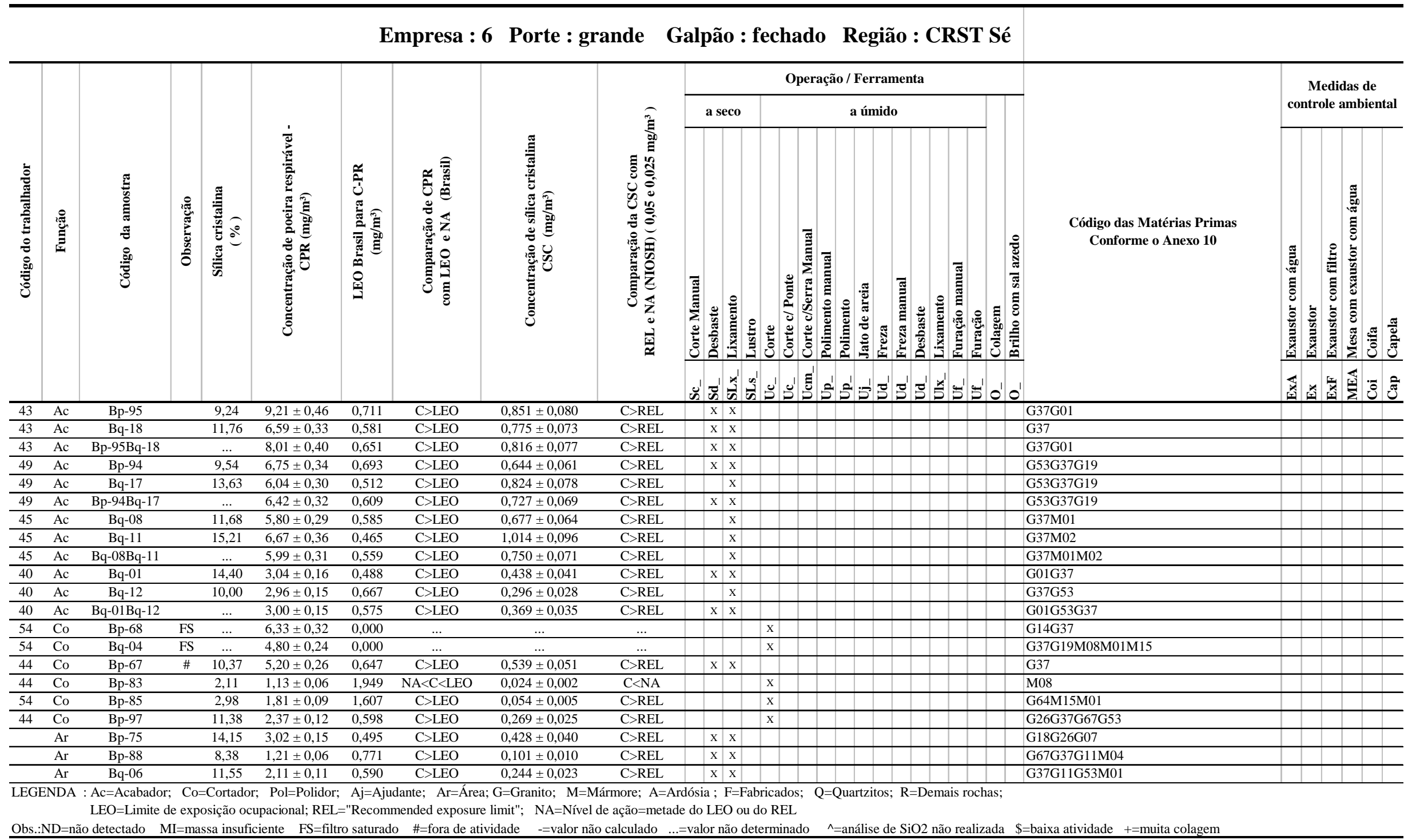


Empresa : 6 Porte : grande Galpão : fechado Região : CRST Sé

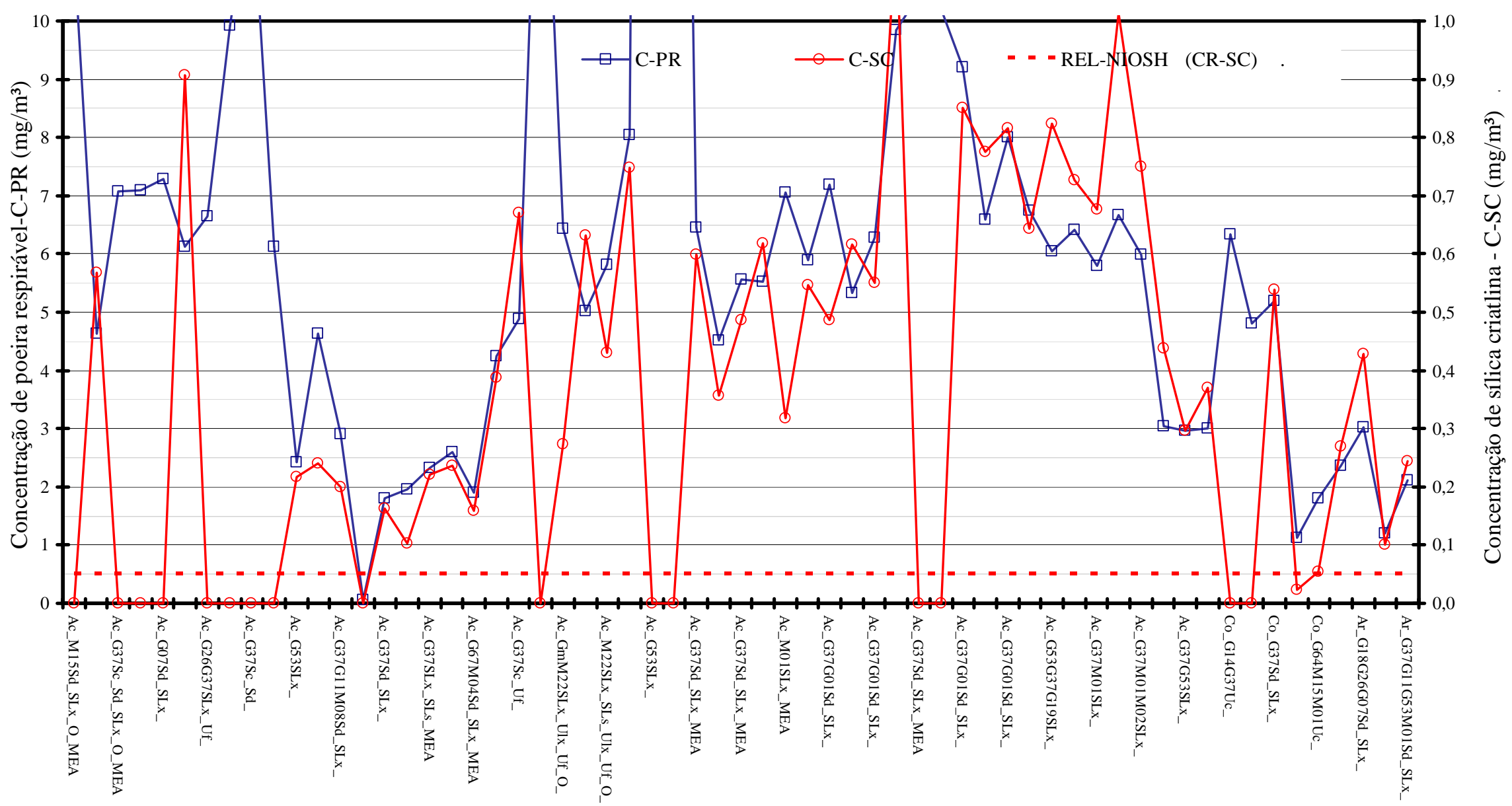

Figura A11. 5 - Concentração de poeira respirável e sílica cristalina com respectiva etapa do processo (conf.Tabela A11.5) 
Tabela A11.6 - Concentração de poeira e de sílica cristalina respirável e informações complementares da Empresa 7. Marmorarias, Município de São Paulo, 2004-2005

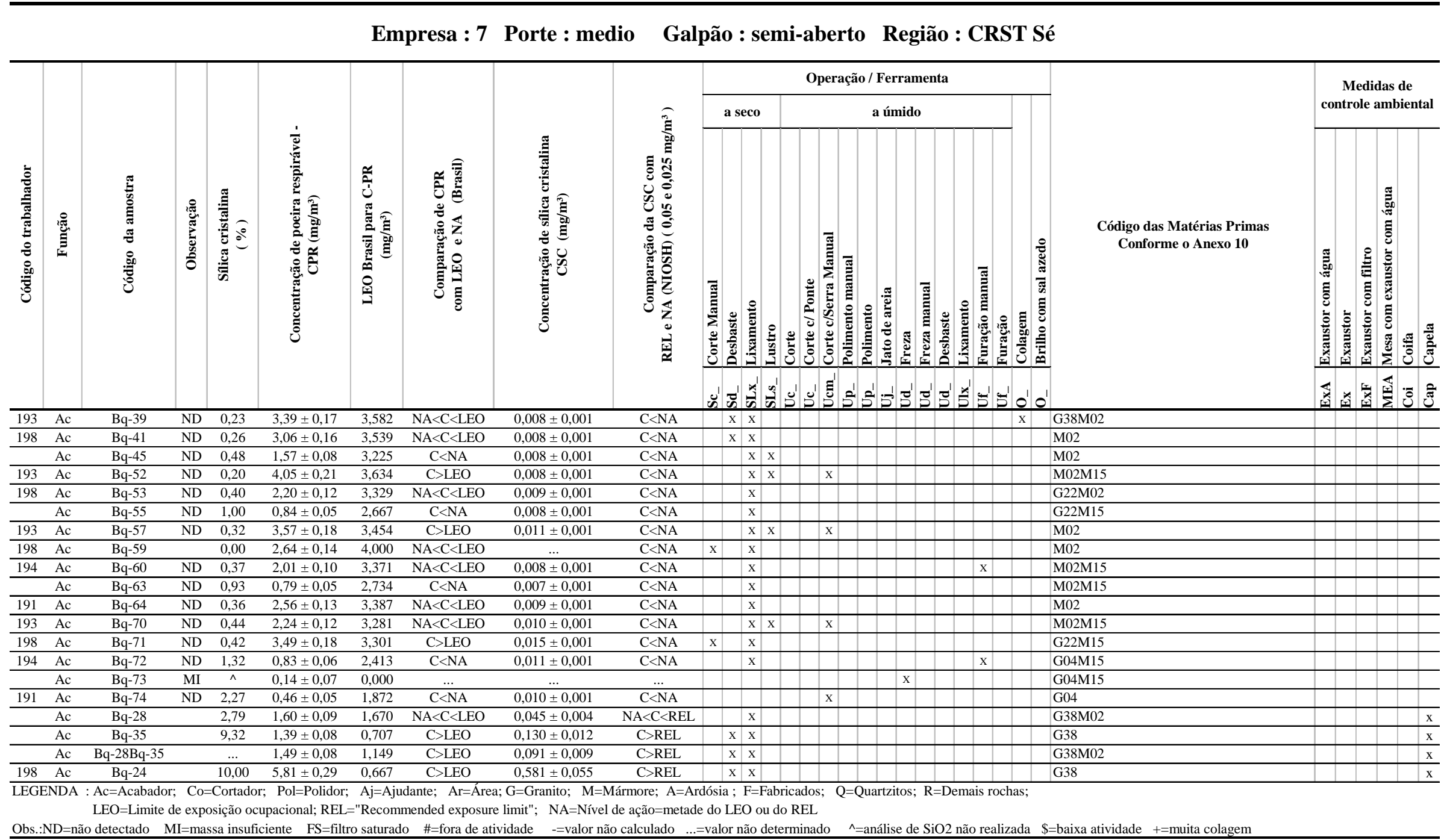

\section{Continua}


Tabela A11.6 - Concentração de poeira e de sílica cristalina respirável e informações complementares da Empresa 7

Empresa : 7 Porte : medio Galpão : semi-aberto Região : CRST Sé

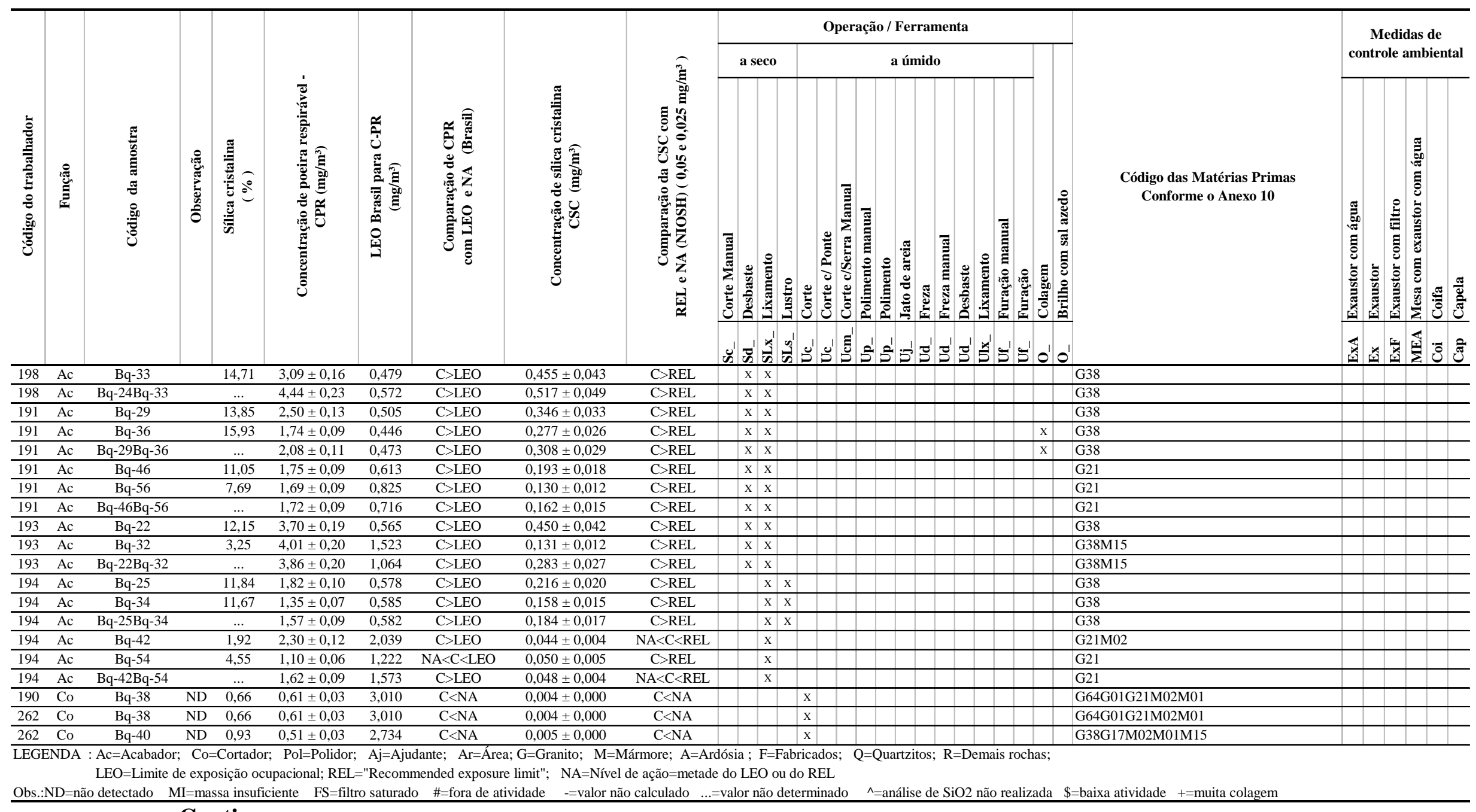

Continua 
Tabela A11.6 - Concentração de poeira e de sílica cristalina respirável e informações complementares da Empresa 7

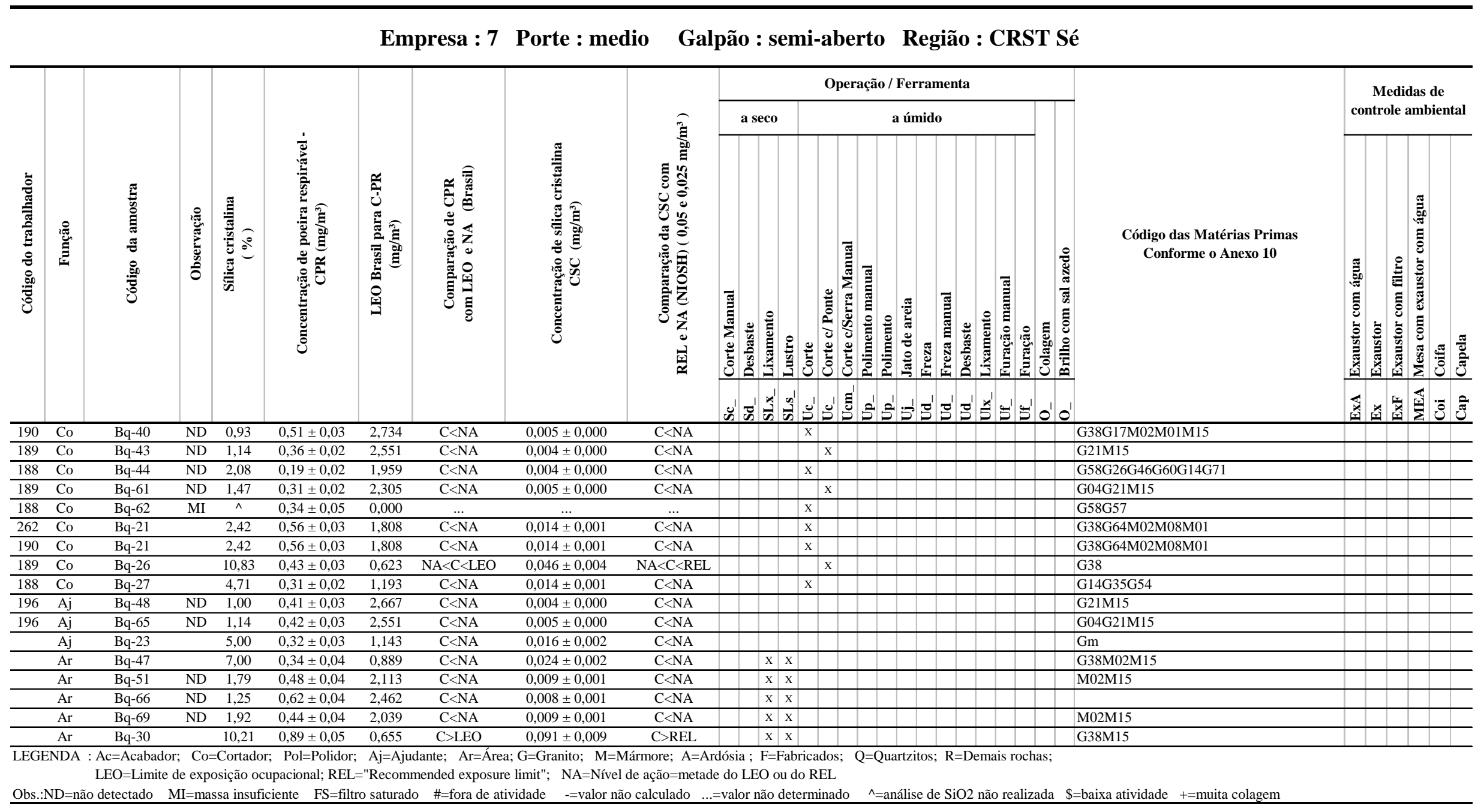


Empresa : 7 Porte : medio Galpão : semi-aberto Região : CRST Sé

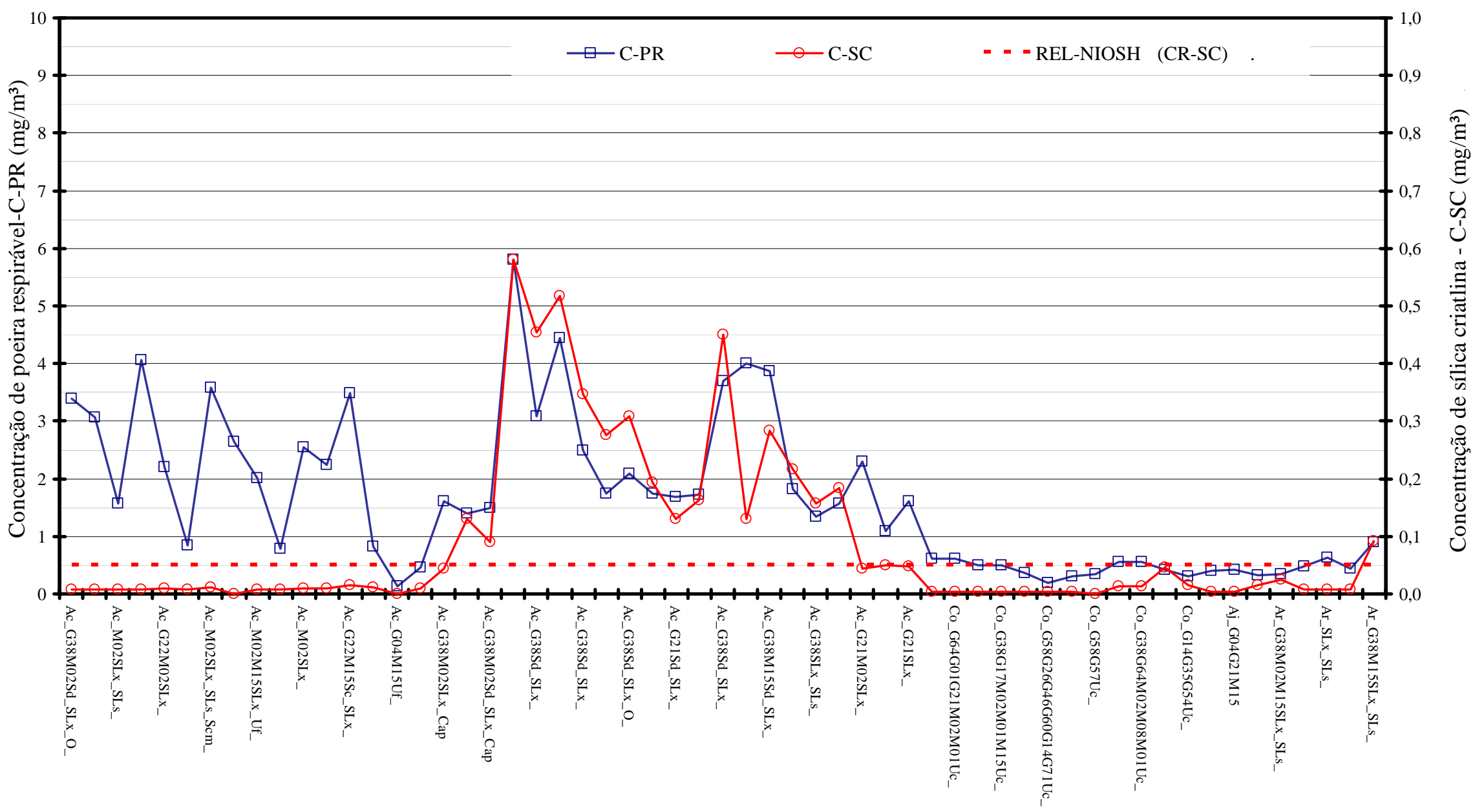

Figura A11.6 - Concentração de poeira respirável e sílica cristalina com respectiva etapa do processo (conf.Tabela A11.6) 
Tabela A11.7 - Concentração de poeira e de sílica cristalina respirável e informações complementares da Empresa 8. Marmorarias, Município de São Paulo, 2004-2005

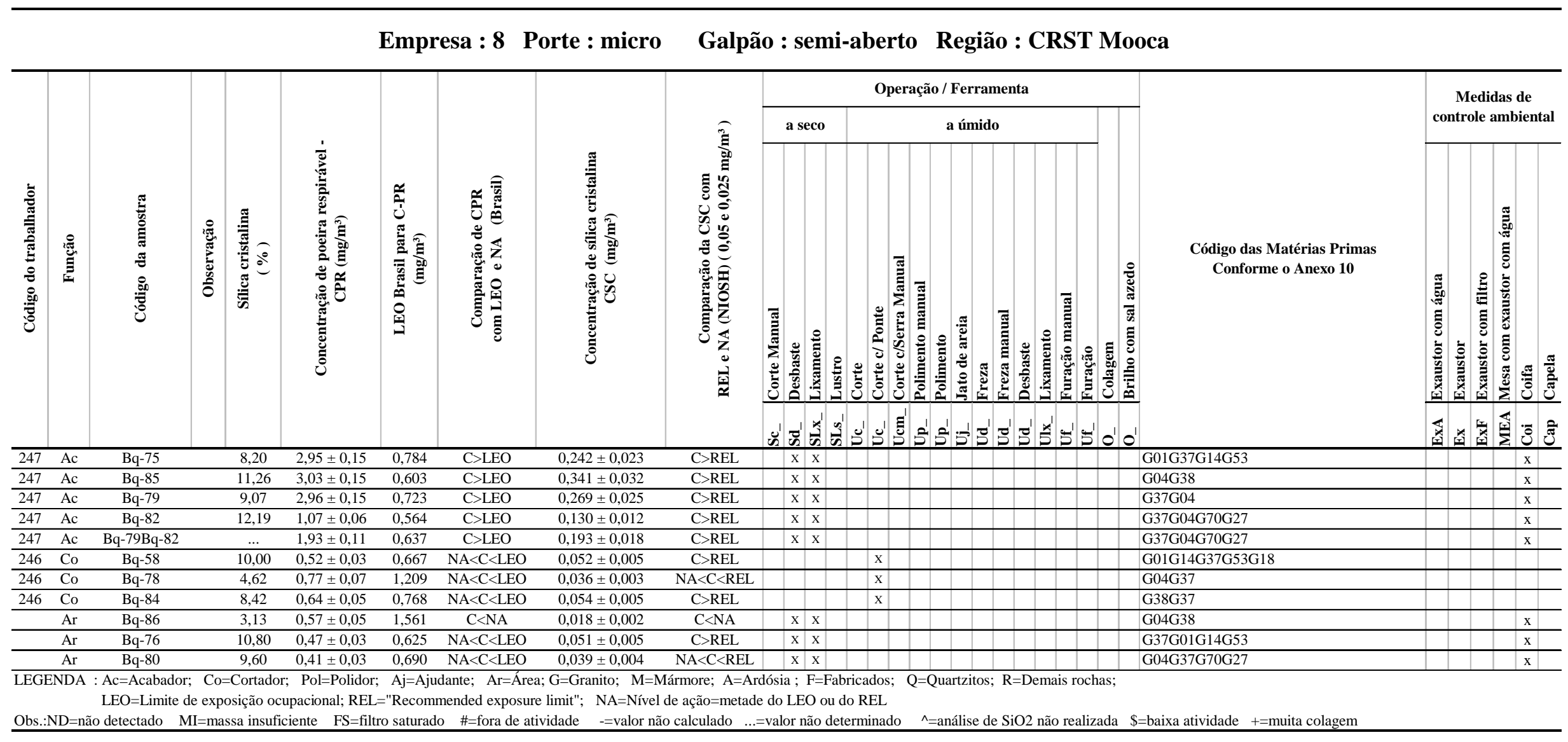


Empresa : 8 Porte : micro Galpão : semi-aberto Região : CRST Mooca

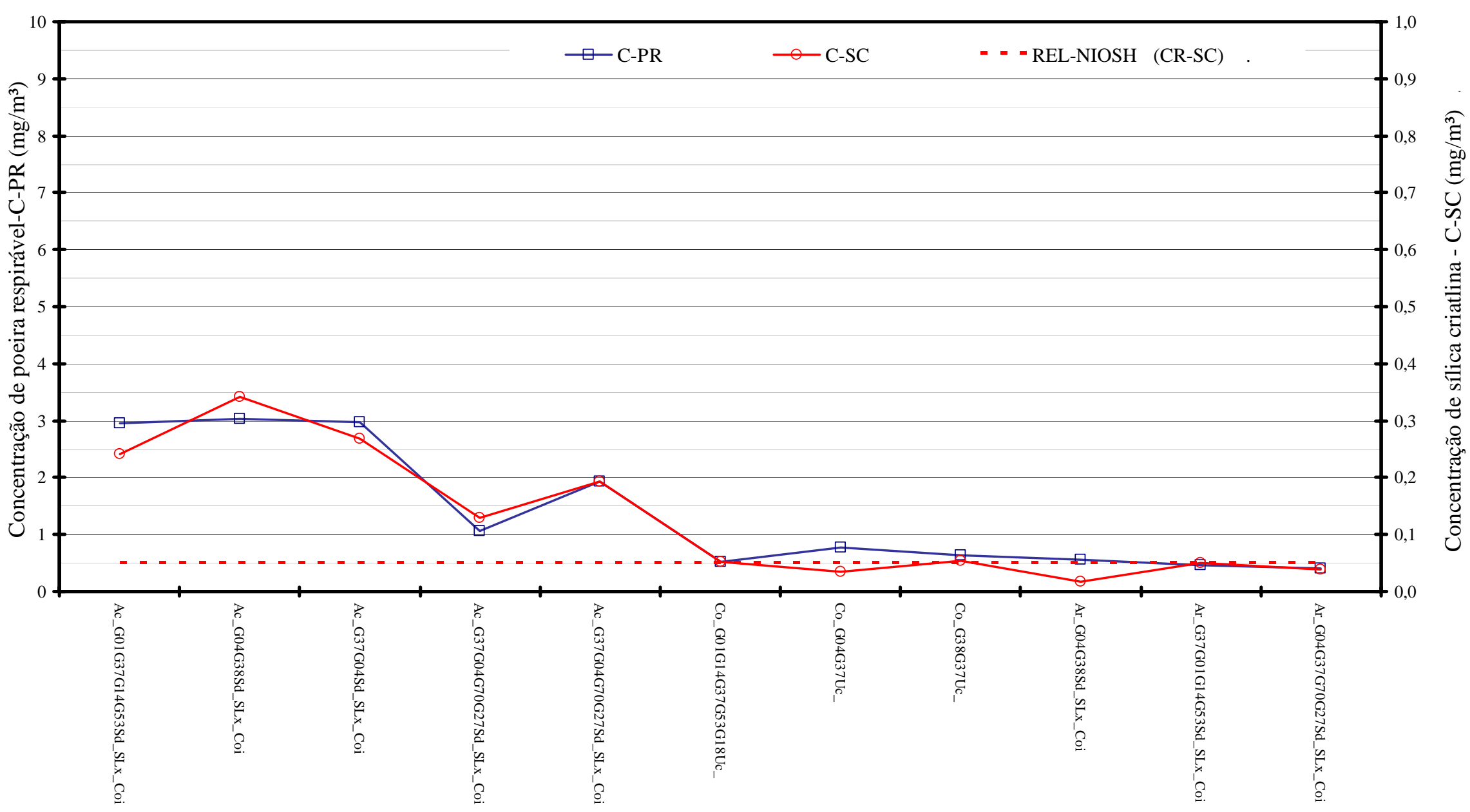

Figura A11. 7 - Concentração de poeira respirável e sílica cristalina com respectiva etapa do processo (conf.Tabela A11.7) 
Tabela A11.8 - Concentração de poeira e de sílica cristalina respirável e informações complementares da Empresa 9. Marmorarias, Município de São Paulo, 2004-2005

Empresa : 9 Porte : pequeno Galpão : semi-aberto Região : CRST Sé

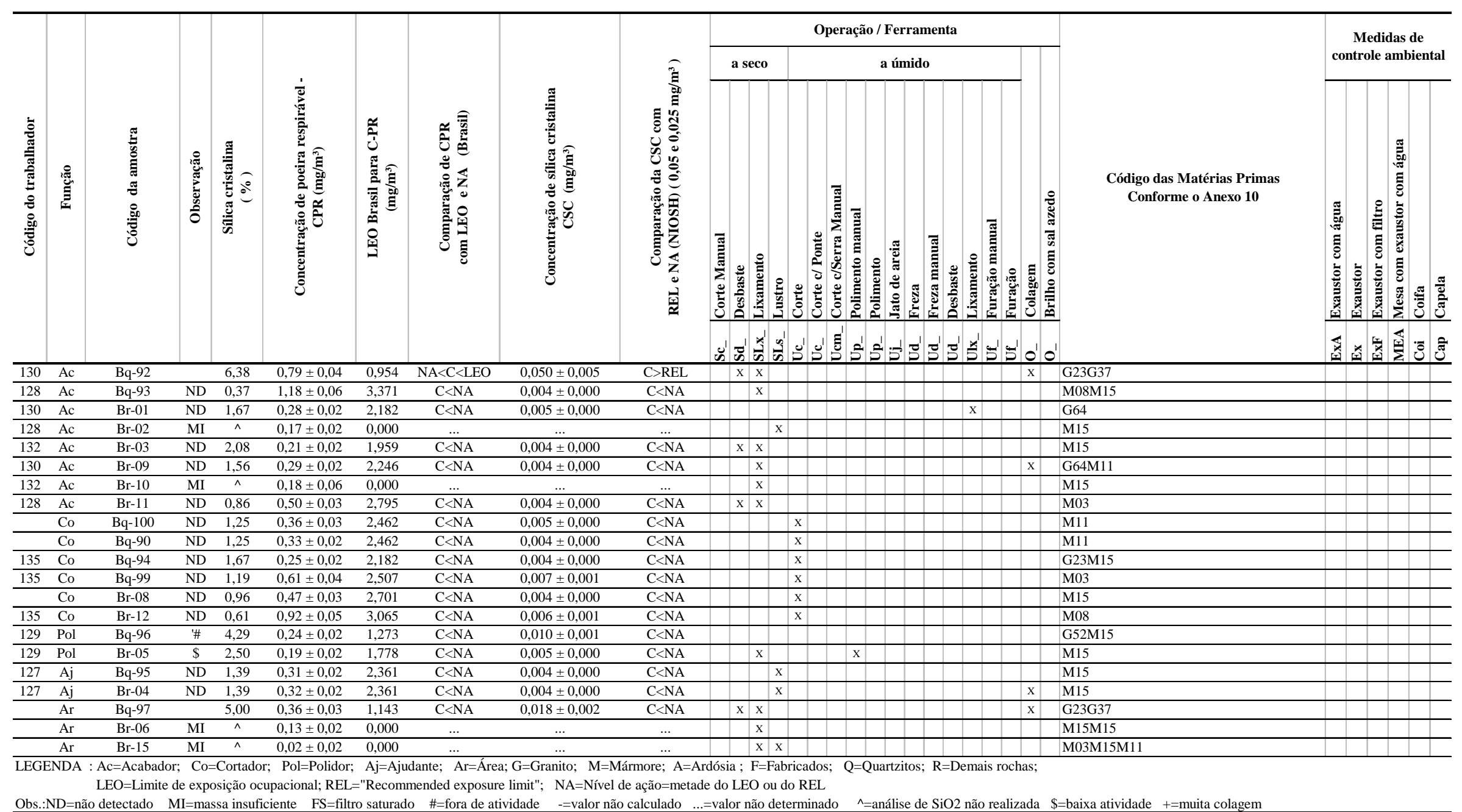


Empresa : 9 Porte : pequeno Galpão : semi-aberto Região : CRST Sé

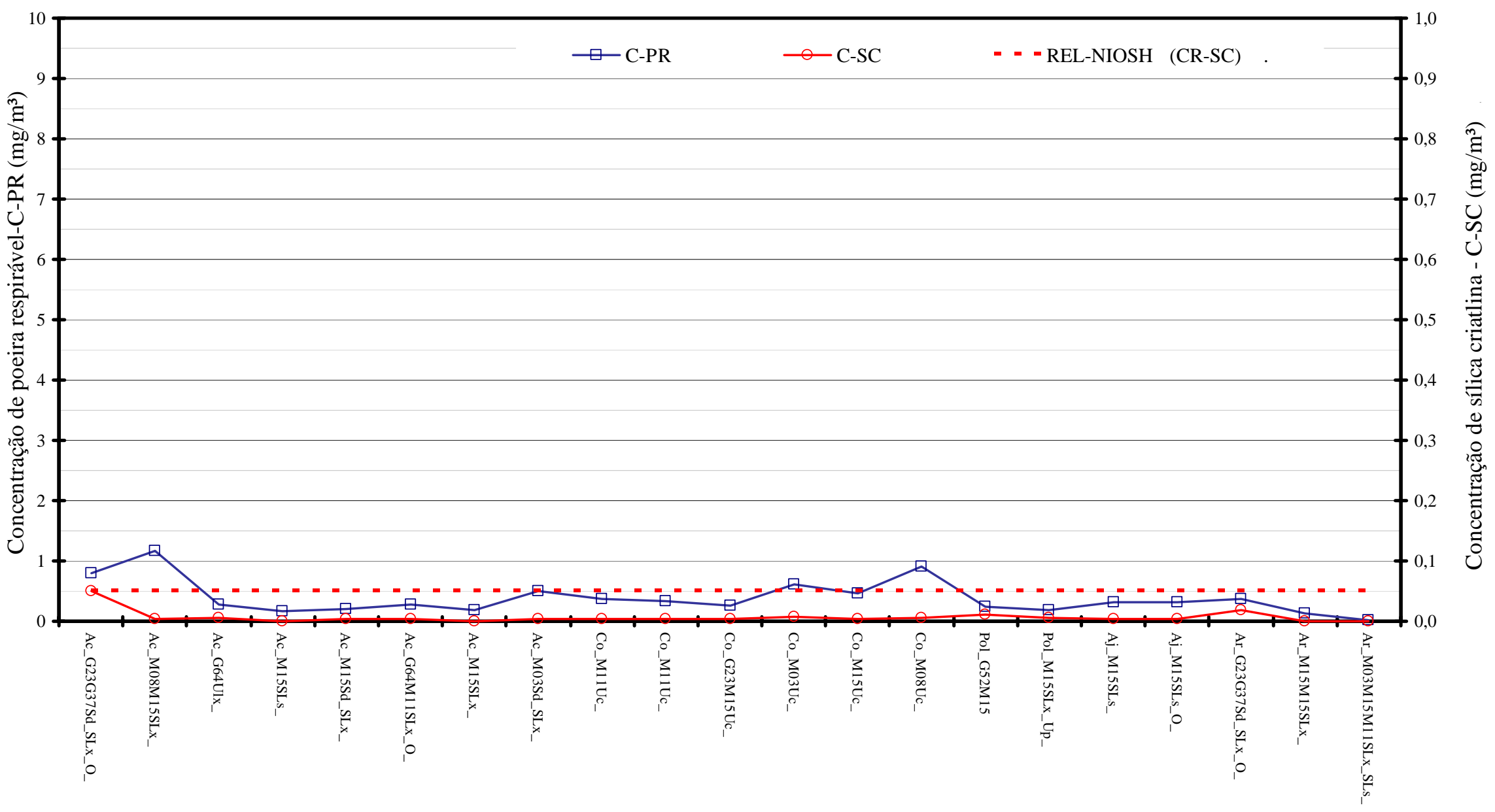

Figura A11. 8 - Concentração de poeira respirável e sílica cristalina com respectiva etapa do processo (conf.Tabela A11.8) 
Tabela A11.9 - Concentração de poeira e de sílica cristalina respirável e informações complementares da Empresa 10. Marmorarias, Município de São Paulo, 2004-2005

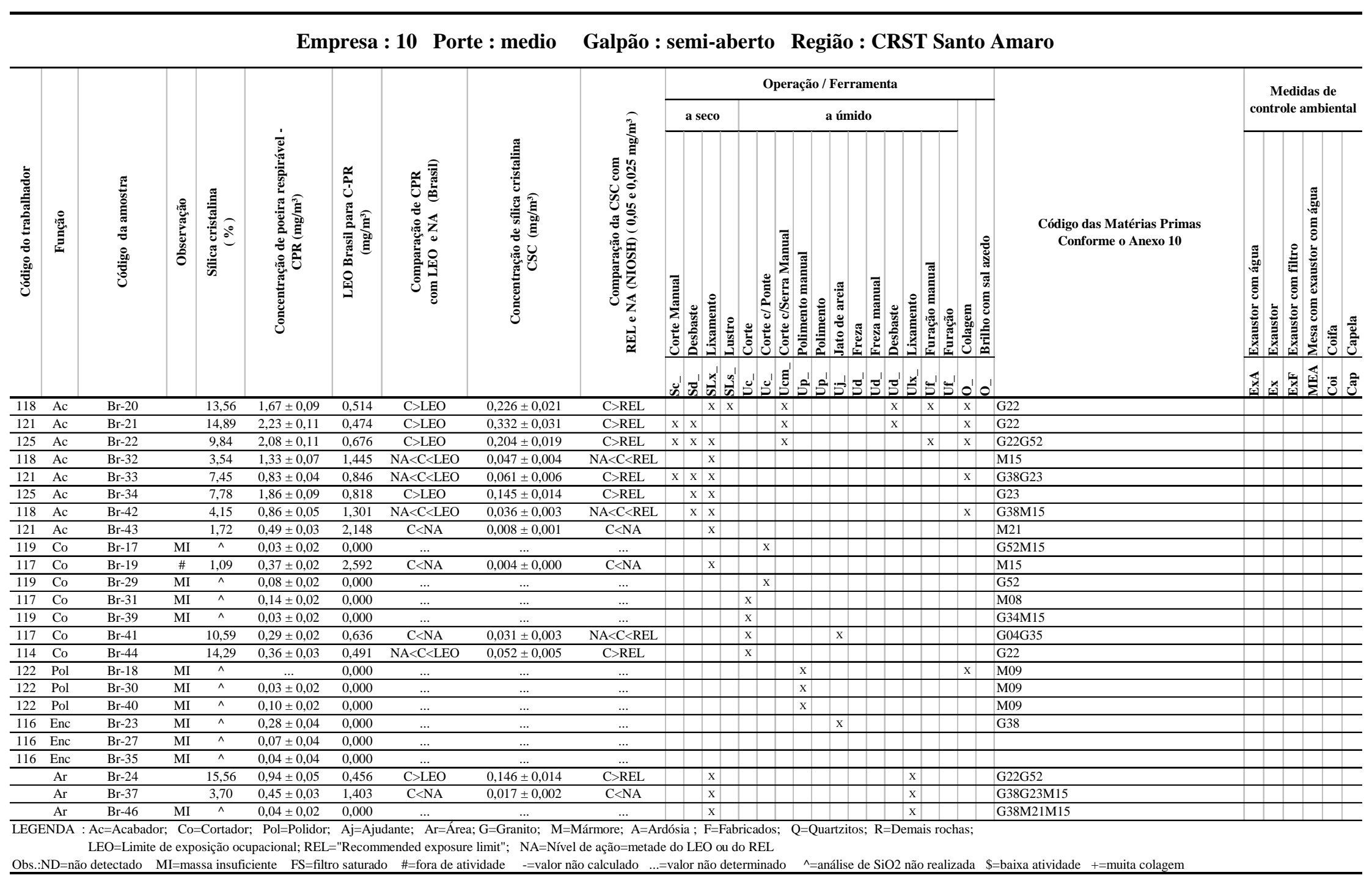


Empresa : 10 Porte : medio Galpão : semi-aberto Região : CRST Santo Amaro

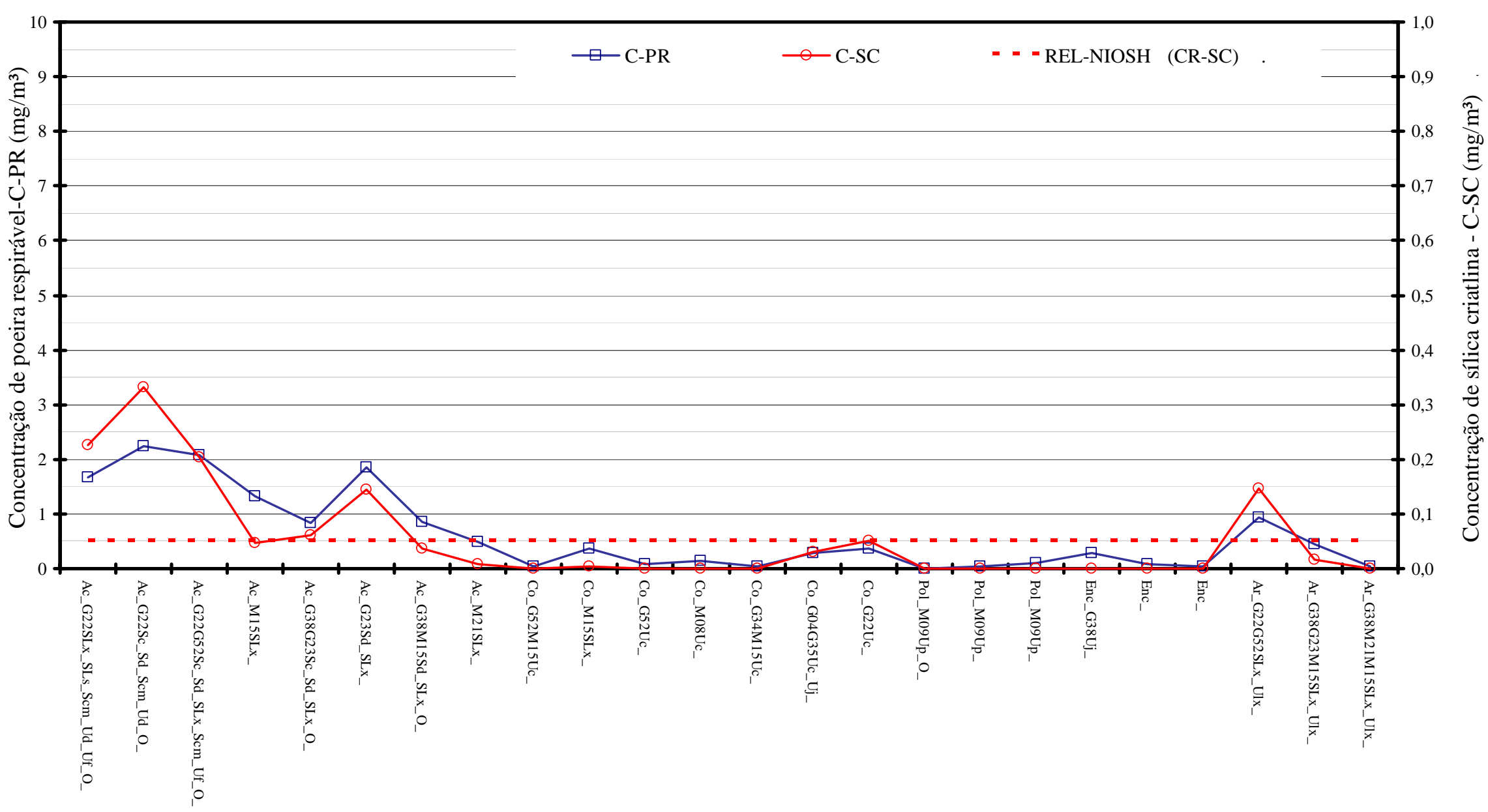

Figura A11. 9 - Concentração de poeira respirável e sílica cristalina com respectiva etapa do processo (conf.Tabela A11.9) 
Tabela A11.10 - Concentração de poeira e de sílica cristalina respirável e informações complementares da Empresa 11. Marmorarias, Município de São Paulo, 2004-2005

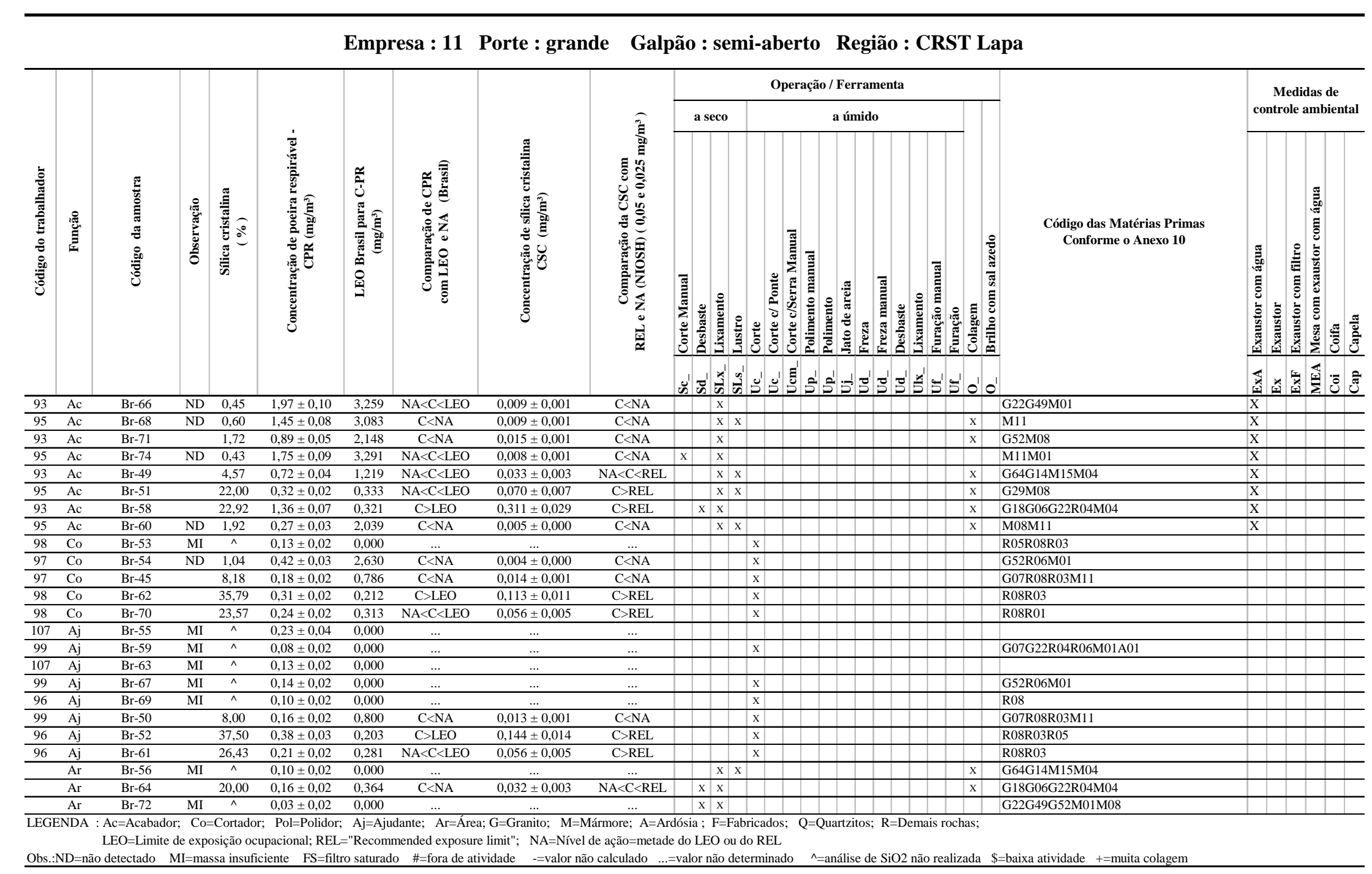


Empresa : 11 Porte : grande Galpão : semi-aberto Região : CRST Lapa

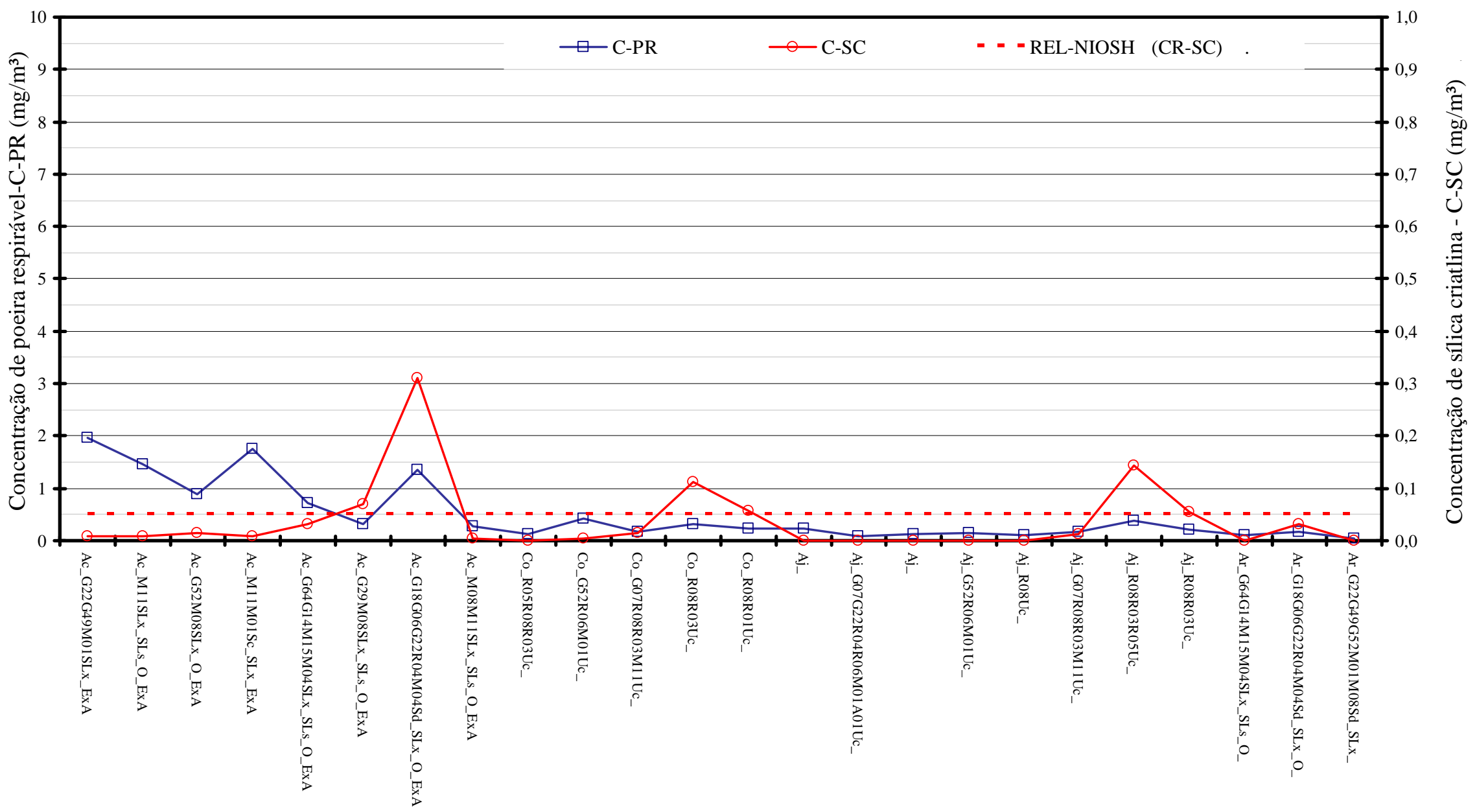

Figura A11. 10 : Concentração de poeira respirável e sílica cristalina com respectiva etapa do processo (conf.Tabela A11.10) 
Tabela A11.11 - Concentração de poeira e de sílica cristalina respirável e informações complementares da Empresa 12. Marmorarias, Município de São Paulo, 2004-2005

Empresa : 12 Porte : pequeno Galpão : semi-aberto Região : CRST Santo Amaro

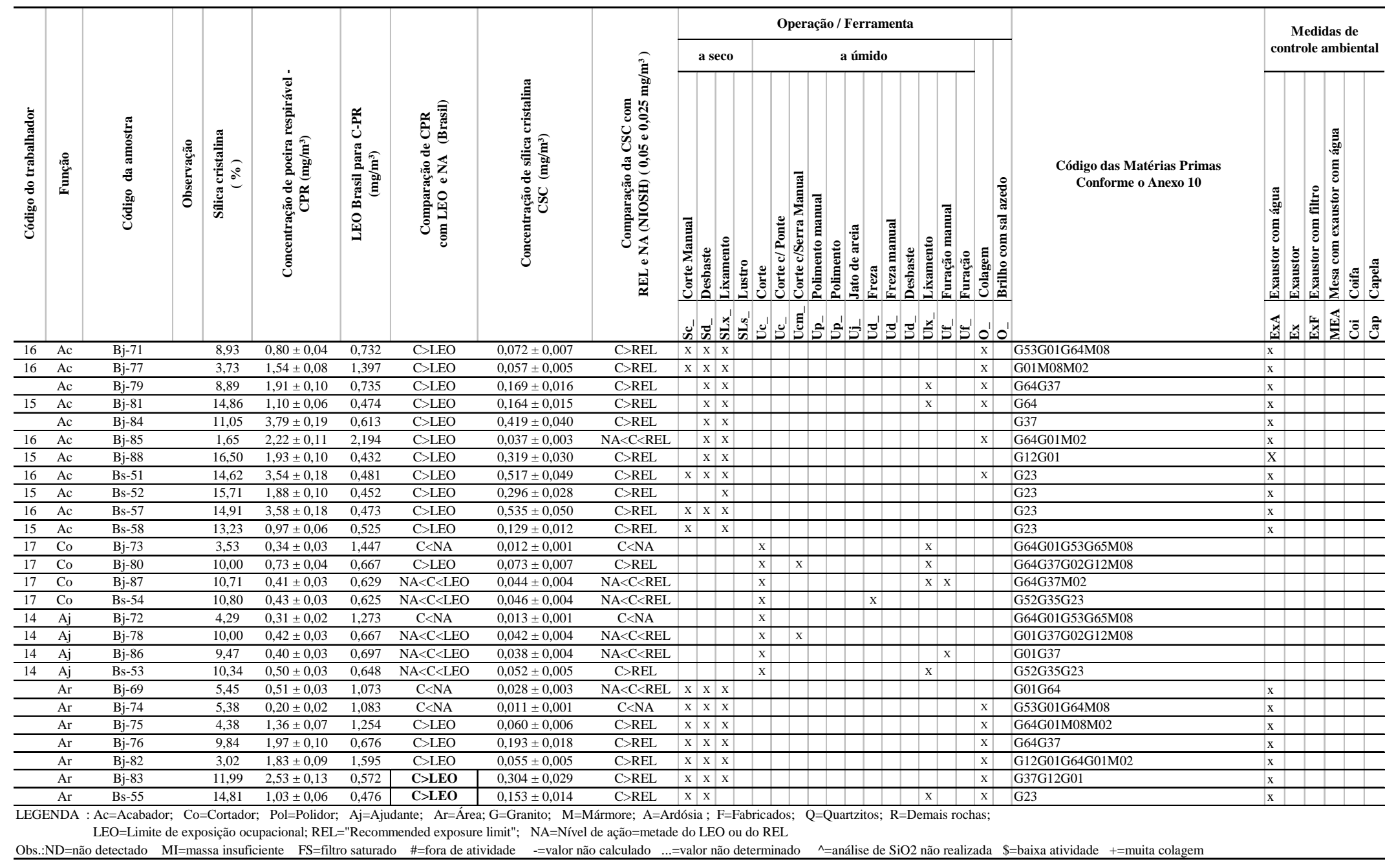


Empresa : 12 Porte : pequeno Galpão : semi-aberto Região : CRST Santo Amaro

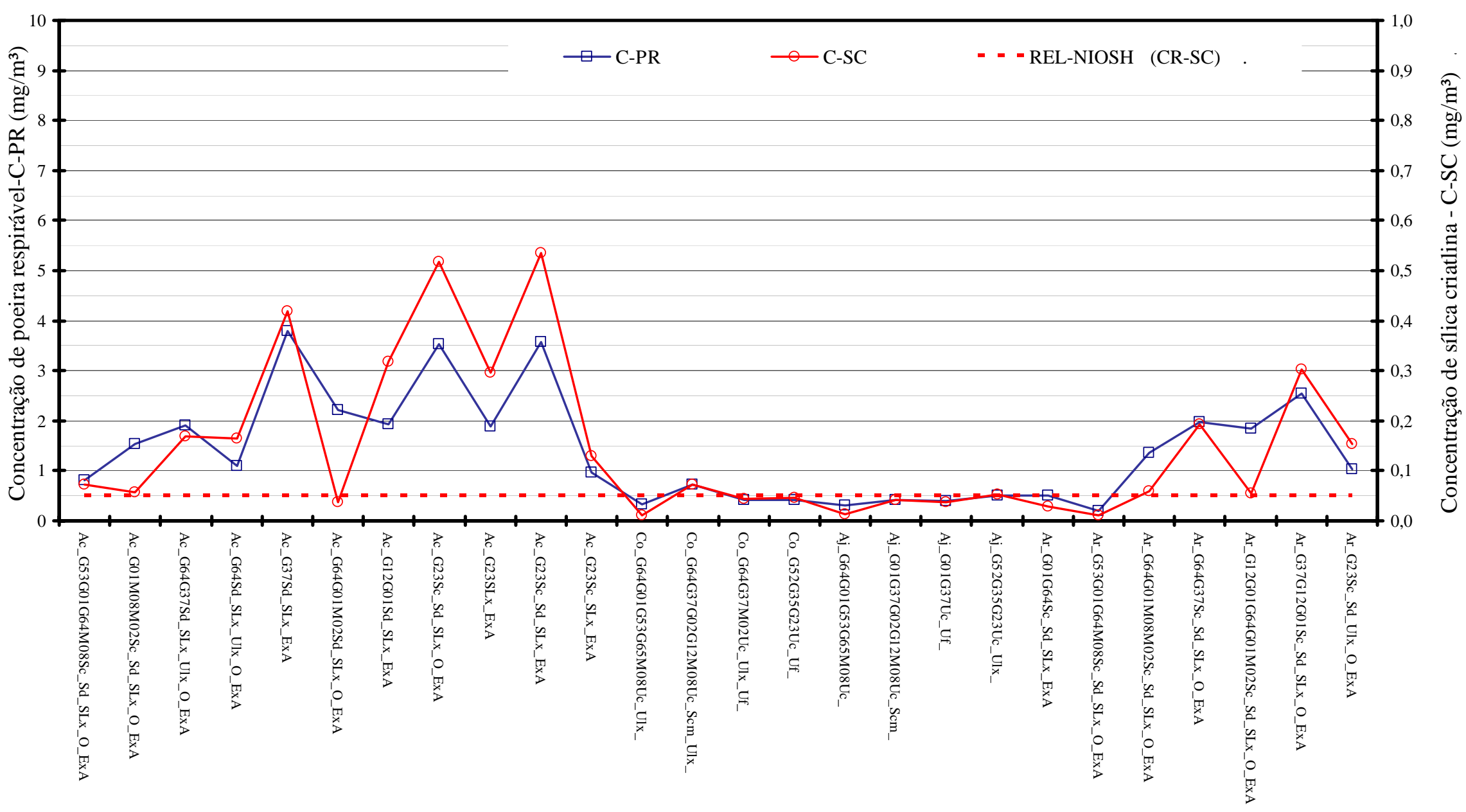

Figura A11.11 - Concentração de poeira respirável e sílica cristalina com respectiva etapa do processo (conf.Tabela A11.11) 
Tabela A11.12 - Concentração de poeira e de sílica cristalina respirável e informações complementares da Empresa 13. Marmorarias, Município de São Paulo, 2004-2005

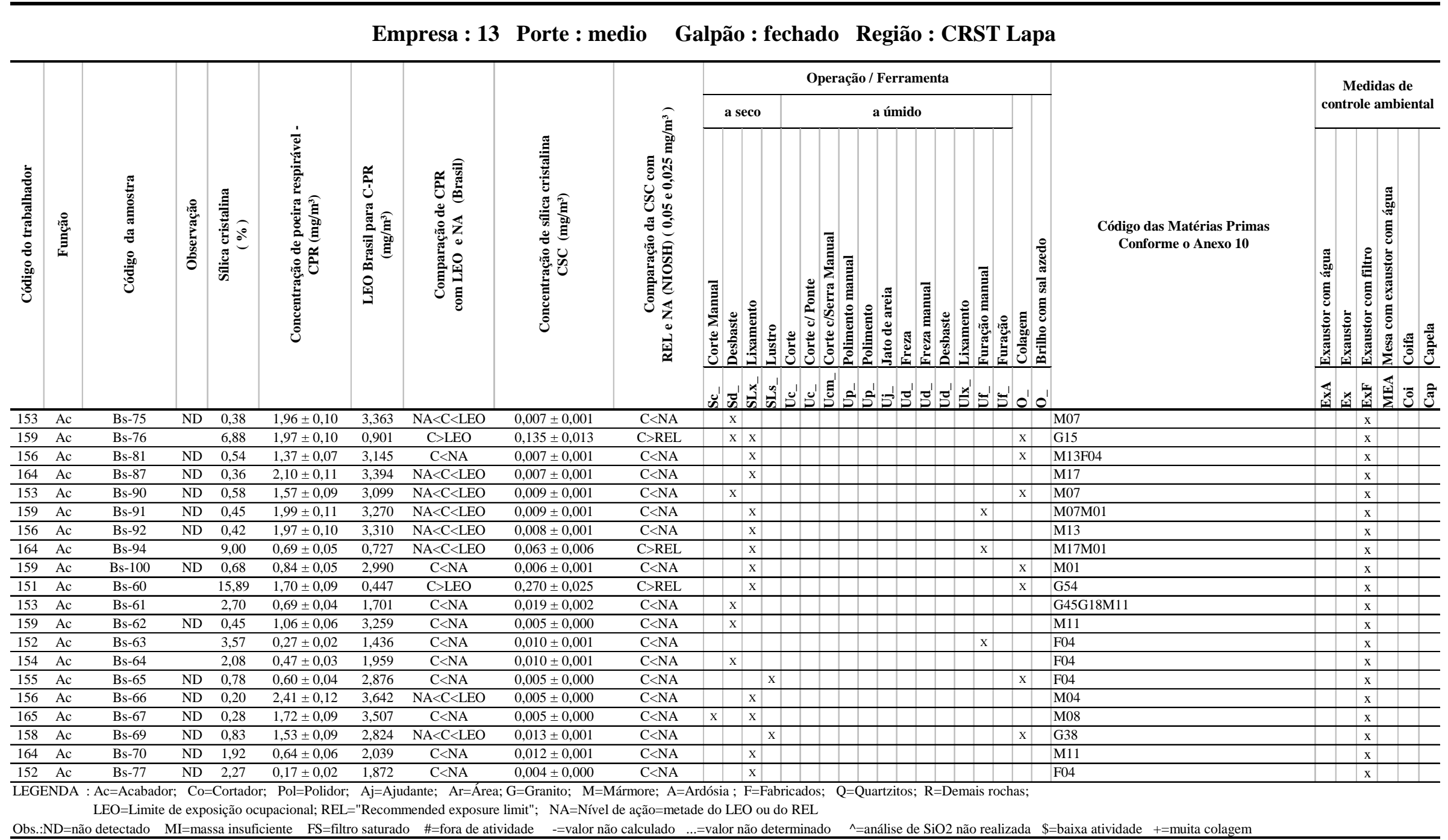

\section{Continua}


Tabela A11.12 - Concentração de poeira e de sílica cristalina respirável e informações complementares da Empresa 13

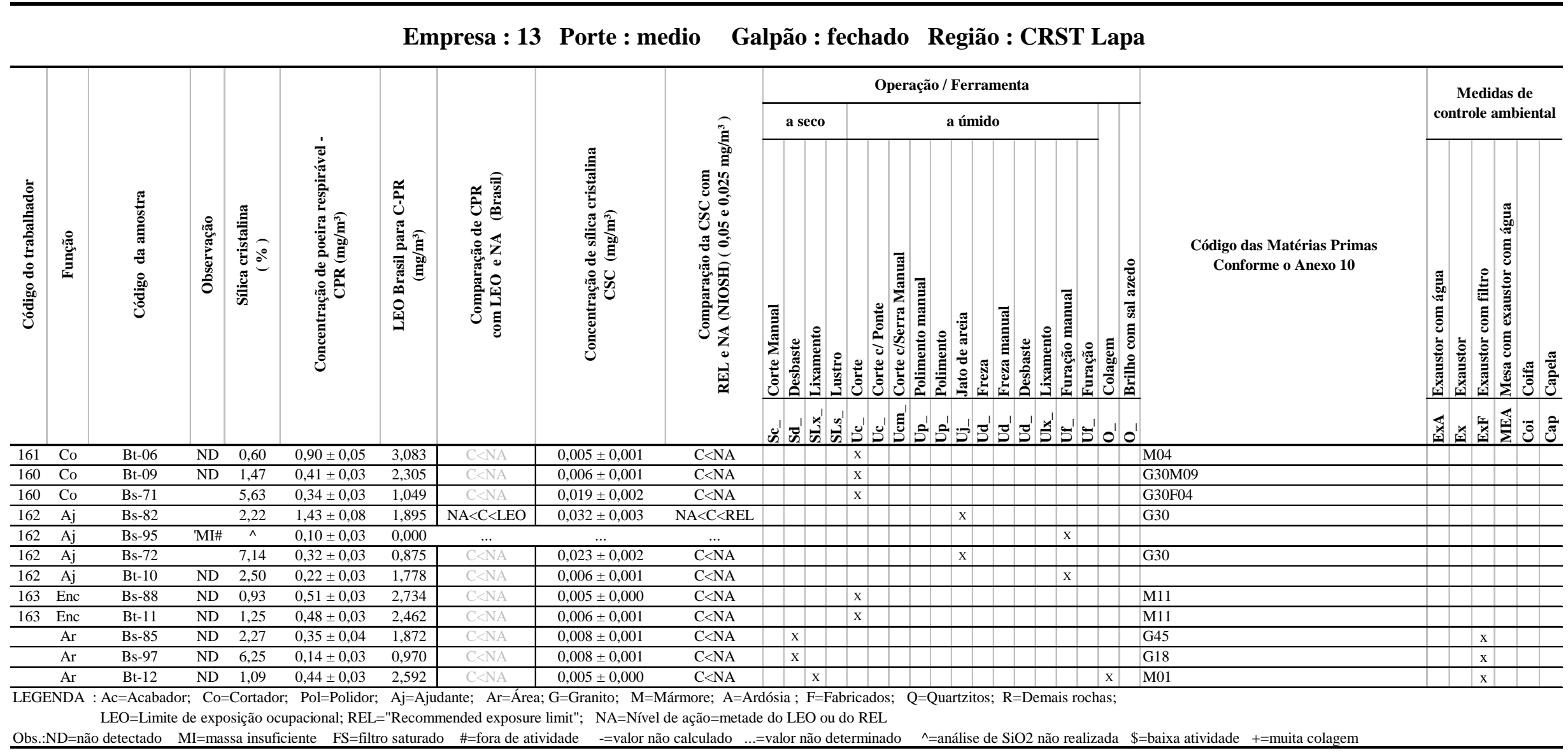


Empresa : 13 Porte : medio

Galpão : fechado Região : CRST Lapa

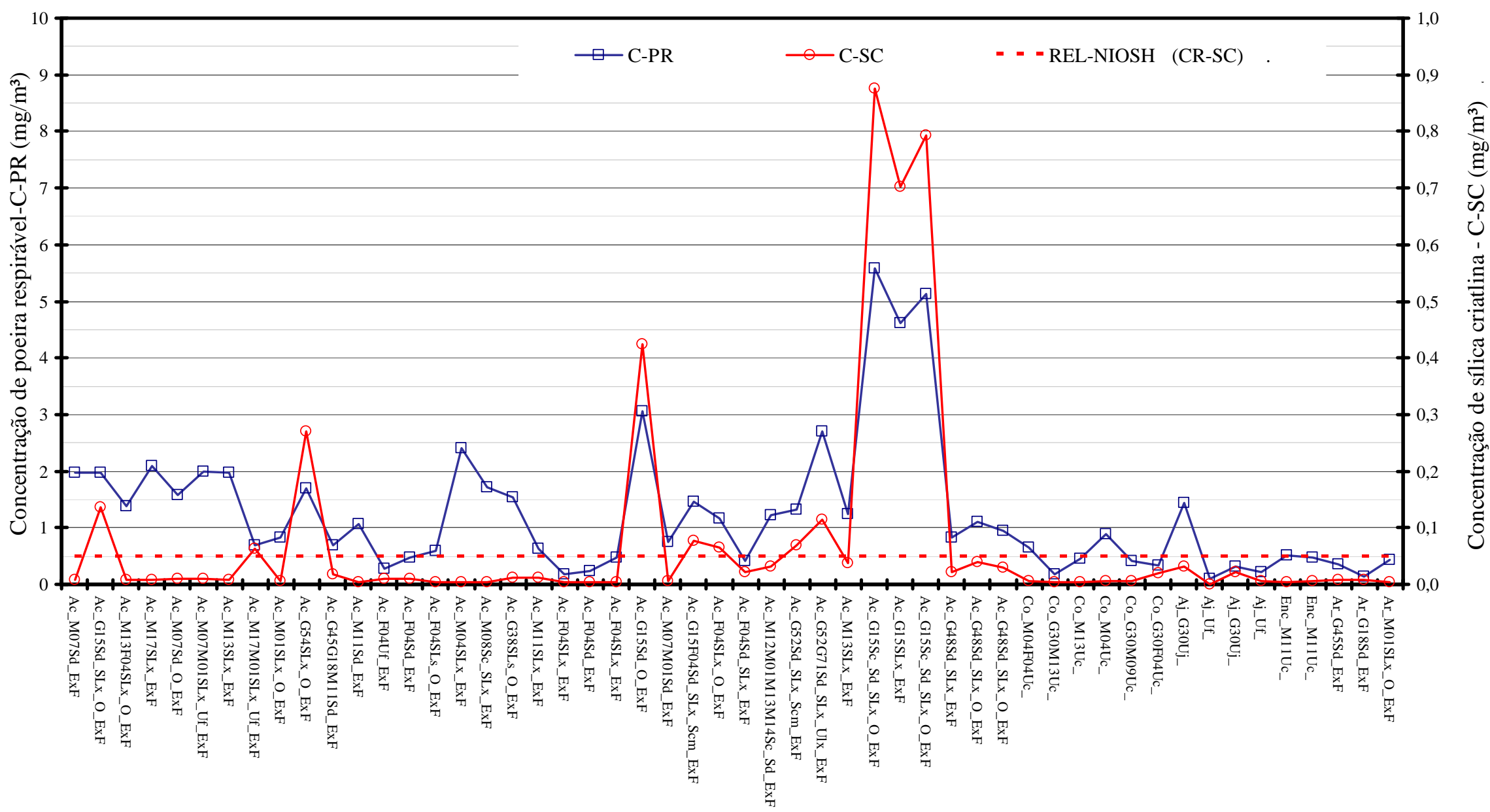

Figura A11.12: Concentração de poeira respirável e sílica cristalina com respectiva etapa do processo (conf.Tabela A11.12) 
Tabela A11.13 - Concentração de poeira e de sílica cristalina respirável e informações complementares da Empresa 14. Marmorarias, Município de São Paulo, 2004-2005

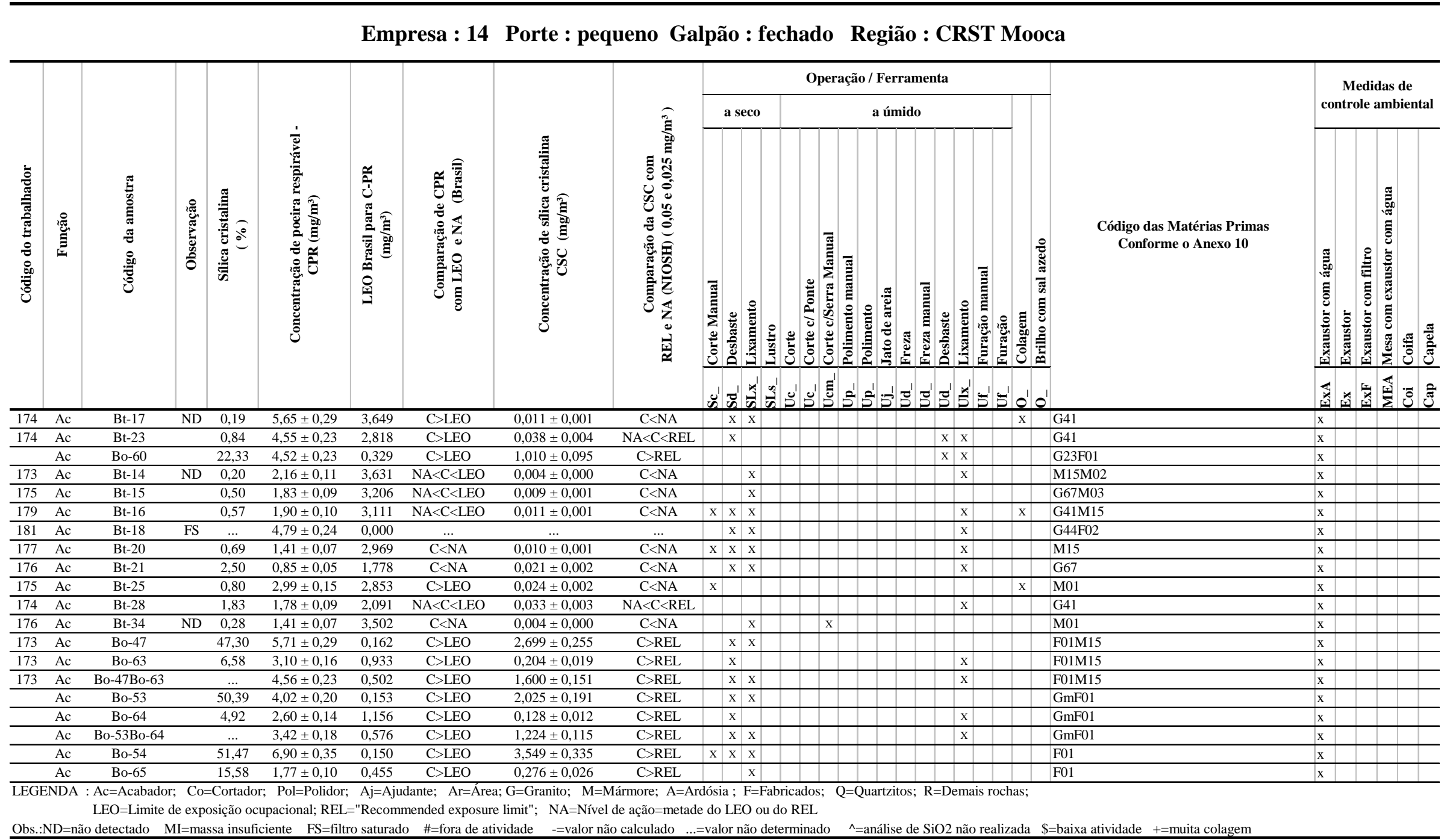

\section{Continua}


Tabela 11.13 - Concentração de poeira e de sílica cristalina respirável e informações complementares da Empresa 14

\section{Empresa : 14 Porte : pequeno Galpão : fechado Região : CRST Mooca}

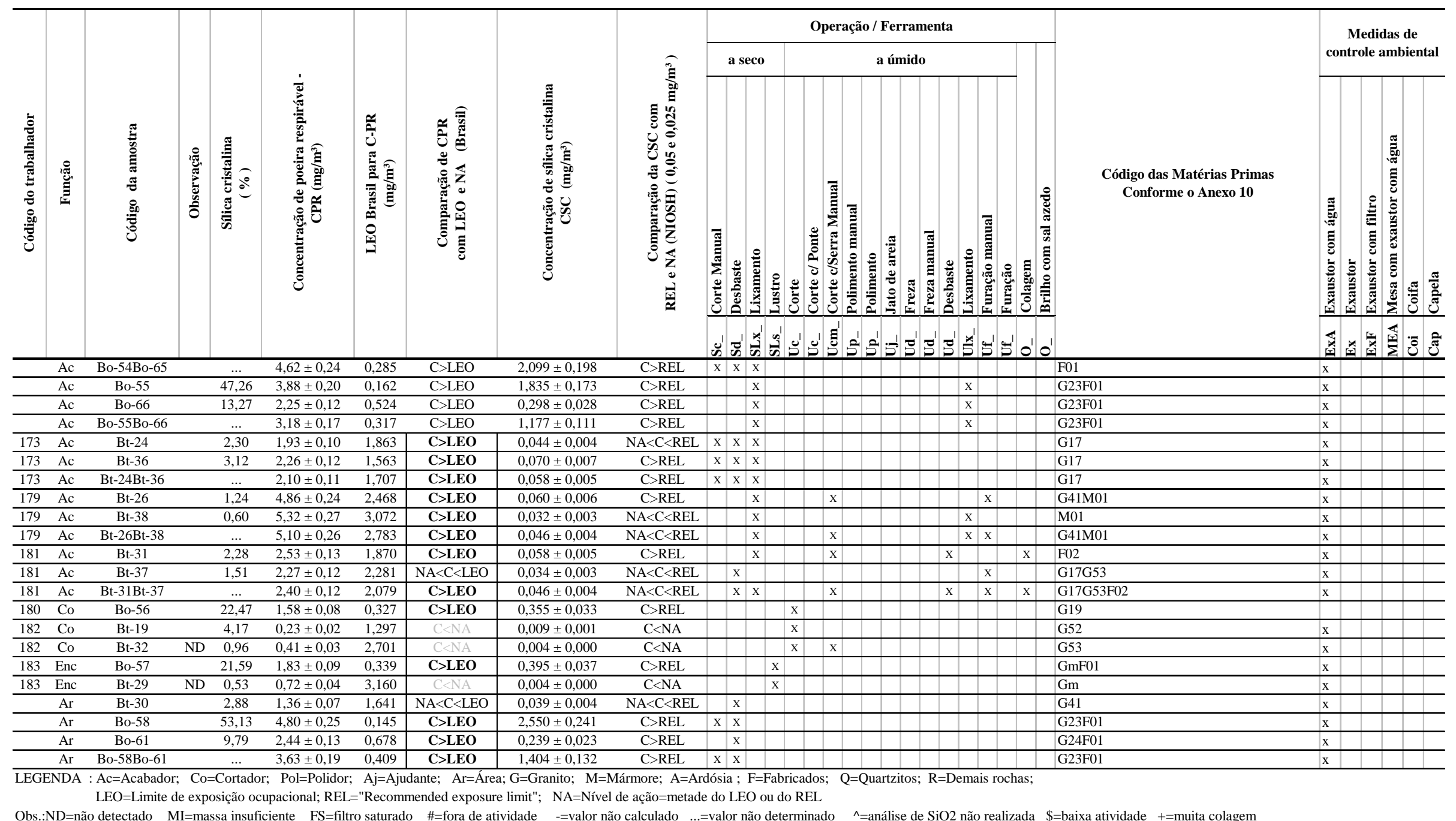


Empresa : 14 Porte : pequeno Galpão : fechado Região : CRST Mooca

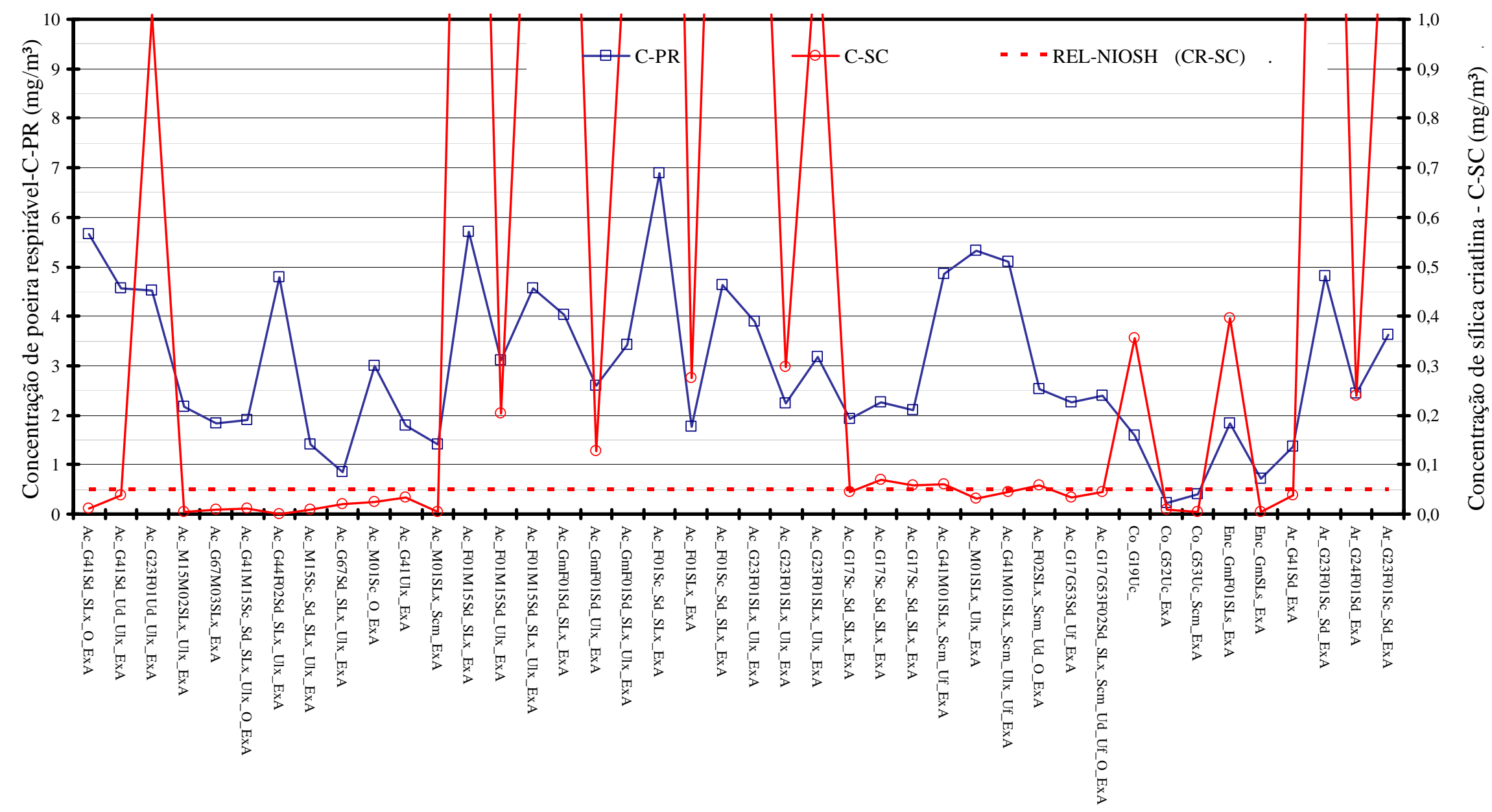

Figura A11.13 - Concentração de poeira respirável e sílica cristalina com respectiva etapa do processo (conf.Tabela A11.13) 
Tabela A11.14 - Concentração de poeira e de sílica cristalina respirável e informações complementares da Empresa 15. Marmorarias, Município de São Paulo, 2004-2005

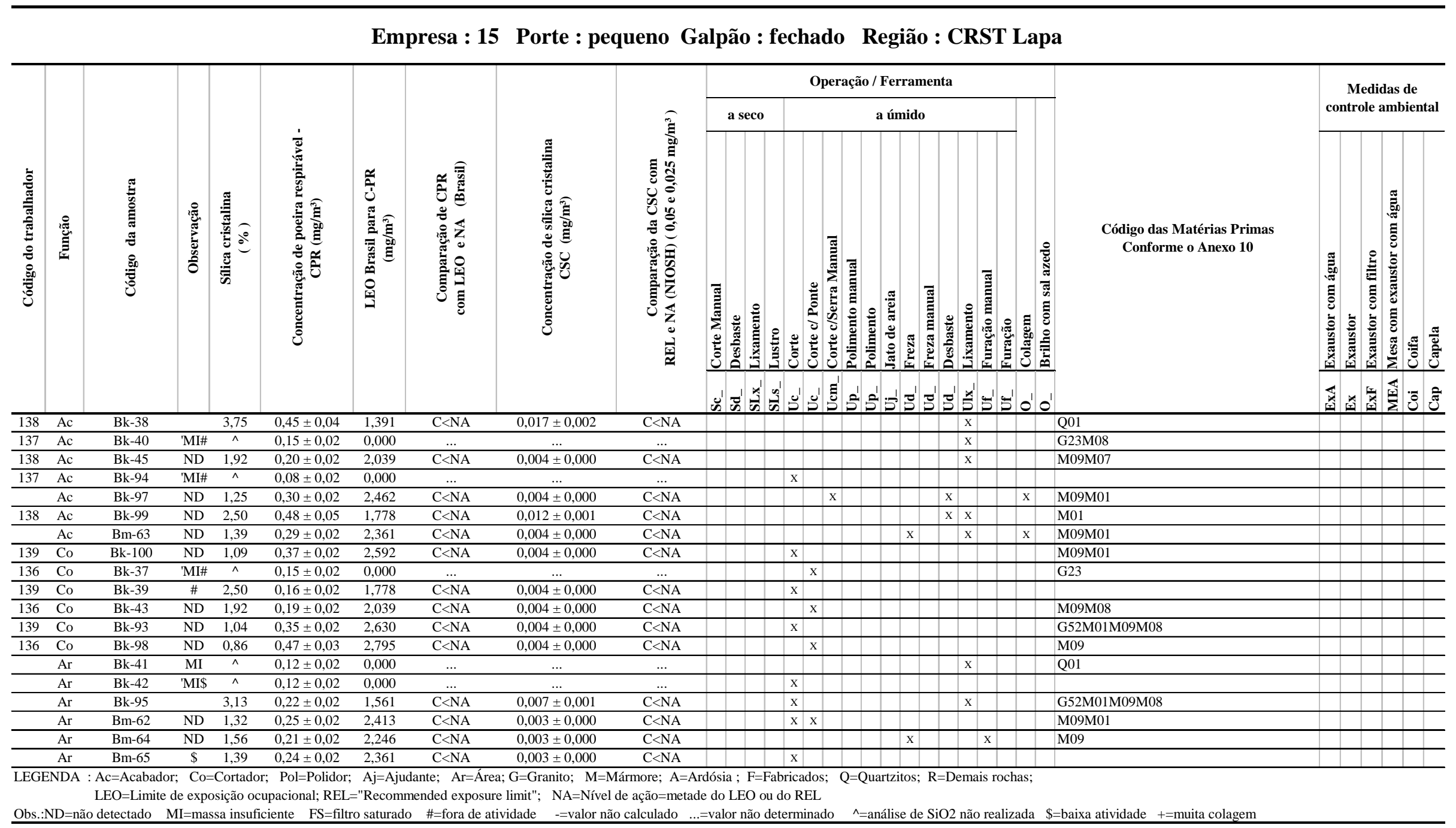


Empresa : 15 Porte : pequeno Galpão : fechado Região : CRST Lapa

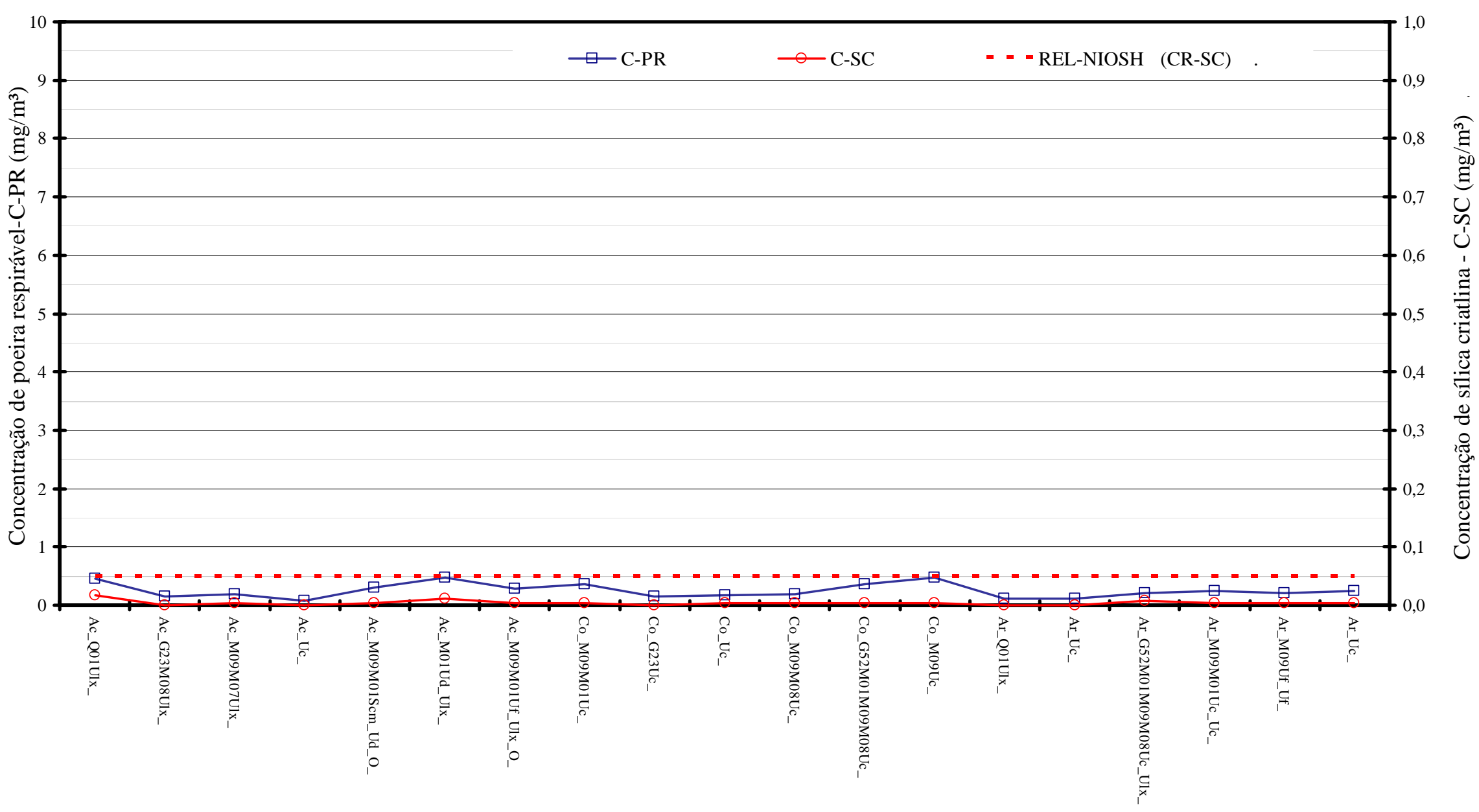

Figura A11.14: Concentração de poeira respirável e sílica cristalina com respectiva etapa do processo (conf.Tabela A11.14) 
Tabela A11.15 - Concentração de poeira e de sílica cristalina respirável e informações complementares da Empresa 16. Marmorarias, Município de São Paulo, 2004-2005

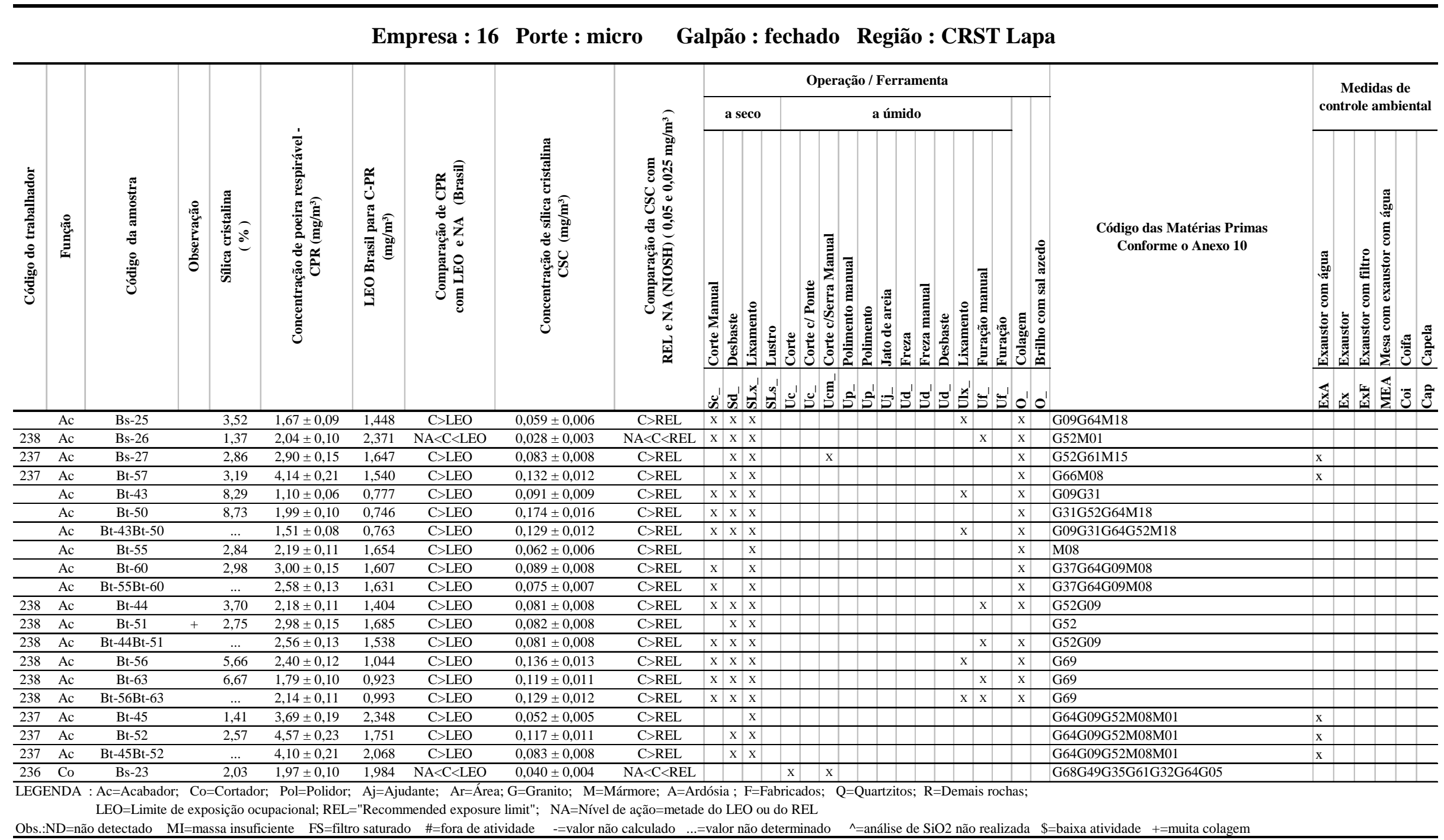

Obs.:ND=não detectado MI=massa insuficiente $\quad$ FS=filtro saturado $\quad$ \#=fora de atividade $\quad$-=valor não calculado $\quad . .=$ =valor não determinado $\quad \wedge=$ análise de SiO2 não realizada $\$=$ baixa atividade $\quad+=$ muita colagem

\section{Continua}


Tabela A11.15 - Concentração de poeira e de sílica cristalina respirável e informações complementares da Empresa 16

Empresa : 16 Porte : micro Galpão : fechado Região : CRST Lapa

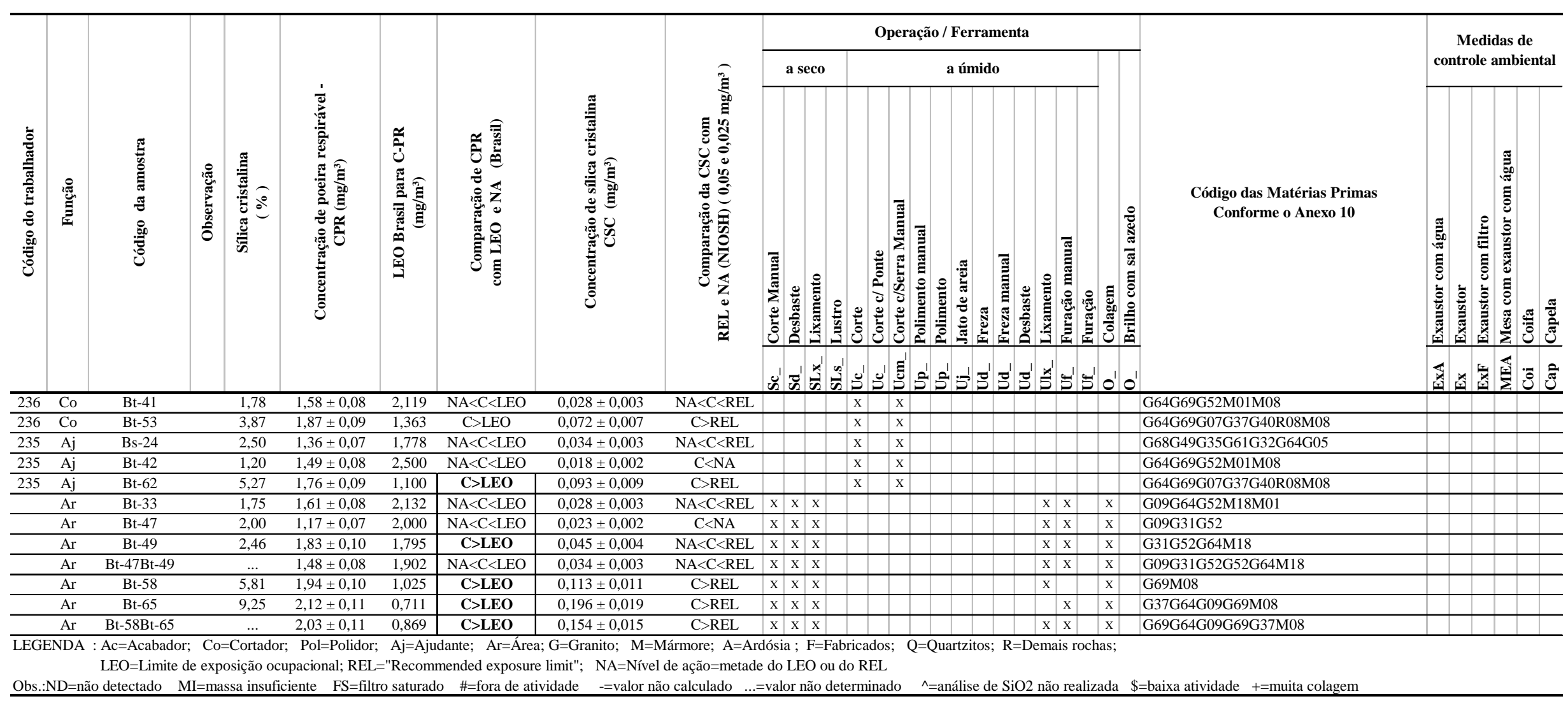


Empresa : 16 Porte : micro

Galpão : fechado Região : CRST Lapa

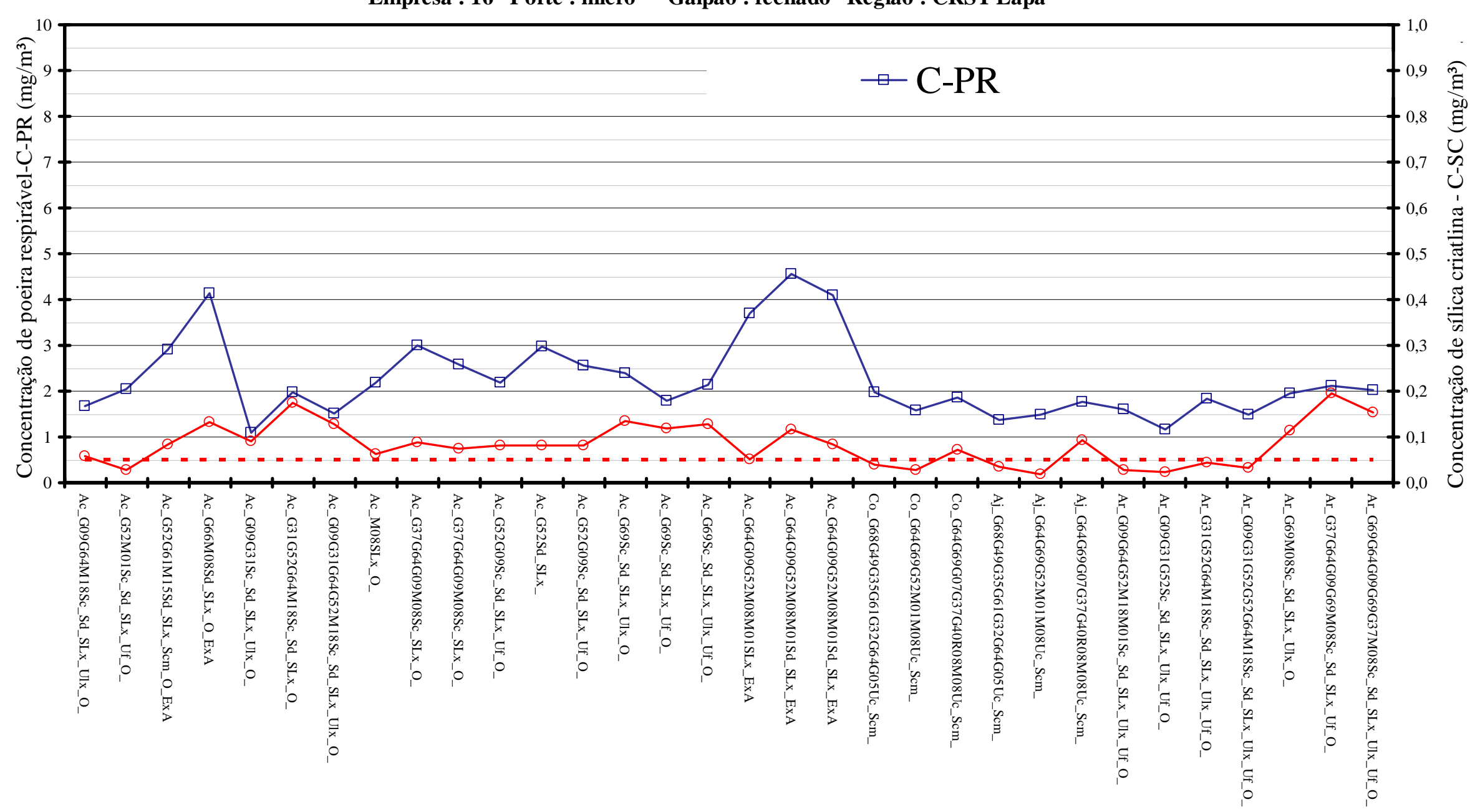

Figura A11.15 - Concentração de poeira respirável e sílica cristalina com respectiva etapa do processo (conf.Tabela A11.15) 
Tabela A11.16 - Concentração de poeira e de sílica cristalina respirável e informações complementares da Empresa 17. Marmorarias, Município de São Paulo, 2004-2005

Empresa : 17 Porte : grande Galpão : fechado Região : CRST Freg.do Ó

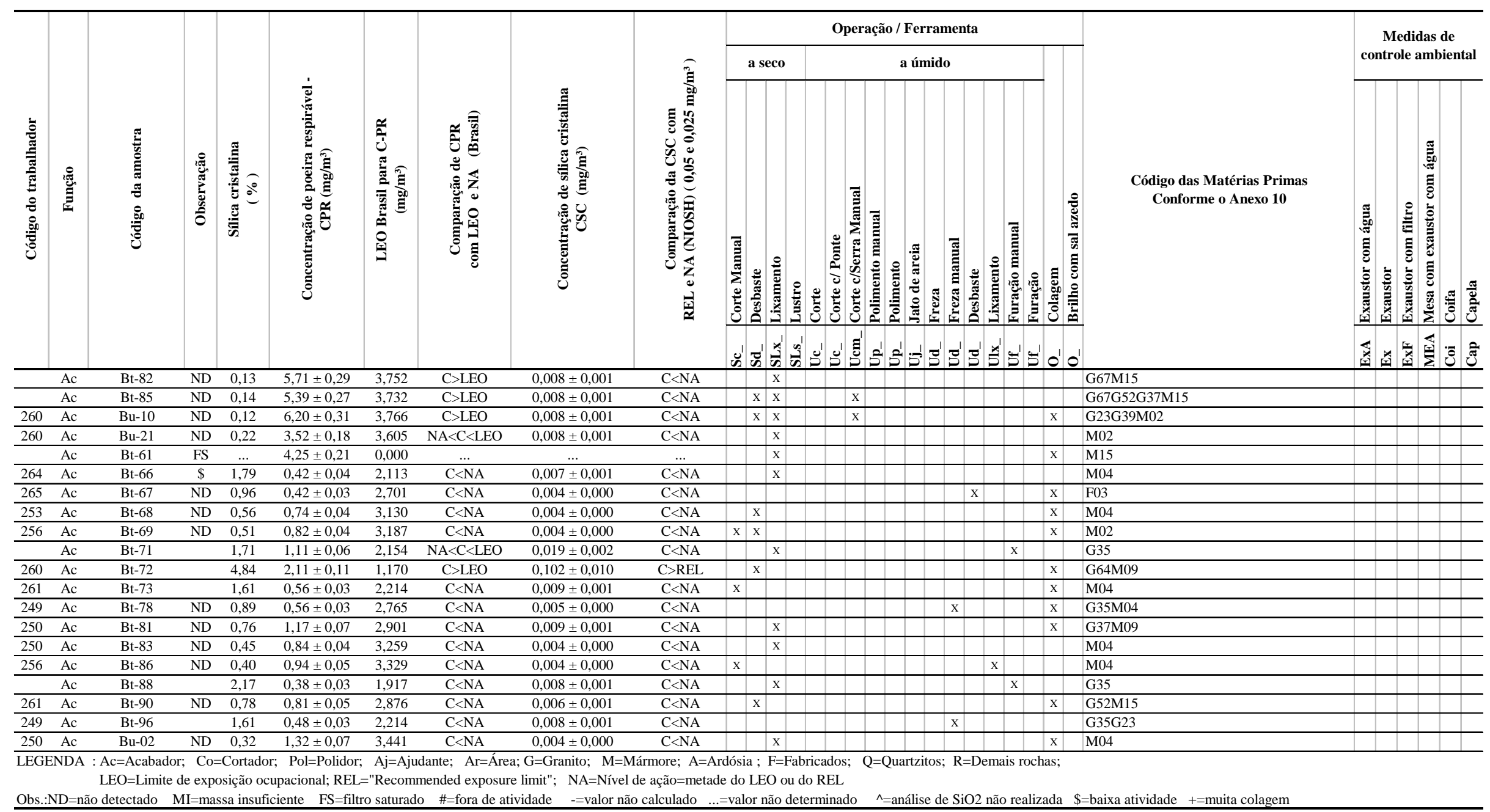

Obs.:ND=não detectado $\quad \mathrm{MI}=$ =massa insuficiente $\quad \mathrm{FS}=$ filtro saturado $\quad$ \#=fora de atividade $\quad-=$ =valor não calculado $\quad . . .=$ valor não determinado $\quad \wedge=$ análise de $\mathrm{SiO} 2$ não realizada $\$=$ =baixa atividade + +=muita colagem 
Tabela A11.16 - Concentração de poeira e de sílica cristalina respirável e informações complementares da Empresa 17

Empresa : 17 Porte : grande Galpão : fechado Região : CRST Freg.do Ó

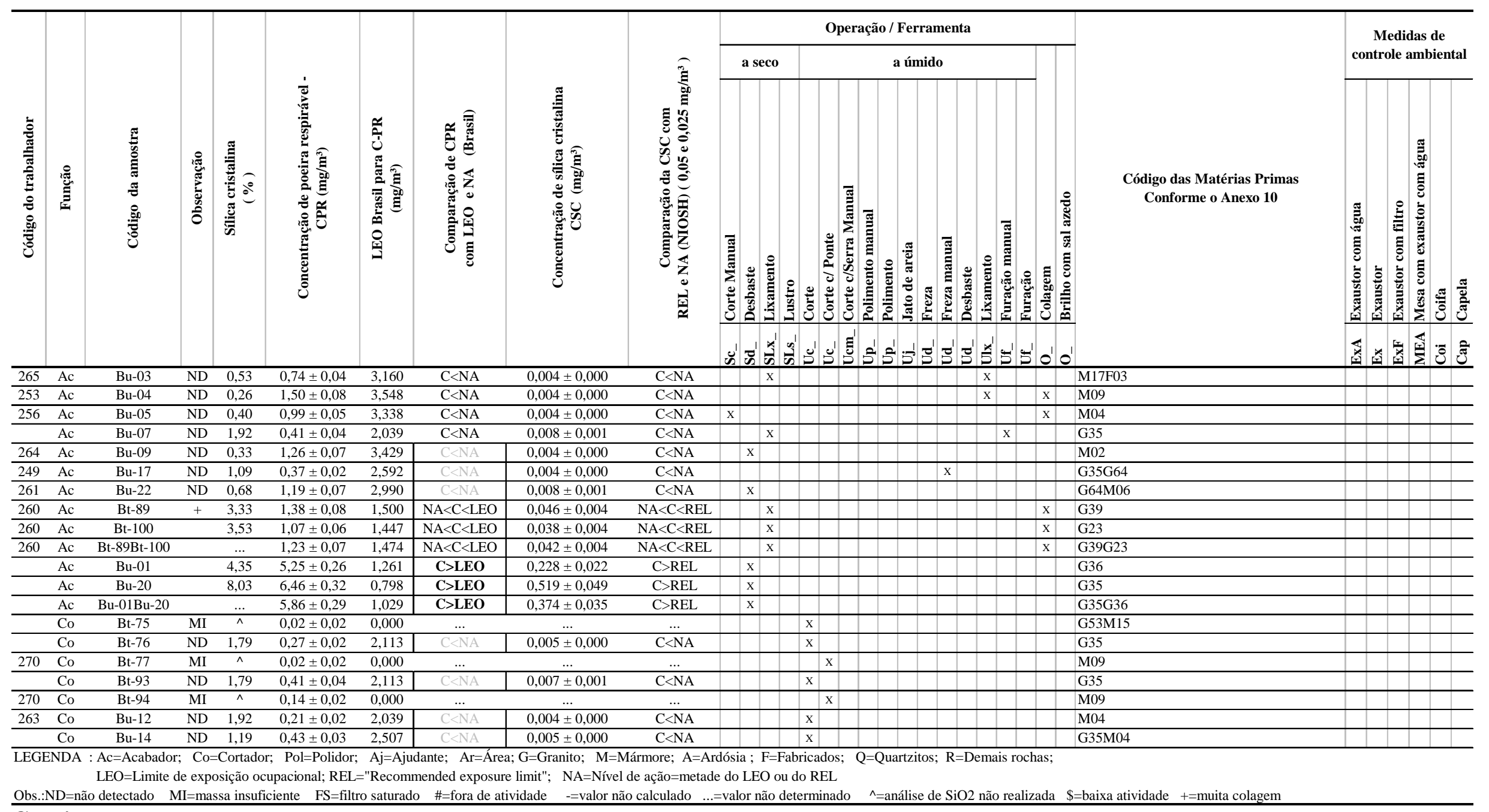

Obs.:ND=não detectado $\quad \mathrm{MI}=$ =massa insuficiente $\quad \mathrm{FS}=$ filtro saturado $\quad$ \#=fora de atividade $\quad$-=valor não calculado $\quad . .=$ =valor não determinado $\quad \wedge=$ análise de SiO2 não realizada $\$=$ =baixa atividade $\quad+=$ muita colagem

\section{Continua}


Tabela A11.16 - Concentração de poeira e de sílica cristalina respirável e informações complementares da Empresa 17

Empresa : 17 Porte : grande Galpão : fechado Região : CRST Freg.do Ó

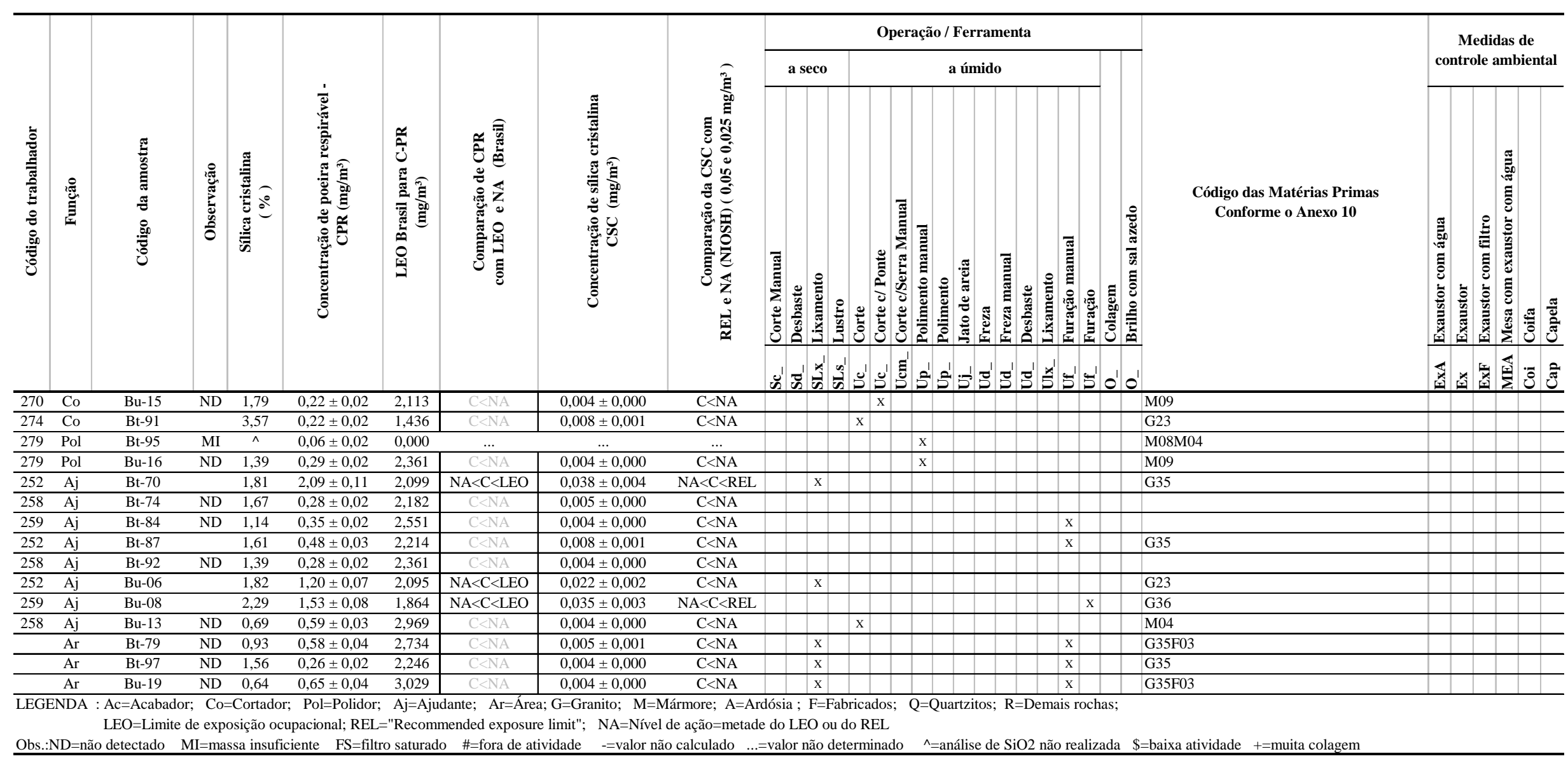


Empresa : 17 Porte : grande Galpão : fechado Região : CRST Freg.do Ó

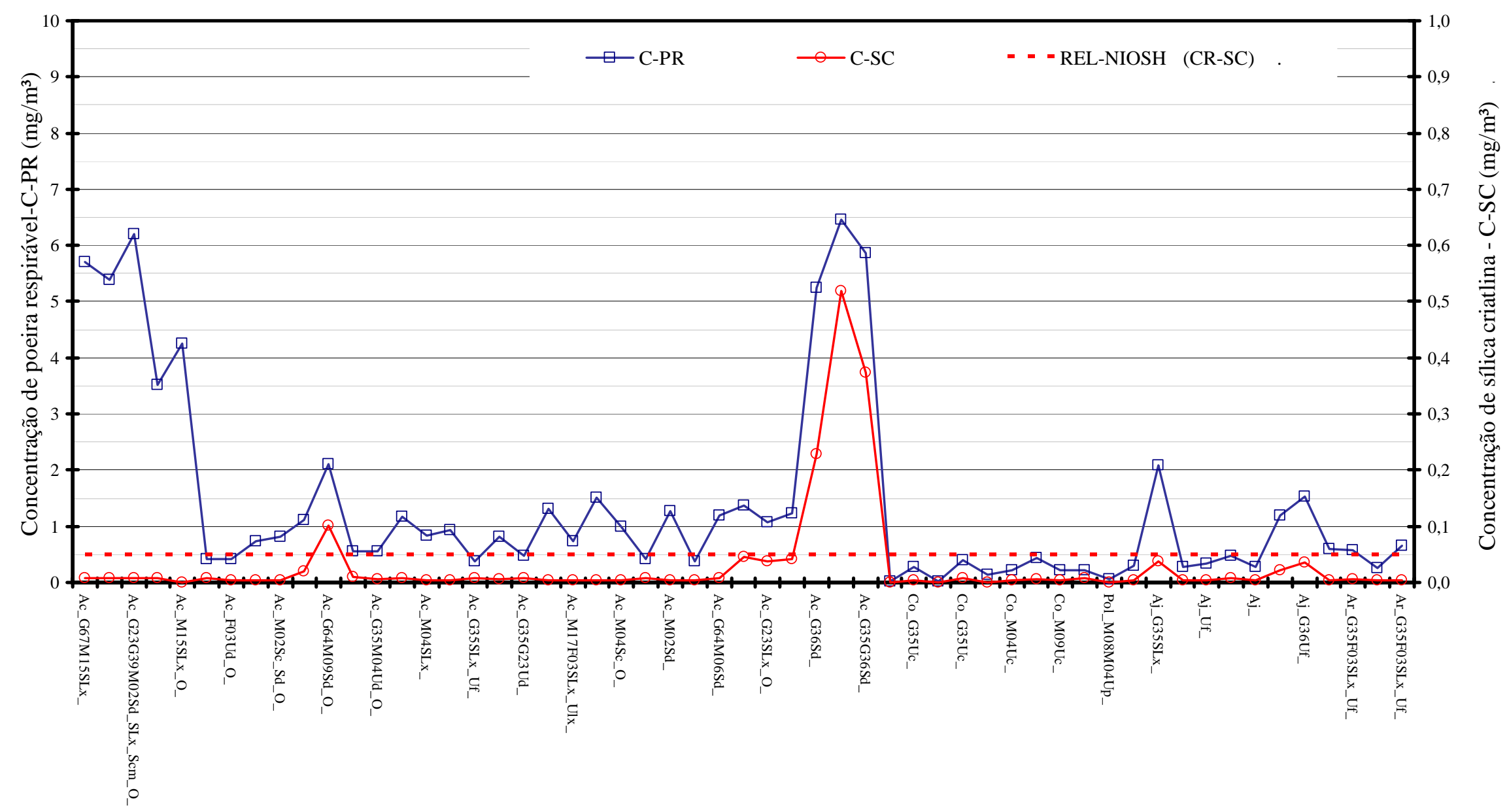

Figura A11.16: Concentração de poeira respirável e sílica cristalina com respectiva etapa do processo (conf.Tabela A11.16) 
Tabela A11.17 - Concentração de poeira e de sílica cristalina respirável e informações complementares da Empresa 18. Marmorarias, Município de São Paulo, 2004-2005

Empresa : 18 Porte : medio Galpão : fechado Região : CRST Freg.do Ó

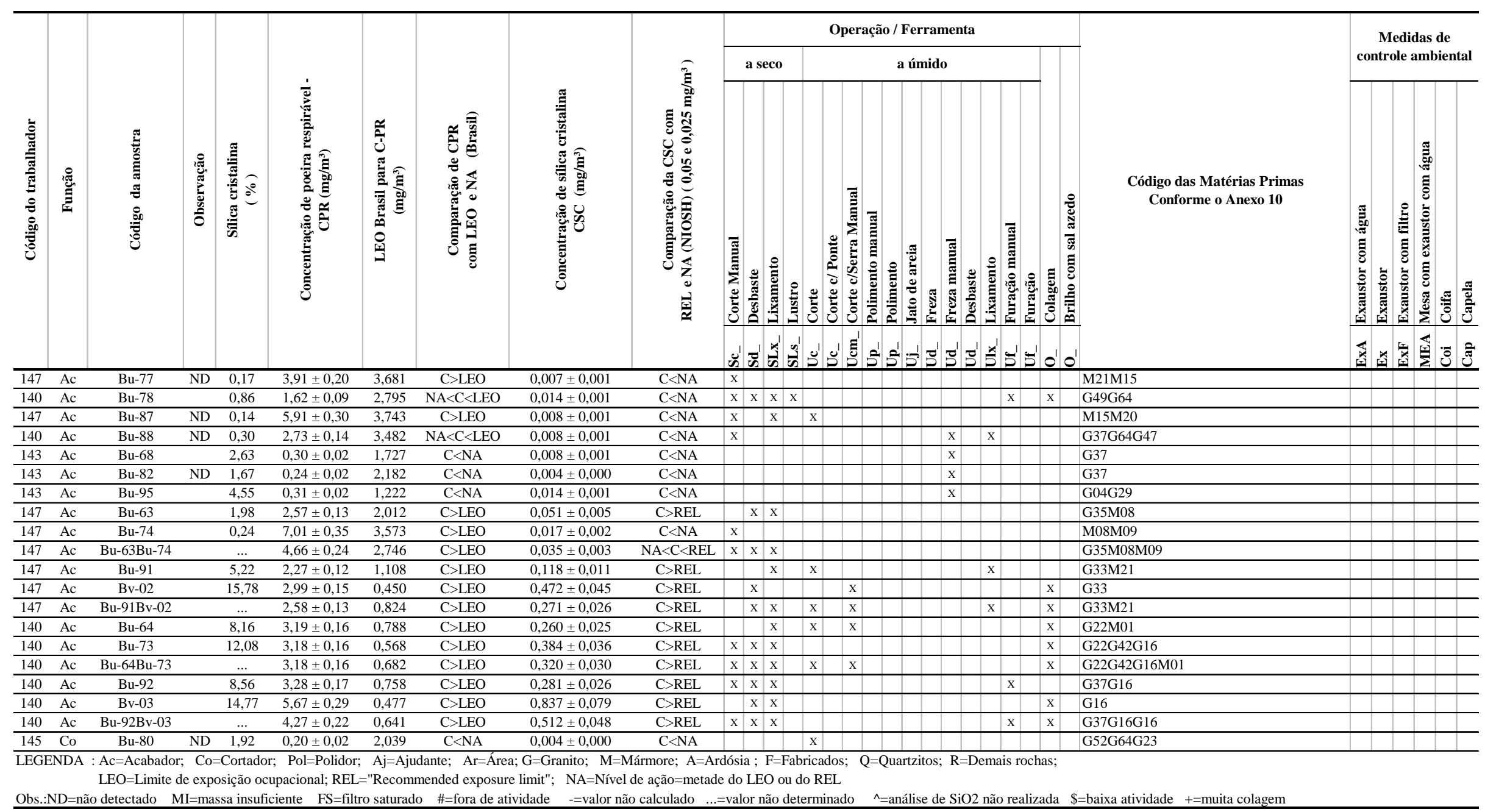

Obs.:ND=não detectado $\quad$ MI=massa insuficiente $\quad \mathrm{FS}=$ filtro saturado $\quad$ \#=fora de atividade $\quad-=$ =valor não calculado $\quad . .=$ =valor não determinado $\quad \Lambda=$ análise de SiO2 não realizada $\$=$ =baixa atividade $+=$ =muita colagem

Continua 
Tabela A11.17 - Concentração de poeira e de sílica cristalina respirável e informações complementares da Empresa 18

\section{Empresa : 18 Porte : medio Galpão : fechado Região : CRST Freg.do Ó}

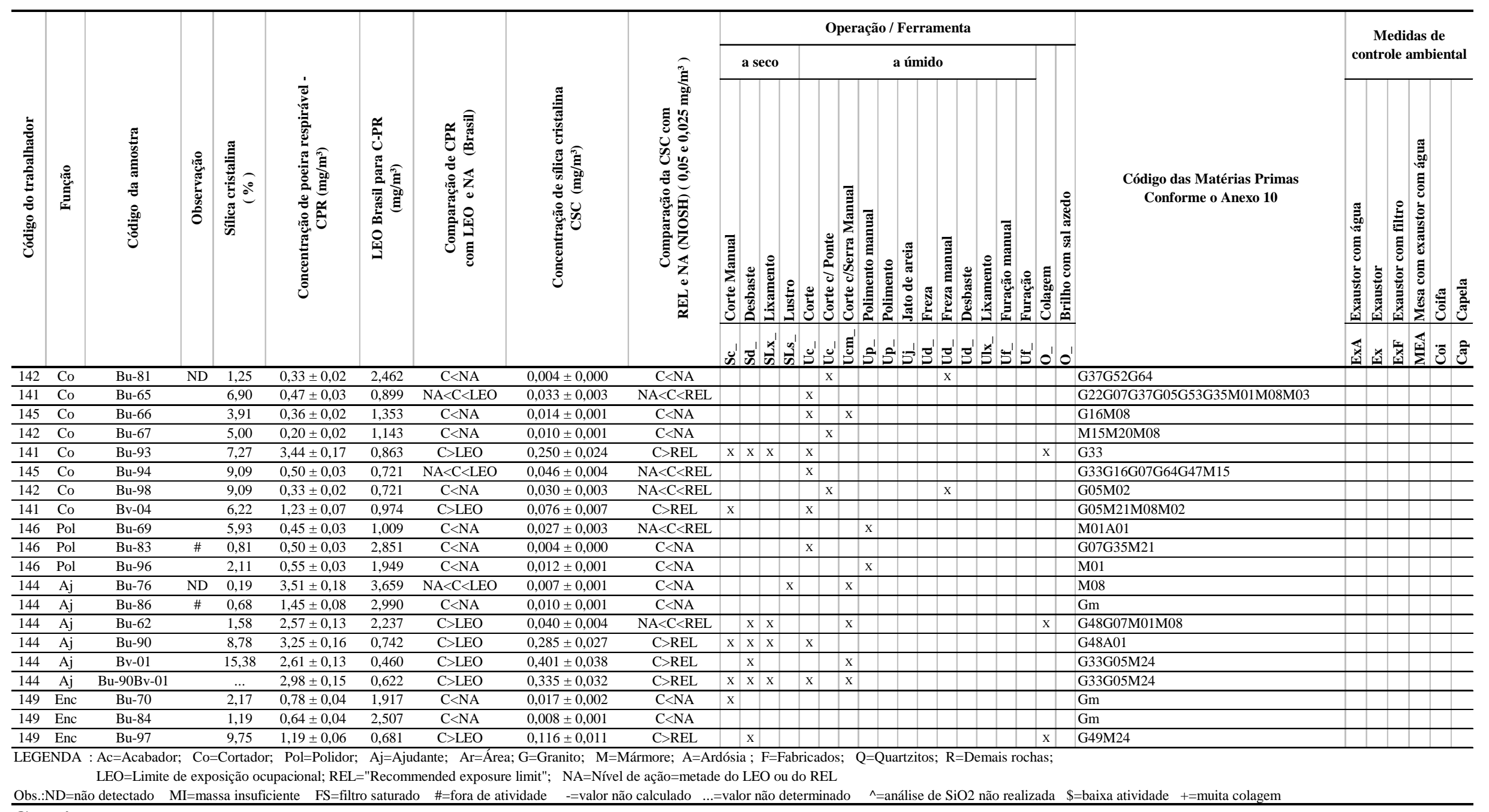

Obs.:ND=não detectado $\quad$ MI=massa insuficiente $\quad F S=$ filtro saturado \#=fora de atividade $\quad$-=valor não calculado $\quad$...=valor não determinado $\quad \wedge=$ =análise de SiO2 não realizada $\$=$ baixa atividade $\quad+=$ muita colagem

\section{Continua}


Tabela A11.17 - Concentração de poeira e de sílica cristalina respirável e informações complementares da Empresa 18

Empresa : 18 Porte : medio Galpão : fechado Região : CRST Freg.do Ó

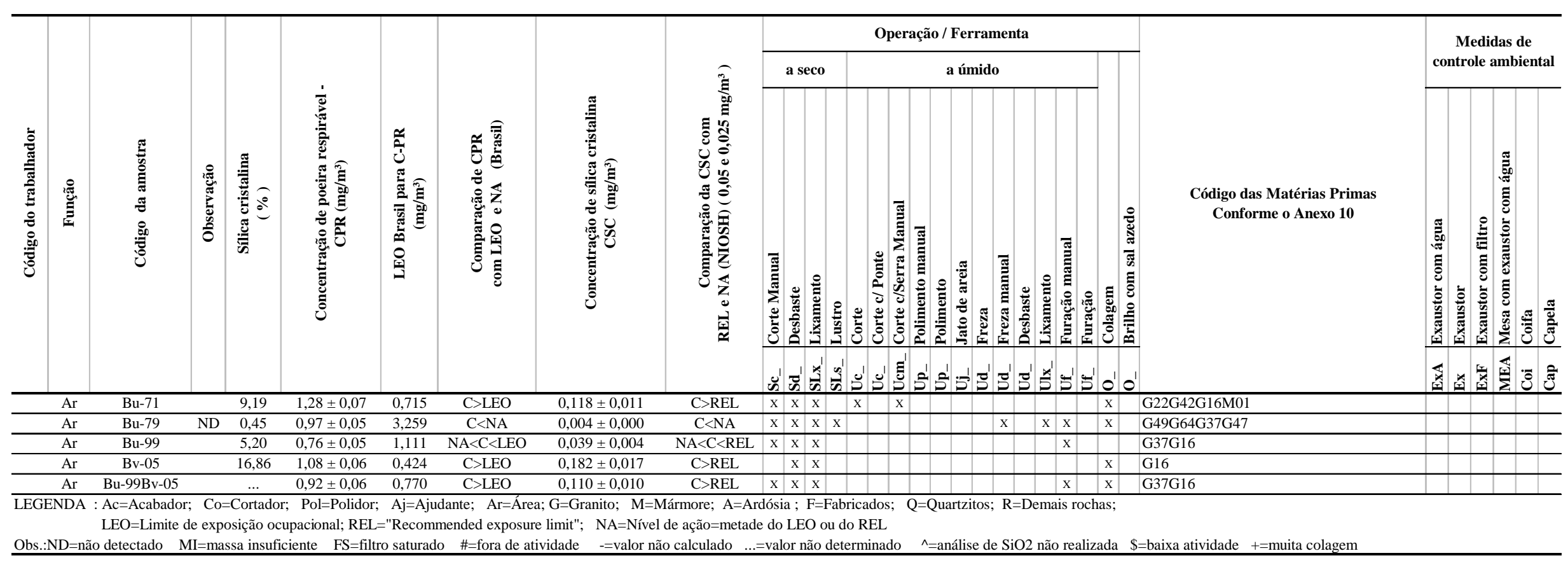


Empresa : 18 Porte : medio Galpão : fechado Região : CRST Freg.do Ó

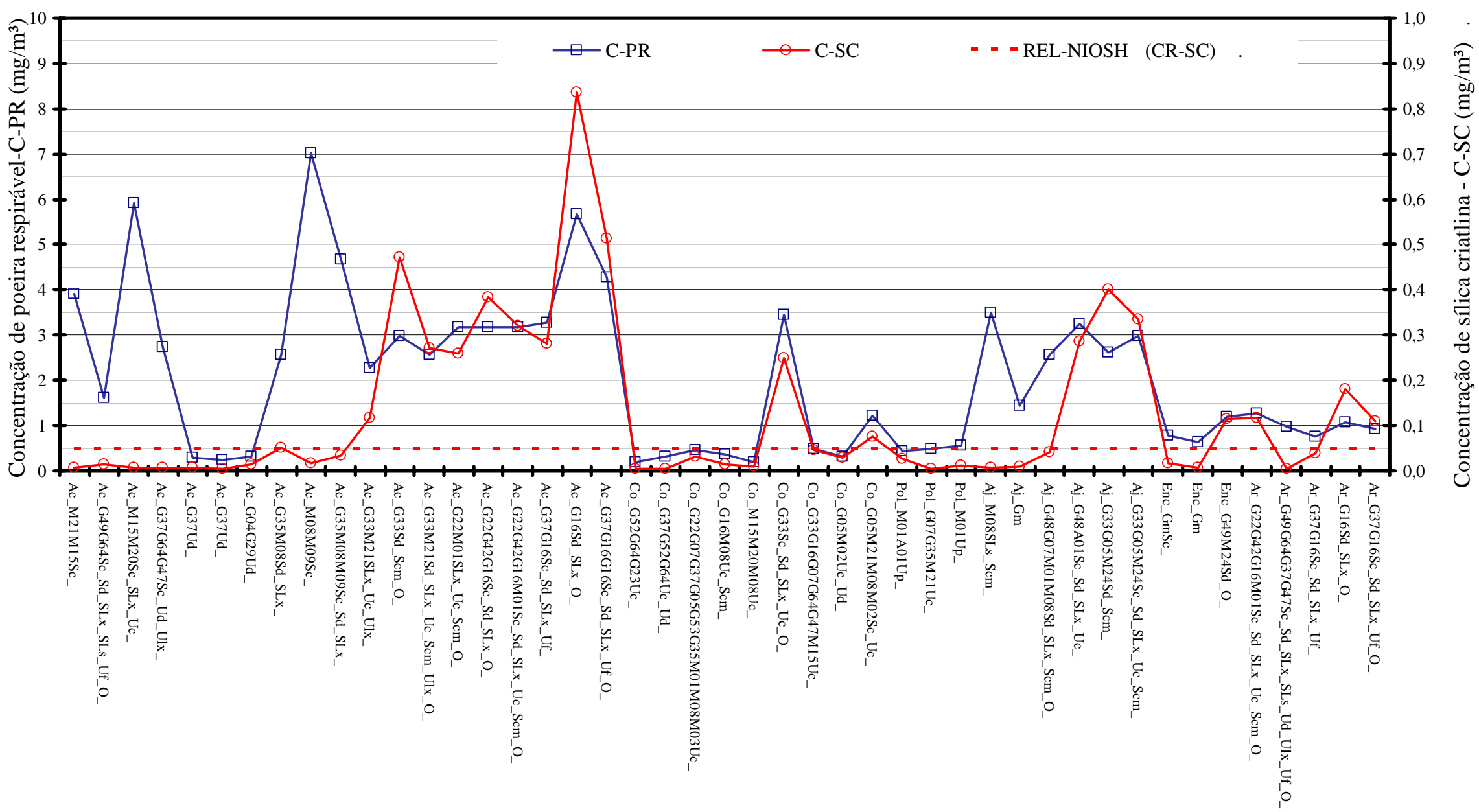

Figura A11.17 - Concentração de poeira respirável e sílica cristalina com respectiva etapa do processo (conf.Tabela A11.17) 
Tabela A11.18 - Concentração de poeira e de silica cristalina respirável e informações complementares da Empresa 19. Marmorarias, Município de São Paulo, 2004-2005

Empresa : 19 Porte : micro Galpão : semi-aberto Região : CRST Freg.do Ó

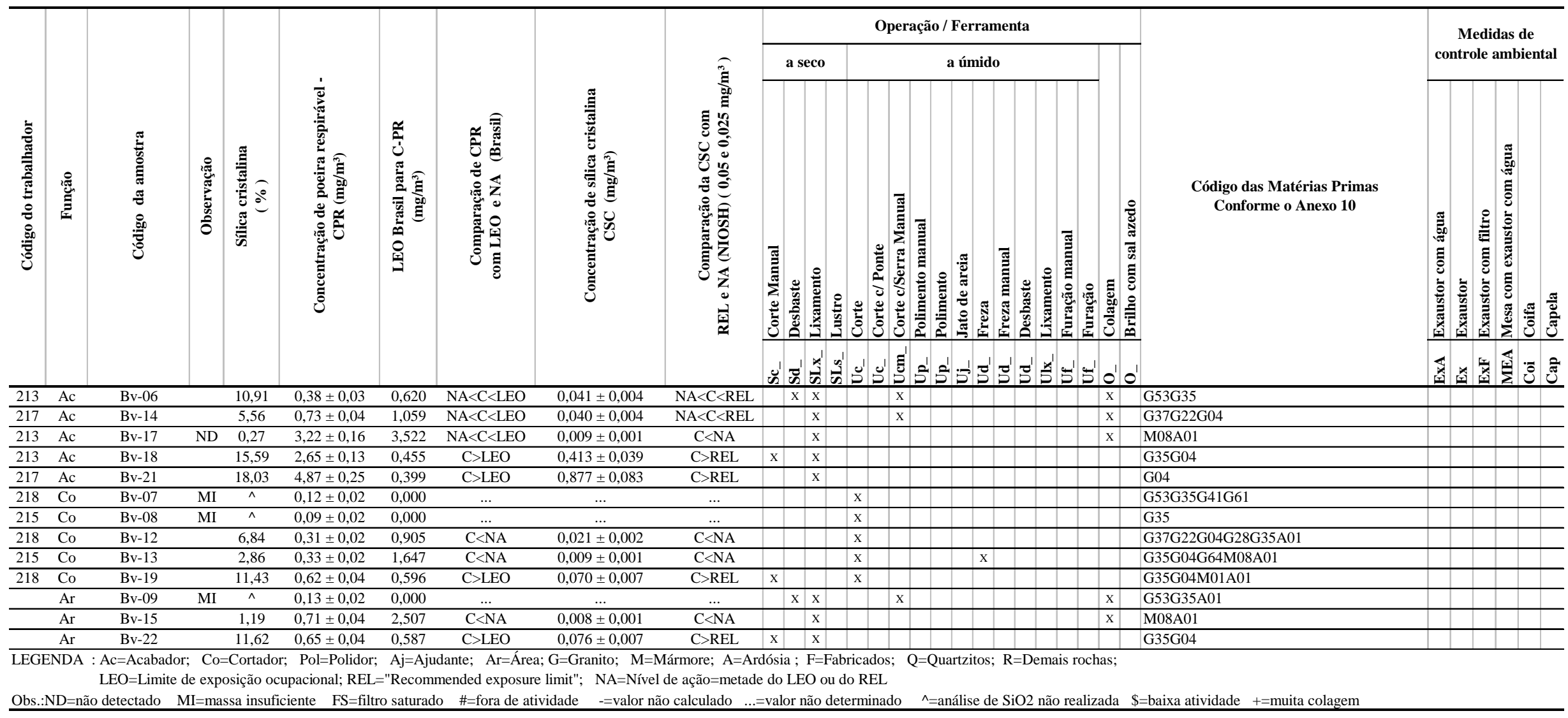


Empresa : 19 Porte : micro Galpão : semi-aberto Região : CRST Freg.do Ó

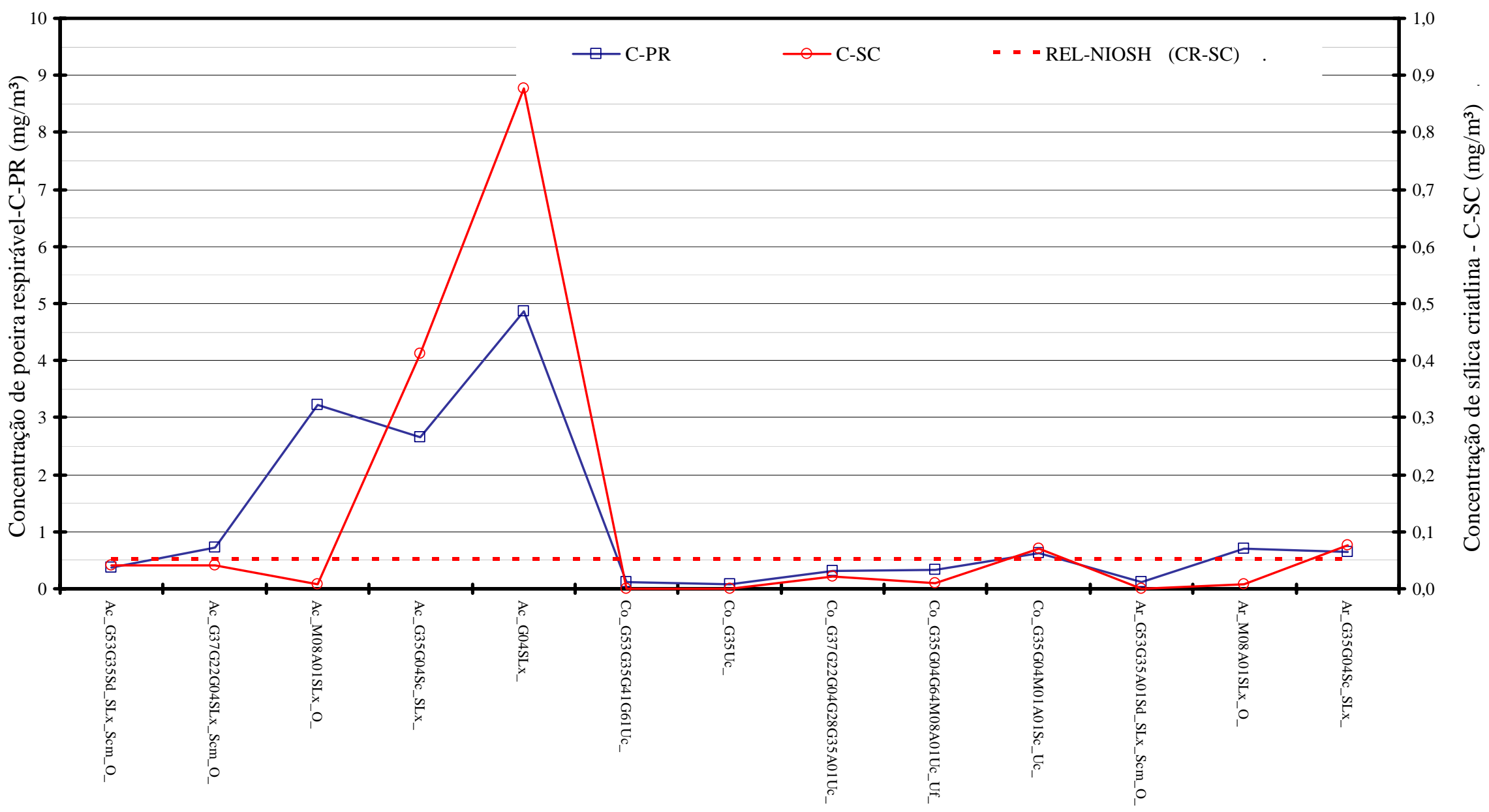

Figura A11.18 - Concentração de poeira respirável e sílica cristalina com respectiva etapa do processo (conf.Tabela A11.18) 
Tabela A11.19 - Concentração de poeira e de sílica cristalina respirável e informações complementares da Empresa 20. Marmorarias, Município de São Paulo, 2004-2005

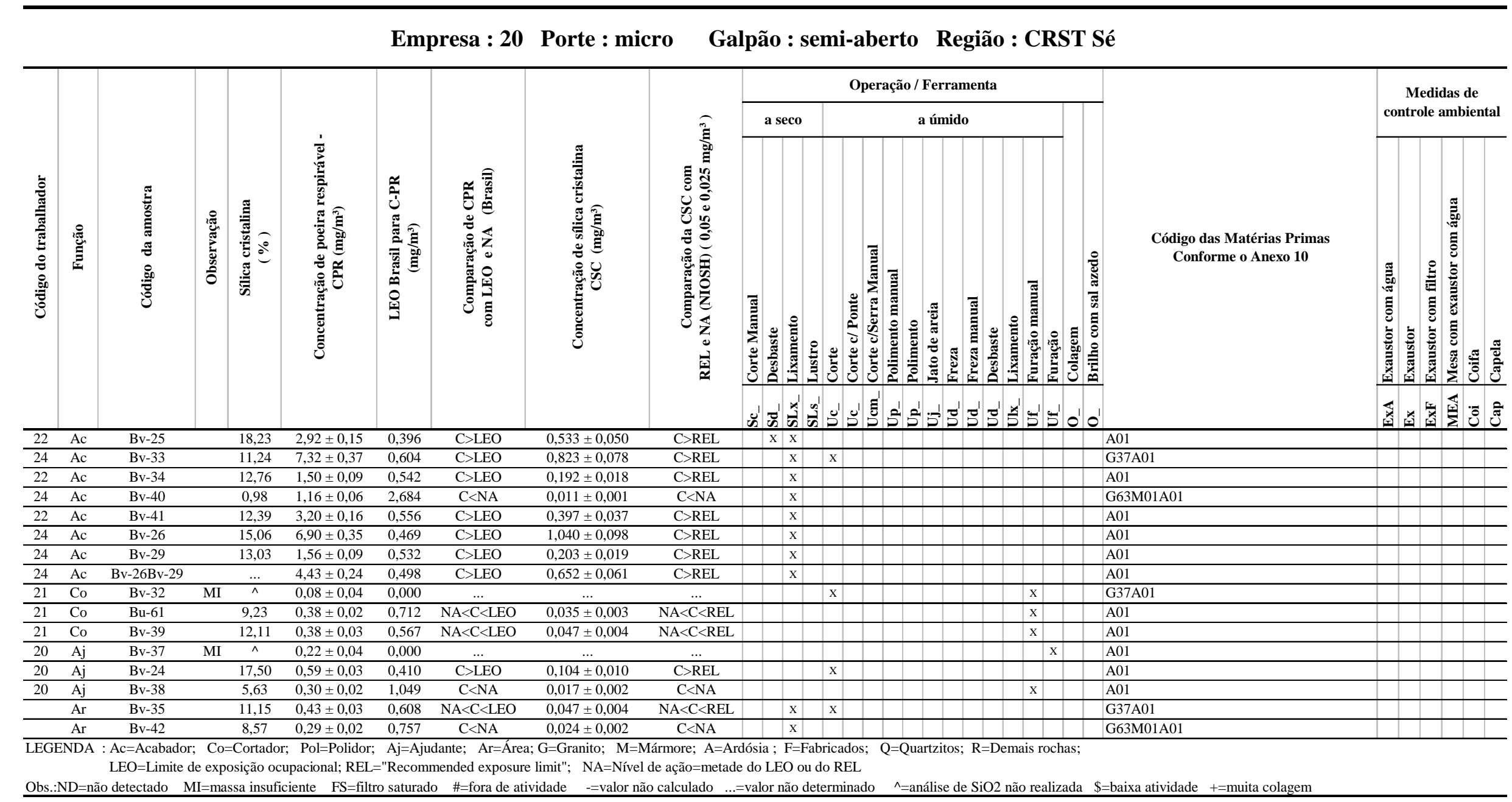


Empresa : 20 Porte : micro

Galpão : semi-aberto Região : CRST Sé

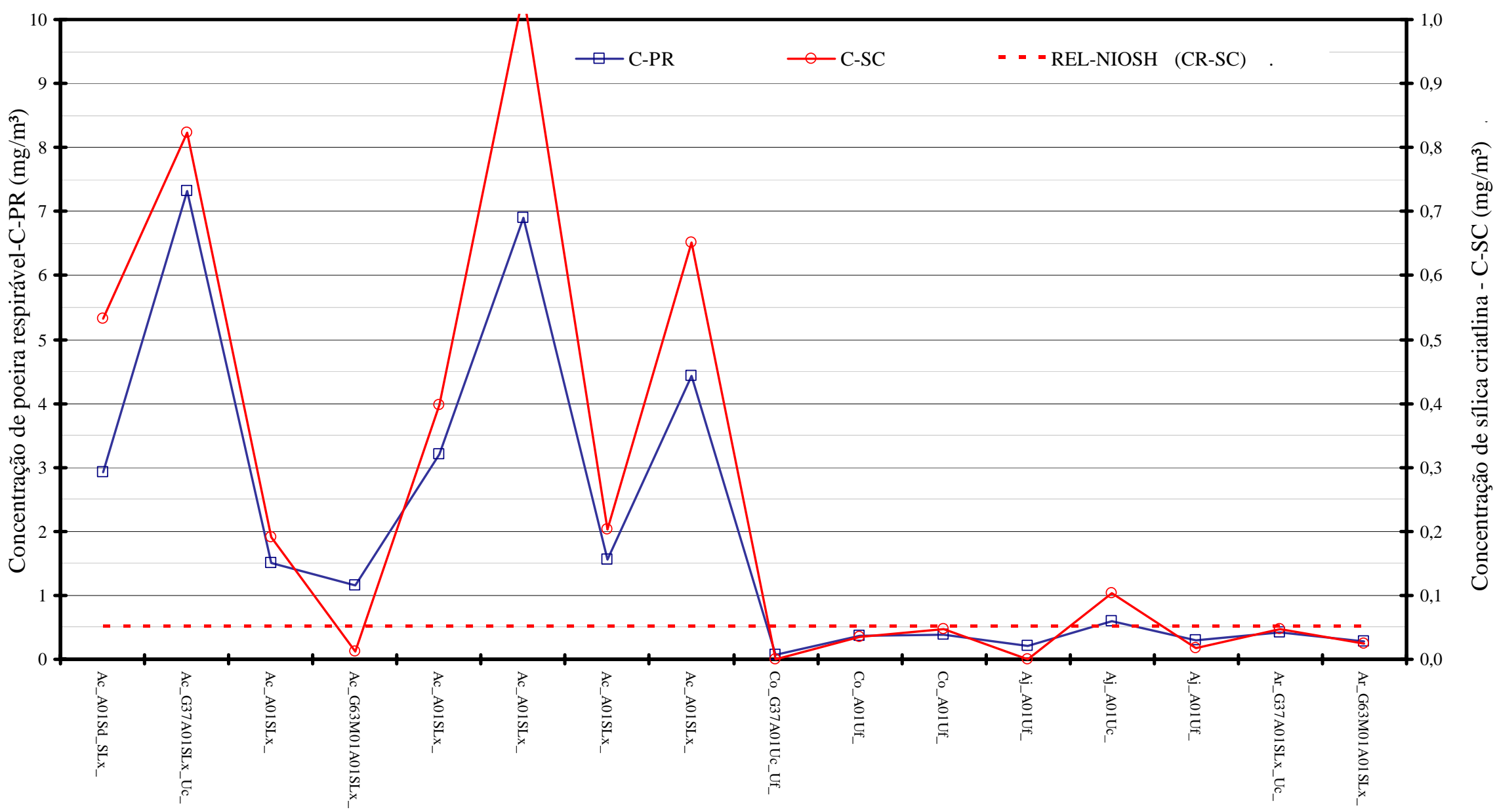

Figura A11.19 - Concentração de poeira respirável e sílica cristalina com respectiva etapa do processo (conf.Tabela A11.19) 
Tabela A11.20 - Concentração de poeira e de sílica cristalina respirável e informações complementares da Empresa 21. Marmorarias, Município de São Paulo, 2004-2005

Empresa : 21 Porte : micro Galpão : semi-aberto Região : CRST Freg.do Ó

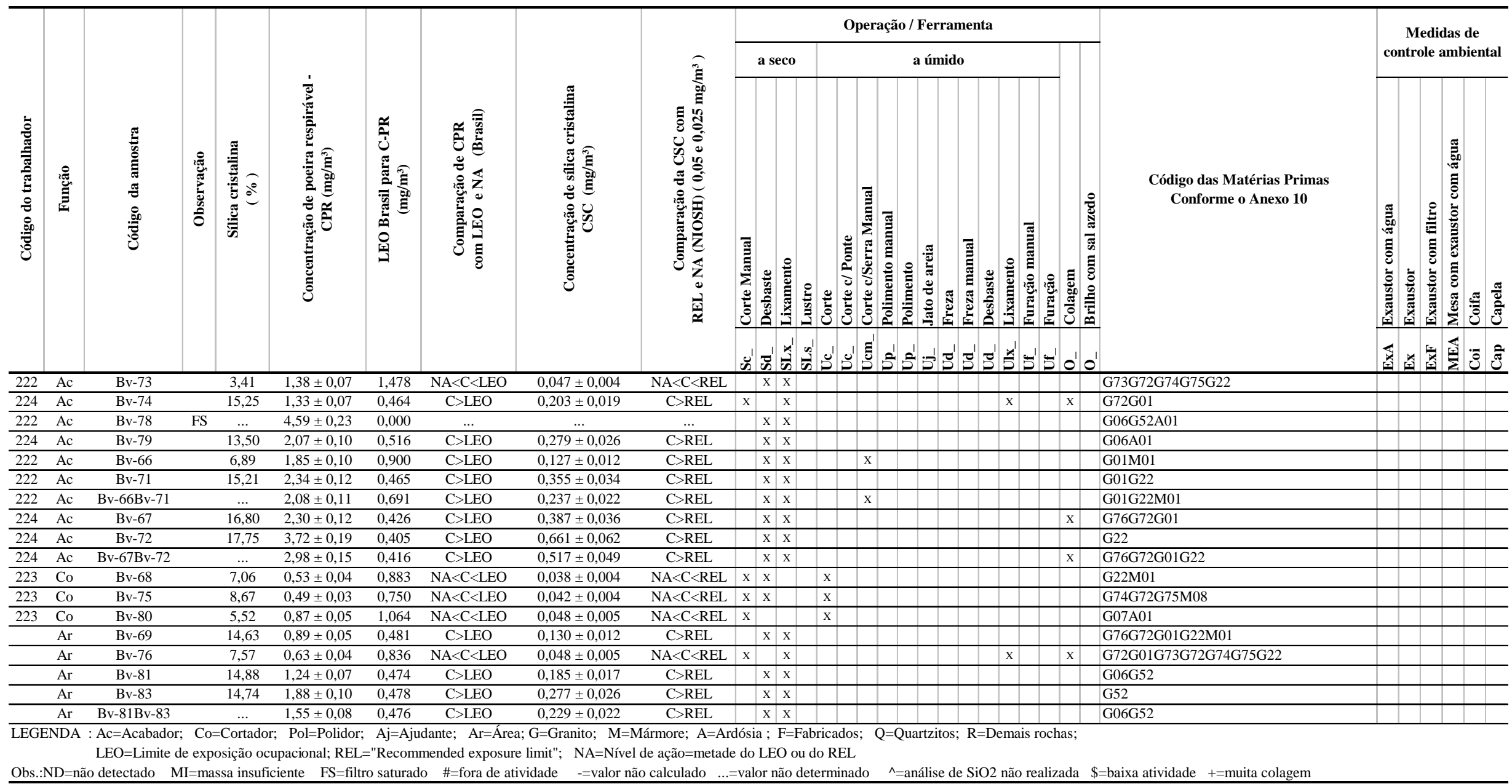


Empresa : 21 Porte : micro Galpão : semi-aberto Região : CRST Freg.do Ó

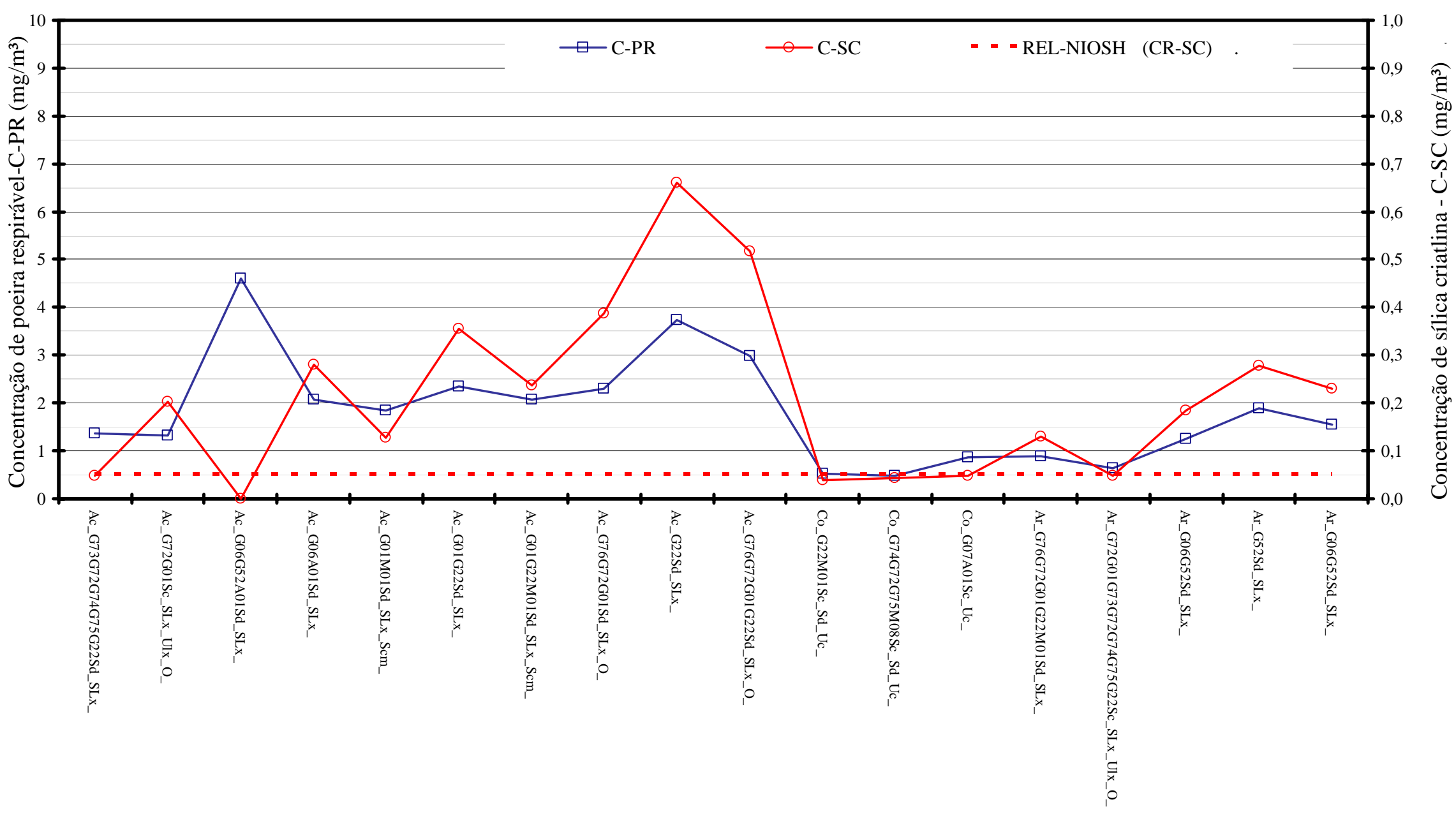

Figura A11.20 - Concentração de poeira respirável e sílica cristalina com respectiva etapa do processo (conf.Tabela A11.20) 
Tabela A11.21 - Concentração de poeira e de sílica cristalina respirável e informações complementares da Empresa 22. Marmorarias, Município de São Paulo, 2004-2005

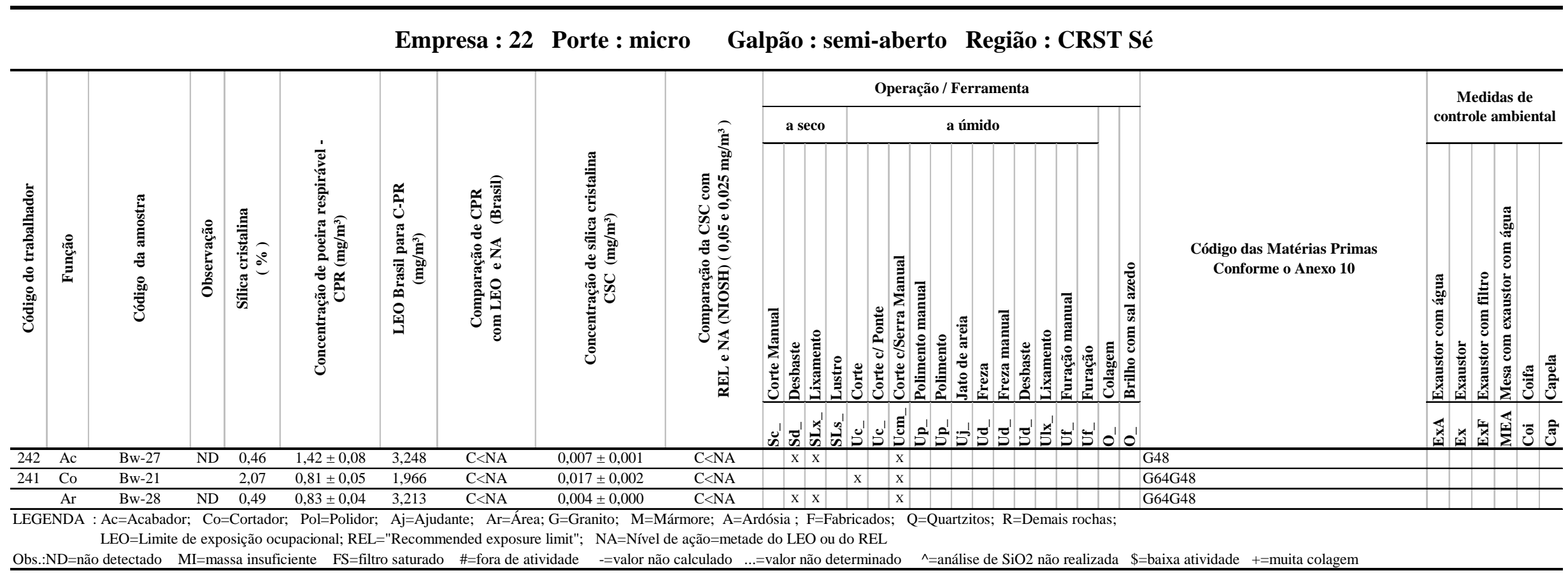


Empresa : 22 Porte : micro

Galpão : semi-aberto Região : CRST Sé

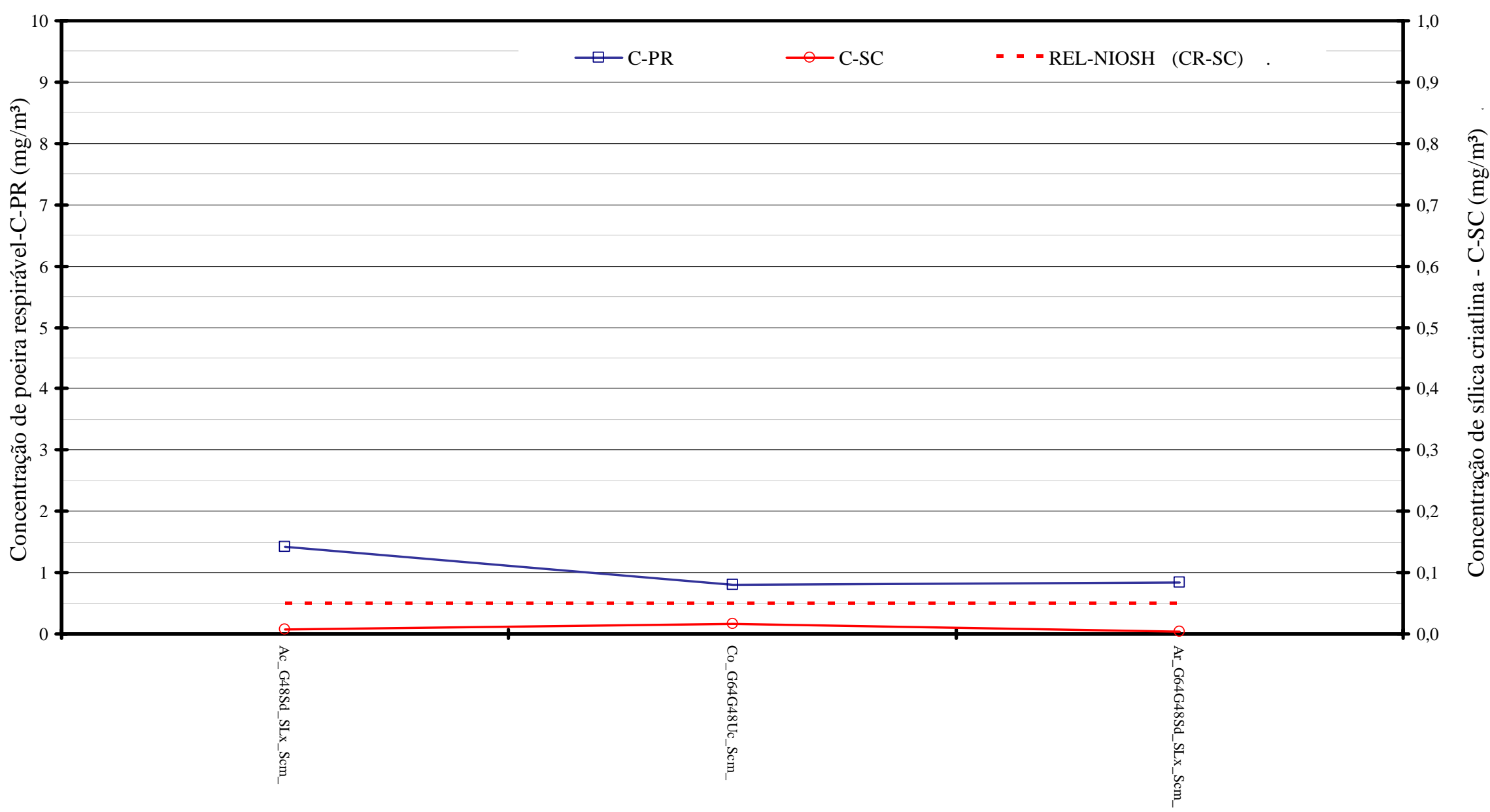

Figura A11.21 - Concentração de poeira respirável e sílica cristalina com respectiva etapa do processo (conf.Tabela A11.21) 
ANEXO 12

RESULTADOS DE ANÁLISE DE POEIRA E SÍLICA CRISTALINA RESPIRÁVEL E INFORMAÇÕES COMPLEMENTARES DO ESTUDO DE ALTERNATIVAS DE CONTROLE NAS MARMORARIAS ESTUDADAS. 
Tabela A12.1 - Concentração de poeira e de sílica cristalina respirável e informações complementares da Empresa M1. Marmorarias, Município de São Paulo, 2003-2005

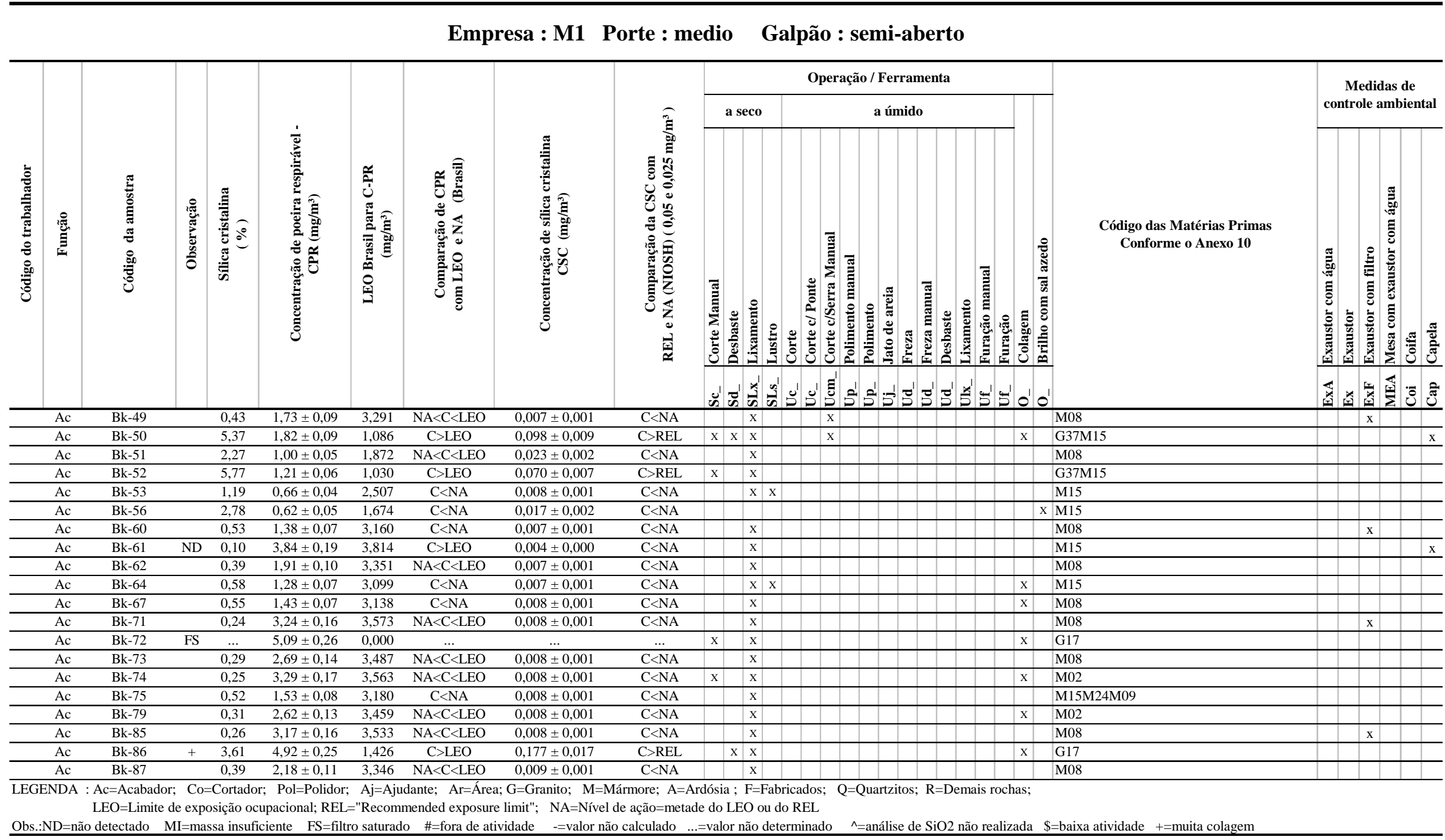

\section{Continua}


Tabela A12.1 - Concentração de poeira e de sílica cristalina respirável e informações complementares da Empresa M1

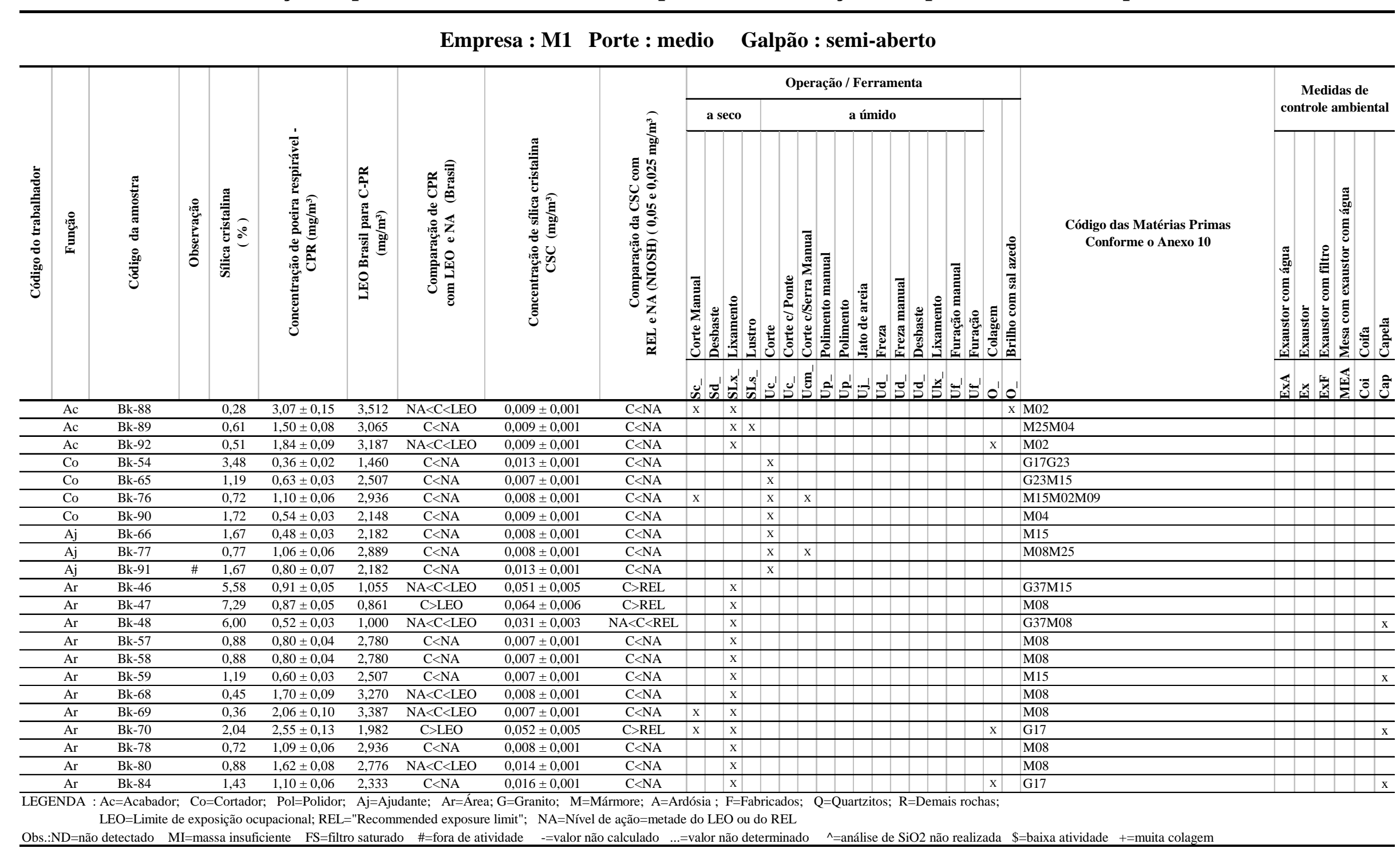




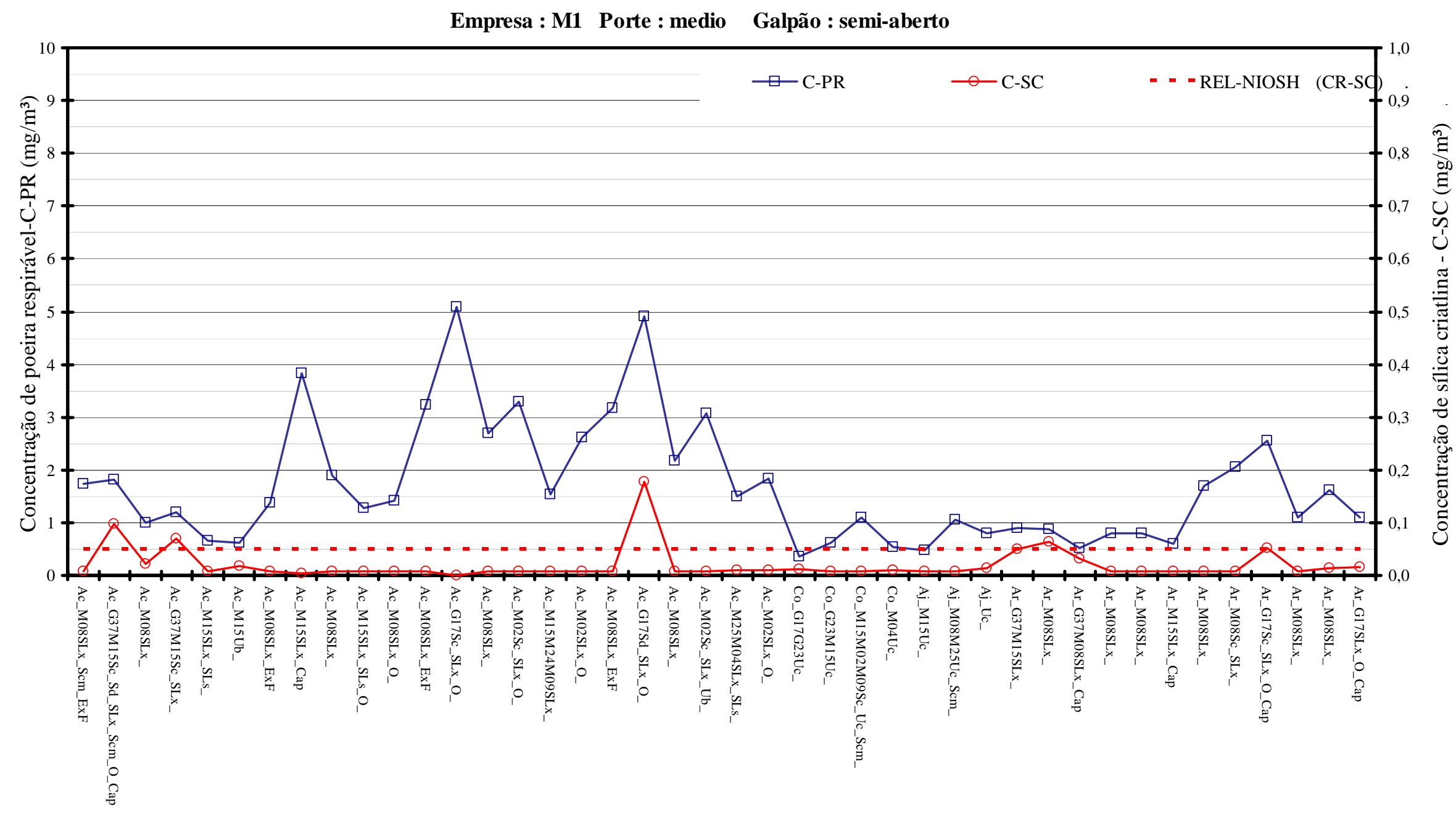

Figura A12.1: Concentração de poeira respirável e sílica cristalina com respectiva etapa do processo (conf.Tabela A12.1) 
Tabela A12.2 - Concentração de poeira e de sílica cristalina respirável e informações complementares da Empresa M2. Marmorarias, Município de São Paulo, 2003-2005

Empresa : M2 Porte : medio Galpão : aberto

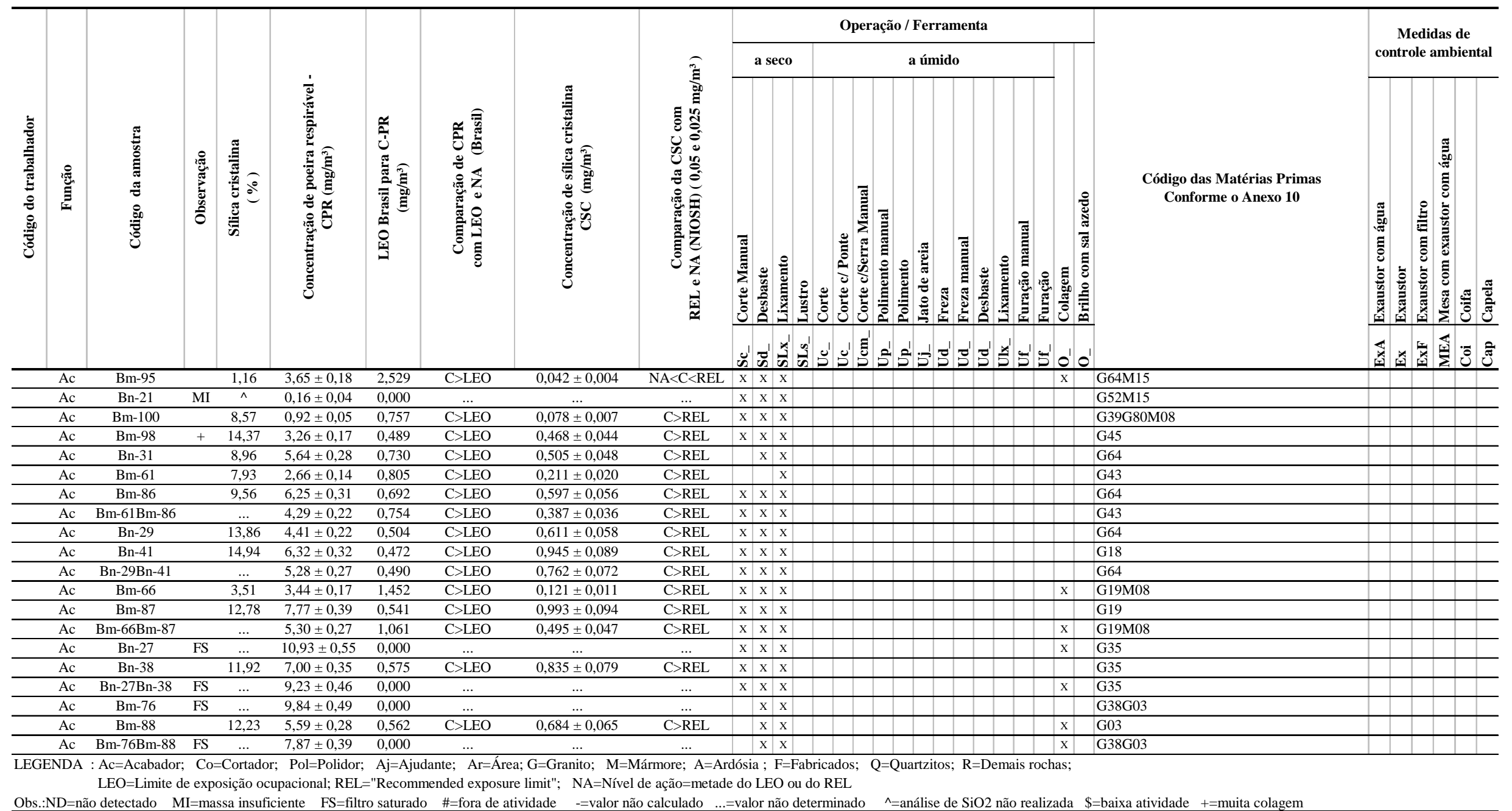

\section{Continua}


Tabela A12.2 - Concentração de poeira e de sílica cristalina respirável e informações complementares da Empresa M2.

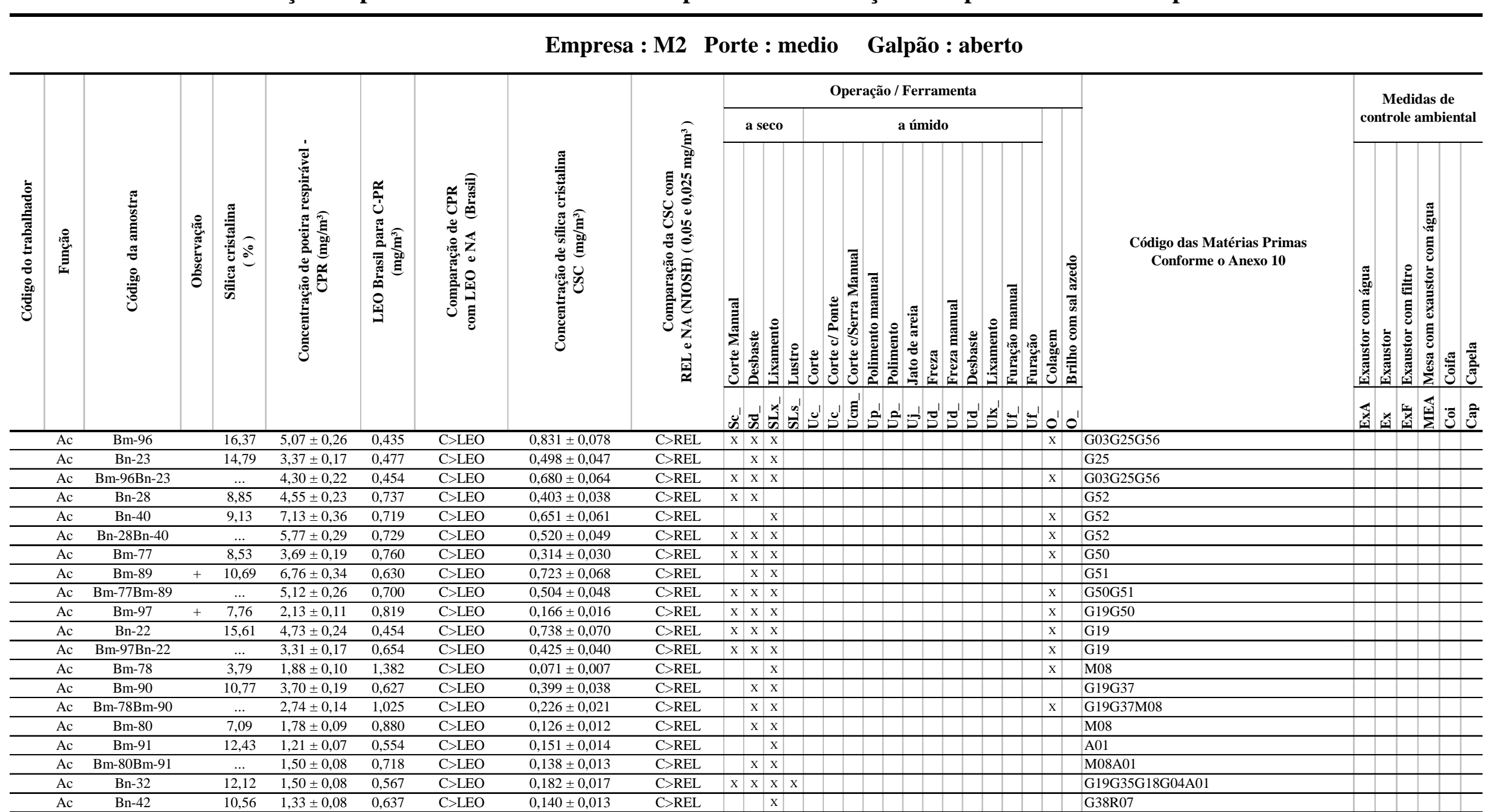

LEGENDA : Ac=Acabador; $\quad$ Co=Cortador; Pol=Polidor; Aj=Ajudante; Ar=Área; G=Granito; M=Mármore; A=Ardósia ; F=Fabricados; Q=Quartzitos; R=Demais rochas;

LEO=Limite de exposição ocupacional; REL="Recommended exposure limit"; NA=Nível de ação=metade do LEO ou do REL

Obs.:ND=não detectado $\quad \mathrm{MI}=$ massa insuficiente $\quad \mathrm{FS}=$ filtro saturado $\quad$ \#=fora de atividade $\quad-=$ valor não calculado $\quad \ldots=$ =valor não determinado $\quad \Lambda=$ =ánlise de $\mathrm{SiO2}$ não realizada $\$=$ baixa atividade $\quad+=$ muita colagem

\section{Continua}


Tabela A12.2 - Concentração de poeira e de sílica cristalina respirável e informações complementares da Empresa M2

Empresa : M2 Porte : medio Galpão : aberto

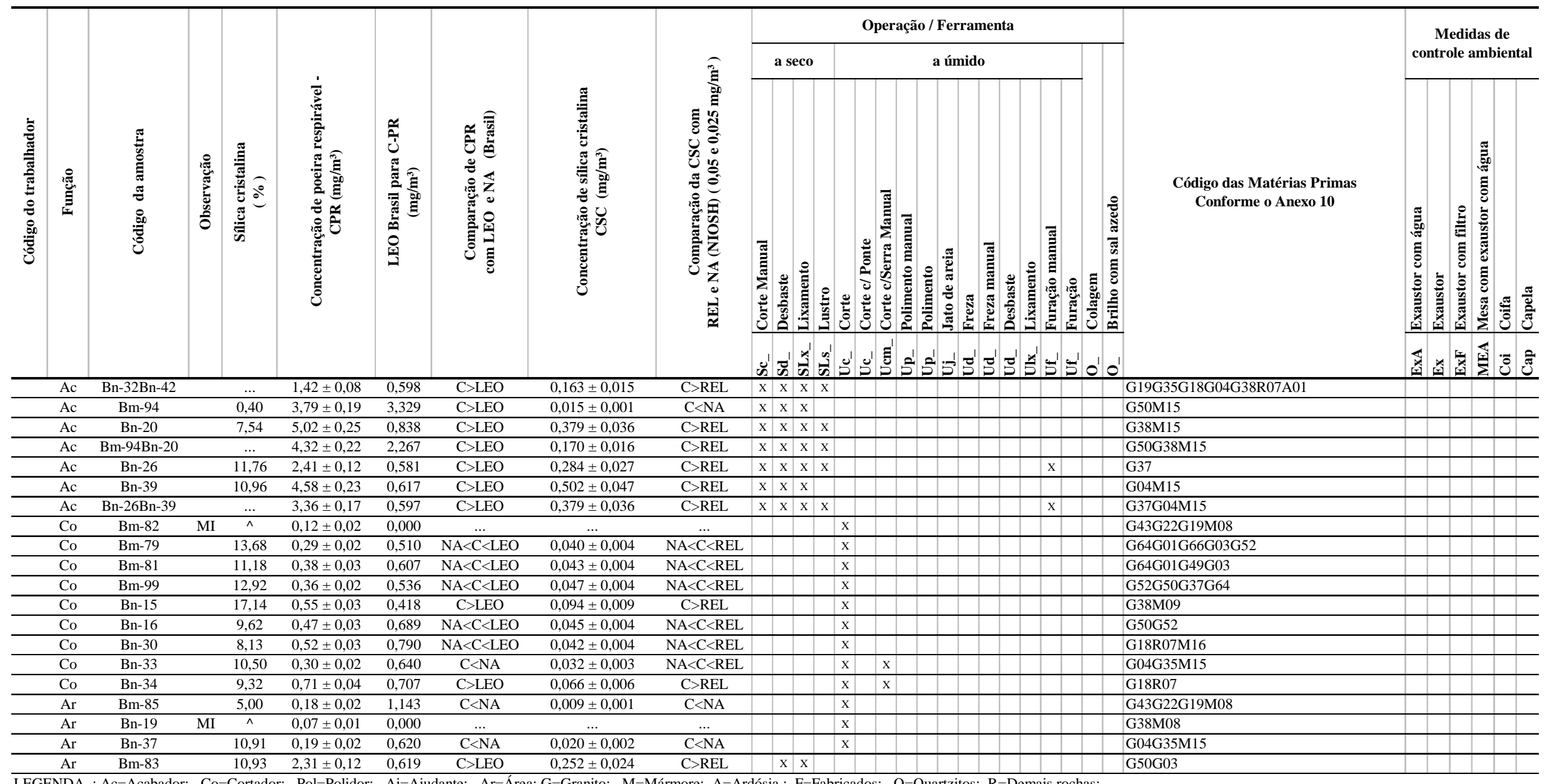

LEGENDA : Ac=Acabador; Co=Cortador; Pol=Polidor; Aj=Ajudante; $\mathrm{Ar}=\mathrm{A} r e a ; \mathrm{G}=$ Granito; M=Mármore; A=Ardósia ; F=Fabricados; Q=Quartzitos; R=Demais rochas;

LEO=Limite de exposição ocupacional; REL="Recommended exposure limit"; NA=Nivel de ação=metade do LEO ou do REL

Obs.:ND=não detectado $\quad \mathrm{MI}=$ =massa insuficiente $\quad \mathrm{FS}=$ filtro saturado $\quad$ \#=fora de atividade $\quad$-=valor não calculado $\quad . .=$ =valor não determinado $\quad \wedge=$ análise de $\mathrm{SiO} 2$ não realizada $\$=$ baixa atividade $\quad+=$ muita colagem

\section{Continua}


Tabela A12.2 - Concentração de poeira e de sílica cristalina respirável e informações complementares da Empresa M2

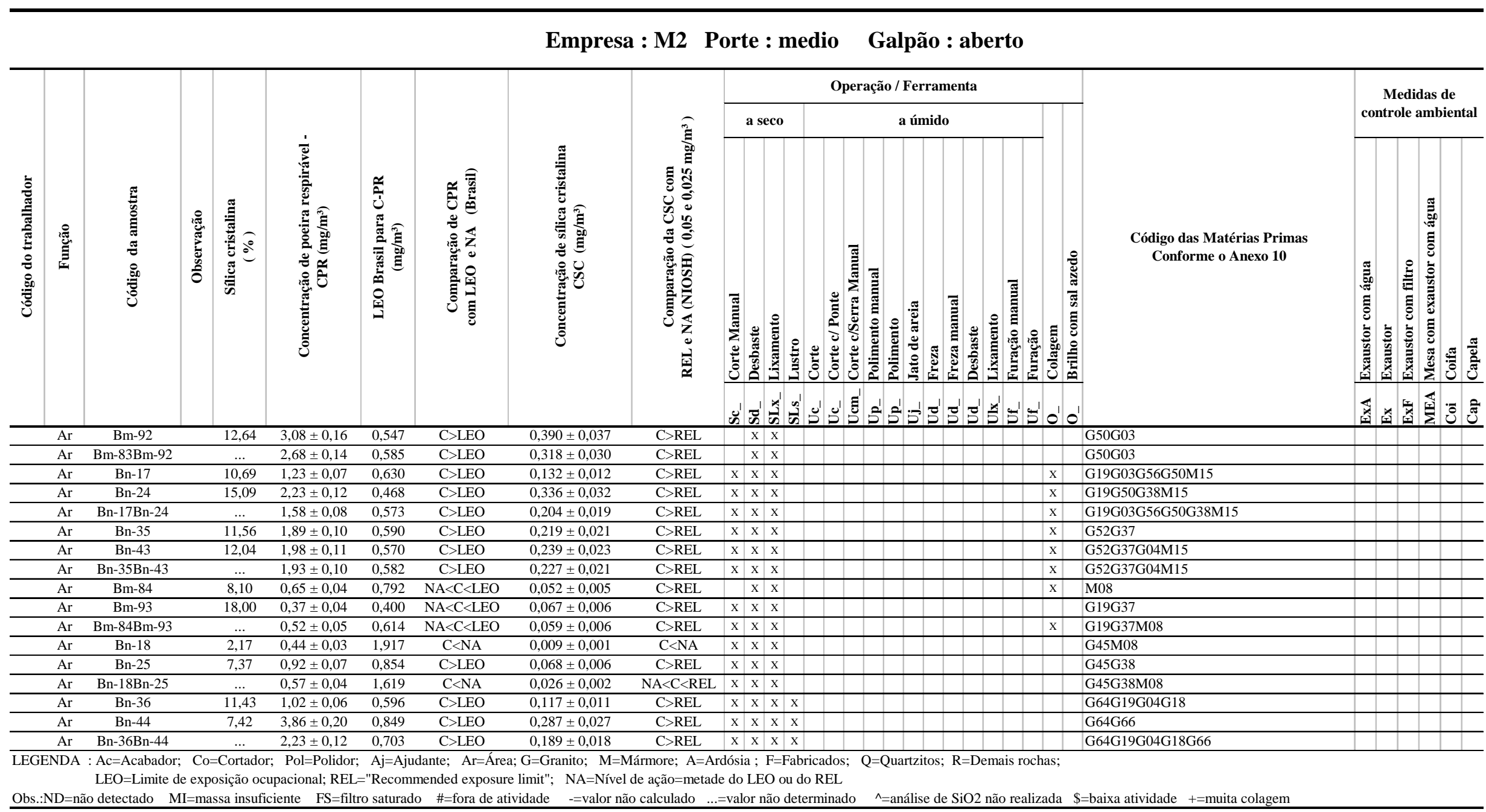


Empresa : M2 Porte : medio Galpão : aberto

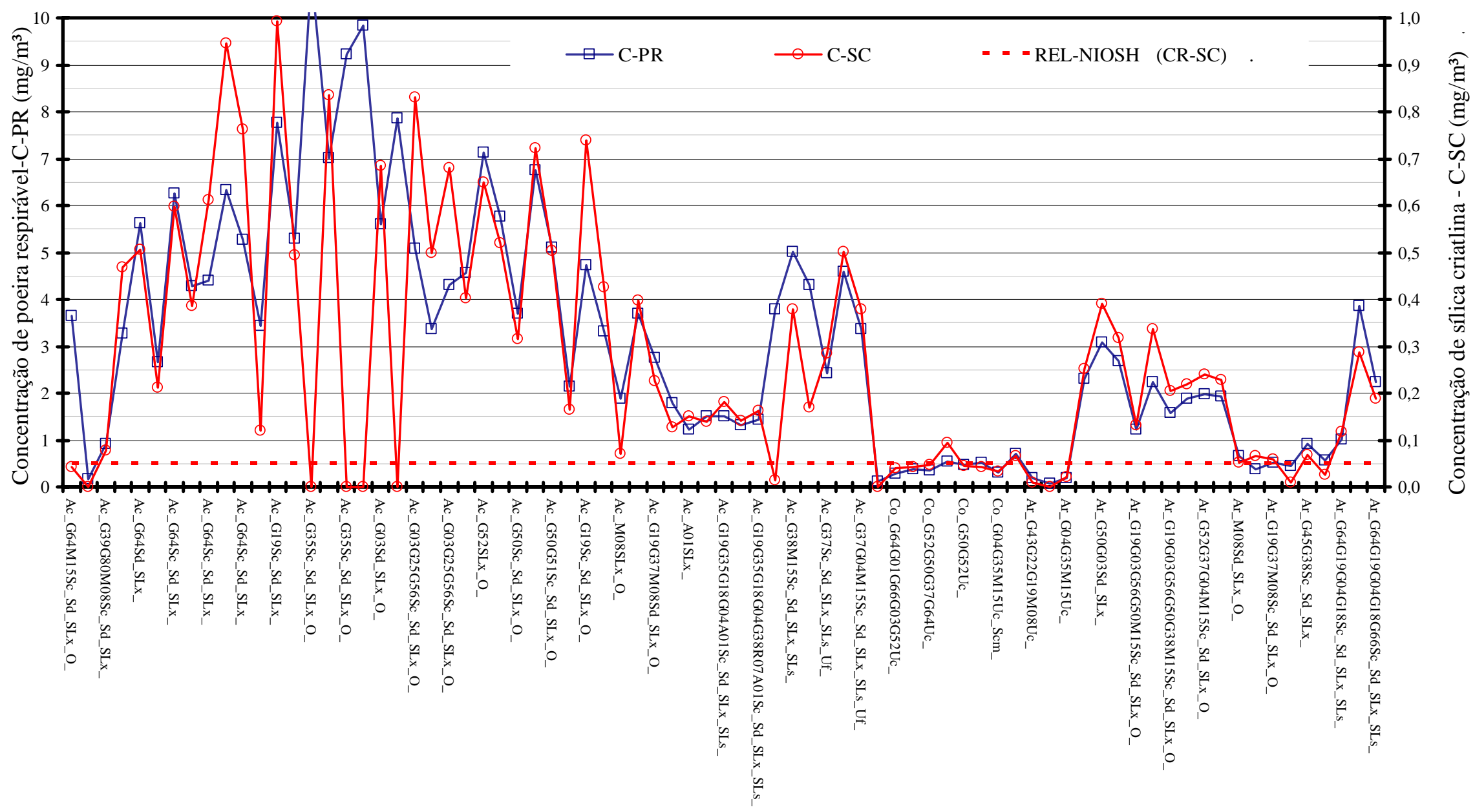

Figura A12.2 - Concentração de poeira respirável e sílica cristalina com respectiva etapa do processo (conf.Tabela A12.2) 
Tabela A12.3 - Concentração de poeira e de sílica cristalina respirável e informações complementares da Empresa M3. Marmorarias, Município de São Paulo, 2003-2005

\section{Empresa : M3 Porte : grande Galpão : semi-aberto}

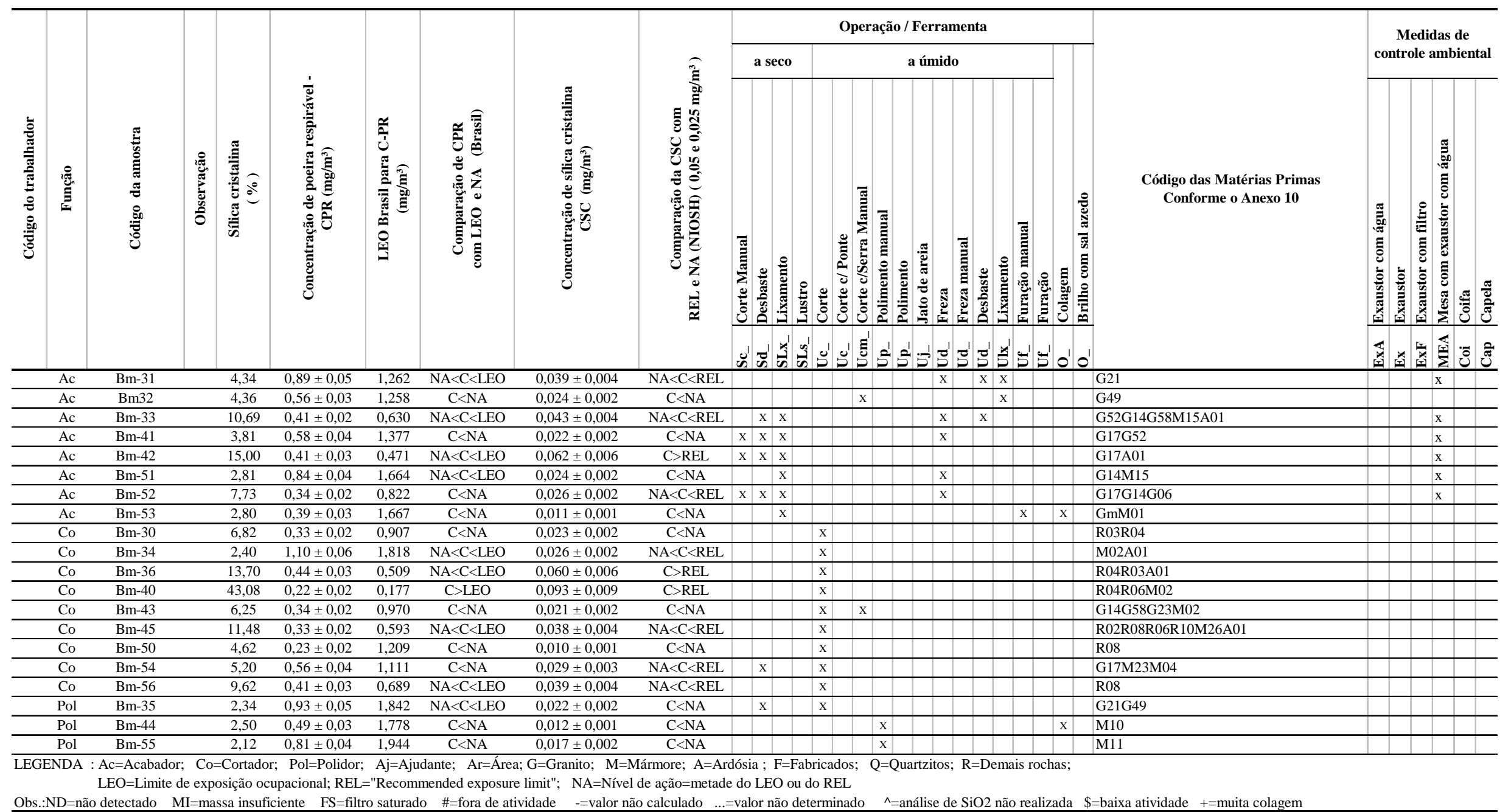

\section{Continua}


Tabela A12.3 - Concentração de poeira e de sílica cristalina respirável e informações complementares da Empresa M3

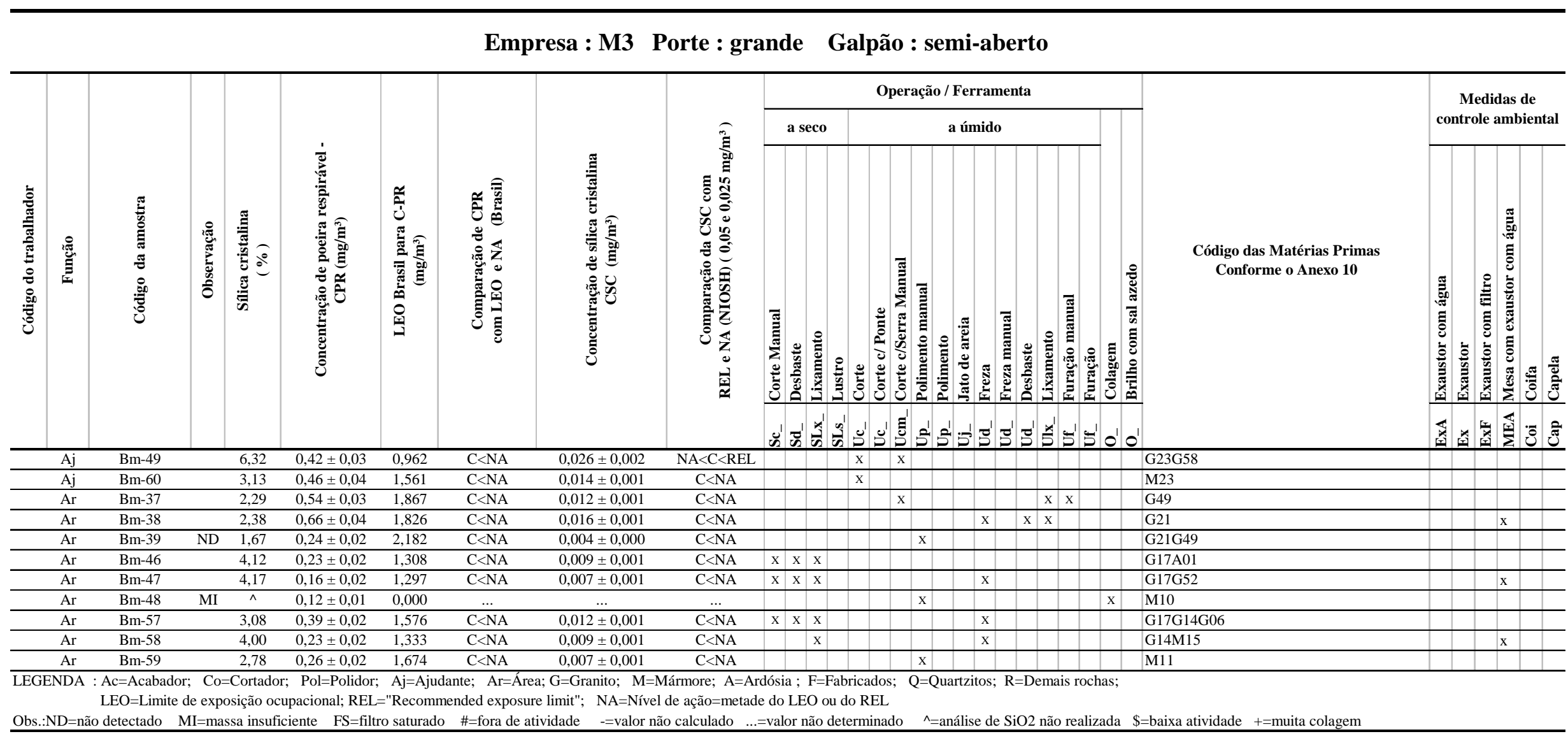


Empresa : M3 Porte : grande Galpão : semi-aberto

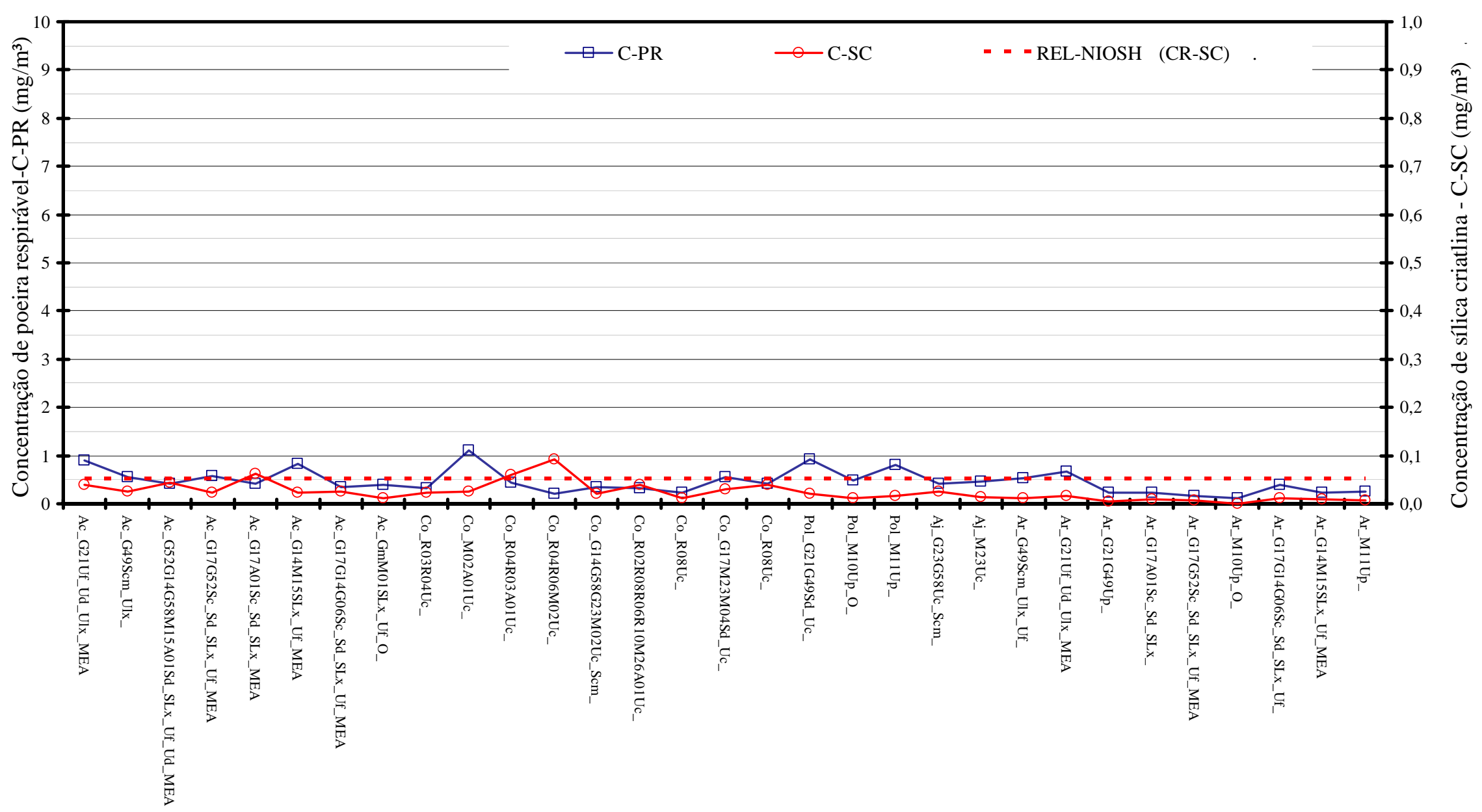

Figura A12.3: Concentração de poeira respirável e sílica cristalina com respectiva etapa do processo (conf.Tabela A12.3) 
Tabela A12.4 - Concentração de poeira e de sílica cristalina respirável e informações complementares da Empresa M4. Marmorarias, Município de São Paulo, 2003-2005

Empresa : M4 Porte : pequeno Galpão : fechado

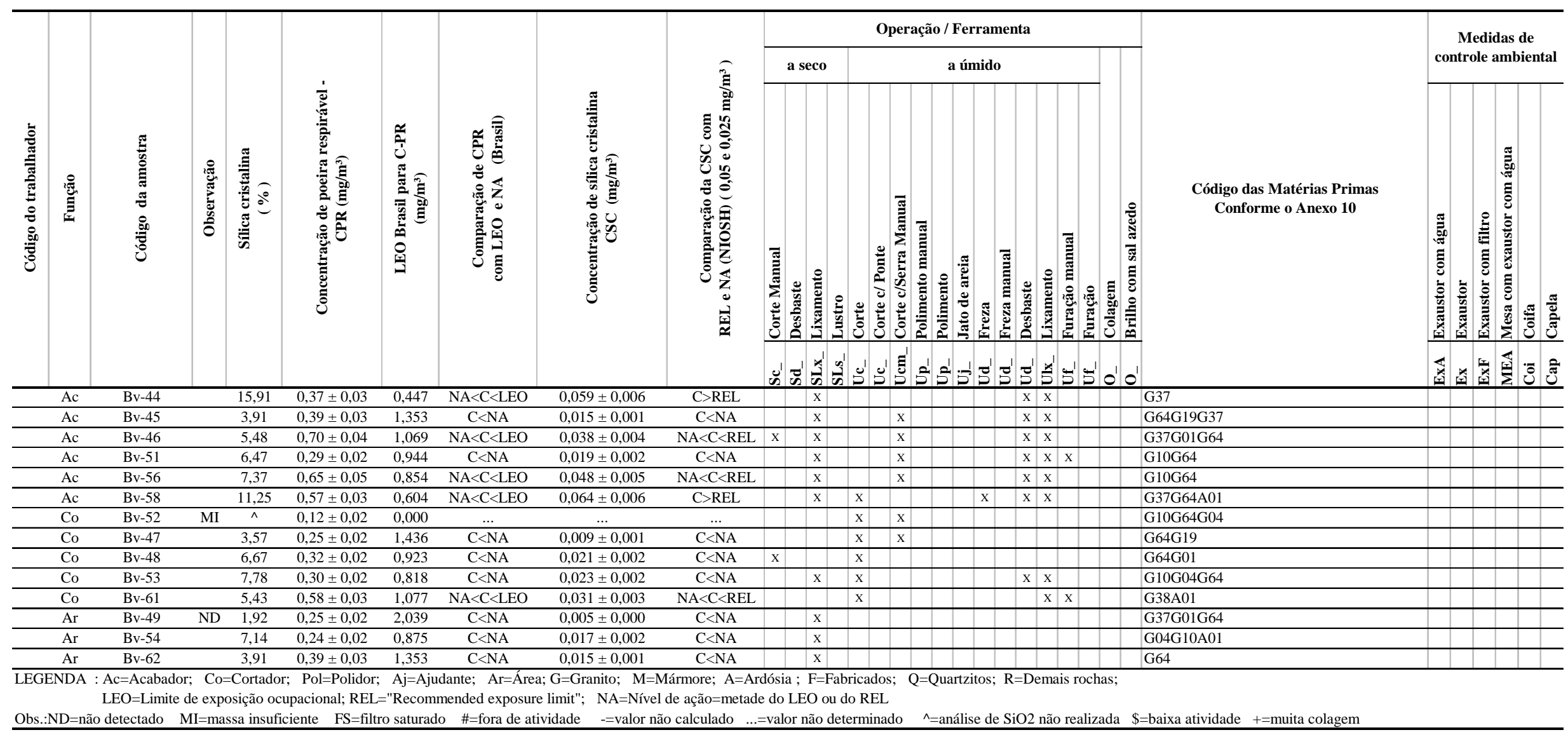


Empresa : M4 Porte : pequeno Galpão : fechado

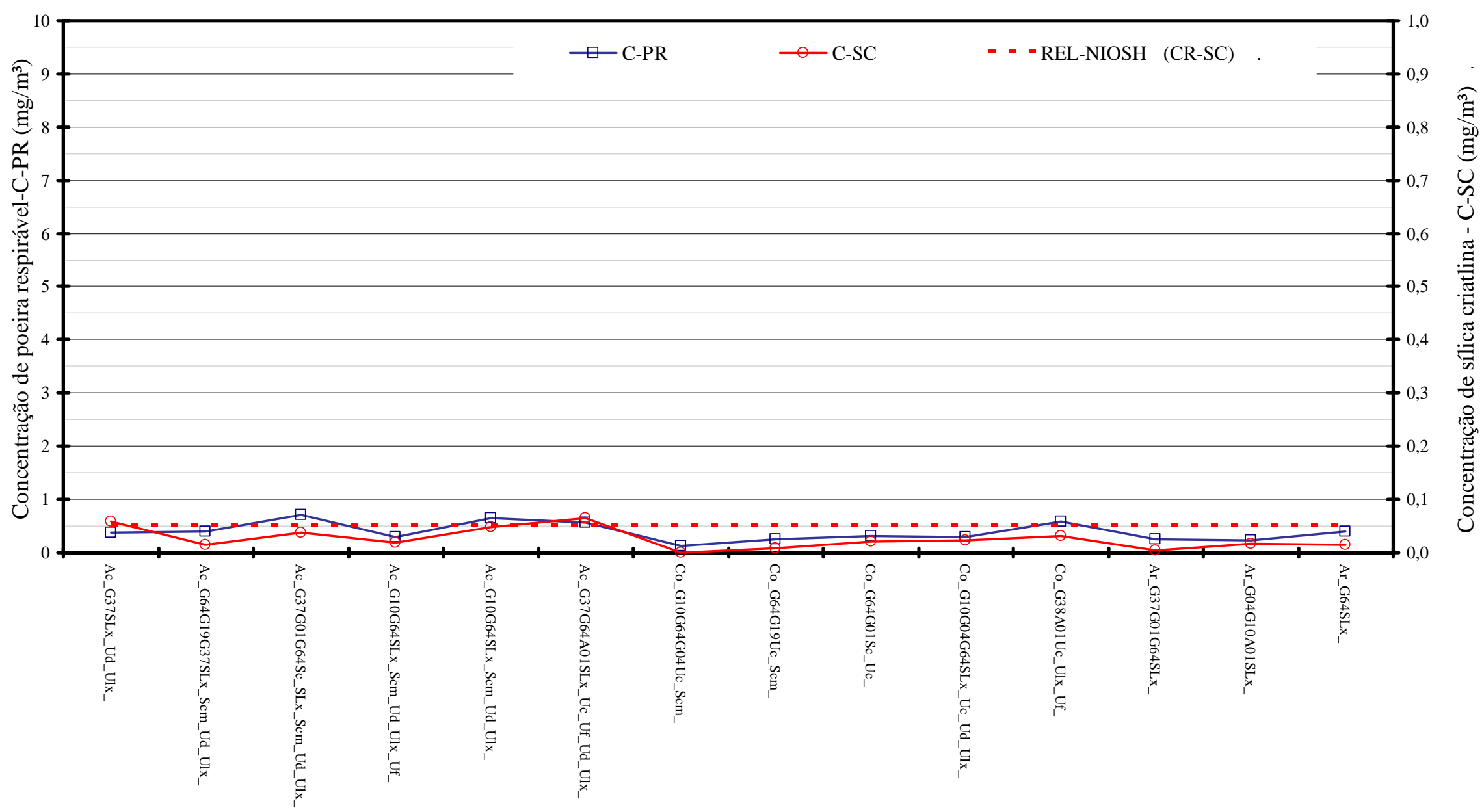

Figura A12.4: Concentração de poeira respirável e sílica cristalina com respectiva etapa do processo (conf.Tabela A12.4) 
Tabela A12.5: Concentração de poeira e de sílica cristalina respirável e informações complementares da Empresa M5. Marmorarias, Município de São Paulo, 2003-2005

\section{Empresa : M5 Porte : micro Galpão : fechado}

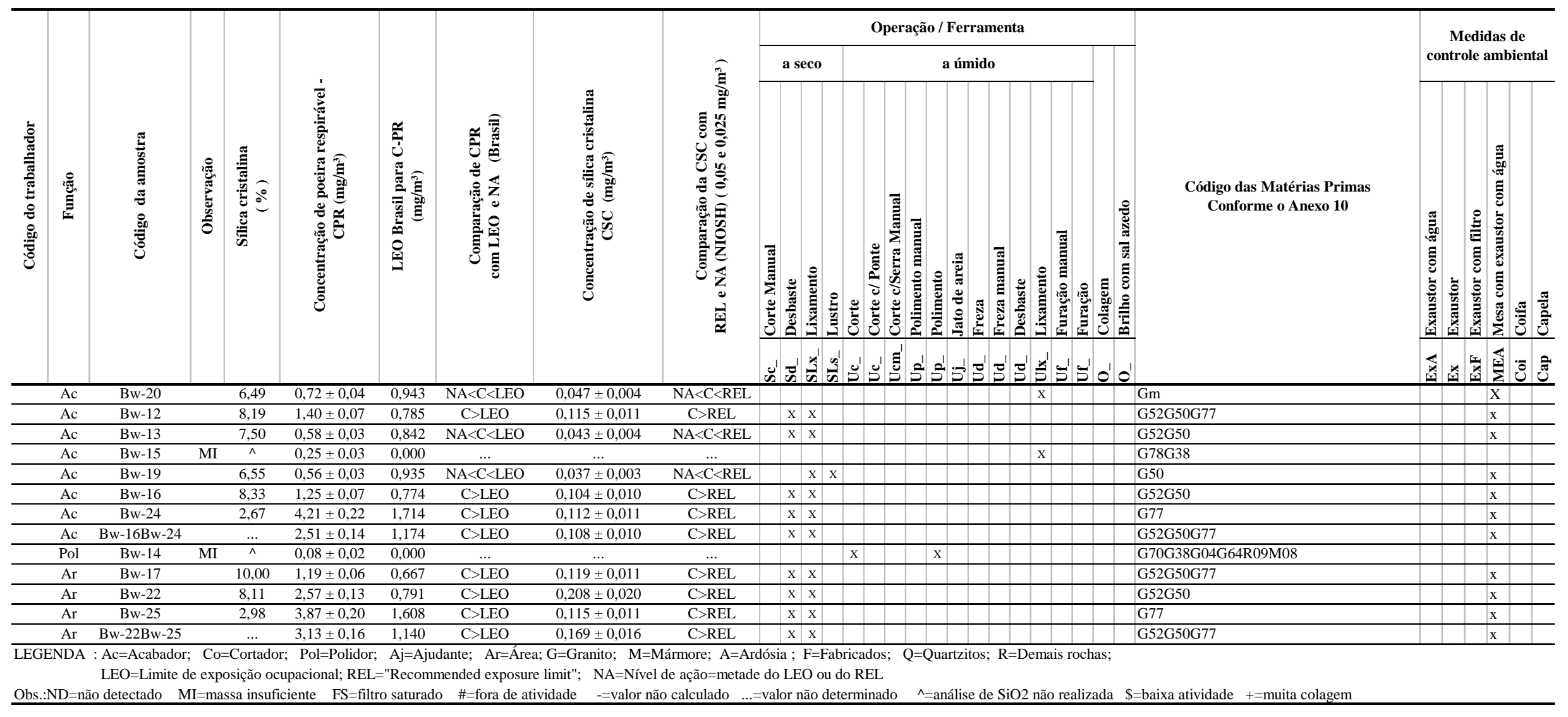


Empresa : M5 Porte : micro

Galpão : fechado

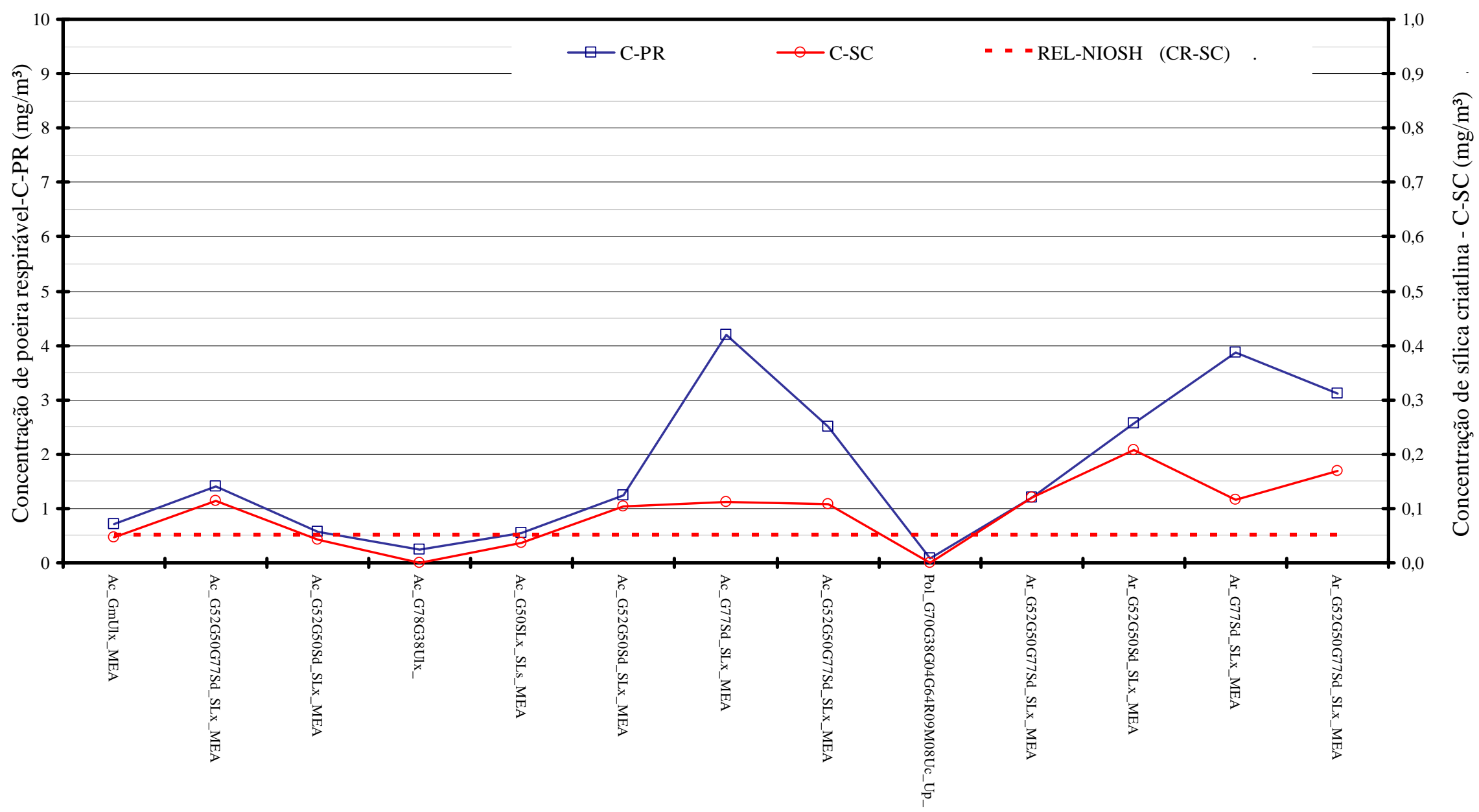

Figura A12.5: Concentração de poeira respirável e sílica cristalina com respectiva etapa do processo (conf.Tabela A12.5) 


\section{EXEMPLOS DE ALTERNATIVAS DE CONTROLE A ÚMIDO DA POEIRA NAS MARMORARIAS ESTUDADAS}

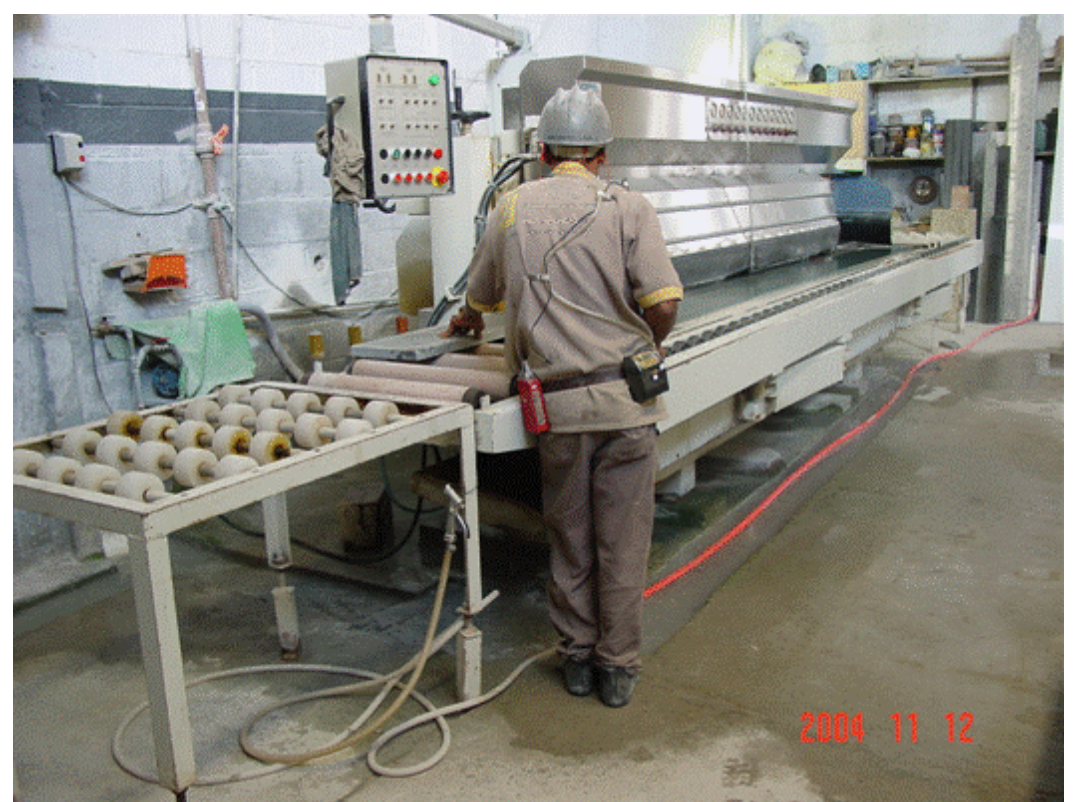

Figura 13.1 - Máquina para acabamento de bordas a úmido - boleadeira

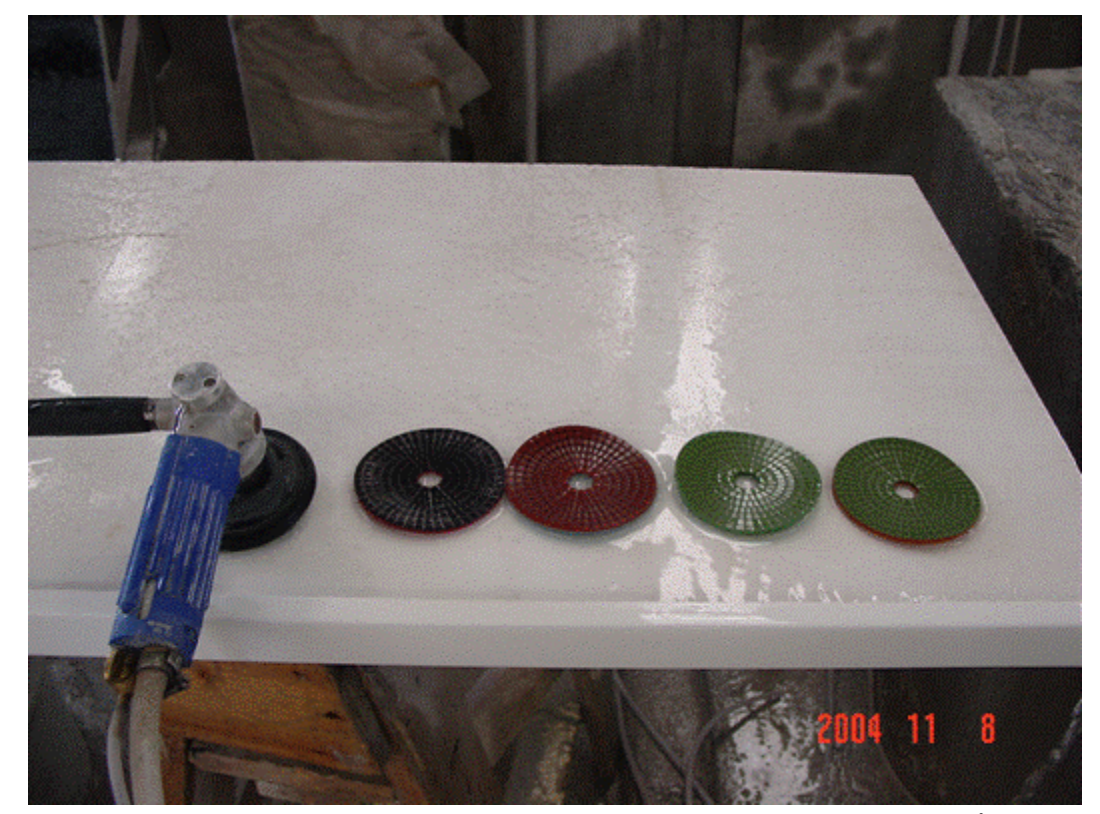

Figura 13.2 - Ferramenta manual para acabamento de bordas a úmido Politriz manual com funcionamento pneumático

Fonte: Com autorização do autor, Irlon Ângelo da Cunha 


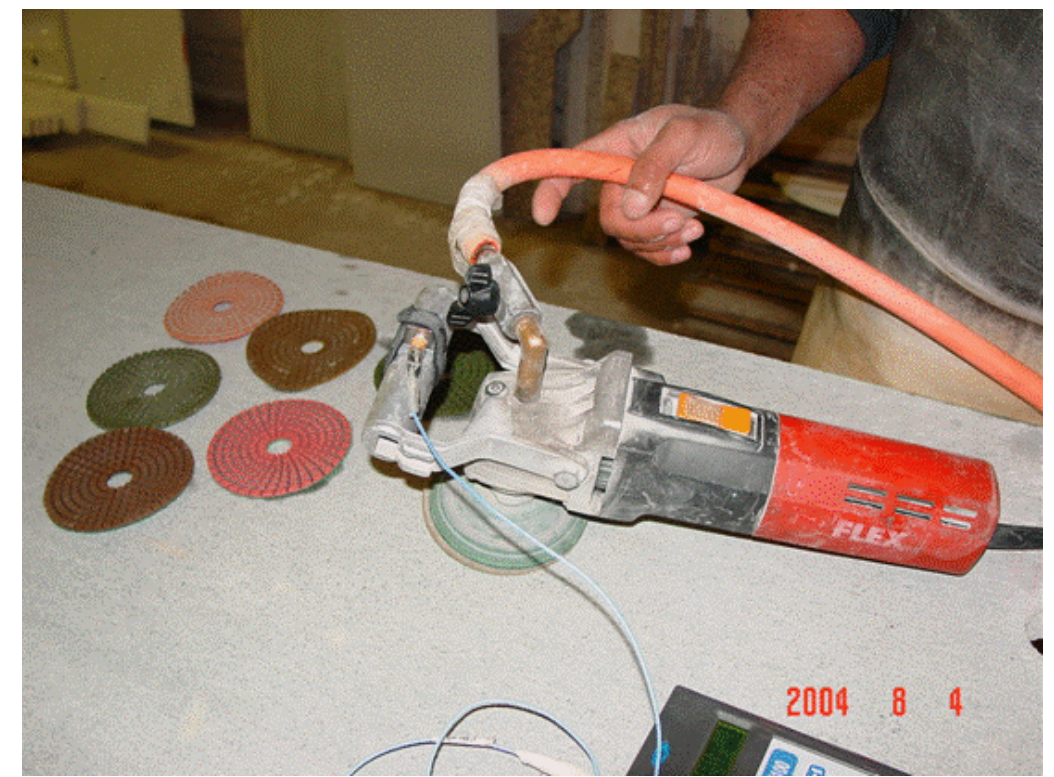

Figura 13.3 - Ferramenta manual para acabamento de bordas a úmido Politriz manual com funcionamento elétrico

Fonte: Com autorização do autor, Irlon Ângelo da Cunha

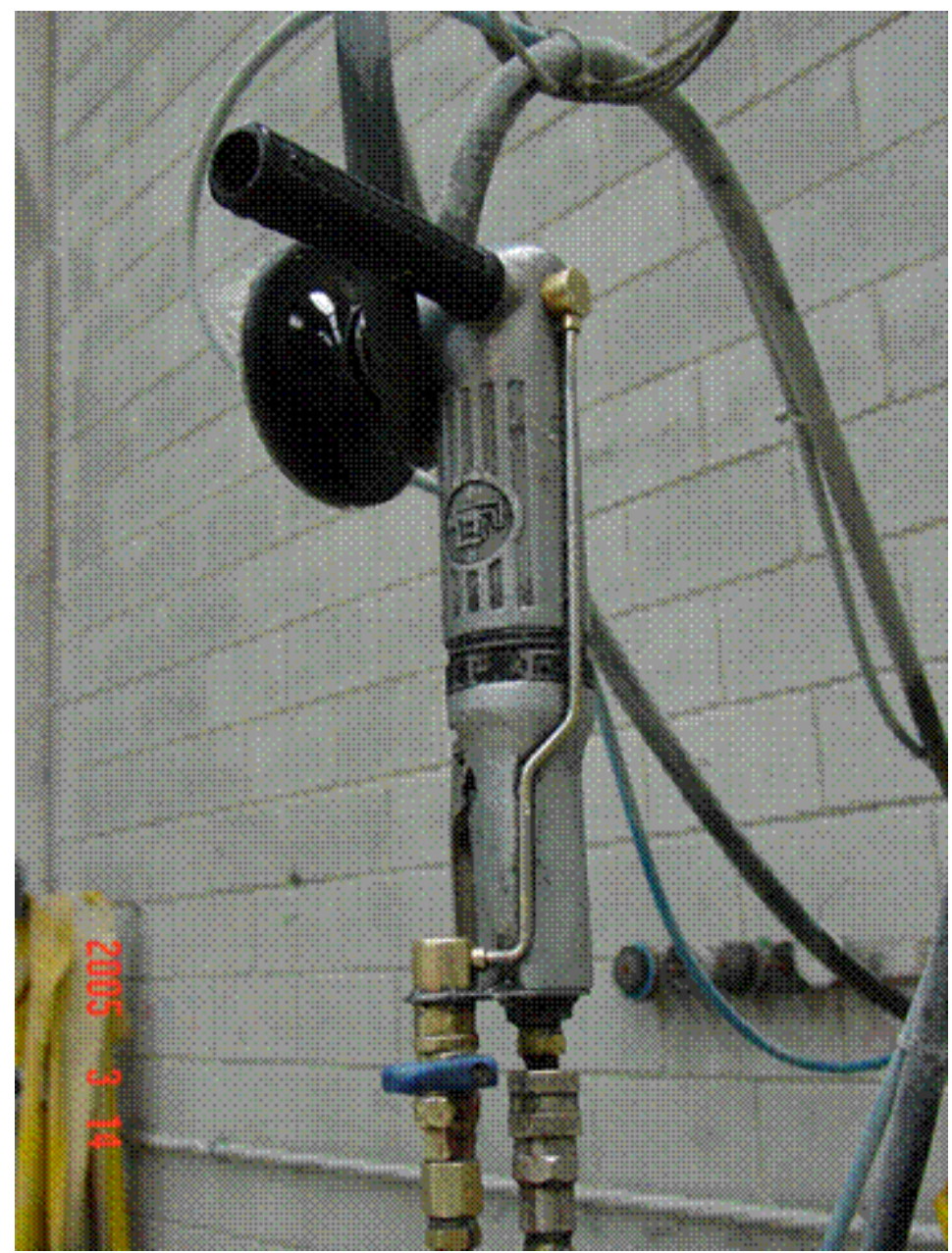

Figura 13.4 - Ferramenta manual para acabamento de bordas a úmido Politriz manual com funcionamento pneumático

Fonte: Com autorização do autor, Irlon Ângelo da Cunha 


\section{ANEXO 14 \\ LISTA DAS MATÉRIAS PRIMAS ENCONTRADAS NAS MARMORARIAS ESTUDADAS}

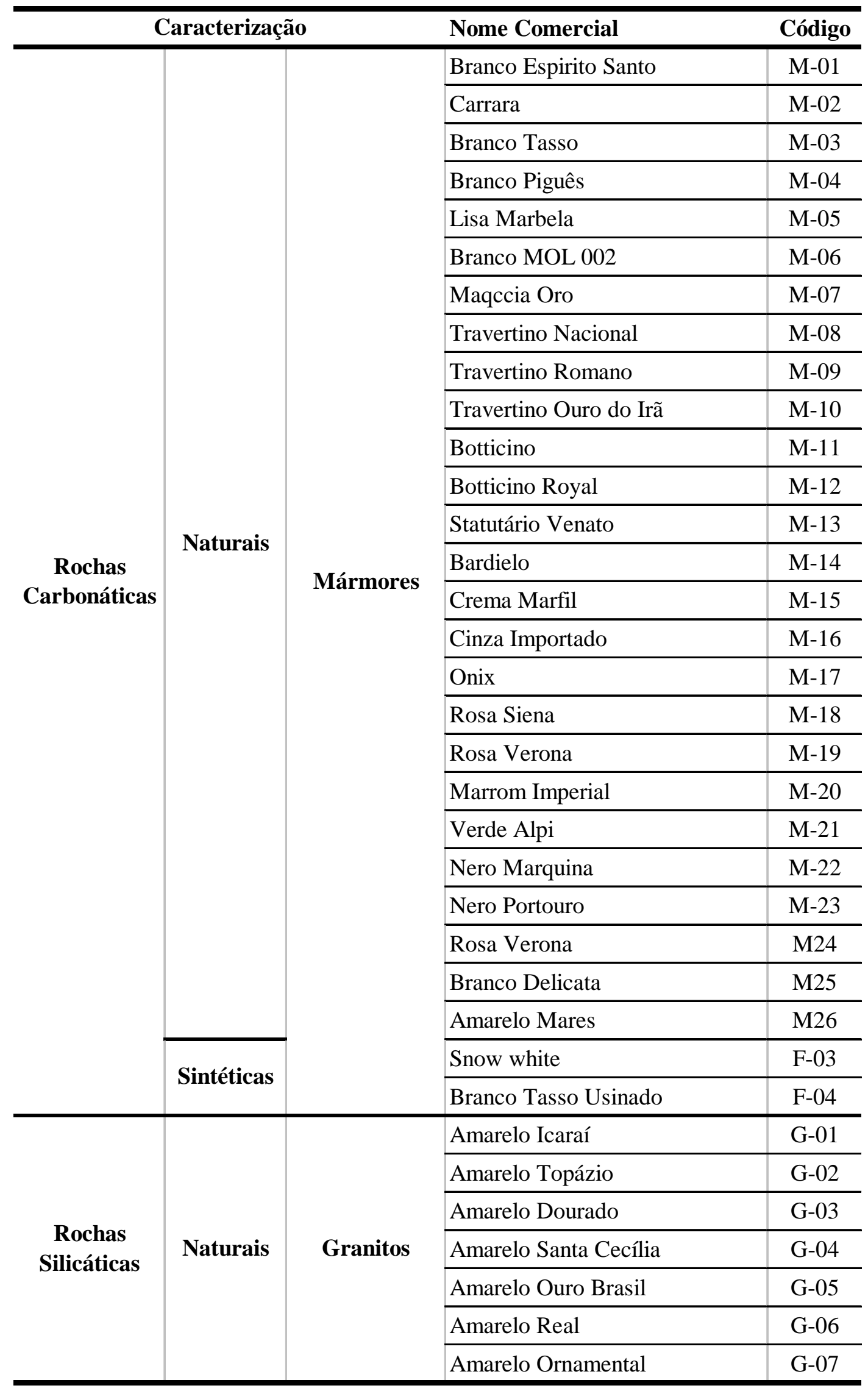




\begin{tabular}{|c|c|c|c|c|}
\hline \multicolumn{3}{|c|}{ Caracterização } & \multirow{2}{*}{\begin{tabular}{|l|} 
Nome Comercial \\
Amarelo Veneza
\end{tabular}} & \multirow{2}{*}{$\begin{array}{c}\text { Código } \\
\text { G-08 } \\
\end{array}$} \\
\hline \multirow{35}{*}{$\begin{array}{c}\text { Rochas } \\
\text { Silicáticas }\end{array}$} & \multirow{35}{*}{ Naturais } & \multirow{35}{*}{ Granitos } & & \\
\hline & & & Amarelo Bahia & G-09 \\
\hline & & & Amarelo Palha & G-10 \\
\hline & & & Amêndoa Maracujá & G-11 \\
\hline & & & Amêndoa Capri & G-12 \\
\hline & & & Laranjeira & G-13 \\
\hline & & & Amêndoa & $\mathrm{G}-14$ \\
\hline & & & Amêndoa Champanhe & G-15 \\
\hline & & & Amêndoa Gold & G-16 \\
\hline & & & Branco Itaúnas & G-17 \\
\hline & & & Branco Dallas & G-18 \\
\hline & & & Aqualux & G-19 \\
\hline & & & Aquamarine & G-20 \\
\hline & & & Arabesco MG6 & G-21 \\
\hline & & & Arabesco=Samoa & G-22 \\
\hline & & & Branco Polar & G-23 \\
\hline & & & Branco Kashimir & $\mathrm{G}-24$ \\
\hline & & & Amestra & G-25 \\
\hline & & & Branco Champanhe & G-26 \\
\hline & & & Branco Ártico & G-27 \\
\hline & & & Branco Fortaleza & G-28 \\
\hline & & & Branco Minas & G-29 \\
\hline & & & Branco Navona & G-30 \\
\hline & & & Branco Nepal & G-31 \\
\hline & & & Branco Ornamental & G-32 \\
\hline & & & Branco Siena & G-33 \\
\hline & & & Cinza Cristal & G-34 \\
\hline & & & Cinza Andorinha & G-35 \\
\hline & & & Cinza Castelo & G-36 \\
\hline & & & Cinza Corumbá & G-37 \\
\hline & & & Cinza Mauá & G-38 \\
\hline & & & Cinza Novo Mundo & G-39 \\
\hline & & & Cinza Prata & $\mathrm{G}-40$ \\
\hline & & & Ocre & G-41 \\
\hline & & & Kinawa & $\mathrm{G}-42$ \\
\hline
\end{tabular}




\begin{tabular}{|c|c|c|c|c|}
\hline \multicolumn{3}{|c|}{ Caracterização } & \multirow{2}{*}{$\begin{array}{l}\text { Nome Comercial } \\
\text { Azul Paulista }\end{array}$} & \multirow{2}{*}{$\frac{\text { Código }}{\text { G-43 }}$} \\
\hline \multirow{38}{*}{$\begin{array}{l}\text { Rochas } \\
\text { Silicáticas }\end{array}$} & \multirow{38}{*}{ Naturais } & \multirow{38}{*}{ Granitos } & & \\
\hline & & & Azul Norueguês & G-44 \\
\hline & & & Marrom Café & G-45 \\
\hline & & & Marrom São Paulo & G-46 \\
\hline & & & Café Bahia & G-47 \\
\hline & & & Café Imperial & G-48 \\
\hline & & & Preto Absoluto & G-49 \\
\hline & & & Preto Indiano & G-50 \\
\hline & & & Preto Piracaia & G-51 \\
\hline & & & Preto São Gabriel & G-52 \\
\hline & & & Preto Tijuca & G-53 \\
\hline & & & Rosa Biritiba & G-54 \\
\hline & & & Rosa Salto & G-55 \\
\hline & & & Red Rubi & G-56 \\
\hline & & & Rodo Alicante & G-57 \\
\hline & & & Vermelho C Bonito & G-58 \\
\hline & & & Vermelho Cajú & G-59 \\
\hline & & & Vermelho Brasil & G-60 \\
\hline & & & Vermelho Brasilia & G-61 \\
\hline & & & Vermelho Kinawa & G-62 \\
\hline & & & Vermelho Bragança & G-63 \\
\hline & & & Verde Ubatuba & G-64 \\
\hline & & & Verde Lavras & G-65 \\
\hline & & & Verde Pavão & G-66 \\
\hline & & & Verde Candeias & G-67 \\
\hline & & & Verde Agata & G-68 \\
\hline & & & Verde Veneziano & G-69 \\
\hline & & & Verde Eucalipto & G-70 \\
\hline & & & Am.Guarapari & G-71 \\
\hline & & & Verde Pérola & G-72 \\
\hline & & & Az de Paus & G-73 \\
\hline & & & Preto S.Benedito & G-74 \\
\hline & & & Am.Florença & G-75 \\
\hline & & & Am.Capri & G76 \\
\hline & & & Rose Kassimir & G-77 \\
\hline & & & Azul Bahia & G-78 \\
\hline & & & Aqua Verde & G79 \\
\hline & & & Amarelo Pavão & G-80 \\
\hline
\end{tabular}




\begin{tabular}{|c|c|c|c|c|}
\hline & \multicolumn{2}{|c|}{ Caracterização } & \multirow{2}{*}{$\begin{array}{l}\text { Nome Comercial } \\
\text { Amarelo Goiás }\end{array}$} & \multirow{2}{*}{$\frac{\text { Código }}{\mathrm{R}-01}$} \\
\hline \multirow{14}{*}{$\begin{array}{l}\text { Rochas } \\
\text { Silicáticas }\end{array}$} & \multirow{12}{*}{ Naturais } & \multirow{10}{*}{$\begin{array}{c}\text { Rochas } \\
\text { Aparelhadas }\end{array}$} & & \\
\hline & & & Arenito Golden Oasis & R-02 \\
\hline & & & Arenito Vermelho Paraná & R-03 \\
\hline & & & Branco São Tomé & $\mathrm{R}-04$ \\
\hline & & & Mineira & $\mathrm{R}-05$ \\
\hline & & & Miracema & R-06 \\
\hline & & & Quartzo Rosa & $\mathrm{R}-07$ \\
\hline & & & Verde Goiás & $\mathrm{R}-08$ \\
\hline & & & Madeira & R-09 \\
\hline & & & Arenito Amarelo São Carlos & $\mathrm{R}-10$ \\
\hline & & Ardósias & Ardósia Cinza & A-01 \\
\hline & & Quartzitos & Azul Macúba & Q-01 \\
\hline & \multirow{2}{*}{ Sintéticas } & \multirow{2}{*}{ Fabricados } & Silestone Branco & F-01 \\
\hline & & & Silestone Aluminum Nube & F-02 \\
\hline
\end{tabular}

